\title{
Early Miocene Thrust Tectonics \\ on Raukumara Peninsula, Northeastern New Zealand
}

Geoffrey Jonathan Rait

Submitted for the degree of Doctor of Philosophy in Geology, Victoria University of Wellington, December 1992. 
Raukumara Peninsula lies at the northeastern end of the East Coast Deformed Belt, a province of deformed Late Mesozoic-Late Cenozoic rocks on the eastern edges of the North Island and northern South Island of New Zealand. Late Cenozoic deformation in this province is associated with westward subduction of the Pacific Plate, which started at about the beginning of the Miocene. Early Miocene tectonism on Raukumara Peninsula took place in a hitherto little-known thrust belt, the East Coast Allochthon. The configuration, evolution and origin of this thrust belt are the subjects of this thesis.

The thrust belt extends $110 \mathrm{~km}$ from the thrust front in the southwest to the northeastern tip of Raukumara Peninsula. Internal structures strike northwest, perpendicular to the present trend of the continental margin but parallel to the Early Miocene trend suggested by plate reconstructions and paleomagnetic studies. The structure and kinematic evolution of the thrust belt were investigated by detailed mapping of three key areas in its central part and by analysis of previous work throughout the region. Gross differences in structure lead to the division of the belt into three zones: southern, central and northern. Deformation in the southern and central zones (the southwestern two-thirds of the system) was thin-skinned, involving southwestward transport of thrust sheets above a decollement horizon at the top of the Maastrichtian-Paleocene Whangai Formation. The décollement is exposed in the northwest due to southeastward tilting accompanying post-Miocene uplift of the Raukumara Range. Deformation in the northern zone involved reactivations of northeastdirected Cretaceous thrusts as well as southwestward emplacement of allochthonous sheets. Stratigraphic relationships show that thrusting took place during $\approx 6 \mathrm{~m}$.y. in the earliest Miocene.

The $18 \mathrm{~km}$ wide southern zone is an emergent imbricate fan of rocks detached from above the Whangai Formation in a piggy-back sequence and transported less than about $18 \mathrm{~km}$ at rates of $2.6-3.6 \mathrm{~mm} / \mathrm{yr}( \pm 20 \%-100 \%)$. The central and northern zones include rocks older than Whangai Formation. The sheets of the central zone and the southwestdirected sheets of the northern zone make up three major allochthonous units: the Waitahaia allochthon, consisting predominantly of mid-Cretaceous flysch above the Waitahaia Fault and equivalent structures, at the bottom of the thrust pile; the Te Rata allochthon, of Late Cretaceous-Early Tertiary continental margin sediments above the Te Rata Thrust, in the middle; and the Matakaoa sheet, an ophiolite body of midCretaceous-Eocene basaltic and pelagic sedimentary rocks, at the top and back of the 
thrust belt. The Waitahaia allochthon was emplaced first and was subsequently breached by the Te Rata Thrust. The mid-Cretaceous rocks of the Waitahaia allochthon are mostly overturned, a result of the southwest-directed Early Miocene thrusting overprinting a Cretaceous structure of predominantly southwestward dips. The Te Rata allochthon comprises a complex pile of thrust sheets and slices with a general older-on-younger stacking order but with common reversals. Synorogenic sedimentary rocks occur within it. The complexity of internal structure of these two allochthons suggests they have undergone more than the $50 \%$ shortening estimated for the southern zone.

The minimum southwestward displacement of the Te Rata allochthon is $60 \mathrm{~km}$. The minimum displacements of the Waitahaia and Matakaoa allochthons are 55-195 km and $115-530 \mathrm{~km}$ respectively, depending on whether the Te Rata allochthon originally lay in front of the original position of the Waitahaia allochthon or was originally the upper part of the Waitahaia allochthon, and on the amounts of internal shortening of the allochthons. Over the $\approx 6 \mathrm{~m}$.y. period of thrusting, these estimates imply displacement rates for the Matakaoa sheet of $19-88 \mathrm{~mm} / \mathrm{yr}$. The average plate convergence rate at East Cape for the period $36-20 \mathrm{Ma}$ is estimated at $25-30 \mathrm{~mm} / \mathrm{yr}$; the rate for the Early Miocene-when subduction was active-may have been faster. Reasonable displacement rates for the Matakaoa sheet would result if the Te Rata allochthon was originally the upper part of the Waitahaia allochthon and if both allochthons have been shortened somewhat less than $50 \%$.

The emplacement mechanism of the Matakaoa ophiolite is elucidated by comparison with Northland, northwest along strike from Raukumara Peninsula, onto which correlative rocks were emplaced at the same time. The thinness of the Northland ophiolite bodies, their composition of rocks typical of the uppermost levels of oceanic crust, and the start of andesitic volcanism accompanying their obduction show that they were emplaced as a thin flake of oceanic crust which peeled off the downgoing slab during the inception of southwestward subduction. The reason the ophiolites were initially peeled from the slab is probably that their upper levels prograded southwestward over sediments of the Northland-Raukumara continental margin. In such a situation, initial compression would have led to formation of a northeast-dipping thrust at the volcanic/sediment interface; this thrust would then have propagated back into the downgoing plate with continued convergence, allowing the ophiolites to climb up the continental slope pushing the allochthonous sedimentary sheets ahead of them. 


\section{Acknowledgements}

This thesis was completed under the supervision of Prof. Dick Walcott, who is thanked for advice and discussions on all aspects. Dr. Dan May assisted in the early stages. Thanks are due to Dr. Jim McDougall, for fruitful discussions and valuable comments; Drs. Angela Jayko and Tim Little, for helpful comments; Prof. Paul Vella, for fossil identifications; Prof. Harold Wellman, for continued interest, for comments on some chapters and for perspective-restoring Friday conversations; Dr. Peter Barrett, for moral and logistic support at intervals; and to other academic, technical and secretarial staff at Victoria for assistance and advice.

Special thanks go to Felicity Maxwell for valuable comments, careful editing, and skillful drafting, for companionship, and for support when it was needed and bullying when it was required. Friends among past and present students are thanked for having been there. Richard Wysoczanski and Randall McDonnell proposed a bet on my finishing date which increased my work rate for a time, but which I lost by almost a year!

Of people presently with the Institute of Geological and Nuclear Sciences or formerly with DSIR Geology and Geophysics and/or N.Z. Geological Survey, I owe thanks in particular to Colin Mazengarb for many discussions, time in the field, and for generously sharing unpublished results. Thanks are also due to Hugh Morgans, for microfossil work and stratigraphic knowledge; Dave Francis, for fruitful discussions in the field and elsewhere; Phil Moore, for discussions; James Crampton, for macrofossil identifications; and Dr. Simon Nathan, for providing published material at favourable rates.

Many East Coast residents are also due thanks: Mike \& Annette, formerly of Mayfair Cabins (Tokomaru Bay), for accommodation and friendship; Tony Hansen (lhungia) for accommodation and motorcycle hire; Lorna \& Les White (Waingakia) for accommodation and hospitality; and Jim \& Awhina White (Makarika), Jeremy \& Jane Williams (Matahiia), and Tim \& Sam Williams (Te Koau) for good food. Alan, Greg and Les (East Coast Pest Control Board) provided entertainment and parts of a pig at Waingakia. Other local landowners and station managers are thanked for access to their rocks.

Finally, much gratitude is due to my parents, Howard and Edna Rait, who provided accommodation, food, logistic and financial support, mechanical and artistic services, who tolerated my at times unpredictable behaviour, and who generally made things easier for me. Thanks folks - this is for you. 


\section{Contents}

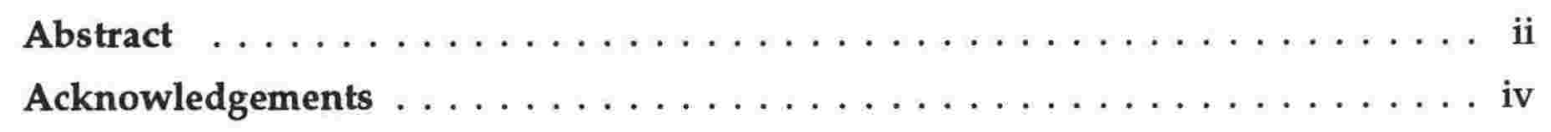

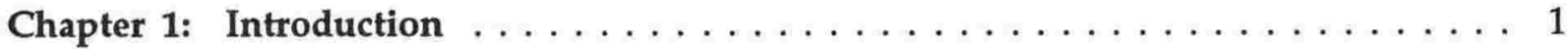

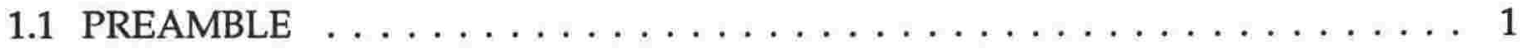

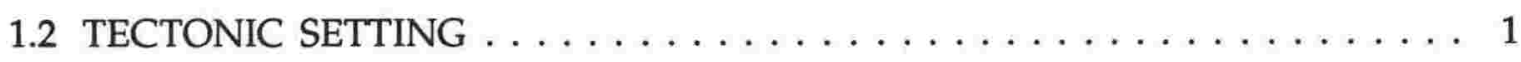

1.3 PREVIOUS WORK . . . . . . . . . . . . . . . . . 2

1.3.1 Early Miocene Deformation and the "East Coast Allochthon" . . . . . 2

1.3.2 Other Previous Work . . . . . . . . . . . . . . . 5

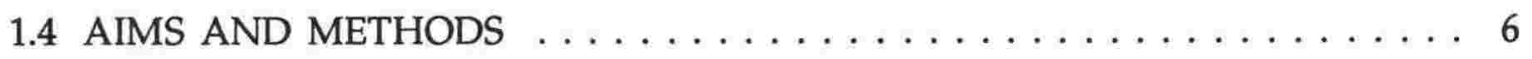

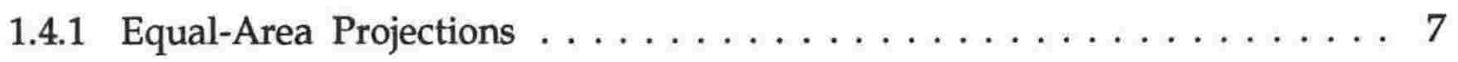

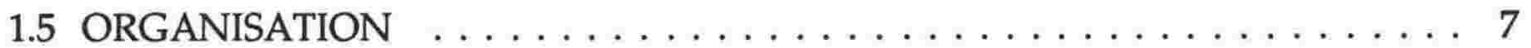

Chapter 2: Regional Stratigraphy $\ldots \ldots \ldots \ldots \ldots \ldots \ldots \ldots \ldots \ldots$

2.1 INTRODUCTION $\ldots \ldots \ldots \ldots \ldots \ldots \ldots \ldots \ldots \ldots \ldots \ldots$

2.1 .1 Nomenclature . . . . . . . . . . . . . . . . . . . . . . . . 9

2.1.1.1 Comparison With Earlier Nomenclature . . . . . . . . . . . . . . 10

2.1.2.2 Additional Names . . . . . . . . . . . . . . . . . 10

2.2 EARLY CRETACEOUS-OLIGOCENE STRATIGRAPHIC DIVISIONS $\ldots \ldots 11$

2.2 .1 Motu Block . . . . . . . . . . . . . . . . . . . . . 11

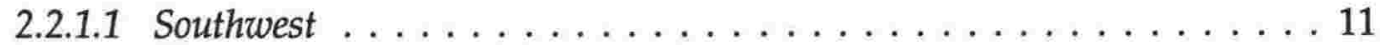

2.2 .1 .2 Central . . . . . . . . . . . . . . . . . 13

2.2.1.3 Northeast . . . . . . . . . . . . . . . . . . 14

2.2 .2 East Coast Allochthon . . . . . . . . . . . . . . 15

2.2.2.1 Northeast . . . . . . . . . . . . . . . . . . 15

2.2.2.2 Southwest . . . . . . . . . . . . . . . . . 19

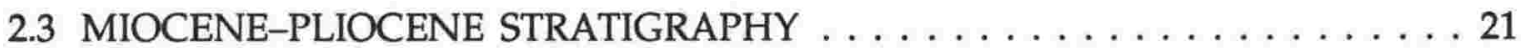

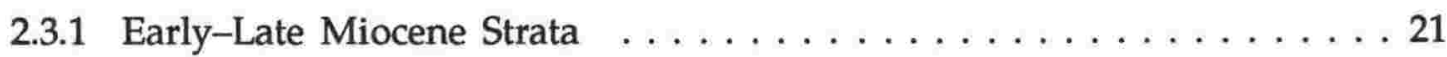

2.3.2 Late Miocene-Pliocene Strata . . . . . . . . . . . . . 23

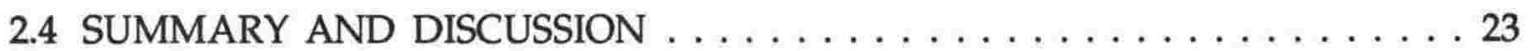

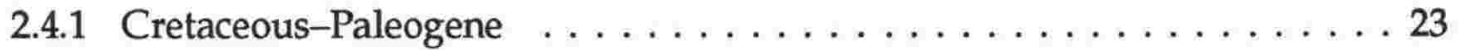

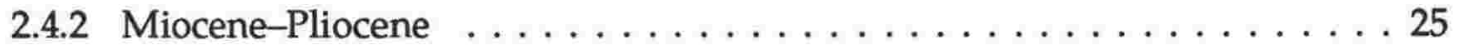


Chapter 3: Structure of the Lower Mata River Area . . . . . . . . . . 27

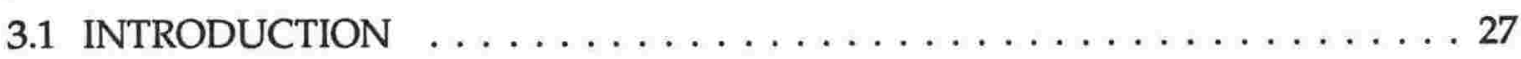

3.1.1 Location, Physiography and Exposure . . . . . . . . . . . 27

3.1 .2 Previous Work . . . . . . . . . . . . . . . 28

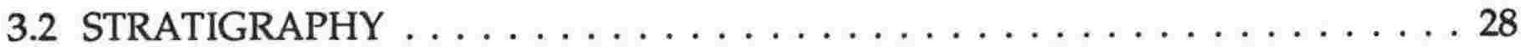

3.2.1 Mokoiwi Formation . . . . . . . . . . . . . . . . . . . . . . 29

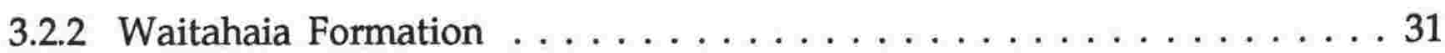

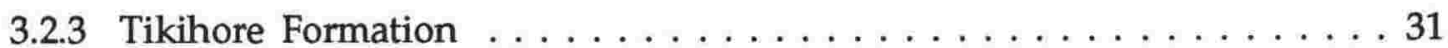

3.2.4 Haumurian-Teurian Rocks . . . . . . . . . . . . . . . . 35

3.2 .5 Eocene Smectite Mudstone . . . . . . . . . . . . . 37

3.3 OVERVIEW OF STRUCTURE . . . . . . . . . . . . . . . 39

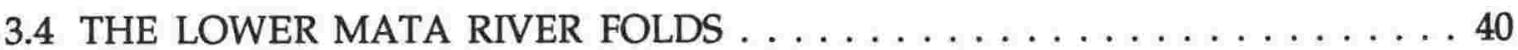

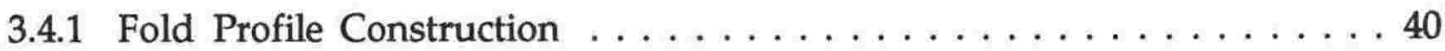

3.4 .2 Fold Geometry and Folding Mechanism . . . . . . . . . . . 43

3.4.2.1 Geometric Models of Fault-Propagation Folds . . . . . . . . . . . . 44

3.4.2.2 Geometric Analysis and Fault Geometry at Depth . . . . . . . . . . . 45

3.4.2.3 Minor Structures and Fold Evolution . . . . . . . . . . . . . 51

3.4 .3 Folding in Makarika and Orua Streams . . . . . . . . . . . 54

3.4 .4 Late High-Angle Faulting . . . . . . . . . . . . . . 55

3.5 STRUCTURE OF HAUMURIAN-TEURIAN ROCKS . . . . . . . . . . 57

3.5 .1 The Basal Unconformity . . . . . . . . . . . . . . . 57

3.5.2 Deformation in the Upper Aorangiwai Valley $\ldots \ldots \ldots \ldots \ldots$

3.5 .2 .1 Folding ...................... 58

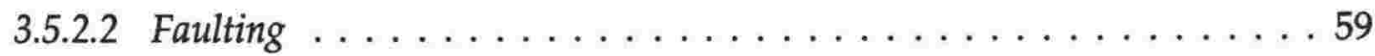

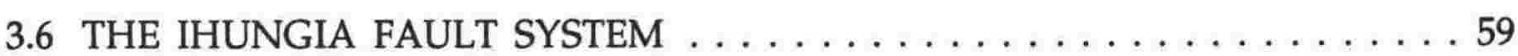

3.6.1 The Mangapekapeka Fault . . . . . . . . . . . . 60

3.6.2 East Branch, Ihungia Fault . . . . . . . . . . . . . . 64

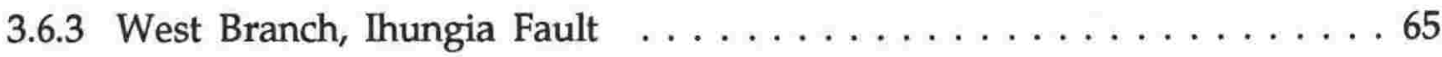

3.6.4 Kinematic History of the Ihungia Fault System $\ldots \ldots \ldots \ldots 7$

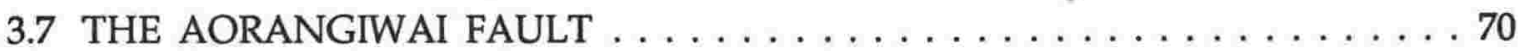

3.8 DISCUSSION AND CONCLUSIONS $\ldots \ldots \ldots \ldots \ldots \ldots \ldots \ldots \ldots \ldots \ldots$

3.8.1 History of Deformation in the Lower Mata River Area . . . . . . . . 71

3.8.2 Deformation History and the "East Coast Allochthon" . . . . . . . . . 72

3.8 .3 Conclusions ...................... . 73

Chapter 4: Structure Between Ihungia River and Puketoro Stream $\ldots \ldots \ldots 76$

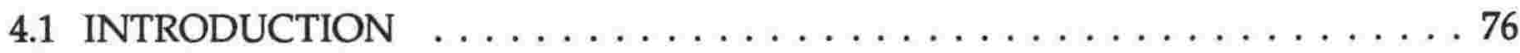

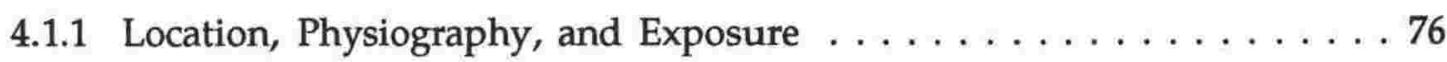

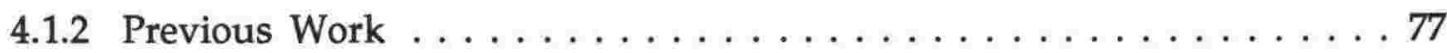




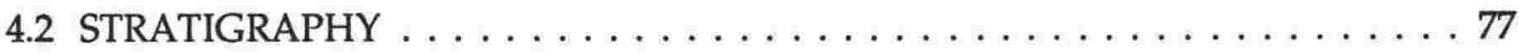

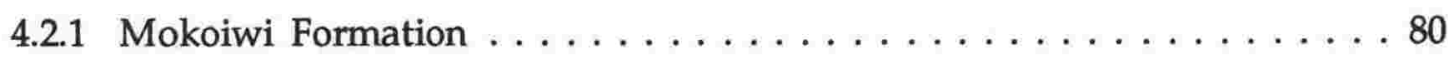

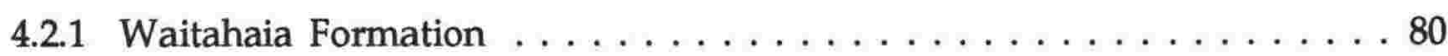

4.2 .3 Karekare Formation . . . . . . . . . . . . . . . . . 80

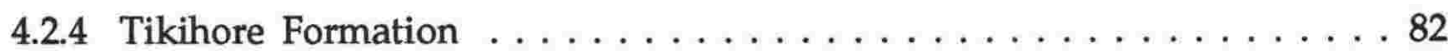

4.2 .5 Haumurian-Teurian Rocks . . . . . . . . . . . . 82

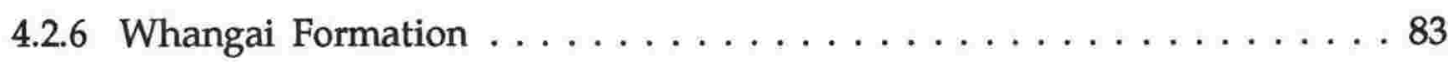

4.2 .7 Smectitic Mélange . . . . . . . . . . . . . . . . . 84

4.2 .8 Limestone/Greensand Lithotype . . . . . . . . . . . . . . 85

4.2 .9 Opossum Creek Sandstone Lithofacies . . . . . . . . . . . . 86

4.2 .10 Sandstone/Breccia Lithotype . . . . . . . . . . . . . . 88

4.2.11 Thungia Formation . . . . . . . . . . . . . . . . 89

4.3 OVERVIEW OF STRUCTURE $\ldots \ldots \ldots \ldots \ldots \ldots \ldots \ldots \ldots \ldots \ldots$

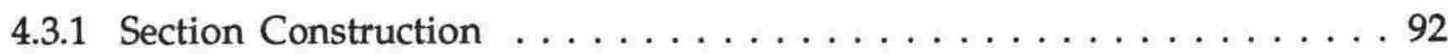

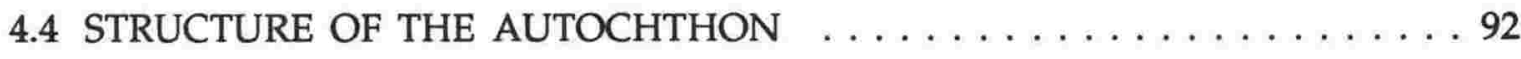

4.4 .1 Waitahaia Formation . . . . . . . . . . . . . . 92

4.4 .2 Karekare and Whangai Formations . . . . . . . . . . . 93

4.4.3 Tikihore Formation and Haumurian-Teurian Rocks . . . . . . . . . 93

4.4.4 Eastern and Western Ihungia Fauits . . . . . . . . . . . . 94

4.5 THE WAITAHAIA AND MANGARAKEKE FAULTS $\ldots \ldots \ldots \ldots$

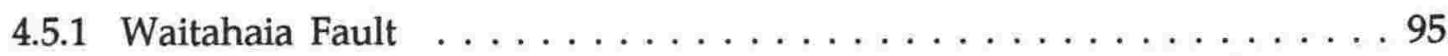

4.5.1.1 Extent and Geometry . . . . . . . . . . . . . . 95

4.5 .1 .2 Kinematics . . . . . . . . . . . . . . . 96

4.5 .2 Mangarakeke Fault . . . . . . . . . . . . . . . . . 99

4.5.2.1 Extent and Geometry . . . . . . . . . . . . . . . . 99

4.5 .2 .2 Kinematics . . . . . . . . . . . . . . . . 100

4.6 STRUCTURE AND KINEMATICS OF THE ALLOCHTHON . . . . . . . . . . 101

4.6 .1 Structure of the Mokoiwi Formation . . . . . . . . . . . . 101

4.6.2 Allochthonous Rocks in the Te Matarau Catchment . . . . . . . . . 102

4.6.3 Allochthonous Rocks in the Mata and Puketoro Valleys . . . . . . . 104

4.6 .4 Steep Extensional Faults . . . . . . . . . . . . . . . . . . 108

4.6 .5 Discussion . . . . . . . . . . . . . . . . . . . . . . . . 109

4.7 THE WHAKOAU AND OPOSSUM CREEK FAULTS $\ldots \ldots \ldots \ldots \ldots$

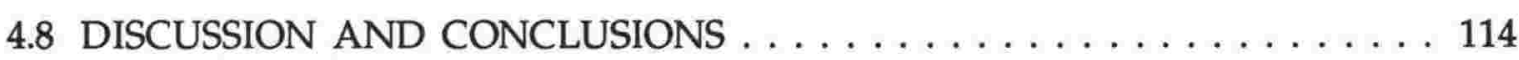

4.8.1 History of Deformation in the Ihungia-Puketoro Area . . . . . . . 114

4.8.2 Thrust Sequence and Synorogenic Sedimentation . . . . . . . . . 115

4.8.3 The Northern End of the East Coast Sole Thrust . . . . . . . . . . 117

4.8 .4 Conclusions . . . . . . . . . . . . . . . . 117 
Chapter 5: The Southern Margin of the Te Puia Inlier $\ldots \ldots \ldots \ldots \ldots \ldots \ldots$

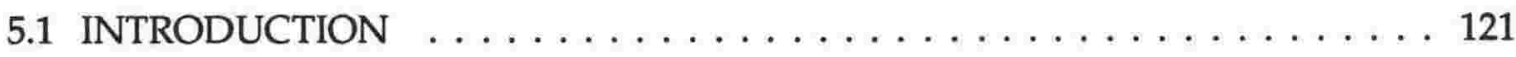

5.1 .1 Location, Physiography, and Exposure . . . . . . . . . . . . . 121

5.1 .2 Previous Work . . . . . . . . . . . . . . . . . 122

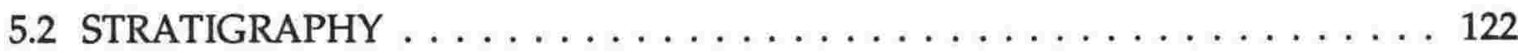

5.2 .1 Mokoiwi Formation . . . . . . . . . . . . . . 123

5.2 .2 Haumurian-Teurian Rocks . . . . . . . . . . . . . . 123

5.2 .3 Whangai Formation . . . . . . . . . . . . . . . . . . . 124

5.2 .4 Smectitic Mélange . . . . . . . . . . . . . . . . . . 124

5.2 .5 Ihungia Formation . . . . . . . . . . . . . . . 125

5.2 .6 Tongaporutuan Mudstone . . . . . . . . . . . . . . . . 127

5.2 .7 Tokomaru Sandstone . . . . . . . . . . . . . . . . . . . . . . . . 129

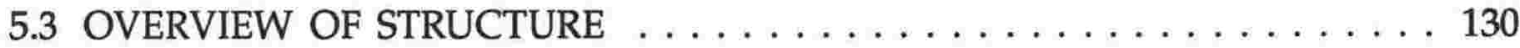

5.4 MOKOIWI FORMATION AND HAUMURIAN-TEURIAN ROCKS $\ldots \ldots 130$

5.5 THE ОтОTO FAULTS $\ldots \ldots \ldots \ldots \ldots \ldots \ldots \ldots \ldots \ldots \ldots \ldots$

5.5 .1 The Sub-Mokoiwi Thrust . . . . . . . . . . . . . . 131

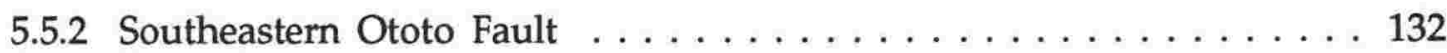

5.5 .3 Northwestern Ototo Fault . . . . . . . . . . . . . . . . . . . 134

5.6 STRUCTURE OF THE WHANGAI FORMATION . . . . . . . . . . . . 135

5.7 FAULTS BOUNDING THE IHUNGIA FORMATION . . . . . . . . . . 135

5.8 LATE MIOCENE AND LATER STRUCTURES . . . . . . . . . . . . . . . 141

5.8.1 Tongaporutuan Mudstone and Tokomaru Sandstone . . . . . . . . . . 141

5.8 .2 The Waikawa Fault . . . . . . . . . . . . . . . . . 142

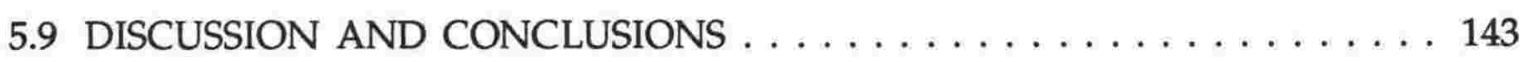

5.9.1 History of Deformation, Southern Margin of Te Puia Inlier . . . . . 143

5.9.2 'Allochthonous' and 'Autochthonous' Rocks . . . . . . . . . . . . . 144

5.9 .3 Conclusions . . . . . . . . . . . . . . . . . 145

Chapter 6: Regional Structure and Kinematics $\ldots \ldots \ldots \ldots \ldots$

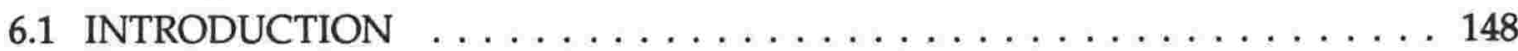

6.2 THE SOUTHERN ZONE $\ldots \ldots \ldots \ldots \ldots \ldots \ldots \ldots \ldots \ldots \ldots \ldots$

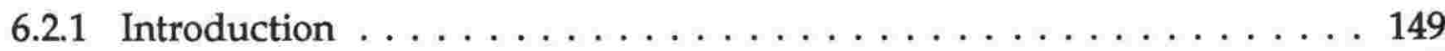

6.2 .2 Map Analysis . . . . . . . . . . . . . . . . . . . . . . . . . . 149

6.2.2.1 Structural Geometry and Thrust Transport Direction . . . . . . . . 149

6.2.2.2 Thrust Sequence and Timing . . . . . . . . . . . . . . 154

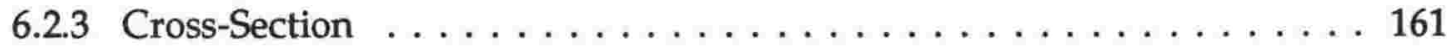

6.2.3.1 Section Orientation, Data Projection, and Basement Geometry . . . . 162

6.2.3.2 Thrust Sheet Geometries . . . . . . . . . . . . . . . . 163

6.2.3.3 Restoration: Amount and Rate of Deformation . . . . . . . . . . 165

6.2 .4 Conclusions . . . . . . . . . . . . . . . . . . . . . . . . 169 


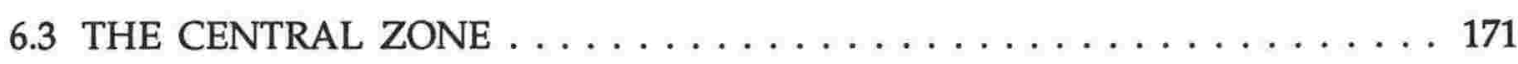

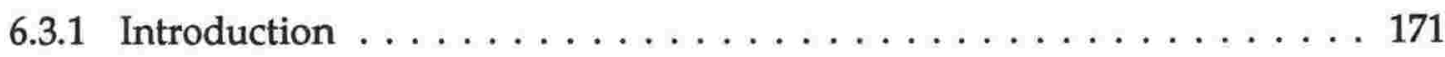

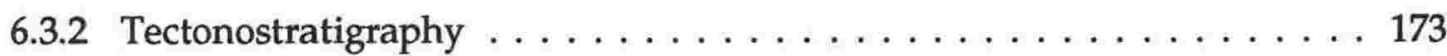

6.3 .3 Geometries of Major Structures . . . . . . . . . . . . . . . . 174

6.3 .4 Profile Construction . . . . . . . . . . . . . . . . . . . 174

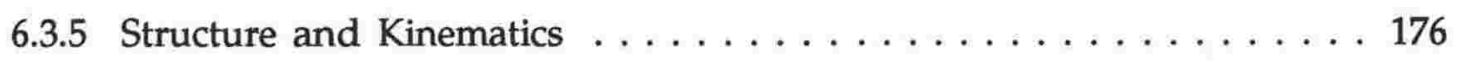

6.3.5.1 Tectonic Units . . . . . . . . . . . . . . . . . . . 176

6.3.5.2 Thrust Sequence and Timing . . . . . . . . . . . . . 179

6.3.5.3 Amount of Thrust Transport . . . . . . . . . . . . . . . 182

6.3 .6 Conclusions . . . . . . . . . . . . . . . . . . . . 184

6.4 THE NORTHERN ZONE . . . . . . . . . . . . . . . . . . . . 185

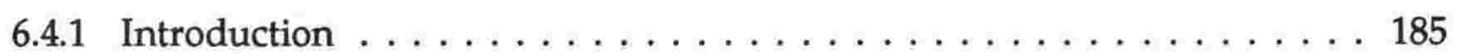

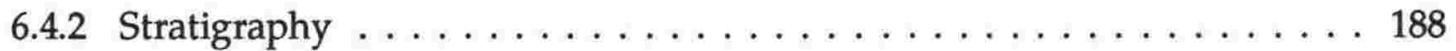

6.4 .3 Structure and Kinematics . . . . . . . . . . . . . . 188

6.4.3.1 Major Structures . . . . . . . . . . . . . . . . . . . 188

6.4.3.2 Thrust Sequence and Timing . . . . . . . . . . . . . . . 194

6.4.3.3 Amount of Thrust Transport . . . . . . . . . . . . . . . . . . 197

6.4 .4 Conclusions . . . . . . . . . . . . . . . . . . 198

Chapter 7: Evolution and Origin of the East Coast Allochthon . . . . . . . 201

7.1 INTRODUCTION . . . . . . . . . . . . . . . . . . . . . . . 201

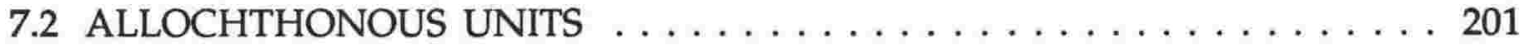

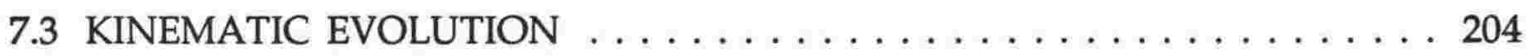

7.4 ORIGIN . . . . . . . . . . . . . . . . . . 207

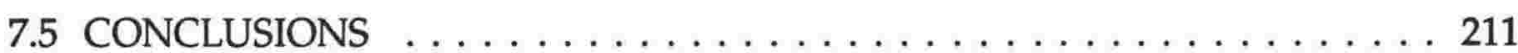

Chapter 8: Regional Tectonics and the Onset of Subduction $\ldots \ldots \ldots 213$

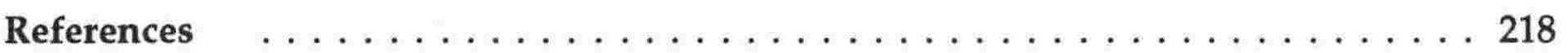

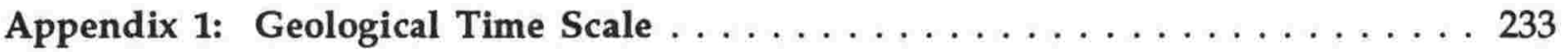

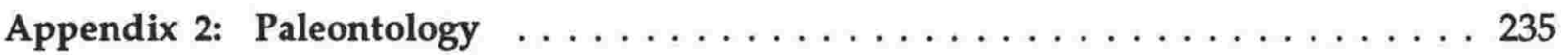

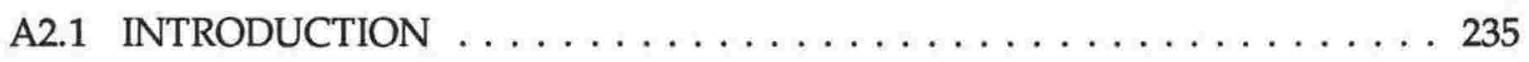

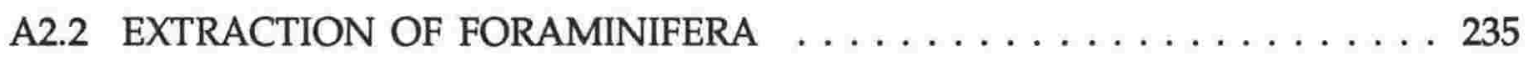

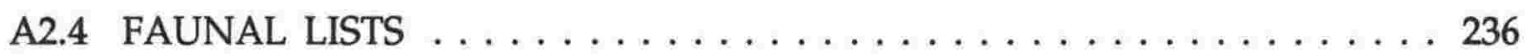

Enclosures $\quad \ldots \ldots \ldots \ldots \ldots \ldots \ldots \ldots \ldots \ldots \ldots \ldots \ldots$ back pocket

Map 1: Geology of the lower Mata River area

Sections A-C, lower Mata River area

Sections D-F, lower Mata River area 
Map 2: Geology of the Ihungia-Puketoro area

Sections G(1 \& 2)-I, Ihungia-Puketoro area

Map 3: Geology of the southern margin of the Te Puia inlier

Sections J-M, southern margin of the Te Puia inlier

Consolidated legend

\section{Figures}

Figure 1.1: Location and tectonic setting $\ldots \ldots \ldots \ldots \ldots \ldots \ldots \ldots \ldots \ldots \ldots \ldots$

Figure 1.2: Sketch geological and location map of Raukumara Peninsula . . . . . . 3

Figure 1.3: Recent geological work in east-central Raukumara Peninsula . . . . . . . 4

Figure 1.4: Areas mapped in this study $\ldots \ldots \ldots \ldots \ldots \ldots \ldots \ldots \ldots \ldots \ldots \ldots \ldots$

Figure 2.1: Locations of Cretaceous-Early Tertiary stratigraphic columns . . . . . 11

Figure 2.2: Cretaceous-Early Tertiary columns, Motu Block . . . . . . . . . 12

Figure 2.3: Cretaceous-Early Tertiary columns, East Coast Allochthon . . . . . . . 15

Figure 3.1: Location and topographic map, lower Mata River area . . . . . . . . . 28

Figure 3.2: Stratigraphic column, lower Mata River area . . . . . . . . . . . . . . . 29

Figure 3.3: Simplified geological map, lower Mata River area . . . . . . . . . 30

Figure 3.4: a: Mokoiwi Formation sandstone/mudstone;

b: Taitai Sandstone, Mt. Aorangi . . . . . . . . . . . . . . . 30

Figure 3.5: Waitahaia Formation $\ldots \ldots \ldots \ldots \ldots \ldots \ldots \ldots \ldots \ldots \ldots \ldots \ldots \ldots \ldots \ldots$

Figure 3.6: Slump folds, Tikihore Formation, lower Mata River section . . . . . . . 34

Figure 3.7: Haumurian-Teurian strata, upper Aorangiwai valley . . . . . . . . 38

Figure 3.8 : Mata River fold profile . . . . . . . . . . . . . . . 40

Figure 3.9: a-f: Equal-area projections, Mata River fold data . . . . . . . . . 41

g-h: Equal-area projections, Mata River fold data (continued) . . . . . . 42

Figure 3.10: Thrust-related folds . . . . . . . . . . . . . . . 43

Figure 3.11: Mata River fold analysis using Jamison (1987) fold model . . . . . . 45

Figure 3.12: Mata River fold sections using Jamison (1987) fold model . . . . . . . 46

Figure 3.13: Combination of three Jamison-mode fault-propagation folds . . . . . . 47

Figure 3.14: Chester and Chester (1990) fault-propagation fold model . . . . . . . 47

Figure 3.15: Chester-and-Chester style model of middle anticline . . . . . . . . 48

Figure 3.16: Pre-middle anticline configuration of southwest anticline . . . . . . 49

Figure 3.17: Section across combined southwest and middle anticlines $\ldots \ldots \ldots 0$ 
Figure 3.18: Section across combined southwest, middle, and northeast anticlines . . 51

Figure 3.19: Folding on backlimb of southwest anticline $\ldots \ldots \ldots \ldots 2$

Figure 3.20: a: Thrust on backlimb of southwest anticline, Mata River;

b: Minor thrust and backthrusts, backlimb of southwest anticline . . . . 52

Figure 3.21: Minor folds in forelimb of southwest anticline $\ldots \ldots \ldots 53$

Figure 3.22: Equal-area projection, minor folds on major fold limbs . . . . . . 55

Figure 3.23: Equal-area projections, minor folds in major fold hinges . . . . . . . 56

Figure 3.24: a: Late normal fault, Mata River;

b: Equal-area projection, late high-angle faults $\ldots \ldots \ldots \ldots 6$

Figure 3.25: Equal-area projections, Haumurian-Teurian, Mata River area . . . . . 58

Figure 3.26: Mangapekapeka fault in Mangapekapeka Stream . . . . . . . . . 6 61

Figure 3.27: Equal-area projection, Mangapekapeka sheet $\ldots \ldots \ldots \ldots$

Figure 3.28: Anticline in Mangapekapeka Stream . . . . . . . . . . . . 63

Figure 3.29: Thungia Fault in Aorangiwai River $\ldots \ldots \ldots \ldots 6$

Figure 3.30: Emplacement kinematics of horse on western Ihungia Fault $\ldots \ldots 68$

Figure 3.31: Development of Ihungia fault system and lower Mata River folds . . . 69

Figure 4.1: Location and topographic map, Ihungia-Puketoro area . . . . . . . 77

Figure 4.2: Slumping in catchment of Mangarakeke stream, Ihungia valley . . . . 78

Figure 4.3: Simplifed geological map, Thungia-Puketoro area . . . . . . . . 80

Figure 4.4: a: Sub-Karekare unconformity, lower Puketoro Stream;

b: Karekare Formation, Puketoro Stream . . . . . . . . . . . . . . . . 81

Figure 4.5: Float boulder, limestone/greensand lithotype, Te Matarau Stream . . . . 87

Figure 4.6: Breccia, sandstone/breccia lithotype, Te Matarau Stream . . . . . . . . .90

Figure 4.7: Equal-area projection, bedding, Karekare and Whangai Formations . . . . 93

Figure 4.8: Extension faults beneath Waitahia Fault, Puketoro valley . . . . . . . 98

Figure 4.9: Equal-area projection, bedding and cleavage, Te Matarau catchment . . 103

Figure 4.10: a: Foliated cataclasite, Kaikomako Stream;

b: Equal-area projection, cataclasite, Kaikomako Stream . . . . . . . . . 105

Figure 4.11: Equal-area projection, sandstone/breccia lithotype . . . . . . . . 107

Figure 4.12: Slickensides on minor fault beneath mélange, Mata valley . . . . . . 107

Figure 4.13: a: Equal-area projection, cataclasite, Makara Stream;

b: Minor normal fault, Te Matarau Stream . . . . . . . . . . . . . . 112

Figure 4.14: Thrust sequence in allochthon, Ihungia-Puketoro area $\ldots \ldots \ldots 116$

Figure 5.1: Location and topographic map, southern margin of Te Puia inlier . . . 122

Figure 5.2: Simplified geological map, southern margin of Te Puia inlier . . . . . . 123

Figure 5.3: Mélange diapir, Mangara Stream . . . . . . . . . . . . . 126

Figure 5.4: Base of Wahingamuku sandstone, Black Hills $\ldots \ldots \ldots \ldots \ldots$

Figure 5.5: Equal-area projection, bedding, Mokoiwi Formation, Ototo valley . . . . 131 
Figure 5.6: a: Smectite-matrix breccia, upper Pauariki Stream;

b: Close-up, smectite-matrix breccia, upper Pauariki Stream . . . . . . . 133

Figure 5.7: Equal-area projections, Whangai, southern Te Puia inlier . . . . . . . 135

Figure 5.8: a: Fabric of Whangai Formation, tributary of lower Ototo Stream;

b: Equal-area projection, Whangai, tributary of lower Ototo Stream . . . 136

Figure 5.9: a: Contraction faults, Whangai, lower Te Matai Stream;

b: Equal-area projection, fractures, lower Te Matai Stream . . . . . . . . 137

Figure 5.10: Normal faults, northwest end of Te Puia inlier . . . . . . . . . . 139

Figure 5.11: Whangai-derived colluvium overlying Ihungia Formation . . . . . . . 140

Figure 6.1: Structural zones of the East Coast Allochthon . . . . . . . . . . . 149

Figure 6.2: Geological map, southern zone (Stoneley, 1968) . . . . . . . . . 151

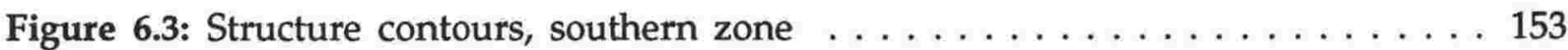

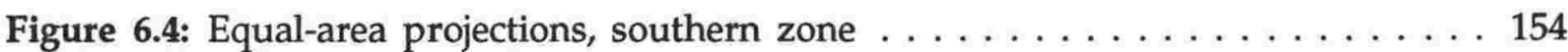

Figure 6.5: Stoneley's (1968) thrust sequence, southern zone . . . . . . . . . 155

Figure 6.6: Partially restorable cross-section, southern zone . . . . . . . . . 162

Figure 6.7: Geological map, central zone . . . . . . . . . . . . . . 172

Figure 6.8: Structure contour maps, central zone . . . . . . . . . . . . . 174

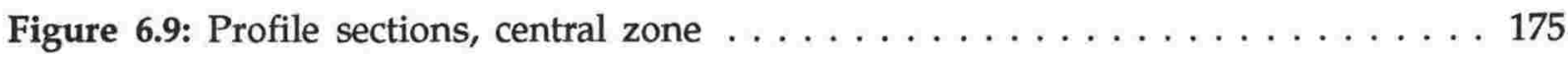

Figure 6.10: Geological map, northern zone . . . . . . . . . . . . . 187

Figure 6.11: Structure section, northern zone . . . . . . . . . . . . . . . 189

Figure 6.12: Structure of Tikihore Formation, Orete-Raukokore area . . . . . . . . . 191

Figure 6.13: Thrust sequence, northern zone . . . . . . . . . . . . . 195

Figure 7.1: Major tectonic elements of the East Coast Allochthon . . . . . . . 203

Figure 7.2: Possible thrust propagation sequences for allochthonous units . . . . 205

Figure 7.3: Obduction mechanism of Matakaoa/Tangihua ophiolites . . . . . . 210

\section{Tables}

Table 2.1: Stratigraphic nomenclature used in this report $\ldots \ldots \ldots \ldots$

Table 3.1: Fault transport statistics, lower Mata River area . . . . . . . . . 71

Table 7.1: Estimated transport distances of allochthonous units . . . . . . . . 206

Table A1.1: Geological time scale . . . . . . . . . . . . . . . . 234 


\section{Chapter 1}

\section{Introduction}

\subsection{PREAMBLE}

This thesis is a study of the structure, tectonic history, and mode of origin of a hitherto little-known thrust belt on Raukumara Peninsula, a segment of the subductionrelated Late Cenozoic orogenic belt in northern and eastern New Zealand, made using a combination of detailed mapping by the author and analysis of published geological information. In this chapter, the thrust belt is put into its regional context and the background and aims of the study are given. Firstly, the setting and regional geology of Raukumara Peninsula are introduced and an account of previous work on the thrust belt is presented. Having thus established the significance and the current state of knowledge of the thrust belt, the aims of this study, its methods, and the organisation of this thesis are explained.

\subsection{TECTONIC SETTING}

Raukumara Peninsula lies at the northeastern end of the East Coast Deformed Belt (Spörli, 1980), a province of deformed Late Mesozoic-Late Cenozoic rocks which lies along the eastern edges of the North Island and northern South Island of New Zealand (Fig. 1.1a). Late Cenozoic deformation in this province and in Northland (Fig. 1.1a) is associated with subduction of the Pacific Plate (e.g., Ballance, 1976; Walcott, 1978, 1987; Spörli, 1980, 1987). The start of andesitic volcanism in Northland, an abrupt change in sedimentation rate and character, and the onset of deformation show that the present phase of subduction started around the beginning of the Miocene (e.g., van der Lingen, 1982; Spörli, 1987).

Plate reconstructions based on seafloor spreading studies show that prior to the onset of subduction, the Chatham Rise (Fig. 1.1a) and the Northland peninsula were approximately collinear and suggest that the East Coast Deformed Belt and the structures within it have rotated from an original northwest trend (relative to a fixed Northland) to their present northeast trend (Walcott, 1984, 1987; Fig. 1.1b). Paleomagnetic declination measurements in Late Cenozoic rocks are consistent with a large clockwise rotation of the the northern Hawke's Bay-Wairarapa sector (Fig. 1.1a), 

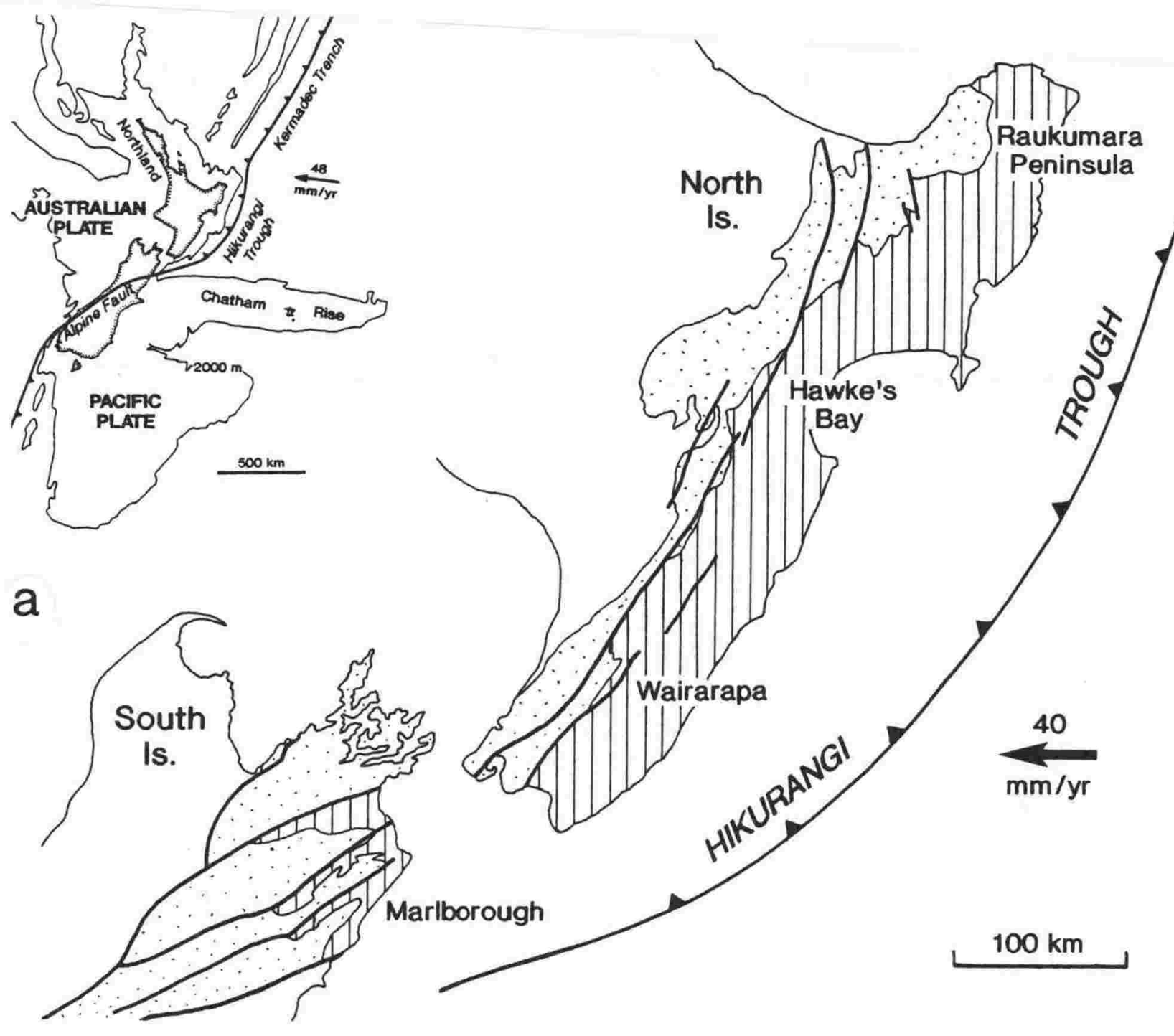

b
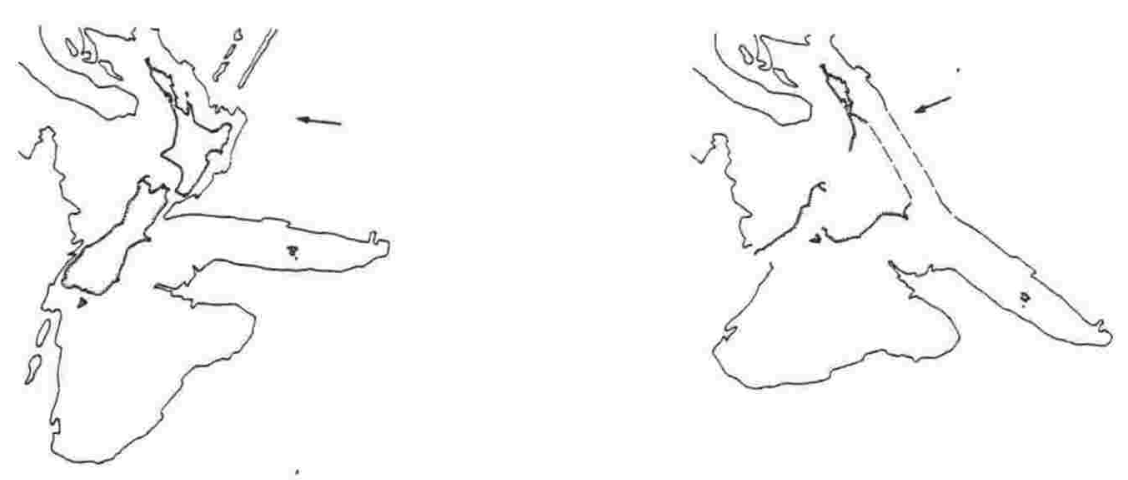

Figure 1.1: a: Location and tectonic setting of regions mentioned in text; ruled areas = Early Cretaceous and younger rocks of East Coast Deformed Belt, stipple = Early Cretaceous and older greywacke and schist 'basement' of Axial Ranges, heavy lines = Late Cenozoic dextral strike-slip and dextral reverse faults. Relative plate motions (arrows) calculated from rotation parameters of De Mets et al. (1990). b: Plate configurations and relative motions at present and at $25 \mathrm{Ma}$ (after Walcott, 1987). Dashed segments on reconstruction show probable postion and orientation of East Coast Deformed Belt. 
but show that Raukumara Peninsula has not rotated (relative to the Australian Plate) since the Early Miocene (Mumme et al., 1989; Walcott, 1989). An arcuate fault zone crossing southwestern Raukumara Peninsula appears to be the boundary between the rotated and unrotated domains (Lamb, 1988). As will be shown in this thesis, Early Miocene and older structures in Raukumara Peninsula trend northwest, parallel to the Early Miocene trend of Northland and southern East Coast Deformed Belt structures and to the continental margin, and roughly perpendicular to the Early Miocene plate convergence direction (Fig. 1.1b).

Deformation associated with the earliest stages of subduction produced structures in Northland and the East Coast Deformed Belt that are in general dissimilar to structures typical of subduction complexes elsewhere (however, see Pettinga, 1982, for an exception) and to structures formed in the Hikurangi subduction complex in the last few million years (e.g., Davey et al., 1986). This was noted in a summary of present knowledge of the Early Miocene structures by Rait et al. (1991; a copy of this paper is included herein as Chapter 8). While present knowledge of Northland (Hayward et al., 1989), southern Hawkes Bay (Pettinga, 1982), Wairarapa (Chanier and Ferrière, 1989) and Marlborough (Waters, 1988; Lamb and Bibby, 1989) is relatively detailed, knowledge of Raukumara Peninsula remains poor. It has recently been appreciated that the Early Miocene tectonics of Raukumara Peninsula were dominated by a regionalscale thrust belt, named the East Coast Allochthon by Moore (1985, 1988a). The configuration, evolution, and origin of this thrust belt are the subjects of this thesis.

\subsection{PREVIOUS WORK}

\subsubsection{Early Miocene Deformation and the "East Coast Allochthon"}

The pre-Quaternary lithostratigraphy of Raukumara Peninsula (Fig. 1.2) can be divided into four major lithologic associations: a complexly deformed, indurated, thick succession of flysch, sandstone, siltstone, and conglomerate, largely or wholly of Early Cretaceous age (Wilson et al., 1988), in the west; a central, northeast-trending strip of Late Cretaceous-Early Tertiary rocks in a fining-upwards sequence; a thick succession of Miocene-Pliocene terrigenous sediments in the east; and two bodies of basaltic submarine volcanic rocks, with associated pelagic sediments and shallow intrusives, in the extreme northeast (Kingma, 1965; Strong, 1976a, 1980; Moore et al., 1989). Prior to the 1960's, geologists studying Raukumara Peninsula recognised several generations of structures affecting these rocks. Deformational episodes were considered to have involved repeated movements on subvertical faults having various strikes, as well as tight to isoclinal upright folding on both northeast and northwest trends. These ideas 


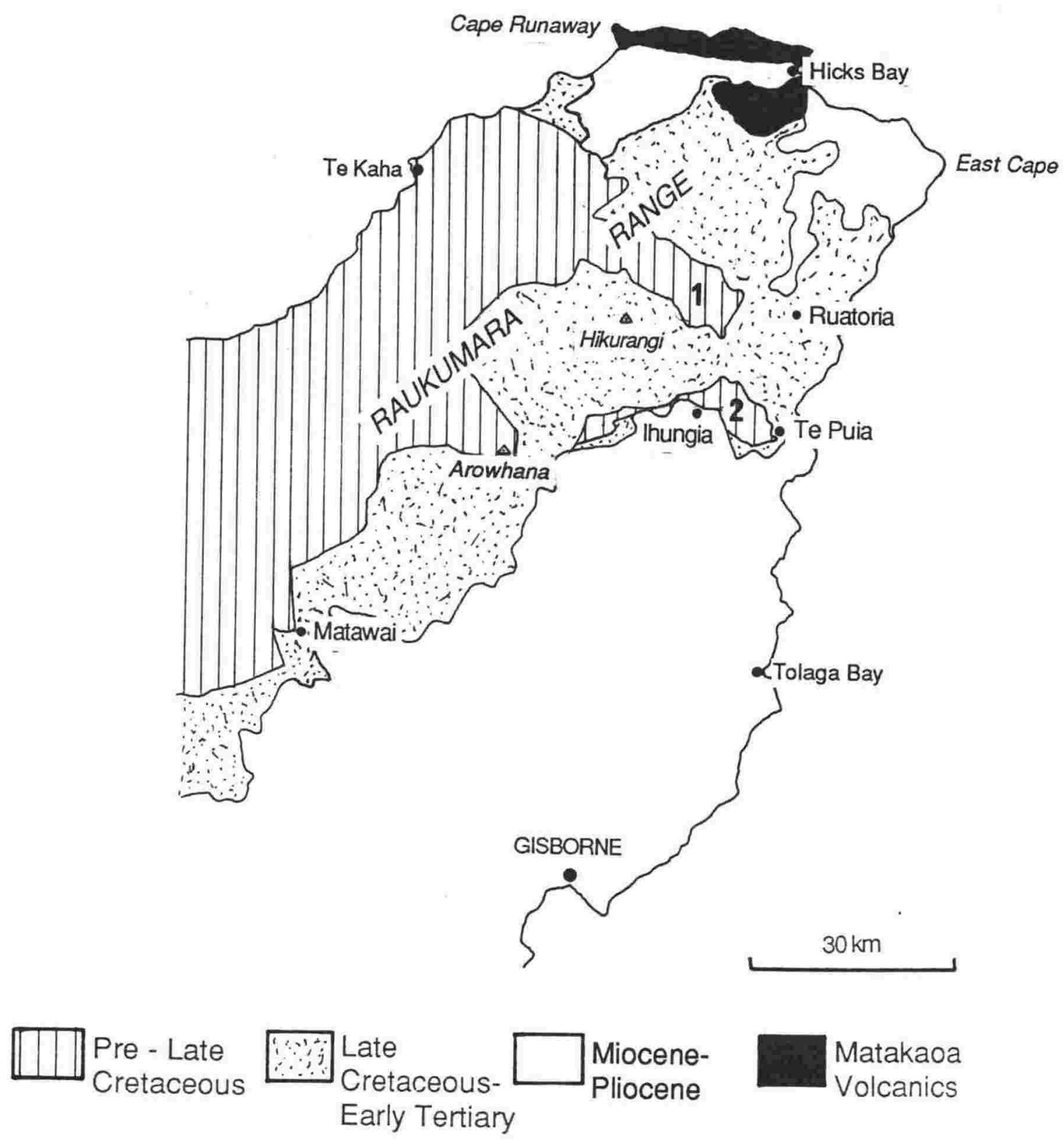

Figure 1.2: Sketch geological and location map of Raukumara Peninsula, showing features and localities referred to in text. $1=$ Mokoiwi inlier, $2=\mathrm{Te}$ Puia inlier. Geology simplified after Moore et al. (1989). 
reached their fullest development in the works of Pick (1962) and Kingma (1965), who interpreted northwest-trending inliers of complexly deformed Lower Cretaceous rocks between Te Puia and Hikurangi (Fig. 1.2) as anticlinal "piercement structures" which had been pushed up through the surrounding younger rocks by "diapiric folding" and reverse movements on steeply outward-dipping faults at their margins.

In the late 1950's and early 1960's, mapping northeast of Matawai (Fig. 1.2) revealed a system of northwest-trending folds and northeast-dipping imbricate thrusts. Unconformities within and above this system were interpreted as showing that it was active between the latest Oligocene and the late Early Miocene ${ }^{1}$ (Stoneley, 1968). The folds and thrusts splay off a sole thrust or décollement, now exposed in the northwest of the area due to post-Miocene southeastward tilting associated with uplift of the Raukumara Range (Fig. 1.2). The gently southeast-dipping sole thrust is subparallel to the Late Cretaceous-Paleocene strata beneath it in the north, but cuts up-section in the south of the area. Stoneley (1968) considered that this thrust system had formed by southwest-directed gravity sliding off an "elevated region" to the northeast, where Pick (1962) and Kingma (1965) had described their anticlinal "piercement structures".

Shortly after the publication of Stoneley's (1968) work, Laing (1972a) reinterpreted the Lower Cretaceous rocks of the Te Puia and Mokoiwi inliers as large blocks within an Eocene "chaos breccia" (olistostrome). Laing considered that the structurally lowest parts of the inliers consisted of brecciated Lower Cretaceous blocks in a matrix of Eocene smectite mudstone and that the higher parts were large coherent blocks of Cretaceous which "floated" on the lower parts. Small outliers of Oligocene limestone near the centre of the Te Puia inlier were mapped as conformably overlying this Eocene olistostrome, which was in turn thought to conformably overlie coherent Eocene strata mapped within a window through the inlier. This interpretation was supported by Alliance Petroleum's Te Puia-1 well, which was spudded into Cretaceous rocks but penetrated Eocene strata at depth (Laing, 1972b). Where the margins of the inliers abutted pre-Eocene rocks, the contacts were mapped as unconformities. The only exception was part of the southwestern margin of the Mokoiwi inlier, which was mapped as a fault (Laing, 1972a, Fig. 3). The olistostrome was thought to have been derived from the west or northwest, from the poorly known rocks of the Raukumara Range.

${ }^{1}$ The angular unconformity which Stoneley (1968) considered to mark the start of thrusting lies within the N.Z. Waitakian Stage, formerly thought to be latest Oligocene but now considered to be earliest Miocene (Edwards et al., 1988). The time scale used in this report is that of Edwards et al. (1988). A copy appears as Appendix 1. 


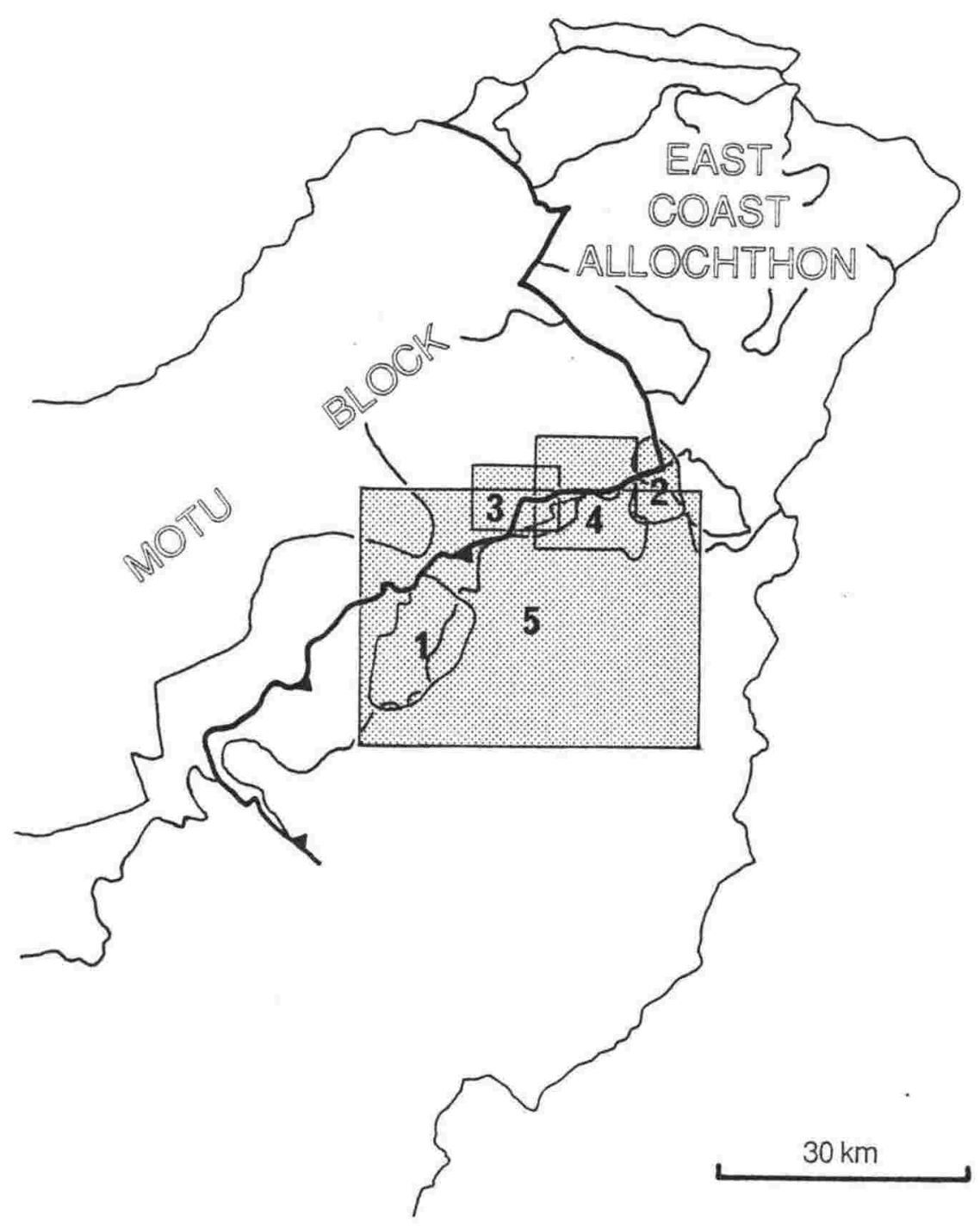

Figure 1.3: Recent geological work in Raukumara Peninsula. 1 = Black (1980), $2=$ Kenny (1980, 1984a), 3 = Phillips (1985), 4 = Kenny (1986), 5 = Mazengarb et al. (1991). Heavy line is boundary between East Coast Allochthon and Motu Block (Moore, 1985, 1988a). Outline geology from Fig. 1.2 is also shown. 
Laing's (1972a) map differed considerably from those produced earlier. It reflected his philosophy that "In general, all the [earlier] geological maps ... suffered from the disadvantage that boundaries were sketched in assuming flat topography instead of attempting to trace them across the considerable relief using stereoscopic airphotograph coverage. Any anomaly was solved by putting in a fault. This created an abundance of faults in places where it was more likely that there was a regional unconformity or where there were large lumps of rocks isolated within the Mokoiwi Chaos Breccia." (Laing, 1972a, p. 46). Laing's geological map (his Fig. 3), which covers approximately $1500 \mathrm{~km}^{2}$, shows only three faults.

Subsequently, Speden (1976), working on the Mokoiwi inlier, challenged many of Laing's interpretations. Speden found that all the contacts around the inlier, rather than being unconformities, were inward-dipping faults. He thus interpreted the inlier as a synclinal klippe. The source for this klippe was thought to have been to the west or northwest, in the Raukumara Range. Citing evidence from elsewhere in the region (Kingma, 1965; Stoneley, 1968), Speden (1976) inferred that emplacement of the klippe took place during a period of "great tectonic activity" in the latest Oligocene and Early Miocene. Later regional reconnaisance mapping (Moore and Speden, 1980) and detailed work in the Ihungia area (Kenny, 1980, 1984a) resulted in the discovery of more thrust sheets and the recognition of a widespread Early Miocene unconformity, showing that the "elevated region" of Stoneley (1968) was itself part of a mid-Tertiary thrust system.

During the 1980 's, mapping in the centre of the peninsula by forestry personnel (Black, 1980; Phillips, 1985), Auckland University students (Kenny, 1986), and N.Z. Geological Survey staff (Mazengarb et al., 1991) (Fig. 1.3) showed that the décollement mapped by Stoneley (1968) could be traced northeastward as far as the Te Puia inlier. It was recognised that below the décollement, Late Cretaceous-Early Tertiary rocks are only gently deformed whereas correlative rocks above it are deformed by folds and thrust faults, and that north of the Mokoiwi inlier, all the exposed Cretaceous-Early Tertiary rocks are deformed. This recognition led to the concept of the "East Coast Allochthon" (Moore, 1985, 1988a), within which all rocks were thought to have been displaced tens of kilometres relative to the underlying "Motu Block" (Fig. 1.3). A new 1:250,000 compilation of recent published and unpublished mapping (Moore et al., 1989) incorporates this concept.

While these recent studies have confirmed that thrust faulting was an important process throughout the region in the Early Miocene, they have raised kinematic questions. For example, Speden (1976) considered that the emplacement of the Mokoiwi klippe and the emplacement of thrust sheets in the area studied by Stoneley (1968) were due to the same tectonic event, but the inferred emplacement directions in the 
two areas differ by approximately $90^{\circ}$ : Stoneley (1968) considered that the transport direction east of Matawai was southwestward, whereas Speden (1976) considered that the Mokoiwi klippe was emplaced from the north or northwest. Kenny (1980, 1984a, 1986) mapped around the northeastern end of the décollement, and inferred a southward to southeastward transport direction from the orientations of paleostress axes determined from the attitudes of minor faults. Phillips (1985), working southwest of and overlapping with Kenny (1986), did not explicitly state a transport direction, but arrows drawn on the faults on his cross-section imply that it was southeastward. However, Black (1980), who mapped an area $10 \mathrm{~km}$ southwest of Phillips (1985) which overlapped with the northeastern part of Stoneley's map, inferred southwestward thrust transport. Thus, synchronous motion on the sole thrust is purported to have been southeastward in the north, and southwestward in the south.

Questions as to the chronology of the deformation are also raised by the recent work. Although all authors agree that the deformation started in the latest Oligocene to earliest Miocene, those who have mapped in the east-central part of the peninsula describe a second "allochthon", emplaced over the first during the Late Miocene. Phillips (1985) considered that the lower boundary of this upper "allochthon" is a gently southeast-dipping fault directly beneath the Miocene succession, and that all the Cretaceous-Early Tertiary rocks beneath that fault are part of the lower "allochthon" and were deformed during its emplacement in the Early Miocene. Kenny (1986), however, considered that much of the material beneath the sub-Miocene fault is part of the upper "allochthon". In the Ihungia area, Kenny (1980, 1984a) also mapped a third "allochthon", comprising Early Tertiary rocks interpreted to have been thrust over the Early Miocene rocks of the second. It is thus unclear from the above work how many phases of deformation are represented in the allochthonous rocks of east-central Raukumara Peninsula, and when the deformation of much of the material within the East Coast Allochthon occurred.

\subsubsection{Other Previous Work}

A complete list of all previous reports on the geology of Raukumara Peninsula will not be given here. Compilations of published and unpublished work are to be found in two N.Z. Geological Survey Reports: Forsyth et al. (1979) give a bibliography of information available prior to 1979, and Heron et al. (1986) give a list of geological maps in student theses and open-file petroleum reports available prior to 1982. Material which bears on interpretations of the mid-Cretaceous-Late Cenozoic geological history of Raukumara Peninsula and which has become available since the production of the above reports (in addition to that previously cited) includes the following: Pirajno (1979, 1980), Black (1981), Moore (1981, 1989), Francis (1983), Francis and Mazengarb (1983), 
Mazengarb (1983, 1984, 1989, 1990), Kenny (1984b), Moore and Challis (1985), Gibson (1987a, b), Joass (1987), Lamb (1988), Mazengarb and Beggs (1990), and Mazengarb et al. (1990).

\subsection{AIMS AND METHODS}

The aim of this thesis is to provide a synthesis of the configuration, evolution, and origin of the Early Miocene thrust belt of Raukumara Peninsula, in the light of the recent advances in knowledge of the region outlined in the foregoing. Particular problems focused on are the structural geometry of the thrust belt, thrust transport directions, the timing and sequence of thrust movements, amounts of shortening, thickening, and thrust sheet transport, and the tectonic regime responsible for the emplacement of the thrust sheets. The methods used were original geological mapping of key areas and the analysis and interpretation of the results of previous studies, in particular the use of published maps to generate new cross-sections through various parts of the thrust belt. The areas chosen for mapping were areas where previous work had indicated important structural relations for understanding the pattern of Early Miocene deformation were present and/or where results of previous studies seemed inconsistent with regional-scale interpretations, or where there were gaps in the earlier knowledge. It was envisaged that the results of this mapping would prove useful in the interpretation of previous work on other parts of the region.

Three adjacent areas, shown in Fig. 1.4 and discussed briefly below, were mapped. These are:

1) The lower Mata River area (area 1, Fig. 1.4). The maps of Moore (1985, 1988a) show the sole thrust of the East Coast Allochthon as continuous from the thrust front northeastward as far as a northwest-striking fault at the southeastern boundary of the Mokoiwi inlier. North of that fault, all Cretaceous-Early Tertiary rocks are considered to be within the allochthon. This implies that the sole thrust has stepped down to a lower structural level to the north. Adjacent to the northwest-striking fault in area 1, Late Cretaceous rocks are folded into a complex anticlinorium which is bounded to the north and west by the Mokoiwi inlier (Kingma, 1965). The area was mapped to determine whether these structures relate to a step in the sole thrust and to the transmission of deformation to higher structural levels.

2) The Ihungia-Puketoro area (area 2, Fig. 1.4). This area lies at the northeastern end of the sole thrust shown by Moore $(1985,1988 \mathrm{a})$. It has been mapped recently by 


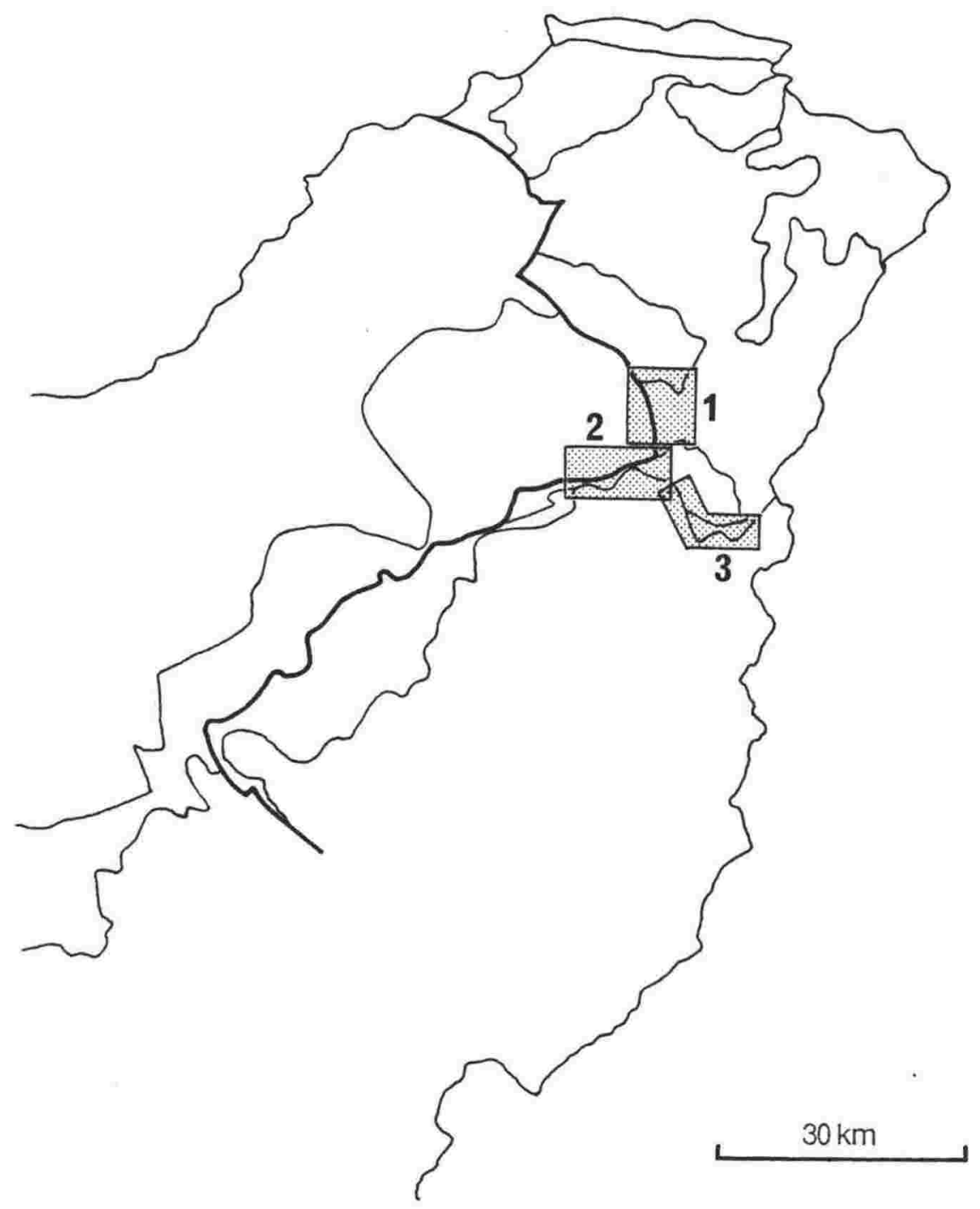

Figure 1.4: Areas mapped in this study. 1 = lower Mata River, 2 = Ihungia RiverPuketoro Stream, $3=$ southern margin of $\mathrm{Te}$ Puia inlier (see text). East Coast Allochthon/Motu Block boundary and outline geology are also shown. 
Kenny (1980, 1984a, 1986), and by Mazengarb et al. (1991), but was considered worth re-examining because: (a) there were apparent inconsistencies between the transport directions on the sole thrust there and at the thrust front (see section 1.3.1); (b) it is immediately southwest of where the sole thrust disappears, so the reason for that disappearance could be investigated; (c) a wide variety of Cretaceous-Early Tertiary rocks are moderately well exposed there; and (d) because the second "allochthon" (see section 1.3.1) has been mapped there.

3) The southern margin of the Te Puia inlier (area 3, Fig. 1.4). In this area, Cretaceous, Early Tertiary, Early Miocene, and Late Miocene rocks occur in close proximity (Kingma, 1965). The northwestern end of this area is where Kenny (1980, 1984a) described three "allochthons". The southeastern end is poorly known. The area was mapped so as to determine the stratigraphic and structural relationships between adjacent strata of widely different ages.

Field sheets used as base maps for these areas were Lands and Survey Department (now Department of Survey and Land Information) 1:25,000 scale contours + detail paper prints enlarged to $1: 9,100$ scale. Stereoscopic examination of aerial photographs was used as a mapping aid in many areas. Details of map sheet numbers, aerial photograph run numbers, etc. are given in the appropriate chapters.

\subsubsection{Equal-Area Projections}

Many of the orientation data obtained in this study are presented on equal-area projections. The data were plotted, analysed, and contoured using the Apple Macintosh program STEREONET (written by R.W. Allmendinger). The contouring method used was that of Kamb (1959), whereby point concentrations in a variable-area counting circle are contoured according to the number of standard deviations by which they vary from a uniform distribution. The user has the choice of either a $2 \sigma$ or $4 \sigma$ contour interval, the interval adopted being shown below and to the right of the final plot. Each contoured plot in this report is shown together with a scatter plot of the raw data.

\section{$\underline{1.5}$ ORGANISATION}

Following this chapter, a review is given of the present state of knowledge of Raukumara Peninsula's regional stratigraphy. This is intended to provide the stratigraphic framework necessary for subsequent interpretation of structural relations, as well as a consistent nomenclature scheme. 
Chapters 3, 4 and 5 are each concerned with the structure of one of the three mapped areas. Each begins with a short introduction in which logistic matters and previous work are discussed, and continues with a section defining and describing the lithologic units recognised in the area and with sections detailing the structure. A discussion section at the end of each chapter puts the findings into the context of the question(s) the area was mapped to address (see sections 1.3.1, 1.4). Maps and crosssections of each area are enclosed in a pocket at the back of this volume. Fossils collected during mapping are listed in Appendix 2.

The findings of Chapters 3, 4 and 5 are made use of in parts of Chapter 6, where previous work over the entire region is analysed and interpreted. Based on gross differences in structural style, the Early Miocene thrust belt is divided into three zones (southern, central and northern) which are each considered separately.

Chapter 7 is a synthesis of all the foregoing information. It consists of a summary description of the regional-scale structure of the thrust belt, a synthesis of the evolution of the belt including estimated amounts of thrust transport, and a discussion of the tectonics responsible for the emplacement of the thrust sheets based on a comparison with the equivalent structure in Northland.

The final chapter, 8, is a copy of an article by G. Rait, F. Chanier and D.W. Waters in which structures along the entire Early Miocene orogenic belt are summarised and discussed in the context of the onset of subduction beneath the New Zealand continental margin. 


\section{Chapter 2}

\section{Regional Stratigraphy}

\subsection{INTRODUCTION}

This chapter is a review of the distributions, lithologies, and thicknesses of the preQuaternary formations of central and eastern Raukumara Peninsula, as well as an introduction to the stratigraphic nomenclature used throughout this report. The information presented here is used in discussions of the style and amount of deformation in the region in subsequent chapters.

\subsubsection{Nomenclature}

The pre-Quaternary stratigraphy of Raukumara Peninsula, like that in the rest of the East Coast Deformed Belt, can be separated into five major divisions (Moore et al., 1986; Moore et al., 1989). These are:

1) Indurated, polydeformed greywacke sandstone and flysch, largely or wholly of Early Cretaceous (Neocomian-Aptian) age.

2) A sequence comprising flysch, sandstone, mudstone, and conglomerate, of Clarence Series (locally Korangan stage) to Mata Series (Aptian-Campanian) age, which rests in part unconformably and in part conformably on the underlying greywacke and flysch.

3) A mostly fine-grained sequence of Mata-Dannevirke Series (MaastrichtianPaleocene) age which becomes more calcareous upwards and rests conformably or unconformably on division two rocks.

4) A sequence dominated by calcareous smectite clay in the lower parts and fine-grained limestone and marl in the upper parts, with glauconitic sandstone locally, of Dannevirke (post-Teurian) to Landon Series (Eocene-Oligocene) strata which rest conformably or disconformably on division three rocks. 
Table 2.1: Stratigraphic nomenclature used in this report. Cretaceous-Oligocene nomenclature from Moore et al. (1986), Moore (1988a), Moore et al. (1989), and Mazengarb and Beggs (1990). Miocene-Pliocene nomenclature modified after Moore et al. (1989).

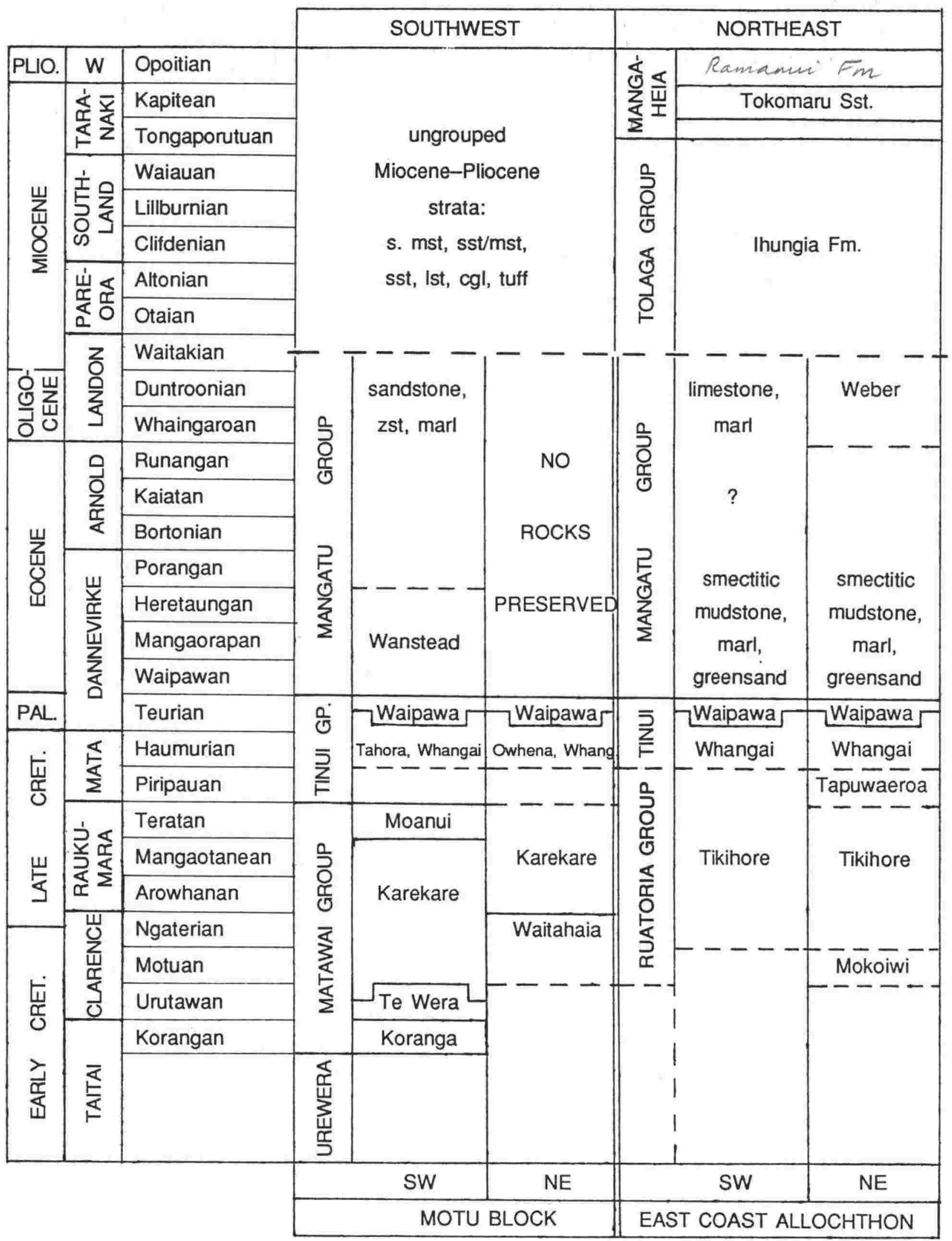


5) A thick, variable succession of sandy mudstone, alternating sandstone and mudstone, sandstone, bioclastic limestone, conglomerate, and tuff of Early Miocene (Waitakian stage) to Pliocene age, resting unconformably on any older rocks or conformably on division four rocks. Rocks of this division reflect a dramatic change in the depositional regime from the slow, carbonate-dominated sedimentation which produced the rocks of division four.

These natural divisions are reflected in the stratigraphic nomenclature adopted herein (Table 2.1). Urewera Group corresponds to division one in the list above, Matawai and Ruatoria Groups to division two, Tinui Group to division three, Mangatu Group to division four, and Tolaga Group, Mangaheia Group, and ungrouped MiocenePliocene strata to division five. Differences in nomenclature between the Motu Block and the East Coast Allochthon, and between southwestern and northeastern areas, reflect differences in stratigraphy which are described later in this chapter.

\subsubsection{Comparison With Earlier Nomenclature}

The synonymy of the nomenclature of the Cretaceous-Early Tertiary part of Table 2.1 is given by Speden (1976), Moore et al. (1986), and Mazengarb et al. (1991), and will not be repeated here. In the Late Tertiary part, the Tolaga Group (Moore et al., 1989) contains the Ihungia (Early Miocene) and Tutamoe (Middle Miocene) "Series" of Ongley and Macpherson (1928) and others, the Whakai Formation (= Ihungia) of Chapman-Smith and Grant-Mackie (1971), the Ihungia and Tutamoe Formations of Laing (1972a), and the Te Arai Formation (= Ihungia + Tutamoe) of Black (1980). The usage of the name "Ihungia Formation" in this report is in the sense of Kenny (1980, 1984a, 1986), who applied it to Early and Middle Miocene strata in the Ihungia-Puketoro area; it is thus equivalent to Ongley and Macpherson's Ihungia and Tutamoe "Series". The Mangaheia Group (Moore et al., 1989) is equivalent to the Tokomaru "Series" of Ongley and Macpherson (1928), and contains the Te Kahika Formation of Chapman-Smith and Grant-Mackie (1971), and the Tokomaru Formation of Black (1980). "Tokomaru Sandstone" is used herein in the sense of Moore et al. (1989), for a ridge-forming Kapitean sandstone in the Te Puia-Tolaga Bay area (Fig. 1.2).

\subsubsection{Additional Names}

In parts of the three mapped areas and at some other places in the region, the presence of characteristic, mappable local units warrants additional subdivision of the Groups or Formations listed in Table 2.1. Also, some rocks present in certain areas do not fit comfortably into any of the listed units. In those cases, the informal lithofacies names of Kenny (1980, 1984a, 1986) and Phillips (1985) are used where appropriate, or 


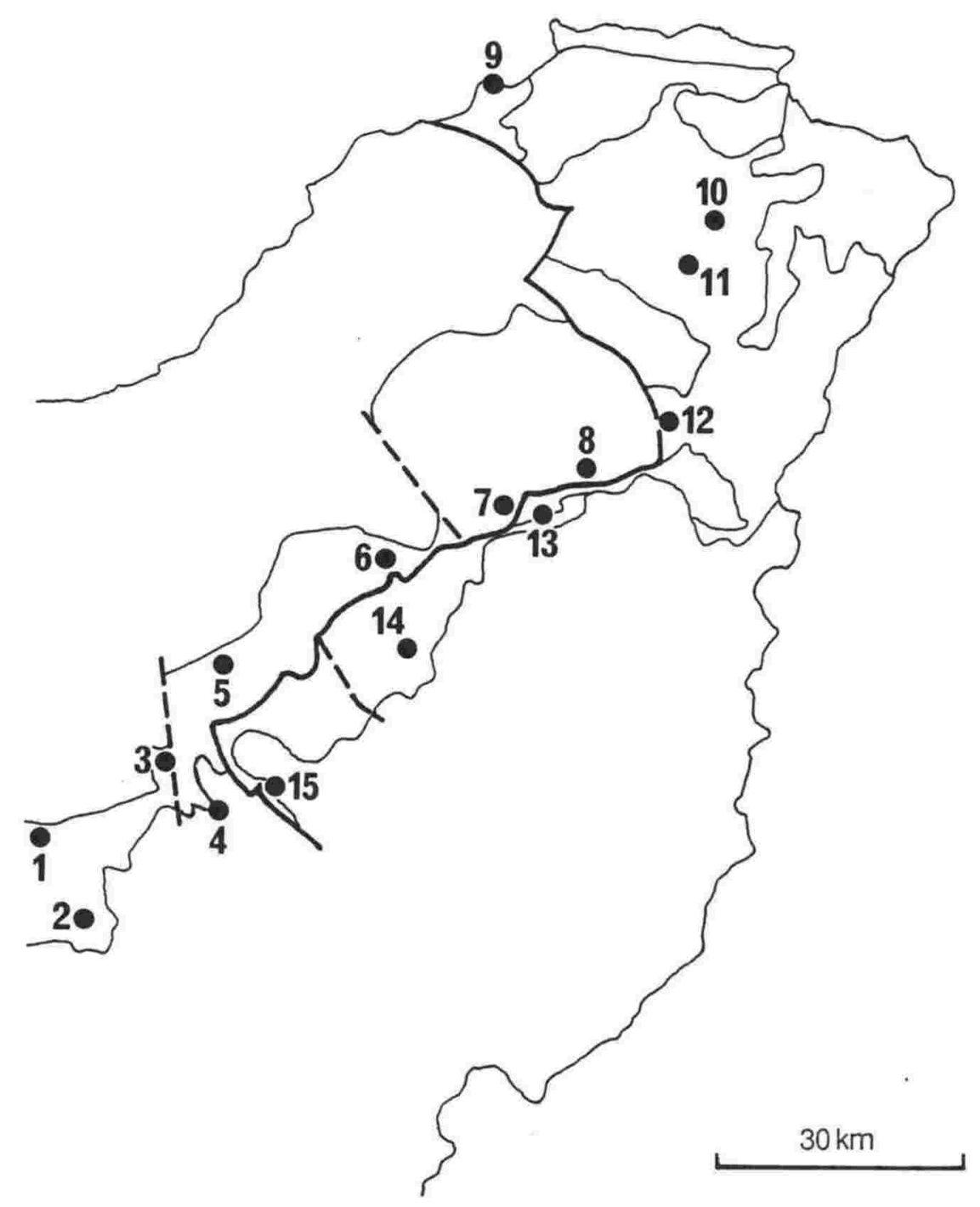

Figure 2.1: Locations of Cretaceous-Early Tertiary stratigraphic columns. Outline geology and Motu Block/East Coast Allochthon boundary are also shown. $1=$ Koranga, $2=$ Tahora, $3=$ Matawai, $4=$ Waikohu, $5=$ Motu Falls, $6=$ Mangaotane, $7=$ Waitahaia, 8 = Puketoro, 9 = Orete Point, 10 = Makorokoro, 11 = Mangaoporo, 12 = lower Mata River-Ihungia River, 13 = Waitahaia, $14=$ Mangatu Forest, $15=$ Mangatawa. Dashed lines divide the Motu Block into southwestern, central, and northeastern sub-provinces, and the East Coast Allochthon into southwestern and northeastern sub-provinces. 
additional lithotype or age units are adopted. The Early Miocene lithofacies units in the East Coast Allochthon which Mazengarb et al. (1991) included in the Mangatu Group are left ungrouped in this report because their lithologies and stratigraphic relations (see sections 4.2.9, 4.2.10, 6.3.2) are markedly different from those rocks traditionally called Mangatu (e.g. by Moore et al., 1986, 1989).

It is emphasised here that it is not the purpose of this report to introduce new stratigraphic names. The additional units defined herein were erected for convenience in local mapping or description only.

\subsection{EARLY CRETACEOUS-OLIGOCENE STRATIGRAPHIC DIVISIONS}

The locations of well known stratigraphic sections through Cretaceous and Early Tertiary rocks are shown in Fig. 2.1. First-order stratigraphic differences exist between Moore's "Motu Block" and "East Coast Allochthon" (Speden, 1978; Moore, 1988a, b), and these two structural provinces are considered separately below. Other variations occur within each province. Note that the intra-province divisions do not coincide exactly with the northeast/southwest divisions in Table 2.1 .

\subsubsection{Motu Block}

Stratigraphic columns at different places in the Motu Block are presented in Fig. 2.2. A feature common to the stratigraphy at all places in this province is an unconformity beneath the basal sandstone of the Whangai Formation which cuts different levels of the Matawai Group strata. The Whangai Formation is of similar thickness and character throughout the province, and is conformably overlain at most places by black shale of the Waipawa Formation. However, other parts of the succession are more variable. Based on this variability, the Motu Block has been divided into southwestern, central, and northeastern sub-provinces (see Fig. 2.1).

\subsubsection{Southwest}

The stratigraphy of the southwestern sub-province is represented by the Koranga, Tahora, and Matawai columns (1, 2, and 3 in Fig. 2.2). The Urewera Group in this subprovince consists of deformed, indurated, alternating sandstone and mudstone. It is thought to be mostly of pre-Clarence age (Speden, 1975; Moore, 1978), although in the western Koranga Valley and in the Waioeka Gorge, $25 \mathrm{~km}$ north-northwest of Koranga, deformed rocks included in the Urewera Group have Clarence ages (Moore, 1978; Speden, 1978). 


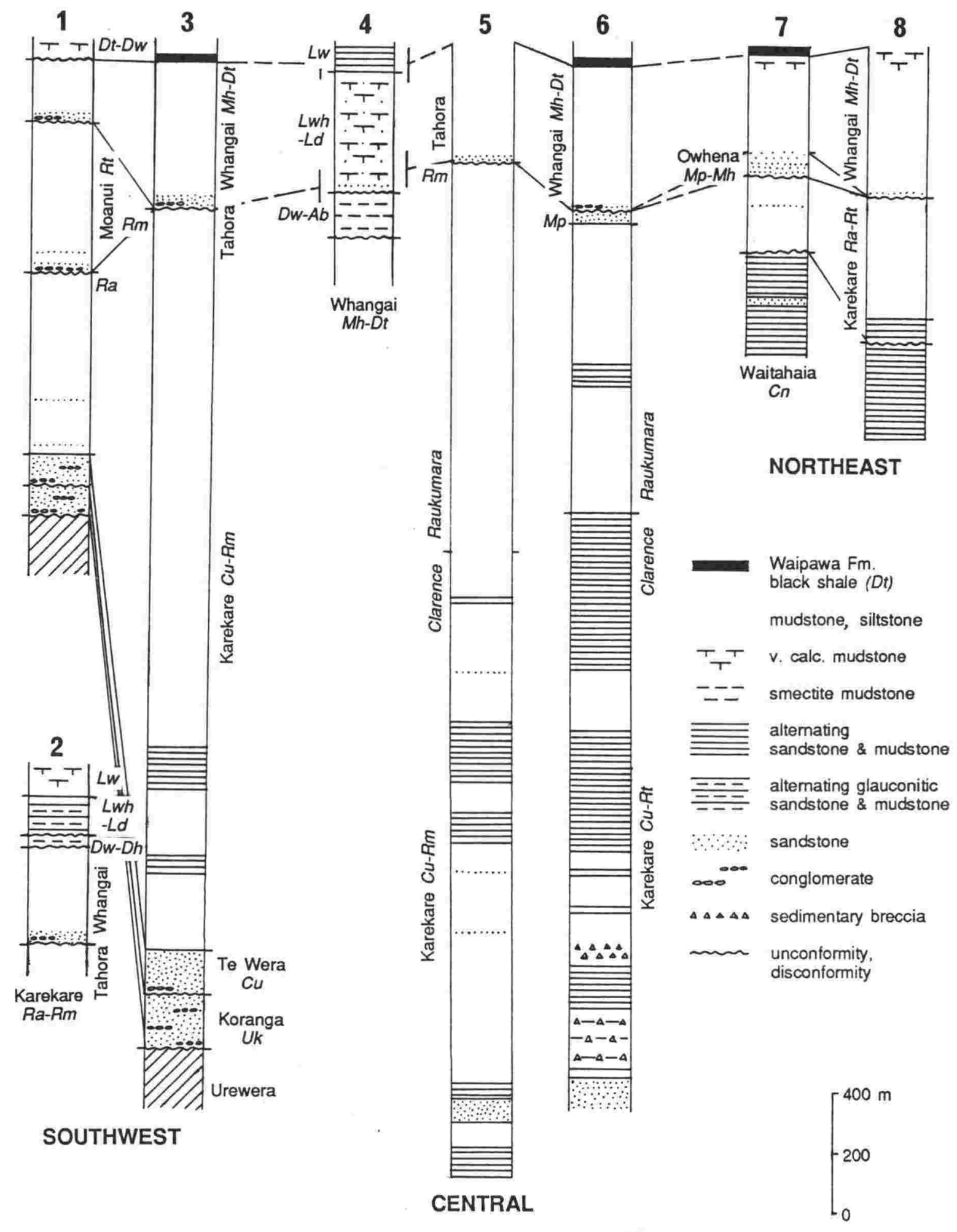

Figure 2.2: Cretaceous-Early Tertiary stratigraphic columns, Motu Block. See Fig. 2.1 for locations. 1 = Koranga (Speden, 1975; Moore, 1978, 1988a), 2 = Tahora (Joass, 1987), 3 = Matawai (Isaac, 1977; Moore, 1988a), 4 = Waikohu (Stoneley, 1968), 5 = Motu Falls (Speden, 1978), 6 = Mangaotane (Moore, 1988a), 7 = Waitahaia (Phillips, 1985; Moore, 1988a), 8 = Puketoro (Speden, 1978; Kenny, 1986). 
Overlying the Urewera Group rocks with a $90^{\circ}$ angular unconformity at Koranga and Matawai are Korangan shelf sandstones of the Koranga Formation (Speden, 1975). This formation is unconformably overlain by an Urutawan shelf sandstone unit, the Te Wera Formation (Speden, 1975), which passes laterally and vertically into the fossiliferous shelf siltstones (with rare alternating sandstone/siltstone packets) of the Clarence-Raukumara Karekare Formation (Speden, 1975). In the Koranga Valley, not all these units occur at every locality; the Koranga column (1 in Fig. 2.2) is a compilation of all the units present in the area. Koranga Formation occurs only in the east, Te Wera Formation resting directly on basement over most of the rest of the valley (Speden, 1975; Moore, 1978). The basal conglomerate of the Teratan Moanui Formation (Moore, 1978), a restricted local unit composed mostly of fossiliferous shelf siltstone, overlies the Urewera Group between two north-trending faults at the western end of the valley (Moore, 1978).

Unconformably overlying Matawai Group rocks in the southwestern sub-province is the Tahora Formation (Isaac, 1977; Moore et al., 1986), which at Koranga is a quartzose, glauconitic fine sandstone of inner shelf affinity (Speden, 1975). It becomes finer grained and better bedded to the southeast at Tahora, indicating a deeper depositional environment there (Joass, 1987). Its thickness varies from 5 to about $50 \mathrm{~m}$ (Moore, 1978; Joass, 1987). Tahora Formation rests on different levels of the Matawai Group. In the Koranga Valley, the basal unconformity cuts Te Wera Formation, Moanui Formation, and Motuan-Arowhanan strata of the Karekare Formation (Speden, 1975; Moore, 1978). At Tahora and Matawai, the unconformity cuts Mangaotanean Karekare Formation (columns 1 and 2, Fig. 2.2). Joass (1987) inferred an angular discordance of up to $20^{\circ}$ across the unconformity at Tahora. The variation in thickness of the Karekare Formation displayed on the three columns is due both to truncation by the unconformity and to original depositional variations; individual stages are of different thicknesses at different places (Moore, 1988a).

Whangai Formation (Moore et al., 1986) conformably overlies Tahora Formation in the southwest. In this sub-province, it consists of poorly bedded, non-calcareous, siliceous shale with common concretions and rare, thin glauconitic sandstone beds (the Rakauroa Member of Moore et al., 1986, and Moore, 1988b). At Koranga and Tahora the top of the Whangai is missing. Near Matawai, it is overlain by up to $10 \mathrm{~m}$ of black shale of the Waipawa Formation. Moore (1988b) estimates that the thickness of the Whangai Formation is over $400 \mathrm{~m}$ in this area (column 3, Fig. 2.2).

Disconformably overlying the Whangai Formation at Koranga are 50-60 m of Teurian-Waipawan calcareous siltstone (Moore, 1978). At Tahora, massive, calcareous, smectitic Waipawan-Heretaungan claystone up to $40 \mathrm{~m}$ thick disconformably overlies 
the Whangai (Joass, 1987). Unconformably overlying the Dannevirke beds and locally transgressing onto Whangai Formation are Whaingaroan-Duntroonian calcareous, glauconitic, alternating sandstone and mudstone, glauconitic sandstone, and glauconitic mudstone, up to $130 \mathrm{~m}$ thick at Tahora. Poorly bedded Waitakian glauconitic siltstone conformably overlies Duntroonian strata at Tahora (Joass, 1987).

\subsubsection{Central}

North of Matawai, the relationship between Urewera Group and Matawai Group rocks is poorly known, but recent geological reconnaisance north of Mangaotane has shown that the Karekare Formation there conformably overlies and grades up from Urewera group greywacke (Mazengarb, 1989; C. Mazengarb, pers. comm., 1989). The contrast between this gradation and the unconformity seen in the southwest led Mazengarb (1989) to suggest division of the Motu Block into two sub-blocks along a fault mapped just east of Matawai by Isaac (1977) and Moore et al. (1989). In this study, that fault is adopted as the boundary between the southwestern and central subprovinces (Fig. 2.1).

In the central sub-province, the thickness of the Clarence-Raukumara part of the column is similar to or greater than that at Matawai, but the character of the sediments changes towards the northeast. At Koranga, the Karekare Formation is almost wholly shelf siltstone (Speden, 1975; Moore, 1978). At Matawai, it is dominated by siltstone with rare packets of alternating sandstone and siltstone (Isaac, 1977; Moore, 1988a). At Motu Falls, these packets are common in the Clarence part of the formation (Speden, 1978). At Mangaotane, the Clarence Series is dominated by alternating sandstone and siltstone, whereas the Raukumara Series is still largely siltstone (Moore, 1988a). Further northeast, near the northeastern boundary of the central sub-province, Mazengarb (1989, and pers. comm., 1989) has mapped an unconformity within the Karekare Formation, with progressively younger (up to Piripauan) rocks onlapping to the east over the older (Ngaterian), alternating part of the formation. Lenses of alternating sandstone and siltstone in the Karekare in this area were mapped as Waitahaia Formation by Mazengarb et al. (1991).

The unconformity at the base of the Tinui Group persists into the central subprovince. At Motu Falls, Tahora Formation overlies Mangaotanean Karekare Formation (Speden, 1978). At Mangaotane, however, Tahora Formation is absent and a thin basal conglomerate of the Whangai Formation rests unconformably on Piripauan alternating sandstone and mudstone, which conformably overlie Teratan Karekare Formation (Speden, 1978; Moore et al., 1989). Tahora Formation appears to persist as far northeast as Kirks Clearing, about half-way between Motu Falls and Mangaotane. There, Moore 
(1989) mapped $30 \mathrm{~m}$ of sandy siltstone and carbonaceous fine sandstone unconformably overlying Mangaotanean Karekare Formation siltstone. This sandstone is replaced to the northeast by a sedimentary breccia (Kirks Breccia Member, Whangai Formation; Moore, 1988b) interpreted as a channelised debris flow deposit by Moore (1989). The breccia persists for about $2.5 \mathrm{~km}$ along strike, then thins and disappears to the northeast, where Piripauan alternating sandstone and mudstone are overlain by Whangai Formation siliceous siltstone (Moore, 1989, Fig. 1).

The total thickness of the Whangai Formation is similar throughout the central subprovince, but the top of the formation becomes more calcareous to the northeast. At Kirks Clearing, the poorly bedded, siliceous Rakauroa Member (which makes up the entire formation in the southwest) is overlain by poorly bedded, slightly calcareous siltstone of Moore's (1988b) Upper Calcareous Member. At Mangaotane, the Rakauroa Member is well bedded but still non-calcareous, and the Upper Calcareous Member is more calcareous than at Kirks Clearing (Moore, 1988b). Kirks Breccia Member, Rakauroa Member, and Upper Calcareous Member together make up Moore's (1988b) Western Facies of the Whangai Formation.

Sediments younger than Whangai Formation are preserved only in the southwestern part of the central sub-province. In the northeast, the basal detachment of the East Coast Allochthon lies at or near the top of the Whangai Formation (Moore, 1988a; Moore et al., 1989), and younger rocks have been tectonically removed. Southwest of the thrust front, in the Waikohu River area, the stratigraphy is similar to that around Koranga and Tahora: Waipawan-Bortonian glauconitic mudstone and marl disconformably overlie Whangai Formation, and Oligocene calcareous siltstone unconformably overlies the Waipawan-Bortonian beds or, in the northwest, Whangai Formation (Stoneley, 1968).

\subsubsection{Northeast}

Matawai Group stratigraphy and structure change across the Urewera Group inlier around Arowhana (Figs. 1.2, 2.1). In the area northeast of the inlier, the sandstone-dominated flysch of the ?Motuan-Ngaterian Waitahaia Formation (Phillips, 1985; Moore et al., 1986) displays tight to isoclinal folding about northwest- to north-northwest trending axes. The unconformably overlying Arowhanan-Teratan Karekare Formation is in contrast only gently folded (Phillips, 1985; Kenny, 1986). The Karekare Formation in this sub-province is dominated by fossiliferous siltstone with thin sandstone interbeds. The age of its base varies along strike, suggesting that a series of small, active basins in the underlying Waitahaia 'basement' were being slowly filled (Kenny, 1986; Mazengarb, 1989). The Karekare also varies in thickness: in the Waitahaia 


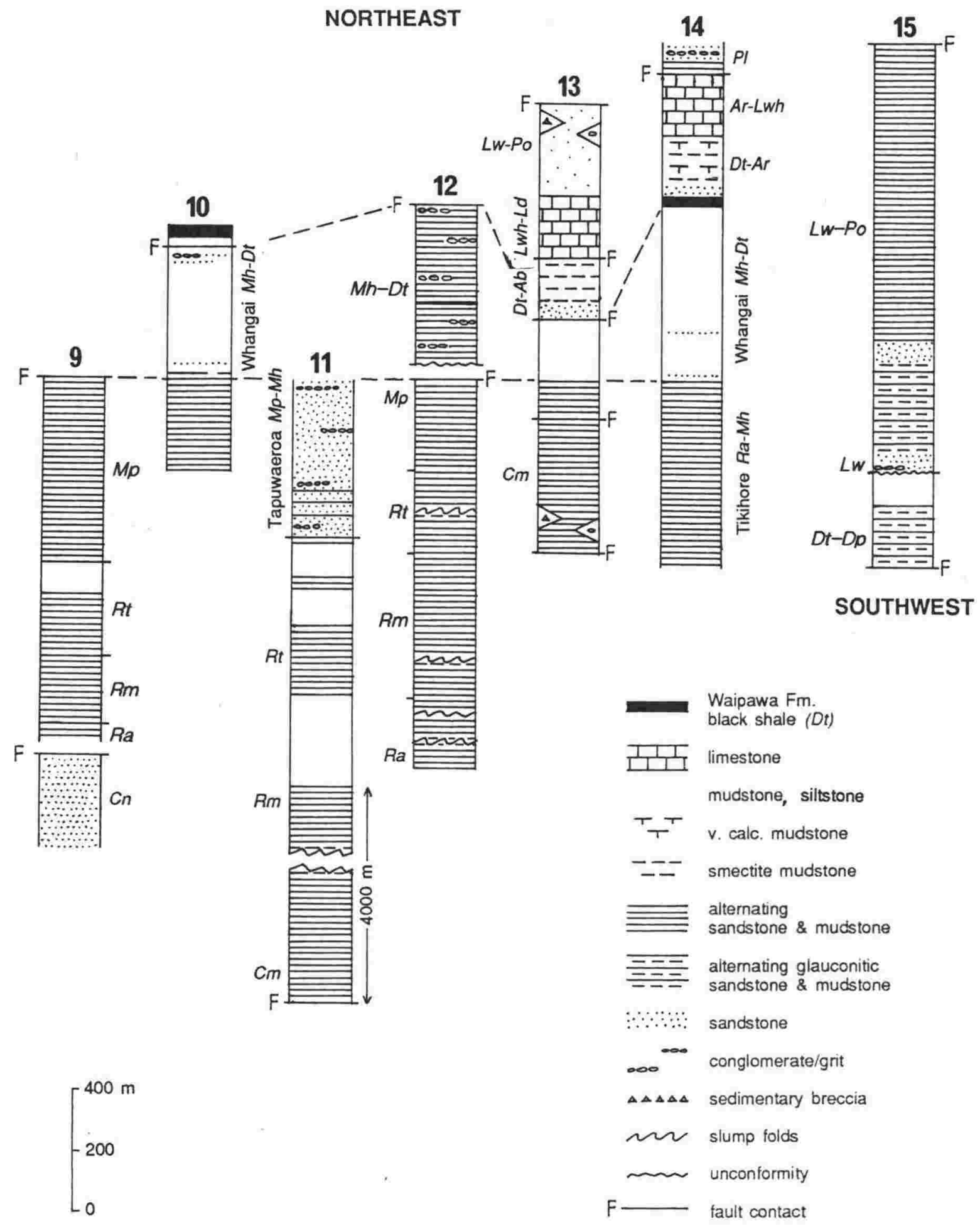

Figure 2.3: Cretaceous-Early Tertiary stratigraphic columns, East Coast Allochthon. See Fig. 2.1 for locations. 9 = Orete Point (Mazengarb, 1990), 10 = Makorokoro (Moore, 1988a), 11 = Mangaoporo (Moore, 1988a), 12 = lower Mata River-Ihungia River (Moore, 1988a; this study), 13 = Waitahaia (Phillips, 1985; Moore, 1988a), 14 = Mangatu Forest (Black, 1980), 15 = Mangatawa (Mazengarb, 1982, and pers. comm., 1990). 
area, it is $250 \mathrm{~m}$ thick, thinning to the northeast, and then thickening again to over 400 $\mathrm{m}$ at Puketoro Stream (Phillips, 1985; Kenny, 1986; Fig. 2.2).

The basal unit of the Tinui Group in the northeastern sub-province is the Piripauan-Haumurian Owhena Formation (Phillips, 1985), which unconformably overlies

Karekare Formation in the Waitahaia area. Owhena Formation consists of a fining-upwards sequence up to $100 \mathrm{~m}$ thick of alternating carbonaceous sandstone and mudstone, very fine sandstone, and micaceous siltstone. It is conformably overlain by Whangai Formation around Waitahaia but is missing to the northeast, where Whangai Formation unconformably overlies Karekare Formation (Kenny, 1986; section 4.2 .6 and Map 2). Whangai Formation in this sub-province consists of poorly bedded, siliceous Rakauroa Member overlain by poorly bedded, slightly to very calcareous Upper Calcareous Member. The Rakauroa Member is thinner, and the Upper Calcareous Member thicker, than in the central and southwestern sub-provinces (Moore, 1988b). Where Whangai Formation overlies Owhena Formation, the former has a basal unit consisting of mudstone with common calcareous concretions and coaly lenses (Phillips, 1985; Moore, 1988b). The thickness of the Whangai in the northeastern sub-province may be up to $500 \mathrm{~m}$ (Phillips, 1985), but is more commonly 300-350 m (Kenny, 1986; Moore, 1988a, b). At some places, a few metres of black shale of the Waipawa Formation are present beneath the basal detachment of the East Coast Allochthon (Kenny, 1986; Moore, 1988b).

\subsubsection{East Coast Allochthon}

Stratigraphic columns at different places in the East Coast Allochthon are presented in Fig. 2.3. Their locations are shown in Fig. 2.1. Rocks within the East Coast Allochthon can be separated into the same broad divisions as those in the Motu Block, and this is reflected in the similar positions of the boundaries between the groups in the two provinces (Table 2.1). Significant differences exist at formation level, however, particularly in the Motuan-Piripauan part of the column, which in the East Coast Allochthon is assigned to the Ruatoria Group (Mazengarb et al., 1991; Table 2.1). Also, there is no unconformity beneath the Tinui Group in the East Coast Allochthon (Speden, 1978; Moore, 1988a, b), except just northeast of the Thungia Fault in the lower Mata River area (section 3.2.4).

\subsubsection{Northeast}

Because of complex deformation, the stratigraphy of the East Coast Allochthon is not as well understood as that of the Motu Block. However, the greater part of this province-from the northeastern tip of the peninsula to about $15 \mathrm{~km}$ northeast of the 
thrust front (Fig. 2.1) - is known to be composed of rocks of similar character. The oldest unit exposed is the ?Urutawan-Motuan Mokoiwi Formation (Speden, 1976). This formation is composed of thin-bedded, siltstone-dominated flysch with bodies of lithic sandstone, breccia and conglomerate of all sizes up to $300 \mathrm{~m}$ thick (Taitai Sandstone Member), which are interpreted as channel-fills (Speden, 1976). The name Mokoiwi Formation is presently restricted to the rocks of the Mokoiwi inlier (Figs. 1.2, 2.1), but very similar strata of the same age occur in the Mangaoporo Valley (Moore, 1988a), in the Te Puia inlier (Laing, 1972a), and in the Ihungia, Puketoro, and Waitahaia areas (Kenny, 1980, 1984a, b, 1986; Phillips, 1985). The base of the formation is faulted at all of these localities. At Mangaoporo, Mokoiwi-like strata pass up into Ngaterian and Raukumara Series flysch (Moore, 1988a). At the other localities, upper contacts are not preserved.

Late Cretaceous rocks occur along the shore platform and further inland around the Orete Point area (Moore, 1957; Mazengarb, 1990; Mazengarb et al., 1990). At Orete Point itself, there is a continuously exposed, overturned, north-dipping Arowhanan-Piripauan section. South of the point, south to southwest-dipping Ngaterian-Piripauan strata are intermittently exposed from a fault contact with the Orete Point section southwestward as far as the northeastern boundary of the Motu Block. Individual stages in this southern section are thicker than their correlatives in the Orete Point section (Moore, 1957; Mazengarb, 1990). Only the Orete Point section and the bottom part of the southern section are shown in Fig. 2.3. Ngaterian rocks in the southern section are decimetre- to metre-bedded sandstones with common alternating sandstone/siltstone packets. Sandstone comprises $90 \%$ of the stage (Moore, 1957). The Raukumara Series of the southern section rests conformably on the Ngaterian; beds older than Arowhanan are not exposed in the Orete Point section, however. Raukumara strata at Orete Point are thin-bedded alternating sandstones and siltstones, with bed thicknesses and sandstone/siltstone ratios decreasing towards the top of the Series. Near the top of the Teratan stage, bedded siltstones and red and green mudstones dominate. The Piripauan is conformable on the Teratan, but is marked by a sudden increase in bed thickness, sandstone/siltstone ratio, and carbonaceous content. Moore (1957) mapped lower Haumurian strata at Orete Point, but dinoflagellate assemblages indicate that the youngest strata preserved there are Piripauan (Mazengarb, 1990; Mazengarb et al., 1990).

In the Mangaoporo and lower Mata River areas, the Raukumara strata are flysch similar to that at Orete Point (Pick, 1962). In the Mangaoporo area, the Piripauan-lower Haumurian is represented at some places by massive, glauconitic sandstones and grits rather than by flysch (Pick, 1962). In this area, these lithologies are referred to as Tapuwaeroa Formation (Speden, 1976; Moore, 1988a). The Raukumara-Mata succession 
is conformable at most places in the East Coast Allochthon, but immediately northeast of the Thungia Fault in the lower Mata River area Haumurian-Teurian strata rest with angular unconformity on folded Raukumara-Piripauan beds (see section 3.2.4). Raukumara strata are not preserved in the Waitahaia area, but in and north of Mangatu Forest there are Arowhanan-Haumurian alternating sandstones and siltstones (Tikihore Formation; Black, 1980) very similar to those seen further northeast (C. Mazengarb, pers. comm., 1988). Because of this similarity, Mazengarb (1990) referred to the Raukumara-Piripauan strata at Orete Point and in the lower Mata River area as Tikihore Formation.

The Whangai Formation in the East Coast Allochthon is generally more calcareous and better bedded than its equivalent in the Motu Block, and is included in the Eastern Facies of Moore (1988b). Its basal contact is generally conformable and gradational (Speden, 1978; Moore, 1988a, b), although Black (1980) considered it to be disconformable in Mangatu Forest. Lower parts of the Whangai are typically well bedded and slightly or non-calcareous. Upper parts are poorly or well bedded and slightly calcareous (Upper Calcareous Member), or well bedded and moderately to very calcareous (Porangahau Member; Moore, 1988b). Total thicknesses are similar to the thickness of the Western Facies in the Motu Block (Moore, 1988b). A possible exception is in Mangatu Forest, where the formation could be as much as $1100 \mathrm{~m}$ thick (Black, 1980), but thrust faults are common there and exposure is poor (Moore, 1988b). Waipawa Formation rests conformably on Whangai Formation wherever the contact is exposed (Moore, 1988b).

The internal stratigraphy of the Mangatu Group in the East Coast Allochthon is poorly known because of its dismemberment by thrust faults. The clay-rich, lower part of the group forms the matrix of widespread tectonic mélange, and the harder rocks of the upper, calcareous part typically occur as isolated, fault-bounded slivers. At places where detailed micropaleontological work has been done, however, it has been possible to piece together the stratigraphy with a degree of confidence. In the Puketoro area, Kenny (1986) mapped an Early Tertiary sequence comprising Paleocene black shale, Paleocene greensand, Paleocene-Eocene smectite mudstone, and Oligocene marl, limestone, and massive greensand. Nearby in the Waitahaia area, a coeval, dismembered sequence of similar rocks has an estimated composite thickness of $400 \mathrm{~m}$ (Phillips, 1985). In and west of Mangatu Forest, there are similar lithologies but the age of the lower part of the marl/limestone unit is Eocene (Stoneley, 1968; Black, 1980).

\section{Igneous Rocks:}

In the Motu Block, igneous rocks have been found on the northwest coast at $\mathrm{Te}$ Kaha (Fig. 1.2), where spilites of Clarence age are faulted against Clarence or older 
greywacke (Hill, 1974). In the Mangaotane Valley and at Puketoro Stream, there are red and green mudstones which may or may not be volcanogenic (Moore, 1985; section 4.2.3). No other volcanic rocks or volcanogenic sediments are known in the remainder of the province. In the East Coast Allochthon, however, volcanic rocks are relatively common. The largest occurrences are the Matakaoa Volcanics (Kingma, 1965), which occur in two bodies at the northeastern tip of the peninsula (Figs. 1.2, 2.1). These rocks are basaltic lava (including pillow lava), basaltic breccia, interbedded tuffaceous and pelagic sediments, dolerite, and minor gabbro (Pirajno, 1980).

The age of the Matakaoas has been the subject of some debate (e.g., see Katz, 1976; Strong, 1976b), but two groups of ages, Clarence Series and Paleocene-Eocene, are now accepted (Moore, 1985, 1988a; Moore et al., 1989). These ages were determined using foraminifera from rare interbedded sediments, which are bathyal pink limestone and interbedded calcareous mudstone. Potassium-argon dating by Brothers and Delaloye (1982) gave a range of ages up to Late Oligocene, but these probably reflect the influence of Early Miocene tectonic activity rather than the ages of formation of the rocks. Pirajno (1980) distinguished two separate geochemical suites, one tholeiitic and one alkali-enriched or calc-alkaline. He suggested that the two suites may correspond to the two paleontological age groups, and that the Matakaoas may be the products of a combination of mid-ocean ridge volcanism and later seamount volcanism.

In addition to the Matakaoas, three other groups of volcanic rocks occur in the northeastern sub-province of the East Coast Allochthon. These are:

1) Spilitic basalt, dolerite, keratophyre, and associated pyroclastics of the informal Rip volcanics member of the Mokoiwi Formation (Pirajno, 1979).

2) Volcanic breccia, conglomerate, agglomerate, and basaltic lava, interbedded with Late Cretaceous flysch.

3) Basalt and dolerite blocks, mostly associated with smectitic mélange zones. This group and group two together constitute the informal "East Coast volcanics" of Moore (1985).

The Rip volcanics occur close to the northern edge of the Mokoiwi inlier, tectonically intercalated with Mokoiwi Formation sediments. They are spilitised, unlike the Matakaoa Volcanics (Pirajno, 1979, 1980; Moore, 1985), although they are in part of similar age. A possible correlative exists at Te Kiwikiwi, about half-way between Mangaoporo and Hicks Bay (Figs. 1.2, 2.1). There, Moore and Challis (1985) described spilitic pillow lava with similar chemistry to that of the Rip Volcanics, and they 
considered that this lava tectonically overlies nearby Whangai Formation. Large diorite boulders are present in Early Miocene breccia and conglomerate in the IhungiaPuketoro area (section 4.2.10) and adjacent to the southern margin of the Te Puia inlier (section 5.2.5). These were probably derived from nearby Mokoiwi-like strata, and may thus be another correlative of the Rip Volcanics.

Rocks of the second group occur intercalated with Late Cretaceous sediments. In Mangatu Forest, up to $10 \mathrm{~m}$ of volcanic breccia, possibly an autobrecciated flow, is interbedded with flysch of Piripauan-lower Haumurian age (Black, 1980; Moore, 1985). Other lavas occur in beds of similar age northeast of Mangaoporo (Moore, 1985). At many other places, large blocks of lava or coarse volcanic conglomerates are present. These are mostly unspilitised, and many occurrences include olivine basalt (Moore, 1985). Most occurrences are within Piripauan-lower Haumurian strata (Moore, 1985; C. Mazengarb, pers. comm., 1989). Red and green mudstones of Teratan-Haumurian age are present at Orete Point (Moore, 1957), in the lower Mata River area (section 3.2.3), and in Mangatu Forest (Black, 1980).

Rocks of the third group occur as isolated blocks or groups of blocks associated with smectitic mélanges or fault zones. At Te Kiwikiwi, blocks of olivine basalt, chemically and petrographically distinct from the $\mathrm{Te}$ Kiwikiwi spilites, are found in mélange-derived float (Moore and Challis, 1985). Other important occurrences are in the Ihungia-Puketoro area, where large blocks of basalt and dolerite occur within mélange (Moore, 1985), and in Mangatu Forest, where there is a $5 \mathrm{~m}$ long outcrop of fractured basalt in a fault zone between Whangai Formation and Miocene strata (Black, 1980). Moore (1985) noted that the Ihungia-Puketoro occurrences have hard, possibly baked, white mudstone adhering to them which he tentatively identified as Whangai Formation. He also noted that the mélanges included intervals of red and green clay, and suggested that there may have been an episode of igneous activity in Paleocene-Eocene time. However, the mélange zones also contain Mokoiwi-like rocks and Late Cretaceous strata, so it is possible that this group of volcanics is derived from a combination of Rip Volcanics and the volcanics of group two. There are, therefore, two or possibly three volcanic episodes recorded in the rocks of the northeastern subprovince, in addition to the Matakaoa Volcanics.

\subsubsection{Southwest}

The southwestern sub-province of the East Coast Allochthon occupies the area within about $15 \mathrm{~km}$ of the thrust front (Fig. 2.1). The boundary between the southwestern and northeastern sub-provinces is the "Te Hua Slide" of Stoneley (1968). North of that fault, Whangai Formation or older rocks overlie the basal detachment. 
South of it, the oldest rocks above the basal detachment are Eocene or Oligocene strata (Stoneley, 1968; Moore et al., 1989). These rocks are less dismembered than their correlatives elsewhere in the East Coast Allochthon, but are still complexly deformed by folds and thrusts.

The stratigraphy of the southwestern sub-province has been examined by Stoneley (1968) and, in the extreme southwest, by Mazengarb (1982). The rocks are transitional in character between their more pelagic correlatives in the northeastern sub-province and the more terrigenous facies in the Motu Block. Eocene strata are "bentonite" (smectite mudstone) in the northeast, but are gradually replaced by alternating glauconitic sandstone and mudstone to the southwest. Oligocene and earliest Miocene strata are limestone and marl in the northeast, but are replaced by calcareous siltstone and alternating fine sandstone and siltstone to the southwest.

A number of unconformities occur in the section. Close to the thrust front, early Eocene strata occur immediately above the basal detachment, which probably follows an original disconformity that is present in the autochthon (section 2.2.2.1 and column 4, Fig. 2.2). These beds are overlain with slight angular unconformity by ?WhaingaroanWaitakian strata (column 15, Fig. 2.3). To the northeast, the basal detachment places Whaingaroan beds on Whangai Formation, and again probably follows an original unconformity. Still further northeast, Stoneley (1968) mapped late Eocene strata immediately above the basal detachment.

According to Stoneley (1968), stratigraphic thickness varies considerably across the southwestern sub-province. His Fig. 2 shows the Porangan-Duntroonian succession as $2500 \mathrm{~m}$ thick in the central area, but about half that figure in the northeast. Immediately northeast of his Te Hua Slide, it shows correlative strata as $600 \mathrm{~m}$ thick. This variation may be more apparent than real, however, as each of Stoneley's columns are composites across several imbricates and may include stratigraphic repetitions across undetected faults. Also, his foraminiferal biostratigraphy has been found to be unreliable in the light of more recent work (Mazengarb, 1982; Moore, 1988b; Moore et al., 1989). The thickness of the Late Cretaceous (Whangai Formation) to Oligocene succession elsewhere in Raukumara Peninsula and in the rest of the East Coast Deformed Belt is typically $500-800 \mathrm{~m}$, with a maximum of $1200 \mathrm{~m}$ (Moore and Morgans, 1989). Whangai Formation is generally $300-500 \mathrm{~m}$ thick (Moore, 1988b), leaving the Eocene-Oligocene part of the sequence with a typical thickness of ca. $200-500 \mathrm{~m}$, and a maximum of $700-900 \mathrm{~m}$. 
At about the beginning of the Miocene, the depositional regime in Raukumara Peninsula (and the rest of the East Coast Deformed Belt) changed dramatically. Terrigenous sedimentation, locally including deposition of coarse breccia-conglomerates, began over the entire region, and the sedimentation rate suddenly became much greater than it had been in the Oligocene. Miocene-Pliocene strata now cover the northern, east-central, and southern parts of the peninsula. They are a laterally variable succession of sandy mudstone, alternating sandstone and mudstone, sandstone, bioclastic limestone, conglomerate, and tuff, of a composite thickness exceeding $7500 \mathrm{~m}$ in the central part of the region (Moore et al., 1989; Mazengarb et al., 1991). Within this succession, unconformities occur in the Tongaporutuan, beneath the Kapitean, and in the south, at the base of the Pliocene. Early-Late Miocene and Late Miocene-Pliocene strata are described separately below.

\subsubsection{Early-Late Miocene Strata}

Early Miocene (Waitakian-Altonian) strata crop out in the East Coast Allochthon, in the northeastern and southwestern parts of the peninsula, and in the western and northern parts of the large body of Neogene strata which occupies the east-central part of the region (Fig. 1.2). In the central part of the East Coast Allochthon, fault-bounded slivers of Early Miocene sandy mudstone, breccia, and conglomerate, all assigned to the Mangatu Group by Mazengarb et al. (1991), are present at some places. In the Waitahaia area, the breccias are dominated by clasts generally $10-20 \mathrm{~cm}$ but up to $50 \mathrm{~m}$ in diameter of Taitai-like sandstone, and the conglomerates are dominated by clasts of Whangai Formation (Phillips, 1985). The breccias and conglomerates occur as lenses within the sandy mudstone, and the age of all three lithofacies is Waitakian-Otaian (Phillips, 1985). Similar rocks of the same age occur in the Ihungia-Puketoro area, where they also contain igneous clasts and, at some places, stringers of probable Whaingaroan-Waitakian marl (section 4.2.10). Waitakian-Otaian beds also occur in the southwestern part of the province. In the frontal few imbricates, Waitakian alternating sandstone and siltstone are conformable on Oligocene beds (Stoneley, 1968; Mazengarb, 1982), but further northeast, there is an angular unconformity between marl which Stoneley (1968) mapped as lower Waitakian, and alternating sandstone and siltstone which he mapped as upper Waitakian.

Outside the East Coast Allochthon, Waitakian strata are exposed in the southwest, in the extreme northeast, and in isolated exposures in other parts of the region. In the southwest, Waitakian calcareous siltstone rests conformably on Oligocene beds around Tahora (Joass, 1987). Northeast of Tahora the contact is also conformable, but Waitakian 
strata are greensand (Moore et al., 1989) or alternating sandstone and siltstone (Stoneley, 1968). In the northeast of the peninsula, coarse conglomerate with basic igneous clasts overlies Matakaoa Volcanics or Mangatu Group and grades up into Waitakian-Otaian calcareous siltstone (Chapman-Smith and Grant-Mackie, 1971). At Whangara, on the coast half-way between Gisborne and Tolaga Bay (Fig. 1.2), coarse, fossiliferous, Waitakian greensand unconformably overlies Oligocene marl (Francis and Mazengarb, 1983). In the Puketoro area and at the southwestern end of the Te Puia inlier, Waitakian sandstones occur in fault contact with the East Coast Allochthon (Kenny, 1986; Mazengarb et al., 1991; sections 4.7, 5.7). Along the western margin of the body of Neogene in the east-central part of the region, Waitakian-Altonian strata are faulted against the East Coast Allochthon (Black, 1980; Phillips, 1985; Kenny, 1986).

Over most of the region, the Early-Late Miocene succession (Tolaga Group; Table 2.1) is internally conformable. In the southwest, however, the Otaian is missing and Altonian greensand, limestone, and sandy siltstone disconformably overlie the Waitakian (Joass, 1987). At the base of the Altonian northeast of Tahora, there is a thin conglomerate which contains clasts including greywacke and dark, fine-grained volcanics (Joass, 1987). Similar conglomerates occur conformably within the Altonian over much of the rest of the region (Black, 1980; Kenny, 1984a, 1986; Phillips, 1985). The conglomerate typically occurs in several beds up to a few metres thick within an interval 10-15 m thick (e.g., Phillips, 1985). Clasts vary from pebbles up to $10 \mathrm{ft}(3 \mathrm{~m})$ in diameter (Adams, 1910), and are supported by a silty to gritty matrix. Clast compositions include diorite, trachyte, granophyre, granite, teschenite, gabbro, amphibolite, and pyroxenite, as well as chert, greywacke, and other sedimentary lithologies (Black, 1980; Kenny, 1984a,b). Some are well-rounded, polished, and probably multicyclic, but others are angular, and many of the sedimentary clasts are probably of local origin (Kenny, 1984a,b). The source of many of the igneous clasts, however, is more problematical. While many were probably derived from the Matakaoa Volcanics, many others have compositions not found in that unit. These latter were probably reworked from Cretaceous conglomerates, particularly those in the Mokoiwi Formation and correlative rocks (see Speden, 1976).

Above the conglomerate, the Early-Late Miocene succession is dominated by sandy mudstone but also includes lenses of alternating sandstone and mudstone, thick-bedded and tuffaceous sandstone, and bioclastic limestone, as well as minor conglomerate and sedimentary breccia (Moore et al., 1989). The age ranges up to late Tongaporutuan, but at many places the unconformity beneath the Late Miocene beds cuts Early or early Middle Miocene strata (e.g., Chapman-Smith and Grant-Mackie, 1971; Black, 1980; Moore et al., 1989). The thicknesses preserved are thus variable. Thicknesses are at least $500 \mathrm{~m}$ for Waitakian-Altonian strata in the north (Chapman-Smith and Grant-Mackie, 
1971); $1600 \mathrm{~m}$ for Altonian-Lillburnian strata (Ihungia Formation) near Ihungia (Kenny, 1984a); $1600 \mathrm{~m}$ for Altonian-Waiauan strata in Mangatu Forest (Black, 1980); and at least $5700 \mathrm{~m}$ for Waitakian-late Tongaporutuan strata in the east-central part of the region (Moore et al., 1989; Mazengarb et al., 1991). Deposition of the Early-Late Miocene beds is thought to have taken place in a mid-shelf to upper slope environment (Black, 1980; Kenny, 1984a, 1986; Phillips, 1985; Joass, 1987).

\subsubsection{Late Miocene-Pliocene Strata}

In contrast to the Early-Late Miocene strata, Late Miocene-Pliocene strata were deposited in shallow-water conditions (Moore et al., 1989). Late Miocene strata, where present, overlie the Tolaga Group with angular unconformity. In the far north, late Tongaporutuan-Opoitian beds are fine to coarse, shelly, pumiceous and carbonaceous sandstone with tuff beds and minor conglomerate, bioclastic limestone, and thin coal seams. They are at least $500 \mathrm{~m}$ thick (Chapman-Smith and Grant-Mackie, 1971; Moore et al., 1989). In the east-central part of the peninsula, the succession includes a thick-bedded Kapitean sandstone (Tokomaru Sandstone; Moore et al., 1989), up to 500 $\mathrm{m}$ thick, and up to $1350 \mathrm{~m}$ of Opoitian mudstone with thick sandstone units in its upper part (Moore et al., 1989). The Late Miocene-Pliocene succession in these areas is included in the Mangaheia Group of Moore et al. (1989). However, thick bedded Tongaporutuan sandstone (Areoma Sandstone) which unconformably overlies Waiauan rocks in the inland area west of Tolaga Bay was included in the Tolaga Group by Mazengarb et al. (1991).

In the south, Pliocene sandstone rests unconformably on Miocene beds at many places (Moore et al., 1989). This is in contrast to further northeast, where basal Pliocene strata are mudstone and conformably overlie the Kapitean. Lenses of bioclastic limestone are present northwest of Gisborne, and synclinal outliers of alternating sandstone and mudstone are present around Tolaga Bay (Moore et al., 1989). All Pliocene rocks in the region are Opoitian; no Waipipian-Nukumaruan strata have been found (Moore et al., 1989). Opoitian and older beds are unconformably overlain at many places by non-marine Castlecliffian-Recent deposits (Moore et al., 1989).

\subsection{SUMMARY AND DISCUSSION}

\subsubsection{Cretaceous-Paleogene}

In general terms, the mid-Cretaceous to Oligocene succession at any one place in the region may be described as a fining-upwards sequence, a thick (over $5 \mathrm{~km}$ locally) 
succession of terrigenous sediments (Matawai and Ruatoria Groups) in the Cretaceous giving way to finer grained, more calcareous sediments in the uppermost Cretaceous and Paleogene. Matawai and Ruatoria Group rocks were deposited during active convergence, as shown by the deformation of the Ngaterian Waitahaia Formation and the diachroneity of the base of the overlying Karekare Formation in the northeastern sub-province of the Motu Block (section 2.2.1.3). The structural style of the Waitahaia Formation suggests deformation on a trench slope (Kenny, 1986; Mazengarb, 1989). In the central sub-province, southwest of the Urewera Group inlier around Arowhana (Figs. 1.2, 2.1), Karekare Formation accumulated through Clarence and Raukumara time without any break. In the southwestern sub-province, Matawai Group sedimentation and deformation were intermittent.

The above features suggest interpretation of the Motu Block as a Late Creataceous subduction complex, with the northeastern sub-province being part of the trench slope, the Urewera Group inlier the highest accretionary ridge, the central sub-province the forearc basin, and the southwestern sub-province the basin margin. The facies distribution, the northwest to north-northwest structural trend, and the northeastward vergence (Kenny, 1986; section 4.4.1) show that this complex faced northeastward. The flysch-dominated Ruatoria Group rocks in the East Coast Allochthon are inferred to have been deposited northeast of the Matawai Group rocks on the trench slope or as trench fill. Ruatoria Group rocks presently structurally above correlative Matawai Group rocks have been displaced southwestward from their original positions northeast of the northern end of the Motu Block. The present distributions of these rocks can be used to estimate amounts of post-Cretaceous thrust transport (see sections $3.7,4.6 .5,6.3 .5 .3$ ).

The Tinui Group covers the older rocks unconformably in the southwest and conformably in the northeast. Its basal sandstone (Tahora Formation) thins and disappears northeastward and the overlying Whangai Formation becomes more calcareous in the same direction. Mangatu Group strata become finer grained, more clay-rich and more calcareous northeastward. These relationships show that the Raukumara Peninsula continental margin faced northeastward in latest Cretaceous to Oligocene time. The fine grained nature, uniform and relatively low (600-1000m) stratigraphic thickness, and the widespread distribution of similar facies show that the margin was not active during Tinui and Mangatu time. The unconformities within the Mangatu Group in the southwest (sub-Waipawan and sub-Whaingaroan) are probably the result of eustatic sea-level fluctuations (see Haq et al., 1987). 


\subsubsection{Miocene-Pliocene}

The abrupt acceleration in sedimentation rate and the onset of terrigenous sedimentation throughout Raukumara Peninsula at the beginning of the Miocene is due to uplift and erosion produced by deformation accompanying the onset of subduction (e.g., van der Lingen, 1982; Rait et al., 1991; see section 1.2). Waitakian-Otaian sediments within the East Coast Allochthon include breccias with coarse, angular clasts derived from exhumed mid-Cretaceous formations which had been buried at depths of several kilometres during the Oligocene (Fig. 2.3). Immediately southwest of the thrust front and in the frontal few imbricates, where the succession is conformable, subsidence from late Oligocene shallow shelf depths and the accumulation of at least $1500 \mathrm{~m}$ of Waitakian-Otaian flysch (Stoneley, 1968; Mazengarb, 1982; column 15, Fig. 2.3) record the development of a local foredeep. Slightly further northeast, late Waitakian rocks overlie folded early Waitakian and older rocks, showing that this area was deforming during deposition of a conformable sequence immediately to the southwest.

The northeast-dipping paleoslope which existed in the region from the Early Cretaceous through to the Oligocene probably was eliminated in the Early Miocene. While conditions were generally shallower at the southwestern limit of Early Miocene outcrop, most rocks of that age elsewhere in the region were deposited at outer shelf to upper slope depths. Considerable subsidence took place from the Early Miocene into the Late Miocene, at least over the east-central part of the region, with the accumulation of at least $6 \mathrm{~km}$ of sediments which were eroded from East Coast Allochthon and possibly Motu Block sources (Kenny, 1984b; Mazengarb et al., 1991). Occasional episodes of shallowing, such as that recorded in the Altonian by the unconformity in the extreme southwest (Joass, 1987) and by shallow water limestones (Mazengarb et al., 1991) and possibly the igneous conglomerate horizon in other parts of the region, are probably due to eustatic sea level fluctuations (Haq et al., 1987).

The internally conformable nature of the widely distributed Early to Late Miocene succession suggests that no major tectonic events took place in the region during that interval. However, shallow water Late Miocene formations which are unconformable on older rocks (Areoma Sandstone and Tokomaru Sandstone) were deposited during active folding and faulting: Areoma Sandstone unconformably overlies Waiauan rocks in the core of the Tutamoe Syncline and south of the Atarau Fault (Mazengarb et al., 1991), Tokomaru Sandstone changes thickness across folds (Mazengarb et al., 1991), and Tongaporutuan mudstone beneath unconformably overlying Tokomaru Sandstone changes thickness across faults (section 5.8.2). Early Pliocene (Opoitian) rocks also show such thickness changes and unconformably overlie the Miocene at places (Moore et al., 1989; Mazengarb et al., 1991). The absence of late Pliocene and early Pleistocene rocks 


\section{Chapter 3}

\section{Structure of the Lower Mata River Area}

\subsection{INTRODUCTION}

\subsubsection{Location, Physiography and Exposure}

The lower Mata River valley and its immediate surroundings constitute area 1 in Fig. 1.4. This area lies within NZMS 260 sheet Y15 (1:50,000), being approximately bounded by grid refs. Y15 610520, 680520, 680440, and 630440. Aerial photographs which the writer examined are from survey number 5975 (December 1981), frames E26-29 and F38-41. Access to the area is by the metalled Makarika Road, which leaves State Highway 35 approximately $17 \mathrm{~km}$ north of Te Puia.

The major physiographic feature of the area is the northeast-draining Mata River, which cuts across the area from southwest to northeast (Fig. 3.1). Other major watercourses include the Aorangiwai River, which drains the north of the area, Mangapekapeka Stream, which drains the west, Makarika and Orua Streams, which drain the southeast, and the Ihungia River, which drains the south. Most of the area is deeply dissected hill country but the lower reaches of the Mata River pass through a wide flood plain flanked by alluvial terraces. Relief is moderate in the south and moderate to high in the north. Elevation is $100-150 \mathrm{~m}$ in the bed of the Mata River, but the land rises steeply to either side. The highest point in the area is Aorangi, in the northwest corner, at $1272 \mathrm{~m}$.

Within the area, access is good along the major watercourses, although the Mata cannot easily be crossed after rain. Horehore Road (Fig. 3.1) can be traversed by car for about $1.5 \mathrm{~km}$ past Waingakia Station. A metalled road which leaves Matahiia Road at the eastern edge of the area follows the ridge between the Mata and Aorangiwai Rivers up to a television translator close to the western edge of the area. A four-wheel-drive track follows the ridge between the Mata River and Makarika Stream. Farm tracks follow ridges in other parts of the area.

Exposure is excellent along the upper and central parts of the Mata, good to fair along the other major watercourses and major roads, but generally poor elsewhere. Most of the area is pasture with patches of scrub and native bush in minor valleys. The 


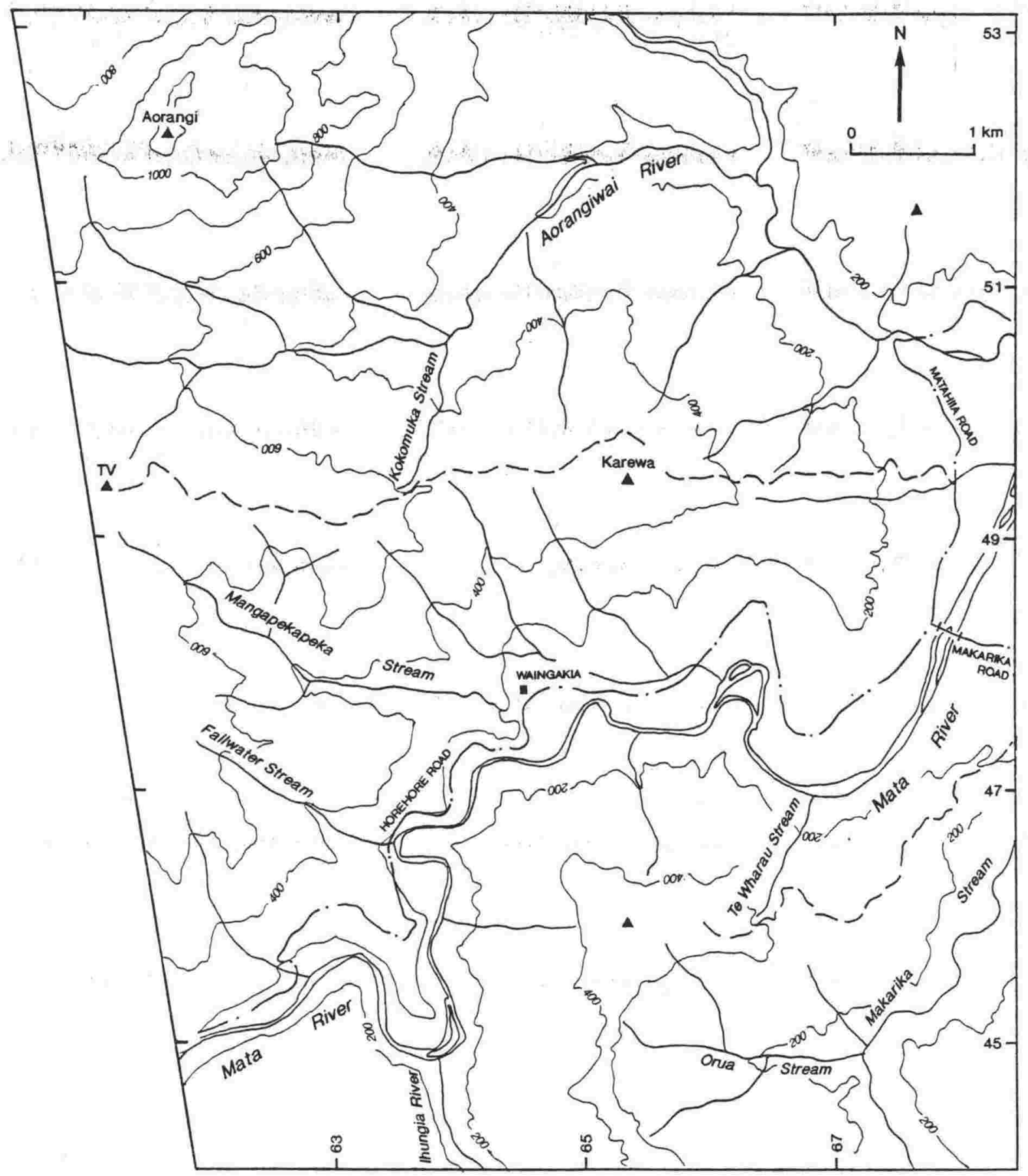

Figure 3.1: Location and topographic map, lower Mata River area (NZMS 260 sheet Y15). Note: the names Fallwater, Kokomuka, and Te Wharau Streams appear on the map of Pick (1962) but not on the NZMS map. 
lower Aorangiwai valley is planted in young pine forest, and the northern slopes of the upper Aorangiwai valley are covered in dense native forest. Much slumping has affected the southern and southwestern slopes of the Aorangiwai valley, and the catchment of Orua Stream.

\subsubsection{Previous Work}

Ongley and Macpherson (1928) examined the folded lower Mata River section and included it in their lithostratigraphic Raukumara Series. Wellman (1959) established a reference section for his chronostratigraphic Raukumara Series there. Moore (1959) and Pick (1962) mapped the lower Mata River area in detail. Laing (1971) produced a revision of Moore's map based on interpretation of aerial photographs and on limited field work. The lower Mata River folds appear on the 1:250,000 maps of Kingma (1965) and Moore et al. (1989). Gibson (1987a) examined the Mokoiwi Formation in the north of the area.

Pick (1962) described the Mata River folds as asymmetric, northeast-verging structures dissected by northwest-striking faults. Moore (1959) and Pick (1962) mapped the Arowhanan-Haumurian strata around the folds as a conformable succession, whereas Laing (1971) shows the Haumurian unconformably overlying the folded Arowhanan-Piripauan beds. Moore (1959) and Pick (1962) show the Mokoiwi Formation in contact with younger beds along a series of straight or gently curved fault segments which have a variety of trends, whereas Laing (1971) shows a sinuous, sedimentary contact-the unconformity beneath his Eocene "Mokoiwi Chaos Breccia" (section 1.3.1).

All maps of the area show the southwestern limit of the folded Raukumara-Mata beds as a north-northwest striking fault (Ihungia Fault; Pick, 1962) which brings Ngaterian rocks into contact with Piripauan-Haumurian rocks. Moore (1985, 1988a) marks this fault and its northwestern continuations as the northeastern limit of his Motu Block (section 1.3.1). Pick (1962) considered that the Thungia Fault is a southwestdipping reverse fault. It is the only fault to appear on the map of Laing (1971).

\subsection{STRATIGRAPHY}

Five lithologic units are distinguished in the lower Mata River area. (Figs. 3.2, 3.3). These are: 


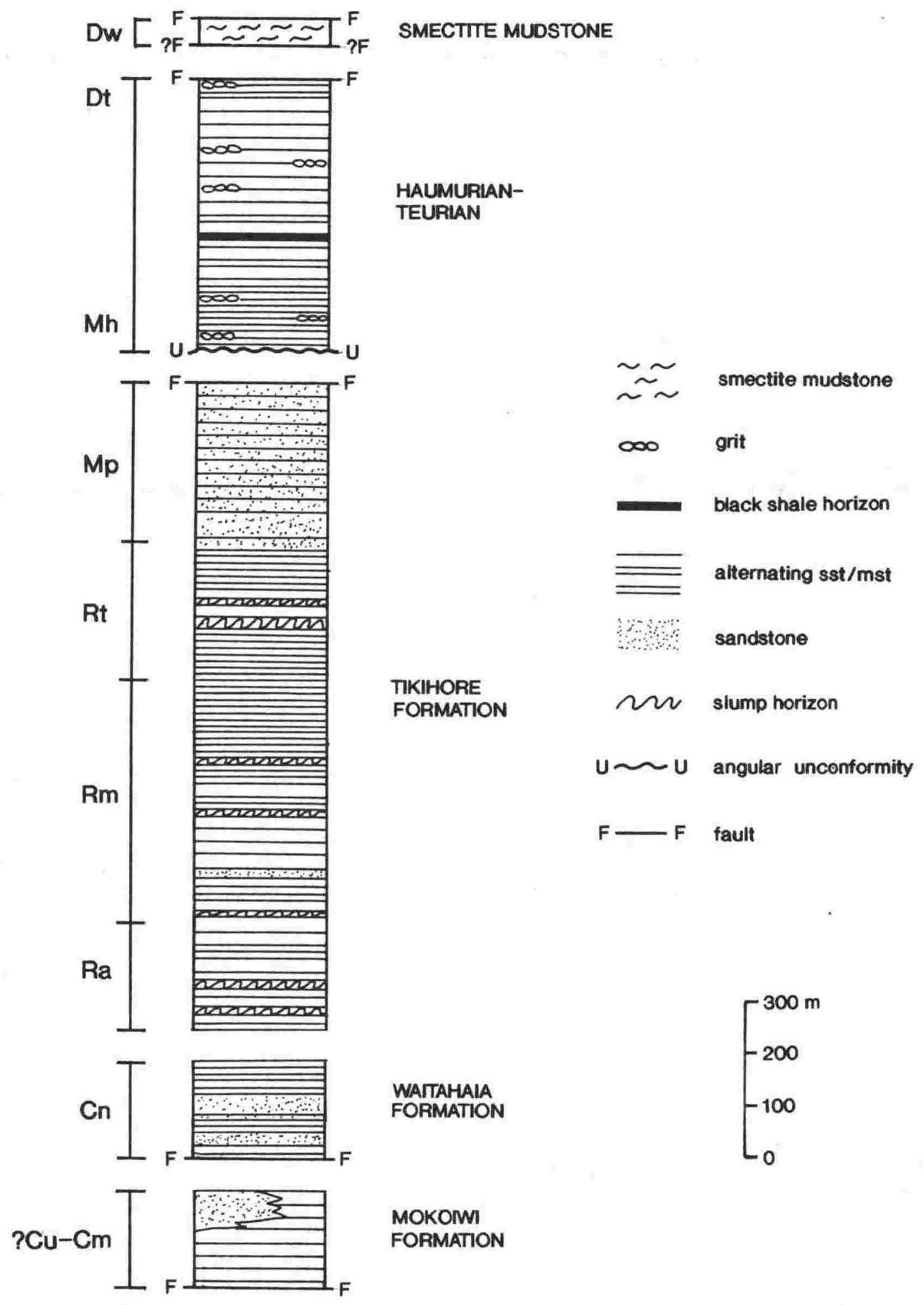

Figure 3.2: Stratigraphic column, lower Mata River area. Haumurian-Teurian stratigraphy from Thungia River section. 
1) ?Urutawan-Motuan (Albian) Mokoiwi Formation, consisting of alternating sandstone and mudstone with large lensoid bodies of coarse sandstone (Taitai Sandstone Member) (Speden, 1976).

2) Ngaterian (Albian-Cenomanian) sandstone and alternating sandstone and mudstone of the Waitahaia Formation (Moore et al., 1989). These rocks are the "Hikurangi beds" of Laing (1972a) and Kenny (1980, 1984a).

3) Raukumara Series and Piripauan stage (Cenomanian-Santonian-?Campanian) alternating sandstone and mudstone and massive sandstone of the Tikihore Formation (Mazengarb, 1990; equivalent to the Raukumara Formation of Laing, 1972a).

4) Haumurian-Teurian (Maastrichtian-Paleocene) alternating sandstone and mudstone, siltstone, glauconitic sandstone, calcareous mudstone, and grit.

5) Eocene calcareous smectite mudstone and greensand.

\subsubsection{Mokoiwi Formation}

Mokoiwi Formation occupies the northernmost part of the area (Fig. 3.3), where it is faulted against the Waitahaia and Haumurian-Teurian formations and slivers of Eocene mudstone. The greater part of the Mokoiwi consists of interbedded grey fine sandstone and dark grey mudstone. The sandstone/mudstone ratio is less than one: sandstone beds are centimetres to decimetres thick, and mudstone beds are generally decimetres thick. This lithology shows complex deformation, with sandstone beds being both folded and boudinaged at many places (Fig. 3.4a).

Taitai Sandstone Member (Speden, 1976) forms Mount Aorangi (Fig 3.4b), in the northwest corner of the area. Taitai Sandstone is a hard, dark greyish green, poorlysorted, medium to coarse massive sandstone which weathers to a rusty brown. Anastomosing cataclastic shear zones pervade the rock. Gibson (1987a) referred to this sandstone as a "deformational breccia".

The thickness of the Mokoiwi Formation in the lower Mata River is unknown because of complex deformation. Pick (1962) estimated the thickness of the entire formation as $900-1200 \mathrm{~m}$. This figure was accepted by Speden (1976), who considered the thickness of the Taitai Sandstone Member to range up to $300 \mathrm{~m}$. The age of the formation, based on the presence of key Inoceramus species as well as other molluscan fossils, was determined by Speden (1976) as ?Urutawan-Motuan (Albian). 


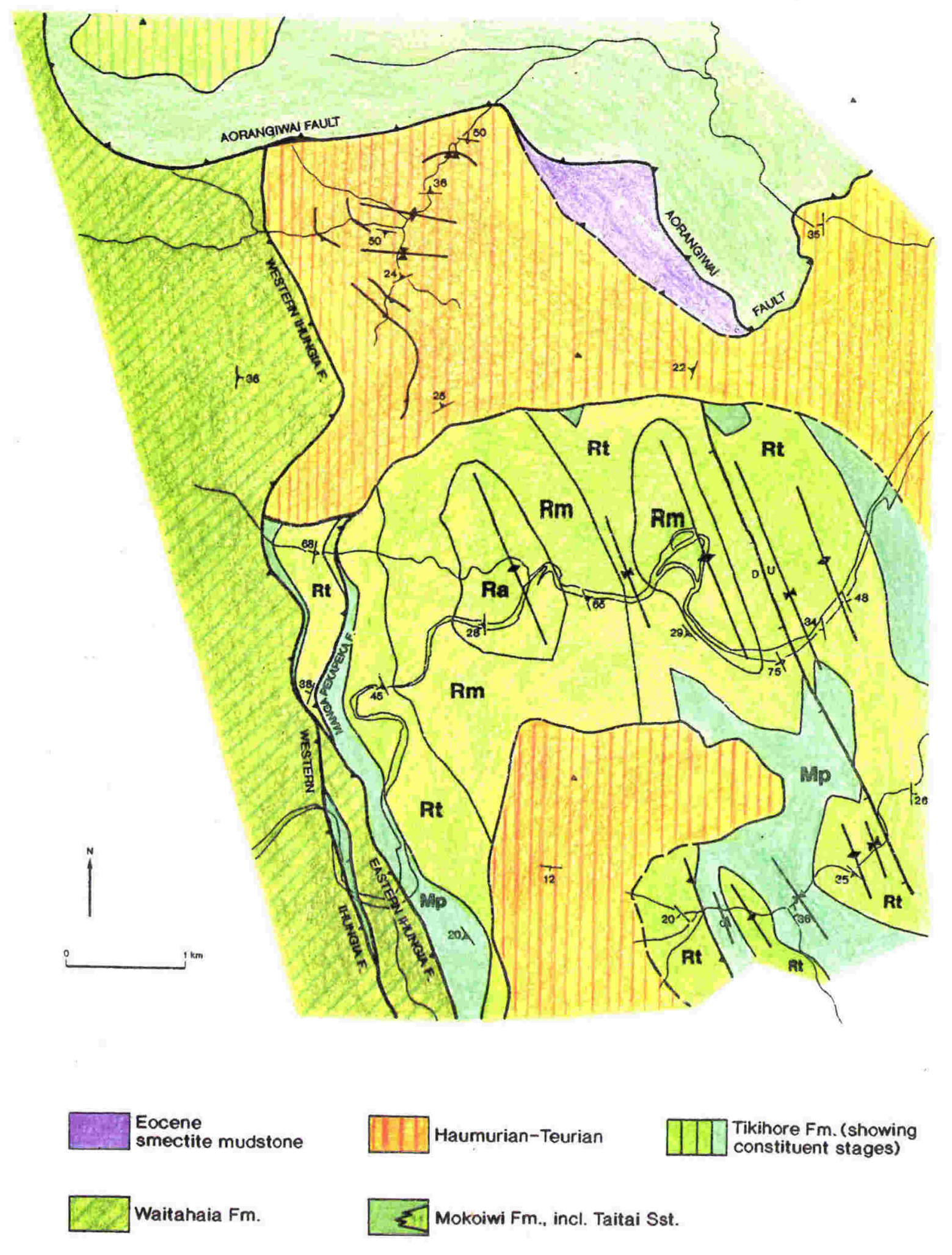

Figure 3.3: Simplified geological map, lower Mata River area. 

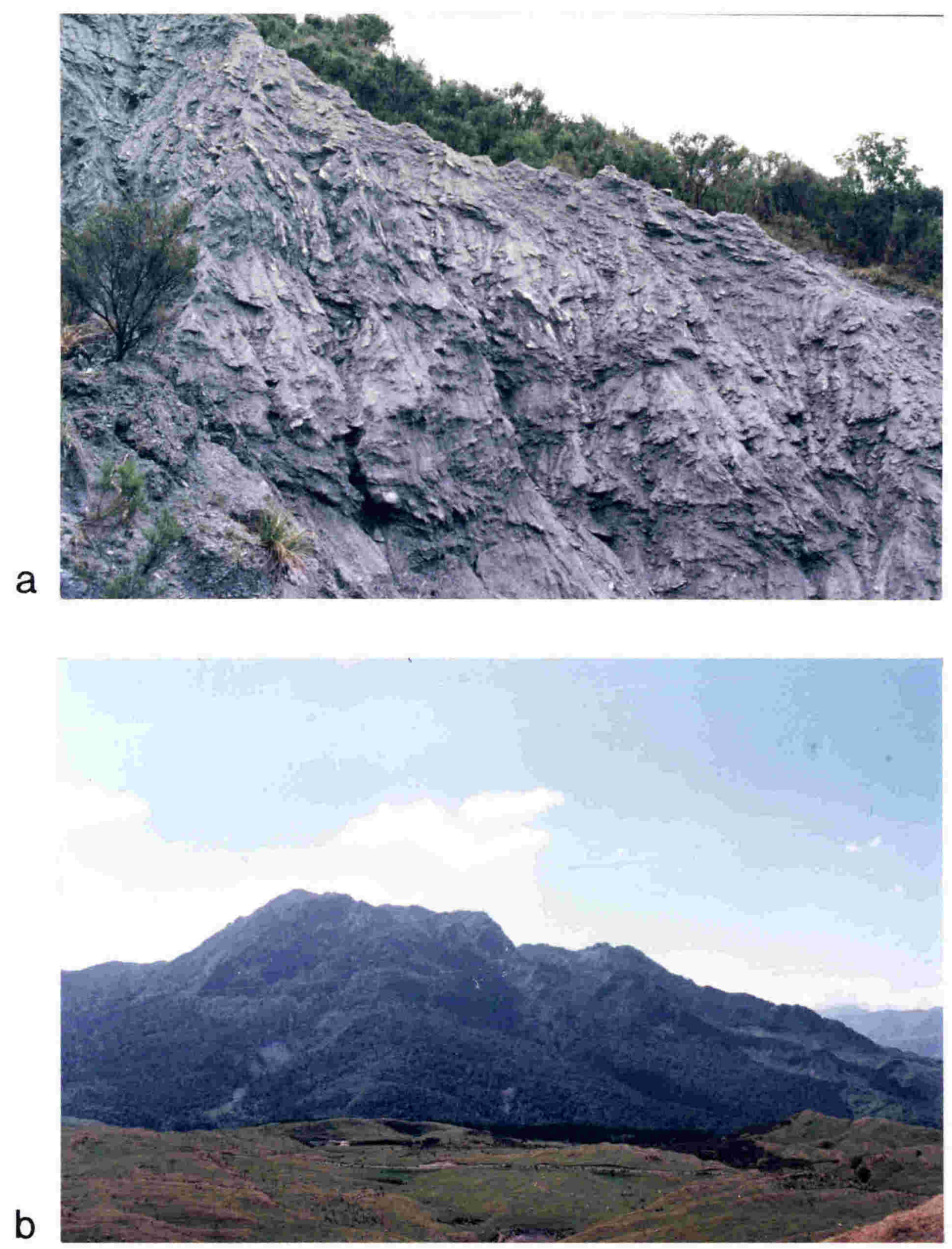

Figure 3.4: Mokoiwi Formation. a: Alternating sandstone/mudstone lithofacies. Note dismemberment of sandstone beds. Lower Aorangiwai valley, grid ref. Y15 66095120. b: Mount Aorangi, a massif composed of Taitai Sandstone. Photo taken looking NW from Y15 65344947. 
Waitahaia Formation (Fig. 3.5) occurs as a north-trending strip along the western edge of the area (Fig. 3.3). It is faulted against Haumurian-Teurian rocks and Tikihore Formation to the east, and Mokoiwi Formation to the north. Waitahaia Formation consists of alternating hard, light greenish grey, fine to medium sandstone and dark blue-grey mudstone. The formation is sandstone dominated: sandstone beds vary from decimetres to a few metres thick, and mudstone beds vary from a few centimetres to a few decimetres thick. Sandstone beds are generally graded, and possess complete or incomplete Bouma sequences. In the thicker sandstones, the massive $\mathrm{A}$ horizons dominate. Some sandstones contain carbonaceous material and/or Inoceramus fragments near their bases. Sandstones weather yellow-brown, and mudstones weather dark brown.

Waitahaia Formation is complexly deformed, so its thickness in the lower Mata River area is unknown. The formation is present over a large area to the south and west of the lower Mata River (see section 2.3.1.3). Its total thickness was considered by Speden (1978) as unlikely to exceed $1000 \mathrm{~m}$. Phillips (1985) suggested a minimum thickness of $300 \mathrm{~m}$ for the formation in the Waitahaia area. The age of the formation, according to Moore et al. (1989), is Motuan-Ngaterian. In the lower Mata River area, it is Ngaterian (Albain-Cenomanian) (Moore, 1959; Pick, 1962; Laing, 1971). Most of the deformation of the Waitahaia Formation took place soon after deposition, as it is overlain by little-deformed Arowhanan Karekare Formation to the south (Kenny, 1986; Mazengarb, 1989; see also section 4.4.1).

\subsubsection{Tikihore Formation}

The Tikihore Formation (Mazengarb, 1990) includes Raukumara Series and Piripauan stage rocks. The Raukumara strata crop out in the centre of the lower Mata River area (Fig. 3.3). They are exceptionally well exposed along the banks of the Mata River, and also occur along Makarika and Orua Streams. They consist of alternating, moderately hard, blue-grey to greenish grey, fine to medium sandstones and dark bluegrey mudstones. Sandstones weather yellow brown, and mudstones weather orange brown. Many sandstones contain flakes of carbonaceous material and Inoceramus fragments, and mudstones commonly contain near-complete Inoceramus specimens. Glauconite is present in upper Teratan beds. Sandstones are decimetre- to rarely metrebedded and mudstones are decimetre-bedded. The thickest sandstone bed, near the base of the Mangaotanean, measures $7.5 \mathrm{~m}$. Most of the Series has sandstone/mudstone ratios exceeding 1:1, but some intervals are mudstone-dominated. The muddiest interval occurs in the mid-Teratan, where red and green mudstone beds are present. Sandstone 


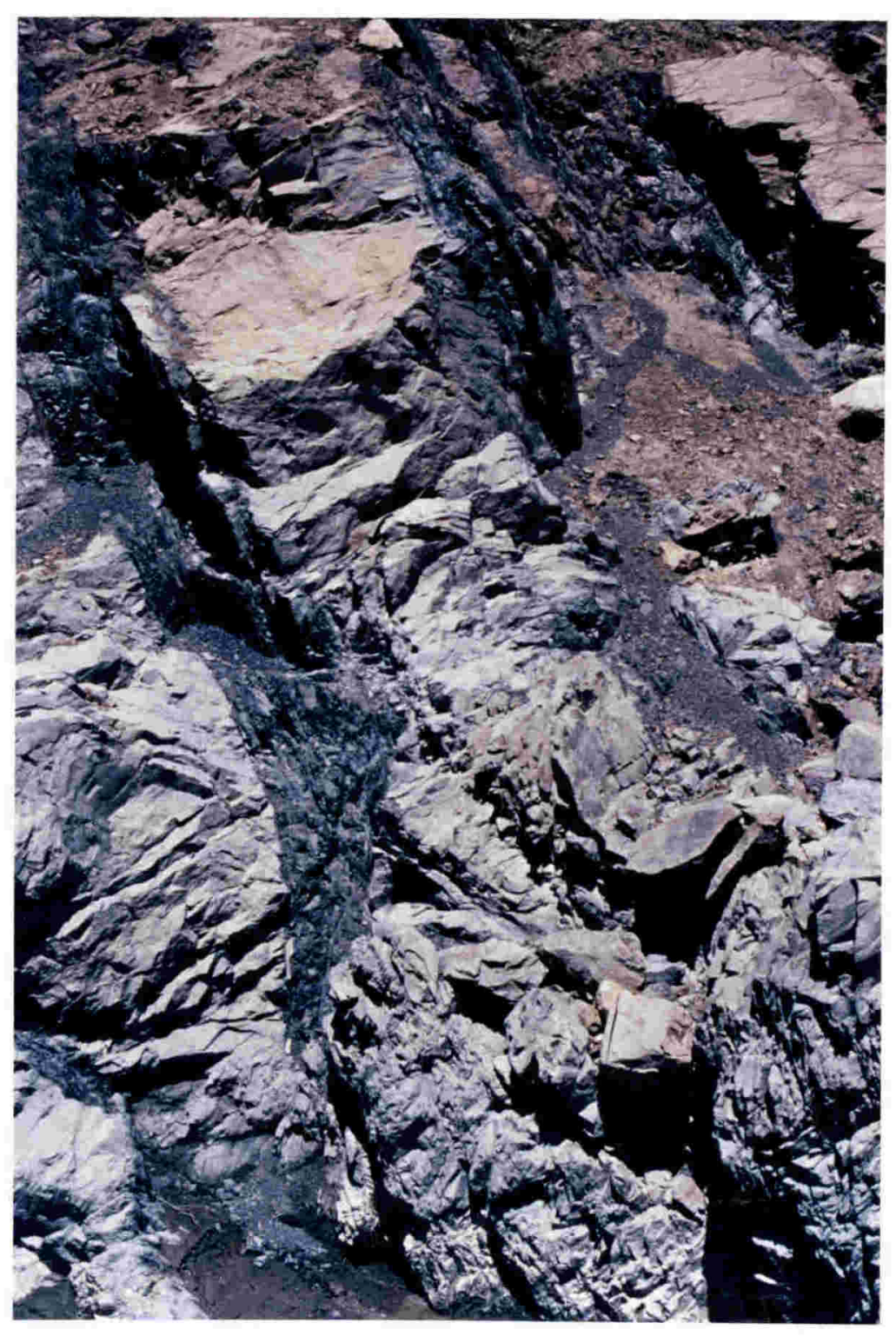

Figure 3.5: Waitahaia Formation beds, Mata River (Y15 62614515). 
beds are typically normally graded, have complete or incomplete Bouma sequences, and commonly have sole markings. Mudstones are finely laminated or massive, and fissile when weathered. Centimetre- to decimetre- sized concretions are common in Mangaotanean sandstones. Cobbles of fine-grained basalt, some with glassy outer margins and/or vesicles filled with zeolite, occur in a slip in beds inferred to be Teratan at Y15 63074655.

The presence of the index fossils Inoceramus rangatira (Arowhanan), I. bicorrugatus (Mangaotanean), and I. nukeus and I. opetius (Teratan) indicate that all the Raukumara stages (Cenomanian-Santonian) are present in the lower Mata River section (Wellman, 1959; see also Appendix 2). The Arowhanan beds, however, lie in the core of an anticline, so their base is not seen. Arowhanan beds are at least $310 \mathrm{~m}$ thick, Mangaotanean beds are $470 \mathrm{~m}$ thick, and Teratan beds are $270 \mathrm{~m}$ thick (Fig. 3.2).

A notable feature of the lower Mata River section is the presence of slump-folded horizons throughout the Raukumara Series (Fig. 3.2). These horizons vary in thickness from a few metres to a few tens of metres. The thickest horizon is associated with the mudstone-rich interval in the mid-Teratan, and can also be seen in Mangapekapeka Stream. Within these horizons, individual beds are variably disrupted. Typically, sandstone beds are broken into fragments some metres long which exhibit asymmetric folds and/or boudinage (Fig. 3.6). However, sandstones in some horizons are completely disrupted, occurring as irregular centimetre- to decimetre- sized blebs completely surrounded by mudstone. The ductility implied by much of the fabric-for example, tight folding and extreme necking or boudinage, with little or no associated fracturing-together with the continuity and parallelism of the strata above and below these horizons, suggests that they are the products of slumping of thin packets of sediment soon after their deposition.

The base of the Piripauan is well exposed near the southwestern end of the Mata River section. The base of the Piripauan is taken at the base of a sandstone immediately above a thickening-upwards sequence of sandstone beds at Y15 633714578 , a few metres below the first occurrence of Inoceramus pacificus (C. Mazengarb, pers. comm., 1988). The basal sandstone is similar to the Teratan ones immediately below it. It is a moderately hard, light greyish green, glauconitic, carbonaceous, fine to medium sandstone, massive at the base, but laminated and cross-bedded nearer the top. Above this bed, the rocks are metre-bedded, fossiliferous, carbonaceous, glauconitic sandstones with gritty layers, which are massive or have well-developed cross-bedding, and centimetre-bedded dark grey mudstones. Sandstones and mudstones have yellow jarosite efflorescences on weathered surfaces, and some sandstones have pyrite nodules filling burrows. Up-section on Horehore Road and in Fallwater Stream, the sandstone 


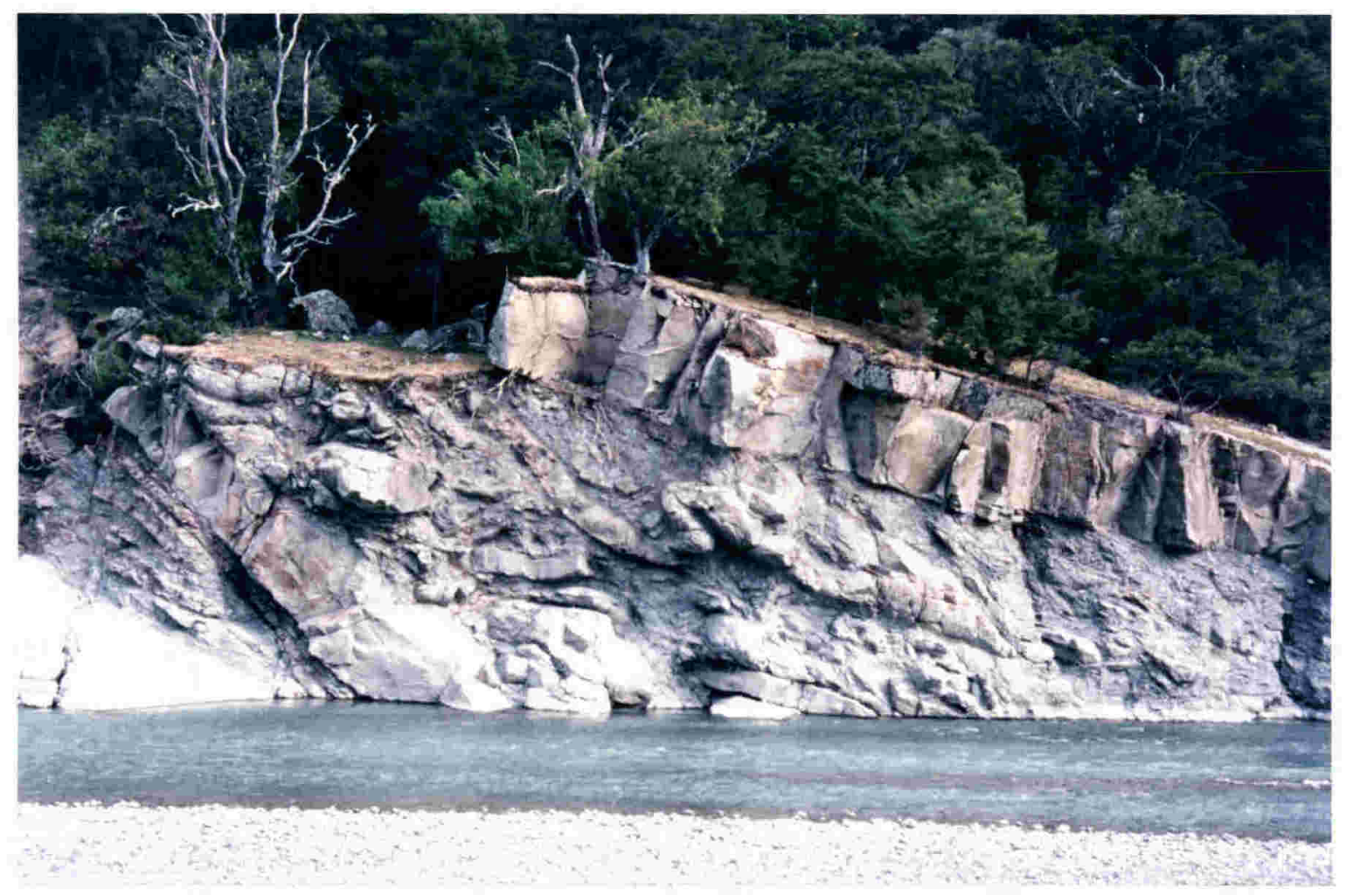

Figure 3.6: Slump-folded horizon in Arowhanan beds, Mata River (Y15 64744722). 
beds decrease in thickness. On Horehore Road, at Y15 63614594, there is an outcrop of glauconitic sandstone and slump-folded red and green mudstone.

Basal Piripauan strata are also seen around the confluence of Makarika and Orua streams, and in Te Wharau Stream. In Makarika Stream, the basal contact is not quite exposed. The lowest visible Piripauan consists of greyish olive, massive, carbonaceous, jarositic, very glauconitic, fine to medium sandstone with fragments of Inoceramus pacificus and concretions up to $2 \mathrm{~m}$ across. Centimetre-thick interbeds of dark blue-grey, very carbonaceous mudstone also occur. The sandstone unit is about $10 \mathrm{~m}$ thick at this locality, and forms prominent ridges distinct from the more subdued topography on the thinner-bedded strata above and below it. In Te Wharau Stream, the basal Piripauan rocks are of similar composition but occur as two sandstone beds, $3 \mathrm{~m}$ and $2 \mathrm{~m}$ thick, separated by $3 \mathrm{~m}$ of centimetre- to decimetre-bedded alternating sandstone and mudstone.

Moore et al. (1989) included the Piripauan beds in the lower Mata River section in the Tapuwaeroa Formation, whereas Mazengarb (1990) classified the conformable Raukumara-Piripauan (Cenomanian-Santonian-?Campanian) succession there as Tikihore Formation. Because Haumurian-Teurian strata also mapped as Tapuwaeroa Formation by Moore et al. (1989) are unconformable on the Raukumara-Piripauan beds (see section 3.2.4), the nomenclature of Mazengarb (1990) is followed here.

\subsubsection{Haumurian-Teurian Rocks}

Rocks mapped here as "Haumurian-Teurian" underlie the upper slopes of the hills north and south of the Mata valley, and the ridge between the Ihungia River and Orua Stream. They also occur in the middle Aorangiwai valley (Fig. 3.3). Lower and central parts of the formation are moderately well exposed in the Aorangiwai River and in Kokomuka Stream. Weathered exposures occur along the road which traverses the ridge between the Mata and Aorangiwai valleys. Scattered exposures occur on ridges and in minor valleys elsewhere in the area.

Haumurian-Teurian strata in the lower Mata River area do not rest conformably on Tikihore Formation. The contact was not actually observed, and poor exposure and an extensive colluvium derived from Quaternary alluvial deposits and volcanic ash on the upper slopes of the Mata valley make its position difficult to determine with any precision. It is particularly poorly controlled in the badly slumped areas in the upper catchment of Orua Stream and on the northeasternmost slopes of the Mata valley, northwest of the road bridge. However, observations of outcrops of the formations either side of the contact, especially on the northern slopes, show that its geometry 
does not follow the folds in the underlying Tikihore Formation (Fig. 3.3, Map 1). It could thus be either an angular unconformity or a gently dipping fault. The degree of deformation of the Haumurian-Teurian rocks increases with increasing elevation and with proximity to the tectonically overlying Mokoiwi Formation, and is not great close to its lower contact. Also, the geometry of the best-controlled part of the contact-the western half of its extent on the north side of the Mata-suggests it dips gently northwest, parallel to the dominant dip of the beds above it. Considered together, these two observations strongly suggest that the contact is an angular unconformity.

This contact, the base of the Haumurian of earlier workers, was mapped by Moore (1959) and Pick (1962) as conformable on the Piripauan beds around the folds in the Mata River. Moore and Pick marked contacts at places where the Haumurian appeared to be juxtaposed against rocks older than Piripauan as steeply dipping faults. Laing (1971), however, mapped the base of the Haumurian as an angular unconformity. On the north side of the Mata valley, the position of the unconformity on Laing's map is close to that determined in this study. On the south side, however, its position is quite different.

The Haumurian-Teurian rocks in the lower Mata River area include a variety of lithotypes, which are best displayed in the middle Aorangiwai River and in Kokomuka Stream. Although the rocks are deformed and not particularly well exposed, the following sequence, from bottom to top, has been determined:

1) Alternating moderately hard, light grey-green, glauconitic, gritty to medium sandstones and light green or dark grey sandy mudstones. Sandstones are decimetre-bedded and some are bioturbated near their bases. Many show welldeveloped cross-bedding. Mudstones are centimetre-bedded, and massive or heavily bioturbated. Some sandstones are pyritic and jarositic, and ?sideritic or baritic septarian concretions up to $2 \mathrm{~m}$ across occur at some places. Sandstones weather light grey to brownish orange. Mudstones weather pale green to light blue-grey, or orange-brown on joint surfaces.

2) Moderately hard, dark blue-grey, calcareous, micaceous, sandy mudstone, which is massive or finely laminated. It weathers to light blue-grey or dark brown on fracture surfaces. This lithology is exposed in the lower Aorangiwai River.

3) Dark purple-grey to black, jarositic, micaceous, carbonaceous sandy siltstone and yellow-green, jarositic, very glauconitic medium to coarse sandstone (greensand). The siltstone weathers light grey to orange, and the greensands weather yellow and become friable. The abundant mica imparts a bedding-parallel fissility to the 
siltstone. This distinctive lithology occurs in a band up to $5 \mathrm{~m}$ thick. Typically, greensand beds are 1-2 m thick. This horizon is remarkably similar in content and thickness to the late Teurian Waipawa Formation, and was mapped by Moore (1959) and Laing (1971) as "Teurian chocolate shale".

4) Alternating decimetre-bedded, dark blue-grey, micaceous, calcareous mudstones and centimetre-bedded, grey-green, glauconitic, graded coarse to fine sandstones. Mudstones weather blue-grey to brown-grey, sandstones weather orange-brown. Some sandstones are gritty and/or have load casts and bioturbation at their bases, and cross-beds at their tops. Mudstone beds become thicker up the section, and sandstone beds become thinner. This is the dominant lithology in the formation. It is well exposed on the higher parts of the southern slopes of the upper Aorangiwai valley (Fig. 3.7), and along the Ihungia River, in the area covered in the next chapter.

Due to complexities in the structure, the thickness of the formation in the lower Mata River area is difficult to estimate. In the Ihungia River, a little-deformed section extending from the unconformity upriver to a major fault has a thickness of $500-550 \mathrm{~m}$ (see also section 4.2.4).

These rocks were included in the Tapuwaeroa Formation by Moore et al. (1989). However, foraminiferal samples from various localities and levels within the unit in the lower Mata River area give Haumurian (Maastrichtian), Haumurian-Teurian, and Teurian (Paleocene) ages (H.E.G. Morgans, pers. comm., 1991; see Appendix 2), whereas the Tapuwaeroa Formation in the Tapuaeroa and Mangaoporo valleys-where it rests conformably on older rocks and is conformably overlain by Whangai Formation-is Piripauan-early Haumurian (Moore, 1988; Moore et al., 1989). The younger age and the presence of an angular unconformity make "Tapuwaeroa Formation" an unsuitable name for the strata in the lower Mata River area. While they are similar in age to the Whangai Formation, they are dissimilar in content. Therefore, they are not included in either of those formations.

\subsubsection{Eocene Smectite Mudstone}

Eocene smectite mudstone occurs in fault-bounded slivers beneath the Mokoiwi Formation in the north of the area. The largest occurence is on the badly slumped southwestern slope of the lower Aorangiwai valley (Fig. 3.3, Map 1). Mass movement in that area has resulted in this mobile lithology appearing in slumps which overlie Mokoiwi Formation further down the hillside and in the Aorangiwai River. The mudstone was also seen beneath the Mokoiwi in a southeast-flowing tributary of the 


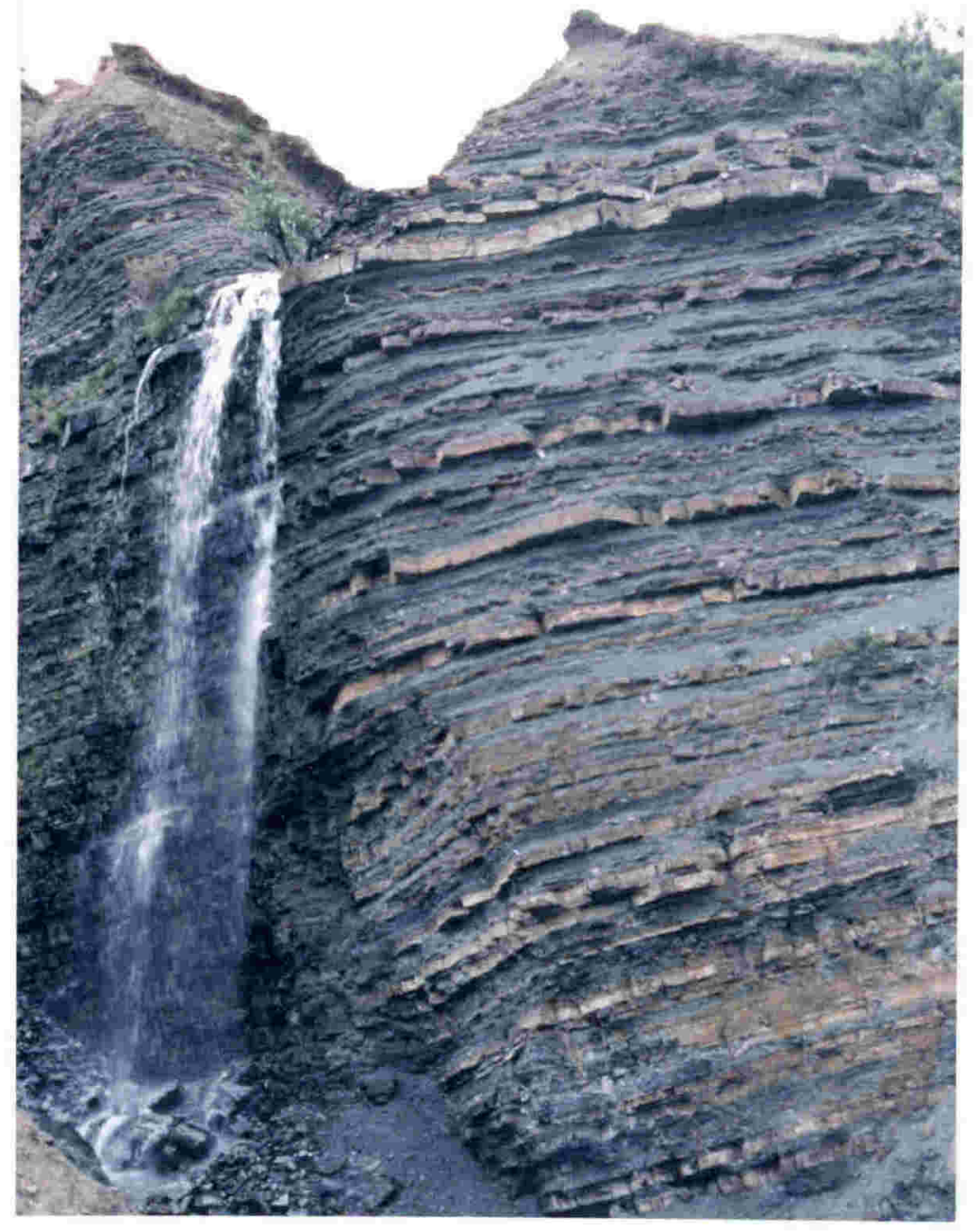

Figure 3.7: Alternating mudstones and sandstones of the Haumurian-Teurian formation, upper Aorangiwai valley (Y15 63714986). 
upper Aorangiwai River. Its occurrence as float further up the Aorangiwai valley suggests that it also underlies the Mokoiwi Formation further west.

This distinctive lithology is pale greenish grey to light yellow-green, slightly micaceous, glauconitic, very calcareous mudstone with large purple-grey streaks and mottlings which are parallel to bedding, giving a slight fissility to the rock. Thin greensand interbeds are rare. It contains an expanding clay, and swells when immersed in water. This lithology is very similar to rocks of similar age elsewhere in Raukumara Peninsula (see Chapter 2) and the East Coast Deformed Belt (Fergusson, 1985; Moore, 1985, 1988a). It has in the past been referred to as "bentonite" (e.g., Pick, 1962; Kingma, 1965), which carries the connotation that it originated from weathering of volcanic ash (e.g., Kingma, 1965). Fergusson (1985), however, found no evidence of a volcanic component in samples of these rocks taken between southern Hawkes Bay and Marlborough, and suggested the term "smectite mudstone" would be more appropriate.

This lithology has previously been dated as Teurian in this area (e.g., Moore, 1959; Pick, 1962). Foraminifera from a sample from the lower Aorangiwai valley (Y15/f110; see Appendix 2) give a Waipawan (Ypresian) age.

\subsection{OVERVIEW OF STRUCTURE}

The detailed structure of the lower Mata River area is shown on Map 1 and the accompanying sections (A-F), to be found in the back pocket. All the structures referred to in this section appear on Fig. 3.3.

In the centre of the area, a train of north-northwest trending fault-propagation folds deform the Tikihore Formation. These folds are asymmetric, northeast-verging, open to close, doubly-plunging structures which are steeply inclined to the west-southwest. They are thought to be underlain by two moderately southwest-dipping blind thrusts. The folds are non-cylindrical; they have different shapes to the southeast, in Makarika Stream. They are truncated by the unconformity beneath the Haumurian-Teurian beds, which in the upper Aorangiwai River are folded about west to west-northwest trending axes.

The folds are bounded to the west by the Ihungia fault system. These faults are westerly-dipping, east- to northeast-directed thrust or reverse faults. The eastern Ihungia Fault juxtaposes Waitahaia and Tikihore Formations, and is unconformably overlain by Haumurian-Teurian beds in the Ihungia valley to the south (Fig. 4.3, Map 2). The western Ihungia Fault juxtaposes Waitahaia Formation with Haumurian-Teurian rocks 


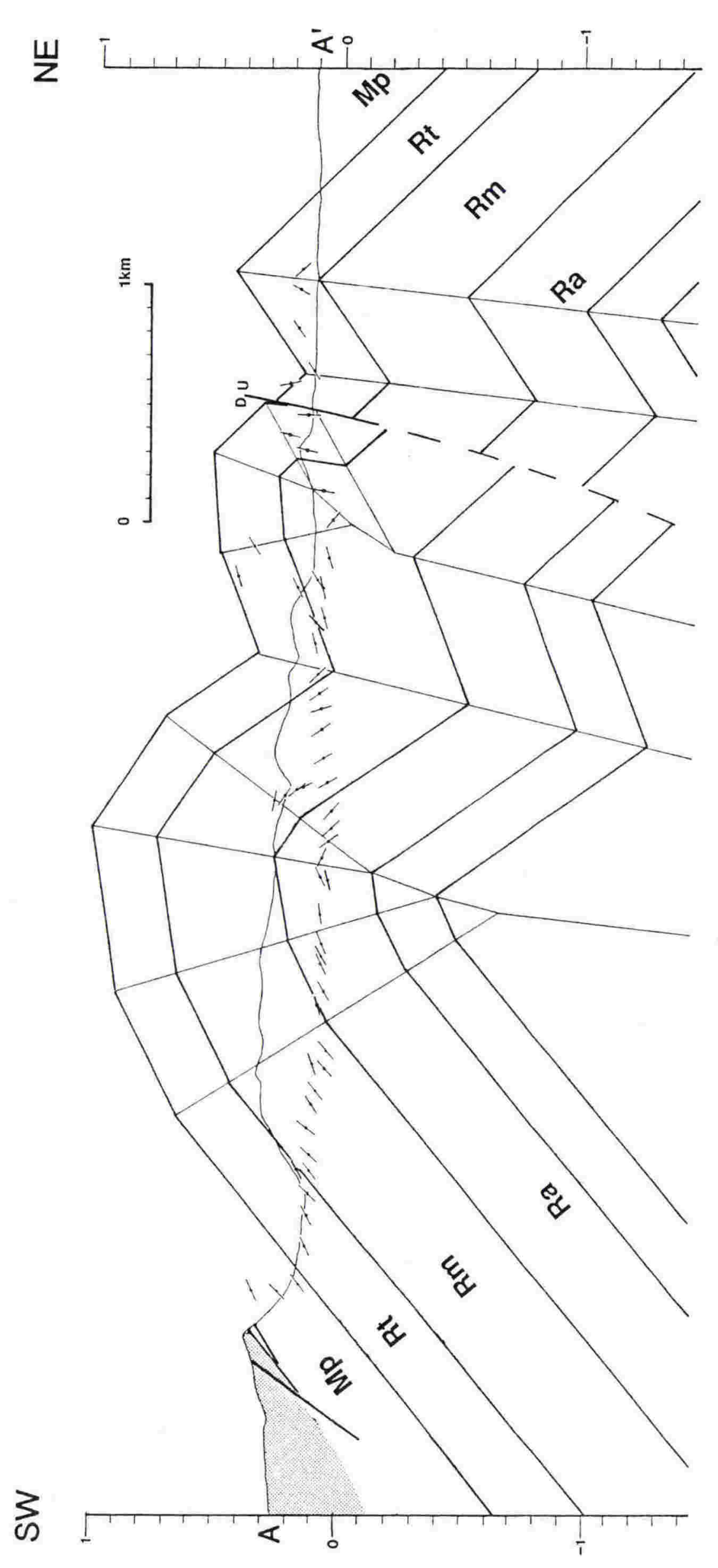

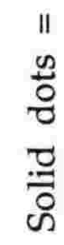

$\stackrel{\dot{1}}{4}$

ఏ

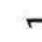

$\stackrel{0}{\Sigma}$

5

క్

을

ह

33

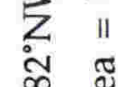

-

@

\& $\frac{\pi}{5}$

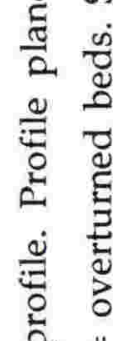

응

เป ปี

는

芹

$\sum$

ஸे

늘

总望 
or Tikihore Formation. A splay in the centre of the area-the Mangapekapeka Faultrepeats Mangaotanean-Piripauan beds. A small sliver of Piripauan rocks is sandwiched between Waitahaia Formation rocks in the south.

In the north of the area, the Haumurian-Teurian and Waitahaia formations are tectonically overlain by Mokoiwi Formation along the southwest-directed Aorangiwai Fault (Pick, 1962), a gently dipping thrust which forms the southeastern margin of the Mokoiwi klippe (section 1.3.1). Thin slivers of Eocene smectite mudstone occur at places beneath this fault, which has a stratigraphic separation of at least $5.6 \mathrm{~km}$.

\subsection{THE LOWER MATA RIVER FOLDS}

\subsubsection{Fold Profile Construction}

The folds in the lower Mata River area are non-cylindrical, so profile sections constructed at different places along the fold axes will have different geometries. The lower Mata River profile (Fig. 3.8 and profile section $\mathrm{A}-\mathrm{A}^{\prime}$; location shown on Map 1) was constructed by projecting bedding attitudes from the exceptionally well exposed Mata River section and nearby outcrops in the Mata valley. The data were plotted as poles to bedding on an equal-area projection (Fig. 3.9a), contoured (Fig. 3.9b), and a best-fit $\pi$-circle was selected. Small circles were constructed at $10^{\circ}$ and $20^{\circ}$ away from this $\pi$-circle to assess the cylindricity of the folds. It was found that $31.5 \%$ of the poles were more than $10^{\circ}$ away from the $\pi$-circle, and $6.3 \%$ were more than $20^{\circ}$ away.

Ramsay and Huber (1987) have suggested that folds in which less than $10 \%$ of bedding poles are more than $10^{\circ}$ away from the best-fit $\pi$-circle be classed as cylindrical, that folds in which more than $10 \%$ of the poles are more than $20^{\circ}$ away be classed as non-cylindrical, and that folds with distributions between these extremes be classed as sub-cylindrical. In terms of these suggestions, the folds defined by bedding attitudes in the Mata valley are sub-cylindrical; deviations from true cylindricity are generally less than $20^{\circ}$. On this basis, the pole to the best-fit $\pi$-circle was adopted as the average fold axis for the structures-the axis along which bedding attitudes could be projected to define the profile geometry. The orientation of this average fold axis matches fold axes derived from bedding measurements around individual fold hinges (Fig. 3.9c-f) satisfactorily.

Once the orientation of a suitable projection axis was determined, bedding attitudes, positions of stage boundaries, and positions of fold hinges were projected along it onto the (nernendicular) nenfillom plane to definothe fold 

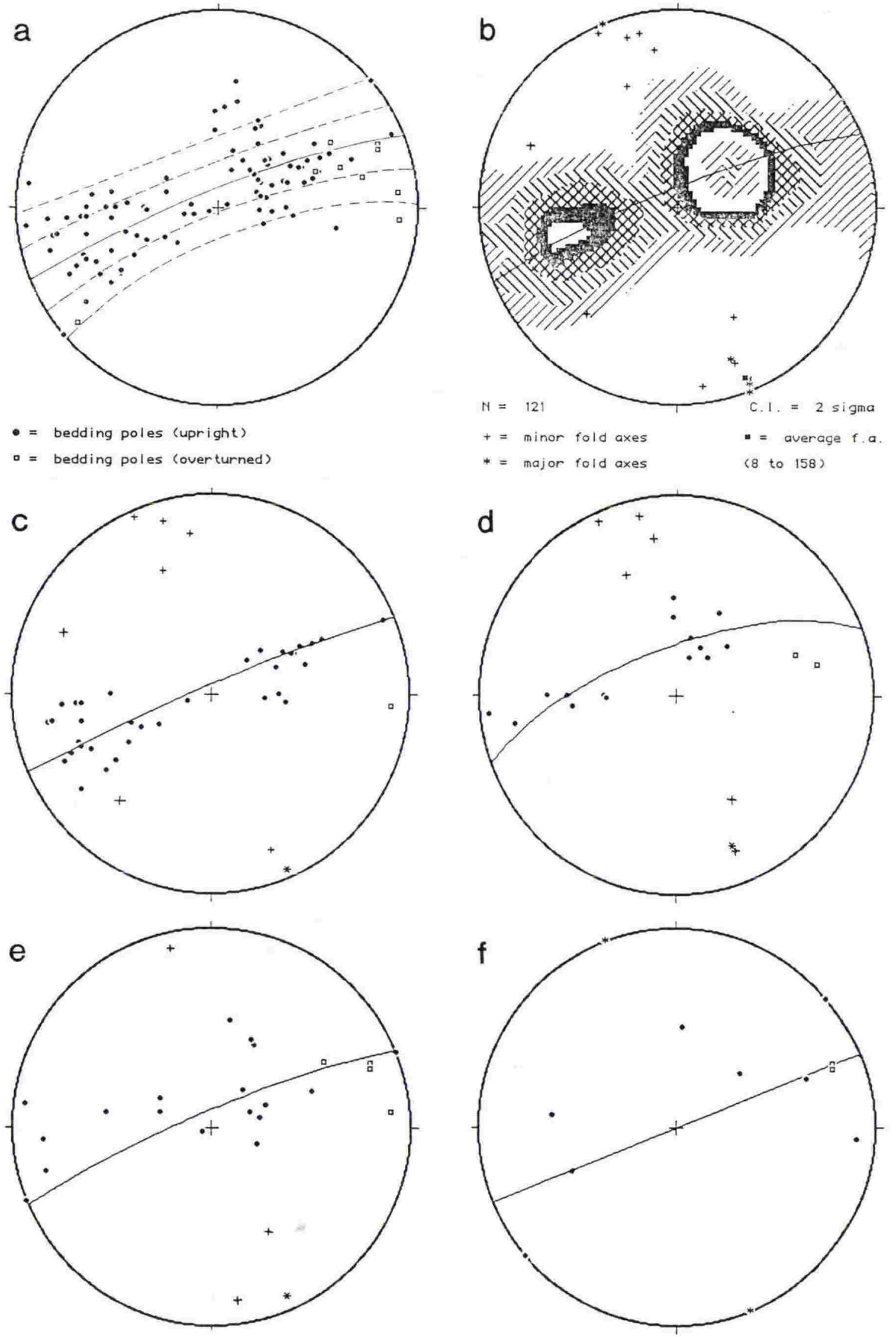

Figure 3.9 (continued over) 
along the Mata River are great in number and closely spaced, it was deemed unnecessary to use them all. Fifty-six points were projected, and their apparent dips in the profile plane are shown on Fig. 3.8. Figure $3.9 \mathrm{~g}$ and $\mathrm{h}$ show that the distribution of the data used is not significantly different from the distribution of the entire data set (Fig. 3.9a and b).

The projected bedding data show that the fold form may be approximated by a series of domains of uniform dip. This suggestion is reinforced by the fractured, angular fold hinges of the southwest anticline and syncline in the Mata River. Given these observations, it was considered appropriate to construct the fold profile using a kink geometry (e.g., Faill, 1969; Wojtal, 1988). At and below the exposure level, fold limbs were drawn as straight segments parallel to the apparent dips. The completed profile shows three anticlines and two synclines, referred to in the following as southwest, middle (anticline only) and northeast.

The positions of stage boundaries within the Tikihore Formation on the southwestern limb of the southwest anticline have been determined by $\mathrm{C}$. Mazengarb and M.G. Laird (C. Mazengarb, pers. comm., 1988; see Mazengarb, 1990). Samples (Y15/f128 and 129; see Appendix 2) and observations of Inoceramus specimens around the Teratan/Mangaotanean stage boundary on the northeastern limb of the southwest anticline constrain the position of that boundary to within approximately $\pm 40 \mathrm{~m}$ stratigraphically. From observations of the thick lower Mangaotanean sandstone (see section 3.2.3), the Mangaotanean/Arowhanan boundary was located to within approximately $\pm 5 \mathrm{~m}$. The positions adopted for these boundaries on the northeastern limb suggest that the Mangaotanean stage is approximately $10 \% \pm 10 \%$ thinner there than in the reference section on the southwestern limb. This difference is assumed to represent a thickness reduction across the entire northeastern limb, and to be due to attenuation of that limb during folding.

The southwest anticline is the fold best constrained by field data. The middle anticline and the folds northeast of it are less well constrained and were constructed using the following data and assumptions (refer to Fig. 3.8):

1) The dips of the limbs of the middle anticline are well constrained by bedding data. The thickness of the southwestern limb was taken to equal the thickness of the southwestern limb of the southwest anticline. The geometry of the hinge region was not constrained by any dip data, and it is portrayed as similar to the geometry of the basal Piripauan sandstone along trend on the northern side of the Makarika valley. (Fig. 3.3, Map 2). The steep northeastern limb was drawn at the minimum thickness needed for all the rocks southwest of a fault which cuts that limb to be 

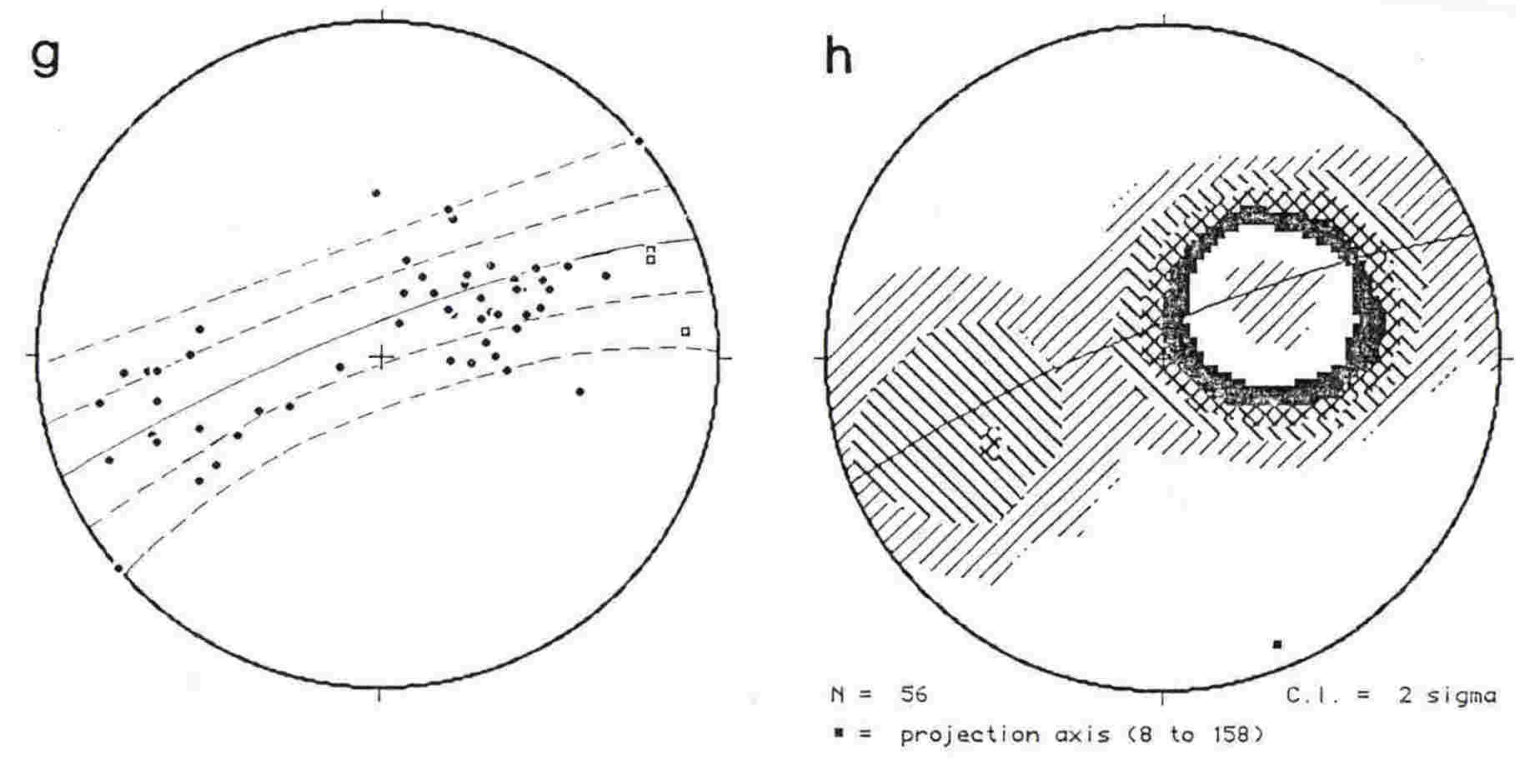

Figure 3.9 (continued): Equal-area projections, Mata River fold profile. a: Total bedding attitudes used to define projection axis, with best-fit $\pi$-circle and small circles at $10^{\circ}$ and $20^{\circ}$. b: Contoured version of $\mathbf{a}$, with major fold axes (c- $\mathbf{f}$ below), minor folds, and derived projection axis. c: Southwest anticline. d: Southwest syncline. e: Middle anticline. f: Northeast syncline/anticline pair. g: Data projected to construct profile. h: Contoured version of $\mathrm{g}$. 
Teratan, as required by field observations. This resulted in a $17 \%$ thinning of the northeastern limb, a figure considered reasonable given the approximately $10 \%$ thinning of the forelimb of the more open southwest anticline.

2) The northeast anticline was constructed to honour the bedding data and to preserve bed thicknesses, which were taken to equal the thicknesses on the southwestern limb of the southwest anticline. The northeast syncline was constructed by assuming constant bed thickness and a kink plane parallel to that of the northeast anticline. These assumptions constrained the dip of the southwestern limb of the northeast syncline (only one bedding measurement was made on that limb). Constant bed thickness may be a reasonable assumption as these folds are more open than the southwest anticline $\left(100^{\circ}\right.$ interlimb angle compared to $\left.86^{\circ}\right)$.

3) A fault, also mapped by Pick (1962) and Kingma (1965) northeast of the middle anticline (see also point 1) dips steeply southwest. Teratan rocks are exposed in the core of the northeast syncline, so the northeastern side of this fault is the upthrown side. The positions of the stage boundaries on northeastern side of the fault were not determined in the field, but they are constrained within a few tens of metres by the dips of the beds and the observation that all the exposed beds are Teratan (Moore, 1959; Pick, 1962; Kingma, 1965; Laing, 1971). The Piripauan/ Teratan boundary adopted here is about $200 \mathrm{~m}$ northeast of that adopted by the earlier workers, in an area with no exposure.

4) The position of the hinge plane between the overturned limb of the middle anticline and the limb of the northeast syncline southwest of the fault was drawn to honour the dip data and also to minimise the throw required on the fault. If the overturned limb of the anticline was longer, the fault would have a greater offset. The estimated minimum throw on the fault is $180 \mathrm{~m}$, northeast side up.

After the profile had been constructed, it was used to further constrain the positions of the stage boundaries on parts of the map where they were poorly known from field observations. The boundaries on the profile were back-projected onto the topography around the Mata valley. Southeast of the central parts of the profile line, the folds were projected using the average fold axis determined earlier $\left(158^{\circ} / 08^{\circ}\right)$. Observations of a thick sandstone marker horizon near the base of the Mangaotanean in two streams approximately 1.5 and $1.8 \mathrm{~km}$ northwest of the profile line, however, are consistent with a plunge of the northwestern side of the southwest anticline of approximately $0^{\circ}$. It was assumed that the plunge of the entire structure changes progressively northwestward, and all stage boundaries more than about $1 \mathrm{~km}$ northwest of the profile line were thus projected onto the map using a plunge of $0^{\circ}$. Still further 


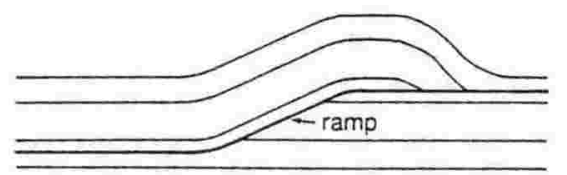

a

fault-bend folding

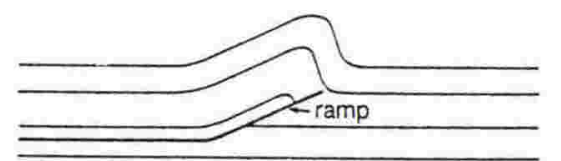

fault-propagation folding

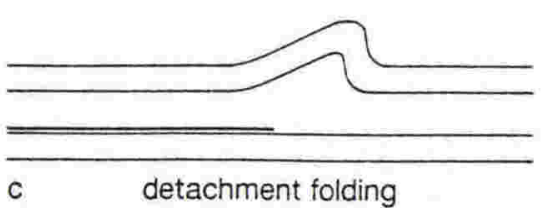

C detachment folding

Figure 3.10: Thrust-related folds (after Jamison, 1987). 
northwest, the folds may begin to plunge northwestward. The base of the HaumurianTeurian formation appears to define a gentle dome centred on the Mata valley (see Map 1 and sections $\mathrm{A}-\mathrm{A}^{\prime}, \mathrm{C}-\mathrm{C}^{\prime}$, and $\mathrm{F}-\mathrm{F}^{\prime}$ ). The earlier-folded Tikihore Formation must also have been affected by this later doming.

The Piripauan/Teratan and Teratan/Mangaotanean boundaries in the area southeast of the southwestern part of the profile line were back-projected using a plunge of $0^{\circ}$. Bedding attitudes in the Mata River and the position of the lowest Piripauan sandstone (known up to about $1.3 \mathrm{~km}$ southeast of the profile line) are consistent with a low plunge of the structure there. Also, the dip of the Piripauan is shallower in that area than further northwest on the same part of the structure (Fig. 3.3, Map 1). Stage boundaries adjacent to the northeastern part of the section plane (northeast of the normal fault) were projected without plunge, consistent with the structure in the Mata River in that area (see Fig. 3.9f and Map 1).

\subsubsection{Fold Geometry and Folding Mechanism}

The folds in Fig 3.8 are very similar to those that form by movement on thrust faults (e.g., Rich, 1934; Faill, 1969; Laubscher, 1977; Suppe, 1983, 1985; Boyer, 1986; Mitra, 1988, 1990). This similarity and the association of the folds with northeastdirected thrusts to their southwest (Map 1 and section 3.3) suggest that the lower Mata River folds are cored by, and were formed in response to movement on, northeastdirected thrust faults.

Folds which form in response to movement on thrusts fall into three genetic groups (Jamison, 1987): fault-bend folds, fault-propagation folds, and detachment folds (Fig. 3.10). Fault-bend folds (Rich, 1934; Suppe, 1983) form as hangingwall beds are thrust over a stepped fault surface cut across a non-deforming footwall. They have flat crests whose lengths depend on the amount of slip, and typically have moderately dipping forelimbs. Fault-propagation folds (Suppe and Medwedeff, 1984; Mitra, 1990) form as a propagating thrust loses displacement upward, with shortening on the fault being progressively transferred to shortening across the fold. These folds have narrow crests and steep or overturned forelimbs. Detachment folds (e.g., Laubscher, 1977) form by the decoupling and folding of competent beds above a ductile layer such as salt or overpressured shale, which deforms disharmonically in the the core of the structure. They may have a variety of shapes, depending on the relative thicknesses of stiff and ductile units (Jamison, 1987).

The lower Mata River folds have narrow crests and moderately to steeply dipping forelimbs, indicating fault-propagation or detachment folding rather than fault-bend 
folding. The exposed Raukumara strata in the lower Mata River area are of uniform composition, being centimetre- to decimetere-bedded alternating sandstone and mudstone (section 3.2.3). Comparison with the stratigraphy of the Mangaoporo area, 20 $\mathrm{km}$ to the north (see section 2.2.2.1), suggests that the Raukumara beds are likely to be underlain by a thick (thousands of metres) succession of very similar Clarence Series rocks; a suitably ductile horizon above which detachment folds could form is unlikely to be present. Therefore, the lower Mata River folds are most probably faultpropagation folds formed above blind thrusts.

\subsubsection{Geometric Models of Fault-Propagation Folds}

For kink-style sections across fault-propagation folds to balance (e.g., Dahlstrom, 1969; Hossack, 1979; Woodward et al., 1989), it can be shown that there are specific geometric relationships between ramp dips, fold limb dips, fold interlimb angles, and bed thickness ratios. Suppe and Medwedeff (1984) and Suppe (1985) presented an analysis of fault-propagation folds in which bed thicknesses were kept constant, and folding was accomplished by flexural slip or flow. They showed that for a given ramp dip there is only one interlimb angle which results in a balanced structure, assuming no net shear into the fold. Jamison (1987) extended these analyses to include folds in which forelimb thickness had changed as a result of folding, and found that thickness changes allow a variety of interlimb angles for a given ramp dip.

Mitra (1990) analysed the evolution of fault-propagation folds with constant or progressively tightening interlimb angles, and allowed bed thickness to vary anywhere in the fold. His results showed that assuming no net shear, thickening of upper units during the early stages of fold evolution is followed by thinning-which observations of natural folds suggest will be localised in the forelimb-if the fold progressively tightens. Mitra's conclusions were similar to Jamison's in that "... a wide variety of kinematically and geometrically balanced fold geometries can be generated by allowing small thickness changes in some of the units" (Mitra, 1990, p. 928).

In the above models, a fault-propagation fold forms as a propagating flat changes trajectory (becoming a ramp) and loses displacement upward. The forelimb lengthens as the fault propagates, and the beds behind the anticlinal axial surface bend into parallelism with the ramp as they are transported onto it. Outcrop and experimental observations led Chester and Chester (1990) to model folds which had formed at points along propagating ramps. Because they do not nucleate at flat-to-ramp bends, the backlimb dips of these folds are not necessarily parallel to the dips of their underlying ramps. When thickness changes are taken into account, the Chester and Chester (1990) 


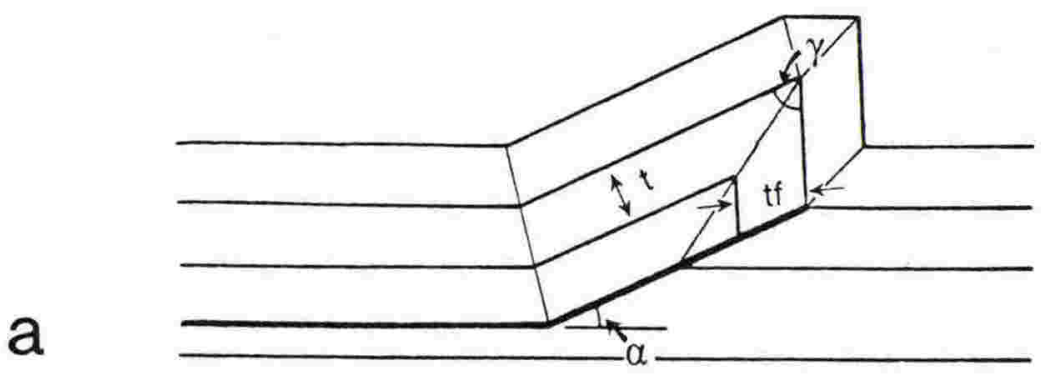

FAULT-PROPAGATION FOLDING

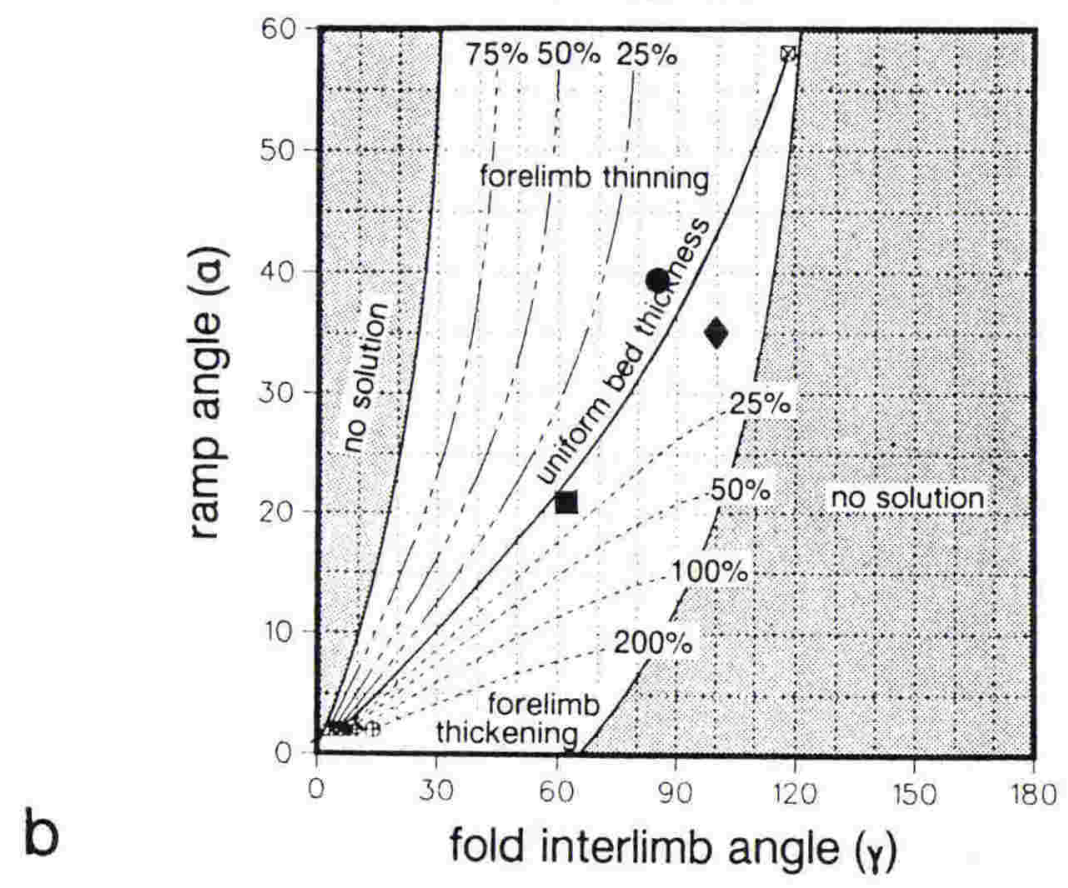

Figure 3.11: a: Parameters used in the geometric analysis of fault-propagation folds, after Jamison (1987). b: Graph from Jamison (1987) showing forelimb thickness change predicted by his balanced model for various values of ramp angle and interlimb angle. Predicted thickness changes are shown for southwest (dot), middle (square) and northeast (diamond) Mata River anticlines. 
model results in a wider variety of fault-propagation fold geometries than the models of Jamison (1987) and Mitra (1990).

\subsubsection{Geometric Analysis and Fault Geometry at Depth}

The three anticlines on the lower Mata River profile (Fig. 3.8) were initially analysed using the fault-propagation fold model of Jamison (1987), which takes into account thickness changes and assumes that folds form with backlimbs parallel to their underlying ramps. The geometry of such folds is described by the ramp angle or backlimb dip $(\alpha)$, the interlimb angle $(\gamma)$, and the forelimb thickness change $(t f / t)$ (Fig. 3.11a). The backlimb dips and interlimb angles of the three Mata River anticlines were plotted on Jamison's (1987) graph relating these three parameters (Fig. 3.11b) to determine the forelimb thickness changes predicted by the model. The model predicts about $10 \%$ forelimb thinning for the southwest anticline-in good agreement with the observed value -and about the same amount of thickening of the poorly constrained forelimbs of the middle and northeast anticlines.

Sections across each fold were constructed using the model geometry in an attempt to determine the configurations of the faults beneath them. The construction of fully restorable sections such as Fig. 3.11a requires a knowledge of the elevation at which a reference horizon returns to horizontal on either side of the structures (the 'regional' elevation). Whether the Tikihore beds in the lower Mata River area become horizontal outside the folds is unknown because of the truncation of the folds at the back by the Ihungia fault system, the angular unconformity beneath the overlying HaumurianTeurian beds, and the post-fold thrusting of younger rocks to the northeast (section 6.4.3.1). The regional level adopted to allow construction of the sections is slightly below the highest possible level allowed by the position of the top of the Teratan in the northeast syncline (Fig. 3.8); if it was much higher, horizontal beds would be present on the backlimb of the northeast anticline where dipping beds are observed. This regional level places the top of the Teratan at an elevation of $-250 \mathrm{~m}$ (on the southwest side of the late normal fault) outside the folds.

Completed fault-propagation fold models for the lower Mata River anticlines are shown in Fig. 3.12. The position of the fault beneath each fold is controlled by the 'regional' level and the fold geometry. The fault tip lies at the intersection between the forward kink plane and the stratigraphic horizon at which the flat crest of the fold disappears (see Fig. 3.11a). From that point, the fault is drawn parallel to the backlimb until the rear kink plane is reached, whereupon it bends into a horizontal detachment. In the Mata River folds, the point at which the fold crest disappears is not as well constrained as it is in the model, and thus there is some flexibility in the positioning of 
a

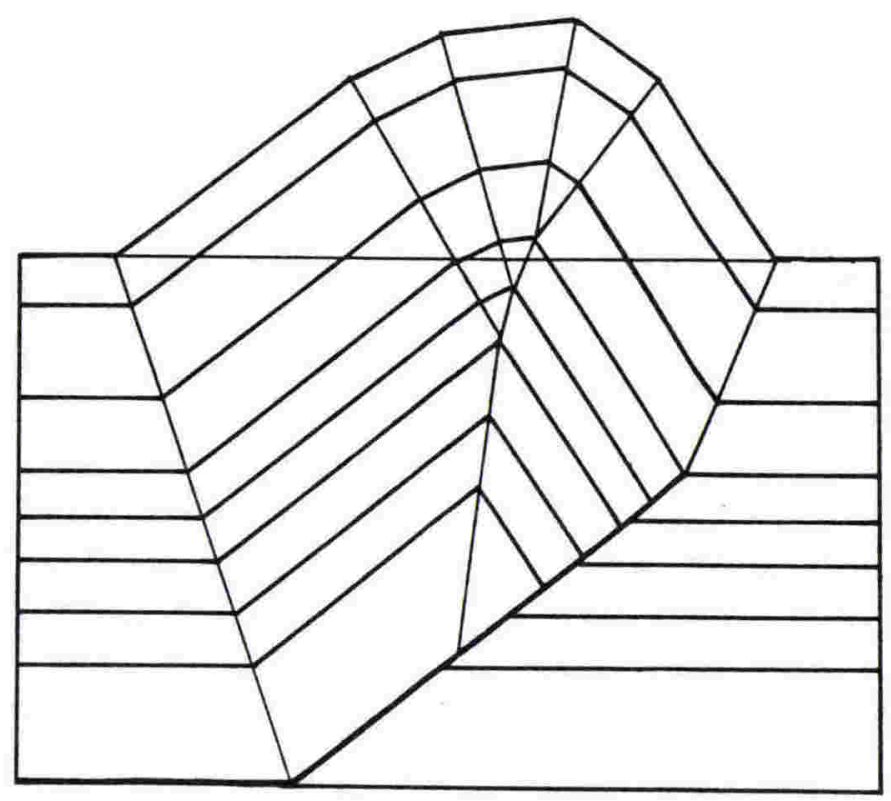

b

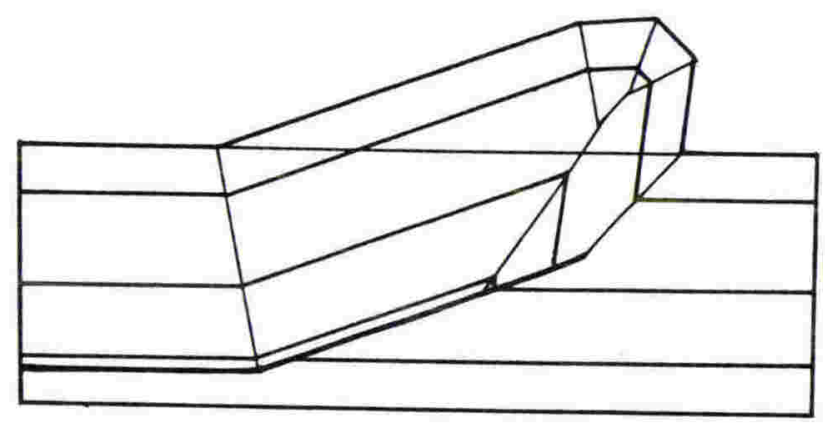

C
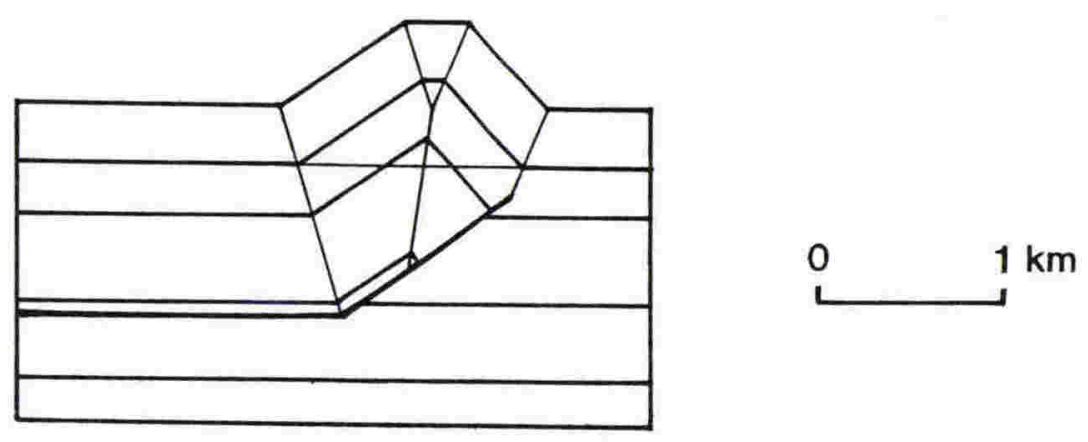

Figure 3.12: Sections across the southwest (a), middle (b), and northeast (c) anticlines, constructed assuming the same regional stratigraphic level (thin horizontal line) and the initiation of folding at the bend in the fault, as modelled by Jamison (1987). 
the fault tips. The southwest anticline has a number of crest segments, and the fault tip beneath it was placed at the horizon where the highest of these disappears (Fig. 3.12a). The middle anticline likewise does not have a flat crest, but two dipping segments which approximate the hinge geometry in the Makarika valley (see section 3.4.1). The fault tip beneath this fold (Fig. 3.12b) was positioned at the horizon where the gently dipping segment disappears. Bedding observations (Fig. 3.8) do not define a flat crest on the northeast anticline. A crest was assumed to appear just above the exposure level, in the lowest possible position allowed by the bedding data. Consequently, the fault tip in Fig. 3.12c is also in the lowest allowable position.

If the lower Mata River anticlines had formed solely by this type of faultpropagation mechanism, with each fold having one fault in its core and the footwalls of each fault remaining undeformed, it should be possible to combine the three structures in Fig. 3.12 into the total fold geometry (Fig. 3.8) in a kinematically viable configuration. Figure 3.13 shows that this is not the case. The fault beneath the southwest anticline is forward of the fault beneath the middle anticline, so neither a forward- nor a backward-stepping sequence of faulting would result in the geometry observed at the surface because of interference between the two anticlines; beds folded by motion on the first fault would be refolded by motion on the second. This configuration is thus not kinematically viable.

Because the southwest and middle anticlines are so close together and interfere in this way, it is likely that both are underlain by the same ramp. If this is the case, then the middle anticline would have formed at some point on a pre-existing ramp rather than as a consequence of a fault bending up from a flat, and the Chester and Chester (1990) fault-propagation model is appropriate. This model is shown in Fig. 3.14. Its geometry is completely specifed by

$$
\cot \alpha+2 \tan \theta-\cot \gamma-2(t f / t) \csc \gamma+(t f / t)^{2}[\cot (2 \theta+\gamma-\alpha)-\cot \gamma]=0
$$

(Chester and Chester, 1990, equation 4), where $\alpha=$ ramp dip, $\gamma=$ interlimb angle, $2 \theta=$ backlimb dip, and $t f / t$ is the ratio of forelimb to backlimb thickness. If the backlimb is parallel to the ramp, $2 \theta=\alpha$ and equation 3.1 reduces to

$$
\cot \alpha+2 \tan (\alpha / 2)-\cot \gamma-2(t f / t) \csc \gamma=0,
$$

which is identical to a combination of equations 9 and 10 of Jamison (1987) with the relation

$$
\cot \gamma_{1}=(t f / t+\cos \gamma) / \sin \gamma
$$



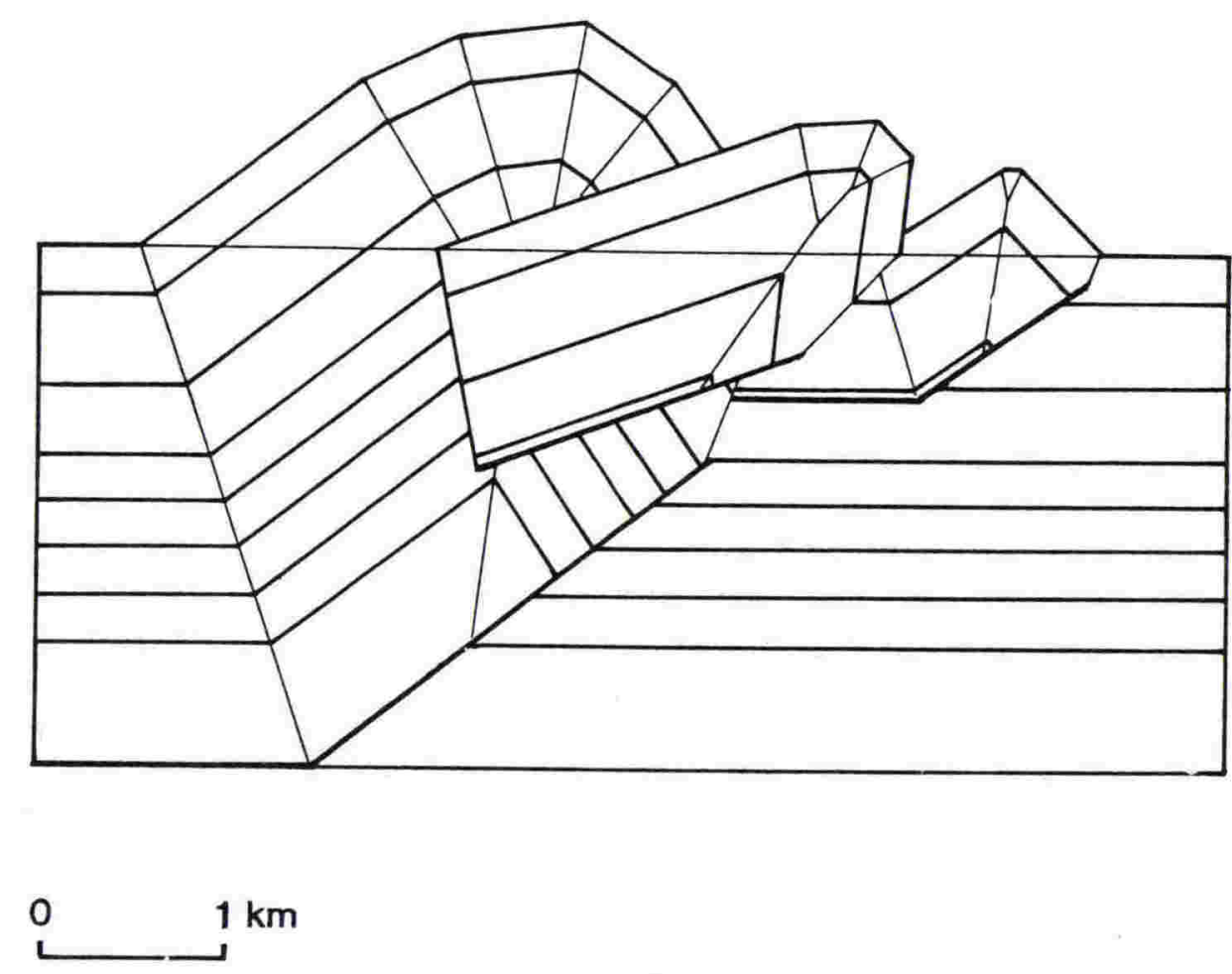

Figure 3.13: Combination of the three fault-propagation folds in Fig. 3.12 into the Mata River structure. Occurrence of fault beneath middle anticline behind fault beneath southwest anticline shows that the structure cannot have been generated by three successive, independent, propagating ramps.

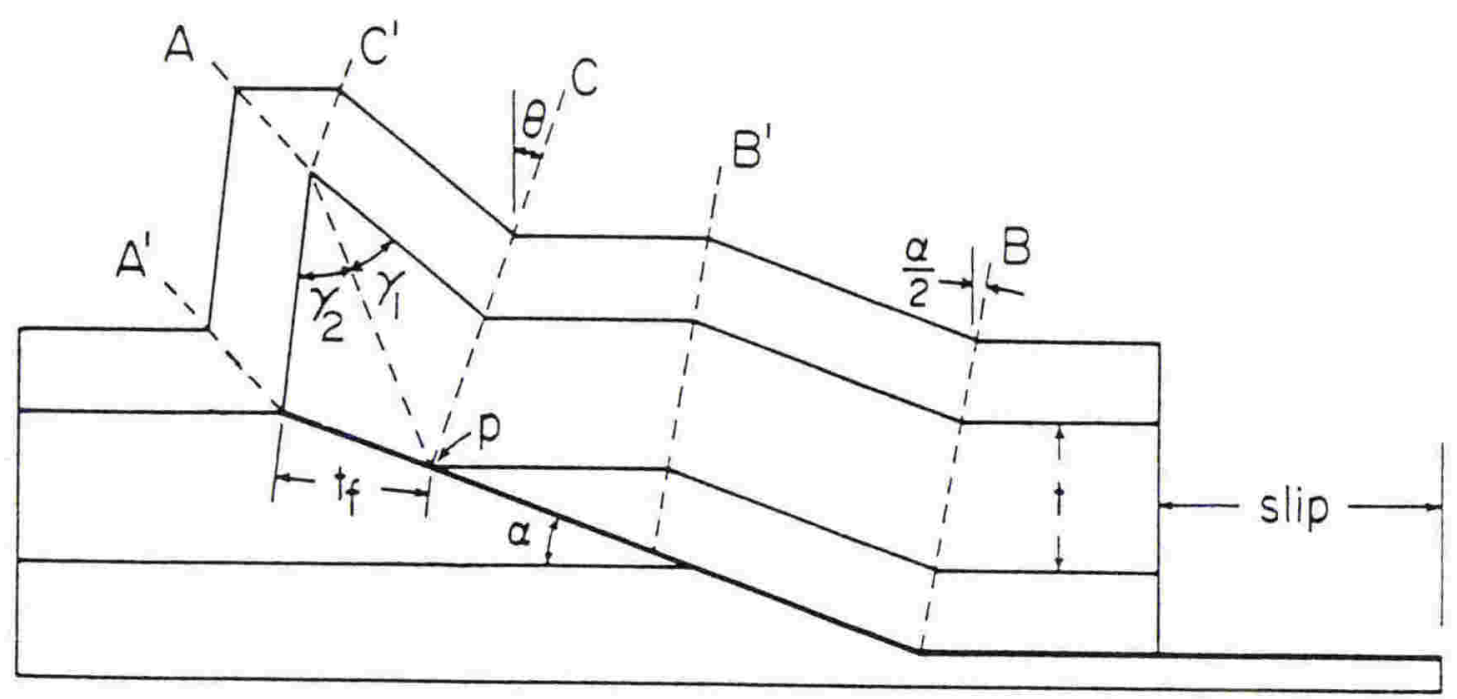

Figure 3.14: Geometric model of a fault-propagation fold which initiated at a point $p$ on a pre-existing ramp, after Chester and Chester (1990). Kink-band boundaries are labelled A, B, C. Interlimb angle $\gamma=\gamma_{1}+\gamma_{2}$. 
(Chester and Chester, 1990, equation A8), where $\gamma=\gamma_{1}+\gamma_{2}$ (see Fig. 3.14). Thus, for the special case in which the ramp is parallel to the backlimb, the Chester and Chester model has an identical geometry to the Jamison model. Folds generated by the two mechanisms can be distinguished, however, by the lengths of their backlimbs-Jamisonmode folds have backlimbs as long as their underlying ramps, whereas Chester-andChester mode folds have short backlimbs (see Fig. 3.14). The southwest anticline is a Jamison-mode fold; if it were not, horizontal beds would appear on the backlimb where dipping beds are observed (see Fig. 3.8).

Once the ramp dip angles have been determined using equation 3.1 , the construction of a Chester-and-Chester style section proceeds in a similar fashion to that of a Jamison-style one. The fault tip is located as before, but the fault is projected down using the calculated ramp dip, not the fold backlimb dip. At the intersection of the anticlinal hinge with the fault (the fold initiation point), the beds become horizontal across a synclinal kink surface $(C$ in Fig. 3.14), while the fault continues down to the point where it bends into a horizontal detachment. The position of this bend, unlike in the Jamison model, is not constrained by the length of the backlimb. Between this bend and the upper horizontal beds, the strata are parallel to the ramp. They become horizontal across two parallel kink surfaces (B and $B^{\prime}$ in Fig. 3.14), the distance between which is equal to the maximum slip on the fault.

The middle anticline is shown as a Chester-and-Chester style fault-propagation fold in Fig. 3.15. The ramp dip beneath it $\left(27^{\circ}\right)$ was determined using the observed backlimb dip and interlimb angle and the assumed forelimb thickness (83\%; see section 3.4 .1 ) in equation 3.1. The maximum slip on this fault-and hence the shortening across the structure-is $880 \mathrm{~m}$. The fault bend was drawn at an arbitrary depth. The restored version of the section shows that the structure balances very well; the shortfall in length in the upper two horizons is due to the fold crest being composed of two dipping segments rather than the theoretical single horizontal one.

If the fault beneath the middle anticline is a continuation of the fault beneath the southwest anticline, as surmised earlier, then the two fault segments meet at a bend somewhere beneath the southwest syncline. This bend would have been the original tip of the fault responsible for the southwest anticline, from which the segment beneath the middle anticline subsequently propagated. Its position is not obtainable merely by combining the fault-propagation fold constructions for the two anticlines (Fig. 3.12a and Fig. 3.15) because the fault beneath the southwest anticline in Fig. 3.12a is too low. That fault was positioned assuming that the present structural elevation of the anticline was due to fault-propagation folding alone; however, the anticline was transported an 

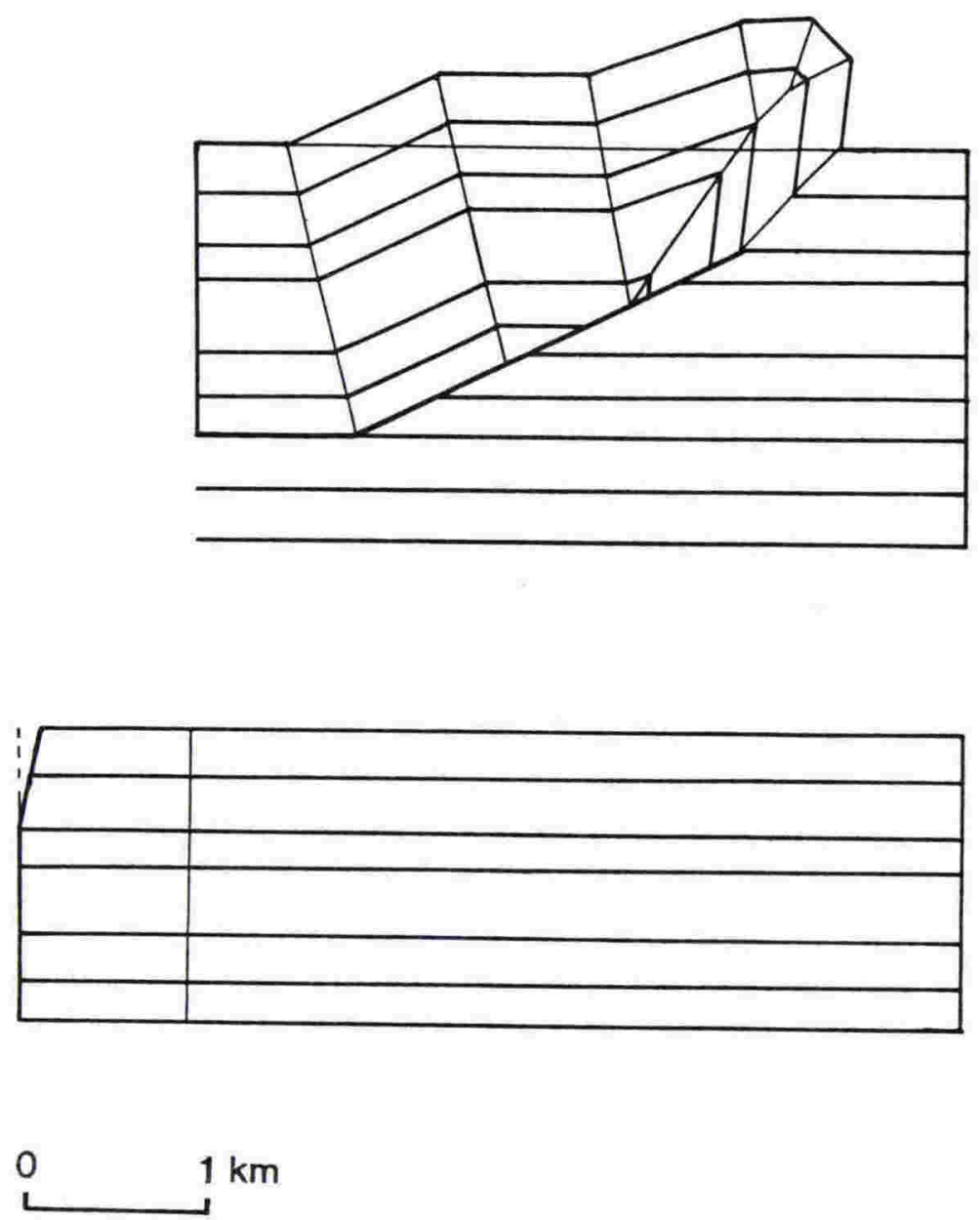

Figure 3.15: Deformed- and restored-state sections across the middle anticline constructed using the fault-propagation fold model of Chester and Chester (1990). Triangular area on upper left of restored section shows shortfall in length of upper horizons due to fold crest geometry. 
extra $880 \mathrm{~m}$ after its formation. To obtain the correct position for its underlying fault, the southwest anticline must first be restored to its pre-middle anticline elevation.

In Fig. 3.16, the original elevation of the southwest anticline was obtained by slipping its axial plane $880 \mathrm{~m}$ down a $39^{\circ}$ ramp. The position of the southwestern fault segment was then obtained by placing its tip at the point where the middle fault segment intersects the forward kink plane. This results in the tip being approximately at the horizon where the gently dipping fold crest disappears, and the section thus balances very well. Again, there is a slight shortfall in the lengths of the upper horizons due to the rounded crest geometry. Maximum fault slip and total shortening across this structure are $550 \mathrm{~m}$.

The post-middle anticline configuration can now be generated by pushing the southwest anticline up the fault shown in Fig. 3.16. The middle anticline initiates at point $\mathbf{p}_{\mathbf{i}}$ along the dashed kink surfaces shown. Interference between its rear kink band and the forward kink band of the southwest anticline produces the southwest syncline. After $880 \mathrm{~m}$ of transport, the middle anticline reaches its present position (point $\mathbf{p}_{\mathrm{f}}$ in Fig. 3.16) and the structure has the configuration shown in Fig. 3.17a.

Although Fig. 3.17a restores reasonably well (Fig. 3.17b), it has a number of features that require further discussion. Firstly, Fig. $3.17 \mathrm{~b}$ shows that there is a marked shortfall in the lengths of the upper horizons compared to those in the middle of the section. This is due partly to a combination of the shortfalls around the southwest and middle anticlines discussed earlier, and partly to a space problem in the upwardnarrowing southwest syncline. This latter is not really significant at the exposure levelthe shortfall at the top of the Mangaotanean is only about $30 \mathrm{~m}$ more than the combination of the shortfalls around the anticlines-but it becomes more acute upward, being about $90 \mathrm{~m}$ at the top of the Teratan. It may eventually be relieved by out-of-thesyncline thrusting (e.g., Butler, 1982).

Secondly, the hinge plane of the southwest anticline has travelled a short distance past the upper fault bend. This should have resulted in the backlimb beds northeast of the dashed line (Fig. 3.17a) dipping at $27^{\circ}$, as they now lie above the middle fault segment. However, these beds were observed dipping around $39^{\circ}$ (Fig. 3.8). This apparent inconsistency can be resolved if the regional stratigraphic elevation adopted is slightly higher than that used in the construction of these sections. A higher level would result in the fault being slightly higher than that shown, and the amount of transport being slightly less. The final position of the southwest anticline hinge plane would then be southwest of the fault bend, allowing the entire backlimb to dip at $39^{\circ}$. 

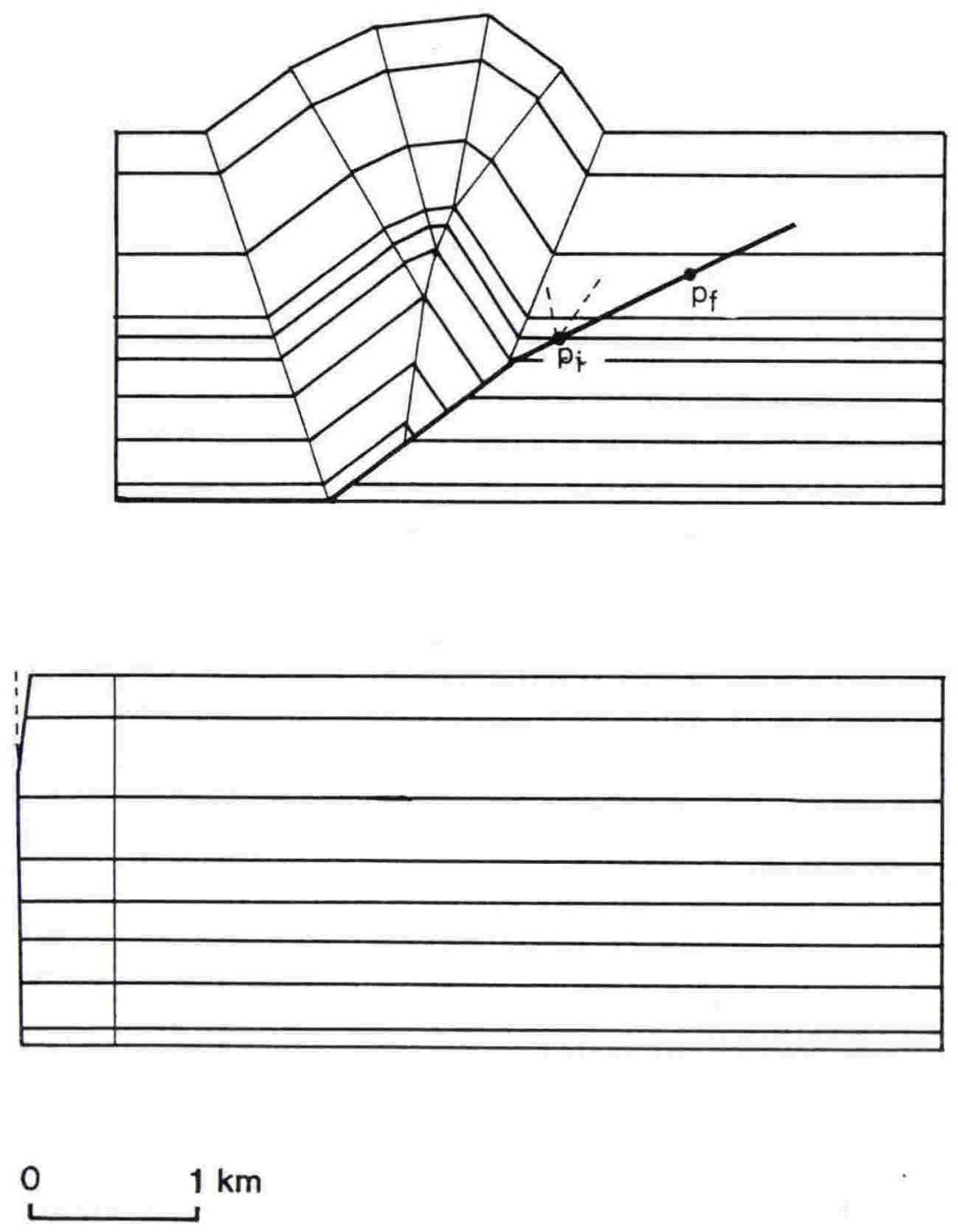

Figure 3.16: Deformed- and restored-state sections across the southwest anticline. Structural elevation of deformed-state section obtained by slipping present-day structure $880 \mathrm{~m}$ down a $39^{\circ}$ ramp. Position of tip of southwestern fault segment taken at intersection of (future) middle fault segment with forward kink surface. $p_{i}$ and $p_{f}$ are initial and final positions of initiation point of middle anticline; dashed lines are its future kink surfaces. 
Thirdly, because the beds in the forelimb of the southwest anticline travel over a fault bend during growth of the middle anticline, they might be expected to change dip. Jamison (1987) produced a balanced model for fault-propagation folds that undergo transport through fault bends in which pre- and post-transport forelimb cutoff angles are related by

$$
\tan \theta_{1}=\tan \theta_{0} /\left[1-2 \tan \theta_{0} \cdot \tan (\beta / 2)\right]
$$

(Jamison, 1987, equation 23), where $\theta_{0}$ is the initial cutoff angle, $\theta_{1}$ is the final cutoff angle, and $\beta$ is the fault bend angle. If the geometric evolution represented by Figs. 3.16 and $3.17 \mathrm{a}$ is correct, the southwest anticline had an initial forelimb cutoff angle (against the southwestern fault segment) of $86^{\circ}$. Using this value and the $12^{\circ}$ fault bend angle in equation 3.4, its predicted final forelimb cutoff angle (against the middle segment) is $98^{\circ}$. The final cutoff angle in Fig. $3.17 \mathrm{a}-$ where there has been no change in dip across the fault bend-is $97^{\circ}$, matching this prediction very closely.

This model also predicts that forelimb thickness will change across a ramp bend such that

$$
t f / t=\sin \theta_{1} / \sin \theta_{0}
$$

(Jamison, 1987, equation 24). Using the appropriate values for $\theta_{0}$ and $\theta_{1}, t f / t$ for the transported southwest anticline is 0.99 ; there is effectively no change in forelimb thickness across the fault bend.

Fourthly, a comparison of Figs. 3.16 and 3.17a shows that the bed lengths on the forelimb of the southwest anticline are longer after the formation of the middle anticline than before. When Fig. 3.17a is restored, this gives rise to bed lengths in excess of the expected bed lengths obtained by adding the shortening figures for the southwest and middle anticlines (shown by the dashed line in Fig. 3.17b). Lengthening of the forelimb beds arises because the crest of the southwest anticline has maintained its shape after travelling across the fault bend. Although Jamison's (1987) model predicts essentially no change in forelimb dip or thickness for this example, it was constructed with the assumption that there is no change in the thickness of the structure measured perpendicular to the fault as the forelimb beds cross the fault bend. To obey this assumption in the present example, the fold crest would have to broaden and flatten as the bend was crossed. The crest geometry in Fig. 3.16 should thus be higher and narrower than that shown. 


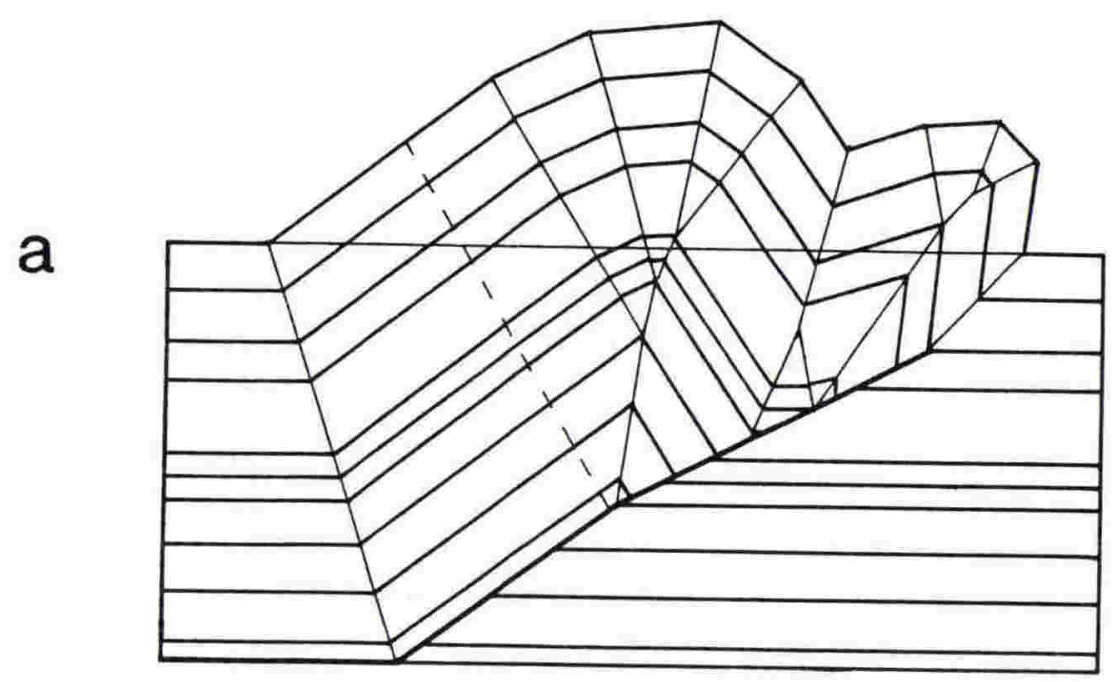

b
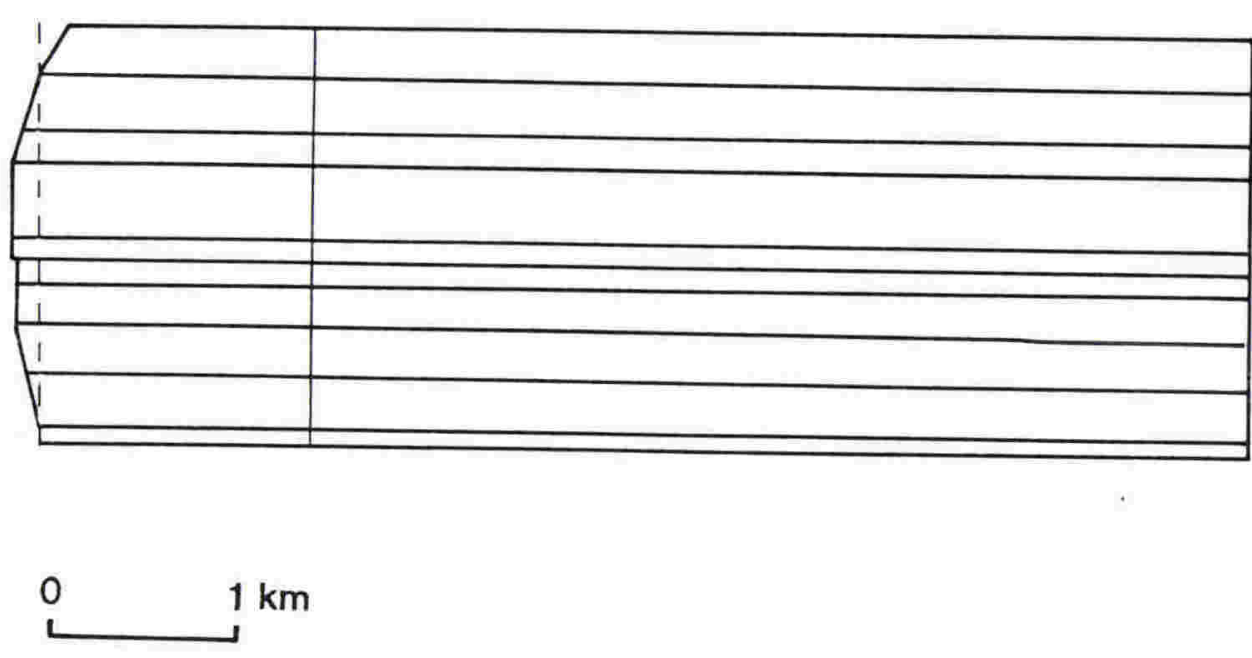

Figure 3.17: Deformed (a) and restored (b) sections across the southwest and middle anticlines assuming sequential fold formation on a single, propagating thrust ramp of the geometry shown in Fig. 3.16. Dashed line on a shows position and orientation of expected kink plane due to travel of backlimb beds over fault bend. Dashed line on $\mathbf{b}$ shows bed lengths expected by combining shortening across southwest and middle anticlines (Figs. 3.15 and 3.16). See text for further discussion. 
The exact pre-transport shape of the crest of the southwest anticline and the position of the fault bend are interdependent; one must be known before the other can be derived. Because construction of a kinematically viable section across the present structure requires knowledge of both of these variables, the geometry of the structure is underconstrained. Construction of a viable section would therefore be a matter of trial and error. However, because the misfits in bed lengths are small $(10 \%$ of total shortening or $3 \%$ of deformed-state length), Fig. $3.17 \mathrm{a}$ is a close approximation to a viable section. Its subsurface configuration was thus used in sections $A-A^{\prime}$ and $C-C^{\prime}$ and is referred to in subsequent discussions.

It now remains to determine the geometry beneath the northeast anticline. Substitution of the backlimb dip, interlimb angle and assumed limb thickness ratio of that structure into equation 3.1 gives a ramp angle of $43^{\circ}$. As this is not parallel to the fold backlimb $\left(35^{\circ}\right)$, it is appropriate to model this fold using the Chester and Chester (1990) geometry.

The northeast anticline is shown as a Chester-and-Chester-style fault-propagation fold in Fig. 3.18, which is a section across the entire lower Mata River structure after restoration of the late normal fault in the northeast syncline. The position of the thrust beneath the northeast anticline is given by the intersection of the backlimb kink plane and the anticlinal axial plane. The fault tip is positioned up dip ( $43^{\circ}$ ) from this point at the horizon where the fold crest dies out, which is assumed to be just above the exposure level as in Fig. 3.12c. The tip position gives the elevation of the undeformed beds northeast of the structure, from which the fault slip and shortening $(600 \mathrm{~m})$ are obtained. Because the crest of the northeast anticline has the 'theoretical' geometry, a section across that fold is 'perfectly' balanced. Its addition to the structure in Fig. 3.17a only alters the restoration above the level where the forelimb kink of the middle anticline and the backlimb kink of the northeast anticline intersect, creating a space problem in the northeast syncline similar to that in the southwest syncline discussed earlier.

The completed section, then, shows that the geometry of the lower Mata River structure can satisfactorily be attributed to flexural-slip, fault-propagation folding on two independent, blind thrusts which transported their hangingwalls northeastward. The total shortening accomodated by these thrusts, assuming the geometry in Fig. 3.18, is approximately $2.1 \mathrm{~km}(26 \%)$. 

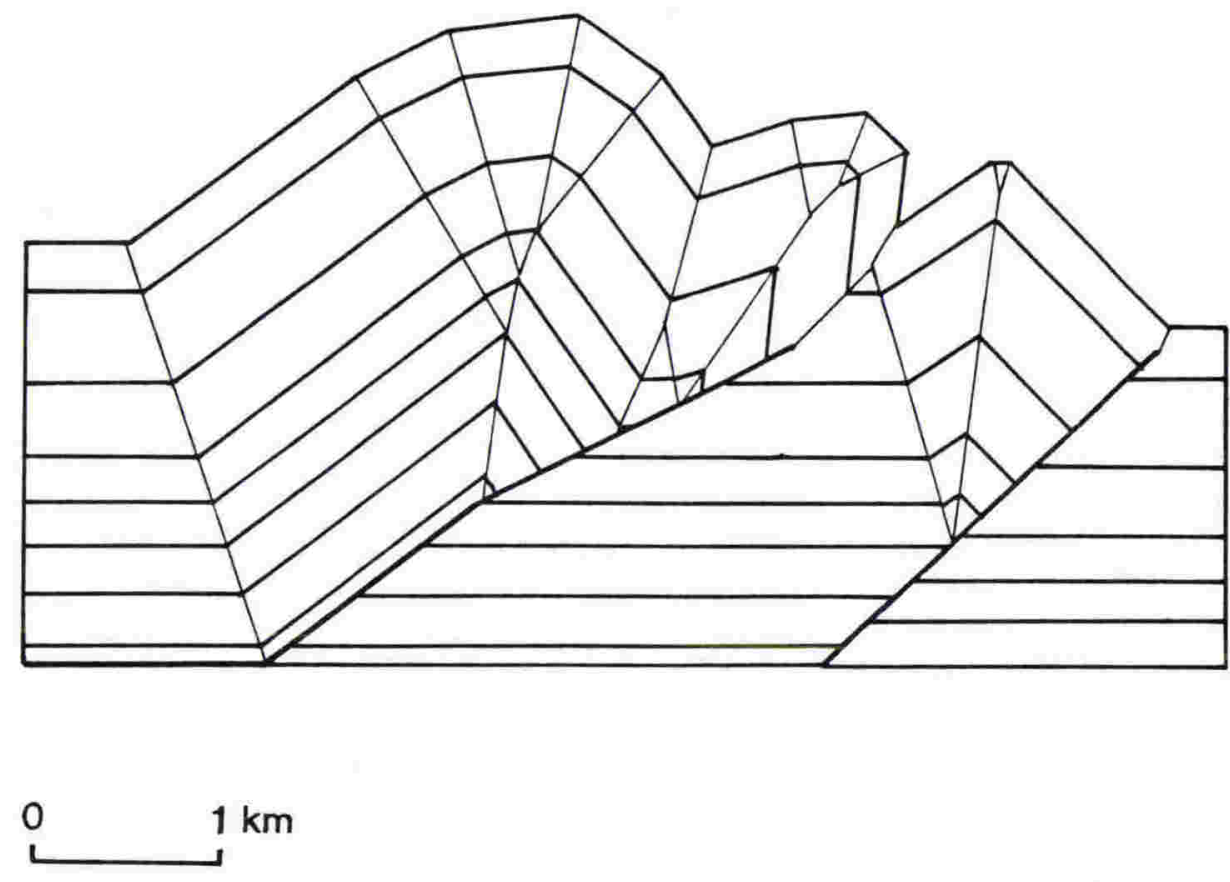

Figure 3.18: Section across the lower Mata River folds after restoration of the late normal fault, constructed by combining Fig. 3.17a with a Chester-and-Chester style fault-propagation fold model for the northeast anticline (see text). 
Mitra (1990) observed that many fault-propagation folds, when traced along trend, tighten in sympathy with increasing displacement on their underlying thrusts. If alongstrike variations reflect different stages in the development of these structures, this observation implies that fault-propagation folds tighten with time and increasing displacement. The geometric models of Jamison (1987), Chester and Chester (1990), and Mitra (1990) suggest that if the fold interlimb angle decreases while the ramp angle remains constant, the fold will undergo changes in bed thickness. Early thickening, when the fold has a large interlimb angle, will be superseded by thinning as the fold tightens. Most or all of the later thinning is likely to occur on the steeply dipping forelimbs (Jamison, 1987; Mitra, 1990). If the Mata River folds tightened during fault propagation, then minor structures in the lower Mata River section could be expected to provide evidence of these thickness changes, as well as the layer-parallel simple shear that is a consequence of folding by flexural slip.

On the backlimb of the southwest anticline, folds and contraction faults suggest both thickening and layer-parallel shear. A folded interval in the mid-Teratan (Fig. 3.19) has thickened the section by perhaps a few tens of metres. Contraction faults have offsets ranging from millimetres to a few metres. They are generally at low angles to bedding, and may parallel it for much of their length. They do not, therefore, result in much thickening. The shear zone shown in Fig. 3.20a is the most obvious fault on the backlimb and may have tens of metres of displacement across it, but it has not thickened the section by more than $35 \mathrm{~m}$ : it is that distance above the base of the Teratan, and it has Teratan fossils in its hangingwall. The sense of shear on the greatest number and larger offset examples of contraction faults is southwest over northeast-in agreement with the shear sense expected on the southwestern limb of an anticline-but many have the opposite sense (e.g., Fig. 3.20b). Offsets on these are generally smaller, the greatest seen being about $1 \mathrm{~m}$. Collectively, contraction faults probably do not account for much thickening, but they are likely to accomodate considerable layerparallel shear.

Exposures on the forelimb of the southwest anticline show evidence of thickening followed by thinning. At Y15 65454752, there is an interval of downward-facing folds of opposing symmetries in steeply dipping Mangaotanean strata (Fig. 3.21). The orientations of these folds indicate thickening of the forelimb. However, precise locations of stage boundaries across the anticline show that its forelimb is thinner than its backlimb. Thinning of the forelimb is presumed to have taken place after folding along a system of approximately bedding-parallel, anastomosing fractures, many of which operated as extension faults. Fracturing is more intense in the forelimb than in 


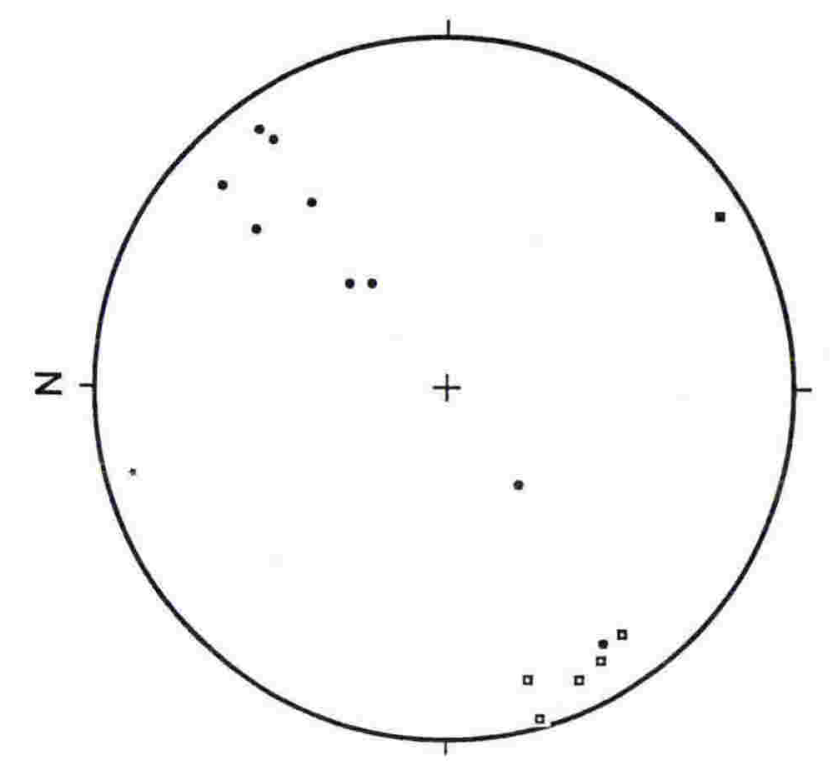

产

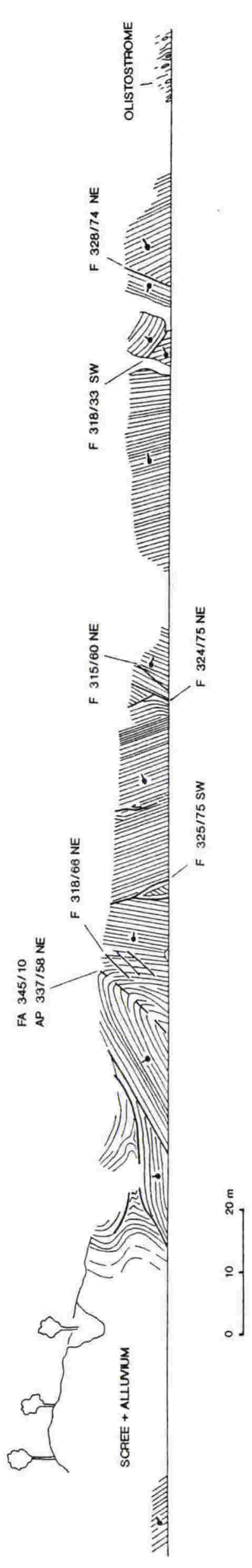

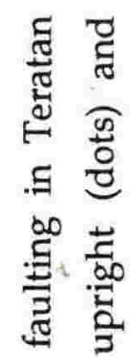

등

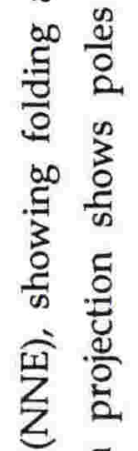

L

号节惫

है

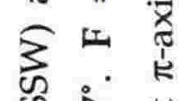

๙

ᄂ

离 导

을

요 त्ञ

竎

त 준

节 $\dot{0}$

苋

2.

它

‥ हี

官

竞 

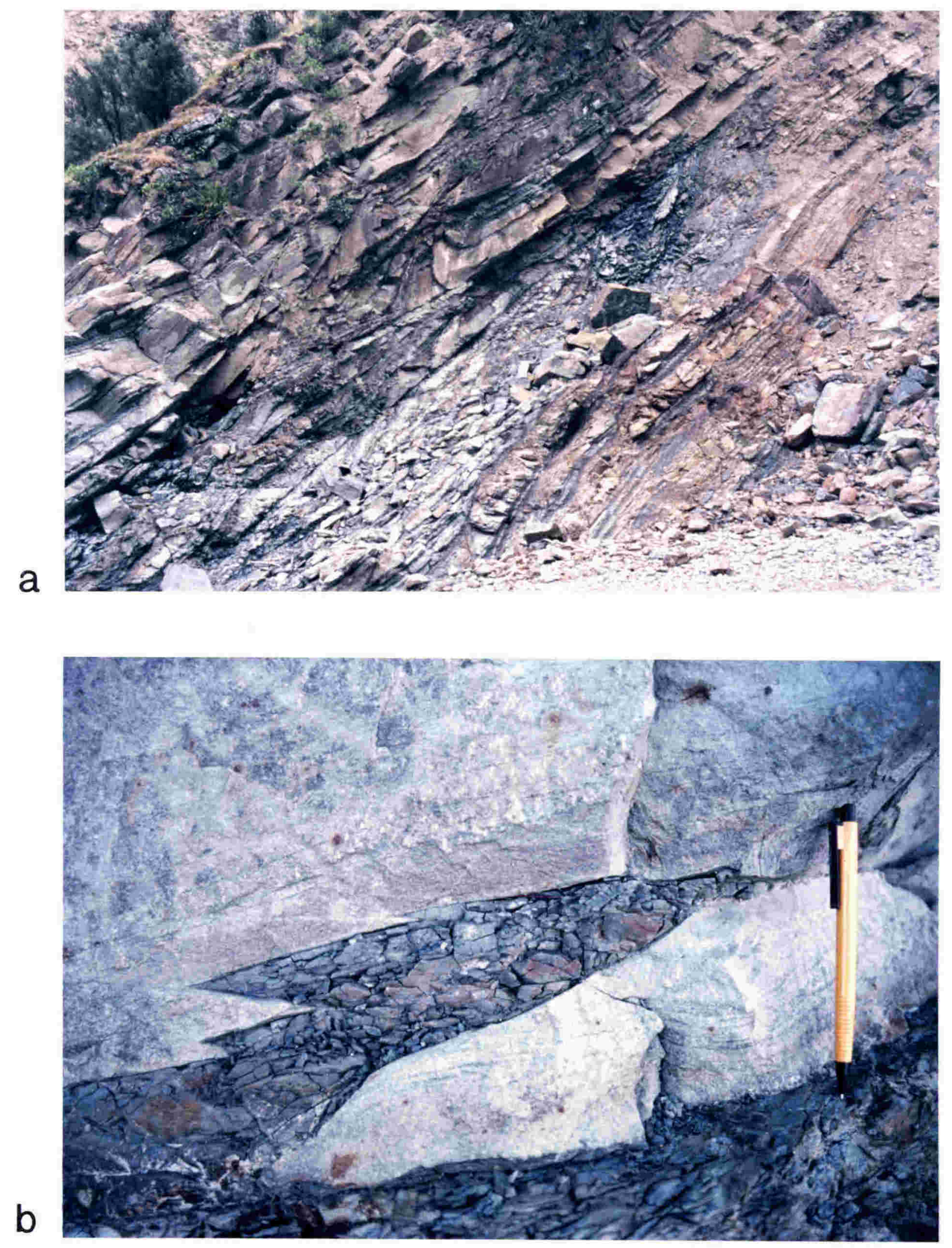

Figure 3.20: Faults on backlimb of southwest anticline. a: Bedding-parallel thrust zone in Teratan beds, Mata River (Y15 63744764). Sense of movement as shown by minor imbricates is top-to-the-northeast (right). b: Contraction faults in Piripauan beds, Mata River (Y15 63754559). Southwest (left) directed faults have small offsets, and are cut by northeast-directed fault along base of mudstone. 


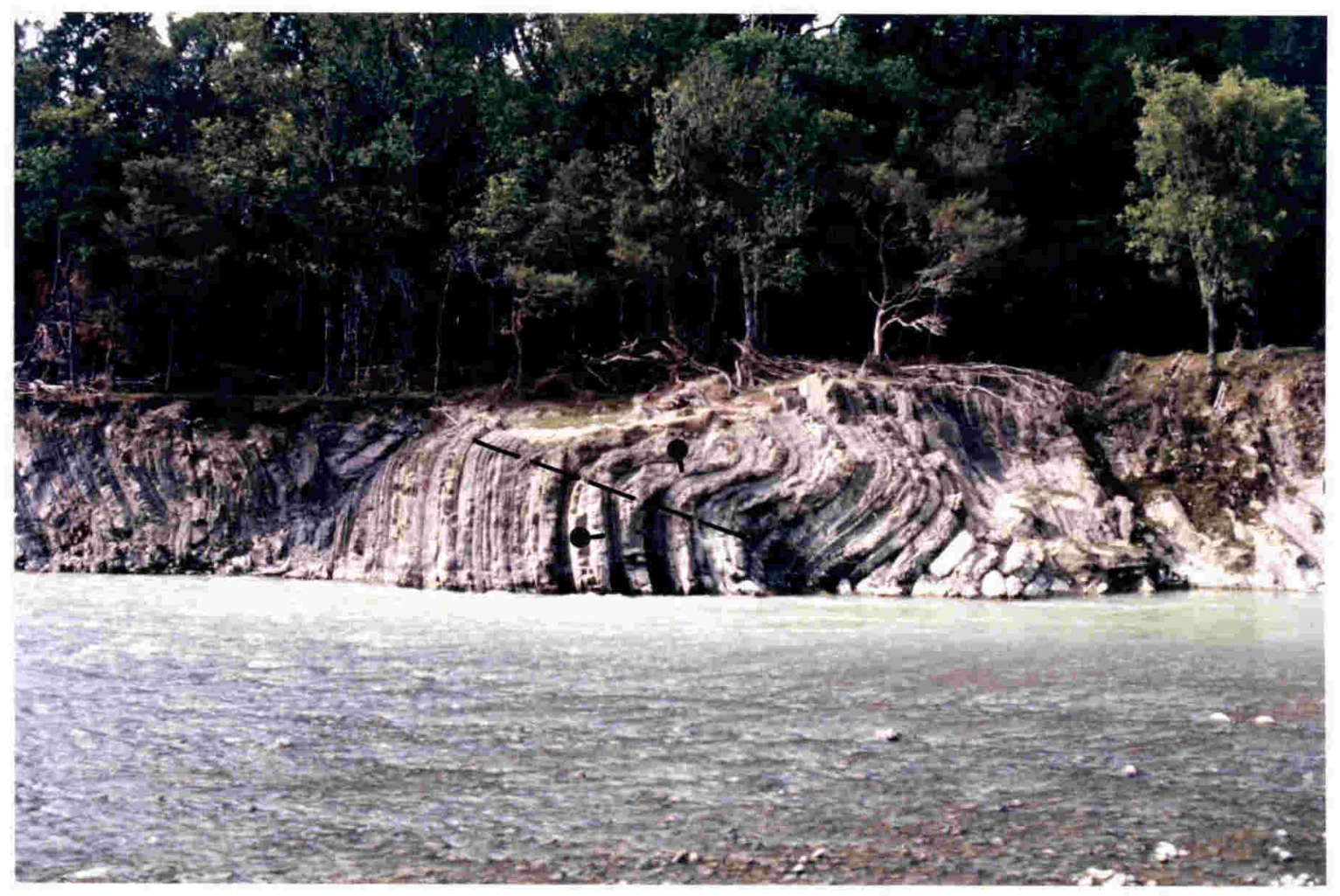

Figure 3.21: Part of an interval of folded strata in the forelimb of the southwest anticline at Y15 65454752, with younging directions and attitude of axial trace. View to northwest. 
the backlimb, but it is concentrated in certain zones and overprinting relationships between the fractures and the folds were not observed.

Some of the minor folds on the planar limb regions of the major anticlines are asymmetric. In many macroscopic flexural slip folds, the senses of vergence of minor folds formed by layer-parallel detachment reflect the shear senses expected on the limbs of the major structures, i.e., toward the anticlinal hinges (e.g., Faill, 1973; Hobbs et al., 1976). Some of the minor folds on the Mata River structures, however, show anomalous vergence. Figure 3.22 shows the orientations of minor fold hinges at different places along the Mata River section. The one asymmetric fold on the backlimb of the southwest anticline verges northeast, as expected, but the two on the forelimb of that structure verge in opposite directions. The southwest-verging one probably reflects the 'normal' sense of shear during growth of the southwest anticline. The northeast-verging one could be the result of transmission of a later, northeast-directed shear through the structure, possibly during growth of the middle anticline (see section 3.4.2.2). The only asymmetric fold measured on the backlimb of the middle anticline verges southwest, away from the anticlinal hinge. This minor fold is near the southwestern end of that limb, and its vergence is thought to be a result of it having formed before the formation of the middle anticline, when it would have been just forward of the northeastern limb of the southwest anticline (see Figs. 3.16 and 3.17a).

Minor folds are also defined by bedding measurements in the hinge regions of the major structures (Fig. 3.23). On the anticlines, the folds have large wavelength to amplitude ratios and are symmetrical. Small asymmetric folds associated with contraction faults in the core of the southwest syncline have opposing asymmetries, giving rise to a box-fold geometry which accomodates shortening and thickening. These structures may partly compensate for the space problem in this syncline discussed earlier. Folding on the anticlines probably reflects thickening of the hinge regions

during buckling, especially in the tight middle anticline. The folding across the broad hinge of the southwest anticline is non-cylindrical, and may reflect significant non-plane strain there.

\subsubsection{Folding in Makarika and Orua Streams}

Southeast of the lower Mata River section in Makarika and Orua Streams (Fig. 3.3 and Map 1), the folds have a somewhat different geometry from that shown in Fig. 3.8. Intermittent exposures of Teratan and Piripauan rocks there allow the construction of a cross-section (cross-section B-B'; location shown on Map 1). This section was drawn assuming a constant thickness of $270 \mathrm{~m}$ for the Teratan. Because of paucity of data, the kink method was not rigidly applied during construction of the section. Nonetheless, 


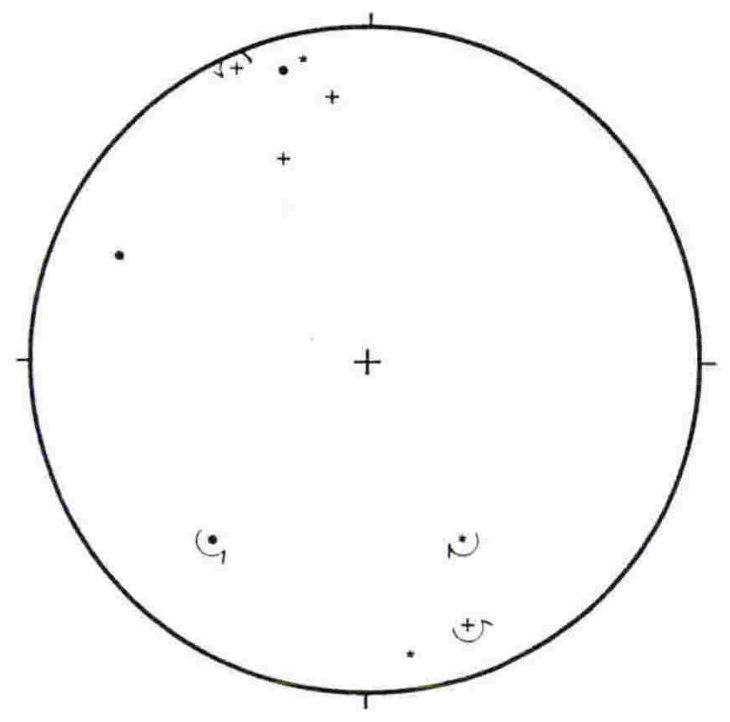

Figure 3.22: Equal-area projection of hinges of minor folds on limbs of major structures, Mata River, showing senses of vergence where appropriate. Dots = backlimb of southwest anticline, crosses $=$ forelimb of southwest anticline, stars $=$ backlimb of middle anticline. 
the folds are depicted as having kink-like geometries so as to be consistent with the style of the folds in the Mata River.

Section B-B' shows that the northeast anticline is broader and gentler in this area than to the northwest. Another syncline/anticline pair must exist northeast of it, as Piripauan beds only appear at stream level about $500 \mathrm{~m}$ further northeast of the projected position of point $\mathrm{B}^{\prime}$. The middle anticline is still recognizable in this area, but it has a shorter wavelength than it does in the Mata. The southwest syncline has a similar wavelength and amplitude in the Mata River and in Makarika Stream, but its southwestern limb is sub-vertical in the latter area. The elevations of the structures are 200-300 m lower in Makarika Stream than in the Mata River, a consequence of their southeasterly plunge (see section 3.4.1).

The southwest anticline is not recognizable in Orua Stream, where instead there is a small syncline cored by Piripauan rocks with a tight (probably faulted) anticline immediately northeast of it. The overturned southwestern limb of the syncline is truncated by a thrust which places upright, probably Teratan beds against the overturned Piripauan ones (cross-section B-B' and Map 1). The dip and displacement of this thrust are unknown. However, the beds immediately southwest of the fault are thought to be Teratan because of their muddy nature and their thin-shelled Inoceramus fragments, which are dissimilar to the thick-shelled I. bicorrugatis. Piripuan beds are not thought to occur any further southwest, as none of the characteristic massive sandstone was seen. The attitude and assumed thickness of the Teratan, together with the (poorly controlled) position of the sub-Haumurian unconformity, suggest that the Teratan/ Mangaotanean boundary is close to the ground surface adjacent to the fault, as depicted on cross-section B-B'.

The tight folds at the southwest end of cross-section B-B' are considered to be noncylindrical structures which die out rapidly northwestward along their trends, along with displacement on the thrust, into the much larger wavelength southwest anticline (see Map 1 and strike section F-F', Enclosure 2).

\subsubsection{Late High-Angle Faulting}

The folded beds in the Mata River section are cut by moderately to steeply dipping faults (e.g., Fig. 3.24a). Most of these are normal, but two are reverse (Fig. 3.24b). Two vertical faults extend strata, and thus are included with the normal faults. A few of the faults strike between northwest and north, but most are northeast-striking. Offsets on most are a few decimetres, but there are two notable exceptions: on the backlimb of the southwest anticline, a north-northwest striking reverse fault has an offset of 

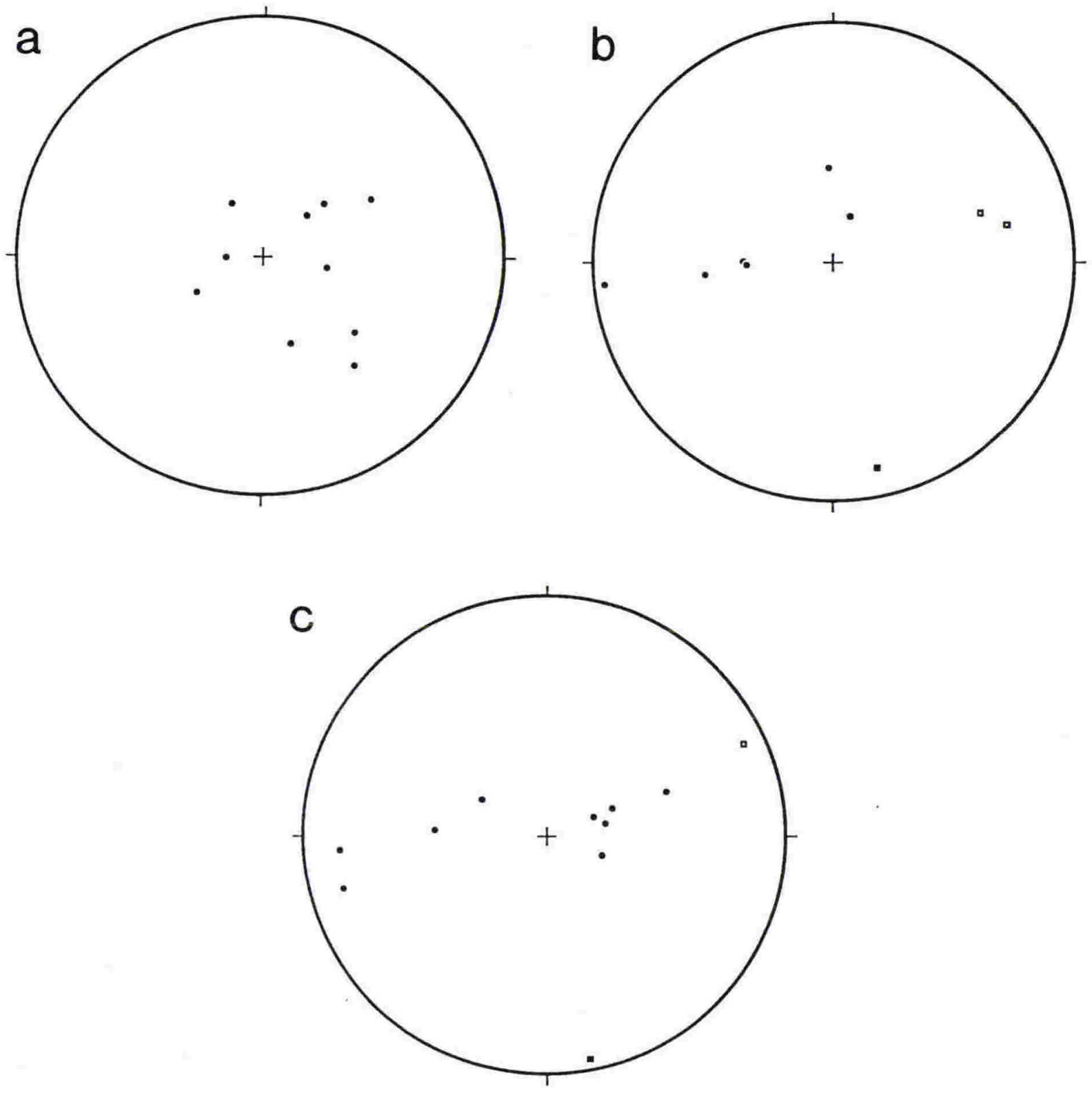

Figure 3.23: Equal-area projection of poles to bedding in hinge regions of major folds. a: Southwest anticline, b: Southwest syncline, c: Middle anticline. Dots = upright beds, hollow squares $=$ overturned beds, filled squares $=$ best-fit $\pi$-axes. 


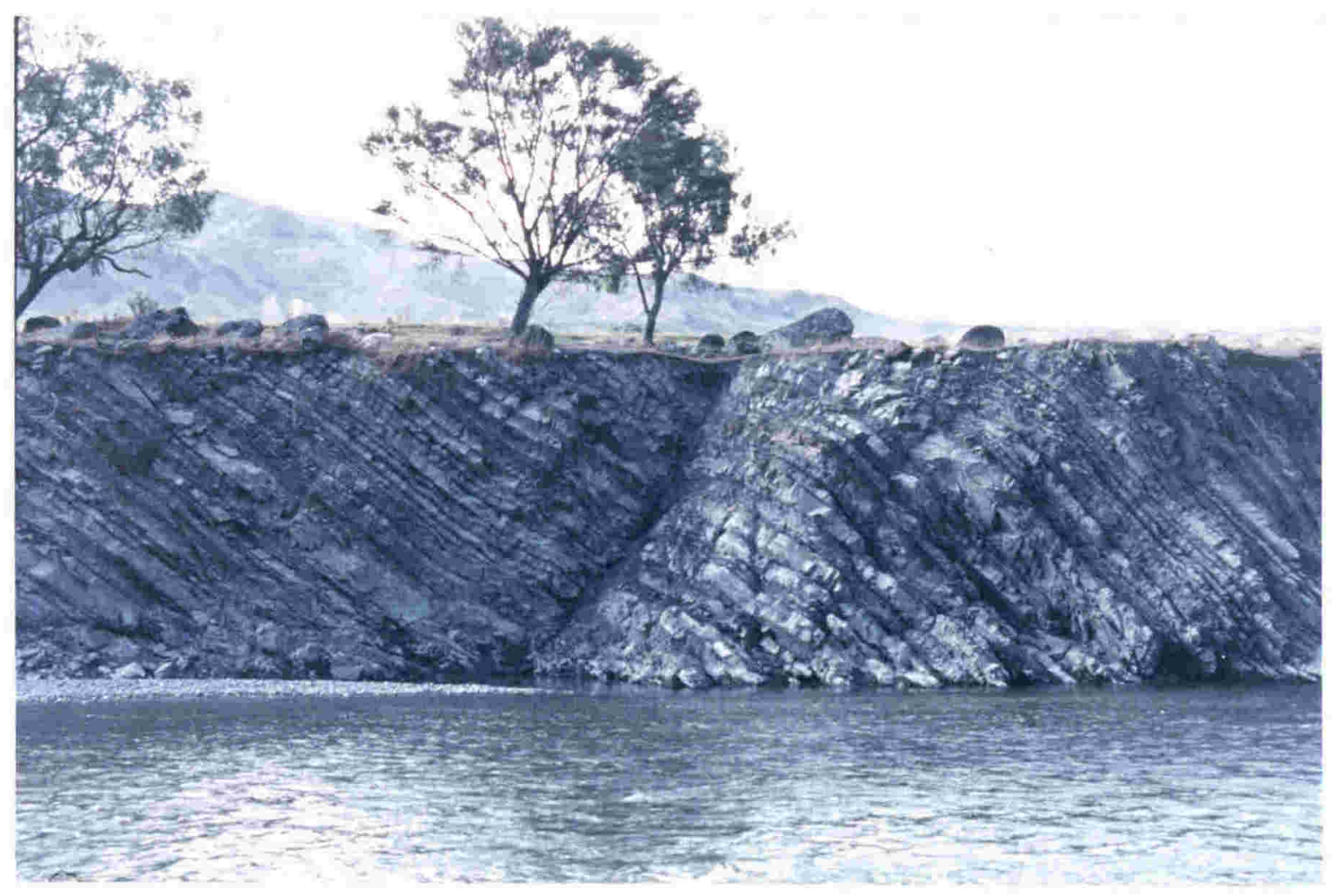

a

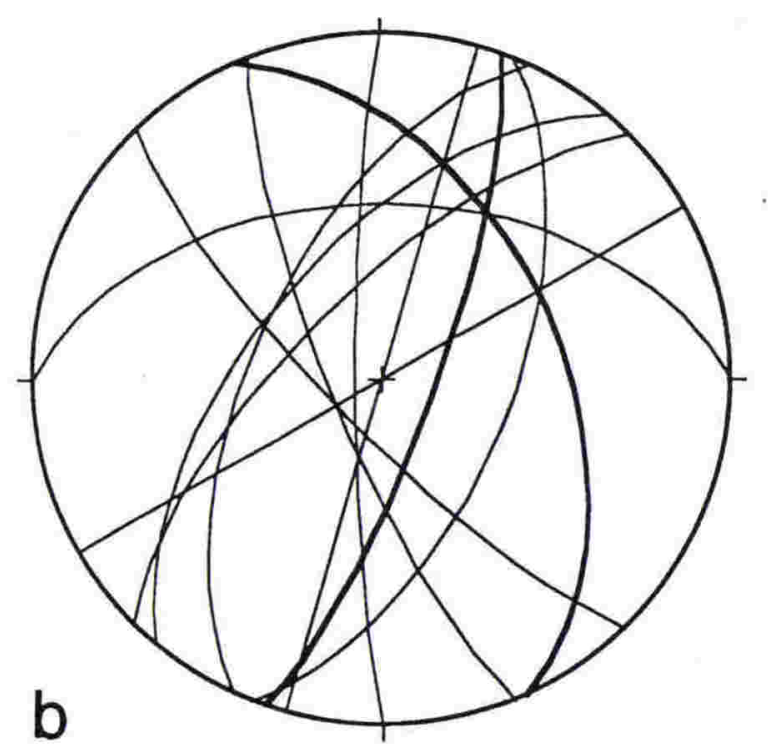

Figure 3.24: a: Late normal fault in Mangaotanean or Teratan strata on the forelimb of the southwest anticline (Y15 65744747). Fault is oriented $025^{\circ} / 60^{\circ} \mathrm{NW}$. b: Equal-area projection of fault planes measured in lower Mata River section. Heavy lines are reverse faults, others are normal faults. The two vertical faults extend strata. 
approximately $5 \mathrm{~m}$, and the normal fault in the northeast syncline has an offset of at least $180 \mathrm{~m}$ (section 3.4.1). Although outcrop control is poor, the normal fault does not appear to cut the base of the Haumurian-Teurian formation. It is steeply dipping at the exposure level, being approximately parallel to the beds on the forelimb of the middle anticline (Fig. 3.8). At depth it may follow the middle anticline's forelimb kink plane and join the southwestern thrust, as depicted on sections $A-A^{\prime}$ and $C-C^{\prime}$, producing a small reversal of motion on that structure. Similar normal faults which accommodate post-thrusting culmination collapse are common above major ramps in the Wyoming thrust belt (Royse et al., 1975; Woodward et al., 1989).

The other north-northwest striking faults could have been generated as bendingmoment faults during late-stage tightening of the folds. The northeast-striking faults may have originated more recently, in association with the post-Early Miocene northeasterly regional structural trend (e.g., Mazengarb, 1984). Most of these faults are extensional, and they may be due to flexure about a northeast-trending axis during formation of the dome in the sub-Haumurian unconformity (see section 3.5.1).

\subsection{STRUCTURE OF HAUMURIAN-TEURIAN ROCKS}

\subsubsection{The Basal Unconformity}

As outlined earlier (section 3.2.4), the Haumurian-Teurian strata do not rest conformably on the Tikihore Formation. On the basis of the small degree of deformation near its base and the parallelism of the best-constrained segment of the base with the attitudes of the beds above it, the contact is thought to be an angular unconformity rather than a gently dipping fault.

On the northern slopes of the Mata valley, the contact has a gentle dip which varies in direction from northwestward at its western end to northward in its central portion (Map 1, sections $\mathrm{C}-\mathrm{C}^{\prime}, \mathrm{E}-\mathrm{E}^{\prime}, \mathrm{F}-\mathrm{F}^{\prime}$ ). The dip direction is inferred to swing to the northeast in the east of the area because of the presence of Haumurian-Teurian rocks in the lower Aorangiwai and Mata Rivers (Pick, 1962; Kingma, 1965; Speden, 1976). Bedding attitudes between the unconformity and the Mata/Aorangiwai ridge and in the lower Aorangiwai River are variable but generally gently southwest- to north-dipping (Map 1, Fig. 3.25a). One outcrop shows a steep westward dip. Distributions of different bedding attitudes around Karewa trig suggest that the rocks there are folded about north- to northwest-trending axes of variable plunge. The exposures in the lower Aorangiwai River form one half of an anticline which plunges northwestward beneath the tectonically overlying Mokoiwi Formation. 

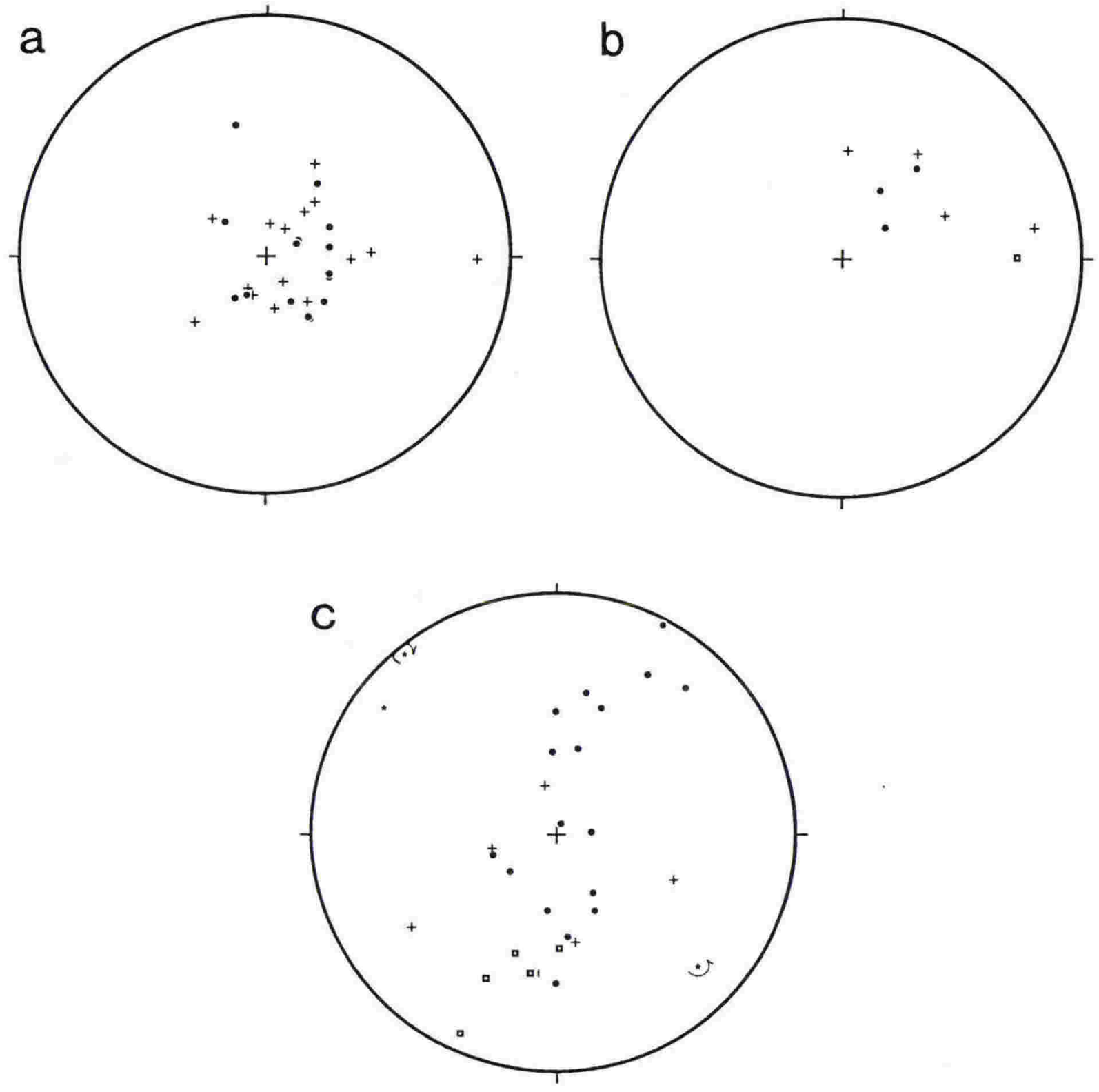

Figure 3.25: Equal-area projections, Haumurian-Teurian formation, lower Mata River area. a: Poles to bedding, unconformity to Mata/Aorangiwai ridge and lower Aorangiwai valley. b: Poles to bedding, Haumurian-Teurian formation south of Mata River. c: Poles to bedding and minor fold hinges, upper Aorangiwai valley. Dots = upright beds, squares = overturned beds, crosses = younging unknown, stars = fold hinges (with senses of vergence where appropriate). 
South of the Mata River, the location and attitude of the unconformity are poorly constrained. It approximately follows the $400 \mathrm{~m}$ contour on the north-facing slope of the Mata valley and the $300 \mathrm{~m}$ contour on the south-facing slope of the Orua valley (Map 1), suggesting a gentle southward dip (see strike section F-F'). Its geometry on the west-facing slope of the lower Ihungia valley supports this conclusion. Its position around the badly slumped upper Orua catchment is particularly poorly controlled. Bedding in an outcrop thought to be just above the contact there dips gently southwest. The outcrop may not be in place, however.

Because Haumurian-Teurian rocks are poorly exposed south of the Mata, only a few bedding attitudes were measured there (Map 1, Fig. 3.25b). One group dips gently to moderately south to southwest. Two outcrops near the eastern extent of the formation have steep westward dips. One of these is overturned. The two most reliable measurements - on the two largest outcrops-were of beds dipping gently south and southwest. Further south, in the Ihungia River, well exposed Haumurian-Teurian beds dip gently south to southeast (see Figure 4.3 and Map 2).

The overall geometry of the sub-Haumurian unconformity is that of a dome, centred on the Mata valley and truncated by the Ihungia Fault. This doming is thought to be largely responsible for the variation in plunge of the underlying Mata River folds outlined in section 3.4 .1 and shown on strike section F-F'.

\subsubsection{Deformation in the Upper Aorangiwai Valley}

\subsubsection{Folding}

At most places in the Haumurian-Teurian formation, the structure is not well known because of poor exposure. Good exposures in parts of the upper Aorangiwai River, however, show that the beds there are folded on wavelengths of several hundred metres about gently plunging, west to west-northwest trending axes (Map 1, Fig. 3.25c). The syncline closest to the Aorangiwai Fault is tight, with an overturned northern limb and a moderately north-dipping axial plane. The other two folds are open with steeply north-dipping axial planes. In the Aorangiwai River upstream of Kokomuka Stream, the rocks are poorly exposed but opposing dips indicate localised open folding on wavelengths of tens of metres. A gently northwest-plunging syncline was observed in that area (Map 1). Two other minor folds were observed in the upper Aorangiwai valley: one plunging gently northwest, and one plunging gently southeast. Both have amplitudes of about $1 \mathrm{~m}$, are tight, and verge northeast (Fig. $3.25 \mathrm{c}$ ). They have gently southwest-dipping axial planes. One is just east of (beneath) the Ihungia Fault, and the other is just beneath a minor thrust in the middle reaches of Kokomuka Stream. 
The subsurface geometry of the folds is shown on sections D-D', E-E', and F-F'. The sub-Haumurian unconformity on those sections has been positioned $250 \mathrm{~m}$ below the black shale marker horizon, which was observed in the Aorangiwai River and in Kokomuka Stream. This is the minimum thickness required for rocks immediately beneath the Aorangiwai Fault in the Aorangi River to be Haumurian. The black shale horizon in outcrops north of Mangapekapeka Stream (Map 1) and in the Ihungia River (Map 2) is 200-250 $\mathrm{m}$ above the base of the formation at both places. The anticline in the Aorangiwai River may be faulted, as exposures in its core are badly slumped, and the rocks there have a crushed appearance. The geometry of the structure beneath the folded unconformity is unknown; the tightly folded Haumurian-Teurian beds may have detached from the underlying, previously folded Tikihore Formation.

\subsubsection{Faulting}

Faults within Haumurian-Teurian rocks in the upper Aorangiwai valley are shown on Map 1. The two faults crossing the Aorangiwai River are inferred on the basis of crushing of the rocks there. Orientations of and offsets on these faults were not determined because of poor exposure. They are possibly northeast-directed thrusts, sympathetic with the Ihungia Fault (see section 3.6). The fault in the middle reaches of Kokomuka Stream is a minor thrust associated with the fold described in the previous section. Its displacement is unknown.

The black shale horizon is exposed in the middle reaches of Kokomuka Stream and at a higher elevation beside the road along the Mata/Aorangiwai ridge (Map 1). Because the strata between these two exposures dip between south and west, the shale must be repeated by a fault; it cannot be repeated by folding. This fault is thought to be a moderately southwest-dipping thrust which crosses Kokomuka Stream just below a fractured and folded zone immediately above the waterfall in Fig. 3.7, crosses the road just east of the sheared black shale outcrop, and crosses the stream south of the road at a place where the rocks are slumped and strongly iron-stained. The geometry on crosssection D-D', which was constructed by projecting bedding attitudes along strike into the section plane, suggests reverse slip of approximately $100 \mathrm{~m}$ near the ground surface. What happens to this fault north and south of the aforementioned localities and at depth is unknown. It may join the Ihungia Fault, to the west.

\subsection{THE IHUNGIA FAULT SYSTEM}

The Ihungia fault system is a group of north-northwest striking faults in the west of the lower Mata River area which separate Waitahaia Formation, to the west, from 
Tikihore Formation or Haumurian-Teurian beds to the east (Fig. 3.3, Map 1). Previous workers have mapped this group in different ways: as a single fault (the Ihungia Fault) across the entire area (Moore, 1959; Pick, 1952; Kingma, 1965; Laing, 1971); as two discrete faults in the south (Kenny, 1980, 1984a); and as a "fault zone" (Gibson, 1987a). All considered the fault or faults to be steeply west-dipping, and to have a large reverse component. In this study, mapping has revealed that the "Ihungia Fault" is an interconnected system of moderately west-dipping thrusts. Between the Aorangiwai River and Mangapekapeka Stream, there is a single fault which corresponds to the Ihungia Fault of the earlier workers. South of Mangapekapeka Stream, other faults splay eastward off the Ihungia Fault. In the following, the individual faults are described in ascending structural order (from east to west).

\subsubsection{The Mangapekapeka Fault}

The easternmost fault of the Ihungia system is a moderately west-dipping thrust which runs from the middle Mangapekapeka valley southward as far as the crest of the hill in the loop of Horehore Road (Fig. 3.3, Map 1). This thrust repeats part of the Tikihore Formation. Immediately beneath it lie Piripauan beds of the backlimb of the southwest anticline. Above it in Mangapekapeka Stream, collections (Y15/f125 and 126; see Appendix 2) and observations of Inoceramus specimens show that Mangaotanean to Piripauan strata are present in a westward-younging sequence. In upper Mangapekapeka Stream, Piripauan strata are overlain by Ngaterian Waitahaia Formation along the Ihungia Fault (Fig. 3.3, Map 1).

The Mangapekapeka Fault was observed in Mangapekapeka Stream (Fig. 3.26), where it juxtaposes a hangingwall anticline in Mangaotanean rocks against a footwall syncline in Piripauan rocks. In this outcrop, the fault is subvertical and strikes $004^{\circ}$. Between Mangapekapeka and Fallwater Streams, the fault trace was approximately located from its topographic expression-the Piripauan sandstones in its footwall form prominent bluffs. Structure contours on this trace show that the fault strikes slightly east of north, oblique to the strata in its footwall, and that it dips moderately to steeply west. On cross-section $C-C^{\prime}$, the fault is drawn with an apparent dip parallel to the backlimb of the southwest anticline, and with a ramp at an arbitrary position and angle $\left(30^{\circ}\right)$ down into the Mangaotanean. This geometry requires a minimum fault transport of $1.5 \mathrm{~km}$ in the section plane. At the exposure level, the fault puts a hangingwall flat on a footwall flat. Because the stratigraphic cutoffs in the hangingwall are eroded, the absolute displacement cannot be determined. The stratigraphic separation of the exposed part of the fault reaches a maximum of approximately $360 \mathrm{~m}$. 


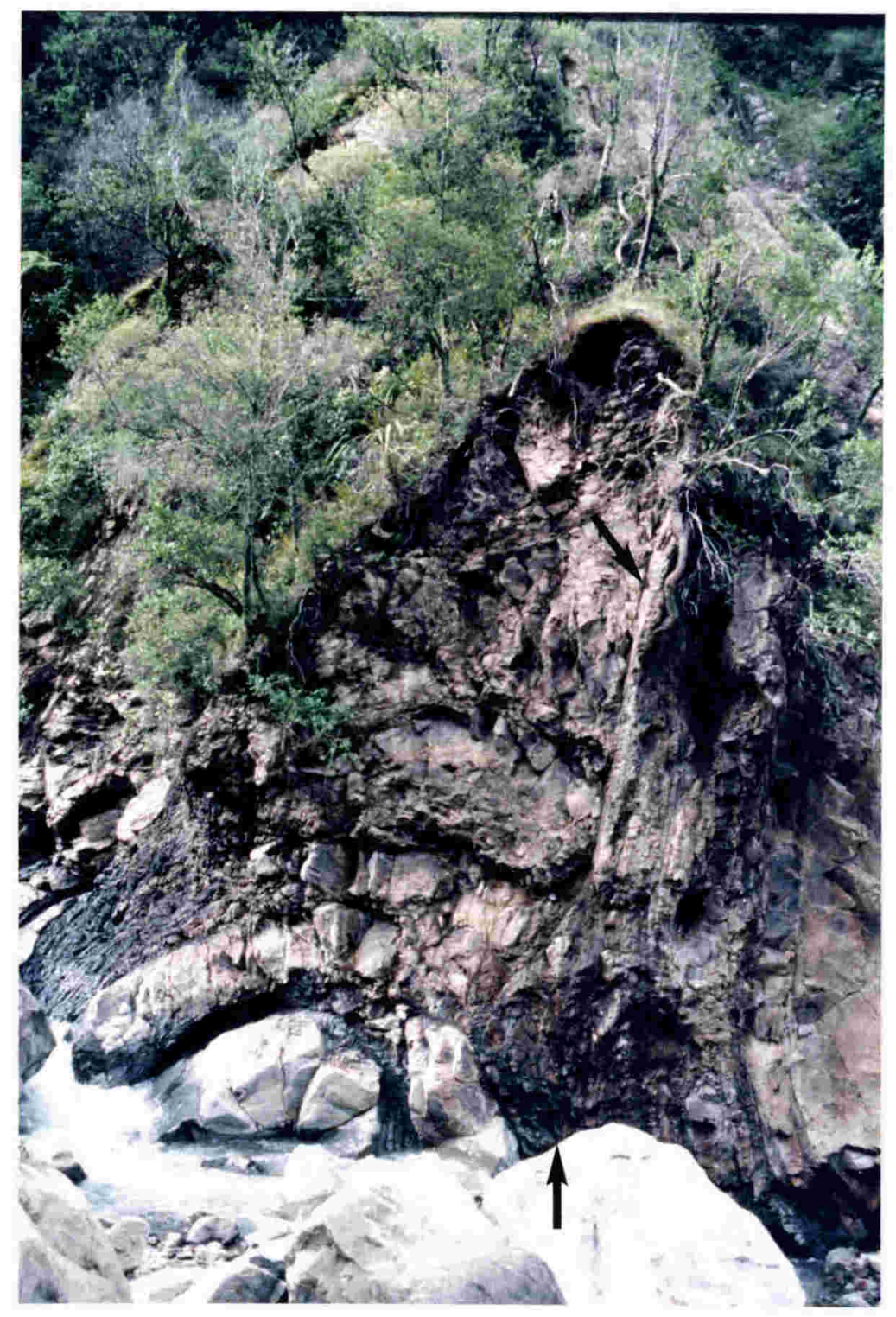

Figure 3.26: Mangapekapeka Fault (arrowed) in Mangapekapeka Stream (Y15 63314779). Anticline on western (left) side is in Mangaotanean rocks, asymmetric syncline on eastern (right) side is in Piripauan rocks. 
The Mangapekapeka Fault was located to within $15 \mathrm{~m}$ in Fallwater Stream, where it lies at a higher level in the Piripauan footwall strata than in Mangapekapeka Stream. It thus cuts up-section in the footwall towards the south. No identifiable fossils were seen in Fallwater Stream, but the beds above the fault were inferred to be Teratan: a thin interval of Piripauan sandstone is present further upstream, immediately beneath the Ihungia Fault, and the dip and thickness of the Teratan suggests that no Mangaotanean should be present above the Mangapekapeka Fault there. Mangaotanean is present in the hangingwall in Mangapekapeka Stream, so the fault also cuts upsection towards the south in its hangingwall. Further south, outcrops in the loop of Horehore Road reveal Ngaterian and Piripauan strata which are juxtaposed across the eastern branch of the Ihungia Fault, with no intervening Raukumara Series. The Mangapekapeka Fault is therefore inferred to disappear beneath the more westerlystriking eastern Thungia Fault south of Fallwater Stream (see strike section E-E'). Because both the Mangapekapeka and eastern Ihungia Faults truncate bedding in the sheet near their intersection, it is likely that their branch line is steeply plunging (see Diegel, 1986).

The beds within the Mangapekapeka sheet generally dip moderately to steeply westward (Fig. 3.27). In Mangapekapeka Stream, approximately parallel upright and overturned beds alternate on a scale of tens of metres, suggesting tight to isoclinal folding. Two anticlinal hinges were observed. These are tight, upright, plunge gently south-southwest, and are upward-facing (e.g., Fig. 3.28). In Fallwater Stream, an eastverging, asymmetric syncline with an overturned, fault-truncated upper limb was observed. Macroscopic and mesoscopic fold axes plunge gently just west of south (Fig. 3.27), approximately parallel to the strike of the Mangapekapeka Fault. The folds are thus assumed to have been associated with movement on the thrust, and to be approximately perpendicular to the thrust transport direction (approximately $100^{\circ}$ ). Fold vergence directions are consistent with eastward transport. The difference in strike and transport direction between the Mangapekapeka and Ihungia Faults (see next two sections) suggests that the former is a diverging splay (Boyer and Elliott, 1982) and probably does not rejoin the Ihungia Fault to the north.

The timing of motion on the Mangapekapeka Fault is closely constrained: it cuts Piripauan rocks and is overlain unconformably by Haumurian-Teurian strata north of Mangapekapeka Stream (Fig. 3.3, Map 1). Its displacement must therefore have taken place between the early Piripauan and the late Haumurian, in the same interval as the formation of the lower Mata River folds. 


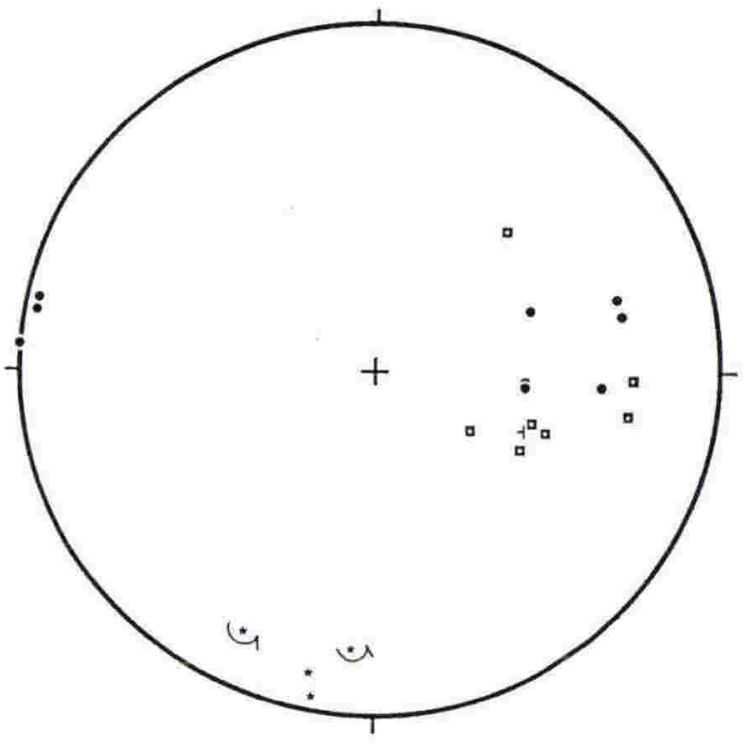

Figure 3.27: Equal-area projection of poles to bedding and minor fold hinges in Mangapekapeka sheet. Symbols as for Fig. 3.25. 


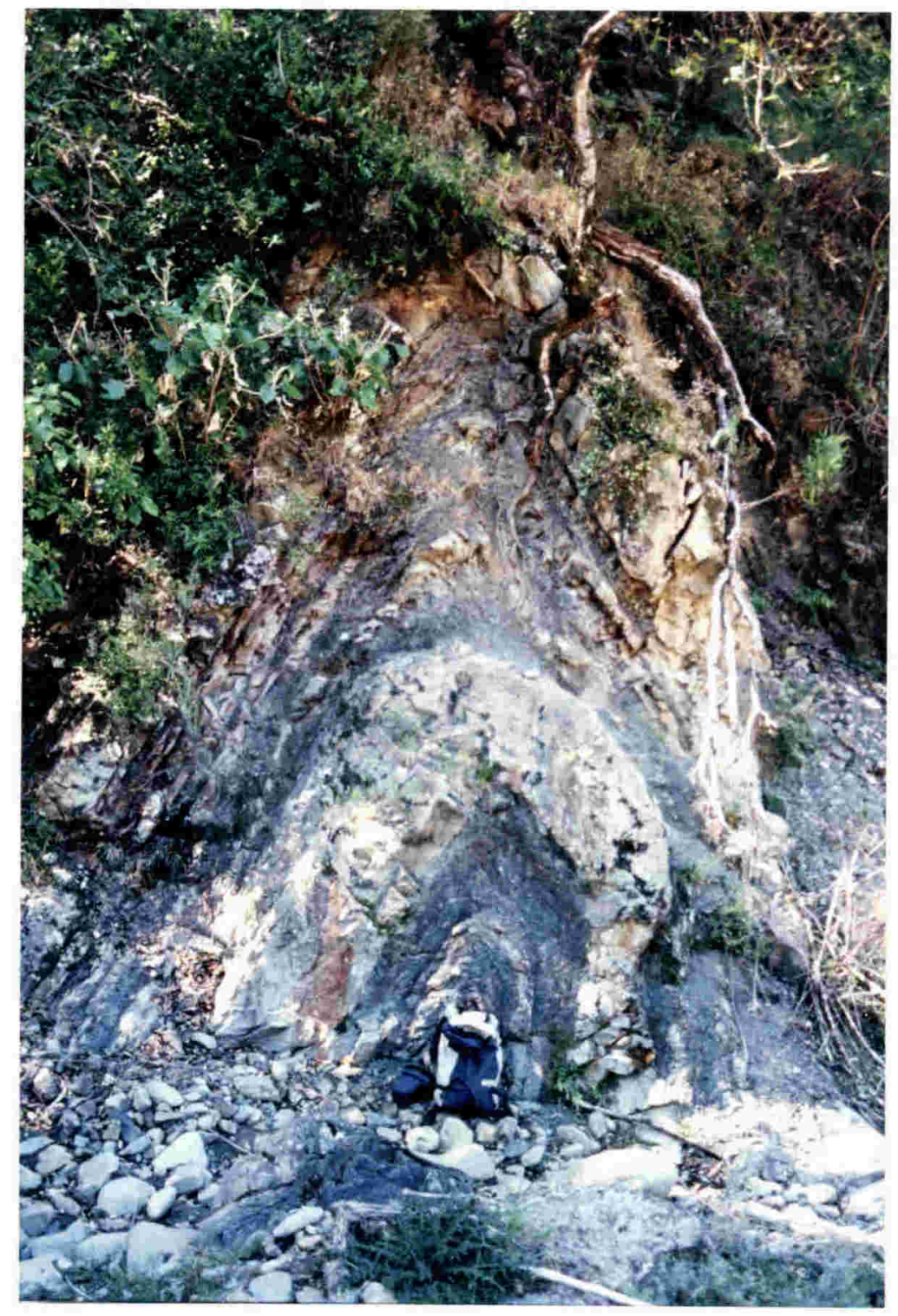

Figure 3.28: Anticlinal hinge in Mangapekapeka Stream (Y15 62954785), looking north. 
Between just south of Fallwater Stream and about $1.5 \mathrm{~km}$ up the Ihungia valley, the "Ihungia Fault" exists as two branches. The easternmost of these places Waitahaia Formation, on the southwest, against Piripauan Tikihore Formation, on the northeast. The position of the fault was located to within about $15 \mathrm{~m}$ on the southeast bank of the Mata River, where Ngaterian rocks crop out just upstream of a slumped area of shattered Piripauan rocks, and to within about the same distance in the loop of Horehore Road. Between these two localities and northward to Fallwater Stream, the fault has a prominent topographic expression due to the rocks immediately west of it being thick, hard sandstones. Structure contours drawn along this stretch of the fault show that it has a strike of $150^{\circ}$ and dips west at $40^{\circ}$, almost parallel to the backlimb of the southwest anticline (see profile section $\mathrm{A}-\mathrm{A}^{\prime}$ ). To the south, the fault trace is less clear. The position of the fault in the Ihungia River, $1.5 \mathrm{~km}$ south of where it crosses the Mata River, indicates that its strike between those two points is approximately $160^{\circ}$. Its inferred position on the slopes between the two points suggests a moderate westward dip. In this southern area, the dip of the beds in the footwall is shallower than further northwest (Fig. 3.3, Map 1) and the fault is thus likely to cut down-section into Teratan rocks towards the southeast (see strike section E-E').

Displacement on the east branch of the Ihungia Fault took place during the same time interval as displacement on the Mangapekapeka Fault, i.e. between the early Piripauan and the late Haumurian. This is demonstrated by the presence of early Piripauan rocks immediately east of the Ihungia Fault, and the angular unconformity beneath the Haumurian-Teurian formation which overlies the fault in the Ihungia River (Figure 4.3, Map 2). The strike of the fault is approximately parallel to the trend of the lower Mata River folds, which also formed during that interval. The transport direction on the fault is thus inferred to have been up-dip in the direction of maximum shortening across the folds-approximately $065^{\circ}$. A northeast-verging minor fold in Piripauan beds not far below the fault on Horehore Road has a hinge line oriented $340^{\circ} / 05^{\circ}$, approximately perpendicular to this inferred transport direction.

The amount of displacement on the eastern Ihungia Fault cannot be precisely determined. It places Ngaterian rocks over Piripauan, so it is responsible for at least $1260 \mathrm{~m}$ of stratigraphic separation (see Fig. 3.2). Because the fault cuts the strata at a low angle, its displacement is likely to be several times this figure. 
The westernmost fault of the Ihungia system is also the longest, running from the north side of the upper Aorangiwai valley southward as far as $3 \mathrm{~km}$ up the Ihungia valley. It is cut by the Aorangiwai Fault at its northern end (Fig. 3.3, Map 1) and the Mangarakeke Fault at its southern end (Fig. 4.3, Map 2). Waitahaia Formation west of the fault is juxtaposed against Haumurian-Teurian strata in the north, Tikihore Formation in the centre of the area, and more Waitahaia Formation in the south, where a small sliver of Piripauan is also present. Further south in the Ihungia valley, Haumurian-Teurian strata are again present east of the fault.

The attitude of the fault surface varies along its length. In the north, its position is constrained by an outcrop beside the Aorangiwai River (Fig. 3.29) and by outcrops close on either side of it southward up to the Mata/Aorangiwai ridge, where it can be located to within about $20 \mathrm{~m}$. Its orientation in that sector, estimated from the outcrop and structure contours on its trace, is about $165^{\circ} / 45^{\circ} \mathrm{W}$. The fault trace was extrapolated north of the river, where there is thick forest cover, assuming that orientation. Close to the crest of the Mata/Aorangiwai ridge, the fault swings abruptly into an oblique ramp with a north-northeast strike and a moderate northwesterly dip before curving more gently back to strike north-northwest south of Mangapekapeka Stream (see cross-section D- $D^{\prime}$ and strike section E-E'). Where it crosses the stream, the fault surface itself is illdefined and there is a broad zone of rocks with a bedding-parallel shear fabric oriented $352^{\circ} / 52^{\circ} \mathrm{W}$.

Between the southern slopes of the Mangapekapeka valley and Fallwater Stream, structure contours on the fault trace-located from the topographic expression of the Piripauan sandstones immediately east of it-show that it strikes approximately $165^{\circ}$ and dips $35^{\circ}-40^{\circ}$ westward. On cross-section $C-C^{\prime}$, the fault has been drawn parallel to the backlimb of the southwest anticline. Piripauan beds are also present in the footwall in the Mata River, where the fault can be located to within $10 \mathrm{~m}$ on the southwest bank and almost as closely on the northeast bank. The exposures show that the fault strikes approximately $165^{\circ}$ there. Between the river and Fallwater Stream, however, its position is less well constrained because there is Waitahaia Formation in both the footwall and the hangingwall. The fault is thought to correlate with a crushed interval seen beside Horehore Road. A trace striking $165^{\circ}$, drawn from the fault in the river through this interval to join the eastern branch just south of Fallwater Stream, would dip westward approximately $60^{\circ}$. South of the Mata, where Waitahaia Formation again occurs in the footwall, correlation of the fault with a prominent break in slope suggests a dip of about $50^{\circ}$. 


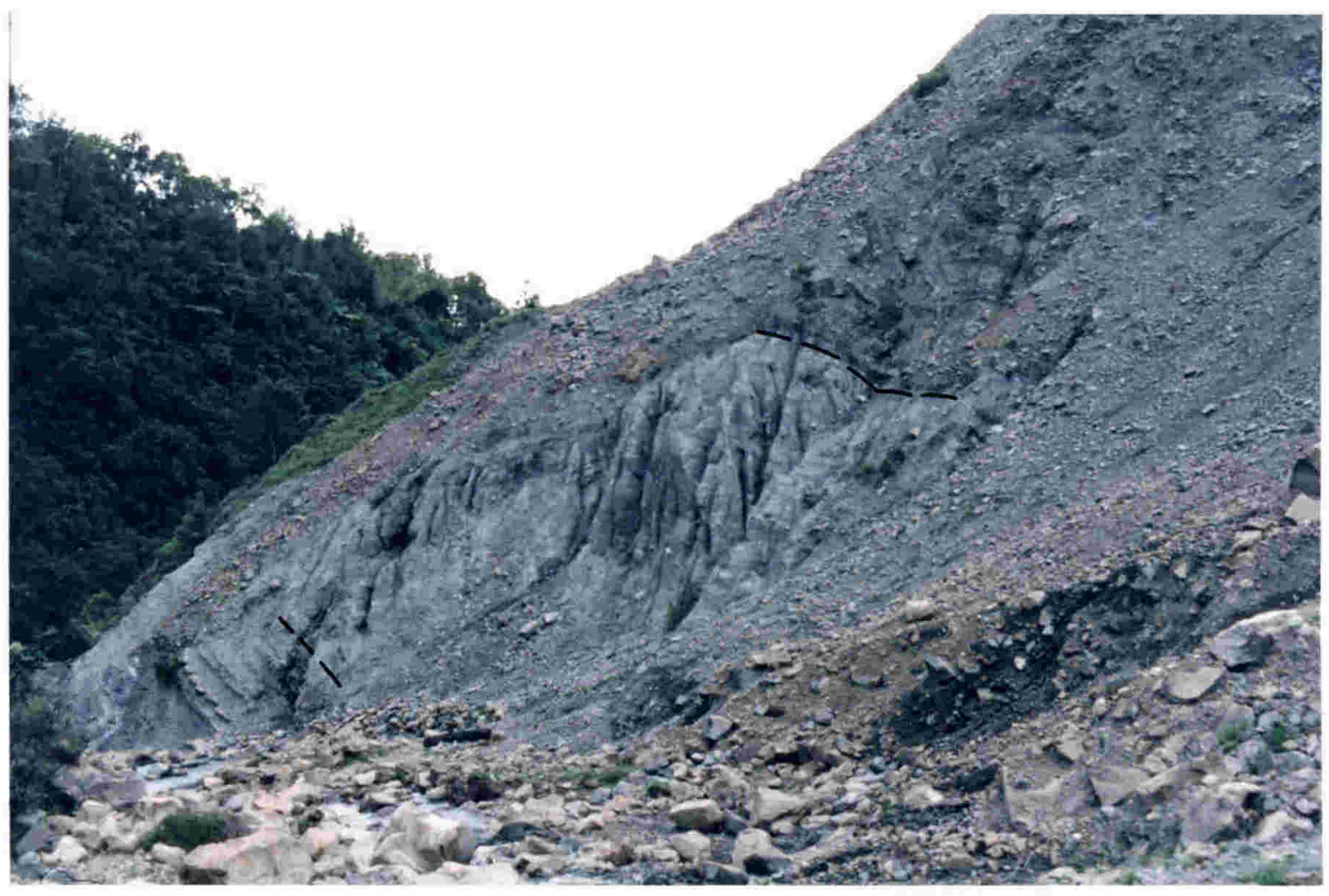

Figure 3.29: West branch, Ihungia Fault. Outcrop in upper Aorangiwai River (Y15 62735045), looking east-southeast. Waitahaia Formation sandstone (above) is separated by $\mathrm{a} \approx 5 \mathrm{~m}$ crush zone from south-dipping Haumurian-Teurian beds. 
Transport on the western Thungia Fault is inferred to have been approximately perpendicular to its dominant strike, i.e. towards the east-northeast. Three minor folds adjacent to the fault, one in the hangingwall and two in the footwall (Map 1), have hinges which plunge southeast, south-southeast, and northwest. One of these is asymmetric and verges northeast. Lozenge shapes in sheared Waitahaia Formation adjacent to the fault in Mangapekapeka Stream suggest a direction of maximum extension approximately perpendicular to the strike of the fabric, i.e. $082^{\circ} / 52^{\circ} \mathrm{W}$.

The western Ihungia Fault cuts Haumurian-Teurian rocks. Its displacement is thus at least $2 \mathrm{~km}$ greater than that on the eastern Ihungia Fault, and its stratigraphic separation is at least $1900 \mathrm{~m}$ (see sections D-D' and E-E').

\subsubsection{Kinematic History of the Ihungia Fault System}

The relations of the faults in the Ihungia system with the sub-Haumurian unconformity and with each other show that there were two phases of fault movement: a pre-late Haumurian phase involving all the faults (with the possible exception of the western Ihungia south of Fallwater Stream) and a post-Teurian phase involving the western Ihungia and possibly the sliver of Piripauan rocks in the south. The Mangapekapeka and eastern Ihungia Faults are overlain by Haumurian-Teurian strata, so their movement must have been entirely pre-late Haumurian. The northern part of the western Ihungia must also have moved at that time, as the eastern Ihungia links up with it just south of Fallwater Stream. The southern part of the western Ihungia and the fault beneath the Piripauan sliver may also have moved then. The entire western Ihungia moved in post-Teurian times, because it cuts Haumurian-Teurian rocks in the north (Fig. 3.3, Map 1) and in the south (Fig. 4.3, Map 2).

The sequence of faulting during the pre-late Haumurian deformation cannot be unequivocally determined from the information available. The faults involved-the western and eastern Ihungia, the Mangapekapeka, and the blind faults beneath the Mata River folds - could have formed in a forward-stepping, backward-stepping, or mixed propagation sequence. Circumstantial evidence, however, suggests forward propagation: fault displacement progressively decreases northeastward, as though the deformation front was propagating in that direction, and the Mangapekapeka Fault must dip steeply to cut down into the Mangaotanean; if it had formed before faultrelated tilting of its footwall, it would have been at a lower, more favourable angle. Forward-stepping fault sequences are the rule in simple thrust belts (e.g., Boyer and Elliott, 1982; Butler, 1987; Woodward et al., 1989), and this is inferred to be the case in the present example. 


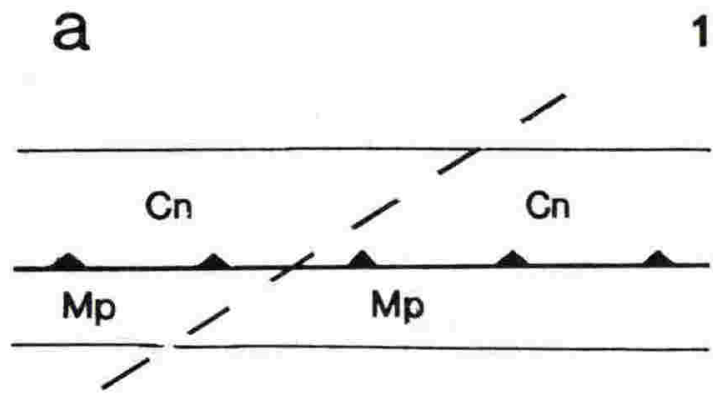

b

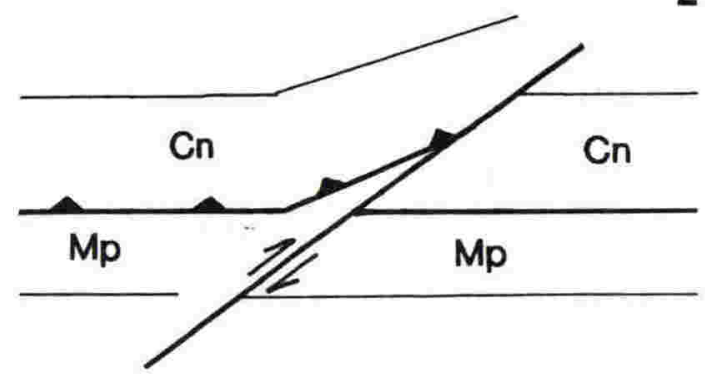

C

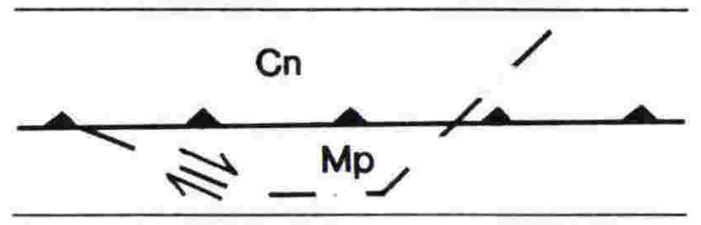

Figure 3.30: Kinematics of emplacement of Piripauan horse along western Ihungia Fault. a: Development of a breaching thrust which cuts through the footwall of an earlier thrust, resulting in younger rocks over older rocks along part of its length. b: Initiation of breaching thrust by thrust propagation. c: Initiation of breaching thrust by footwall plucking. 
The sliver of Piripauan sandwiched between Waitahaia Formation in the south of the area shows that there, the western Ihungia Fault has cut across the eastern branch: the Piripauan rocks must have been derived from the footwall of the eastern fault and emplaced over older rocks when their underlying fault 'breached' the eastern branch (Fig. 3.30a). The Piripauan rocks are thus completely fault bounded (a 'horse'; Boyer and Elliott, 1982). 'Breaching' (Butler, 1983) appears to be common where large, fartravelled thrust sheets are emplaced on long flats (e.g., the Moine thrust sheet of Scotland, Coward, 1980, and Butler and Coward, 1984; the Oman Mountains allochthon, Searle, 1985; and the Kvitvola sheet of the Norwegian Caledonides, Morley, 1988).

Presuming the western and eastern Ihungia Faults join at depth, removal of the Piripauan from the footwall of the eastern fault may have occurred by two processes: thrust propagation followed by breaching, whereby the western fault initially propagated in front of the eastern fault as a thrust which later cut up-section across its roof (Fig. 3.30b); or breaching preceded by 'footwall plucking' (Platt and Leggett, 1986), whereby the western fault initiated as an extensional fault which cut down-section across the footwall of the eastern fault, and later cut up-section as a breaching thrust (Fig. 3.30c). Extensional faults-interpreted as synthetic Riedel shears-which cut downsection in the transport direction and then ramp up to rejoin their parent thrusts have been described by Platt and Leggett (1986) from the Makran of Pakistan. Extensional faults, again interpreted as Riedel shears, in the hangingwall of the Lewis Thrust in Montana have recently been documented by Yin and Kelty (1991). Extensional faults adjacent to other major thrusts have been documented by Coward (1982), Wojtal (1986), Casas and Sàbat (1987), and Woodward et al. (1988), among others.

Emplacement of the Piripauan horse may have taken place during the pre-late Haumurian deformation or in post-Teurian times. The fault beneath the horse is markedly non-planar (see Map 1 and strike section E-E'), whereas the fault above it has a similar orientation to the western Ihungia Fault north and south of the horse (see section 3.6.3). This is compatible with the latter fault having been the last one to move. The horse may therefore have been emplaced during the pre-late Haumurian deformation, and the fault above it is likely to have been the one reactivated with the rest of the western Ihungia Fault in post-Teurian times.

Figure 3.31 shows a history of the Ihungia fault system and the lower Mata River folds assuming a forward-stepping sequence of faulting. The sections are drawn along approximately line C-C' (Map 1), so the Mangapekapeka sheet is present but the two branches of the Ihungia Fault and the Piripauan horse are not. The Ihungia Fault is sub-parallel to the Piripauan in its footwall along most of its length (see previous two sections) so its configuration in the Mangapekapeka-Mata area is shown as flat-on-flat 

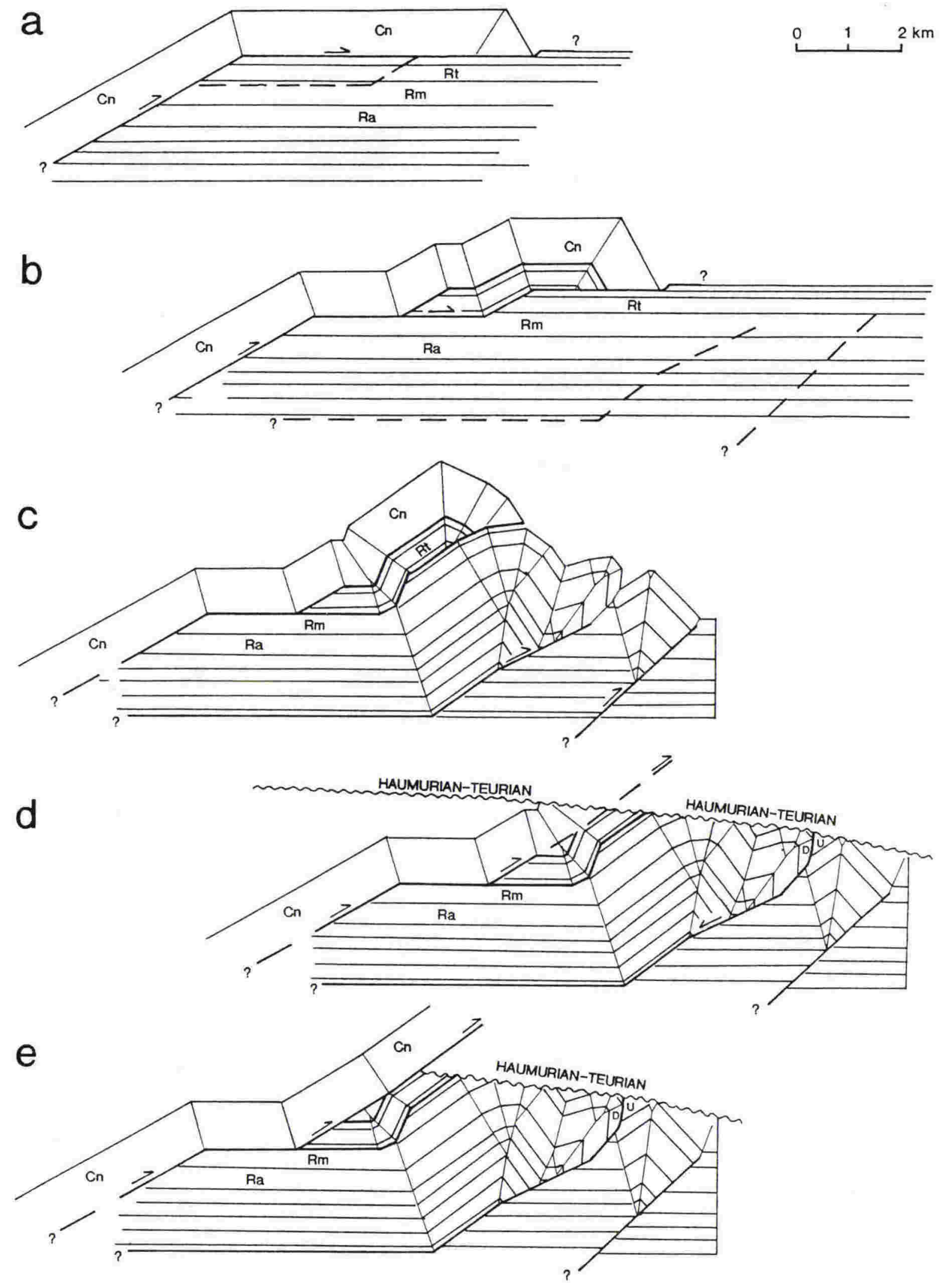

Figure 3.31: Sections along line $C-C^{\prime}$ (Map 1) showing development of Ihungia fault system and lower Mata River folds. See text for details. 
in Fig. 3.31a. The length of this flat is unknown. The fault is shown as cutting down through the Raukumara succession at an arbitrary angle $\left(30^{\circ}\right)$ to the southwest. Because the upper flat of the Ihungia Fault is in Piripauan rocks and thrusting took place between the early Piripauan and the early to mid-Haumurian, the thrust would have been at a very shallow level in the study area, and was probably emergent not much further northeast.

The Mangapekapeka Fault is shown on Fig. 3.31a as forming by footwall collapse within the Mangaotanean in front of the Ihungia Fault and ramping up at $30^{\circ}$ to the Piripauan (as shown in cross-section $C-C^{\prime}$ ) where the two faults rejoin, creating a single-horse duplex. This geometry is consistent with the flat-on-flat relationship across the Mangapekapeka Fault at the exposure level, and with both faults having similar thicknesses of Piripauan in their footwalls. It should be noted, however, that the transport direction on the Mangapekapeka Fault is oblique to the section plane, and that the horse wedges out southward and becomes thicker northward (see Map 1 and strike section E-E'). The Mangapekapeka Fault is shown on Figs. 3.31a and b with an apparent displacement of $1.5 \mathrm{~km}$ and a pre-thrusting length of $3 \mathrm{~km}$. The minimum displacement for the ramp geometry in cross-section $C-C^{\prime}$ is $1.5 \mathrm{~km}$ (see section 3.6 .1 ). Many natural examples of duplexes have displacement/length ratios of around 0.5 , as well as ramp angles of $30^{\circ}$ (Boyer and Elliott, 1982).

The configuration after the development of the lower Mata River fault-propagation folds is shown in Fig. 3.31c. The fault beneath the southwest anticline initially propagated as a flat-which presumably branches from the Ihungia Fault somewhere to the southwest-before ramping up to form the southwest and middle anticlines in a two-stage process (see section 3.4.2.2). Other ramps may splay off the flat southwest of those folds. The northeast anticline formed above a ramp which propagated up from an unknown depth. Formation of the southwest anticline tilted the Ihungia and Mangapekapeka Faults to dips of $40^{\circ}$ and tightened the monocline above the ramp in the Mangapekapeka Fault. This tightened monocline narrows upward, and thus requires increasing shortening with increasing structural elevation. This space problem could be relieved by out-of-the-syncline type thrusting (e.g., Butler, 1982), but this is not shown on the figure for the sake of clarity.

Figure 3.31d and e show the post-Haumurian-Teurian structural configuration. All the faults, including the late normal fault between the middle and northeast anticlines, were truncated by the sub-Haumurian unconformity. Subsequently, the reactivated western Ihungia Fault propagated up its old ramp at the back of the Mangapekapeka horse. It then cut through the Waitahaia Formation in its former hangingwall before 
occupying approximately its old position across the top of the horse, and cutting through the Haumurian-Teurian rocks.

\subsection{THE AORANGIWAI FAULT}

The Aorangiwai Fault (Pick, 1962) is a gently to moderately dipping, undulating thrust surface which separates Mokoiwi Formation of the Mokoiwi inlier (above) from Waitahaia Formation or Haumurian-Teurian rocks (below). Locally, thin sheets of Eocene smectite mudstone (section 3.2.5) occur beneath it. The fault plane is nowhere exposed, but it can be positioned to within a few metres at two locations where it crosses a tributary of the lower Aorangiwai River: Y15 67235032 (downstream) and Y15 66655000 (upstream). The fault can be approximately positioned in other tributaries further northwest, and structure contours on its trace show that it strikes approximately $140^{\circ}$ and dips gently northeast (see cross-section $C-C^{\prime}$ ). The areally extensive sheet of Eocene mudstone beneath the Aorangiwai Fault in this area has been affected by considerable mass movement, and is poorly exposed. Slump deposits of it overlie the structurally higher but topographically lower Mokoiwi Formation at many places. The fault that forms the southwestern limit of the Eocene rocks was approximately located (Fig. 3.3, Map 1).

The Aorangiwai Fault crosses the middle Aorangiwai River, where exposures close on either side of it show that it puts Mokoiwi Formation on overturned HaumurianTeurian beds with no intervening Eocene. On the thickly forested hills north of the river, the topographic trace of the fault runs westward to a tributary of the upper Aorangiwai immediately beneath Aorangi, where Eocene is present (Map 1). From there, the trace continues westward across the projected position of the Ihungia Fault and steepens as it curves north out of the Aorangiwai catchment. Its attitude in this area is variable and poorly known; its trace on cross-sections $C-C^{\prime}$ and $D-D^{\prime}$ was constructed by projecting it southeastward from the map, and raising it so that it lay above the Mata/Aorangiwai ridge (see also strike sections E-E' and F-F'). Further northwest, the fault (there referred to as the Hukanui Fault; Gibson, 1987a) dips northeast at approximately $30^{\circ}$, and is locally underlain by Eocene smectite mudstone similar to that in the Aorangiwai area (Gibson, 1987a).

The Mokoiwi Formation above the Aorangiwai Fault is complexly deformed (e.g., Fig. 3.4a). Much of this deformation occurred in the mid-Cretaceous (Gibson, 1987a), so the structure of the Mokoiwi was not examined in detail in this study. Gibson (1987a) showed that the Mokoiwi Formation has a dominantly northwest strike, and that $25 \%$ of the beds have been extensionally dismembered into "broken formation". He also 
Table 3.1: Slip, stratigraphic separation, shortening, and transport direction estimates for major faults and fault-propagation folds, lower Mata River area. Asterisks beside slip and shortening figures for Mangapekapeka fault denote reliance on adopted fault geometry (cross-section $\mathrm{C}-\mathrm{C}^{\prime}$ ). Figures for anticlines correspond to adopted regional elevation.

$\begin{array}{lcccc}\text { Fault/fold } & \text { Slip } & \text { Strat. separation } & \text { Shortening } & \text { Transport } \\ \text { Eastern Thungia F. } & >>2 \mathrm{~km} & >1260 \mathrm{~m} & ? & \approx 070^{\circ} \\ \text { Mangapekapeka F. } & >1500 \mathrm{~m}^{*} & 360 \mathrm{~m} & >1510 \mathrm{~m}^{*} & \approx 100^{\circ} \\ \text { Southwest anticline } & 550 \mathrm{~m} & 340 \mathrm{~m} & 550 \mathrm{~m} & 067^{\circ} \\ \text { Middle anticline } & 880 \mathrm{~m} & 400 \mathrm{~m} & 880 \mathrm{~m} & 067^{\circ} \\ \text { Northeast anticline } & 600 \mathrm{~m} & 400 \mathrm{~m} & 600 \mathrm{~m} & 067^{\circ} \\ \text { Western Ihungia F. } & >>\mathrm{km} & >1900 \mathrm{~m} & ? & 070^{\circ}-080^{\circ} \\ \text { Aorangiwai F. } & ? & ? 5.6 \mathrm{~km} & ? & \approx 215^{\circ}\end{array}$


showed that bedding and broken formation were affected by at least two episodes of folding, resulting in two thirds of the beds having been overturned. Fold axes in the Mokoiwi mudstone trend dominantly northwest, but macroscopic folds in the Taitai sandstone massifs of Taitai, Wharekia and Aorangi trend northeast. Analysis of minor structures adjacent to the "Hukanui Fault" and the fault at the northeastern boundary of the inlier suggest motion of the hangingwall to the southwest or south (Gibson, 1987a), compatible with the sense of overturning of the syncline beneath the Aorangiwai Fault in the Aorangiwai River (section 3.5.2.1).

The transport direction on the Aorangiwai Fault, and of the Mokoiwi klippe as a whole, is inferred from the foregoing to have been southwestward. The Aorangiwai Fault cuts the Ihungia Fault, and locally has early Eocene mudstone in its footwall. Its motion therefore post-dates motion on the Ihungia Fault and is post-early Eocene. The amount of motion on the Aorangiwai Fault is difficult to estimate. If the Mokoiwi Formation is a correlative of the lithologically similar Motuan strata in the Mangaoporo area (Moore, 1988a; see section 2.2.2.1), then the Mangaoporo section (column 11, Fig. 2.3) and the local thickness of the Whangai and Waipawa formations (e.g., column 10, Fig. 2.3) suggest that about $5.6 \mathrm{~km}$ of strata once separated the top of the Mokoiwi and the base of the Eocene. However, the Mokoiwi sheet was derived from somewhere northeast of the present position of the Matakaoa Volcanics (see sections 6.3.5.3, 6.4.3.3) and the Cretaceous succession is likely to have thinned offshore (i.e., northeastward).

\subsection{DISCUSSION AND CONCLUSIONS}

\subsubsection{History of Deformation in the Lower Mata River Area}

The following sequence of tectonic events took place in the lower Mata River area. Magnitudes and transport directions of major thrust movements during each event are summarised in Table 3.1.

1) Tikihore Formation was deposited into a basin east of the Ihungia Fault between the Arowhanan (or earlier) and the Piripauan.

2) East-northeastward thrusting took place on the Ihungia fault system. Waitahaia Formation was emplaced over Piripauan Tikihore Formation on the eastern Ihungia Fault and the northern part of the western Ihungia Fault, and Mangaotanean to Piripauan Tikihore Formation was repeated along the Mangapekapeka Fault. The eastern Ihungia Fault was breached by the southern part of the western Ihungia Fault either at this time or during event 5. 
3) The Ihungia fault system was tilted and the Tikihore Formation east of it was deformed into fault-propagation folds by east-northeastward thrusting on two blind thrusts, at least one of which is likely to splay from the Ihungia fault system. After folding, the southwest and middle anticlines were downthrown along a normal fault in the northeast syncline which may join the southwestern thrust at depth.

4) The above structures were eroded, and the Haumurian-Teurian strata were deposited unconformably over them.

5) Renewed east-northeastward thrusting took place on the western Ihungia Fault, juxtaposing Waitahaia Formation and Haumurian-Teurian rocks. Some faulting also took place in the Haumurian-Teurian rocks immediately east of the western Ihungia Fault.

6) Mokoiwi Formation and horses of Eocene smectite mudstone were emplaced across Haumurian-Teurian rocks, the Ihungia Fault system, and the Waitahaia Formation on the southwest-directed Aorangiwai Fault. Folding and possible detachment of the Haumurian-Teurian rocks from the unconformably underlying Tikihore Formation took place close to this fault.

7) All the above structures were folded into a gentle dome centred on the present site of the central Mata valley.

\subsubsection{Deformation History and the "East Coast Allochthon"}

Moore $(1985,1988 a)$ showed part of the southwestern boundary of his East Coast Allochthon as formed by the Ihungia Fault. Southwest of that fault, Upper Cretaceous and Paleocene rocks are only gently deformed and were considered by Moore to be part of the 'autochthonous' Motu Block, the base of the 'allochthon' being a gently southeast-dipping thrust above the Haumurian-Teurian Whangai Formation (see section 1.3.1 and Fig. 1.2). Northeast of the Ihungia Fault, all the exposed Upper Cretaceous and Lower Tertiary rocks are deformed, and were included by Moore in the East Coast Allochthon. This implies that the sole thrust of the allochthon steps down across the Ihungia Fault to a lower structural level in the northeast. As stated in section 1.4, the structures in the lower Mata River area were mapped partly to determine how, if at all, they relate to this apparent step in the sole thrust.

Emplacement of the East Coast Allochthon took place in the Early Miocene (section 1.3.1). In the lower Mata River area, the first phase of movement on the Ihungia fault system and the generation of the Mata River folds occurred in the Late Cretaceous. 
Tectonic events which could be Early Miocene are the second phase of movement on the western Ihungia Fault (post-Teurian) and the emplacement of the Mokoiwi Formation and its underlying horses of smectite mudstone on the Aorangiwai Fault (post-early Eocene). The latter event is probably Early Miocene because clasts of Mokoiwi Formation lithologies are present in conglomerates of that age to the south (see section 4.2.10). The former event can be constrained with certainty only to between the Teurian and the emplacement of the Mokoiwi sheet, but it is probably also Early Miocene as the regional stratigraphy indicates tectonic quiescence earlier in the Tertiary (see Chapter 2). The western Ihungia Fault thus accommodated east-northeastward movement of the Motu Block over the previously deformed Cretaceous and Lower Tertiary rocks to the northeast probably just prior to southwestward thrusting of the Mokoiwi Formation over those rocks and the Motu Block. The base of the allochthon further south also has Mokoiwi Formation in its hangingwall, and it is probable that this fault and the Aorangiwai Fault are the same structure (see also section 4.8.2).

There are, then, three major structural blocks in the lower Mata River area which moved relative to each other in the Early Miocene: the rocks above the Aorangiwai Fault; The Motu Block, above and southwest of the western Ihungia Fault; and the Upper Cretaceous-Teurian rocks beneath and northeast of the western Ihungia Fault. Of these, the Motu Block is defined as the 'autochthon' to the Early Miocene deformation, and the East Coast Allochthon comprises the block above the Aorangiwai Fault and the block northeast of the western Ihungia Fault.

\subsubsection{Conclusions}

Examination of the lower Mata River area during the present study has led to the following conclusions:

1) The lower Mata River area contains a group of faults which form part of the boundary between the Motu Block and the East Coast Allochthon, a group of associated folds, and the southern end of the Mokoiwi inlier. Five lithologic units are distinguished there: Mokoiwi Formation (?Urutawan-Motuan/Albian), Waitahaia Formation (Ngaterian/Albian-Cenomanian), Tikihore Formation (ArowhananPiripauan/Cenomanian-Santonian-?Campanian), Haumurian-Teurian (MaastrichtianPaleocene) beds, and Eocene smectite mudstone.

2) Tikihore Formation in the Mata valley is folded into three anticlines and two synclines. These structures are north-northwest trending, doubly-plunging, steeply west-southwest inclined, open to close, and northeast-verging. Their angular style, the probable lack of a weak detachment horizon beneath them, and their 
association with northeast-directed thrusts to their southwest makes it likely that they are fault-propagation folds cored by northeast-directed blind thrusts. Application of geometric models shows that a section across the folds can be balanced if the southwest and middle anticlines are underlain by a single thrust whose dip varies from $39^{\circ}$ to $27^{\circ}$ and the northeast anticline is underlain by a thrust whose dip is $43^{\circ}$. Shortening across the folds is $\approx 2.1 \mathrm{~km}(26 \%)$. The folds are cut by a late normal fault which probably joins one of the thrusts at depth, and are unconformably overlain by Haumurian-Teurian strata which define a gentle dome centred on the Mata valley.

3) The folds are bounded to the west by the westerly-dipping reverse faults of the Ihungia Fault system. The eastern Ihungia Fault juxtaposes Waitahaia Formation with Piripauan Tikihore Formation and thus has a stratigraphic separation of over $1260 \mathrm{~m}$. The Mangapekapeka Fault, a footwall splay from the eastern Ihungia Fault, repeats Mangaotanean-Piripauan beds of the backlimb of the southwest anticline. Both the eastern Ihungia and Mangapekapeka Faults are overlain by HaumurianTeurian beds. The western Ihungia Fault juxtaposes complexly deformed Waitahaia Formation of the Motu Block, on the west, against Waitahaia, Tikihore, and Haumurian-Teurian rocks of the East Coast Allochthon on the east. It cuts the northern end of the eastern Ihungia Fault and also breaches that fault at depth. Because it cuts Haumurian-Teurian rocks, its displacement is at least $2 \mathrm{~km}$ greater than that of the eastern Thungia Fault, and its stratigraphic separation is at least $1900 \mathrm{~m}$.

4) The southern end of the Mokoiwi inlier is underlain by the Aorangiwai Fault, a gently north- to east-dipping, southwest-directed thrust which cuts across the western Ihungia Fault and separates complexly deformed Mokoiwi Formation (above) from Waitahaia Formation and Haumurian-Teurian beds (below). Locally, the Haumurian-Teurian beds beneath it are deformed into tight to isoclinal folds. Thin sheets of Eocene smectite mudstone are present along it at places. Its stratigraphic separation may be as much as $5.6 \mathrm{~km}$, and its transport distance is some tens of kilometres.

5) The sequence of tectonic events in the lower Mata River area was as follows: deformation of the Waitahaia Formation, probably concurrently with movement on the Ihungia fault system, and deposition of the Tikihore Formation in a basin east of the faults; between the late Piripauan and early Haumurian, east-northeastward thrusting on the Ihungia Fault system which put Waitahaia Formation over Tikihore Formation and repeated a sliver of Tikihore strata; tilting of the Ihungia Fault system and deformation of the Tikihore Formation east of it into fault- 
propagation folds by east-northeastward thrusting on two blind thrusts, at least one of which probably splayed from the Ihungia fault system, and minor dislocation of these folds by a post-thrusting normal fault; Erosion of the faults and folds and deposition of the Haumurian-Teurian beds over the area; in the Early Miocene, renewed east-northeastward thrusting on the western Ihungia Fault and minor faulting of the Haumurian-Teurian rocks east of it; emplacement of the Mokoiwi Formation and horses of Eocene smectite mudstone southwestward across Haumurian-Teurian rocks, the Ihungia fault system, and the Waitahaia Formation, on the Aorangiwai Fault; and folding of all the above structures into a gentle dome centred on the Mata valley.

6) There are three major structural blocks in the lower Mata River area which moved relative to one another in the Early Miocene. These are: the sheet of Mokoiwi Formation above the Aorangiwai Fault; the Motu Block, above and southwest of the western Ihungia Fault; and the Upper Cretaceous-Paleocene rocks beneath and northeast of the western Ihungia Fault. The Motu Block moved northeastward over the northeastern block, and the Mokoiwi Formation subsequently moved southwestward over both. The boundary between the Motu Block and the East Coast Allochthon in this area is thus compound, consisting of the northeast-directed western Ihungia Fault and that part of the southwest-directed Aorangiwai Fault west of the western Ihungia Fault. The western Ihungia Fault is not the location of a simple step in the sole thrust of the East Coast Allochthon, and the lower Mata River folds were formed during an earlier phase of deformation than the East Coast Allochthon. 


\section{Chapter 4}

\section{Structure Between Ihungia River and Puketoro Stream}

\subsection{INTRODUCTION}

\subsubsection{Location, Physiography and Exposure}

The area between Ihungia River and Puketoro Stream constitutes area 2 in Fig. 1.4. This area straddles the boundary between NZMS 260 sheets Y15 and Y16 $(1: 50,000)$. It is L-shaped, being approximately bounded by grid refs. Y15 660450, Y15 630450, Y15 630420, Y15 540420, Y16 540380, and Y16 650380 (Fig. 4.1). The northern projection of the area overlaps with the southwestern part of the lower Mata River area (area 1; Chapter 3). Aerial photographs examined by the writer are from run number 2277A (1957), frames 5-13, and run number 2278A, frames 5-12. Access to the area is by the metalled Ihungia Road, which leaves State Highway 35 approximately $7 \mathrm{~km}$ north of $\mathrm{Te}$ Puia.

Physiographically, the area is divided in half by the north-trending ridge which separates the catchment of the Mata River, in the west, from that of the Ihungia River in the east (Fig. 4.1). Elevation is highest along a line extending from the northern end of this ridge (Rangikohua trig) westward along the northern edge of the area, where it reaches $740 \mathrm{~m}$. Elevation is lowest in the bed of the Ihungia River, at 150-210 m. Relief is moderate over most of the area, which is mostly dissected hill country. Adjacent to the Mata River in the southwest, there is a broad alluvial terrace. Remnants of higher terraces, many of which are underlain by thick tephras, are preserved on the sides of the Mata valley.

Access by car is limited to the Ihungia Road and to a farm road down the Ihungia River as far as the second river crossing, about $3 \mathrm{~km}$ north of Ihungia Station. Fourwheel-drive tracks follow the ridge across the centre of the area and other ridges in the Ihungia catchment. Foot access to the Mata River and its tributaries is easiest from a farm track which leaves Ihungia Road between Waimata Stream and Opossum Creek.

Exposure is generally poor, good outcrop being restricted to Puketoro Stream, the lower Thungia River, and stretches of the Mata River and the lower reaches of its major tributaries. Considerable mass-movement has affected much of the area, notably in the 


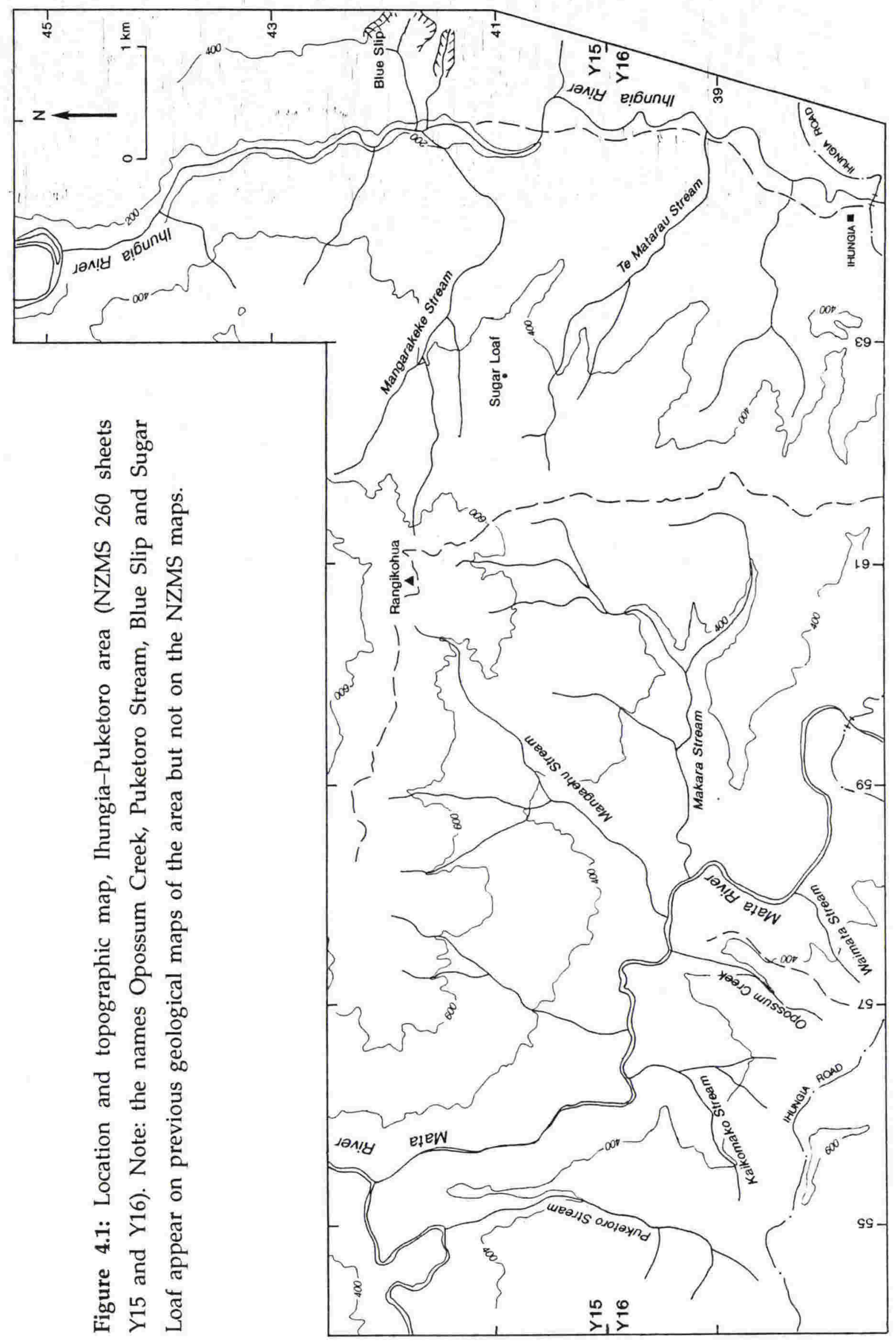


catchments of Mangarakeke and Te Matarau Streams in the Ihungia valley (Fig. 4.2) and Mangaehu Stream and the northern branches of Makara Stream in the Mata valley. Geologic relations are very difficult to determine in those areas. Most of the area is pasture, with patches of scrub and bush in minor valleys. The southwestern slopes of the Mata valley and the area between lower Mangaehu Stream, Makara Stream, and the Mata River are planted in young pine forest. Patches of native bush are preserved on the lower slopes of the Mata valley.

\subsubsection{Previous Work}

The earliest map of the area was that of Ongley and Macpherson (1928). Pick (1962) produced a detailed map, and more recently Kenny (1980, 1984a, 1986), in two separate studies, mapped the Ihungia catchment and a larger area to the west which includes the area presently under discussion. The southern half of the area lies within the Y16 1:50,000 map of Mazengarb et al. (1991). The area was included in the regional surveys of Kingma (1965) and Moore et al. (1989).

Pick (1962) and Kingma (1965) mapped a west-southwest trending zone of steeply dipping faults (Waitahaia Fault Zone; Pick, 1962) which placed Haumurian-Teurian rocks and Mokoiwi Formation, on the south, against Raukumara Series and PiripauanTeurian (Whangai Formation) rocks on the north. These faults were mapped as cutting across the south end of the north-northwest trending Ihungia Fault (section 3.6). Subsequently, Kenny (1980, 1984a, 1986) and Mazengarb et al. (1991) showed that many of the Waitahaia faults dip gently to moderately south-southeast. The lowest (the Waitahaia Fault) has Mokoiwi Formation in its hangingwall and Whangai Formation in its footwall at most places, and the highest has Miocene rocks in its hangingwall and cuts across the lower ones. The Waitahaia Fault and the Thungia Fault form the boundary between the East Coast Allochthon and Motu Block of Moore (1985, 1988a) (section 1.3.1). Kenny (1986) considered the Waitahaia Fault to be the product of latest Oligocene-Early Miocene thrusting from the north or northwest, and higher faults, including the sub-Miocene structure, to be products of post-Middle Miocene thrusting, also from the north or northwest.

\subsection{STRATIGRAPHY}

Eleven lithologic units are distinguished in the Ihungia-Puketoro area (Fig. 4.3). These are: 


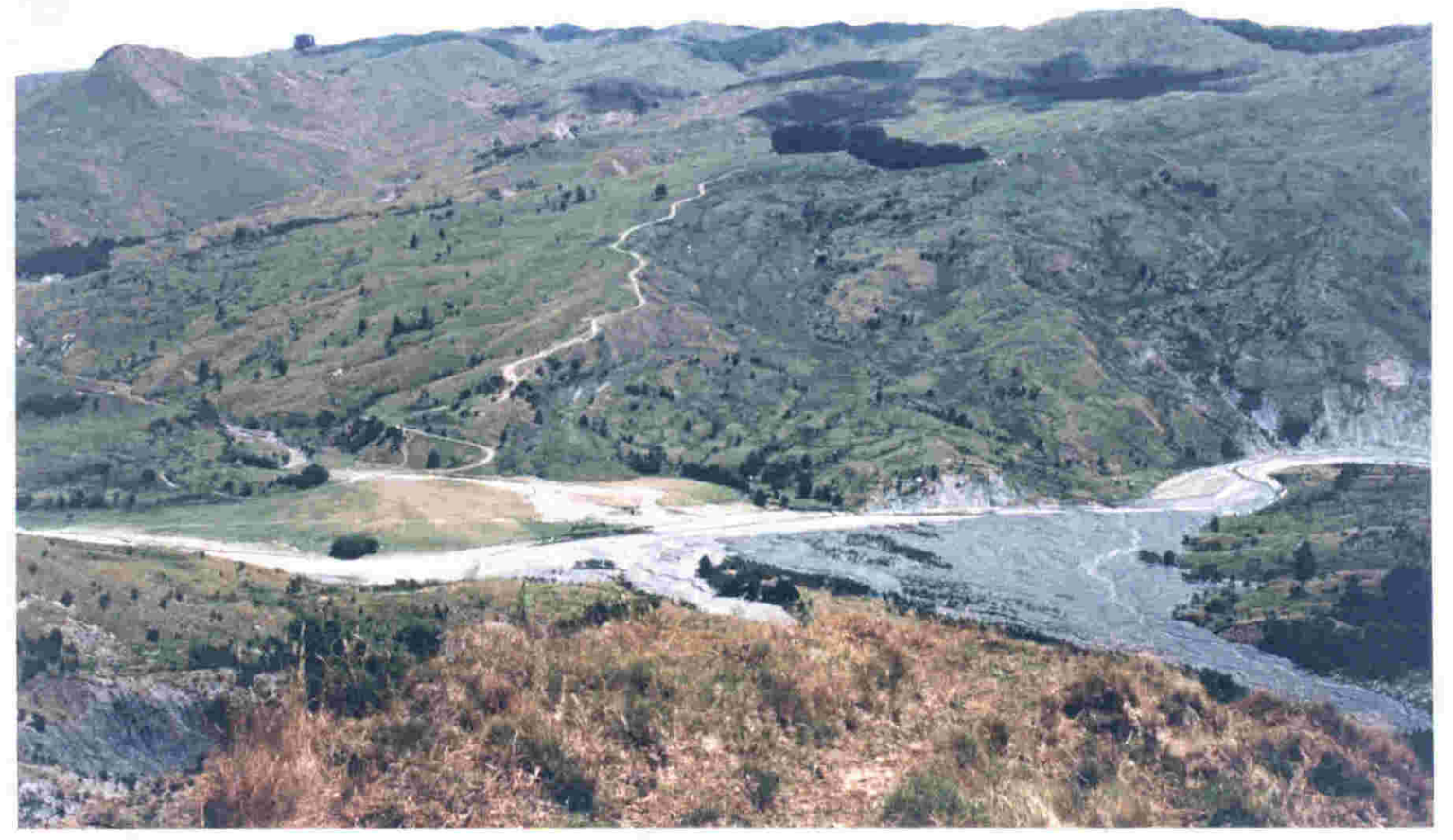

Figure 4.2: Catchment of lower Mangarakeke Stream, looking westward from across Ihungia River. Badly slumped areas are underlain by Mokoiwi and Waitahaia Formations, prominent hill at top left (Sugar Loaf) is Oligocene limestone and greensand. 
1) Alternating sandstone and mudstone with lensoid bodies of coarse sandstone, mapped as "undifferentiated Clarence Series" by Moore et al. (1989) and "undifferentiated Ruatoria Group" by Mazengarb et al. (1991), but here referred to as Mokoiwi Formation, following Pick (1962) and Kenny (1980, 1984a, 1986). The age of this unit is ?Urutawan-Motuan (Albian) (Kenny, 1986).

2) Ngaterian (Albian-Cenomanian) sandstone and alternating sandstone and mudstone of the Waitahaia Formation (Kenny, 1986; Mazengarb et al., 1991). These are the "Hikurangi beds" of Laing (1972a) and Kenny (1980, 1984a).

3) Raukumara Series (Cenomanian-Santonian) mudstone with interbedded sandstone of the Karekare Formation (Kenny, 1986; Moore et al., 1989; Mazengarb et al., 1991).

4) Teratan-Piripauan (Coniacian-Santonian-?Campanian) sandstone and alternating sandstone and mudstone of the Tikihore Formation.

5) Haumurian-Teurian (Maastrichtian-Paleocene) alternating sandstone and mudstone and calcareous mudstone.

6) Haumurian-Teurian siliceous and calcareous mudstone of the Whangai Formation (Pick, 1962; Kenny, 1980, 1984a, 1986; Moore et al., 1989; Mazengarb et al., 1991).

7) Smectitic mélange (Kenny, 1986; Moore et al., 1989; Mazengarb et al., 1991). This has a matrix of Eocene smectite mudstone and may contain blocks of all preMiocene lithologies, as well as minor igneous rocks (Moore, 1985).

8) Whaingaroan-Waitakian (Oligocene-Aquitanian) muddy limestone, fine-grained limestone, and greensand, referred to herein as the limestone/greensand lithotype.

9) Waitakian (Aquitanian) alternating sandstone and mudstone of the Opossum Creek sandstone lithofacies (Kenny, 1986).

10) Waitakian-Otaian (Aquitanian-Burdigalian) fine sandstone and mudstone with lenses of poorly sorted breccia and conglomerate, referred to herein as the sandstone/breccia lithotype.

11) Waitakian-Otaian and younger sandy mudstone, alternating sandstone and mudstone, sandstone, and bioclastic limestone of the Thungia Formation (Pick, 1962; Laing, 1972a; Kenny, 1980, 1984a, 1986). 


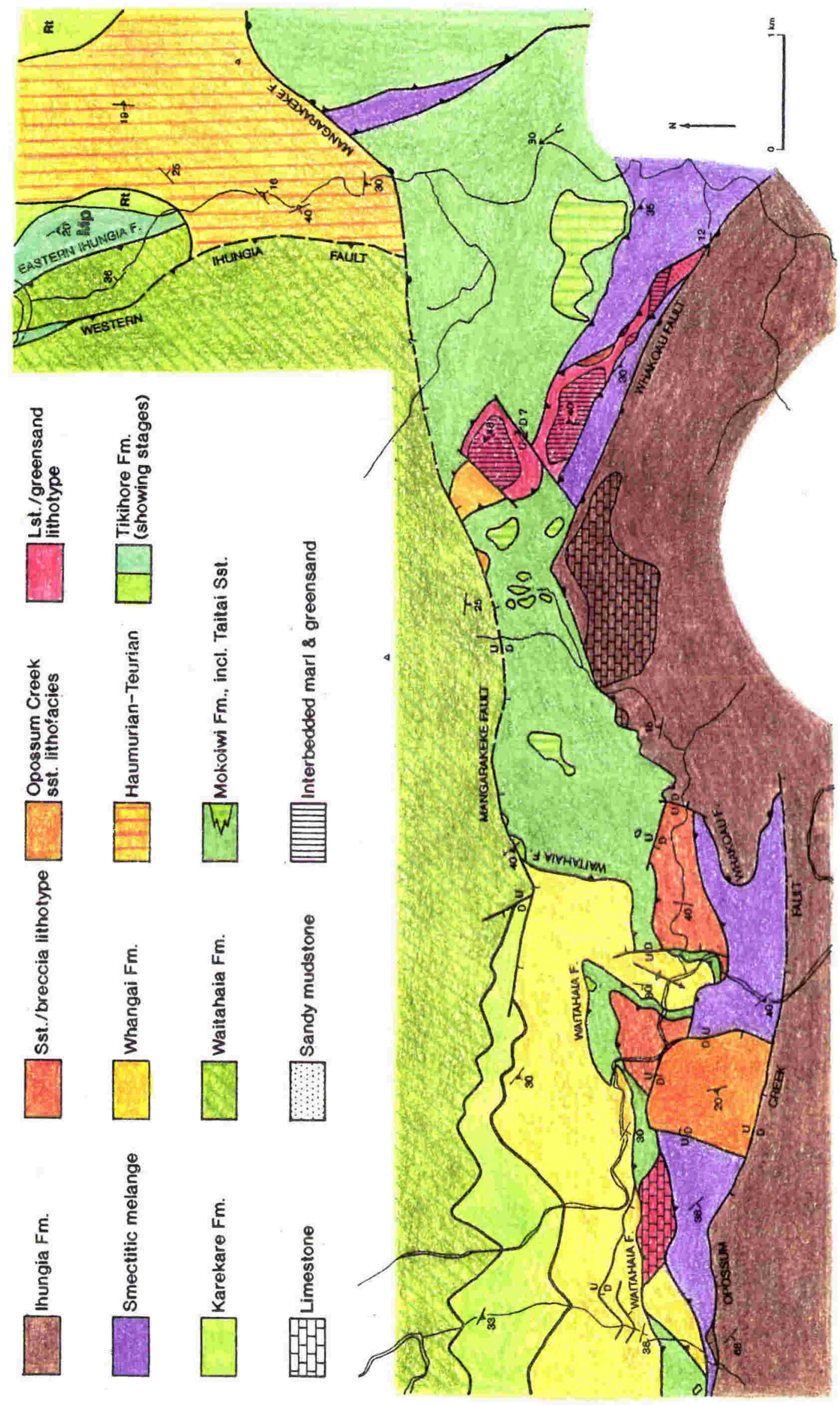

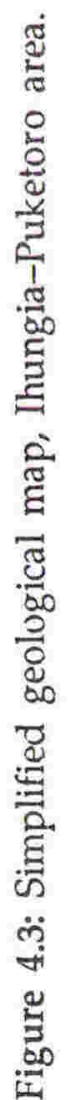


Because many of these units are in fault contact (Fig. 4.3) and their thicknesses are not complete, no stratigraphic column is presented. Where approximate minimum thicknesses have been determined, they are given in the following descriptions.

\subsubsection{Mokoiwi Formation}

Mokoiwi Formation occurs as a west-trending strip across the centre of the area (Fig. 4.3). It structurally overlies Waitahaia Formation and Haumurian-Teurian strata in the east, and Whangai Formation in the west. Bodies of Taitai Sandstone up to $1 \mathrm{~km}$ long are present in the east. The composition and age of this formation are as described for correlative rocks in the lower Mata River area (see section 3.2.1).

\subsubsection{Waitahaia Formation}

Waitahaia Formation occupies the north of the area (Fig. 4.3), where it is contiguous with correlative rocks in the southwest of the lower Mata River area. East of the western Ihungia Fault, it is faulted against Tikihore Formation and lies stratigraphically beneath Haumurian-Teurian strata. In central parts of the area, it structurally underlies Mokoiwi Formation. In the west, it lies stratigraphically beneath Karekare Formation. The composition of the Waitahaia Formation has been described in section 3.2.2, and will not be repeated here. The age of the formation in this area is Ngaterian (Albian-Cenomanian) (Wellman, 1959; Pick, 1962; Kenny, 1980, 1984a, 1986).

\subsubsection{Karekare Formation}

The Ihungia-Puketoro area contains the northernmost occurrence of the regionally extensive Karekare Formation (see section 2.2.1.3). It occurs as a west-trending strip in the northwest of the area (Fig. 4.3), where it overlies Waitahaia Formation along an angular unconformity (Fig. 4.4a).

Karekare Formation in the Puketoro area consists of interbedded blue-grey mudstone and moderately hard, yellow-grey fine sandstone. The mudstone weathers medium grey, and the sandstone weathers light grey to yellow-brown. Complete Inoceramus specimens are present in some mudstones, and many sandstones contain Inoceramus fragments. Sandstone dominates near the base of the formation, sandstone beds being decimetres to metres thick and mudstones being centimetres to decimetres thick. Up-section, however, the formation rapidly becomes mudstone-dominated, and the 'typical' Karekare consists of metre-bedded mudstones with centimetre- to decimetre-bedded sandstones (Fig. 4.4b). Near the top of the formation, in the Teratan, sandstones become thinner and finer, and red and green mudstone beds appear. This 

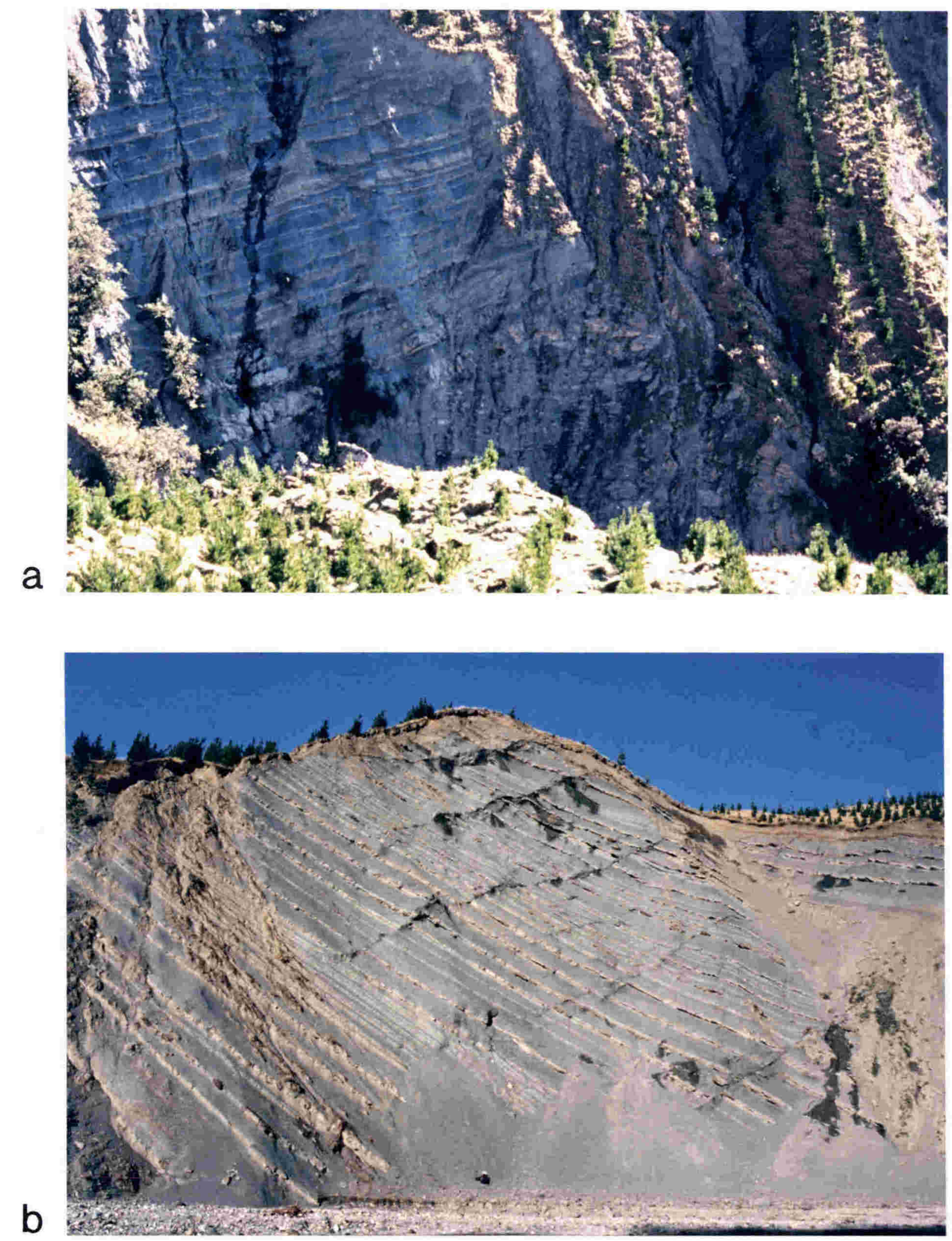

Figure 4.4: a: Karekare Formation (Arowhanan) unconformably overlying Ngaterian Waitahaia Formation, lower Puketoro Stream (Y15 38054113). b: Karekare Formation interbedded mudstones and sandstones, Puketoro Stream (Y15 38154098). 

overlie "Tapuwaeroa Formation". However, the similarity of this unit to the underlying beds and the lack of any fault between the two makes it likely that this unit is a variant of the Haumurian-Teurian formation.

Rocks similar to lithotype 3 in the lower Mata River area are also present in the Ihungia River section. At Y15 64734300, there are beds of light grey to orange-brown weathering, dark purple-grey to black, jarositic, fissile, micaceous shale with thin greensand interbeds, and yellow-green, very glauconitic medium sandstones. The mudstones are up to $2 \mathrm{~m}$ thick, the sandstones are up to $1.5 \mathrm{~m}$ thick, and the composite thickness of the unit is about $6 \mathrm{~m}$. It is conformably overlain by more 'typical' Haumurian-Teurian, which also crops out stratigraphically below it about 100 $\mathrm{m}$ further down the river.

The age of this association, as outlined in section 3.2.4, is Haumurian-Teurian (Maastrichtian-Paleocene). Kenny $(1980,1984 a)$ found Ostrea lapillicola, which has an age range of ?Teratan-Haumurian, but is most common in the Haumurian (Speden, in Kenny, 1984a). A foraminiferal sample from not far above the black shale horizon in the Ihungia River, Y15/f9870 (collected by M.C. Pick, 1957), gave a Teurian age (H.E.G. Morgans, pers. comm., 1991). A sample from further up the river (Y15/f122) gave a Haumurian-Bortonian age (see Appendix 2).

The thickness of the Haumurian-Teurian rocks in the Ihungia River section is $500-550 \mathrm{~m}$ (see section 3.2.4 and Fig. 3.2).

\subsubsection{Whangai Formation}

Whangai Formation is present beneath the Waitahaia Fault in the west, where it is structurally overlain by Mokoiwi Formation. It is also present above the Waithahaia and Mangarakeke Faults, where it occurs as isolated, fault-bounded slivers (Fig. 4.3). Beneath the Waitahaia Fault, the Whangai overlies Karekare Formation disconformably or with slight angular unconformity. It cuts down across Karekare Formation towards the east. The basal contact of the formation is obscured in Puketoro Stream by slumping. Kenny (1986) mapped the contact there as a normal fault. Elsewhere, the contact is not exposed.

Speden (1978) shows the base of the formation in Puketoro Stream as being sandy (see Fig. 2.2). Above the base, the Whangai can be subdivided into two members, the lower Rakauroa Member and the Upper Calcareous Member (Moore et al., 1986; Kenny, 1986; Moore, 1988b. See also section 2.2.1.2). The Rakauroa Member consists of moderately hard, blue-grey, fissile, micaceous, siliceous siltstone, which weathers light 
grey to orange and is pyritic and jarositic at places. It contains large (up to $2 \mathrm{~m}$ ) ?sideritic or baritic septarian concretions. The Upper Calcareous Member consists of a lower portion of poorly bedded, calcareous, medium grey mudstone with dark grey mottlings which weathers to light grey, and an upper portion of well bedded, white weathering, medium and dark grey very calcareous mudstone and muddy limestone. This upper portion was referred to by Pick (1962) and Kenny (1986) as Waingata limestone. It is similar to Moore's (1988b) Porangahau Member.

The Whangai above the Waitahaia Fault is generally similar to the upper Whangai beneath it. In upper Puketoro Stream, the Whangai is well bedded and very calcareous, with thin interbeds of glauconitic fine sandstone. In the upper Te Matarau catchment, it is poorly bedded.

The thickness of the Whangai Formation beneath the Waitahaia Fault in the Puketoro area is about $350 \mathrm{~m}$. The age of the formation is Haumurian-Teurian (Maastrichtian-Paleocene) (Kenny, 1986; Moore, 1988b).

\subsubsection{Smectitic Mélange}

Mélange is present above the Waitahaia and Mangarakeke Faults. It is extensively developed around the Mata River and in the Te Matarau catchment. The composition of the mélange matrix varies with location. At most places, the dominant component is smectitic late Paleocene and Eocene mudstone (Kenny, 1980, 1984a, 1986), which is mostly mid-grey but may be grey-green, white, purple, or red. Where the mélange is in contact with Mokoiwi Formation, crushed Mokoiwi mudstone may form part of the matrix. The distinction between 'mélange' and 'Mokoiwi Formation' in those areas then becomes somewhat arbitrary. In the thin sliver of mélange in the extreme east, a large part of the matrix is crushed calcareous mudstone similar to that in the upper part of the adjacent Haumurian-Teurian beds.

The blocks in the mélange have a variety of compositions and sizes. Whangai Formation is a common constituent, as are glauconitic sandstone and grey calcareous mudstone-both probably Paleogene, by comparison with similar rocks nearby (Phillips, 1985; Kenny, 1986) - and Taitai sandstone. Most blocks cannot be correlated with particular formations with any certainty, but many are probably Cretaceous, having appearances resembling Mokoiwi Formation, Tikihore Formation, and HaumurianTeurian rocks. Blocks of erosion-resistant Oligocene limestone, marl, and greensand are prominent in the otherwise subdued topography of the mélange. Most do not exceed 20 $\mathrm{m}$ across, but the largest, around Te Matarau Stream, have been mapped separately (see section 4.2.8). Moore (1985) described boulders of dolerite and basalt in mélange in 
Makara Stream, and as float in Kaikomako Stream (see section 2.2.2.1). Igneous rocks also occur rarely as float in the bed of the Mata River, where they may have been derived from nearby mélange (see section 2.2.2.1). Miocene blocks only occur immediately adjacent to the tectonic contact between the mélange and Ihungia Formation.

The dominant composition of the blocks varies across the area, although blocks of any of the common lithologies described above may be present at any one locality. The mélange north of Te Matarau Stream is dominated by Oligocene blocks, and the sliver in the extreme east is dominated by blocks similar to the upper part of the Haumurian-Teurian formation, the distinctive glauconitic grit being common. In the west, Cretaceous lithologies and Whangai Formation dominate.

\subsubsection{Limestone/Greensand Lithotype}

This lithotype is present as large fault-bounded slivers in the upper Te Matarau and Kaikomako catchments, and as small blocks in the mélange in the lower Te Matarau and Makara catchments. Rocks included in this lithotype correspond with the Sugar Loaf greensand member of Wanstead Formation of Kenny (1980), the greensand lithofacies of Mangatu Group of Kenny (1984a), Hauturu greensand lithofacies and Whakoau limestone lithofacies of Kenny (1986), fine-grained limestone of Moore et al. (1989), Weber Formation of Kenny (1980, 1984a), and the lower limestone lithofacies of the upper Mangatu Group of Mazengarb et al. (1991).

The dominant lithology within the limestone/greensand lithotype is moderately hard, poorly bedded, cream to light green, very calcareous mudstone to muddy limestone with dark grey mottlings. This is best exposed in Te Matarau Stream just below the forks. This lithology is very similar to Weber Formation in southern Hawkes Bay and in other parts of Raukumara Peninsula (e.g., Lillie, 1953; Joass, 1987). At places, it has thin $(<10 \mathrm{~cm})$ interbeds of dark green, fine to medium grained greensand. Associated with this lithology in lower Te Matarau Stream is blue-grey, very calcareous sandy mudstone.

Forming the peaks of Sugar Loaf (Y15 627409) and the prominent hill separating the two branches of Te Matarau Stream, there are interbeds of calcareous mudstone and calcareous greensand. Kenny $(1980,1984 a)$ considered that this association underlies the limestone, but exposures in the northern branch of Te Matarau Stream show that the converse is true. This association consists of alternating hard, yellow-brown weathering, olive green, centimetre-bedded, fine to medium grained calcareous greensand, and pale green-grey to cream, centimetre-bedded, calcareous mudstone. Higher in the succession, 
there is massive greensand or decimetre-bedded greensands with interbeds of angular clasts of white calcareous mudstone, presumably rip-up clasts incorporated into the bases of the sandstones during transport in sediment gravity flows (Fig. 4.5).

West of lower Kaikomako Stream, rocks included in this lithotype are light grey, flaggy, muddy limestones, crystalline at places, with thin, fine to medium grained greensand interbeds. These rocks were included in the Whakoau limestone lithofacies of Kenny (1986), and are equivalent to the limestone lithotype of Phillips (1985).

The age of the limestone/greensand lithotype in the Ihungia-Puketoro area is Whaingaroan to probably Waitakian (Oligocene-Aquitanian). Scott (in Kenny, 1984a) considered that foraminifera in a sample from Kenny's greensand lithofacies on Sugar Loaf were probably (but not definitely) Whaingaroan-Duntroonian. However, this lithofacies was subsequently correlated with Hauturu greensand lithofacies, which is Waitakian (Kenny, 1986). Samples from a number of places in the limestone have yielded foraminifera with Whaingaroan (Rupelian-Chattian), Whaingaroan-Duntroonian (Oligocene), and Waitakian (Aquitanian) ages (Mazengarb et al., 1991). Moore et al. (1989) considered that the "Weber Formation" in this area has ages of Whaingaroan to Waitakian.

\subsubsection{Opossum Creek Sandstone Lithofacies}

In and around Opossum Creek, there is a fault-bounded occurrence of alternating moderately hard, yellow-grey, graded, medium to fine calcareous sandstones and dark blue-grey calcareous mudstones, referred to as Opossum Creek sandstone lithofacies by Kenny (1986) and as the calcareous sandstone lithofacies of the upper Mangatu Group by Mazengarb et al. (1991). Near the base of this lithofacies, sandstones are decimetrebedded and mudstones are centimetre-bedded, but higher in the succession both sandstones and mudstones are centimetre- to decimetre-bedded.

This unit can be seen to grade up from marl similar to that of the limestone/ greensand lithotype. In the bed of the Mata River around the mouth of Opossum Creek, poorly bedded, cream-coloured muddy limestone becomes darker and sandier upward and light-coloured sandstone beds appear. The transition to well bedded Opossum Creek lithofacies occurs over a few metres so that in the lowest reaches of Opossum Creek, 'typical' alternating sandstone and mudstone beds are found. This transition can also be seen in the hills just east of Opossum Creek. A pebble composed of black, fine-grained, crystalline material, similar to those common in the sandstone/ breccia lithotype (section 4.2.10) was observed in the lower material in the bed of the Mata River. 


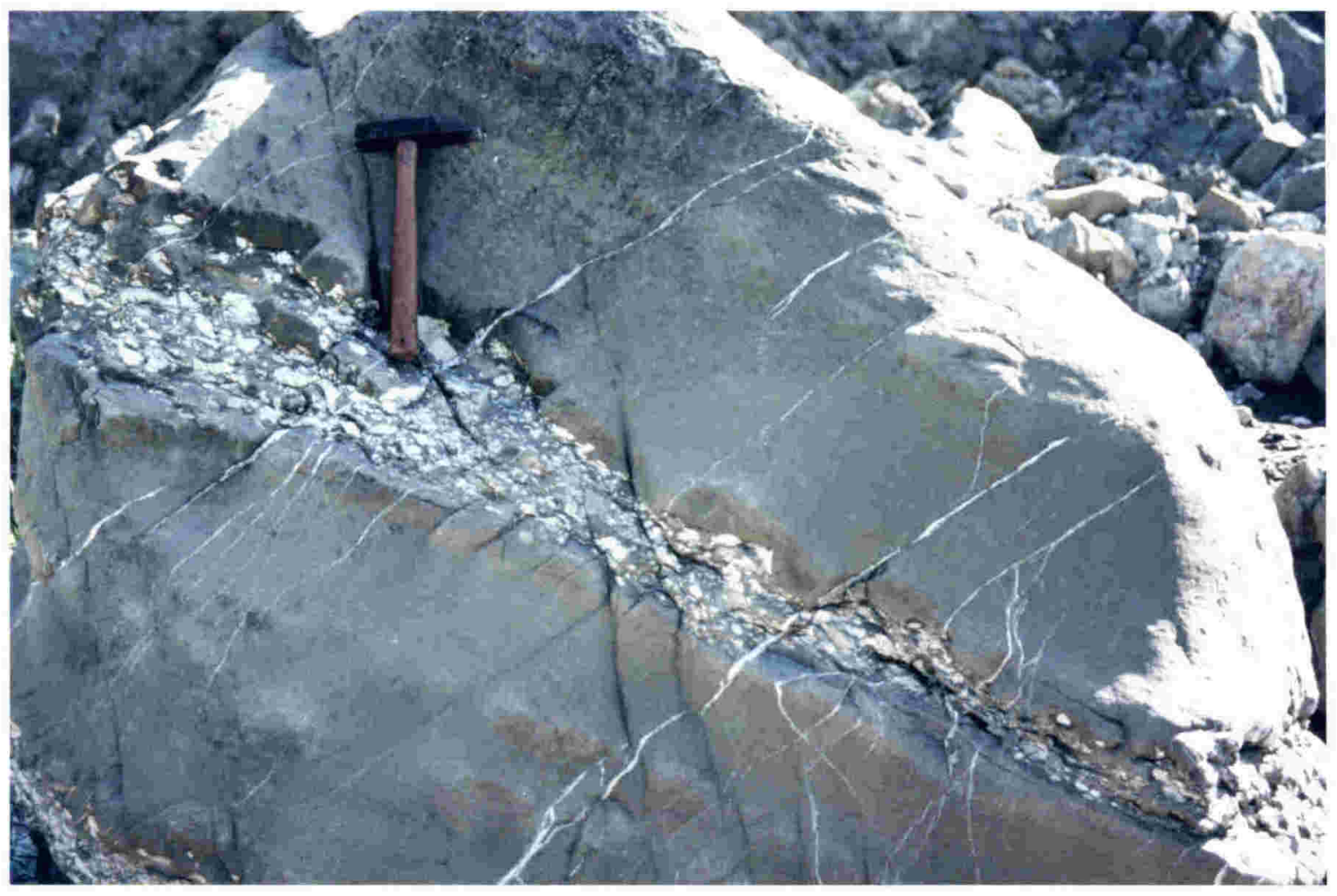

Figure 4.5: Float boulder in Te Matarau Stream (Y15 63314010) derived from the upper part of the limestone/greensand lithotype. The boulder is composed of greensand beds with interbedded angular limestone clasts. 
Kenny (1986) considered that the Opossum Creek Lithofacies is Waitakian. A foraminiferal sample from the middle reaches of Opossum Creek (Y16/f243) gave a Waitakian (Aquitanian) age (Mazengarb et al., 1991).

\subsubsection{Sandstone/Breccia Lithotype}

The sandstone/breccia lithotype (in part the breccia lithofacies of the upper Mangatu Group of Mazengarb et al., 1991) is present as two thin bodies in the Mata valley, one in the lower Makara catchment and one in the lower Mangaehu catchment (Fig. 4.3). In addition, there is a small occurrence of breccia associated with the limestone/greensand lithotype in Te Matarau Stream, centred on Y15/Y16 634400 . Where it can be observed, the basal contact of the western Mata River occurrence is a gently to moderately dipping fault with Mokoiwi Formation in its footwall. The eastern occurrence is inferred to rest with low-angle fault contact on Mokoiwi Formation around the Mata River and north of Makara Stream. Its contacts with Mokoiwi Formation at other places are high-angle faults. The contact with the limestone/ greensand lithotype in Te Matarau Stream is thought to be depositional. All occurrences are structurally overlain by mélange and/or Opossum Creek sandstone lithofacies. The eastern end of the sandstone/breccia body in the Makara valley is juxtaposed against Ihungia Formation along a moderately to steeply east-southeast dipping fault.

The sandstone/breccia lithotype is dominated by alternating dark grey to dark green-grey, coarse to very fine sandstones and dark grey to black mudstones. The dominant grain size of the sand is fine, but where it is associated with breccia there is a gradation through to coarse sand and grit. The alternating facies may be sandstoneor mudstone-dominated in any particular outcrop, but occurrences dominated by poorly sorted muddy sandstone with isolated clasts or thin beds of conglomerate are by far the most common. Bedding varies from a centimetre to a decimetre scale, to indistinct in outcrops which are almost wholly sandstone. In most outcrops, the rock is pervasively sheared and contains numerous calcite veinlets.

The other component of this lithotype is a hard, poorly sorted, poorly bedded coarse breccia to breccia-conglomerate. This has a gritty, commonly glauconitic, poorly sorted sand matrix. Its clasts are a variety of sizes, shapes, and compositions. They are dominated at most places by pebble to boulder sized, sub-rounded Cretaceous lithologies, including sandstone and mudstone resembling Mokoiwi, Tikihore, and Whangai lithotypes. Many clasts of the distinctive Taitai Sandstone are present, and tend to be large and angular; the largest are several metres across. A breccia body near the mouth of Mangaehu Stream is dominated by Taitai Sandstone clasts. Poorly cemented greensand clasts are present at some localities. Pebble to cobble size, polished, 
well rounded clasts of dark, mafic igneous material are common at all localities. Most of these are entirely fine grained, but some are plagioclase-phyric. Banded diorite and red argillite clasts are present in upper Makara Stream. In the Te Matarau Stream occurrence, stringers and small clasts of pale grey or white, very calcareous mudstone or muddy limestone similar to that of the nearby limestone/greensand lithotype are present (Fig. 4.6). The shapes of these suggest that they were unlithified at the time of their inclusion into the breccia. The stringer shown in Fig. 4.6 was sampled for foraminifera, but proved barren.

Kenny (1986) included the sandstone/breccia bodies in the Mata valley in the Ihungia Formation, and implied that they were Altonian because of the presence of "igneous conglomerate" (see section 2.3.1). She recovered no fossils from this material. Foraminifera recovered in this study (Y16/f793; see Appendix 2) gave an upper Waitakian-Otaian (Aquitanian-Burdigalian) age (H.E.G. Morgans, pers. comm., 1991). A pre-Ihungia age for this unit is consistent with its presence within the thrust system rather than structurally above it, and with its high degree of deformation relative to the Ihungia Formation. A Waitakian age (at least for the Te Matarau occurrence) is consistent with the incorporation of unlithified limestone/greensand lithotype (Whaingaroan-Waitakian) into the unit.

\subsubsection{Ihungia Formation}

Ihungia Formation occupies the south of the mapped area. It is juxtaposed against older rocks along a series of gently to moderately southward-dipping faults. Moore et al. (1989) and Mazengarb et al. (1991) mapped these rocks as part of their Tolaga Group.

The major part of this formation consists of massive to poorly bedded or finely laminated, calcareous, dark blue-grey fine sandy mudstone. Packets of alternating bluegrey fine sandstone and sandy mudstone are common. The sandstones are generally centimetre-bedded and graded, with massive bases and parallel-laminated tops. They weather to brown-grey. Sandstones and mudstones weather orange-brown on fracture surfaces. On the ridge between the Te Matarau and Makara catchments, there are about $100 \mathrm{~m}$ of yellow-brown weathering, medium grey, flaggy, bryozoan bioclastic limestone, the limestone lithofacies of Kenny (1984a, 1986) and Kouetumarae Limestone (Formation) of Mazengarb et al. (1991). Shellbeds within this lithotype contain Chlamys, Serripecten and oyster specimens (Kenny, 1980, 1984a).

According to Kenny (1980, 1984a, 1986) and Mazengarb et al. (1991) the age of the Ihungia Formation (Tolaga Group) in this area ranges upward from Waitakian-Otaian 


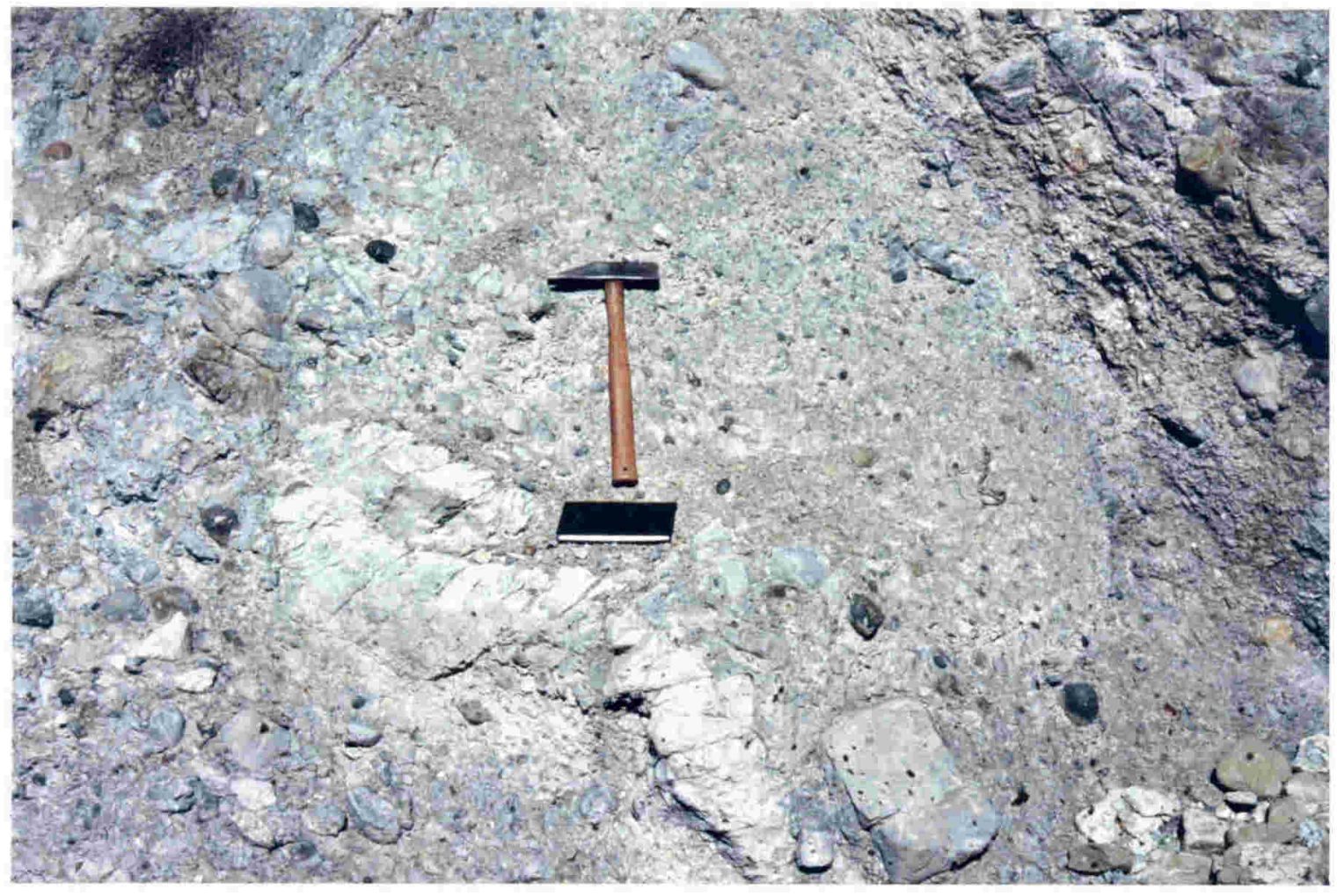

Figure 4.6: Breccia-conglomerate body in Te Matarau Stream (Y16 63463987). Notebook rests on a stringer of very calcareous mudstone. Well rounded, dark coloured clasts are igneous. 
(Aquitanian-Burdigalian). The limestone lithotype, according to Kenny (1980, 1984a, 1986) is early Altonian (late Burdigalian).

\subsection{OVERVIEW OF STRUCTURE}

The detailed structure of the area between the Ihungia River and Puketoro Stream is shown on Map 2 and the accompanying sections ( $G(1 \& 2)-I)$, to be found in the back pocket. The macroscopic structures of this area have an overall south to southeasterly pitch, in common with much of the rest of the region (sections 1.3.1, 6.3.3). Waitahaia Formation in the north of the area displays tight to isoclinal folding about gently to moderately southerly-plunging axes and reverse offsets on steeply westerly-dipping faults (see Kenny, 1986). The unconformably overlying Karekare and Whangai Formations are by contrast only gently folded. The only map-scale fault cutting the Karekare Formation is a northwest-striking dip-slip fault at its eastern limit. The upper part of the Whangai Formation is cut by south-dipping normal faults. The overall dip of the Karekare and Whangai Formations is gentle to moderate toward the south-southeast.

In the west of the area, Whangai Formation is structurally overlain by Mokoiwi Formation along the Waitahaia Fault, a southwest-directed thrust which is approximately parallel to the top of the Whangai. In the east, the Waitahaia Fault is cut by the Mangarakeke Fault, a southeast-side-down normal fault which dips moderately to steeply south in the Mangaehu Stream area and gently south-southeast near the Ihungia River. The Mangarakeke Fault juxtaposes Mokoiwi and Waitahaia Formations along most of its length. Hereafter, those rocks structurally below (north of) the Waitahaia and Mangarakeke Faults will be referred to as 'the autochthon' and those above-with the exception of the Ihungia Formation-as 'the allochthon'. It is emphasised that the terms autochthon and allochthon as used in this chapter are not synonymous with the Motu Block and East Coast Allochthon of Moore (1985, 1988a); Moore's East Coast Allochthon includes Haumurian-Teurian rocks in the lower Ihungia River which are included herein in 'the autochthon' (see also sections 3.8, 6.4.1).

The structure of the allochthon is dominated by closely spaced, gently to moderately southerly-dipping thrusts which have transported material southwestward. Many of these were later reactivated as down-to-the-southeast normal faults. The stacking order across these faults is complex, with both older-on-younger and youngeron-older relationships. Moderately to steeply dipping extensional faults with a variety of strikes cut the thrusts. Displacement on these extensional faults generally ranges up to 
a few tens of metres, but it may be hundreds of metres on the faults bounding the Opossum Creek sandstone.

The structurally complex allochthon is juxtaposed against Ihungia Formation along the normal Opossum Creek and Whakoau Faults. The Opossum Creek Fault dips steeply south-southwest. The Whakoau Fault dips gently south, and has transported the Ihungia Formation in its hangingwall southeastward. Where the two faults meet, the Opossum Creek probably cuts the Whakoau.

\subsubsection{Section Construction}

Four sections accompany this chapter: $\mathrm{G}-\mathrm{G}^{\prime}(1), \mathrm{G}-\mathrm{G}^{\prime}(2), \mathrm{H}-\mathrm{H}^{\prime}$, and $\mathrm{I}-\mathrm{I}^{\prime} . \mathrm{H}-\mathrm{H}^{\prime}$ and $\mathrm{I}-\mathrm{I}^{\prime}$ are sections across the strike of local structures, and were constructed in the usual manner. Sections G-G' were constructed as profiles to take advantage of the obliquely exposed section through the allochthon. Because the thrusts cut up- and down-section in all directions (Map 2), the profiles do not in general represent the structure directly beneath the line. Rather, they show the structures at the surface projected a short distance up- or down-dip. The projection axis used $\left(162^{\circ} / 25^{\circ}\right)$ is perpendicular to the profile plane and approximately parallel to the dip of the autochthonous beds and the faults in the allochthon. Line $G-G^{\prime}$ on Map 2 is the zero elevation of the profile plane. On profile $G-G^{\prime}(1)$, late high-angle faults-including the Opossum Creek Fault-were restored or removed to show the initial structural geometry of the low-angle faults. Profile $G-G^{\prime}(2)$ shows the present structural geometry.

\subsection{STRUCTURE OF THE AUTOCHTHON}

\subsubsection{Waitahaia Formation}

Kenny (1986) described the structure of the Waitahaia Formation in the IhungiaPuketoro area in some detail. Angular, close to isoclinal, north-northwest trending, symmetrical or eastward-verging folds have axial planes that are sub-vertical in the west and steeply west-dipping in the east and hinges which plunge $15^{\circ}-20^{\circ}$ southsoutheast. Fold wavelengths exceed $1 \mathrm{~km}$ in thick-bedded rocks, but are smaller in thinner bedded intervals. These folds are associated with north-northwest striking, eastside-down faults which are sub-vertical in the west and steeply west-dipping in the east. Offsets on these reach $200-300 \mathrm{~m}$. On the outcrop scale, eastward-verging folds are commonly associated with steeply westward-dipping reverse faults (e.g., Fig. 8.9 of Kenny, 1986). 


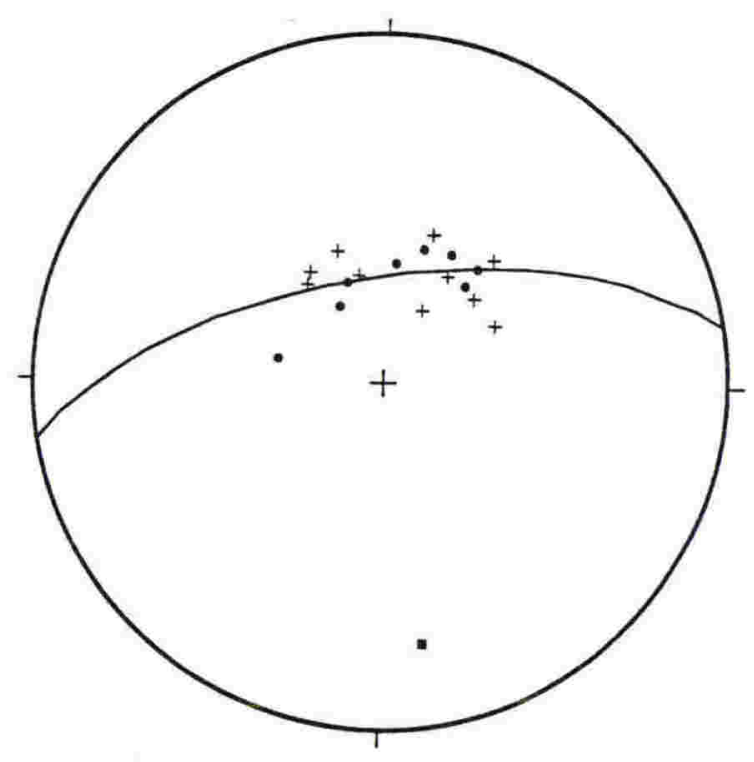

Figure 4.7: Equal-area projection of poles to bedding in Karekare and Whangai Formations in the autochthon. Dots $=$ upright beds, crosses = younging not determined at outcrop. Best-fit $\pi$-circle and $\pi$-axis (square) also shown. Some data from Kenny (1986). 
These structures are younger than the Ngaterian Waitahaia Formation, and older than the unconformably overlying Arowhanan Karekare Formation. The nature of the rocks (section 3.2.2), their structural style, and their deformation soon after deposition suggest deposition and deformation on an east-northeast facing, active trench slope (Kenny, 1986; Mazengarb, 1989). Because this deformation is mid-Cretaceous, it is not of direct interest here and is not discussed further.

\subsubsection{Karekare and Whangai Formations}

Karekare Formation overlies Waitahaia Formation along an angular unconformity (see Fig. 4.4a). Whangai Formation rests on Karekare Formation disconformably or with slight angular unconformity. The structure of these two formations, with the exception of the uppermost part of the Whangai Formation, is simple; their overall orientation is southward-dipping between $20^{\circ}$ and $35^{\circ}$. Gentle, upright, gently south-plunging folds are defined by swings in strike between southwest and southeast (Map 2, Fig. 4.7).

At its eastern extent, Karekare Formation is juxtaposed against Waitahaia Formation along an inferred dip-slip fault (also mapped by Kenny, 1986) along upper Mangaehu Stream. This fault does not cut Whangai Formation. Other faulting in the Karekare Formation is limited to decimetre-scale offsets on northwest-striking, moderately northeast-dipping $\left(\approx 305^{\circ} / 50^{\circ} \mathrm{NE}\right)$ normal faults. These are best observed in Puketoro Stream (see Fig. 4.4b). Kenny (1986) mapped two east-striking, $30^{\circ}$ and $35^{\circ}$ southdipping normal faults crossing Puketoro Stream and the Mata River, but these were not observed by this writer. Three east-striking, gently to moderately south-dipping faults were mapped in the upper half of the Whangai Formation in Puketoro Stream. One of these is also present in a small east-flowing tributary of the Mata River (Map 2). No kinematic indicators were observed on these faults. The fault in the Mata tributary puts the uppermost Whangai (Porangahau Member or "Waingata limestone") over stratigraphically lower, less calcareous rock along a few tens of metres up the fault trace. This fault thus has a normal component of at least a few tens of metres.

Other fractures are present near the top of the Whangai Formation near the Waitahaia Fault. These, and the fault, are described in section 4.5.

\subsubsection{Tikihore Formation and Haumurian-Teurian Rocks}

Tikihore Formation is juxtaposed against Waitahaia Formation along the eastern Ihungia Fault (Fig. 4.3). Its structure is described in section 3.4. Haumurian-Teurian rocks are exposed in the extreme northeast of the area, structurally beneath the western Ihungia and Mangarakeke Faults and unconformably overlying the Tikihore Formation 
(Fig. 4.3, Map 2). Above the unconformity, beds in the Ihungia River section generally dip gently south to southeast and show little deformation. Kenny (1980, 1984a) showed all these beds as overturned. However, graded bedding, sole marks and cross-beds show that most are upright. Overturned, moderately west-dipping, north- and northnorthwest striking beds occur in two outcrops on the west side of the river. Eastsoutheast striking, moderately south-dipping, overturned beds were observed just east of the Ihungia Fault (Map 2). These outcrops may be separated from the more easterly, upright beds by a north-northwest striking fault along the northern part of the Ihungia River. Overturning of the beds probably accompanied reverse movement on the western Ihungia Fault.

Minor folds in Haumurian-Teurian strata were observed adjacent to the Mangarakeke Fault (described in section 4.5.2) and on the ridge between the Ihungia and Orua catchments (Map 2). This latter fold is a tight (nearly isoclinal), reclined structure with an axial plane oriented $320^{\circ} / 20^{\circ} \mathrm{W}$ and a hinge line oriented $225^{\circ} / 20^{\circ}$. It closes to the northwest, and its gently west-dipping upper limb is overturned. The style of this structure suggests slump folding, but lack of exposure precluded determination of how it relates to structurally overlying beds.

\subsubsection{Eastern and Western Ihungia Faults}

The eastern and western branches of the Ihungia Fault continue south up the Ihungia valley from the lower Mata River area. The orientations, transport directions, amounts of displacement, and kinematic histories of these faults were described in section 3.6. The eastern Ihungia Fault is a moderately west-southwest dipping thrust which puts Waitahaia Formation over Piripauan Tikihore Formation (>1260 m stratigraphic separation) and was active entirely in pre-Haumurian times, as it is overlain by Haumurian-Teurian rocks (Fig. 4.3, Map 2). It is cut at depth by the western Ihungia Fault, a moderately to steeply west-southwest to west-dipping thrust which cuts Haumurian-Teurian strata ( $>1900$ m stratigraphic separation further north; see sections D-D' and E-E') and was thus active in post-Teurian times, although it may also have been active earlier.

The position and attitude of the southern part of the western Ihungia Fault is poorly controlled due to hillside mass-movement. It has a more northerly strike than in the lower Mata River area, but its dip is not well known. Kenny (1980, 1984a) showed the Ihungia Fault offsetting the trace of the Mangarakeke Fault about $400 \mathrm{~m}$. Although exposure where these faults intersect is poor, this offset can be constrained to less than $100 \mathrm{~m}$. Because the projection of the Ihungia Fault does not cut a large mass of Taitai 
Sandstone $1.5 \mathrm{~km}$ south of the Mangarakeke Fault (Map 2), it is inferred that the Ihungia Fault does not offset the Mangarakeke Fault at all.

Projection of the sub-Haumurian unconformity down-dip $\left(\approx 20^{\circ}\right)$ results in an elevation at the position of profile $\mathrm{G}-\mathrm{G}^{\prime}$ of $\approx-450 \mathrm{~m}$. The Haumurian-Teurian rocks and the Whangai Formation are different formations (see section 3.2.4) but both include latest Cretaceous and Paleocene rocks and probably originally interfingered in the area between the Ihungia Fault and the present eastern extent of the Whangai, $5 \mathrm{~km}$ to the west. If these two formations were originally continuous across the western Ihungia Fault, the offset of their bases can be used to estimate the slip on the fault. The base of the Whangai Formation probably continued to rise eastward (see profile $G_{-} G^{\prime}(1)$ ) before erosion. Its projected position just west of the Ihungia Fault relative to the position of the base of the Haumurian in the east suggests a throw of about $1.5-2 \mathrm{~km}$.

\subsection{THE WAITAHAIA AND MANGARAKEKE FAULTS}

\subsubsection{Waitahaia Fault}

\subsubsection{Extent and Geometry}

The Waitahaia Fault extends from west of Puketoro Stream to the upper reaches of Mangaehu Stream, where it is cut by the Mangarakeke Fault (Fig. 4.3, Map 2). The Waitahaia Fault is the sole thrust of the Raukumara Peninsula thrust belt and continues to the southwest as the "autochthon/allochthon boundary" of Phillips (1985) and Kenny (1986), the Te Rata-Waitahaia Thrust Zone of Moore et al. (1989), and the Waitahaia Thrust Fault of Mazengarb et al. (1991).

The Waitahaia Fault is poorly exposed. In Puketoro Stream, a small exposure just above stream level shows highly fractured, soft Mokoiwi Formation with an anastomosing foliation oriented $060^{\circ} / 50^{\circ} \mathrm{SE}$ resting on Whangai Formation which, just downstream, is little deformed. The contact itself could not be measured. On the ridge between Puketoro and Kaikomako Streams where the fault is entirely within Whangai Formation, it dips southward about $30^{\circ}$.

Profile $G-G^{\prime}(1)$ shows that the fault between Puketoro Stream and where it first crosses the Mata River is approximately parallel to the structurally underlying Whangai Formation. East of the river crossing, the fault trace steps to the north and cuts downsection in that direction (see section $\mathrm{H}-\mathrm{H}^{\prime}$ ). Around the mouths of Mangaehu and Makara Streams, the fault trace defines a fold plunging gently to the south-southwest. 
The position of the fault on the southeastern side of this fold suggests it cuts up-section to the south (section $\mathrm{H}-\mathrm{H}^{\prime}$ ), but this may be partly or wholly due to the assumption that the underlying autochthonous rocks maintain a constant south-southeast dip there.

Kenny (1986) mapped part of the Whangai Formation in the core of this fold as allochthonous, on the basis of the difference in bedding and foliation orientations between it and the autochthonous Whangai further north. She showed that an anticlockwise rotation of $80^{\circ}$ about a vertical axis brought bedding and cleavages into orientations similar to those in the adjacent autochthon, and she postulated that the 'aberrant' block had been dislodged and rotated clockwise during movement on the Waitahaia Fault. However, the 'aberrant' Whangai in lower Mangaehu Stream can be traced into the autochthon without any major structural break. The orientation differences in that area are thus better explained by folding of the autochthon about the gently south-southwest plunging axis defined by the folded Waitahaia Fault (Map 2).

From the upper Mangaehu catchment eastward, the Waitahaia Fault is displaced by the Mangarakeke Fault. The subsurface positon of the Waitahaia Fault in that area is uncertain. From about where it cuts the Ihungia Fault eastward, the position of the Waitahaia Fault shown on profile $G_{-} G^{\prime}(1)$ corresponds with the projection of the outcrop trace of the Mangarakeke Fault, which dips $\approx 25^{\circ}$ south-southeast in that area. The relationship between the Waitahia and Mangarakeke Faults in the east is discussed in section 4.5.2.2.

\subsubsection{Kinematics}

The Waitahaia Fault is a gently dipping structure which puts mid-Cretaceous Mokoiwi Formation over Paleocene rocks. It is thus a thrust fault with over $5.5 \mathrm{~km}$ of stratigraphic separation (Fig. 2.3; see also section 3.7). On the regional map (Moore et al., 1989; see also Moore, 1985, 1988a) it continues southwestward into an area where folds above it trend northwest, and thrusts splay off it and cut up-section to the southwest. Its transport direction in that area is thus southwestward. In the Puketoro area, however, only a narrow strip of the allochthon is exposed between the fault and the Ihungia Formation (Map 2) and map-scale structures within it which could reflect the transport direction are not obvious. The fault plane itself is poorly exposed there, and no kinematic indicators were measured on it. Inferences about its transport direction are thus from analyses of minor structures in outcrops of the rocks adjacent to it.

Beneath the Waitahaia Fault in the Puketoro valley, Whangai Formation has a complicated fabric dominated by mesoscopic extension faults. These strike southeast $(\approx$ 
$140^{\circ}$ ), dip moderately southwest, and cut a phacoidal fabric produced by dominantly contractional faults at low angles to bedding (Fig. 4.8). In the upper part of the outcrop shown in Fig. 4.8, these faults are closely spaced and have rotated bedding to moderate northeast dips. They are not as strongly developed in the lower part, where they can be seen displacing the earlier phacoidal fabric and the prominent sub-horizontal fault. Gently to moderately dipping extension faults which cut a gently dipping fabric of contraction faults and/or shear bands have been documented adjacent to thrusts at many other places (e.g., Platt and Leggett, 1986; Wojtal, 1986; Casas and Sàbat, 1987; Woodward et al., 1988). At each, the dominant group of extension faults dips parallel to the thrust transport direction. The southwest-dipping extension faults beneath the Waitahaia Fault thus indicate that hangingwall transport on that fault was southwestward.

The outcrop in Fig. 4.8 also contains faults with other transport directions. The major east-southeast dipping fault cuts the extension faults, and has a displacement of at least $10 \mathrm{~m}$ but an unknown sense. It may belong to the same generation as the extensional faults described in section 4.6.4. There are also northeast-striking $\left(\approx 040^{\circ}\right)$, moderately southeast-dipping extension faults with millimetre- to centimetre-scale offsets, and a set of closely spaced, sub-vertical tension fractures, commonly calcitefilled, striking $\approx 025^{\circ}$. The two latter fracture sets accomodate southeast-directed shear. Although mesoscopic extension faults which dip and transport material at high angles to the transport directions of nearby thrusts have been described elsewhere (e.g., Wojtal, 1986; Casas and Sàbat, 1987), a tensional fracture cleavage has not. The northeaststriking fractures are thus probably not due to three-dimensional (flattening) strain during southwestward thrusting, but to a separate deformation involving southeastward material transport.

There is further evidence for separate episodes of approximately perpendicular displacement on the Waitahaia Fault elsewhere in the area. For about $1 \mathrm{~km}$ east of Kaikomako Stream, the Mata River runs just north of and parallel to the fault trace. In river-bank exposures of upper Whangai Formation (Porangahau Member or "Waingata limestone") beneath the fault, a southeast-striking, sub-vertical stylolitic cleavage $\left(\mathrm{S}_{1}\right)$ is cut by a similar fabric $\left(\mathrm{S}_{2}\right)$ striking northeast (Kenny, 1986). $\mathrm{S}_{1}$ could be associated with the southwestward thrusting, and $\mathrm{S}_{2}$ with the deformation which produced the northeast-striking structures in the Puketoro valley. If so, the cross-cutting relations suggest that the southwestward thrusting was the earlier event. Kenny (1986) also described two sets of folds from this area. First-phase folds were described as gentle, with steeply dipping north-northwest striking axial planes and gently plunging hinges. They are defined by low-amplititude, long-wavelength undulations. Kenny (1986, p. 269) stated that "an eastward vergence is strongly represented", but this writer observed only 

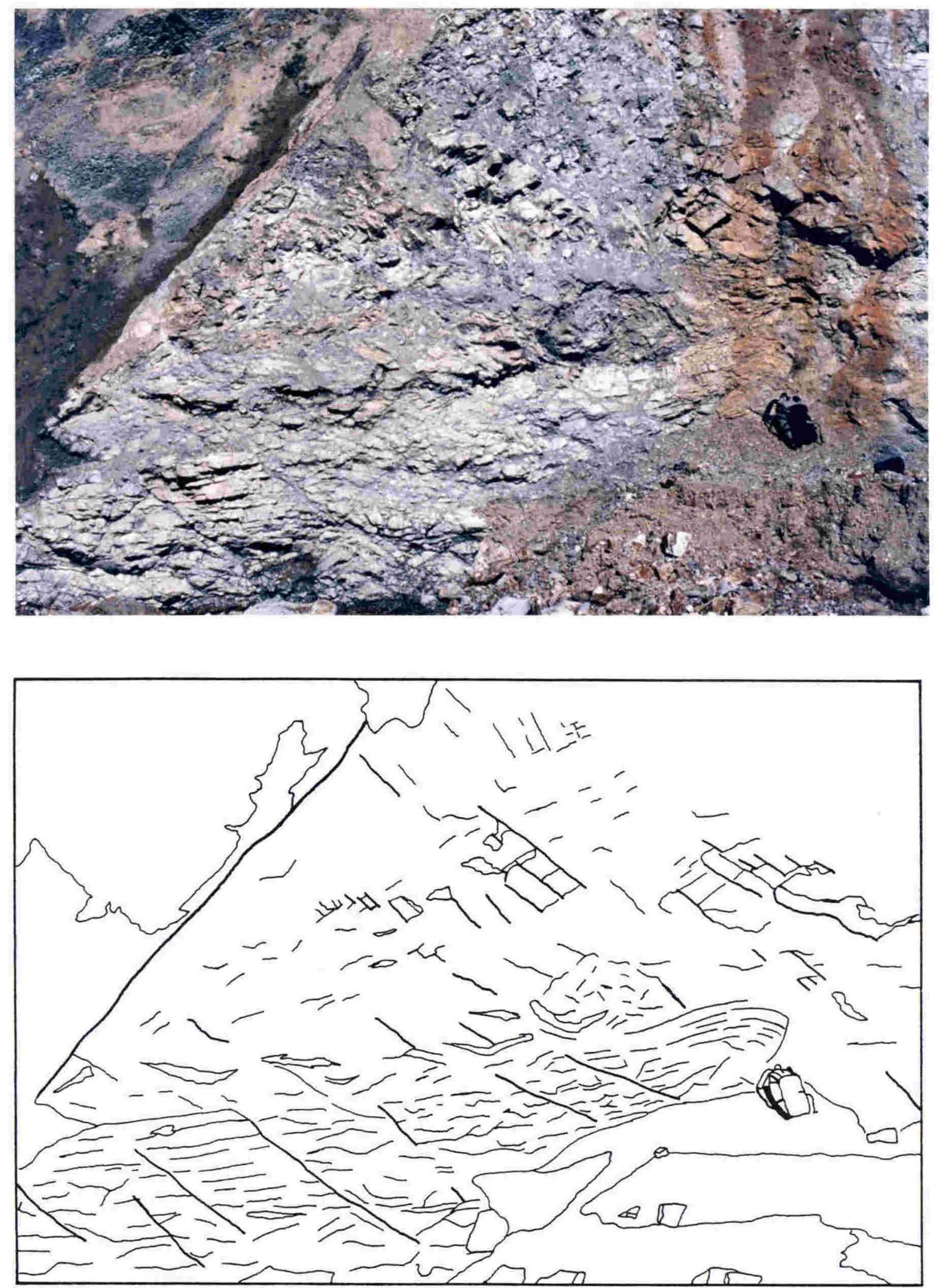

Figure 4.8: Photograph and line drawing of an outcrop of Whangai Formation structurally beneath Waitahaia Fault in a tributary of Puketoro Stream (Y16 54753955). View looking south. 
one open, eastward-verging, minor fold. Second-phase folds are gentle to open with steep east-northeast striking axial planes, gently plunging hinges, and variable vergence.

Kenny (1986) also described two sets of minor faults from these outcrops, an earlier set related to an "east-west compressive phase" (p. 270) and a later set of beddingparallel faults which cut up-section and transport material to the southeast. Two minor fault sets also exist further east. Beneath the Waitahaia Fault in Mangaehu Stream, there are two prominent sets of mesoscopic faults in outcrops of Whangai Formation. One set dips moderately southwest, and the other dips moderately northwest. Senses of offset on these faults are difficult to determine in many cases owing to the uniform bedding thickness of the rocks, but some faults of each set are extensional. No cross-cutting relationships between faults of these two sets were observed.

Minor structures, then, indicate two displacement episodes on the Waitahaia Fault, one involving southwestward transport of the hangingwall, the other involving southeastward transport. Where overprinting relationships have been observed, they indicate that the southwest-directed episode preceded the southeast-directed one.

\subsubsection{Mangarakeke Fault}

\subsubsection{Extent and Geometry}

The Mangarakeke Fault (Kenny, 1980, 1984a, 1986) is a south-dipping structure extending from west of upper Mangaehu Stream, where it cuts the Waitahaia Fault, eastward to north of Blue Slip and out of the map area (Fig. 4.3, Map 2). At its western end, it puts Whangai Formation over Waitahaia and Karekare Formations. Further east, it puts Mokoiwi Formation and associated allochthonous rocks over Watahaia Formation and, further east still, Haumurian-Teurian strata.

The Mangarakeke Fault was well located in the eastern branch of Mangaehu Stream, where it dips steeply south. It puts Whangai Formation over Waitahaia Formation near the stream junction, and over Karekare Formation further west. It does not omit much section in this area (see profiles $G-G^{\prime}$ ), and is inferred to lose displacement completely further to the west. The eastern end of the fault was mapped by Kenny (1980, 1984a) as sub-vertical. However, its trace across the Thungia River and up the slopes to the east-located reasonably precisely from outcrops either side of it-is curved, indicating a gentle dip. Structure contours drawn across the Ihungia valley suggest a dip of $\approx 25^{\circ}$ south-southeast. Rocks structurally beneath the Mangarakeke Fault are not exposed in deep gullies adjacent to the fault at the extreme eastern edge of the map, so this figure is a minimum. 
Between its relatively well-located eastern and western ends, the position of the Mangarakeke Fault trace is poorly known due to extensive slumping, particularly in the Mangarakeke catchment (Fig. 4.2). It is roughly parallel to the contours in the upper Makara catchment, so its dip there is hard to judge. Kenny (1980, 1984a, 1986) mapped the Mangarakeke Fault between the Ihungia Fault and its western end as dipping steeply.

\subsubsection{Kinematics}

Over most of its length, the south-dipping Mangarakeke Fault puts Mokoiwi Formation-on the south-over younger rocks, suggesting that it is a reverse or thrust fault. West of where it cuts the Waitahaia Fault, however, the Mangarakeke Fault is normal; it appears to be reverse in the east because it has removed the Waitahaia Fault from the map. The Mangarakeke Fault is thus an extensional fault which puts allochthonous Mokoiwi Formation-initially emplaced on the Waitahaia Fault-down against rocks of the autochthon.

Kinematic indicators on the Mangarakeke Fault were only observed in the east. On the west bank of the Ihungia River just beneath the fault, greensand and grit beds of the uppermost part of the Haumurian-Teurian formation are tightly to isoclinally folded about an axis oriented $300^{\circ} / 40^{\circ}$, with a moderately southwest-dipping axial plane. These folds may have been formed during northeast-southwest contraction. It is possible, however, that they were formed in another orientation and subsequently rotated, as there is deformation beneath them: about $30 \mathrm{~m}$ downstream, a foliated cataclasite derived from mudstone and greensand is tightly folded about an axis oriented $245^{\circ} / 15^{\circ}$, with an axial plane oriented $130^{\circ} / 15^{\circ} \mathrm{SW}$. This fold closes to the southeast. On the upper limb near the hinge, the cataclasite is crenulated on axes parallel to the mesoscopic fold axis and planes parallel to the fold axial surface. These crenulations are southeast-verging, consistent with their position on the fold, but the fact that they occur only on the upper limb may indicate an overall southeastward shear. The cataclasite, fold, and crenulations may have formed during a single, progressive deformation involving southeast-directed shear, or the cataclasite may have formed in an earlier event (southwestward thrusting?) and been subsequently folded and crenulated by southeastward shear.

On the ridge at the eastern edge of the area, a minor fault in Haumurian-Teurian rocks is oriented $165^{\circ} / 40^{\circ} \mathrm{E}$, at a high angle to the immediately adjacent Mangarakeke Fault. Stepped frictional-wear striations on this minor fault plunge $110^{\circ} / 35^{\circ}$. Step risers on the footwall face up-plunge, and are interpreted as incongruous (Hancock, 1985) because the striations are frictional rather than accretionary. This fault is thus 
interpreted as normal-dextral, with movement of the hangingwall block to the southeast.

The above observations indicate that the hangingwall of the Mangarakeke Fault has moved down to the southeast. The amount of displacement cannot be determined precisely, but it is probably not great. In the west, the steeply-dipping Mangarakeke Fault cuts the Waitahaia Fault, but does not displace it greatly as it does not remove much section from adjacent autochthonous rocks. In the east, the gently dipping 'Mangarakeke Fault' is probably the Waitahaia Fault reactivated as a down-to-thesoutheast extensional fault, because the present structural position of the base of the allochthon in the east is similar to that of the Aorangiwai Fault, $10 \mathrm{~km}$ to the north, which puts Mokoiwi Formation over Waitahaia Formation and Haumurian-Teurian rocks (see section 3.7) and has not been affected by down-to-the-southeast extensional faulting. Also, the elevation of the base of the allochthon in the east is not far below the elevation of the Waitahaia Fault further southwest (see profiles $G-G^{\prime}$ ); if the throw on the 'Mangarakeke Fault' is more than a few hundred metres, the base of the allochthon would originally have sloped down considerably in the thrust transport direction, which seems unlikely.

The Mangarakeke Fault, then, is probably a combination of two faults: the Waitahaia Fault, in the east, a southwest-directed thrust which has been reactivated as a down-to-the-southeast extensional fault (as it has further west; see section 4.5.2), and a steeply south-dipping extensional fault which cuts the Waitahaia Fault between upper Mangaehu Stream and the Mangarakeke valley, losing displacement into the rocks of the autochthon at each end. This steeply dipping fault was probably initiated during or after the second (extensional) phase of movement on the Waitahaia Fault. Also, the Waitahaia Fault is probably a southerly equivalent of the Aorangiwai Fault, as identical lithologic relations exist across each and their transport directions are the same (see section 3.7). The equivalence of those two structures is discussed further in section 4.8.2.

\subsection{STRUCTURE AND KINEMATICS OF THE ALLOCHTHON}

\subsubsection{Structure of the Mokoiwi Formation}

Mokoiwi Formation comprises the lowest of the fault-bounded sheets within the allochthon. It is poorly exposed and is affected by considerable slumping over much of its outcrop area (e.g., Fig. 4.2). The structure of these rocks is more complex than that of other allochthonous rocks, which is probably due to mid-Cretaceous deformation (see also section 3.7). Kenny (1986) noted that the structural style was similar to parts of the 
slightly younger Waitahaia Formation of the autochthon. Because much of its structure is pre-Miocene, the Mokoiwi Formation was not examined in detail in this study. The brief description that follows is largely from Kenny (1986).

The dominant strike of bedding in the Mokoiwi Formation is northwest to northnorthwest. Early folds are tight to isoclinal, with gently dipping axial planes. Fold axes plunge south-southeast, northwest, and south around Blue Slip. Later disharmonic folding occurs about axes with a variety of trends. Broken formation produced by northeast-southwest extension is common. Mesoscopic faults occur mostly in two groups, one dipping moderately northeast and one dipping steeply southeast. Around the mouth of Kaikomako Stream, striations on mesoscopic faults fall into two groups, northeast-trending and south-southeast trending.

In the Blue Slip area, there is a north-northwest trending strip of mélange faulted into the Mokoiwi Formation (Fig. 4.3, Map 2). The mélange there consists of jumbled blocks of Upper Cretaceous and Lower Tertiary lithologies, with rocks of the Haumurian-Teurian formation being dominant. The gritty greensand from the uppermost part of that formation is common. Also common are Whangai Formation and mottled Eocene smectite mudstone similar to that in the lower Mata River area (section 3.2.5). While many blocks are internally relatively undeformed, much of the material is a soft, sticky cataclasite, probably derived largely from the Eocene smectite mudstone. The eastern and western faults dividing the mélange from the adjacent Mokoiwi Formation are sharp and dip steeply east-northeast (see profiles $G-G^{\prime}$ ). To the north, they are cut by the Mangarakeke (Waitahaia) Fault, as they cannot be traced into the Haumurian-Teurian rocks across it. To the south, along strike in a tributary of the Ihungia River, there is a narrow crushed interval in Mokoiwi Formation but no other lithologies were seen despite good exposure. The two faults presumably meet and completely enclose the mélange between this stream and the more northerly exposures.

\subsubsection{Allochthonous Rocks in the Te Matarau Catchment}

In the Te Matarau catchment (Fig. 4.3, Map 2), Whangai Formation, smectitic mélange, limestone/greensand lithotype, and a small occurrence of the sandstone/ breccia lithotype are present in the allochthon. These rocks occur in two adjacent masses, an eastern one comprising mélange, limestone/greensand, and sandstone/ breccia around Te Matarau Stream itself, and a western one on the ridge between $\mathrm{Te}$ Matarau and Mangarakeke Streams which consists of limestone/greensand and Whangai Formation. This latter occurrence includes "Sugar Loaf", a prominent hill capped by thick greensand beds (see Fig. 4.2). There is also a small pod of Whangai Formation further west (Map 2). 


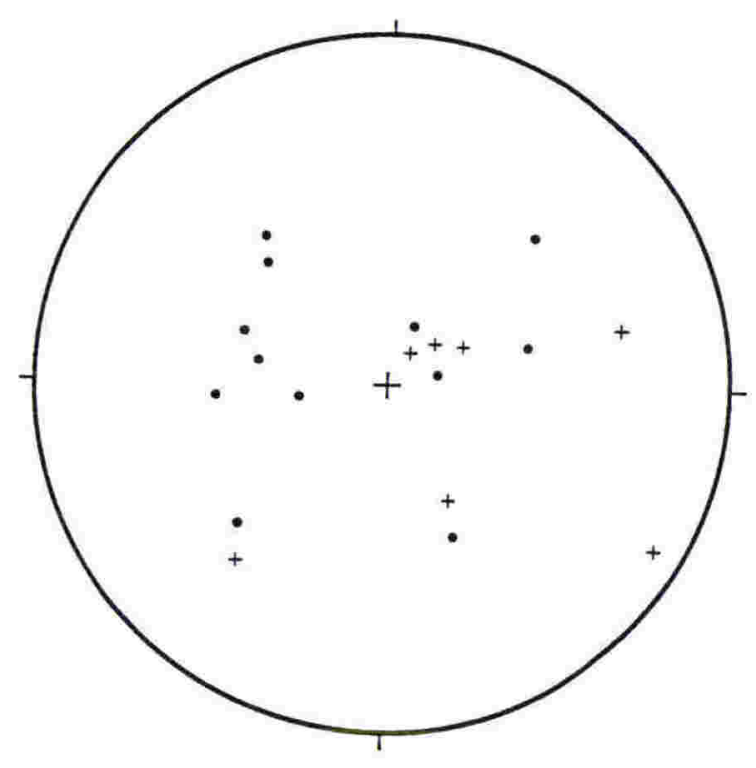

Figure 4.9: Equal-area projection of poles to (upright) bedding (dots) and poles to stylolitic cleavage (crosses) in limestone/greensand lithotype, Te Matarau catchment. 
In the western mass, limestone/greensand and Whangai Formation are bounded to the northeast and southwest by Mokoiwi Formation. The contacts are obscured by slumping and talus, so their dip is speculative. Kenny (1986) mapped them as two sides of a single, gently dipping thrust that separates the whole Tertiary mass from structurally underlying Mokoiwi Formation. This relationship exists between the same lithologies further west (Kenny, 1986; Mazengarb et al., 1991), and is thus adopted here (see sections $\mathrm{G}-\mathrm{G}^{\prime}, \mathrm{I}-\mathrm{I}^{\prime}$ ). Whangai Formation and limestone/greensand lithotype in the western mass are separated by a southwest-striking, steeply dipping fault whose position and attitude is closely constrained by the local relief. The northwestern end of the mass is cut by the Mangarakeke Fault.

In the eastern mass, a central strip of limestone/greensand is flanked by two bodies of mélange. The eastern mélange body consists of a matrix of smectite mudstone enclosing blocks of mostly limestone/greensand lithotype, some up to $30 \mathrm{~m}$ across. The western body comprises mostly smectite mudstone and Mokoiwi Formation. A shear foliation in the mélange dips gently to moderately south-southwest, reflecting the orientations of its contacts with the structurally underlying Mokoiwi Formation and limestone/greensand lithotype (Map 2). The western boundary of this mass is obscured by slumping but nevertheless appears abrupt, and is inferred to be a steep, southweststriking fault similar to that which cuts the western mass. This fault has an apparent dextral and southeast-side-down displacement, but because the faults around the units either side of it have different orientations-with one being gently dipping-this may not be its true sense.

Bedding in the allochthonous rocks of the Te Matarau catchment has a variety of attitudes. Limestone/greensand beds on Sugar Loaf generally strike southeast and have variable dips. Limestone/greensand beds in the other mass generally strike northnortheast and dip moderately eastward, but attitudes are more variable around its margins. A stylolitic cleavage at a moderate to high angle to bedding is developed in the limestones. The orientation of this cleavage is uniform over areas where bedding is uniform, but the scatter of bedding and cleavage orientations within and between the limestone/greensand masses (Fig. 4.9) shows that complicated folding has taken place since its formation.

Because of the scatter in their orientations, bedding/cleavage relationships cannot be used to derive the orientations of tectonic axes during deformation. However, the transport direction during thrusting may be reflected by the orientations of the two steeply dipping faults. These faults do not cut the Mangarakeke or Makara Faults, so they were presumably active earlier. If they were active during the activity of the gently dipping faults bounding the Tertiary allochthonous units, they would have to 
have been dominantly strike-slip to maintain kinematic compatibility. Their northeastsouthwest strike would thus require thrust transport along that direction. This is consistent with the proposed southwestward transport direction on the sole thrust of the allochthon, the Waitahaia Fault (see section 4.5.1.2).

\subsubsection{Allochthonous Rocks in the Mata and Puketoro Valleys}

From lower Makara Stream westward, the allochthon consists of thin sheets of a variety of different lithologies juxtaposed along closely spaced, anastomosing, gently to moderately southerly-dipping faults. The lowest of these is the Waitahaia Fault, which puts mid-Cretaceous rocks over Paleocene ones. Across the other faults, however, both older-on-younger and younger-on-older relationships exist (Map 2, profile G-G'(1)): around the Makara and Mangaehu Stream mouths, two bodies of Waitakian-Otaian sandstone/breccia rest on Mokoiwi Formation; around Kaikomako Stream, Oligocene limestone rests on Mokoiwi Formation and on the Whangai Formation of the autochthon; and between Kaikomako and Puketoro Streams, allochthonous Whangai rests on limestone in the east, on the autochthon, and on Mokoiwi Formation in the west. All these sheets are overlain by a sheet of mélange that contains blocks of all the above lithologies (see section 4.2.7).

A foliated cataclasite a short distance above one of these faults is exposed in lower Kaikomako Stream (Fig. 4.10a), where Oligocene limestone tectonically overlies Mokoiwi Formation. The general dip of the anastomosing foliation is gently westward, and it contains a lineation defined by scratch striations, calcite slickensides, isolated calcite rods, and rare rootless, reclined, minor fold hinges, that trends west (Fig. 4.10b). The sense of shear on this lineation was not determined, but just west of this outcrop a phacoidal fabric in interbedded muddy limestone and greensand is dominated by extensional faults oriented $\approx 155^{\circ} / 30^{\circ} \mathrm{SW}$, suggesting southwestward transport.

The thrusts cut across the internal structures of individual thrust sheets. Folding within each sheet is generally not simple (e.g., Fig. 4.9), and conditions of exposure in most cases-as well as the small size of each sheet-precluded the collection of sufficient data for satisfactory analyses. Limited bedding data from the sandstone/breccia bodies, however, define a south-trending fold axis approximately coincident with the hinge of an outcrop-scale anticline observed in Makara Stream (Fig. 4.11). A large number of fractures, many calcite-filled, cut the sandstone/breccia bodies. These have a great variety of orientations. Many are irregularly curved and discontinuous, which may indicate that the rock was not very indurated during deformation. 


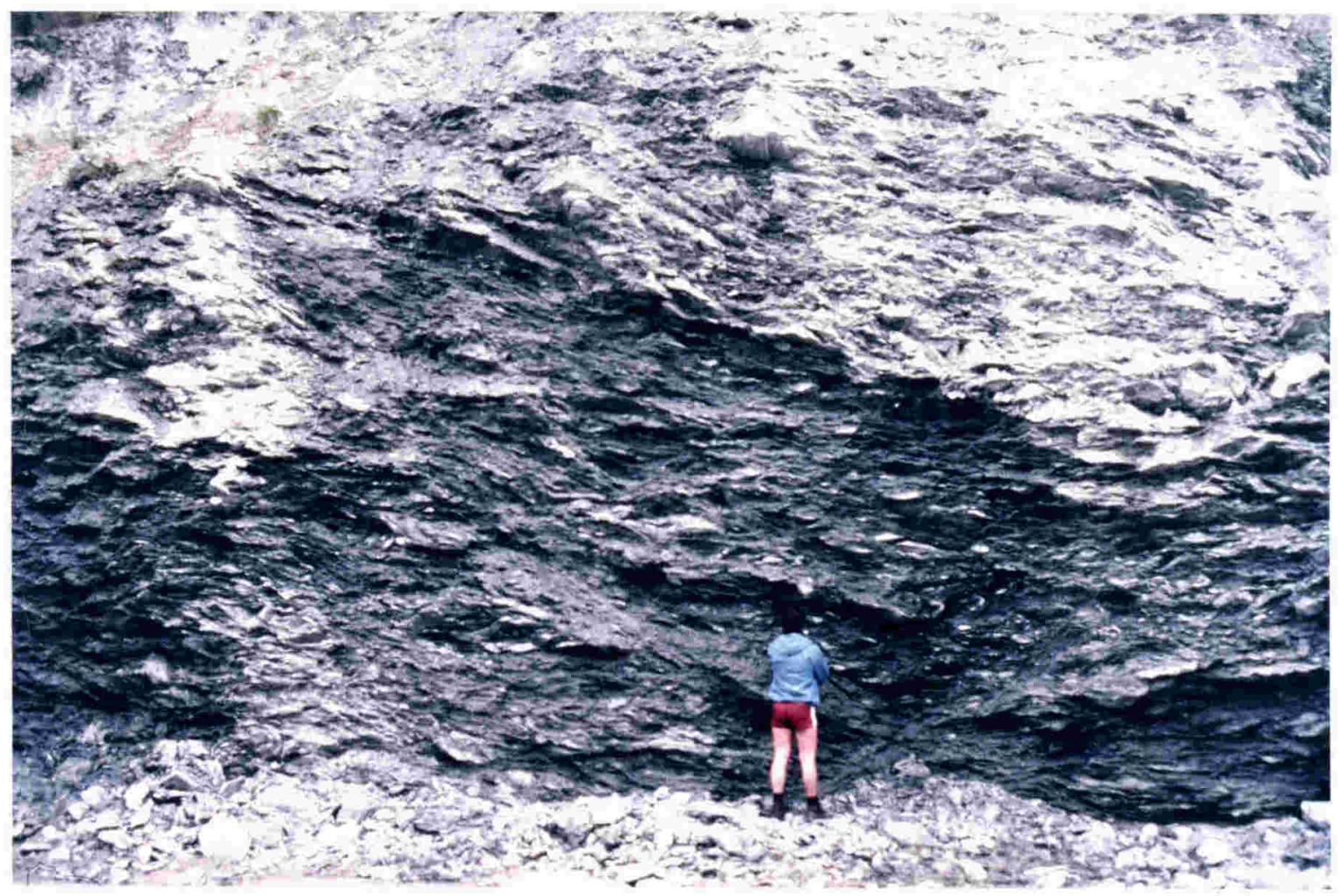

a

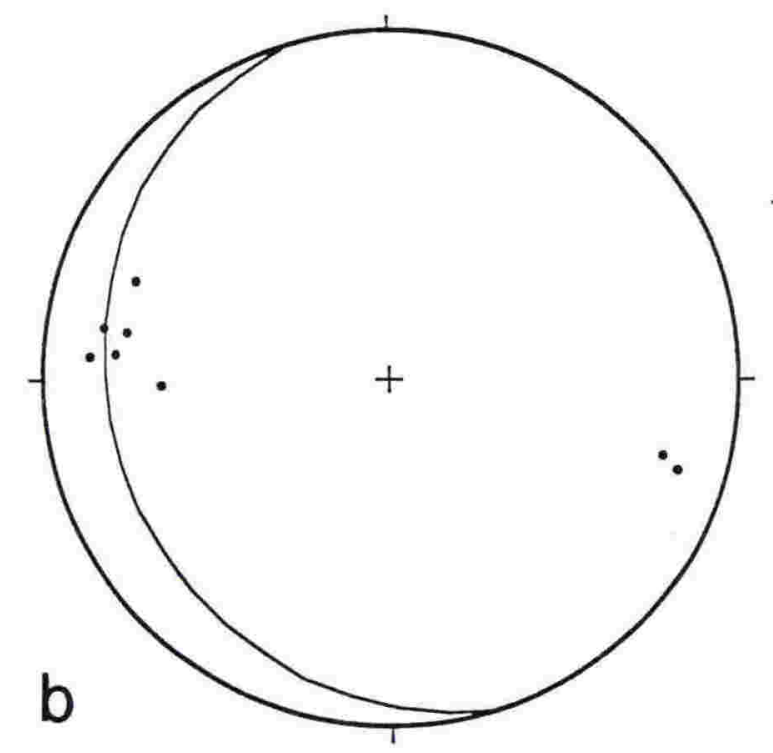

Figure 4.10: a: Foliated cataclasite in Kaikomako Stream (Y16 56423946), just above the contact of Oligocene limestone with Mokoiwi Formation. View looking west. b: Equalarea projection showing orientations of linear structures (dots) and average orientation of cataclastic foliation (great circle) in the outcrop shown in a. 
The mélange is the highest tectonic unit in the stack in this area, although further west it encloses or is overlain by sheets of other Cretaceous and Tertiary lithologies (Phillips, 1985; Kenny, 1986, Mazengarb et al., 1991). The fault beneath the mélange is poorly exposed and only approximately located along much of its length, but it clearly cuts across the faults beneath it (Fig. 4.3, Map 2). It can be seen beside upper Puketoro Stream, where allochthonous Whangai Formation beneath it becomes progressively more sheared and develops into a moderately southeast-dipping foliated cataclasite incorporating more smectite mudstone and Mokoiwi Formation up-structure. The fault can also be seen on the west bank of the Mata River, where mélange overlies sandstone/breccia. There, a foliated cataclasite derived from the mélange dips moderately southwest. Just beneath the contact, calcite slickensides on an irregular fault surface in the sandstone/breccia unit (Fig. 4.12) indicate southeastward movement of the hangingwall.

Southeastward movement on the sub-mélange fault may have been preceded by southwestward movement. This fault may be the same structure as the fault beneath the mélange in the Te Matarau valley, which is inferred to have moved along a northeast-southwest direction (section 4.6.2). The predominantly northwest strike of rocks within and above the mélange further southwest (Kenny, 1986; Mazengarb et al., 1991) also supports this inference.

The internal structure of the mélange is obscure because of poor exposure and intense slumping. Where a fabric can be observed in the mélange matrix, it comprises a foliation made up of shear surfaces which anastomose at a variety of scales and which is commonly cut by minor extension and contraction faults (see Kenny, 1986). Shear surfaces are commonly polished and many of the larger ones contain scratch striations. The significance of this fabric at many localities in Raukumara Peninsula is questionable. Foliations in many mélanges dip parallel to topographic slopes, and at some places the stems of plants were seen embedded in the shear surfaces, parallel to striations. Calcite slickensides occur on some shear surfaces, however, and these presumably reflect displacement at deeper structural levels. Kenny (1986) analysed slickensides on surfaces dipping less than $45^{\circ}$ in better-exposed parts of the mélange in the Puketoro area, and found that most indicated movement of hangingwalls towards $120^{\circ}-160^{\circ}$. She also analysed the geometries of blocks within the mélange, finding that if displacement perpendicular to the intersection of block bedding and a bounding fault is assumed, southeastward hangingwall movement was dominant. 


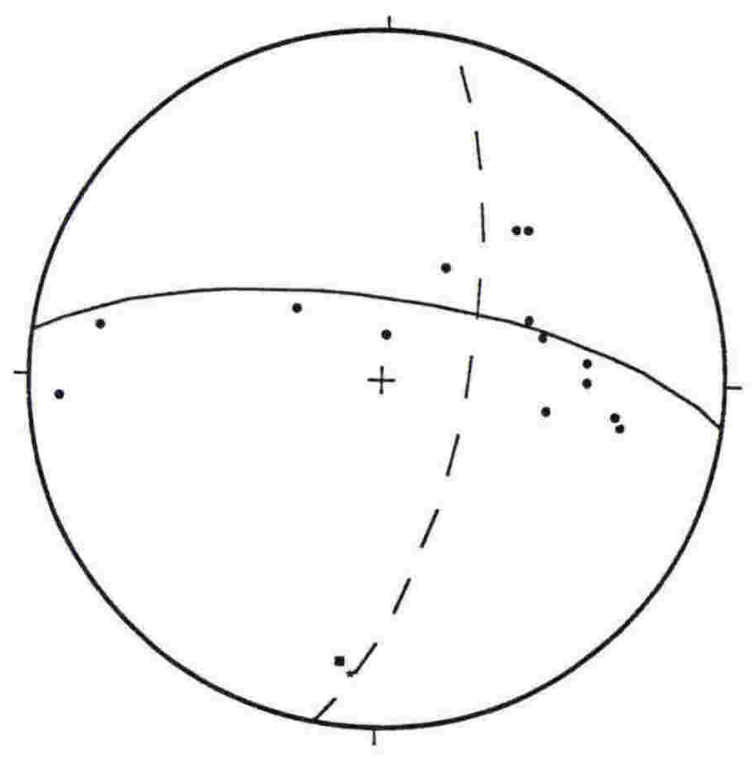

Figure 4.11: Equal-area projection of poles to bedding in sandstone/breccia lithotype (dots), best-fit $\pi$-axis and $\pi$-circle (square and solid great circle), and hinge (star) and axial-plane cleavage (dashed great circle) of anticline in Makara Stream. 


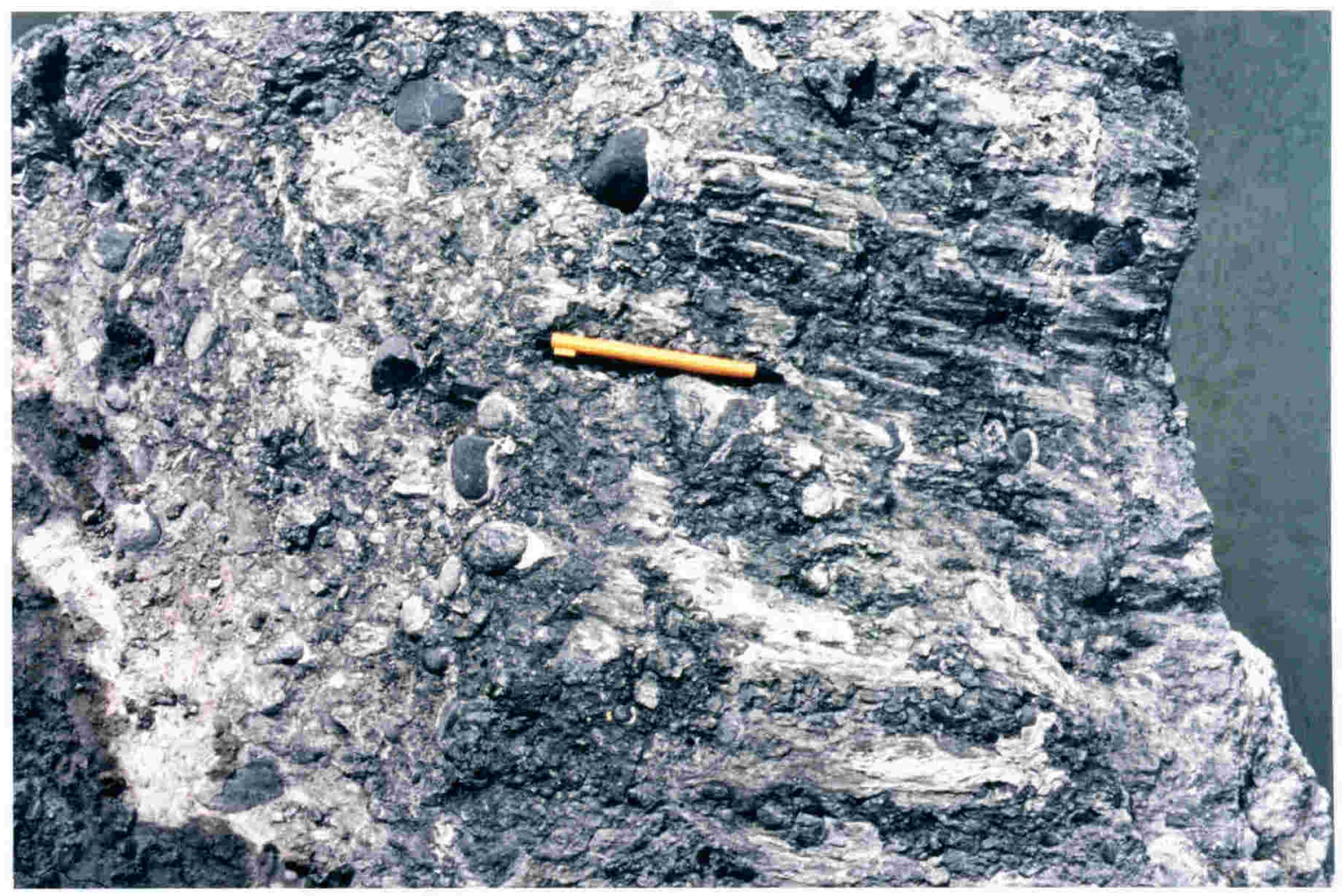

Figure 4.12: Minor fault in sandstone/breccia lithotype immediately beneath structurally overlying mélange on west bank of Mata River (Y16 58133893). Calcite slickensides indicate movement of the hangingwall (missing) toward $143^{\circ}$. 


\subsubsection{Steep Extensional Faults}

In addition to the Mangarakeke (section 4.5.2), Whakoau, and Opossum Creek Faults (section 4.7), the gently dipping faults of the allochthon are cut by a few other map-scale, moderately to steeply dipping faults. The most prominent of these surround the Opossum Creek sandstone lithofacies. These faults appear to be linked, as they do not noticeably offset other strata or contacts along the projections of their strikes. No direct observations of these faults were made-although their traces were very closely positioned at some places-so their attitudes are uncertain. A foliation in mélange immediately adjacent to the fault east of the sandstone dips moderately west-southwest, and may reflect the orientation of that fault; it is compatible with the pattern of the trace across the topography. The fault west of the sandstone is obscured by gravel, silt, and tephra underlying a high-level Quaternary terrace and by slumped mélange, but the limits on the position of its trace indicate that it dips moderately to steeply. The intersection of the northern and eastern faults is beneath Recent alluvium in the bed of the Mata River, and thus was not observed.

Internally, the Opossum Creek sandstone block is only weakly deformed. The rocks are jointed and cut by a few mesoscopic faults near the margins of the block but do not show the pervasive fracturing, calcite veining, and chaotic bedding of the structurally lower but coeval or slightly younger sandstone/breccia bodies. This lack of deformation of rocks coeval with rocks in the allochthon suggests that the Opossum Creek beds were originally deposited structurally above the gently dipping thrusts of the allochthon-perhaps in a piggy-back basin-and were subsequently downthrown against it after thrusting had ceased. The faults around the Opossum Creek block are thus probably dominantly extensional. The amount of throw on these faults is unknown. It may not be great, as the stratigraphically lowest Opossum Creek material is a marl similar in age and appearance to that of the limestone/greensand lithotype of the allochthon (sections 4.2.8, 4.2.9) which contains rare igneous pebbles similar to those in the sandstone/breccia lithotype. The relationship of the Opossum Creek sandstone body to the allochthon is discussed further in section 4.8.3.

Two steeply dipping faults were mapped at the margins of the Makara Stream sandstone/breccia body. The westernmost of these is exposed in Makara and Mangaehu Streams. It strikes north and dips east between $65^{\circ}$ and $90^{\circ}$. Its eastern side is downthrown, offsetting the Waitahaia Fault by about $70 \mathrm{~m}$ (see profiles $\mathrm{G}-\mathrm{G}^{\prime}$ ). Whether this fault cuts the sub-mélange fault could not be ascertained owing to poor exposure. The other fault strikes west-northwest, dips southward about $70^{\circ}$, and throws the sandstone/breccia on its southern side down a few tens of metres. A number of gas vents occur in the crushed rock along the trace of this fault. 
Other moderately to steeply dipping extensional faults may exist along parts of other unit boundaries within the allochthon, but none were observed because of poor exposure and hillside mass-movement. Particularly poorly constrained contacts which may be high-angle faults are the northern edges of both sandstone/breccia bodies and the northern edge of the Mokoiwi Formation north of Mangaehu Stream.

\subsubsection{Discussion}

Two phases of movement on the gently to moderately dipping faults of the allochthon have been recognised: southwestward thrusting and subsequent southeastward extension. The southwestward thrusting was responsible for the emplacement of the Mokoiwi Formation on top of Whangai Formation along the Waitahaia Fault. If the Mokoiwi Formation is stratigraphically equivalent to the Motuan rocks in the Mangaoporo area (see section 2.2.2.1), this represents over $5.5 \mathrm{~km}$ of stratigraphic separation. The Waitahaia sheet was derived from northeast of the Mangaoporo area, however (sections 6.3.5.3, 6.4.3.3), and the Cretaceous succession is likely to thin northeastward (offshore). Evidence for southwestward or westward thrusting is also seen in the other allochthonous units beneath the mélange, although the amounts of transport of these rocks cannot be assessed from the disposition of equivalent strata to the northeast. Southwestward displacement of the mélange also took place, but again, the amount of transport is not immediately apparent. Southeastward extension subsequently reactivated the Waitahaia/Mangarakeke Fault, the sub-mélange fault, and presumably the mélange fabric-to give rise to the minor structures observed by Kenny (1986)-and possibly also other faults in the pile. Extension on the Waitahaia/ Mangarakeke Fault, at least, was probably not great as its structural position is similar to that of the Aorangiwai Fault (section 3.7). During or after this phase, the low-angle faults were cut by high-angle extensional faults with a variety of strikes.

The kinematic history outlined above for the low-angle faults differs from that proposed by Kenny (1986), who considered that the allochthonous rocks had reached their present positions entirely by southeastward transport. Although she recognised many minor faults and a cleavage due to "east-west compression" immediately beneath the Waitahaia Fault, she attributed them to "the final expression of the major E-W compression phase analysed in the basement" (p. 272), and thus considered them genetically unrelated to allochthon emplacement. The lack of deformation lower in the Whangai and Karekare Formations of the autochthon, however, makes this interpretation untenable. 
Kenny (1986) also stressed the importance of the large number of down-to-thesoutheast movements revealed by slickensides in Oligocene limestone and in mélange. The slickensides in the limestone, however, are amongst the latest of a number of generations of minor structures (see Kenny, 1986, p. 341); earlier elements include veins and minor faults, as well as two cleavages at high angles to bedding which have a wide variety of orientations (cf. cleavage in the Te Matarau valley, Fig. 4.9). Kenny considered all these earlier structures to be pre-emplacement. The predominantly northwest strike of these units (Kenny, 1986; Mazengarb et al., 1991) strongly suggests that northeast-southwest movement was important in their emplacement. The southeasttrending slickensides probably originated during extensional reactivation of the already assembled thrust stack. Their abundance is probably explained by the high structural position of these units, close to the southeast-directed detachment beneath the Ihungia Formation (see section 4.7) and to their genesis in a denudational regime: extension would have led to thinning of the structural pile and to reduced confining pressure, thus facilitating the deposition of calcite on fault planes.

Kenny (1986), then, recognised only the second and less important of two episodes of displacement on the faults of the allochthon. The present structural geometry of the allochthonous rocks is due largely to southwest-directed thrusting, with subsequent minor modification by southeast-directed extension.

\subsection{THE WHAKOAU AND OPOSSUM CREEK FAULTS}

Ihungia Formation in the south of the area is faulted against the allochthon along two faults: the Whakoau Fault (Mazengarb et al., 1991), in the east, and the Opossum Creek Fault, in the west (Fig. 4.3, Map 2). The Whakoau Fault is a gently dipping structure which is cut at its western end by the steeper Opossum Creek Fault. These faults have a large normal component, as they dip southward and have younger rocks on their southern sides.

The structure of the Ihungia Formation above these faults is far simpler than that of the rocks within the allochthon. The Ihungia rocks are also far less indurated. Bedding close to the faults has a variety of attitudes (Map 2), but not far south of them it is predominantly northwest to west-northwest striking and gently to moderately dipping, defining gentle to open folds. Further south, the beds dip gently southeast into the northeast-trending Tutamoe syncline (Kingma, 1965; Kenny, 1986; Mazengarb et al., 1991). Faults affecting these rocks are predominantly normal, and are widely spaced (Moore et al., 1989; Mazengarb et al., 1991). With the possible exception of the northwest-trending folds, which may have been produced by blind thrusts beneath 
them, the effects of southwestward thrusting are not visible in the Thungia Formation. The Whakoau and Opossum Creek Faults are thus major tectonic boundaries-the upper structural limits of the East Coast Allochthon.

The Whakoau Fault was traced from the lower Makara Stream area to where it disappears beneath the alluvium in the Ihungia valley. The position of its trace is obvious from the sudden change in topography across it: the Ihungia Formation is more cohesive than the underlying allochthonous material, and supports steep slopes. The gentle dip of the fault can be appreciated from the geometry of the contact around Makara Stream. The fault trace there is strongly curved as it runs around the highstanding Miocene outcrops on the south-sloping northern side of the valley. Structure contours constructed on the trace between upper Makara and lower $\mathrm{Te}$ Matarau Streams show that it dips approximately $15^{\circ}$ toward $175^{\circ}$. At its western end, however-west of a moderately east-southeast dipping fault which offsets it-the Whakoau Fault trace runs around the ridge between the Makara and Mata valleys, suggesting a very gentle eastward dip. Bedding in Ihungia Formation near the contact is generally not parallel to it, showing that the contact is a fault rather than an unconformity.

The transport direction on the Whakoau Fault, determined from minor structures, is between east-southeast and south-southeast. A cataclasite in Mokoiwi Formation beneath the fault in uppermost Makara Stream (Map 2) has a strong anastomosing foliation which dips gently south and contains scratch striations trending southeast (Fig. 4.13a). In the limestone above the fault further west, a minor normal fault oriented $075^{\circ} / 55^{\circ} \mathrm{S}$ has a conjugate oriented $080^{\circ} / 80^{\circ} \mathrm{N}$ and associated extension fractures, interpreted as pinnate joints (see Hancock, 1985), oriented $085^{\circ} / 80^{\circ} \mathrm{N}$. These suggest north-northwestsouth-southeast extension. Near the bottom of Te Matarau Stream, again just above the fault, a minor antithetic normal fault oriented $055^{\circ} / 52^{\circ} \mathrm{NW}$ (Fig. 4.13b) has calcite slickensides oriented $280^{\circ} / 50^{\circ}$. Of these minor structures, the striated surfaces of the cataclasite probably most precisely reflect the transport direction on the fault. Transport is thus inferred to be southeastward, similar to transport on the faults of the allochthon during their second (extensional) phase of movement.

The Opossum Creek Fault (Kenny, 1986; Mazengarb et al., 1991) can be traced from the western end of the Whakoau Fault, which it is thought to cut (this was not observed owing to poor exposure), west to Puketoro Stream and out of the map area. Its strike swings from approximately west in the east to west-northwest between Opossum and Kaikomako Streams, and back to just south of west at the western end of the area. The fault dips steeply $\left(\approx 70^{\circ}\right)$ where it crosses the branches of Kaikomako Stream. Between Puketoro Stream and the ridge immediately east of it, two fault 

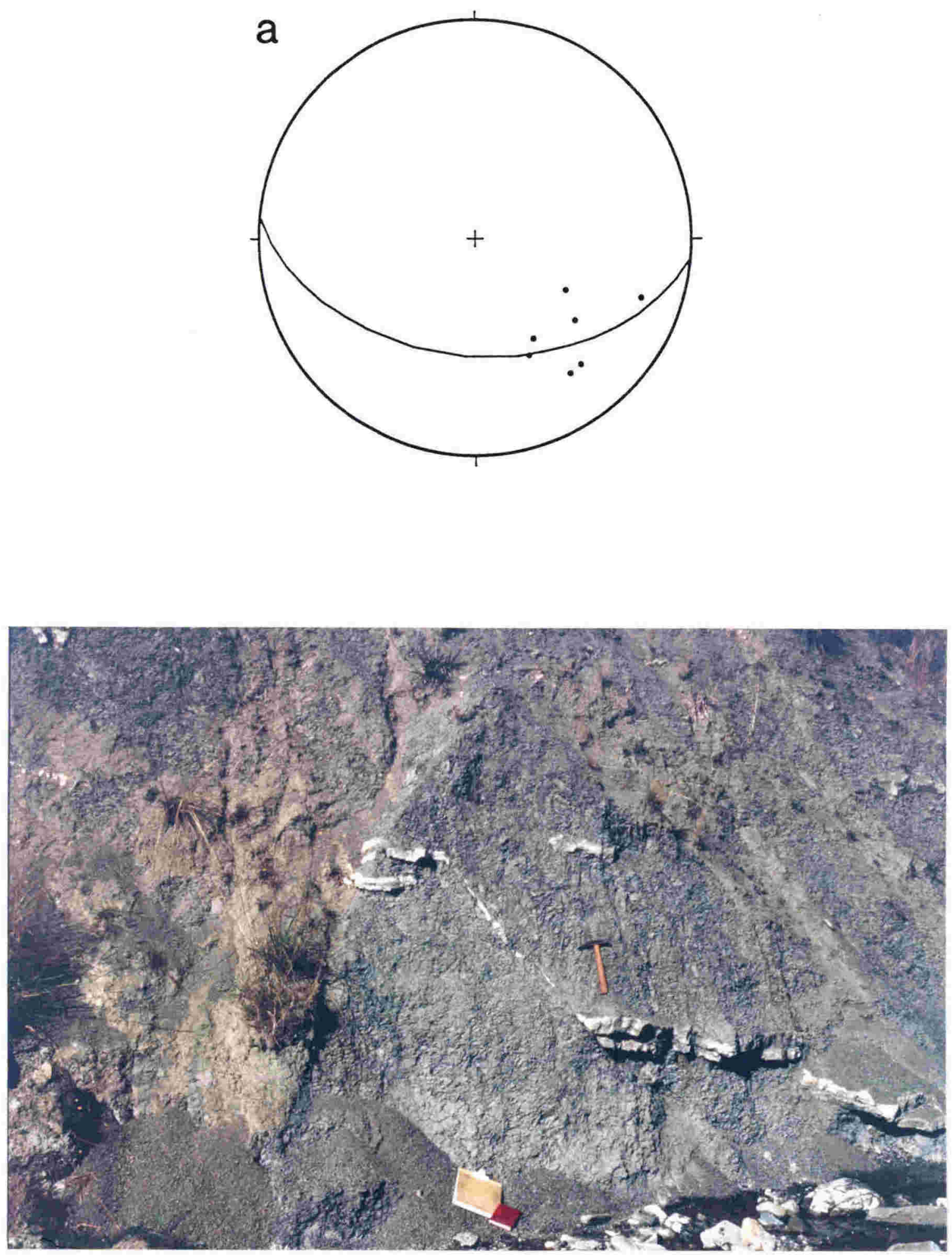

b

Figure 4.13: a: Equal-area projection showing structures in foliated cataclasite beneath Whakoau Fault, upper Makara Stream. Dots are scratch striations, great circle is average orientation of anastomosing foliation. b: Minor antithetic normal fault just above Whakoau Fault near the bottom of Te Matarau Stream (Y16 64403955). 
strands are seen. The northernmost strand is approximately parallel to the foliation in the mélange beneath it $\left(060^{\circ} / 50^{\circ} \mathrm{SE}\right)$ and is cut by the steeper, more westerly-striking southern strand.

The details of the kinematics of the Opossum Creek Fault are unknown. If its transport direction was southeast, parallel to that of the Whakoau Fault, it would have a large sinistral component. Moderately to steeply dipping, predominantly normal-slip faults affecting Miocene rocks in other parts of Raukumara Peninsula have a variety of strikes between north and east (Moore et al., 1989; Mazengarb et al., 1991). The Opossum Creek Fault is thus probably a dominantly dip-slip fault.

The amount of offset on the Whakoau and Opossum Creek Faults can be estimated from the age of the Ihungia Formation in their hangingwalls. The eastern end of the Opossum Creek Fault cuts Altonian rocks, but around Kaikomako and Puketoro Streams, foraminifera from rocks close to the fault give Waitakian-Otaian ages (Mazengarb et al., 1991). These rocks are sandier than 'typical' Ihungia Formation, being more similar to Opossum Creek sandstone; in fact, the rocks in upper Kaikomako Stream and the Opossum Creek beds were mapped as parts of the same unit ("Mangatu" sandstone) by Mazengarb et al. (1991). It has been argued (section 4.6.4) that because the lowest material in the Opossum Creek block is similar to material in the allochthon, the faults surrounding that block do not have very great throws. The similarity in age and appearance of the rocks immediately above the Opossum Creek Fault to the Opossum Creek sandstone suggest also that the Opossum Creek Fault does not have a very great throw. Thus, relative to the allochthon, the Miocene rocks above the Opossum Creek Fault are likely to have been downthrown in the order of hundreds of metres rather than kilometres. The Whakoau Fault, which cuts Altonian (Mazengarb et al., 1991) and possibly Otaian (Kenny, 1986) rocks, is likely to have a somewhat greater throw than the Opossum Creek Fault.

Kenny $(1980,1984 a, 1986)$ shows a number of steep faults with a variety of strikes cutting the Ihungia Formation. These were postulated largely to explain apparent offsets of biostratigraphic horizons (Kenny, 1986, p. 384); they do not offset lithologic horizons greatly. Kenny's map shows a number of north-northwest striking faults of this set cutting the Whakoau and Opossum Creek Faults and the rocks of the allochthon. No such structures have been observed by this writer, despite good outcrop where certain of them were postulated to exist. One, Kenny's Makara Fault, is the topographic expression of the base of the limestone lithotype of the Ihungia Formation (a cliff). 


\subsection{DISCUSSION AND CONCLUSIONS}

\subsubsection{History of Deformation in the Ihungia-Puketoro Area}

Two tectonic events involving displacement on gently dipping faults were identified in the preceding sections: southwestward thrusting and subsequent southeastward extension. Prior to southwestward thrusting, the northeast-directed Ihungia fault system was active-the eastern Ihungia Fault in the late Piripauan to early Haumurian, and the western Ihungia Fault after the Teurian. Because there are no indications in the regional stratigraphy of any major tectonic events between the Teurian and the onset of southwestward thrusting, it was concluded in section 3.8 that the western Ihungia Fault was active early in the same contractional phase as the southwestward thrusting.

Structures produced by southwestward thrusting in the Ihungia-Puketoro area are contiguous with similar structures further southwest (Moore et al., 1989; Mazengarb et al., 1991) which stratigraphic relations show were initiated in the Waitakian (Stoneley, 1968; see sections 1.3.1 6.2.2.2). The stratigraphy in the Ihungia-Puketoro area also indicates that the onset of deformation was Waitakian. The autochthonous Late Cretaceous to late Paleocene rocks are deformed by fracturing close to the Waitahaia Fault, but otherwise show only gentle folding, which probably accompanied allochthon emplacement. Paleocene to Waitakian units within the allochthon are thin, fine grained, and carbonate-dominated-similar to those in other parts of the East Coast Deformed Belt-suggesting little or no tectonic activity during their deposition. Waitakian and late Waitakian-Otaian rocks, however, are sandstone and breccia. The Opossum Creek sandstone shows a transition from marl to sandstone during the Waitakian, suggesting that erosion of a terrigenous source began at that time. The composition of the sandstone/breccia lithotype shows that Mokoiwi Formation was exposed to erosion in the late Waitakian to Otaian.

The cessation of thrusting at the thrust front, as shown by rocks overlying the thrusts, was during the Altonian (Stoneley, 1968; see sections 1.3.1, 6.2.2.2). In the Ihungia-Puketoro area, cessation of thrusting early in the Miocene is supported by the lack of post-Otaian rocks within the thrust system, by the small degree of deformation of the synorogenic Opossum Creek sandstone, and by the structure of the tectonically overlying Ihungia Formation: only the oldest Ihungia beds (Waitakian-Altonian) close to the boundary with the allochthon have northwest-trending folds which could have been produced by blind, southwest-directed thrusting beneath them; higher, more southeasterly parts of the formation are gently folded about a northeast trend (see also section 6.3.5.2). 
Some time after the cessation of thrusting, the area was affected by extensional tectonics. The thrusts were reactivated as down-to-the-southeast extension faults and cut by moderately to steeply dipping extension faults with a variety of strikes. Miocene rocks - which accumulated on top of the allochthon, probably both unconformably and conformably in piggy-back basins (Opossum Creek sandstone) and later unconformably over structural highs-were downthrown along some of these faults, as well as along the gently dipping Whakoau Fault and the steeper Opossum Creek Fault. These extensional structures are at the northeastern limit of a regional structural association of predominantly down-to-the-southeast normal faults (Mazengarb, 1984; Moore et al., 1989; Mazengarb et al., 1991), accomodating extension which is active today (Walcott, 1978, 1987; Mazengarb, 1984). The internal conformity of the Waitakian-Waiauan rocks cut by these faults shows that faulting began after the Middle Miocene (Kenny, 1984a, 1986). During this extension, the area was tilted to the south-southeast as part of the regional southeastward tilting associated with the post-Early Pliocene uplift of the Raukumara Range (section 1.3.1).

The kinematic questions raised by Kenny's (1986) conclusion that Early Miocene thrusting in the Ihungia-Puketoro area was southeastward while coeval thrusting further southwest was clearly southwestward (section 1.3.1) are answered by the recognition that Early Miocene thrusting in the north was in fact southwestward. The southeastward displacements there are due to post-Early Miocene extension. Questions as to the timing of emplacement of the allochthonous material between the Ihungia and Mokoiwi Formations (section 1.3.1) are also answered-all the material beneath the Ihungia Formation was thrust southwestward before being affected by southeastward extension associated with the "emplacement" of the Ihungia Formation (cf. Kenny, 1986). Southeastward extension has occurred since the Middle Miocene, whereas southwestward thrusting was an Early Miocene event. Therefore, all the material beneath the Ihungia Formation was emplaced during the Early Miocene.

\subsubsection{Thrust Sequence and Synorogenic Sedimentation}

The cross-cutting relationships of the thrusts in the allochthon and the ages of the formations in each thrust sheet show that the thrust sequence within the allochthon in the Ihungia-Puketoro area was complicated (Fig. 4.14). The earliest thrust was the Waitahaia/Aorangiwai Fault. This originated some distance to the northeast and carried Mokoiwi Formation over Haumurian-Teurian rocks, the Ihungia Fault, Waitahaia Formation, and Whangai Formation. In the Mata River-Puketoro Stream area and to the southwest, its tip propagated a few hundred metres below the synorogenic surface, along the top of the Whangai Formation. The Waitahaia thrust sheet was extensive, as shown by the presence of Mokoiwi Formation in its hangingwall over a large area. The 


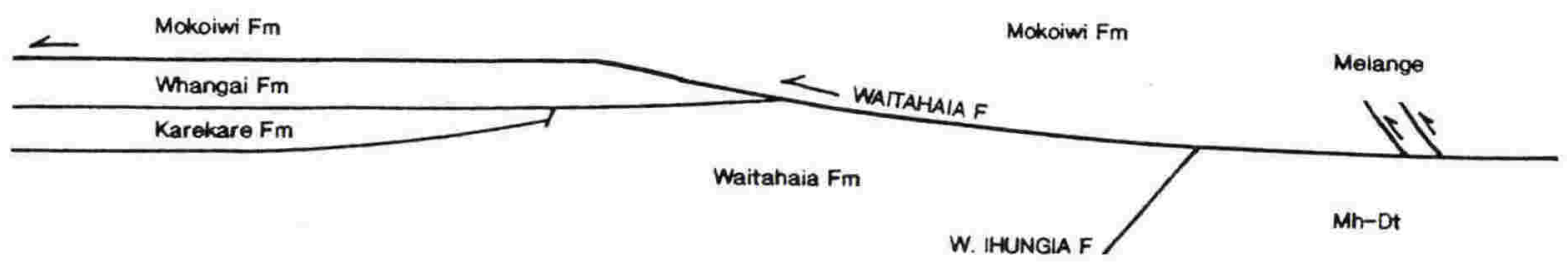

1. EMPLACEMENT OF WAITAHAIA SHEET; EROSION TO LEVEL OF MOKOIWI FM.

$$
1
$$

ASSEMBLY OF UPPER THRUST PILE TO NE; CREATION OF MELANGE.
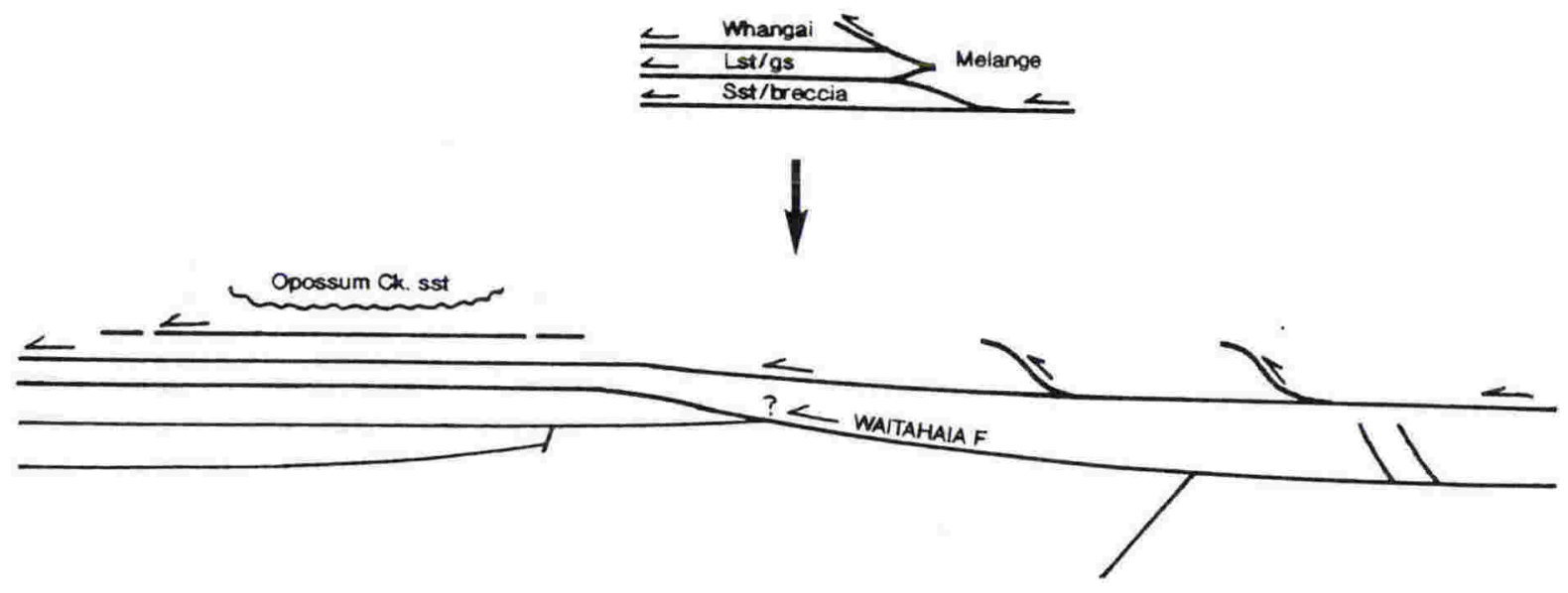

2. EMPLACEMENT \& CONTINUING DEFORMATION OF UPPER THRUST PILE; DEPOSITION OF OPOSSUM CREEK SST.

Figure 4.14: Schematic sections showing the evolution of the allochthon in the IhungiaPuketoro area. 
presence of the eastern mélange body shows it was internally faulted during transport: a wedge of material underlying the Waitahaia Fault was incorporated into the sheet by breaching or footwall plucking processes (see section 3.6.4, Fig. 3.30) and was later truncated at its base by further fault movement.

After initial movement on the Waitahaia Fault, the rocks above it were eroded down to the level of the Mokoiwi Formation and cut by a group of thrusts carrying uppermost Cretaceous and Lower Tertiary rocks. These thrusts locally cut down-section as far as the autochthon. The presence of horses of sandstone/breccia containing clasts of Mokoiwi Formation and of lithologies from these higher sheets indicates that thrusting during this stage was emergent or nearly so, with material eroding from the underlying parautochthon and from the fronts of the higher sheets subsequently being overridden. Other weakly deformed synorogenic material (Opossum Creek sandstone and the oldest rocks above the Opossum Creek Fault) probably accumulated on top of the moving thrust pile at this stage or later. The Waitahaia Fault may also have been active during this phase, because the later faults do not cut down past it into the autochthon (Profile G-G'(1)); they may have transferred displacement into it.

Within this upper pile in the Ihungia-Puketoro area, small, lower sheets of sandstone/breccia, limestone/greensand, and Whangai Formation are overlain by a sheet of mélange. Further southwest, the maps of Kenny (1986) and Mazengarb et al. (1991) show that thrusts above the Waitahaia Fault generally put older rocks over younger; Early Miocene synorogenic rocks generally are near the bottom of the pile, and Whangai, Tapuwaeroa, and Tikihore Formations near the top (section 6.3.5.1). This indicates that forward and downward (piggy-back) thrust propagation was dominant during the assembly of this pile. Common reversals in this older-on-younger sequence and the occurrence of the mobile mélange enclosing many of the smaller sheets, however, show that deformation of the pile continued after its initial assembly; it probably continued to deform during its emplacement across the Waitahaia sheet.

The thrusting history in the allochthon in the Ihungia-Puketoro area, then, can be summarised as follows (see Fig. 4.14):

1) Emplacement (with some internal deformation) of the Waitahaia sheet, accompanied or followed by erosion down to the level of the Mokoiwi Formation.

2) Emplacement of a largely assembled stack of uppermost Cretaceous, Lower Tertiary, Lower Miocene, and mélange on thrusts with tips close to or at the synorogenic surface; deposition of sediments into piggy-back basins on top of this stack. 
One of the objectives of studying the Ihungia-Puketoro area (section 1.4) was to determine what happened to the northern end of the sole thrust of the East Coast Allochthon north of the Ihungia Fault. Moore (1985, 1988a) shows the boundary between his East Coast Allochthon and Motu Block as turning from the Mangarakeke (Waitahaia) Fault into the Ihungia Fault, implying that the sole thrust steps down to a lower structural level north of the Ihungia Fault and that all rocks north of that fault are 'allochthonous'. It was shown in section 3.8.2 that in the lower Mata River area, there are three structural blocks which moved relative to each other in the Early Miocene: the Motu Block, the block northeast of the western Ihungia Fault, and the block above the Aorangiwai Fault. The two latter comprise the East Coast Allochthon. In the Ihungia area, there are also three blocks: the Motu Block and the block east of the western Ihungia Fault, which are direct continuations of the blocks in the lower Mata River area; and the block above the Waitahaia and Mangarakeke Faults (referred to in this chapter as 'the allochthon'; see section 4.3). It was suggested in section 4.5.2.2 that because of the similarity in their structural positions, the Aorangiwai and Waitahaia Faults are likely to be different parts of the same structure. Thus, the third block present in the lower Mata River area also exists in the Ihungia-Puketoro area.

The sole thrust of the 'allochthon' defined in this chapter (section 4.3) is the Waitahaia/Aorangiwai Fault, which accomodated movement of the Mokoiwi Formation relative to the Motu Block and the 'eastern' block. A detachment must join the Ihungia Fault at depth to accomodate the movement of the 'eastern' block relative to the Motu Block. This detachment could extend southwestward from the western Ihungia Fault to underlie the Motu Block, or northeastward to underlie the northern part of the East Coast Allochthon. Because northeast-directed, Early Miocene thrusts like the Ihungia Fault exist in the north (see section 6.4.3.1), the latter possibility is likely. This detachment, then, would be the sole thrust of the northern East Coast Allochthon.

\subsubsection{Conclusions}

Examination of the Thungia-Puketoro area during the present study has led to the following conclusions:

1) The Ihungia-Puketoro area contains the sole thrust of the East Coast Allochthon and the Ihungia faults, across which the sole thrust disappears. Eleven lithologic units are distinguished there: Mokoiwi Formation (?Urutawan-Motuan/Albian); Waitahaia Formation (Ngaterian/Albian-Cenomanian); Karekare Formation (Raukumara Series/Cenomanian-Santonian); Tikihore Formation (Teratan-Piripauan/ 
Coniacian-Santonian-?Campanian); Haumurian-Teurian (Maastrichtian-Paleocene) sandstone and mudstone; Whangai Formation (Haumurian-Teurian); mélange, with a matrix of Eocene smectite mudstone; the limestone/greensand lithotype (Whaingaroan-Waitakian/Oligocene-Aquitanian); the Opossum Creek sandstone lithofacies (Waitakian/Aquitanian); the sandstone/breccia lithotype (WaitakianOtaian/Aquitanian-Burdigalian); and the Ihungia Formation (Waitakian-Otaian and younger).

2) The area has a south to southeasterly structural pitch, leading to the exposure of structurally lower rocks to the north and structurally higher rocks to the south. The Motu Block, in the north and west, comprises Waitahaia Formation, which is deformed into upright to steeply westerly-inclined, gently south-southeast plunging folds which verge northeast and are commonly associated with west-side-up reverse faults; Karekare Formation, which dips gently south above an angular unconformity; and, above another unconformity, gently south-dipping Whangai Formation. The Karekare and Whangai Formations are gently folded about a southplunging axis. The western Ihungia Fault, at the eastern limit of the Motu Block, is a moderately westerly-dipping reverse fault which has displaced HaumurianTeurian rocks $1.5-2 \mathrm{~km}$. East of that fault, Haumurian-Teurian rocks unconformably overlie Waitahaia Formation and Tikihore Formation which are juxtaposed along the westerly-dipping, reverse, eastern Ihungia Fault. These structures and formations are continuations of those in the lower Mata River area.

3) The Motu Block, the western Ihungia Fault, and the Haumurian-Teurian rocks are structurally overlain by Mokoiwi Formation along the Waitahaia and Mangarakeke Faults. The Waitahaia Fault, in the west, is a southwest-directed thrust which lies approximately at the top of the Whangai Formation. To the east the Waitahaia Fault is cut by the Mangarakeke Fault, which is a steeply south-dipping extensional fault around the centre of the area and a gently dipping, southeast-directed extensional fault further east. Also, minor structures show that the Waitahaia Fault was reactivated as a down-to-the-southeast extensional fault. The complexly deformed Mokoiwi Formation above the Waitahaia and Mangarakeke Faults constitutes the Waitahaia thrust sheet, which was originally probably continuous with the sheet above the Aorangiwai Fault in the lower Mata River area. Stratigraphic separation on the Waitahaia Fault may be as much as $5.5 \mathrm{~km}$, and southwestward transport on it was some tens of kilometres.

4) Structurally overlying the Waitahaia sheet is a complex of mélange and slices of Late Cretaceous-Early Miocene units, including Waitakian-Otaian breccias with clasts of Mokoiwi Formation and younger lithologies. Within this complex, younger 
rocks are generally closer to the base and older rocks closer to the top, showing that forward and downward thrust propagation was important in its assembly, although reversals in the stacking order are common further southwest. Minor structures within this complex and the predominant northwest strike of units within it further southwest show that it was thrust southwestward over the Mokoiwi Formation. The Opossum Creek sandstone was deposited on top of it, probably during its motion, and later downthrown against it by movement on extensional faults. Structures in the mélange suggest a phase of southeastward extension affected it. High-angle extensional faults with a variety of strikes cut some of the sheets.

5) Ihungia Formation in the south of the area overlies the thrusted rocks to the north along two normal faults, the gently south- to east-dipping Whakoau Fault, in the east, and the moderately south-dipping Opossum Creek Fault in the west. Where the two faults meet, the Opossum Creek cuts the Whakoau. Minor structures show that the hangingwall of the Whakoau Fault moved southeastward. The hangingwall of the Opossum Creek Fault probably moved in a similar direction. The throws on these faults are likely to be hundreds of metres rather than kilometres. The Waitakian-Altonian Ihungia Formation just south of the faults strikes northwest and defines gentle to open folds which may have been produced by blind thrusting at depth. Further south the Altonian and younger Ihungia dips gently southeast into the northeast-trending Tutamoe Syncline and is cut by northeast-striking normal faults.

6) The sequence of Late Cretaceous tectonic events was: deformation of the Waitahaia Formation, probably concurrently with movement on the Ihungia fault system; deposition of the Karekare Formation into a basin southwest of the Ihungia faults; between the late Piripauan and early Haumurian, east-northeastward thrusting on the Ihungia Fault system which put Waitahaia Formation over Tikihore Formation; tilting of the Ihungia Fault system associated with fault-related folding of the Tikihore Formation east of it; and erosion across the area followed by deposition of the Haumurian-Teurian beds in the east and the Whangai Formation in the west.

7) The sequence of Early Miocene tectonic events was: east-northeastward thrusting on the western Ihungia Fault; emplacement of the Waitahaia sheet southwestward across the Haumurian-Teurian rocks, the western Ihungia Fault, and the Motu Block along the Waitahaia Fault; erosion of the Waitahaia sheet down to the level of the Mokoiwi Formation, southwestward emplacement of a largely assembled stack of uppermost Cretaceous, Lower Tertiary, Lower Miocene, and mélange on thrusts with tips at the synorogenic surface, and deposition of sediments on top of 
this stack during its motion; after thrusting had ceased, deposition of the remainder of the Ihungia Formation; after the Middle Miocene, southwestward extension on reactivated thrusts and the newly generated Mangarakeke, Whakoau, and Opossum Creek Faults, and extension on the northeast-striking normal faults in the Ihungia Formation.

8) There are three structural blocks in the Ihungia-Puketoro area which moved relative to each other during the Early Miocene. These are: the sheet of Mokoiwi Formation above the Waitahaia/Mangarakeke Fault; the Motu Block, above and west of the western Ihungia Fault; and the upper Cretaceous-Paleocene rocks beneath and east of the western Ihungia Fault. The Waitahaia sheet is equivalent to the sheet of Mokoiwi Formation above the Aorangiwai Fault, and the other two are direct continuations of the blocks in the lower Mata River area. The Motu Block moved eastward over the eastern block, and the Waitahaia sheet subsequently moved southwestward over both. The structure which forms the sole thrust of the East Coast Allochthon southwest of the western Ihungia Fault is thus also present northeast of it; rather than this structure 'disappearing' across the Ihungia Fault, the Ihungia Fault 'appears' from beneath it. A detachment must join the Ihungia Fault at depth to accomodate movement of the Motu Block relative to the 'eastern' block. This detachment probably extends northeastward to form the sole thrust of the northern part of the East Coast Allochthon. 


\section{Chapter 5}

\section{The Southern Margin of the Te Puia Inlier}

\subsection{INTRODUCTION}

\subsubsection{Location, Physiography and Exposure}

The strip along the southern margin of the Te Puia inlier between State Highway 35 and Ihungia Road constitutes area 3 in Fig. 1.4. This area lies within NZMS 260 sheets Y16 and Z16 (1:50,000), being approximately bounded by grid refs. Y16 660380, Y16 680400, Y16/Z16 700350, Z16 760350, Z16 760320, and Y16/Z16 700320. Aerial photographs examined by the writer are from run numbers 2278A (1957, frames 13-16), 2279A (frames 15-17), 2279B (frames 16-18), and survey number 8132 (1981, frames B19-22). Access to the eastern end of the area is by State Highway 35 and by Puketiti Road, which leaves the highway $2 \mathrm{~km}$ south of Te Puia (Fig. 1.2). The northwestern end of the area is reached from Ihungia Road. Foot tracks link Ihungia and Puketiti Roads.

Physiographically, the area is dominated by a ridge which runs west from State Highway 35 to Puketiti (Fig. 5.1) and thence northwest to the northwestern end of the area. Elevations along this ridge reach $609 \mathrm{~m}$ at Puketiti, the highest point in the area, and $537 \mathrm{~m}$ at Wahingamuku trig. Remnants of old alluvial terraces are preserved near the northwestern end of this ridge. South and east of Puketiti, moderately incised streams drain southward or eastward to the sea. Streams north of the ridge and west of Puketiti drain westward, their water eventually joining the Mata River to the northwest. Elevations are lowest in the eastern valleys, being $\approx 100 \mathrm{~m}$ around the confluence of Ototo and Te Matai Streams (Fig. 5.1).

Exposure is poor over most of the area, the best outcrops being in Ototo and Pipiko Streams in the east and in Makahikatoa Stream and its tributaries in the west. Exposures on the ridges are deeply weathered, making lithological identifications difficult in many cases. The northern slopes of the Ototo and uppermost Pauariki valleys are badly slumped. Repeated mass movement above Pipiko Stream has resulted in large blocks of Kapitean sandstone resting on a slurry of Tongaporutuan mudstone over much of the catchment, obscuring the underlying geology. The most recent incidence of such movement was during Cyclone Bola in early 1988, after mapping of the area had been completed. 


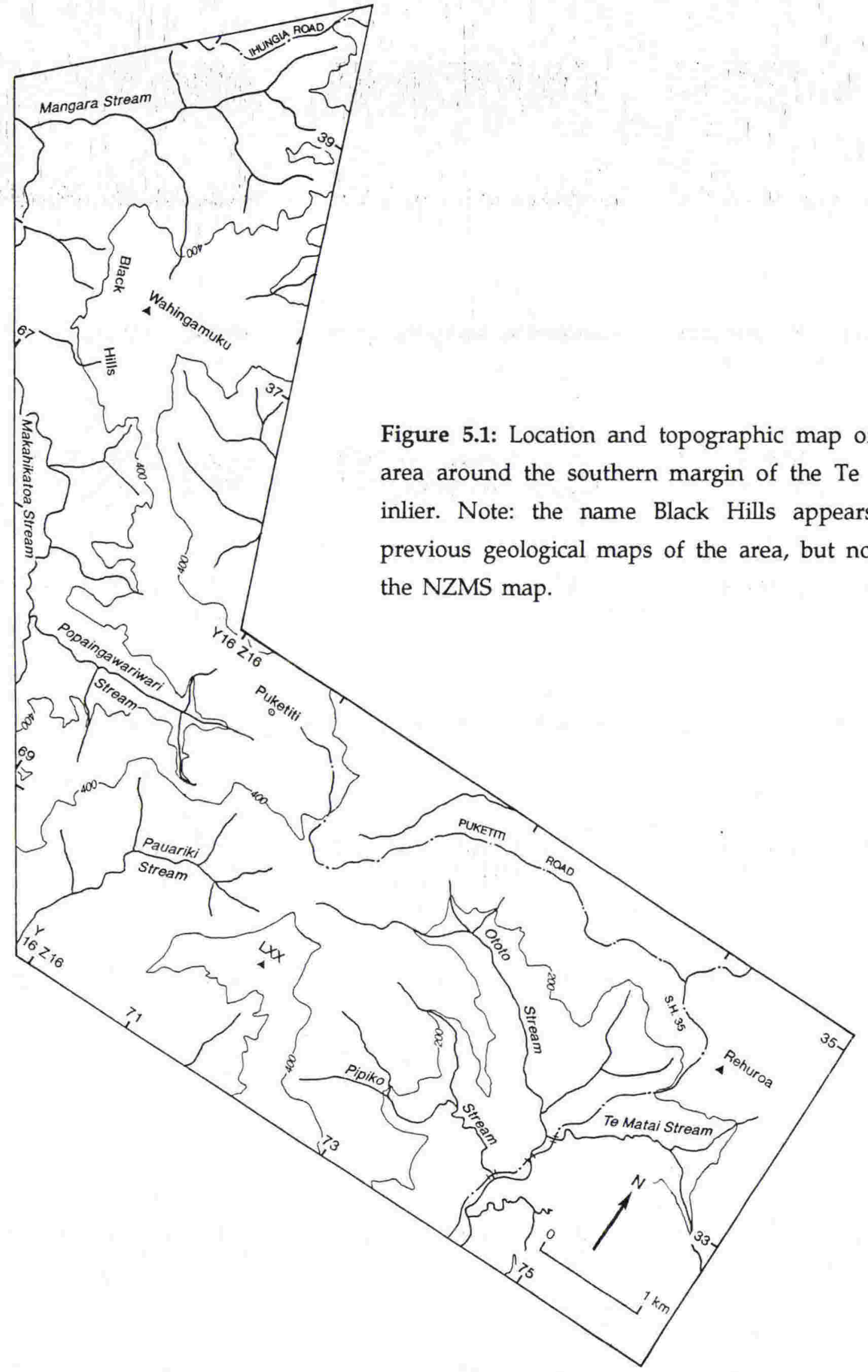




\subsubsection{Previous Work}

Apart from regional surveys (Ongley and Macpherson, 1928; Kingma, 1965; Moore et al., 1989), the area was mapped by Pick (1962) and Laing (1972a). Kenny (1980, 1984a) and Mazengarb et al. (1991) mapped the northwestern part. Pick (1962) mapped most contacts in the area as steeply dipping faults, and considered that the Cretaceous rocks of the Te Puia inlier formed the core of a "diapiric fold" which had been pushed up through the surrounding stratigraphy. In contrast, Laing (1972a) mapped all contacts as sedimentary. He considered the structurally complex rocks of the inlier to be part of an Eocene olistostrome which unconformably overlies "Wanstead Formation" (early Eocene) and is in turn unconformably overlain by Miocene rocks (section 1.3.1).

In the northwest of the area, Kenny (1980, 1984a) mapped three 'allochthons', the lowest comprising the Mokoiwi Formation and Lower Tertiary rocks which structurally overlie Waitahaia Formation in the Ihungia Valley (see section 4.5.2), the middle comprising the Ihungia Formation, and the highest comprising supposedly Lower Tertiary lithologies tectonically overlying the Ihungia. Subsequently, however, it was found that most of the material in this highest sheet is in fact Miocene (Mazengarb, in Kenny, 1984b; Mazengarb et al., 1991) and the third 'allochthon' was reduced to two small outcrops at either end of the Black Hills (Fig. 5.1).

\subsection{STRATIGRAPHY}

Seven lithologic units are distinguished in this area (Fig. 5.2). These are:

1) Urutawan-Motuan (Albian) alternating sandstone and mudstone with lensoid bodies of coarse sandstone, mapped as "undifferentiated Clarence Series" by Moore et al. (1989) and "undifferentiated Ruatoria Group" by Mazengarb et al. (1991), but here referred to as Mokoiwi Formation, following Pick (1962) and Kenny (1980, 1984a).

2) Sandstone, mudstone, and grit mapped as "Haumurian-Teurian".

3) Haumurian-Teurian (Maastrichtian-Paleocene) well bedded calcareous mudstone of the Whangai Formation (Pick, 1962; Kenny, 1980, 1984a; Mazengarb et al., 1991).

4) A small occurrence of mélange with a matrix of Eocene smectite mudstone. 


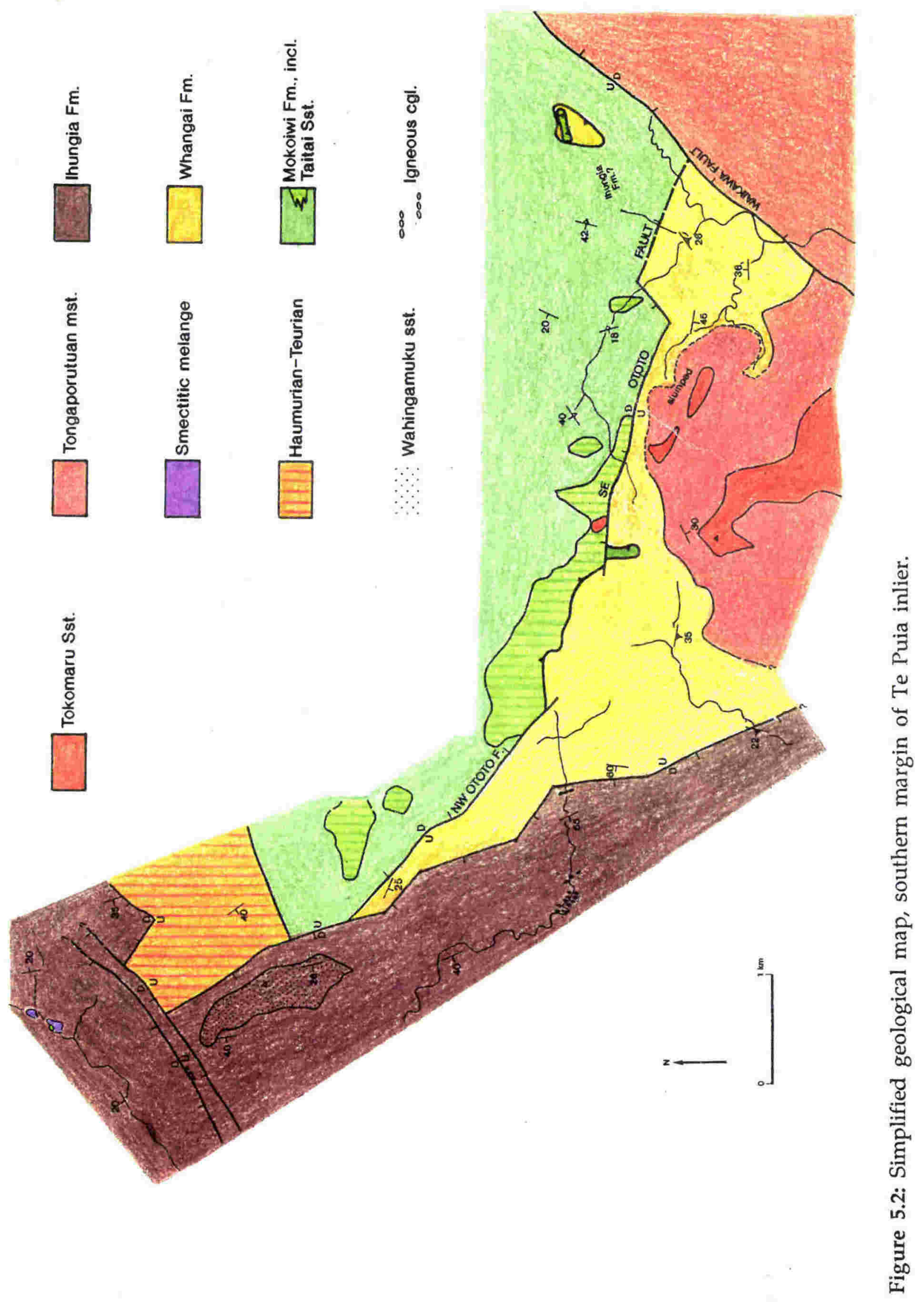


5) Waitakian-Otaian to Altonian (Aquitanian-Burdigalian) alternating sandstone and mudstone, mudstone, and conglomerate of the Ihungia Formation (Pick, 1962; Laing, 1972a; Kenny, 1980, 1984a).

6) Tongaporutuan (Tortonian) mudstone and alternating sandstone and mudstone.

7) Kapitean (Messinian) poorly bedded, well sorted sandstone of the Tokomaru Sandstone (Moore et al., 1989, after Laing, 1972a).

Many of these units are in fault contact (Fig. 5.2) and their thicknesses are not complete, so no stratigraphic column is presented. Where approximate maximum thicknesses have been determined, they are given in the following descriptions.

\subsubsection{Mokoiwi Formation}

Mokoiwi Formation of the Te Puia inlier occupies the northeast of the area. Large bodies of Taitai sandstone (e.g., Puketiti, Fig. 5.2) lie along or close to the faulted southwestern margin of the formation.

The composition of the Mokoiwi Formation in the Te Puia inlier is as described in the lower Mata River area (section 3.2.1). The age, based on Inoceramus collections recorded in the N.Z. Fossil Record File (e.g., NZMS 1 N80/f6508) is Urutawan-Motuan (Albian).

\subsubsection{Haumurian-Teurian rocks}

In the northwest of the area, poor quality, weathered exposures reveal moderately hard, green-grey to dark green, poorly sorted, slightly micaceous, carbonaceous, glauconitic, medium to coarse sandstone and grit, and light to medium blue-grey, calcareous, micaceous mudstone. Sandstones and mudstones weather red-brown to orange-brown on fracture surfaces, and some weathered mudstones show yellow jarosite staining. Highly weathered mudstones are pale yellow or white. Centimetre- to decimetre-bedded sandstones or interbedded sandstones and mudstones dominate at some localities, whereas poorly bedded mudstone dominates at others.

No fossils have been obtained from these rocks. The lithologies present are similar to lithologies in the Tapuwaeroa Formation in its type area (section 2.2.2.1), to the Haumurian-Teurian rocks in the lower Mata River and Ihungia-Puketoro areas, and to the Whangai Formation. Sandstone-dominated occurrences could reasonably be assigned to the Tapuwaeroa or Haumurian-Teurian formations, and mudstone-dominated 
occurrences could be assigned to the Haumurian-Teurian or Whangai formations. Mazengarb et al. (1991) show some of these rocks as Tikihore Formation and some as Whangai Formation, separated by a system of faults with a variety of orientations. Because outcrop is poor and boundaries between sandstone-dominated and mudstonedominated areas could not be delineated with any precision, these rocks are shown as "Haumurian-Teurian" on Fig. 5.2 and Map 3. They may be a combination of Tikihore (or Tapuwaeroa) and Whangai Formations, as shown by Mazengarb et al. (1991), or they may in fact be equivalent to the Haumurian-Teurian formation in the lower Mata River and Ihungia-Puketoro areas.

\subsubsection{Whangai Formation}

Whangai Formation is present in a northwest-trending strip across the centre of the area and in a small, fault-bounded body in the northeast (Fig. 5.2, Map 3). It is well exposed in Ototo, Pipiko, and Pauariki Streams.

Whangai Formation in this area can be classified as belonging to the Porangahau Member of Moore's (1988b) Eastern Facies (see section 2.2.2.1). It consists predominantly of well bedded (centimetre-decimetre scale), light green-grey to dark grey, jarositic, commonly pyritic, calcareous to very calcareous mudstone. Light green-grey beds quickly weather white. Highly weathered outcrops are light yellow-brown with red-brown staining on fracture surfaces. Thin, cross-bedded, fine to medium grained, yellow-brown weathering, dark green greensand interbeds are common. Intervals of dark grey, finely laminated to massive, non-calcareous to slightly calcareous, micaceous mudstone are also present. Around the heads of Pauariki and Ototo Streams, the rocks are badly crushed due to their proximity to the thrust contact with the adjacent Mokoiwi Formation (see section 5.6.1) and their original sedimentary fabric is difficult to discern. The presence of lenses of black shale resembling Waipawa Formation, stringers of red claystone, numerous greensand blocks, and much swelling clay suggest proximity to the stratigraphic top of the Whangai Formation.

The age of the Whangai Formation in this area-from previous microfossil collections and by comparison with the Whangai in other areas-is Haumurian-Teurian (Maastrichtian-Paleocene) (Pick, 1962; Kenny, 1980, 1984a; Moore et al., 1989; Mazengarb et al., 1991).

\subsubsection{Smectitic Mélange}

In the headwaters of Mangara Stream in the extreme northwest of the area (Fig. 5.2), there are two small bodies of mélange dominated by pale greenish grey smectite 
mudstone with common darker grey and brick red stringers. This is very similar to the matrix of the mélange in the Ihungia-Puketoro area (section 4.2.7), and is thus thought to be Eocene. The mélange bodies contain blocks of other lithologies, notably Mokoiwi Formation. A large block of Taitai Sandstone is present on the western edge of the downstream body (Map 3).

Both of these bodies are completely surrounded by Ihungia Formation (e.g., Fig. 5.3), and are probably diapiric in origin. The Ihungia Formation overlies Mokoiwi Formation along a gently southeast-dipping fault approximately $500 \mathrm{~m}$ northwest of Mangara Stream (Kenny, 1980, 1984a), so the base of the Ihungia is not far below the outcrops of mélange. Also, the mélange bodies occur approximately along strike from the the faultbounded strip of mélange in the Thungia valley (section 4.2.6; see also Kenny, 1980, 1984a). The smectite-rich mélange bodies would have a low density when water-saturated and could easily have risen the short distance through the overlying Ihungia Formation to their present positions, particularly if aided by excess fluid pressure.

\subsubsection{Ihungia Formation}

Ihungia Formation is present in the southwest and northwest of the area, in fault contact with the older rocks of the Te Puia inlier (Fig. 5.2). Moore et al. (1989) and Mazengarb et al. (1991) mapped these rocks as part of their Tolaga Group.

The major part of the Ihungia Formation in this area consists of massive to poorly bedded or finely laminated, calcareous, dark blue-grey fine sandy mudstone. Intervals tens to hundreds of metres thick of centimetre- to decimetre-bedded alternating blue-grey fine sandstone and sandy mudstone are common. Sandstones are generally graded, with massive bases and parallel-laminated tops. Sandstones weather to brown-grey, and both sandstones and mudstones weather orange-brown on fracture surfaces. In Popaingawariwari Stream and in a northwest-flowing tributary of Mangara Stream, the mudstone contains lenses of poorly to moderately sorted, matrix- and clast-supported conglomerate, with pebble to boulder sized clasts of a variety of igneous lithologies (see Kenny, 1984a, b, and sections 2.3 .1 and 4.2.10) in a sandy to gritty matrix. Many of the smaller clasts are well rounded, but the boulders are commonly sub-angular. The conglomerate occurs in beds up to a few metres thick, separated by sandy or gritty mudstone.

The age of the Ihungia Formation in this area is Waitakian-Otaian to Altonian (Aquitanian-Burdigalian) (Mazengarb et al., 1991). In the area southeast of the faults at the northwestern end of the Black Hills (Fig. 5.2, Map 3), foraminiferal samples (Y16/f127, 128, 148, 239, 512, 560, 573, 574, N.Z. Fossil Record File) give 


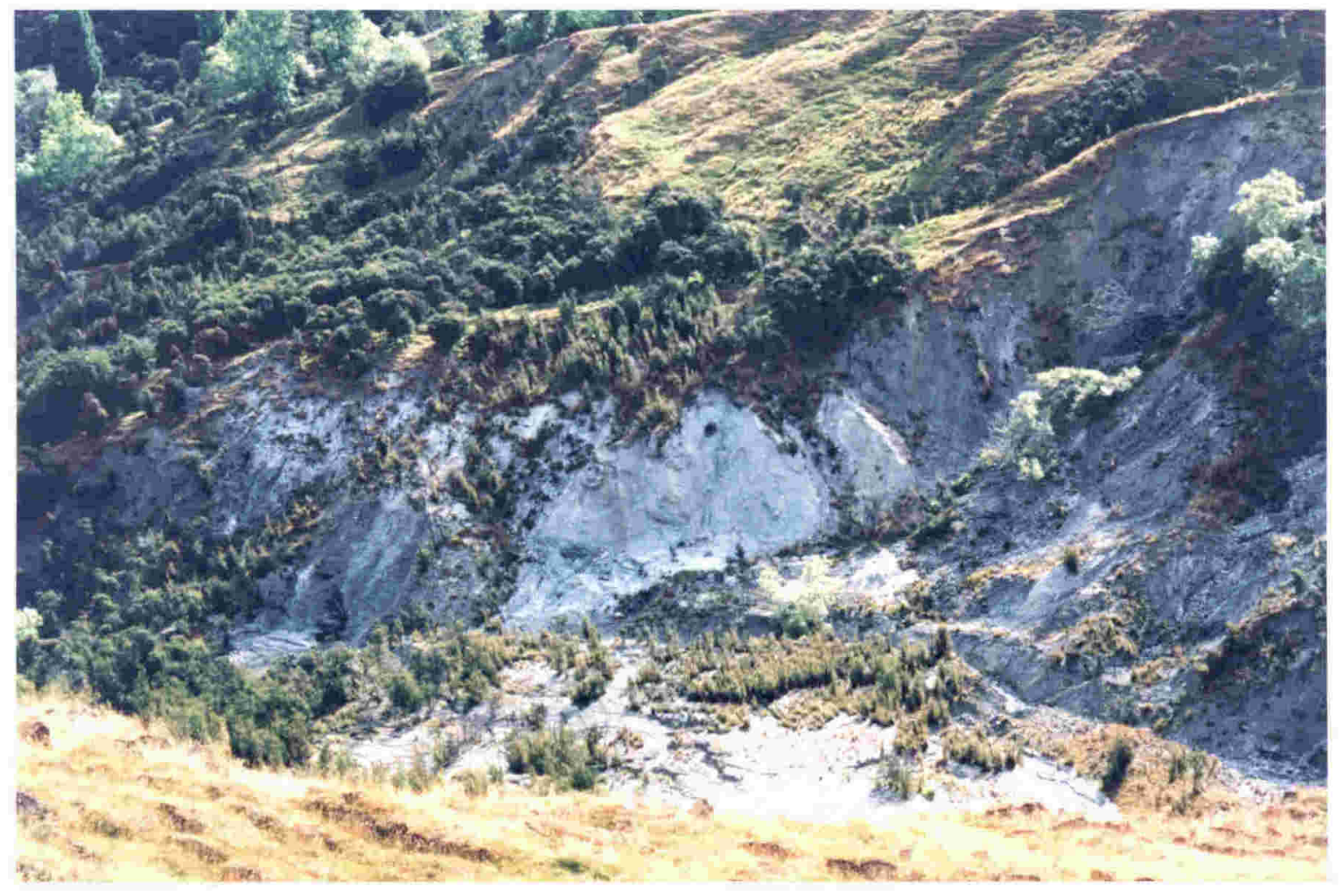

Figure 5.3: Smectitic mélange body in upper Mangara Stream (Y16 67553910). Mélange (pale green) is flanked and overlain by Ihungia Formation (dark grey), which also underlies the slope in the foreground. 
Waitakian-Otaian ages. Northwest of the faults, samples (Y16/f102, 103, 113, 114) give Altonian ages.

Around Wahingamuku trig (Fig. 5.2), there is an up to $200 \mathrm{~m}$ thick interval of decimetre- to metre-bedded, yellow-brown, carbonaceous, fine grained sandstones interbedded with centimetre-scale dark grey mudstone beds, which forms the prominent north-northwest trending ridge of the Black Hills (Fig. 5.2). This unit was referred to as Wahingamuku sandstone by Kenny (1980) and as the brown sandstone lithofacies of the Mangatu Group by Kenny (1984a), who assigned it an Eocene age on the basis of its palynomorph assemblage (she found no foraminifera). This sandstone overlies Ihungia Formation west of Wahingamuku (Fig. 5.2, Map 3), so Kenny (1980, 1984a) concluded it was allochthonous and drew a subhorizontal thrust beneath it, around the flanks of the Black Hills. However, the base of the sandstone clearly grades up from Ihungia Formation mudstone east of Wahingamuku (Fig. 5.4), and the sandstone is overlain concordantly by more Ihungia Formation mudstone to the west (Fig. 5.2, Map 3). Furthermore, a foraminiferal sample (Y16/f239, N.Z. Fossil Record File) from within the sandstone gave a Waitakian-Otaian age (Mazengarb, in Kenny, 1984b; Mazengarb et al., 1991), the same as that of the surrounding mudstone. Therefore, the "Wahingamuku sandstone" lies within the Ihungia Formation; the Eocene palynomorphs presumably were reworked from older strata.

In addition to the bulk of the Ihungia Formation in the southwest and northwest, there is also a small occurrence in the severely slumped and poorly exposed area around the small stream just west of Rehuroa trig (Figs. 5.1, 5.2, Map 3). In the lower part of this stream, float boulders of Ihungia igneous conglomerate lithologies-notably the banded diorite-are present, as are boulders of blue-grey mudstone, one of which ( $\mathrm{Z} 16 / \mathrm{f}$ 68, Appendix 2) gave a lower to mid-Altonian age. No Ihungia Formation was seen in place, however; outcrops observed further upstream were all of Mokoiwi Formation. The extent and contact relations of the Ihungia Formation in this area are thus unknown.

\subsubsection{Tongaporutuan Mudstone}

Tongaporutuan rocks, mapped as part of the Tolaga Group by Moore et al. (1989), occupy the south and east of the area. They consist dominantly of massive or finely laminated, blue-grey to green-grey, calcareous, sandy mudstone. At some places thin, graded, fine to very fine blue-grey sandstones are present. A pale, $5 \mathrm{~cm}$ thick tuff bed was seen in one outcrop. A lens of very fine blue-grey sandstone is present on the knoll southwest of trig LXX (Fig. 5.1). 


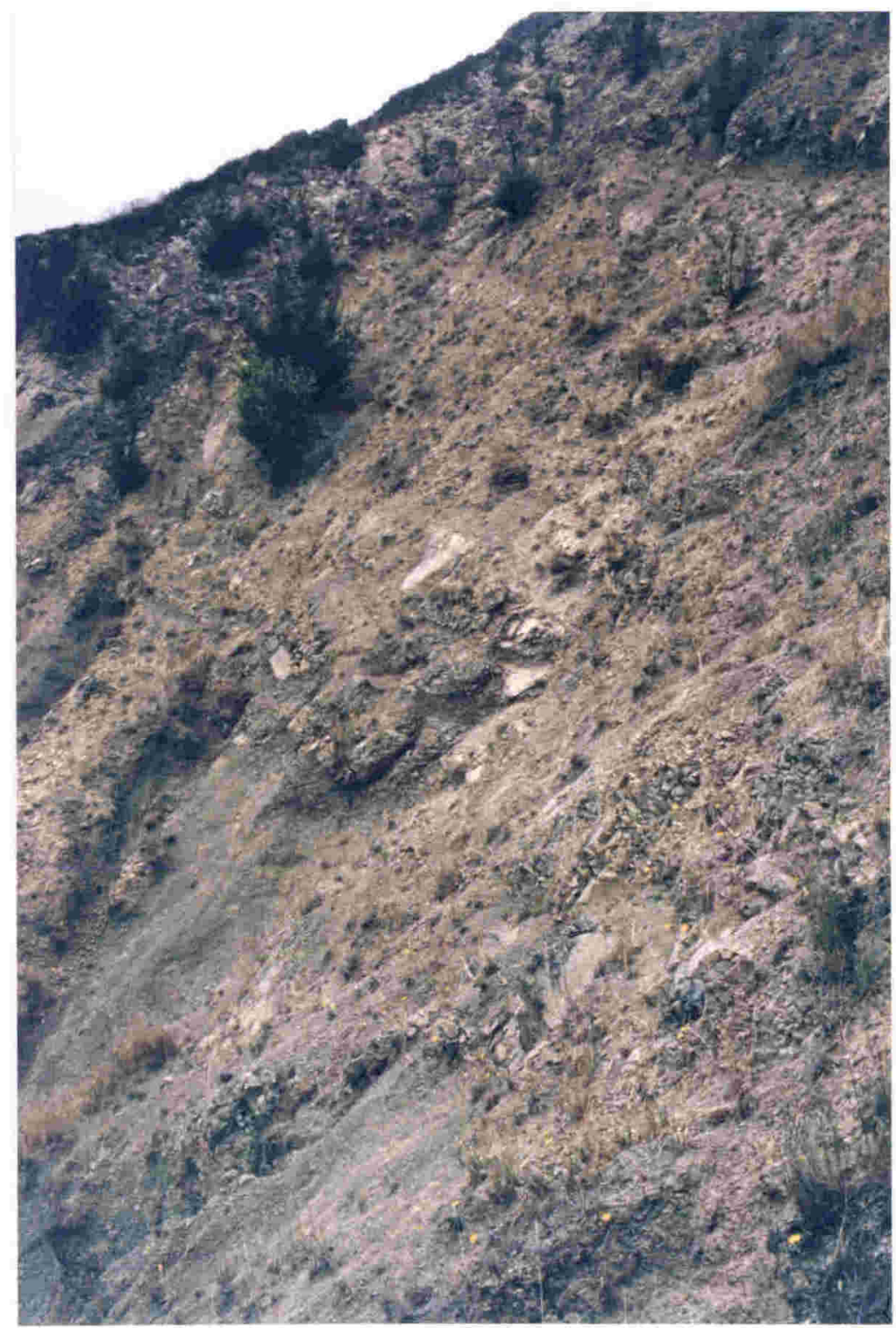

Figure 5.4: Wahingamuku sandstone conformably overlying Ihungia Formation mudstone on the western slopes of the Black Hills (Y16 67723738). 
West of State Highway 35, the Tongaporutuan overlies Whangai Formation along a gently dipping contact. This contact was not observed in outcrop and its position in the Pipiko valley is obscured by slumping (Fig. 5.2, Map 3), so its geometry is not well known. East of Pauariki Stream and south of Pipiko Stream, relations with topography suggest it has a gentle south-southeasterly dip. Moore et al. (1989) showed this contact as a normal fault because of the crushing of the Whangai beneath it around the head of Pauariki Stream (D.A. Francis, pers. comm., 1986). This crushing, however, is probably due to the thrusting of the nearby Mokoiwi Formation over the Whangai before the Tongaporutuan was deposited (sections 5.5, 5.6.1). Because only two bedding attitudes were observed, both somewhat above the base of the formation, concordance or discordance of the contact and the beds above it cannot be proved. The contact may thus be a fault or an angular unconformity, but it is most likely to be an unconformity because of its very low dip (see section 5.8 .1 and cross-section $\mathrm{L}^{-} \mathrm{L}^{\prime}$ ). In the east, the Tongaporutuan rocks occur in the hangingwall of a steeply dipping normal fault (the Waikawa Fault, section 5.8.2) which has Tongaporutuan rocks in its footwall in the southwest, and Whangai and Mokoiwi Formations in its footwall in the northeast.

The age of the mudstone, as shown by foraminiferal samples from throughout the formation on both sides of the fault (NZMS 1 N80/f6240, 6706, 6707 and NZMS 260 Z16/f5, 6, N.Z. Fossil Record File; Z16/f65-67, Appendix 2), is Tongaporutuan (Tortonian).

\subsubsection{Tokomaru Sandstone}

Tokomaru Sandstone (Moore et al., 1989, after Laing, 1972a) forms the high bluffs in the south of the area. This distinctive unit is a massive to metre-bedded, blue-grey to grey-green, fine to very fine sandstone which weathers to yellow-brown. It contains shellbeds that are most commonly seen as float boulders in streams which drain areas where the sandstone is present.

The main mass of sandstone (Fig. 5.2, Map 3) overlies Tongaporutuan mudstone along a gently dipping contact which is a slight angular unconformity (see cross-section L-L'). At the coast $8 \mathrm{~km}$ to the northeast, Tokomaru Sandstone unconformably overlies Whangai Formation. In the upper Pipiko valley, there are two large masses of sandstone which have broken off the cliffs of the main body and slipped down over the underlying slumped mudstone. A small occurrence in the north overlies Mokoiwi Formation.

The age of this unit, from fossil collections elsewhere in the region, is Kapitean (Messinian) (Moore et al., 1989; Mazengarb et al., 1991). In this area, up to about $100 \mathrm{~m}$ are preserved. 


\subsection{OVERVIEW OF STRUCTURE}

The detailed structure of this area is shown on Map 3 and the accompanying sections $(J-M)$, to be found in the back pocket. All the structures referred to in this section are shown on Fig. 5.2.

Mokoiwi Formation, in the northeast, is complexly deformed. Its predominant strike around Ototo Stream is northeast. Its contact with Whangai Formation was mapped as a single, steeply dipping fault (Ototo Fault) by Pick (1962) and Kenny (1980, 1984a), but is actually a group of faults. Near Puketiti, the contact is a northeast-dipping thrust. Northwest and southeast of Puketiti, this thrust is cut by steeply dipping northeast-sidedown faults referred to herein as the northwestern and southeastern Ototo Faults (Fig. 5.2). The southeastern Ototo Fault has a northeast-striking segment in the lower Ototo valley. In the extreme northwest, Mokoiwi Formation is juxtaposed against HaumurianTeurian rocks along a steep east-northeast striking fault. Beneath Rehuroa trig, a small thrust slice of Whangai Formation overlies Mokoiwi Formation and is in turn overlain by Taitai Sandstone.

Along the southwest margin of the Te Puia inlier, moderately west-southwest dipping, Waitakian-Otaian Ihungia Formation is bounded by a series of steeply dipping, probably normal faults. One of these cuts the northwestern Ototo Fault and the fault between Mokoiwi Formation and the Haumurian-Teurian rocks. North of the Black Hills, northeast-striking normal faults cut northwest-striking ones and juxtapose Altonian Ihungia Formation against older Ihungia and Haumurian-Teurian rocks.

In the southeast of the area, complexly deformed, mainly west-northwest striking Whangai Formation is unconformably overlain by gently south- to east-dipping Tongaporutuan mudstone. This is in turn unconformably overlain by Tokomaru Sandstone. In the extreme east, a moderately southeast-dipping normal fault-the Waikawa Fault-juxtaposes Tongaporutuan mudstone against Mokoiwi and Whangai Formations and cuts the southeastern segment of the Ototo Fault.

\subsection{MOKOIWI FORMATION AND HAUMURIAN-TEURIAN ROCKS}

The structure of the Mokoiwi Formation in this area, like that in the lower Mata River and Ihungia-Puketoro areas, is complex. Bedding in the Ototo catchment is predominantly gently to moderately northwest-dipping and overturned (Map 3, Fig. 5.5). Reversals of dip and younging direction along Ototo Stream indicate isoclinal folding, but no outcrop-scale fold hinges were observed there. The rocks are cut by fractures with a 


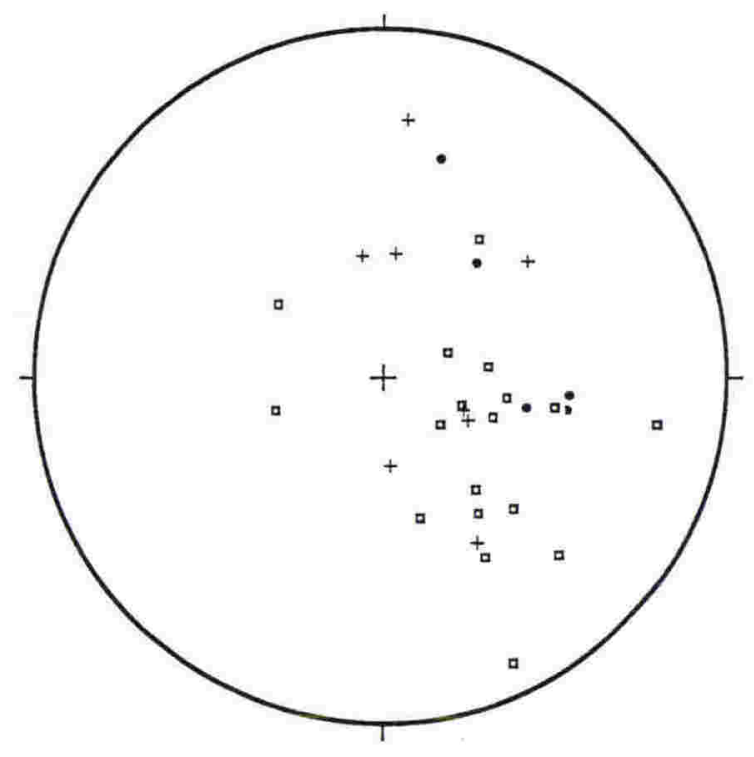

Figure 5.5: Equal-area projection of poles to bedding in Mokoiwi Formation, Ototo catchment. Dots $=$ upright beds, open squares $=$ overturned beds, crosses $=$ younging not determined at outcrop. 
great variety of orientations. Because the structural complexity of the Mokoiwi Formation results partly from a mid-Cretaceous deformation (see sections 3.7, 4.4.1, 4.6.1), its structure in this area was not analysed in detail. That there was an important postCretaceous deformation is shown by the presence of the thrust slice of Whangai Formation within the Mokoiwi Formation around Rehuroa trig (Fig. 5.2, Map 3); this was probably incorporated during thrusting of the Mokoiwi over the Whangai structurally beneath it (see section 5.5.1).

The Haumurian-Teurian rocks are poorly exposed and their structure is not clear. They may, as discussed in section 5.2 .2 , be a faulted amalgam of Tapuwaeroa and Whangai Formation rocks. The boundary between the Haumurian-Teurian rocks and the Mokoiwi Formation is an east-northeast striking fault. Its trace was located reasonably closely by identification of the lithologies in outcrops on either side of it. The relationship of the trace with topography shows that the fault dips steeply. The direction and sense of displacement on this fault are uncertain. However, the strike of the fault is close to the transport direction of the allochthon in the Ihungia-Puketoro area (and in this area-see section 5.9) and by analogy with the steep faults in the Te Matarau catchment (section 4.6.2), it may be a strike-slip transfer fault, coeval with movement on an underlying thrust. The Haumurian-Teurian rocks may originally have been tectonically beneath Mokoiwi Formation, as in the Ihungia valley, or tectonically above it, like the Whangai Formation in the Mata valley (Fig. 4.3, Map 2). Any vertical component on the fault could thus be north-side-up or north-side-down.

\subsection{THE OTOTO FAULTS}

\subsubsection{The Sub-Mokoiwi Thrust}

Although the faults along most of the southern margin of the Mokoiwi Formation are steeply dipping structures, the sequence encountered in the Te Puia-1 exploration well (Laing, 1972b; see also section 1.3.1), $5 \mathrm{~km}$ north-northeast of Puketiti (see Fig. 6.10), shows that the contact at depth is a thrust. Te Puia- 1 penetrated Taitai Sandstone to a depth of $558 \mathrm{ft}$, and Eocene through to Paleocene siltstone, 'bentonitic' mudstone and glauconitic sandstone from $558 \mathrm{ft}$ to its total depth of $6700 \mathrm{ft}$. Mokoiwi Formation is thus structurally above younger rocks, which from the lithologic description and age probably include Whangai Formation. Also, the thickness of Paleocene-Eocene rocks in Te Puia-1 $(1.9 \mathrm{~km})$ is four to five times the typical thickness of the Paleocene-Eocene section elsewhere in the region (see section 2.2). It presumably was thickened by thrusting. 
A short segment of the sub-Mokoiwi thrust crops out south and southeast of Puketiti (Fig. 5.2, Map 3). The irregular fault trace in this area indicates a shallow dip. Due south of Puketiti trig, the gently $\left(\approx 15^{\circ}\right)$ north-sloping topographic surface developed on Whangai Formation-upon which a few small blocks of sheared, highly weathered Taitai Sandstone are scattered-probably approximates the fault plane.

The southeast end of the sub-Mokoiwi thrust is cut by the steeply dipping southeastern Ototo Fault. Immediately south of that fault along the ridge between Puketiti Road and trig LXX, there are concretionary boulders containing Inoceramus fragments. These boulders were probably derived from Mokoiwi Formation, which is thus inferred to underlie the poorly exposed ridge. Southwest of the ridge in the upper Pauariki catchment, highly sheared uppermost Whangai Formation (section 5.2.3) comprises a thick crush zone beneath the sub-Mokoiwi thrust. This crush zone is rich in smectite clay, which in places forms the matrix to a fine breccia with clasts of Whangai Formation siltstone (Fig. 5.6). The smectite content makes this lithology extremely prone to slumping when wet; striations on the major through-going foliation surfaces (Fig. 5.6a) are generally parallel to the local slope. A finer foliation, present on outcropping surfaces of this material, is limited to the outermost part: surfaces sawn into breccia specimens show no foliation and a random arrangement of clasts. The surficial foliation probably results from shrinkage during drying. Because the present structure of this material is largely very recent, no information on the direction and sense of displacement on the sub-Mokoiwi thrust can be obtained from it.

It is not known with certainty whether the sub-Mokoiwi thrust persists across the Mokoiwi/Haumurian-Teurian fault and underlies the Haumurian-Teurian rocks. However, by analogy with the steep faults which cut the limestone/greensand lithotype in the Te Matarau valley (section 4.6.4), the Mokoiwi/Haumurian-Teurian fault is thought likely to be a strike-slip transfer fault between different parts of the same thrust sheet. This fault is therefore shown on cross-section J-J' as terminating at depth into the sub-Mokoiwi thrust, which is thus depicted as underlying both the Mokoiwi Formation and the Haumurian-Teurian rocks.

\subsubsection{Southeastern Ototo Fault}

The southeastern Ototo Fault juxtaposes Mokoiwi Formation and Whangai Formation between Puketiti Road and Te Matai Stream. Its position was closely constrained at its western end, where Taitai Sandstone is present on its north side. The relationship of its trace with topography indicates that it dips moderately to steeply. Its strike seems to vary, however, so its attitude cannot be determined precisely. 

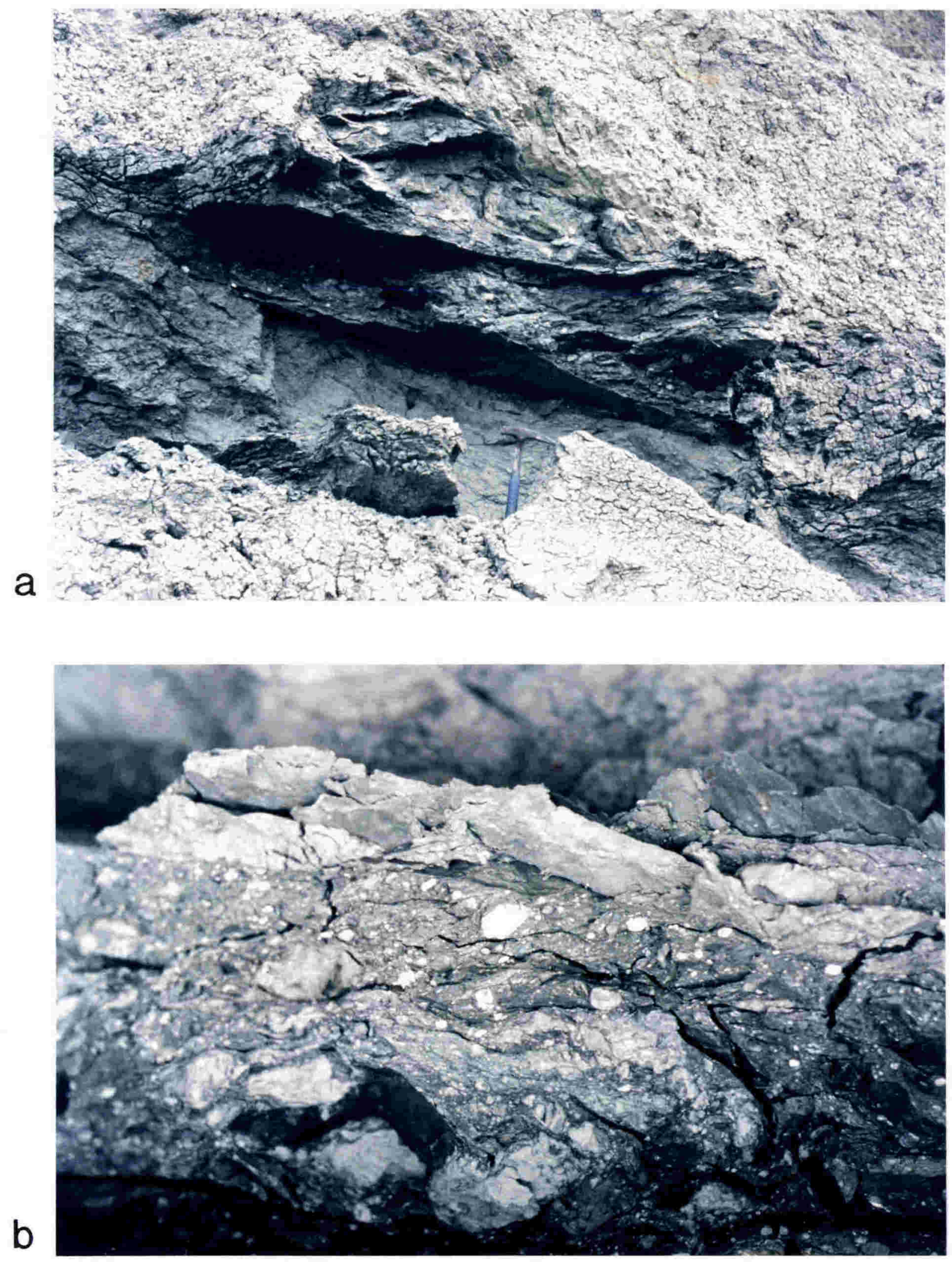

Figure 5.6: General (a) and close-up (b) views of smectite-matrix breccia beneath subMokoiwi thrust in upper Pauariki Stream (Z16 714332). 
Because Mokoiwi Formation tectonically overlies Whangai Formation, the presence of Whangai south of the southeastern Ototo Fault shows that the south side of that fault is the upthrown side. The amount of throw suggested by the difference in elevation between the very gently dipping Tokomaru Sandstone south of the fault around trig LXX and the small Tokomaru Sandstone body immediately north of the fault is approximately $100 \mathrm{~m}$. However, the offset of the sub-Mokoiwi thrust in this area is less than $10 \mathrm{~m}$. The small body of Tokomaru Sandstone may, like the isolated blocks around Pipiko Stream, be a remnant of a slump sheet and thus an inappropriate marker for calculating fault displacement. Throw near the western end of the southeastern Ototo Fault is thus likely to be small, but probably increases eastward.

The generally east-southeast striking southeastern Ototo Fault has a northeast-striking segment which crosses lower Ototo Stream. This segment has an apparent sinistral strikeslip offset, but it does not appear to continue northeast and southwest of where it juxtaposes different lithologies. It is therefore probably coeval with the segments of the southeastern Ototo Fault on either side of it, linking the two rather than cutting them. If so, its slip vector must be parallel to the slip vectors of those segments.

\subsubsection{Northwestern Ototo Fault}

The northwestern Ototo Fault, like the southeastern, cuts the sub-Mokoiwi thrust. Its northeastern side is downthrown. Constraints on the position of its trace indicate it dips moderately to steeply. Its throw is unknown, so the position of the sub-Mokoiwi thrust on secitons $\mathrm{J}-\mathrm{J}^{\prime}$ and $\mathrm{K}-\mathrm{K}^{\prime}$ are speculative. The northwestern end of the northwestern Ototo Fault is cut by a westerly-dipping normal fault which has Thungia Formation in its hangingwall.

Although the dips of both the northwestern and southeastern Ototo Faults can be constrained as moderate or steep, their dip directions are unknown. They could thus be either contractional or extensional. These faults, like the normal fault between the northeast and middle Mata River anticlines (section 3.4.4) and like many late faults around the margins of high-level thrust sheets in the Oman Mountains (e.g., Cawood et al., 1990; Hanna, 1990) may be the result of post-thrusting culmination collapse. If so, they are likely to be extensional. They are therefore shown on cross-sections $\mathrm{K}-\mathrm{K}^{\prime}$ and $\mathrm{M}-\mathrm{M}^{\prime}$ as northeast-dipping. 

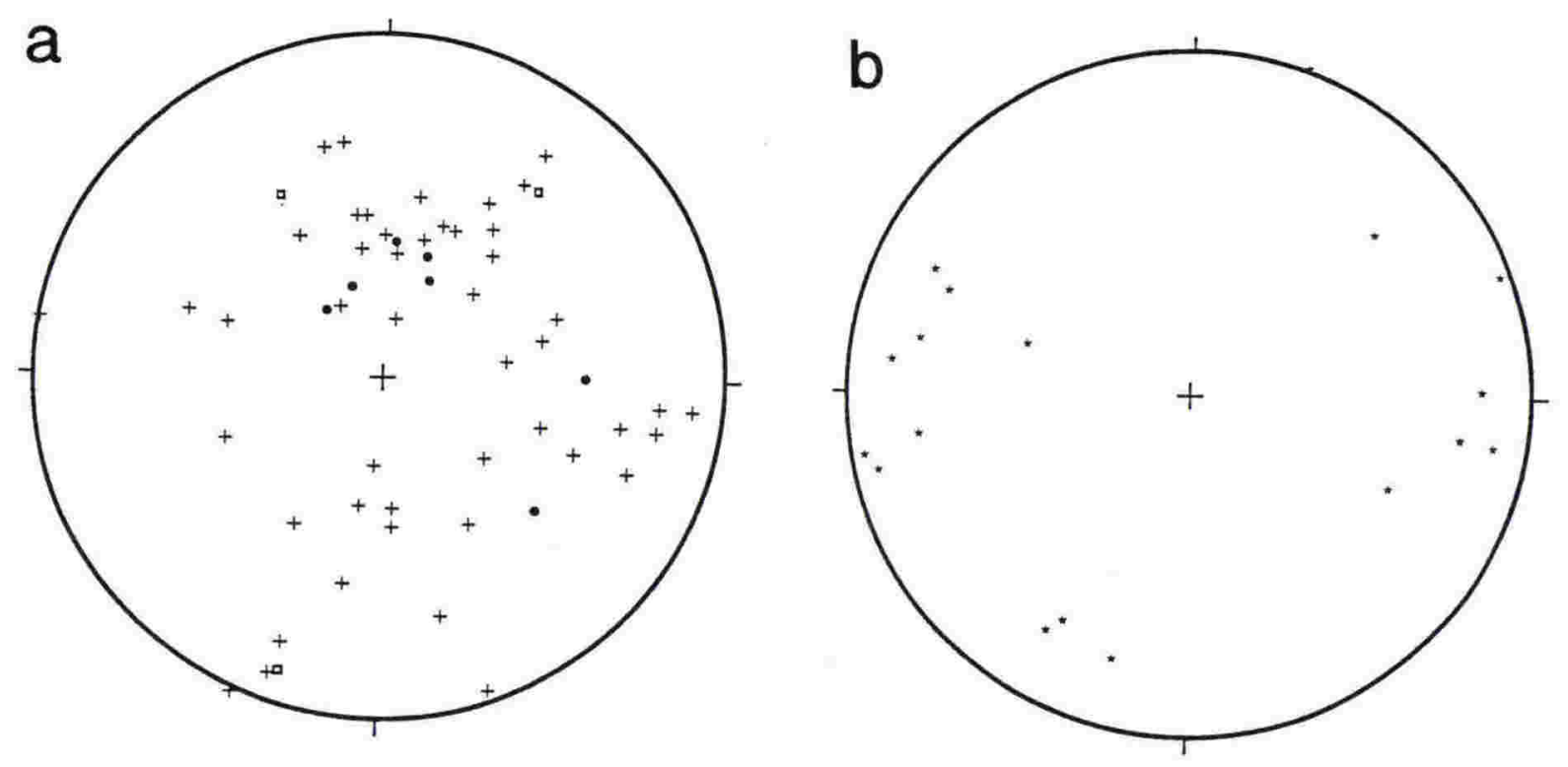

Figure 5.7: Equal-area projections, Whangai Formation, southern margin of Te Puia inlier. a: Poles to bedding; symbols as for Fig. 5.5. b: Minor fold hinges, Ototo and Pipiko valleys. 
The structure of the Whangai Formation on the southern Margin of the Te Puia inlier is complex. This is in contrast to its structure in the Puketoro area, where it lies beneath the Waitahaia Fault. Bedding in the Te Puia Whangai has a great variety of attitudes (Map 3, Fig. 5.7a). In upper Pauariki Stream and to the west, it is generally gently to moderately south to south-southeast dipping. In the Ototo and Pipiko valleys its dips are more variable, but east-west striking beds predominate. Minor fold hinges in this area are predominantly east-west trending (Fig. 5.7b).

Mesoscopic kinematic indicators show that the tectonic transport direction during deformation of the Whangai Formation was toward the west or southwest. Evidence of the direction (but not the sense) of transport can be seen in a tributary of lower Ototo Stream. There, two sets of mesoscopic extension faults cut a lozenge fabric created by extension in the bedding plane (Fig. 5.8a). Intersection of the two fault sets in the plane of the lozenge fabric (Fig. 5.8b) suggests that all three types of structure may have operated synchronously. This suggestion is confirmed by the observation that many of the faults transfer their displacement into the lozenge fabric. For such a system of slip surfaces to be kinematically compatible, slip on each must be perpendicular to the intersection of all three. This indicates west-southwest-east-northeast extension in the plane of the lozenge fabric.

Evidence for the sense of transport is displayed in lower Te Matai Stream, where Whangai Formation is displaced northeast-over-southwest by a set of minor contraction faults (Fig. 5.9a). Associated with these faults is a weakly developed set of pinnate joints. These dip moderately southwest, making an angle of $66^{\circ}$ with the faults. The transport direction indicated by this fabric is assumed to lie in the fault planes at $90^{\circ}$ to their intersection with the pinnates. The sense is assumed to be toward the acute intersections in the footwalls of the faults. These assumptions indicate southwestward transport (Fig. $5.9 \mathrm{~b}$ ). Also present in this area are calcite-filled tension gashes up to $2 \mathrm{~cm}$ thick, which have developed along segments of some bedding planes (Fig. 5.9a). These gashes also dip southwest, but their dips are more variable than the dips of the pinnates because they are controlled by the local orientation of bedding.

\subsection{FAULTS BOUNDING THE IHUNGIA FORMATION}

Along the southwestern margin of the Te Puia inlier, two sets of faults juxtapose Waitakian-Otaian Ihungia Formation against older rocks (Fig. 5.2, Map 3). Although no fault planes were observed, the faults were located reasonably closely-very closely in 


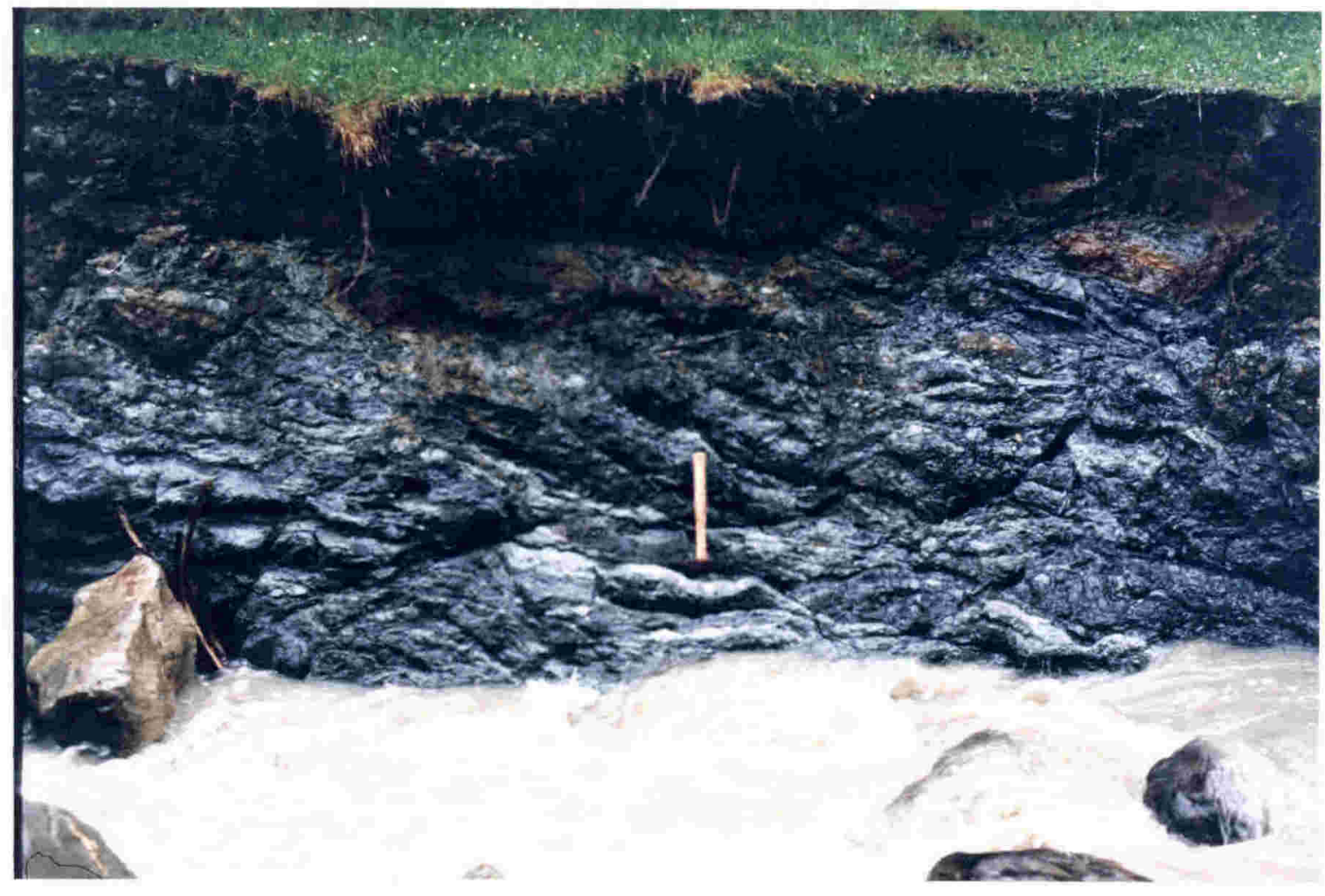

a

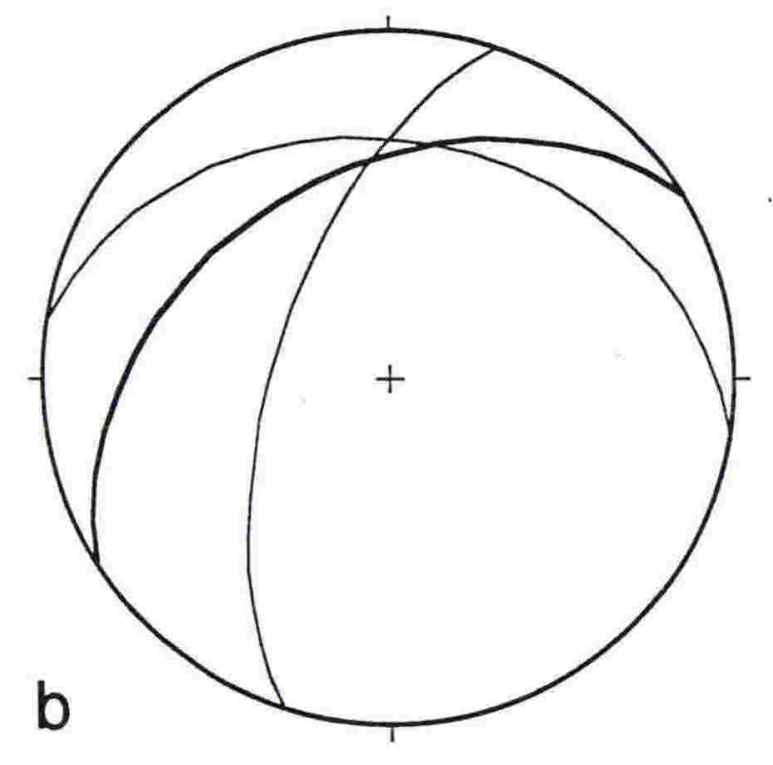

Figure 5.8: Photograph (a) and equal-area projection (b) showing structure of an outcrop of Whangai Formation in a tributary of lower Ototo Stream (Z16 74463333). On b, heavy great circle is general orientation of lozenge fabric, light great circles are general orientations of two sets of extension faults. 


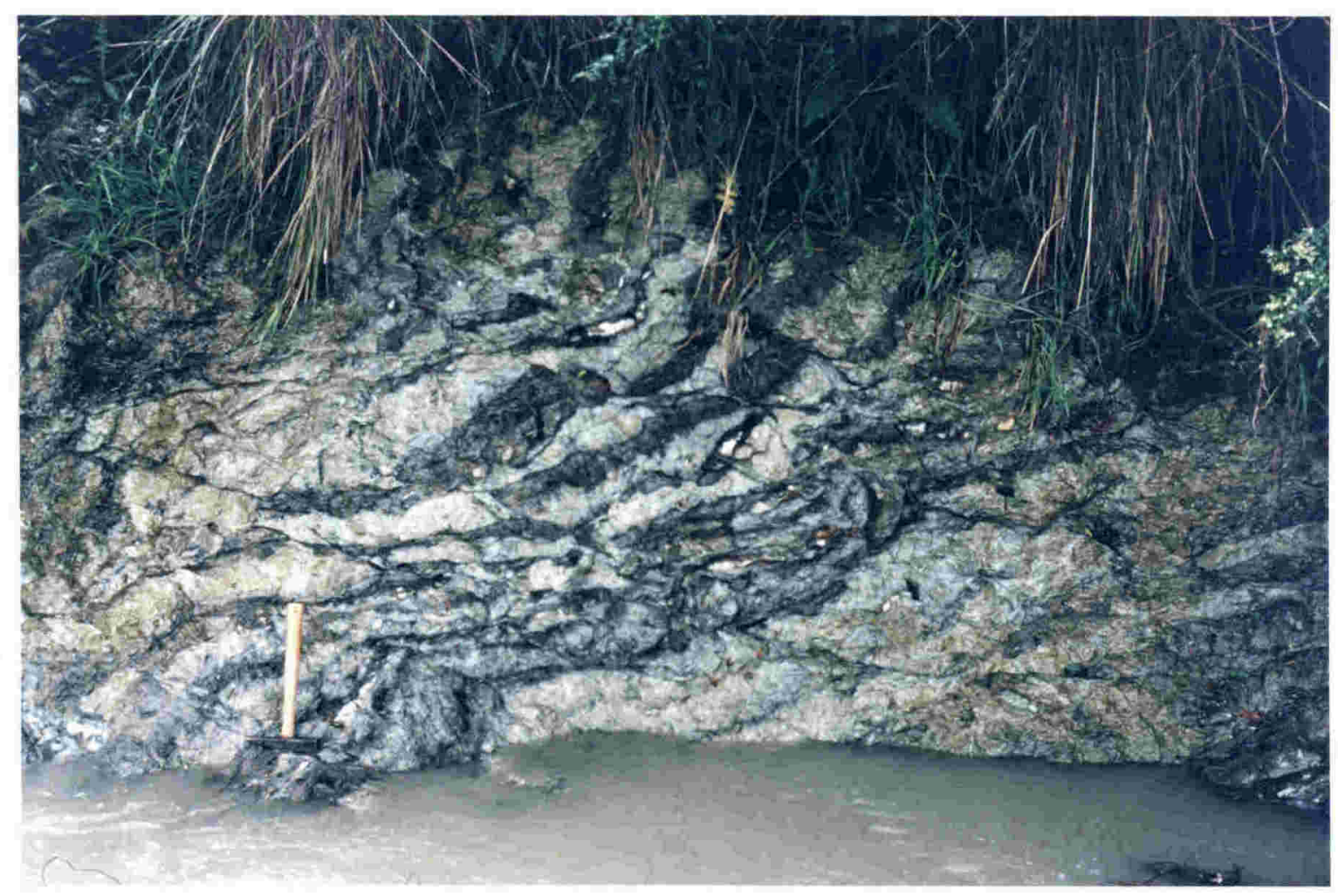

a

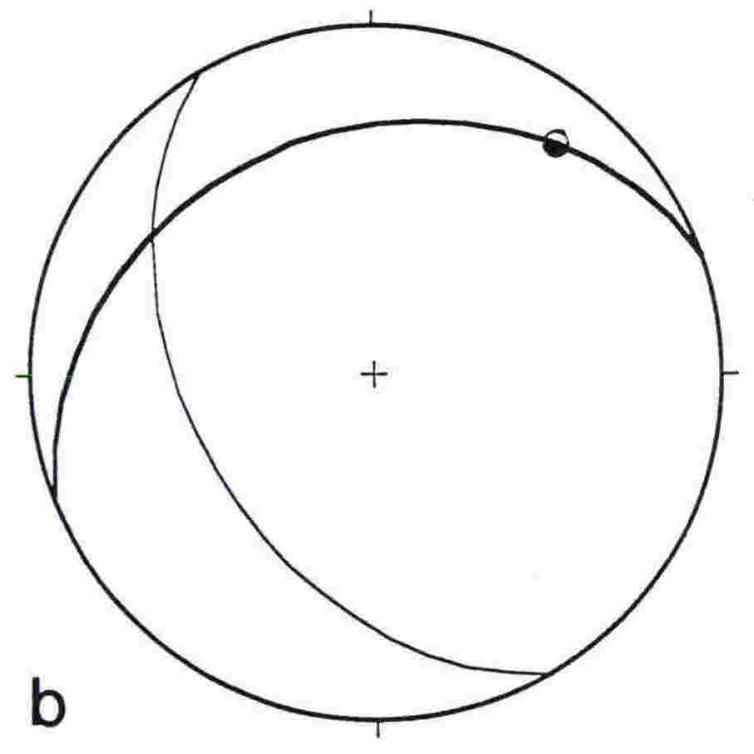

Figure 5.9: Photograph (a), looking northwest, and equal-area projection (b) showing structure of an outcrop of Whangai Formation in lower Te Matai Stream (Z16 74623315). On b, heavy great circle is general orientation of minor contraction faults, light great circle is general orientation of pinnate joints. Split circle indicates direction and sense of motion on contraction faults (open side up, filled side down). 
some cases-by observations of outcrops either side of them and by a change in the nature of the topography across them. These observations and the relations of the fault traces with the contours show that one fault set strikes northwest and the other northnorthwest, and that faults of both sets dip steeply. The dip directions of the faults could not be determined but the faults are suspected to be normal, like almost all the faults cutting Ihungia Formation elsewhere in the region (Moore et al., 1989; Mazengarb et al., 1991), and thus southwest-dipping. One of these faults cuts both the northwestern Ototo Fault and the fault between the Mokoiwi Formation and the Haumurian-Teurian rocks.

At the northwestern end of the Te Puia inlier, Altonian Ihungia Formation is juxtaposed against Haumurian-Teurian rocks along two northeast-striking normal faults linked by a short northwest-striking segment. The trace of the northwesternmost of these faults was precisely located, and its relationship with topography indicates a $60^{\circ}-70^{\circ}$ northwest dip. This fault has another, parallel normal fault immediately northeast of it, entirely within Ihungia Formation (Map 3, Fig. 5.2, Fig. 5.10). These faults cut one of the north-northwest striking faults, and juxtapose Altonian Ihungia Formation against Waitakian-Otaian Ihungia immediately northwest of the Black Hills (section 5.2.5).

The description in the preceding paragraphs of steeply dipping faults between the Ihungia Formation and older rocks contrasts with the maps of Kenny (1980, 1984a), which show older rocks overlying the Ihungia along subhorizontal thrust faults. Kenny initially considered the Whangai and the supposedly Eocene "Wahingamuku sandstone" (see section 5.2.5) to form part of an 'allochthon' thrust over the Ihungia Formation after the Middle Miocene. Subsequently it was recognised that the "Wahingamuku sandstone" was the same age as the Ihungia Formation and was not thrust-bounded (Mazengarb, in Kenny, 1984b; section 5.2.5). There was no revision of the nature of the contact between the Whangai and Ihungia Formations, however.

In support of her hypothesised thrust beneath the Whangai Formation, Kenny (1980) showed a photograph of an outcrop at the south end of the Black Hills in which Whangai Formation was stated to overlie Ihungia Formation along a "... plane ... dipping $10^{\circ} \mathrm{W}$ (caption to her Fig. 6-11, p. 97). Mazengarb et al. (1991), although showing the contacts of the Ihungia Formation with the Te Puia inlier as steeply dipping faults, also show a small patch of Whangai Formation within the Ihungia in this area. Close examination of this outcrop (Fig. 5.11) and its surroundings shows that Whangai is present not in a thrust sheet but as blocks in an extensive colluvium, which underlies a terrace at approximately $570 \mathrm{~m}$ elevation and also forms an apron sloping up to the hills to the northeast and northwest. This colluvium is dominated by Whangai-derived material, but in some places it contains blocks of Taitai Sandstone, red and green mudstone, carbonaceous glauconitic sandstone (probably Haumurian-Teurian) and rare 


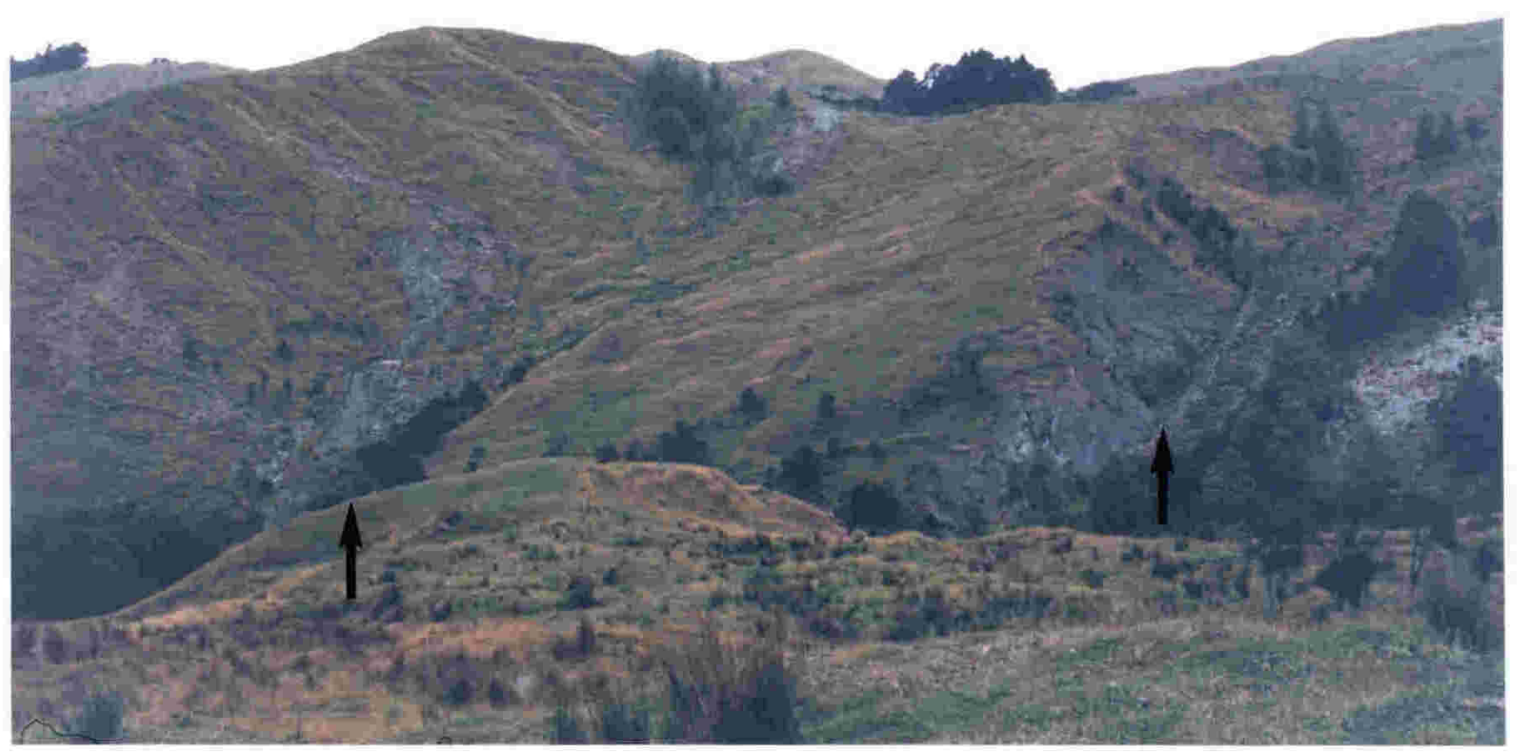

Figure 5.10: View looking northeast from the northwestern end of the Black Hills (Y16 673378) at a pair of northwest-dipping normal faults (arrowed). Fault on right (southeast) juxtaposes Miocene rocks (on the left) against crushed Haumurian-Teurian rocks. 


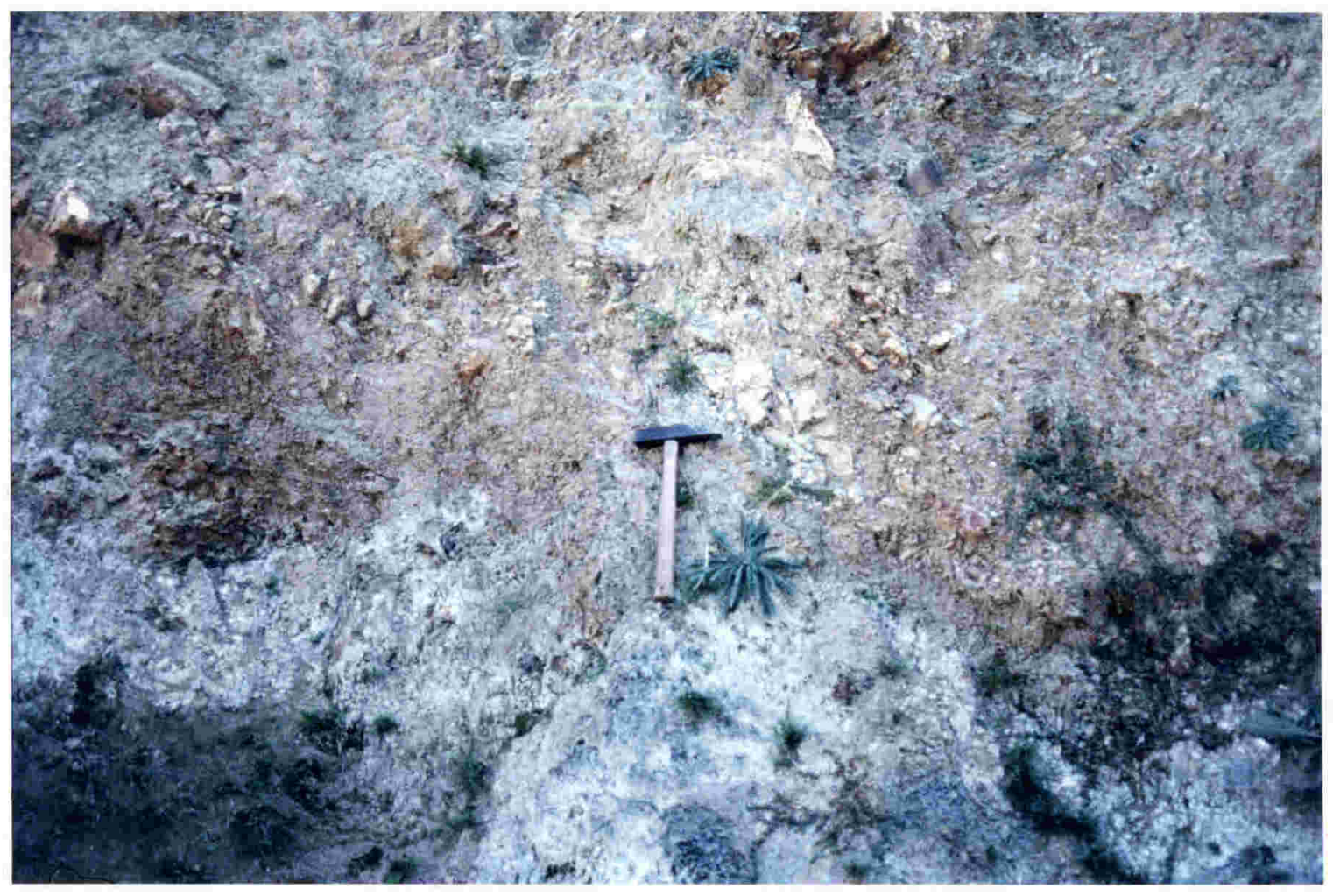

Figure 5.11: Outcrop at Y16 68173584 shown by Kenny (1980, Fig. 6-11) as example of thrust contact of Whangai Formation on Ihungia Formation. Material from about hammer upward is colluvium derived mostly from Whangai Formation. 
calcite-veined sandstone boulders. "Wahingamuku sandstone" is present toward the top of the colluvium, becoming more common as the Black Hills are approached. Blocks of Ihungia Formation are incorporated into the colluvium near its base, so a sharp boundary between colluvium and bedrock is hard to define (Fig. 5.11). The recognition that this 'allochthonous' Whangai is in fact colluvial, coupled with the recognition that the southern margin of the Te Puia inlier is formed by steeply dipping faults, removes the basis for Kenny's assertion that upper Cretaceous and lower Tertiary rocks were thrust over Ihungia Formation.

In addition to their small patch of Whangai Formation around the outcrop in Fig. 5.11, Mazengarb et al. (1991) show a similar patch at the other end of the Black Hills, just to the northwest of the northeast-striking normal fault at Y16 670377. The writer's investigations in that area revealed no Whangai Formation. There are, however, some outcrops in which sandstone very similar to the "Wahingamuku sandstone" is associated with igneous conglomerate. These outcrops presumably lie conformably within the Ihungia Formation.

\subsection{LATE MIOCENE AND LATER STRUCTURES}

\subsubsection{Tongaporutuan Mudstone and Tokomaru Sandstone}

The basal contact of the Tongaporutuan mudstone is gently dipping. East of Pauariki Stream, the intersection of its trace with the contours indicates a southward dip of approximately $5^{\circ}$, and south of Pipiko Stream a south-southeastward dip of about $7^{\circ}$. The elevation difference between the contact in these two areas indicates a component of easterly dip (see cross-section L-L'). Moore et al. (1989) showed this contact as a fault because of the crushing of the Whangai beneath it around Pauariki Stream, but the likelihood that this crushing is due to overthrusting of the nearby Mokoiwi Formation (section 5.5.1) and the very shallow dip of the contact (see cross-section L-L') make it more likely to be an angular unconformity.

Two bedding attitude measurements were made within the formation near trig LXX (Map 3). The significance of these is uncertain. A northwest-dipping outcrop is in an area where there has been considerable slumping, and thus it may not be in place. The $30^{\circ}$ south-southeast dip of the other outcrop-more likely to be in place-is steeper than the dip of the basal unconformity, which suggests short-wavelength folding within the formation. Because of mass movement, poor exposure, and lack of bedding planes in this predominantly massive formation, no other bedding attitudes could be measured. 
The base of the Tokomaru Sandstone is subparallel to the base of the Tongaporutuan mudstone around trig LXX but not to the southeast, where the Tokomaru Sandstone appears horizontal (Map 3, cross-section L-L'). This suggests slight southeastward tilting of the Tongaporutuan before the Tokomaru was deposited. No bedding attitudes could be measured in this massive sandstone. Just south of the area mapped, Moore et al. (1989) show a north-northeast trending syncline. The hinge of this structure projects into Map 3 about $300 \mathrm{~m}$ west of where cross-section L-L' crosses Pipiko Stream. Because the base of the Tongaporutuan east of that point dips east, not west, it appears that the syncline dies out before it reaches the map area.

The base of the Tongaporutuan and the fault between the Ihungia and Whangai Formations converge toward the south-central part of Map 3 and may intersect further south. The nature of the intersection of these two structures, if indeed they do intersect, is not clear from the maps of Pick (1962), Kingma (1965), Laing (1972a), or Moore et al. (1989). If the fault were younger than the unconformity, Tongaporutuan rocks would occur on the downthrown side not far south of the map boundary. If the fault were older, however, the unconformity may or may not cut across it, depending on the relative orientations of the two structures in the south. Foraminifera in a sample collected by M.C. Pick (N.Z. Fossil Record NZMS 1 N80/f6679) from Pauariki Stream, about 1.5 $\mathrm{km}$ south of the map boundary and in the hangingwall of the fault, gave an age of "Pareora to lower Altonian". This suggests that activity on the fault predated the deposition of the Tongaporutuan.

\subsubsection{The Waikawa Fault}

The Waikawa Fault is a major northeast-striking, southeast-dipping normal fault which cuts Tongaporutuan mudstone in the study area and Tokomaru Sandstone where it crosses the coast $4 \mathrm{~km}$ to the northeast. Its trace was located reasonably closely, and its relationship with topography indicates a dip of about $60^{\circ}$. Tongaporutuan mudstone, rather than Tokomaru Sandstone, occurs in the footwall, suggesting that the throw of the fault in this area is less than a few hundred metres. This fault is a member of a regional association of post-Middle Miocene north- to east-striking normal faults, some of which are active (Mazengarb, 1984; Moore et al., 1989; Mazengarb et al., 1991; see also sections 4.7, 4.8.1). A thicker section of Tongaporutuan mudstone is preserved beneath Tokomaru Sandstone on the downthrown side of the fault than on the upthrown, which may indicate that some activity on the fault preceded deposition of the sandstone. 


\subsubsection{History of Deformation, Southern Margin of Te Puia Inlier}

The earliest deformational event recorded in this area is the probably mid-Cretaceous event thought to be responsible for much of the complexity in the Mokoiwi Formation. Examinations of Mokoiwi Formation elsewhere in the region (Kenny, 1986; Gibson, 1987a) have led to the conclusion that its deposition and early deformation took place in a subduction complex.

Following this event, there was a post-Whangai, pre-Ihungia deformation in which Mokoiwi Formation and the Haumurian-Teurian rocks were deformed and juxtaposed, Mokoiwi and Whangai Formations were interleaved (around Rehuroa trig), Mokoiwi Formation and the Haumurian-Teurian rocks were thrust over Whangai Formation, and Whangai Formation was deformed and structurally thickened, presumably by thrusting. Minor structures in the Whangai Formation indicate that transport during its deformation was toward the southwest quarter. They are also presumed to reflect the transport direction on the sub-Mokoiwi thrust, southwesterly transport on which is consistent with interpretation of the Mokoiwi/Haumurian-Teurian fault as a strike-slip transfer fault. If the Mokoiwi Formation is stratigraphically equivalent to the Motuan rocks in the Mangaoporo area (see section 2.2.2.1), there is about $5.5 \mathrm{~km}$ of stratigraphic separation on the sub-Mokoiwi thrust at the southern margin of the Te Puia inlier. However, the Mokoiwi sheet was derived from northeastward of the present position of the Matakaoa Volcanics (sections 6.3.5.3, 6.4.3.3), in which direction the Cretaceous succession is likely to thin. All this deformation is correlated with the early Miocene southwestward thrusting documented in the lower Mata River and Ihungia-Puketoro areas.

The older part of the Ihungia Formation was probably being deposited while this thrusting was going on; the moderately west-southwest dipping beds now in high-angle fault contact with the Te Puia inlier may originally have been in the steep limb of a fault-propagation fold formed by southwestward thrusting at depth. This process was invoked to explain the northwest-trending folds in Ihungia Formation adjacent to the allochthon in the Puketoro area (section 4.8.1). The southeastern and northwestern Ototo Faults-inferred to be extensional structures - probably cut the sub-Mokoiwi thrust after this folding. The northwestern Ototo Fault, in turn, was cut by a fault of the group now forming the eastern boundary of the Ihungia Formation, probably during the same extensional episode. This episode is thought to have occurred soon after the cessation of thrusting, but is only constrained to pre-Tongaporutuan by the observation that the Tongaporutuan rocks do not appear to be cut by the fault around Pauariki Stream (section 5.8.1). The northeast-striking normal faults bounding the Ihungia Formation at 
the northwest end of the Te Puia inlier cut the northwest-striking faults, but their time of activity is otherwise unconstrained. They may have formed at the same time as the Waikawa Fault and other faults of the regional, northeast-striking association.

Deposition of the Tongaporutuan may have been accompanied or immediately followed by movement on the Waikawa Fault. This is suggested by the different thicknesses of Tongaporutuan preserved on either side of the fault (cross-section L- $\mathrm{L}^{\prime}$ ). Some eastward tilting also appears to have taken place before the Tongaporutuan was eroded and the Tokomaru Sandstone was deposited. Following sandstone deposition, there was folding about a northeast trend (Moore et al., 1989) and normal faulting on the northeast-striking Waikawa Fault. Throughout the region, north- to east-striking normal faults cut northeast-trending folds (Moore et al., 1989). Normal faulting and associated northwest-southeast extension are presently active (Walcott, 1978, 1987; Mazengarb, 1984; Moore et al., 1989).

\subsection{2 'Allochthonous' and 'Autochthonous' Rocks}

In the lower Mata River and Ihungia-Puketoro areas, the 'autochthon' was defined as the material beneath the Aorangiwai, Waitahaia and Mangarakeke Faults. The autochthon thus includes the Waitahaia, Karekare and Whangai Formations west of the Western Ihungia Fault and the Waitahaia and Haumurian-Teurian formations east of it. By this definition the Mokoiwi Formation and (probably) the Haumurian-Teurian rocks of the Te Puia inlier are allochthonous, as they structurally overlie Whangai Formation; the subMokoiwi thrust, because of its similar stratigraphic separation and similar inferred horizontal displacement, is probably an equivalent structure to the Aorangiwai and Waitahaia Faults. However, the Whangai Formation beneath the sub-Mokoiwi thrust is also likely to be allochthonous because in contrast to the autochthonous Whangai of the Puketoro area, it is deformed and has been structurally thickened, presumably by southwest-directed thrusting. The base of the 'allochthon' beneath the Te Puia inlier therefore lies some distance beneath the sub-Mokoiwi thrust. It must cut down-section southeastward from the Mangarakeke Fault to a lower structural level.

Because the Ihungia Formation is in low-angle fault contact with Mokoiwi Formation on the southern slopes of the Ihungia valley (northwest of Map 3), Kenny (1980, 1984a) referred to it as a second 'allochthon'. This low-angle fault is a continuation of the Whakoau Fault (section 4.7); it is a normal fault whose hangingwall moved southeastward, probably on the order of a few hundred metres, after the Middle Miocene (Kenny, 1980, 1984a, 1986; sections 4.7, 4.8.1). Its movement is likely to have been synchronous with movement of the faults at the northwest end of the Te Puia inlier. Whether it terminates in those faults or continues southeast of them and beneath the Te 
Puia inlier is unknown. The Ihungia Formation may certainly be regarded as 'allochthonous' as it is fault-bounded. However, its displacement is minor when compared to that of the Mokoiwi Formation and associated rocks.

Kenny (1980, 1984a) referred to the "Wahingamuku sandstone" and the Whangai Formation as part of a third 'allochthon' which has been thrust over the Ihungia Formation. It has been shown, however, that the aforementioned rocks and the Ihungia Formation are not in fact in thrust contact (sections 5.2.5, 5.7).

\subsubsection{Conclusions}

1) Along the southern margin of the Te Puia inlier, there are rocks of widely differing ages whose structural relationships have been in doubt. Seven lithologic units are distinguished there. These are: Mokoiwi Formation (Urutawan-Motuan/Albian); sandstone, mudstone and grit mapped as "Haumurian-Teurian" (MaastrichtianPaleocene), but which may be a combination of Whangai and Tikihore or Tapuwaeroa Formations; Whangai Formation (Maastrichtian-Paleocene); mélange with a matrix of Eocene smectite mudstone; Ihungia Formation, including the Wahingamuku sandstone (Waitakian-Altonian/Aquitanian-Burdigalian); Tongaporutuan (Tortonian) mudstone; and Tokomaru Sandstone (Kapitean/Messinian).

2) The Te Puia inlier comprises Mokoiwi Formation in the southeast, HaumurianTeurian rocks in the northwest, and Whangai Formation in the south. Also, a small slice of Whangai Formation is present within the Mokoiwi Formation in the east. Mokoiwi Formation and the Haumurian-Teurian rocks are separated by a steep eastnortheast striking fault which is probably a strike-slip transfer fault. The sequence encountered in the Te Puia-1 exploration well $5 \mathrm{~km}$ to the north shows that the Mokoiwi Formation structurally overlies the Whangai Formation. A segment of the outcropping boundary of these two formations is a northeast-dipping thrust, but this thrust is cut by the northwestern and southeastern Ototo Faults, steep, north-sidedown faults which define most of the length of the boundary. These faults are probably extensional and related to post-thrusting culmination collapse. The structure of the Whangai Formation is complex, and the sequence in the Te Puia- 1 well shows that it has been structurally thickened. Minor structures indicate it has been thrust southwestward, probably together with the structurally overlying Mokoiwi Formation.

3) Ihungia Formation is juxtaposed against the rocks of the Te Puia inlier along a series of northwest- to north-northwest striking, southwest-dipping normal faults in the southwest, and along northeast-striking, northwest-dipping normal faults-which cut the northwest-striking faults-in the northwest. In the southwest, the Ihungia 
Formation dips moderately southwest and includes within it a lens of sandstone (Wahingamuku sandstone) containing reworked Eocene palynomorphs. Blocks of Whangai Formation are present in an extensisve colluvium which overlies Ihungia Formation there. In the northwest, two diapiric bodies of smectite-matrix mélange intrude Thungia Formation, which overlies Mokoiwi Formation and mélange along the low-angle normal Whakoau Fault. A small area of Ihungia Formation also exists in the east, but its relations with other units are unknown.

4) Whangai Formation in the south of the area is unconformably overlain by gently south- to east-dipping Tongaporutuan mudstone, which is in turn unconformably overlain by gently southeast-dipping Tokomaru Sandstone. The base of the Tongaporutuan approaches the northwest-striking fault bounding the Ihungia Formation toward the southern boundary of the map. Further south, the lack of Tongaporutuan rocks in the hangingwall of the fault indicates that its activity was pre-Tongaporutuan. Tongaporutuan mudstone in the east is juxtaposed against Whangai and Mokoiwi Formations along the Waikawa Fault, a major southeastdipping normal fault with a throw of a few hundred metres. A thicker section of Tongaporutuan is preserved beneath Tokomaru Sandstone in the hangingwall, suggesting that some fault activity predated Tokomaru deposition.

5) The sequence of tectonic events along the southern margin of the Te Puia inlier was as follows: deformation and juxtaposition of Mokoiwi Formation and HaumurianTeurian rocks, thrusting of these rocks over Whangai Formation and incorporation of a slice of Whangai into the Mokoiwi, and southwestward thrusting and deformation of the Whangai, all probably in the Early Miocene; deposition of the oldest Ihungia Formation during this thrusting, and possibly also its deformation in the steep limb of a fault-propagation fold; after thrusting, offset of the sub-Mokoiwi thrust and downthrow of the Ihungia Formation along extensional faults; deposition of the Tongaporutuan, together with some movement on the Waikawa Fault and probably also the normal faults at the northwest end of the Te Puia inlier; some eastward tilting of the Tongaporutuan before deformation of the Tokomaru Sandstone; and further motion on the Waikawa Fault and probably also the normal faults in the northwest.

6) The sub-Mokoiwi thrust is probably an equivalent structure to the Aorangiwai and Waitahaia Faults. However, the Whangai Formation beneath it, in contrast to the rocks beneath those other faults, has been thrust southwestward. The sub-Mokoiwi Whangai in this area is thus part of the East Coast Allochthon. Wahingamuku sandstone and Whangai Formation were not thrust over Ihungia Formation after the Middle Miocene; rather, Wahingamuku sandstone lies stratigraphically within Thungia 


\section{Chapter 6}

\section{Regional Structure and Kinematics}

\section{$6.1 \quad$ INTRODUCTION}

In this chapter, recent intermediate- and small-scale geological maps of parts of Raukumara Peninsula are examined in the light of the information presented in Chapters 2-5 in order to elucidate the structure and kinematic evolution of the Early Miocene orogen throughout the region. For the purposes of this examination it is convenient to divide the East Coast Allochthon into three zones of contrasting stratigraphy and structure: southern, central and northern (Fig. 6.1).

The southern zone comprises the imbricated late Paleocene to Early Miocene rocks between the frontal thrust and a thrust about $18 \mathrm{~km}$ to the northeast which is the first to carry Whangai Formation in its hangingwall. It is bounded beneath and to the northwest by a gently-dipping sole thrust and above and to the southeast by faults and an unconformity beneath late Early Miocene strata. It corresponds to the southwestern stratigraphic sub-province (of the allochthon) defined in Chapter 2 (Fig. 2.1). The central zone consists of the group of thrust sheets and slices bounded to the southwest by the sub-Whangai thrust at the northeastern limit of the southern zone, to the northeast by the western Ihungia Fault, beneath and to the northwest by the Te Rata/Waitahaia thrust zone (Moore, 1988a; see Fig. 6.1), and above and to the southeast by the lower structural limit of the overlying Neogene rocks. It has an underlying 'autochthon' which was only mildly affected by Early Miocene deformation. Northern zone is the term used for the pre-Miocene rocks which underlie Raukumara Peninsula northeast of the western Ihungia and Aorangiwai/Hukanui Faults and their northwestward and southeastward continuations. In contrast to the southern and central zones, no lower boundary to the northern zone can be defined; it appears that all the rocks in the north were affected by Early Miocene thrusting.

In the following sections the structure, the sequence and timing of thrusting, and the amounts of thrust transport in each zone and its surroundings are described and discussed zone by zone. The discussions are based largely on a number of new crosssections, constructed from the available geological maps in directions close to the local thrust transport directions. 


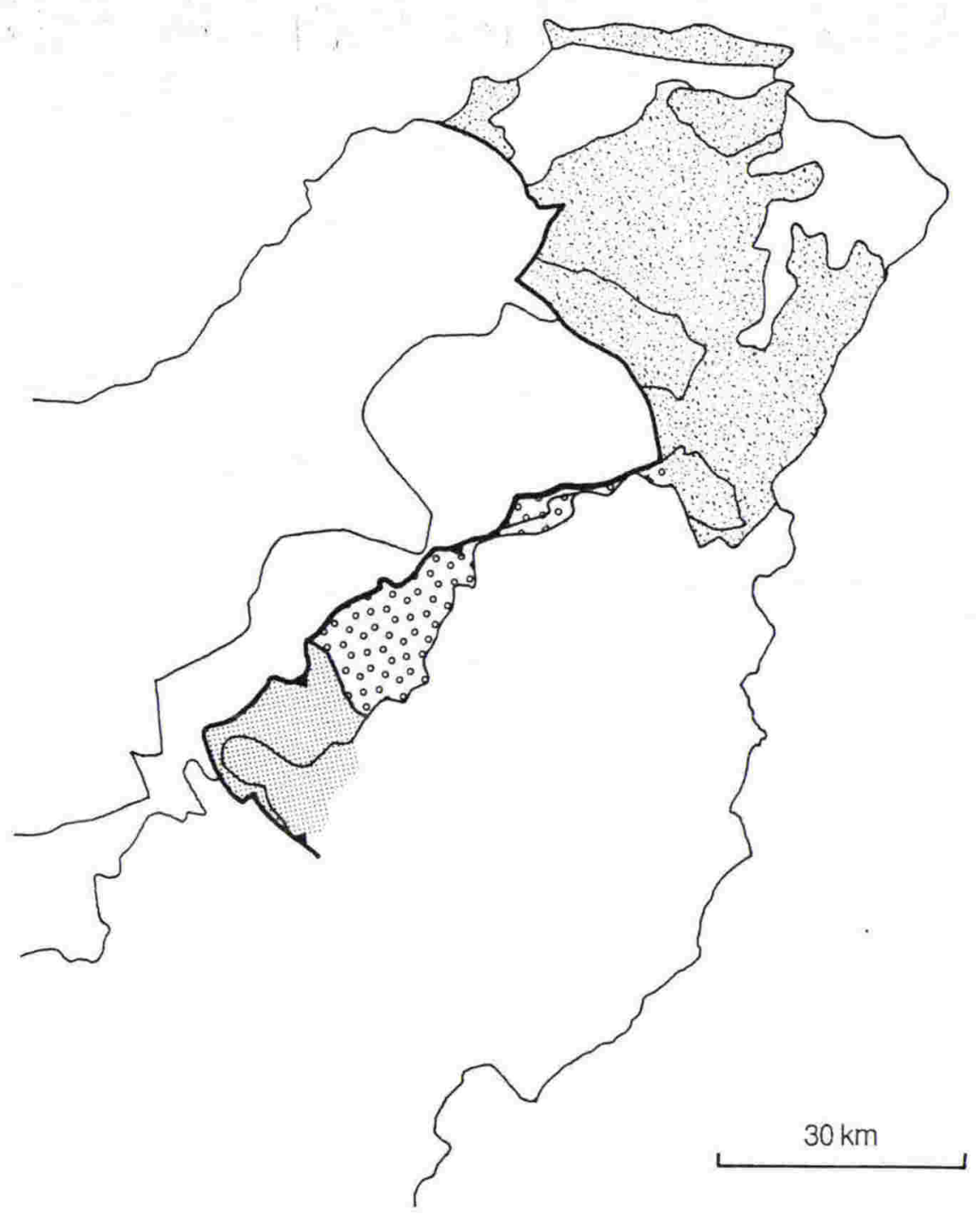

Figure 6.1: Outline geological map of Raukumara Peninsula showing distribution of southern (stipple), central (circles) and northern (shingle pattern) zones of the East Coast Allochthon. 


\subsection{THE SOUTHERN ZONE}

\section{$\underline{\text { 6.2.1 Introduction }}$}

The southern zone constitutes the thrust front region of the East Coast Allochthon. Thrust fronts are boundaries between the deformed rocks of thrust belts and their adjacent, undeformed forelands. Although factors such as sedimentary facies changes and foreland structure can influence their deformational style (e.g., Morley, 1986), thrust fronts are nonetheless important in the study of thrust belt kinematics and mechanics because they represent 'snapshots' of deformation in progress; processes evident at and close to a thrust front probably also operated further back in the belt-where evidence of them may not now be obvious - at other times. Thrust fronts therefore offer the opportunity to determine the mechanisms by which deformation proceeds. Those mechanisms may then provide insights into the tectonic processes originally responsible for the deformation. Also, preservation of syn- and postorogenic sediments adjacent to emergent thrust fronts-those which cut up to the synorogenic surface-commonly allows the chronology and rate of thrust belt deformation to be determined.

The southern zone of the East Coast Allochthon has been examined by Stoneley (1968) and Mazengarb (1982). Mazengarb's map covers a small area around the frontal thrust, whereas Stoneley's map covers approximately 400 square miles of the thrust belt and its immediate surroundings at a scale of 1:63,360. Most of our present knowledge of the frontal portion of the East Coast Allochthon is thus from Stoneley (1968). Great advances in the knowledge of thrust belt geometry and kinematics (e.g., Bally et al., 1966; Royse et al., 1975; Price, 1981; Boyer and Elliott, 1982; and many others) and in techniques of cross-section construction (Dahlstrom, 1969; Hossack, 1979; Woodward et al., 1989) since Stoneley's work mean that his interpretations are now dated. It is therefore worth re-examining his map in the light of these new ideas. In the following, Stoneley's (1968) map is used to determine the style, sequence and chronology of the deformation in the frontal part of the East Coast Allochthon, and a partially restorable cross-section, constructed to extend the interpretation into the third dimension and to constrain the amount and rate of deformation, is presented.

\subsubsection{Map Analysis}

\subsubsection{Structural Geometry and Thrust Transport Direction}

Stoneley's (1968) map (reproduced herein at 1:100,000 minus bedding orientation measurements as Fig. 6.2) shows a series of northwest-striking thrust sheets composed of Paleocene to Early Miocene rocks. The thrusts between these sheets cut up-section toward 
the southwest. The sheets have an overall southeastward pitch; their bases-gently dipping faults-are exposed in the northwest, and they disappear beneath unconformably overlying Miocene strata in the southeast. Stoneley subdivided the stratigraphy in the sheets into most of the component stages of the New Zealand lower and middle Tertiary on the basis of the foraminiferal assemblages present. Because of advances in New Zealand foraminiferal biostratigraphy since the early 1960's, many of Stoneley's stage identifications are likely to be in error. Some are known to be so; for example, the Runangan (Eocene) limestone he identified in thrust sheets XI-XIII (see Fig. 6.2) is now known to be Oligocene, equivalent to the Whaingaroan limestone in the lower sheets (C. Mazengarb, pers. comm., 1988). Because Stoneley's map is the only one available, however, his stratigraphic subdivisions are used, with caution, in the following analysis.

In the northwest, the thrust sheets overlie Stoneley's "Haumurian" (now mapped as the Haumurian-Teurian Whangai Formation; Moore, 1988b, 1989). On his cross-sections, Stoneley (1968, Fig. 4) showed their bases as a number of discrete faults which are folded about a northwest trend to the same degree as the overlying strata. Together, the faults form a strongly undulating surface, consistent with Stoneley's interpretation that the thrust sheets moved independently or in groups and that the more southwesterly sheets were folded by the motion of those behind (see section 6.2.2.2). Structure contours derived from 1:63,360 topographic maps of the area (published in 1973 and 1974), however, suggest that the surface defined by the faults is more nearly planar, with a consistent northeast strike and a southeast dip of $7^{\circ}-14^{\circ}$ (increasing southeastward) in the northeast and $\approx 6^{\circ}$ in the southwest (Fig. 6.3). The only exception is around the northwestern ends of sheets III and IV, which are separated by an anticline in the underlying autochthon. It is thus likely that rather than being independent bodies, the thrust sheets are all underlain by a single, gently southeast-dipping sole thrust off which steeper, northwest-striking imbricates splay and cause or accomodate the folding of the overlying rocks. This conclusion is supported by structure contours on the base of the underlying Haumurian, which show that surface to be very gently southeast-dipping; it is folded about a northwest trend only in the extreme northeast (Fig. 6.3) and the extreme southwest (Fig. 6.2).

The autochthon beneath the sole thrust and southwest of the thrust front comprises folded Clarence and Raukumara beds overlain unconformably by gently southeastdipping Haumurian strata (Whangai Formation), which is in turn disconformably overlain by Waipawan mudstone. Whaingaroan and Waitakian to Otaian strata (Stoneley did not separate the Duntroonian from the lower Waitakian) overlie the Waipawan and the Haumurian above another unconformity. The sole thrust, which puts Whaingaroan or Waipawan over Haumurian along much of its length, is probably a result of detachment along the sub-Waipawan and sub-Whaingaroan surfaces. All units of the allochthon are 


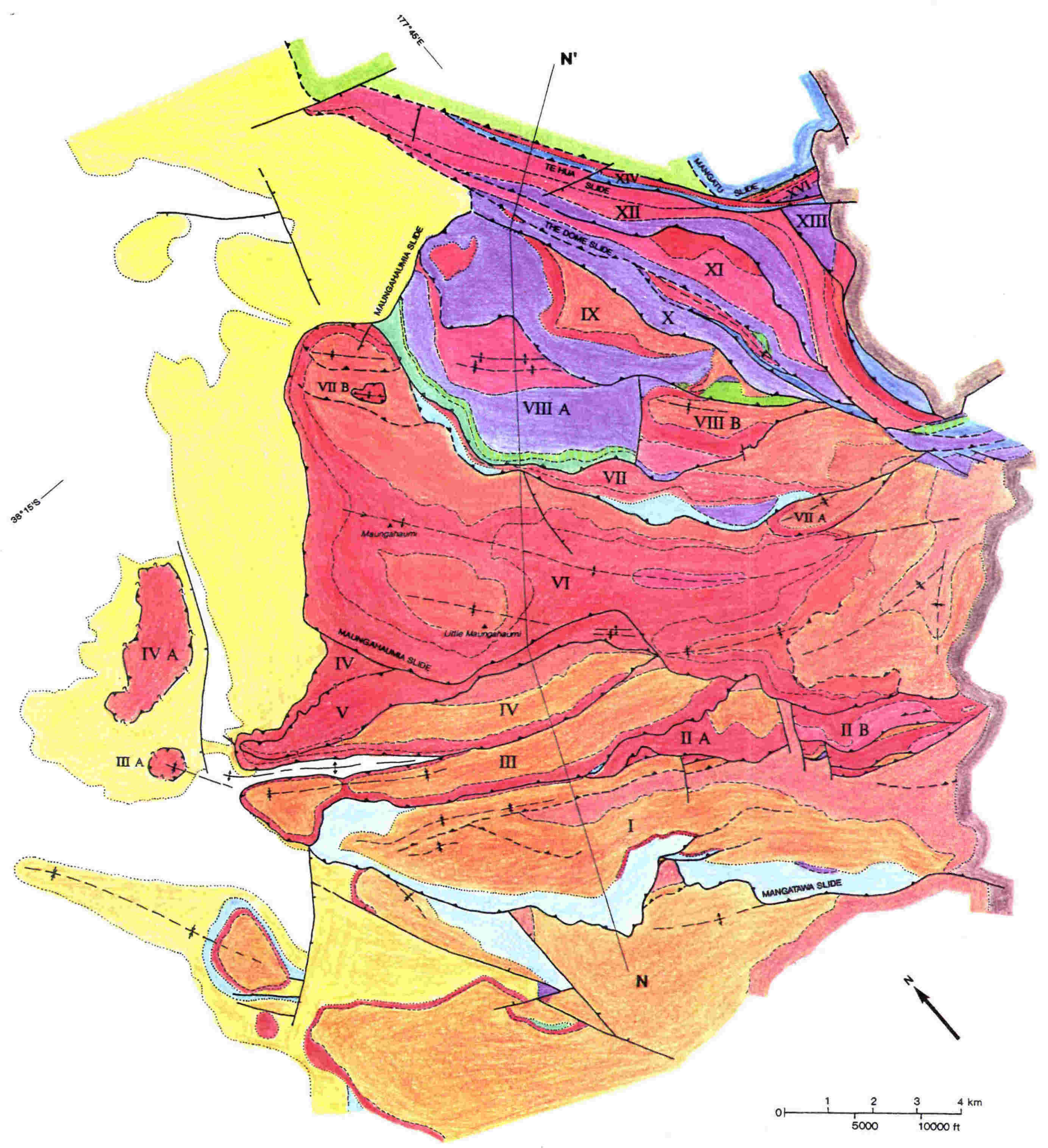

$\square$ Otaian

3 "Awamoan"-Altonian

$\square$ Waitakian (undifferentiated)

$\square$ Upper Waitakian

$\square$ Lower Waitakian (incl. Duntroonian) $\square$ Mangaorapan

Whaingaroan

$\square$ Runangan (?incl. Kaiatan)

$\square$ Waipawan

Upper Teurian-Waipawan

$\square$ Bortonian

$\square$ Porangan

$\square$ Heretaungan

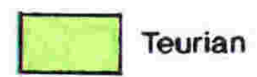

(bentonites)

Normal fault

$\square$ Teurian

$Y_{\text {Thrust fault }}$

Haumurian

$x^{7}$ Plunging anticline

$x^{\prime}$ Plunging syncline

Stage or formation boundary

Unconformity

IV Thrust sheet numbers

$\mathbf{N}^{\mathbf{N}^{\prime}}$ Section line

Figure 6.2: Geological map of the southern zone of the East Coast Allochthon, after Stoneley (1968). See Fig. 6.1 for location. N-N' is line of cross-section (Fig. 6.6). Arrow points to grid north (NZMS 1 grid). 
affected by steep faults which strike predominantly northwest and northeast. Two of these appear to be overlain by the frontal thrust. In the southwest, autochthonous units are gently folded about a northwest trend. Bedding attitudes in the Whangai close beneath the sole thrust define (albeit poorly) a gently southeast-plunging axis of gentle folding (Fig. 6.4a).

Above the sole thrust, Stoneley (1968) distinguished five groups of thrust sheets on the basis of their internal stratigraphy, structural strike, and the apparent cross-cutting relationships between their underlying faults, which he considered to show the relative timing of their movements. These groups were: sheets I-V, sheets VI-X, sheets XI-XIII, sheets XIV-XVI, and, northwest of the boundary of the southern zone, the "Higher Thrust Masses". Sheets I-V (see Fig. 6.2) carry Waipawan to Otaian strata, but mostly comprise Whaingaroan and younger rocks. Whaingaroan rocks overlie the sole thrust in sheets III and IV. The Waipawan strata immediately above the sub-I fault, the "Mangatawa Slide" (the frontal thrust of the East Coast Allochthon) were mapped as unconformably overlain by Whaingaroan and Waitakian beds, but C. Mazengarb (pers. comm., 1990) now considers these overlying beds to be entirely Waitakian (see column 15, Fig. 2.3). The thrusts appear to be sub-parallel to lithologic contacts in their hangingwalls, although they do cut across section along strike at a few places. Thrust sheets I, III and IV are synclinal, with moderately to steeply dipping northeastern limbs. Bedding attitudes in sheets $\mathrm{I}-\mathrm{V}$ define a sub-cylindrical fold axis plunging very gently east-southeast (Fig. 6.4b). This axis is perpendicular to a group of steep faultspresumably strike-slip transfer faults - which cut some of the thrusts at high angles. The orientations of the fold axis and the faults both suggest a thrust transport direction toward the south-southwest $\left(\approx 204^{\circ}\right)$.

Thrust sheets VI-X are soled by a fault referred to by Stoneley (1968) as the "Maungahaumia Slide" (Fig. 6.2). These sheets carry Teurian to Waitakian rocks, and a small amount of Otaian in the extreme southeast. In contrast to sheets I-V, a thick Eocene succession is present, as is a strong intra-Waitakian angular unconformity which shows that these thrusts were emergent and constrains their time of movement (see section 6.2.2.2). The unconformity shown at the base of the Whaingaroan in sheet IX is also strongly angular. The lower Waitakian and much of the Whaingaroan are limestone and marl, in contrast to the sandstone in sheets I-V. At its northwestern limit, the Maungahaumia Slide is shown cutting down-section southwestward from Runangan to Mangaorapan-Heretaungan rocks in sheet VIII, and down-section in the Whaingaroan in sheet VI. Most of the imbricate thrusts again appear to be sub-parallel to the bedding in their hangingwalls, although some cut across a considerable section along strike at places. Southwest-verging asymmetric synclines are present in the footwalls of some thrusts. A major anticline, with a complementary syncline to the southwest, is present in sheet VI. 


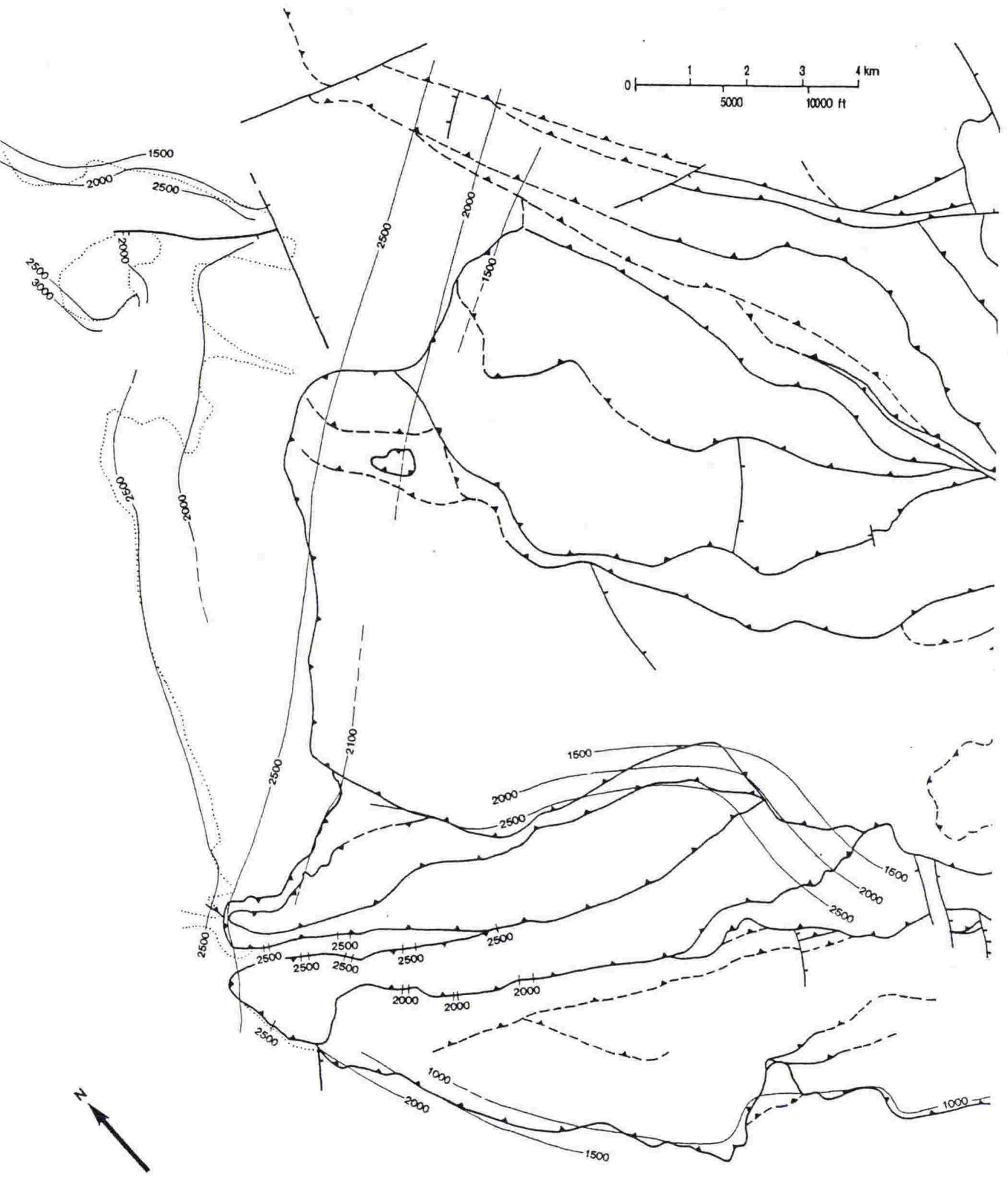

Figure 6.3: Map showing structure contours and and spot elevations (derived from NZMS 1 sheets N79 and N88, 1:63,360) on base of autochthonous "Haumurian" (Whangai Formation) and on some thrusts in the southern zone of the East Coast Allochthon. Values are feet above sea-level. 
Stoneley (1968, Fig. 4, section B-B"') inferred that the anticline reflected a fold in the underlying Maungahaumia Slide. A smaller anticline/syncline pair is present in sheet VIIIA. The folds trend north-northwest in the northwest, but swing more westerly in the extreme southeast (Fig. 6.4c and d). The strike of the northwestern girdle $\left(219^{\circ}\right)$ is subparallel to a steep fault which divides thrust sheet VIII into two halves with different structural elevations. The transport direction of these sheets thus appears to have been slightly more westerly than that of sheets I-V.

Thrust sheets XI-XIII overlie a fault mapped by Stoneley (1968) as "The Dome Slide" (Fig. 6.2). On his map, this fault appears to truncate the northern end of the Maungahaumia Slide. Stoneley considered it to do so, and this was his reason for not including thrust sheet $X$ in the group of similarly steeply dipping, north-northwest striking sheets (XI-XIII) above it. However, the area where the Dome and Maungahaumia Slides meet is a valley; structure contours across it (Fig. 6.3) suggest that the V-shaped outcrop pattern was produced by erosion of a single, gently southeast-dipping fault rather than by the intersection of two differently oriented ones. The Maungahaumia Slide beneath thrust sheet $X$ therefore continues northward beneath sheets XI and XII. Sheets XI-XIII carry Eocene to Whaingaroan rocks, including the limestone that Stoneley (1968) mapped as Runangan but which is now known to be Whaingaroan (see earlier). They strike south-southeast except in the southeast, where sheets XII and XIII swing around to the south-southwest. The dips of the faults and the beds are steep to vertical on the ridges but moderately northeastward at stream level, and gentle in the extreme northwest immediately above the sole thrust. These thrusts thus have listric geometries. The general south-southeast strike of the greater parts of these sheets suggests a west-southwesterly transport direction.

The remaining two thrust sheet groups distinguished by Stoneley (1968) were sheets XIV-XVI above the "Te Hua Slide" and the "Higher Thrust Masses" above the "Mangatu Slide". Sheet XIV was separated from those below because the it appears to cut across their southeast ends. Sheet XIV carries steeply dipping Teurian-Waipawan to Waitakian rocks. Sheets higher than XIV and the southeastern sliver of XVI (marked incorrectly on Stoneley's map as XIV, but clearly described on his p. 145 as XVI) are in the central zone of the East Coast Allochthon. They are not shown on Fig. 6.2 because Stoneley was not confident about their structure. On his map, the rocks above XIV are dominated by "Teurian" (Whangai Formation according to Moore et al., 1989), although slivers of material as young as Bortonian are also shown. A steep west- northwest striking fault is shown cutting the sole thrust and sheet XII (Fig. 6.2). The Mangatu Slide is shown cutting down onto thrust sheet XIV in the southeast. East of Fig. 6.2, Stoneley (1968) mapped continuations of the thrust sheets from VII to the Higher Thrust Masses in the "Waitangi Structure", an internally complex, probably partly diapiric, fault-bounded inlier 

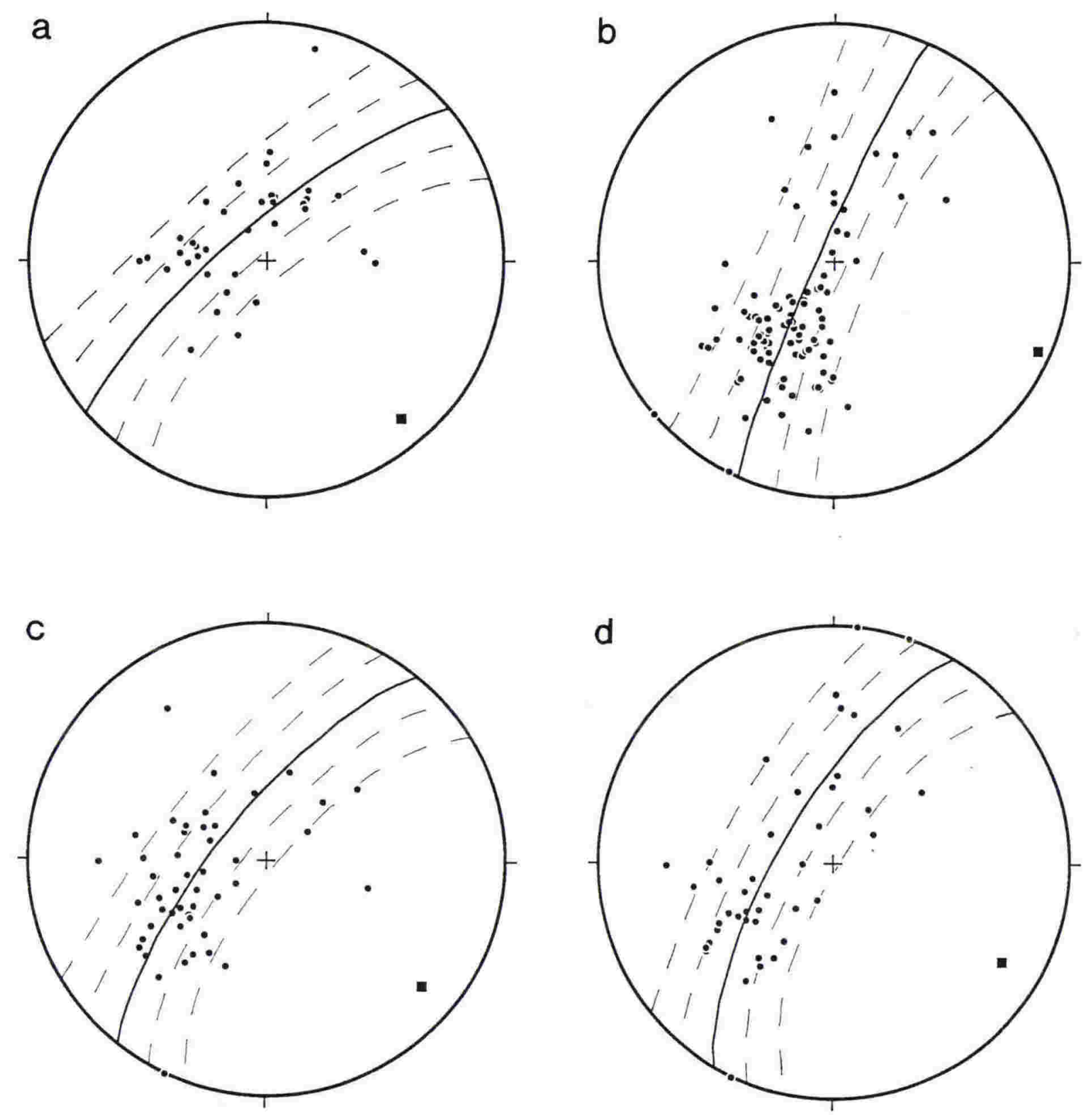

Figure 6.4: Equal-area projections, southern zone of East Coast Allochthon. Dots = poles to bedding (from Stoneley, 1968, Fig. 3); squares = poles to best-fit $\pi$-circles; dashed lines are small cirles at $10^{\circ}$ and $20^{\circ}$ from best-fit $\pi$-cirlces (see Fig. 3.9, section 3.4.1). a: "Haumurian" (Whangai Formation) of autochthon; pole to best-fit $\pi$-circle $=140^{\circ} / 13^{\circ}$. b: Thrust sheets I-V; best-fit pole $=114^{\circ} / 06^{\circ}$. c: Northwestern parts of sheets VI-IX; bestfit pole $=129^{\circ} / 17^{\circ}$. d: Southeastern parts of sheets VI-IX; best-fit pole $=120^{\circ} / 18^{\circ}$. 
surrounded by Miocene rocks. He mapped one sheet in this structure, XV, that he did not distinguish further west.

\subsubsection{Thrust Sequence and Timing}

The sequence and chronology of emplacement of the thrust sheets that Stoneley (1968) proposed is shown in his Fig. 12, reproduced herein as Fig. 6.5. The first phase of displacement is shown occurring after the deposition of the lower Waitakian, when a postulated uplift in the Te Puia area to the northeast resulted in the detachment and west-southwestward sliding of sheets VII to $X$, in an 'overstep' (youngest at the top) sequence, onto what was to become the back of sheet VI. Sheet VII developed a 'shovel front'-an asymmetric tip-fold-during movement. Emplacement of these sheets is shown as followed by a quiescent period during which upper Waitakian and Otaian siltstone was deposited over them. Southwest of these sheets, Waitakian sedimentation was uninterrupted.

In the next phase of movement, part of the earlier 'autochthon' broke away along the Maungahaumia Slide to become Sheet VI, and sheets VI to X moved west-southwest as a unit. The push imparted by this mass resulted in detachment along the Mangatawa Slide, emplacing the body later to become sheets I-V over the Waitakian and Otaian rocks of the autochthon. This body was internally deformed by further motion on the Maungahaumia Slide to form sheets V, III, II, and IV in that order. Continued movement on the Maungahaumia Slide pushed II further over I, formed the small 'flyers' (splays) of the Mangatawa Slide, and folded the autochthon. Finally, the Maungahaumia Slide overrode the the lower sheets and was folded. Minor reactivation of the sub-VII thrust, cutting across its previously-formed 'shovel front' and isolating it (as sheet VIIA), was also postulated to have occurred during this second phase of movement.

The final stages of movement involved the emplacement of sheet XI (above The Dome Slide), followed by sheets XII and XIII. Sheet XIV (above the Te Hua Slide) subsequently cut across the two immediately beneath it. The sole thrust and the sheets below XVI were then cut by the west-northwest striking high-angle fault. Sheet XVI was then emplaced, truncating the high-angle fault. Finally, the Higher Thrust Masses were emplaced on the Mangatu Slide. All thrusting-except for a small displacement on the Mangatawa Slide-ceased before the deposition of the unconformably overlying "Awamoan"-early Altonian (late Otaian-early Altonian on the current N.Z. geological time scale) succession.

This proposed sequence of events is dominated by overstep thrust propagation; in general, successively younger thrusts occur successively higher and further back in the 


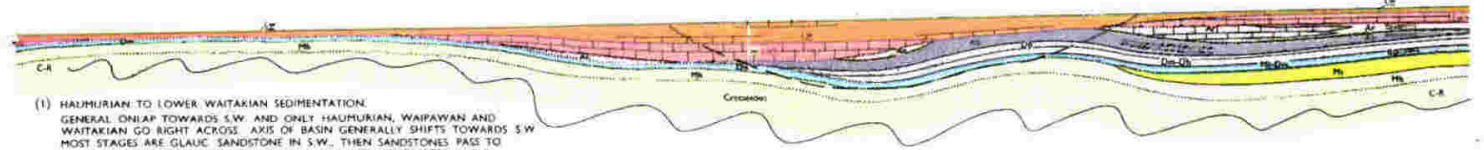

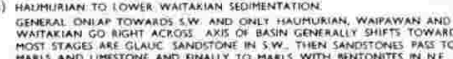

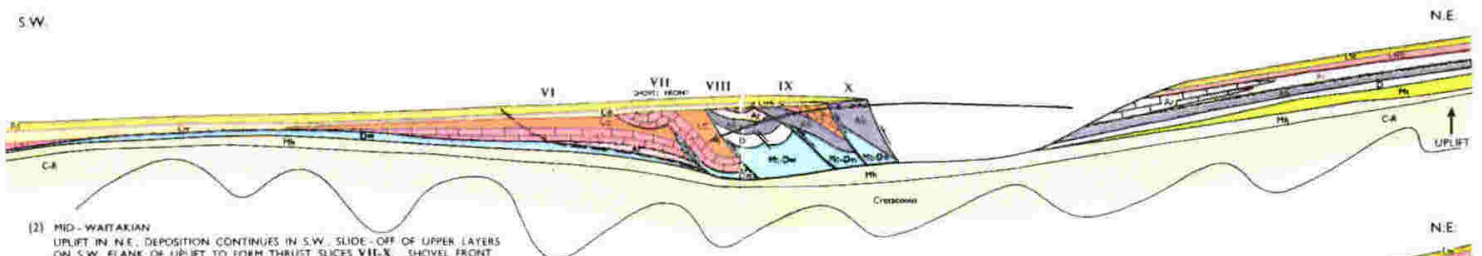

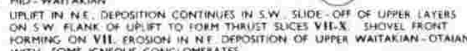

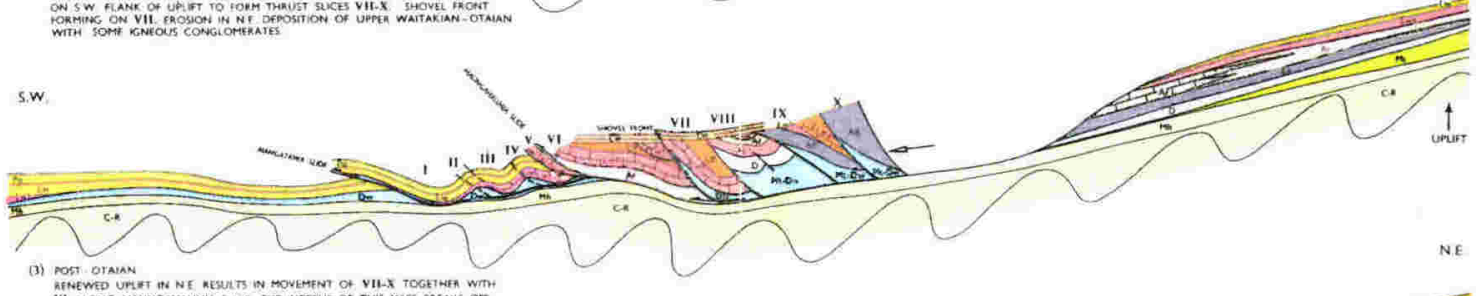

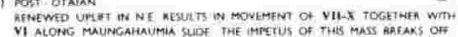

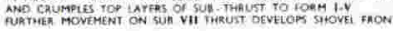

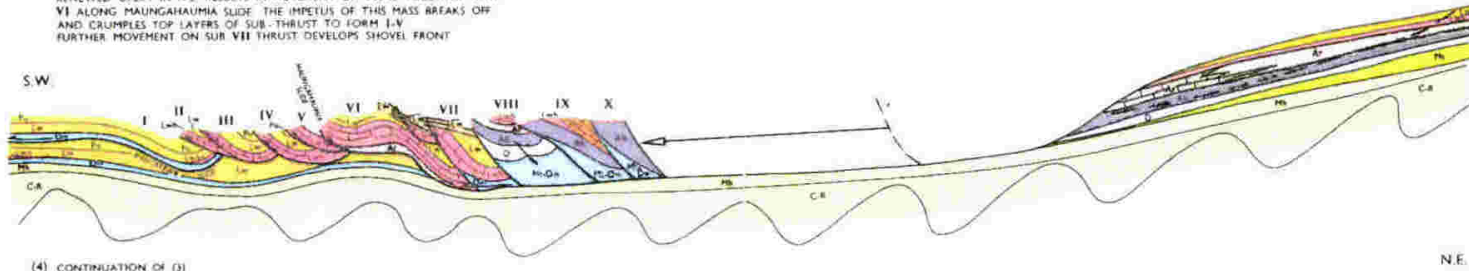

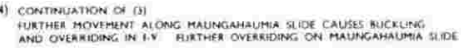

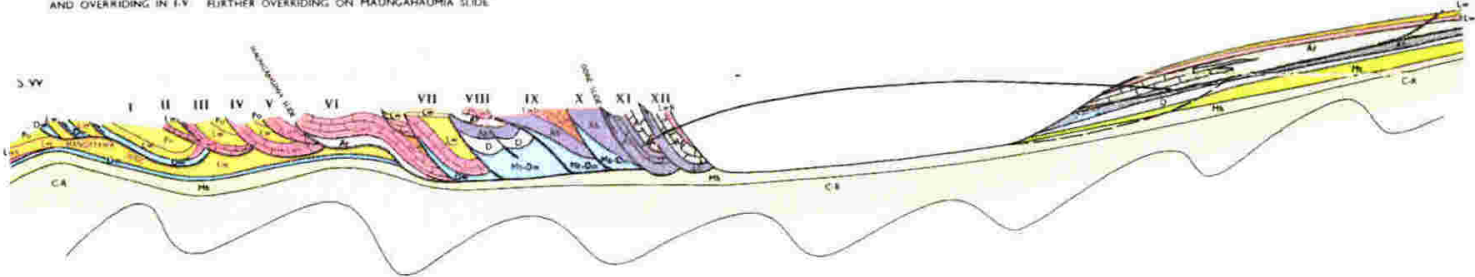

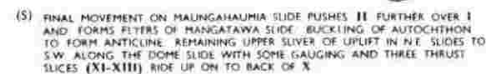

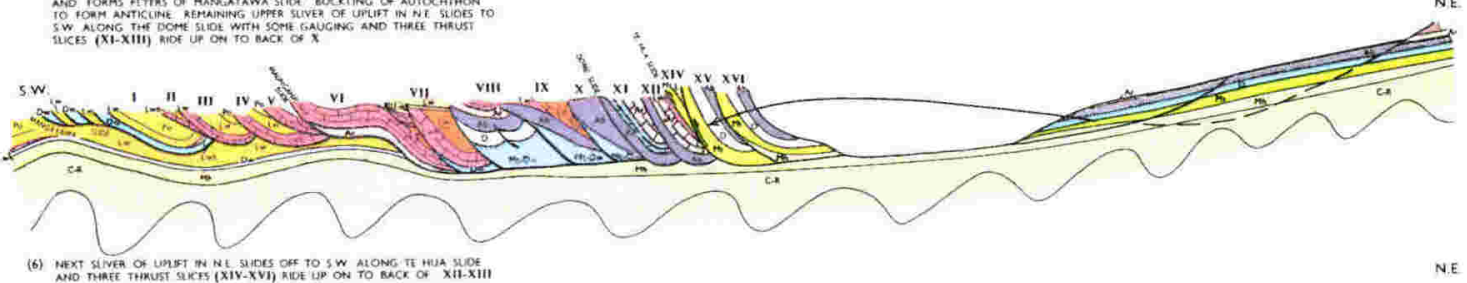

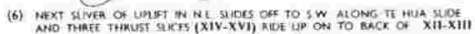

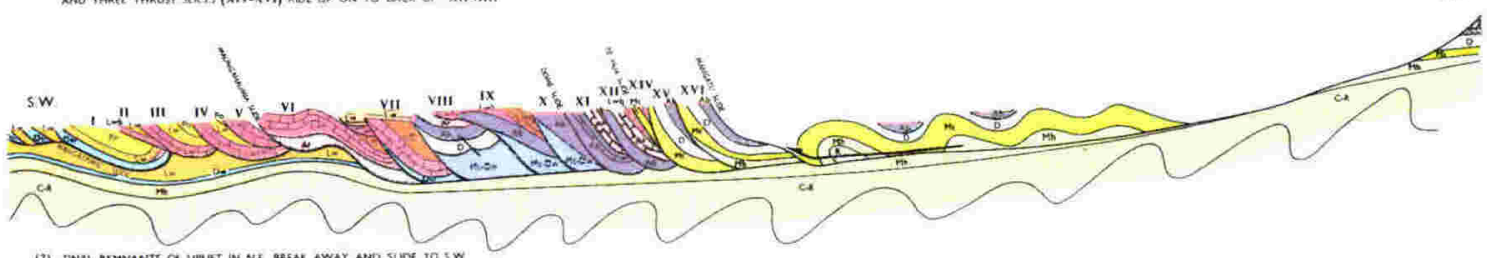

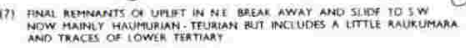

NE

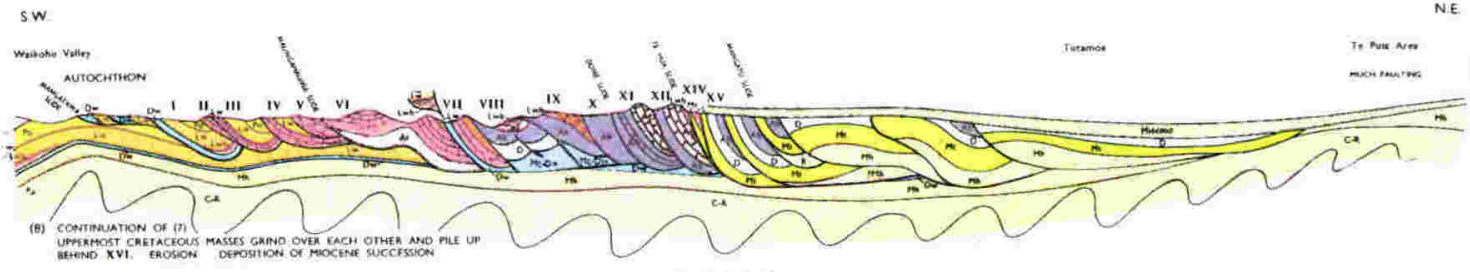

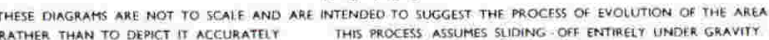

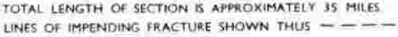

Figure 6.5: Figure 12 of Stoneley (1968), showing his proposed sequence of thrusting in the southern zone of the East Coast Allochthon. 
thrust stack. Overstep sequences have been taken as evidence that thrust sheet movement was due to gravity sliding (e.g., Milici, 1975; Cooper, 1981) because shedding of successively older strata off a vertically rising 'high' onto an adjacent autochthon (a process termed 'diverticulation' by Lugeon, 1943) would produce a thrust stack in which the higher faults are the younger. Stoneley used his conclusion that the thrusts he mapped were generated in a dominantly overstep sequence to support his contention that the mechanism of the thrusting was gravity sliding.

At the time of Stoneley's work, gravity sliding was generally thought to be the only mechanism whereby thin allochthonous sheets could be emplaced over a rigid autochthon. However, many more recent studies (e.g., Jones, 1971; Elliott and Johnson, 1980; Boyer and Elliott, 1982; Butler, 1987) have demonstrated that the geometric relationships between thrusts most commonly show that they propagate in a generally rear-to-front (piggy-back) sequence, although reactivations or hindward-imbricating initiations of new faults may occur locally (e.g., Allmendinger, 1981; Delphia and Bombolakis, 1988; Morley, 1988). A generally forward-imbricating thrust sequence is consistent with transmission of compression from the rear rather than with gravity sliding. Correct interpretation of the thrust sequence, therefore, is important in determining the mechanism of the deformation. It is also important for the correct depiction and restoration of structures on any cross-sections which are to be drawn. In the following paragraphs, the evidence used by Stoneley (1968) to establish the thrust sequence is critically evaluated.

Stoneley (1968) used as evidence for his proposed thrust sequence the intersection patterns between the thrust sheets, the relationships between folds and thrusts, the intersections of thrusts with high-angle cross-faults, and stratigraphic relations. Of these, stratigraphic relations are the least ambiguous: the presence of the intra-Waitakian unconformity in sheets VI and VII but not in sheets I-V clearly shows that the former sheets moved first. The other lines of evidence, however, are more equivocal. One criterion which Stoneley used at many places was the truncation of stratigraphic horizons in the footwall of a fault. For example, his map (Fig. 6.2) shows the sub-II thrust and the overlying, sub-parallel stratigraphic horizons truncated against the sub-III thrust. Milici (1975) referred to such map patterns as 'type-A intersections' and proposed that they result "from a thrust block moving to the [foreland] over an older, previously stabilised thrust fault" (Milici, 1975, p. 1317). He used the common occurrence of type-A intersections in the southern Appalachians to argue for a hinterland-younging thrust sequence there. Thrust intersections are not necessarily places where one thrust cuts another, however; they may be branches, where faults splay or reconnect (see Boyer and Elliott, 1982). The block models of Diegel (1986), constructed assuming a foreland-directed thrust sequence, show that stratigraphic horizons may be truncated against either fault of 
a branching pair depending on the orientation of the branch line at depth. Type-A intersection patterns, therefore, cannot be used as evidence of a hinterland-directed sequence of thrusting. In the following, other types of structural relations between the thrust sheets are examined to see what they demonstrate about the thrust sequence.

In each of sheets I, III, and IV, bedding measurements define an asymmetric syncline with its steep limb adjacent to the fault which overlies it. Stoneley (1968) made the reasonable assumption that these footwall synclines were created by motion on the overlying faults. However, he also assumed that the fault beneath each syncline was folded to the same degree as the beds, leading him to the conclusion that the structurally higher faults are younger that those below. His evidence that the thrusts were folded comes from the northwest ends of sheets III and IV. These two sheets are separated by a northwest-trending anticline in the autochthon which Stoneley presumed to have been formed by the emplacement of sheet IV after the emplacement of sheet III. However, this anticline and the other, similarly-trending folds to the southwest (Fig. 6.2; Moore et al., 1989) may have formed after the emplacement of all the thrusts in response to continued northeast-southeast compression. The planar nature of the sole thrust and the base of the Haumurian further northeast (Fig. 6.3) shows that folding of the sole thrust is not general; the folds in bedding in the other 'synclinal' sheets probably formed as detachment anticlines (see Fig. 3.10c) ahead of a propagating décollement which stepped up from the glide horizon at intervals to cut through the steep fold limbs. The anticlinal closures of these folds are now eroded.

Thrust sheet II, confined to the southeast, is divided into two halves-A and B-by a pair of steeply dipping faults which are truncated by the overlying thrust sheet VI. This does not necessarily mean that sheet VI moved after sheet II, however-the two steep faults may have acted as transfer faults, relaying displacement along their lengths to the segment of VI between them, while the rest of VI was being passively transported on the back of the moving sheet II. Another steep fault divides the minor imbricate to the south of IIB but does not cut IIB itself. If the steep fault is a transfer fault which accomodates a step in the detachment level of the southwestern thrust, it would not offset a preexisting sub-II thrust.

Stoneley (1968) stated that the beds in thrust sheets II and V dip into and are truncated by their underlying thrusts. There is no evidence to support this contention in sheet II, but two measurements of moderately northeast-dipping beds near the trailing edge of sheet $\mathrm{V}$ suggest that bedding is truncated there. If so, the fault beneath sheet $\mathrm{V}$ must have moved out-of-sequence across a pre-existing, presumably thrust-related anticline to the southwest. It should be noted, however, that the sub-V fault carries the same units in the hangingwall and footwall in this area and that it is depicted with 
dashes and question marks at places (Fig. 6.2); its position, and therefore its truncation of bedding, is not absolutely certain.

Thrust sheet VI oversteps sheets V, IV, III, and II. Stoneley (1968) proposed that movement of VI on the Maungahaumia Slide deformed its 'autochthon' to form sheets $\mathrm{I}-\mathrm{V}$, and that after final folding of these sheets "the front edge of VI rode up over the top and was itself folded" (Stoneley, 1968, p. 151). Stoneley's evidence that sheet VI overrode the lower ones after their formation was that it appears to 'truncate' those sheets and the steep faults which cut one of them (II). It is evident from the preceding discussions, however, that the lower faults could have branched from the sub-VI fault after its motion and that the steep faults could be transfer faults. Structure contours around the embayment in the Maunghaumia Slide near its common branch point with the sub-V and sub-IV thrusts show that it has a shape consistent with it having been buckled by the stacking of the lower, later sheets (Fig. 6.3).

As with the folds in sheets I, III, and IV, the folds at the surface of sheet VI were presumed by Stoneley (1968) to reflect folding of the underlying thrust, in this case the Maungahaumia Slide, which was assumed to be the sole thrust beneath the entire body of VI. These folds appear to die out to the northwest where structure contours show the Maungahaumia Slide to be planar. Folds in thrust sheets are commonly caused by motion on later, lower thrusts (e.g., Jones, 1971). Rather than being due to a fold in the sole thrust, the anticline in sheet VI is probably due to folding of the Maungahaumia Slide over a concealed blind imbricate or horse block which splays from it southeast of where it is exposed as the sole thrust (see section 6.2.3.2). The southeast end of the syncline in sheet VI is tighter in the Whaingaroan to lower Waitakian succession than in the unconformably overlying upper Waitakian. Stoneley's contention that all the motion and folding of sheet VI postdated Waitakian-Otaian deposition made it necessary for him to postulate a detachment between the two units, the upper Waitakian being pushed off the underlying beds during folding rather than being folded with them. It seems more likely, however, that the contact is stratigraphic and that deformation occurred before (and possibly during) as well as after deposition of the upper Waitakian. Pre-upper Waitakian folding due to the ramping of sheet VI over the underlying autochthon would have been tightened by post-upper Waitakian (post-early Otaian) motion of the blind imbricate or horse block beneath sheet VI (see also section 6.2.3.3).

Thrust sheets VII to $\mathrm{X}$, which all terminate northwestwards in the Maungahaumia Slide, were thought by Stoneley (1968) to have been emplaced in a northeast-younging sequence. Sheet VII was stated to be "gradually transgressed and cut out towards the north-west by the succeeding slice" (Stoneley, 1968, p. 140). Although this is not good evidence for sheet VIII being emplaced after VII, there is evidence for some minor out-of- 
sequence movement of the thrust which separates sheet VII from its 'shovel front', sheet VIIA. Sheet VIIA is a strongly asymmetric syncline of Whaingaroan which is unconformably overlain by very gently folded upper Waitakian beds. Fig. 8 of Stoneley (1968) shows that the sub-VII thrust cuts the more southwestward sub-VIIA thrust. Both thrusts cut the upper Waitakian, showing that some thrust motion persisted in this area after the main, mid-Waitakian movements. This motion may have been synchronous with later thrusting on the major sub-VI fault to the south; local synchronous motions and hindward-imbricating thrust sequences have been shown to have taken place in the hangingwalls of major ramps (e.g., Allmendinger, 1981; Delphia and Bombolakis, 1988).

The steep fault dividing thrust sheet VIII into two halves was thought by Stoneley (1968) to predate thrust motion, as it is truncated by both the sub-VIII and sub-IX thrusts at both ends. Termination of this fault in the sub-VIII fault would be expected if the footwall block from which VIII was derived contained a step in its detachment level. After displacement onto a planar footwall, such a step would be reflected in the hangingwall block and in any thrust sheet overlying it. The apparent truncation of the step by the sub-IX thrust could be taken as evidence that this thrust is younger. The stratigraphic repetition across the sub-IX thrust is not as great as the apparent offset across the step fault, though, so even if sheet IX moved later the step should still be expressed in it. The two faults are shown meeting within a single unit, the Bortonian, so the structural relationships on the map may not be completely accurate. To the northwest, the Mangaorapan-Heretaungan to Porangan beds of sheet VIIIA are shown truncated against the sole thrust. This relationship suggests that the sole thrust cuts abruptly down-section in the transport direction. No bedding measurements are shown in this area, however; it may be that the beds flatten into parallelism with the sole thrust, as they do in the higher sheets (see section 6.2.2.1), rather than terminate against it.

Thrust sheet IX contains an angular unconformity which Stoneley (1968) shows as Whaingaroan to lower Waitakian. It is possible that this unconformity is in fact intraWaitakian; uppermost Whaingaroan beds mapped by Stoneley in sheet I are now known to be Waitakian (C. Mazengarb, pers. comm., 1990; column 15, Fig. 2.3), and Mazengarb et al. (1991, p. 21) described Waitakian-Otaian limestone unconformably overlying allochthonous Tikihore Formation $25 \mathrm{~km}$ further north. The unconformity in sheet IX may be older than the mid-Waitakian unconformity shown in sheets VI and VII, therefore demonstrating earlier movement of sheet IX, but this cannot be stated with certainty. Sheet $X$ repeats a small part of the unconformity. Stoneley assumed this sheet to have moved after sheet IX because it truncates the lower sheet in the south. The steep dip of sheets $X$ and higher, however, is more consistent with them having been emplaced first and then steepened by the subsequent movement and tilting of lower sheets. 
Thrust sheet XI overlies The Dome Slide, which Stoneley (1968, p. 143) stated "is the lowest to truncate definitely the extensive Maunghaumia Slide". He thus concluded that sheet XI was emplaced after sheet X. Structure contours, however, show that the northwestward end of The Dome Slide is contiguous with the Maungahaumia Slide rather than truncating it (Fig. 6.3). Sheet XI was not, then, necessarily emplaced after sheet X. A poorly developed 'shovel front' to sheet XI is exposed in the southeast. Stoneley's model of development of a 'shovel front' (his Fig. 9) suggests that the fault behind the syncline was the last to move, as was the case in thrust sheet VII. In this case, however, the northeastern fault may have moved first, causing folding in its footwall, and the southeastern fault second. The sub-XII thrust cuts down-section across sheet XI in the southeast, where the rocks in sheets XII and XIII swing to a northnortheast strike. Stoneley (1968) considered this to reflect 'cutting out' of XI by XII. Bedding in these sheets is steep, and the sub-XII thrust in this area has the geometry of an oblique ramp, cutting up-section in the footwall to the northwest and down-section in the hangingwall to the southeast. Many of the lower faults merge with this thrust near its southeast end; the pronounced Z-bend in the beds of sheet XII and their steepness in its central part could be due to stacking of the (younger) thrust sheets below it.

Thrust sheet XIV above the Te Hua Slide was thought by Stoneley (1968) to cut across sheets XII and XIII in the southeast. The Te Hua Slide may be an oblique ramp in that area, and buckling due to branching of the sub-XIII thrust from it may explain its slight deflection to the northeast. The relative linearity of its outcrop, however, seems more compatible with at least some out-of-sequence motion on this thrust, leading to truncation of the underlying structures. The sole thrust and the sheets between XII and the northwestern outcrop of XVI (not shown on Fig. 6.2) were shown by Stoneley as cut by a steep, west-northwest striking fault. This fault was shown as cut by sheet XVI which was itself shown as truncated by the Mangatu Slide, which cuts down onto sheet XIV in the southeast (Fig. 6.2). From these relationships, Stoneley inferred that emplacement of XIV was followed by high-angle faulting, then by emplacement of XVI, and finally by emplacement of the Higher Thrust Masses on the Mangatu Slide. Stoneley's mapping in this area (the southernmost part of the central zone) was largely conjectural, however. The map of Moore et al. (1989) shows a similar high-angle faultwhich does not cut the sole thrust-but it does not show structures equivalent to Stoneley's sheet XVI or Mangatu Slide; the fault simply dies out into the Whangai Formation. The evidence for Stoneley's proposed thrust sequence does not appear to be present.

The structural and stratigraphic relationships shown on Stoneley's (1968) map, then, are more compatible with, and in many cases better explained by, a dominantly forelanddirected (piggy-back) sequence of thrusting than the complicated sequence which Stoneley 
proposed (Fig. 6.5). Thrusting probably began in the northeast and generally propagated toward the southwest with time, although at least minor out-of-sequence thrusting (the sub-VII thrust, possibly the Te Hua Slide, and perhaps other faults) took place as well. At least in the frontal few sheets, detachment folds formed ahead of the thrusts. Sheets VII and above moved in the mid-Waitakian. Some of the motion of sheet VI probably also took place during this time as well as during the later Waitakian and early Otaian, when synorogenic sediments were accumulating over the area to become sheets I-IV. Sheet VI also moved after the early Otaian, when sheets I-IV were generated. Minor motion on the sub-VII and sub-VIIA thrusts also took place then. All motion (except for a slight offset on the Mangatawa Slide) was over by the "Awamoan"-early Altonian (late Otaian-early Altonian), when the thrust sheets were covered unconformably by postorogenic sediments. Thrusting in this area therefore took place over a period of $\approx 4$ m.y. in the Early Miocene, between ca. $23 \mathrm{Ma}$ and ca. $19 \mathrm{Ma}$ (see the time scale of Edwards et al., 1988, in Appendix 1). The thrusting was caused by the transmission of compression from behind the sheets rather than by gravitational sliding of individual sheets or groups of sheets off a rising 'high' to the northeast.

\subsubsection{Cross-Section}

Stoneley's (1968) map is accompanied by four cross-sections which illustrate his interpretation of the structure at depth. The style of these sections reflects his interpretation that the sole thrust was a number of individual thrusts, the more southwesterly of which were folded by the motion of those behind. However, structure contours (Fig. 6.3) show that the sole thrust is not folded along most of its length, and a consideration of the fault intersection patterns on his map suggests that the overall sequence of thrusting was from northeast to southwest (section 6.2.2.2). Also, Stoneley's sections cannot be restored to their undeformed states. Recent advances in the knowledge of thrust tectonics and in techniques of section construction has led to most sections through thrust belts being constructed so that they are restorable or 'balanced'. Construction of such sections allows the progression of deformation to be visualised and the amount and in some cases the rate of deformation to be quantified. Even though some of the geology shown on Stoneley's map is known to be incorrect, newly constructed sections would give a better indication of the style and amount of deformation across the region. In the following, one new, partially restorable section across the southern zone of the East Coast Allochthon (Fig. 6.6) is presented and discussed. 


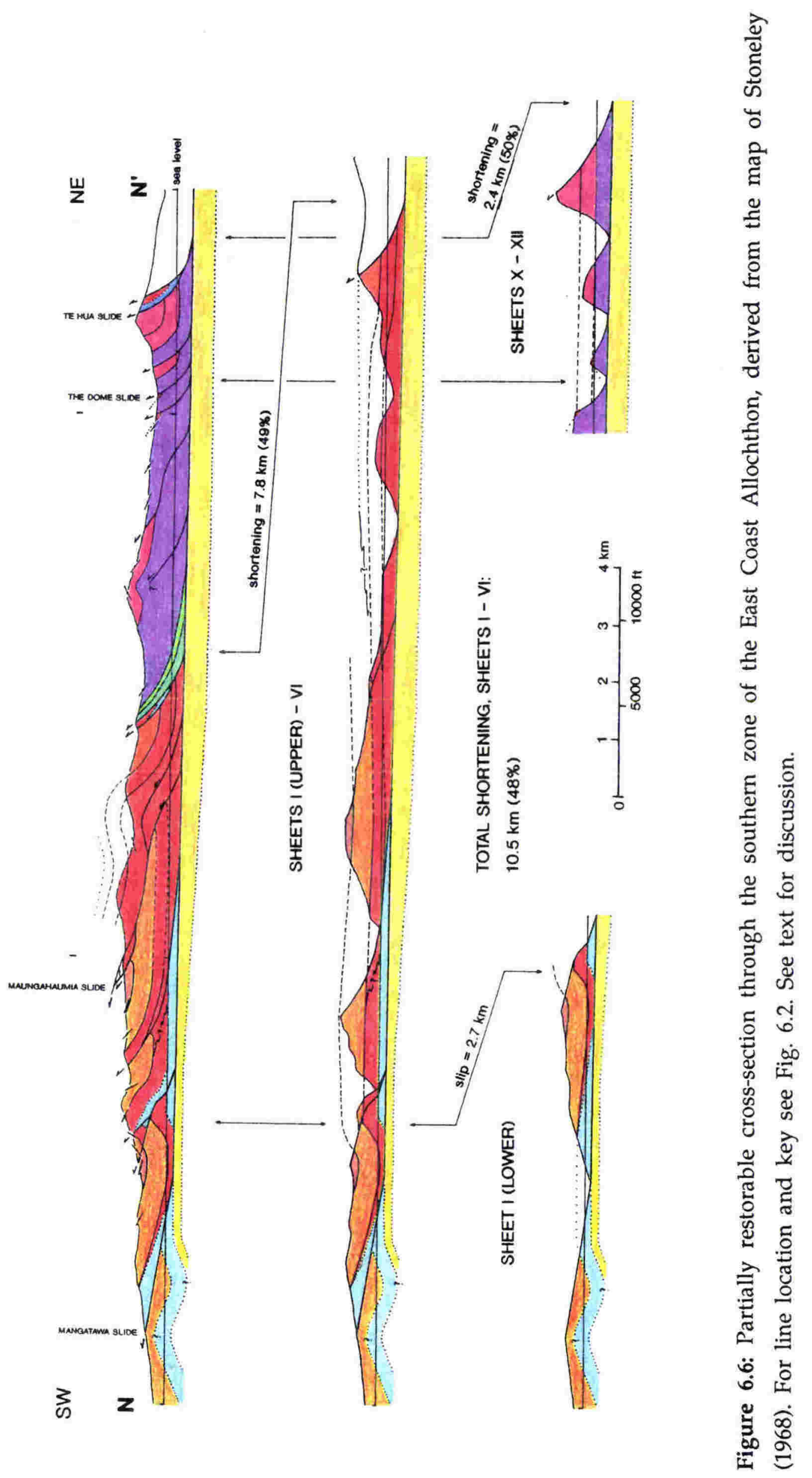




\subsubsection{Section Orientation, Data Projection, and Basement Geometry}

The line of the new cross-section (Fig. 6.6) is shown on Fig. 6.2 as $\mathrm{N}-\mathrm{N}^{\prime}$. It is positioned in the northwestern part of the structure partly because the sole thrust and the structurally lower parts of the thrust sheets are exposed nearby and partly to avoid the lateral ramp geometry of the southeastern ends of sheets $X$ to XIII. It crosses areas where dip measurements are relatively common. The line is divided into three differently oriented segments which parallel the inferred transport directions of different thrust sheet groups (section 6.2.2.1; Fig. 6.4). This division is justified because the differences in transport direction between the southwestern and central and central and northeastern parts of the line are $\approx 15^{\circ}$ and $\approx 18^{\circ}$, respectively. Woodward et al. (1989) have suggested that a section line should be within $5^{\circ}$ of the transport direction unless the structure is perfectly cylindrical. The section plane was chosen vertical for ease of construction, although the fold axes in sheets I-V and the northwestern parts of VI-IX plunge at $06^{\circ}$ and $17^{\circ}$, respectively (Fig. 6.4). Cooper (1983) has shown that sections inclined less than $10^{\circ}$ to the structure produce no significant errors in the calculation of shortening. Because of the poor cylindricity of the folding, bedding orientation measurements and contact geometries were only projected short (generally $<1.5 \mathrm{~km}$ ) distances onto the section plane, so projection errors are not likely to be significant.

The sole thrust was located on the section by projection down dip from its exposure in the northwest. In the vicinity of the northeastern bend in the section, its dip was taken as $20^{\circ}$. Structure contours in that area show that it steepens southeastward from $7^{\circ}$ to $11-14^{\circ}$ where it is exposed (Fig. 6.3); it presumably continues to steepen toward the section line. In the southwestern part of the section, its dip was taken as $6^{\circ}$. Use of these values resulted in a planar sole thrust dipping very slightly northeastward in the section plane (Fig. 6.6). The sole thrust was assumed to lie at the top of a $350-400 \mathrm{~m}$ thick "Haumurian" section in the northeast (a typical thickness for the Whangai Formation; see columns 3 \& 6, Fig. 2.2) and to cut down across it-following the sub-Whaingaroan and sub-Waipawan unconformities - to the southwest, as suggested by the map (Fig. 6.2). Both the base of the Whangai and the sole thrust are shown as planar beneath the front of sheet IV; the folds further to the northwest (Fig. 6.2) are presumed to die out completely before reaching the section plane. The form of the anticline in the autochthon in the extreme southwest is derived from dip measurements but the position of the Waitakian/Waipawan boundary is speculative, as is the position of syncline to the northeast. The thickness of the Waipawan is shown the same as the maximum thickness at the front of sheet $\mathrm{I}, \approx 250 \mathrm{~m}$. The anticline may be a detachment fold above a blind flat and thus have the same origin as proposed for the folds in the sheets to the northeast (section 6.2.2.2). However, other folds in the autochthon nearby do not appear 
to be thrust-related. Because its existence cannot be proven, no fault is shown beneath the anticline.

\subsubsection{Thrust Sheet Geometries}

The overall style of the cross-section (Fig. 6.6) reflects the structural style shown on the map (Fig. 6.2). Dip measurements (Stoneley, 1968, Fig. 3) show that the folds have rounded rather than angular hinges. Near the surface, the faults are generally depicted as parallel to the beds in their hangingwalls as suggested by the map pattern (section 6.2.2.1). At depth, they are shown as curved rather than stepped, following the trajectories suggested by bedding attitudes in the sheets above them. Faults and beds are assumed to flatten into the sole thrust, except where the map shows otherwise (sheet VIIIA). Only two blind thrusts are inferred. The faults which cut the topographic surface do not lose displacement up-section into hangingwall folds, and thus were probably emergent through the synorogenic Waitakian-Otaian sediments when active.

At the front of the synclinal thrust sheet I, Waitakian rocks unconformably overlie Waipawan. Whaingaroan rocks are present across the syncline at the back of sheet I, and in the overlying sheet III they are $\approx 250 \mathrm{~m}$ thick. On Fig. 6.6, they are depicted as thickening beneath the syncline at the expense of the Waipawan. The Whaingaroan at the back of sheet I was flattened above the same thickness of Waipawan as is present in sheet III (see later). The syncline is too deep for the entire Waipawan-Otaian succession to fit above the projected position of the sole thrust. The syncline may have formed after thrusting, folding the sole thrust with it, or before thrusting, to be subsequently cut by the sole thrust. The latter alternative is depicted on Fig. 6.6; the sole thrust thus cuts down-section southwestward from Whaingaroan to Waipawan beneath the syncline. Sheet I contains a subsidiary thrust beneath its moderately to steeply dipping northeastern limb. This thrust is shown carrying a full thickness of Whaingaroan and some Waipawan rocks, and joining the sub-III thrust at depth.

Branch line analysis (Diegel, 1986) shows that thrust sheet II intersects sheet III along a trailing branch line which plunges away from the section line. Sheet II is thus not present on the section plane. At the surface, sheet III carries a small sliver of Waipawan as well as Whaingaroan to Otaian rocks (Fig. 6.2). Analysis of cutoff geometries (see Diegel, 1986) shows that the Waipawan is present in the section plane at depth but that the Otaian is not. The sub-III thrust is shown as a hangingwall ramp down to its intersection with the subsidiary thrust in sheet I to incorporate the Waipawan. The thickness of Waipawan shown $(\approx 130 \mathrm{~m})$ is a consequence of the requirement to fill the space between the Whaingaroan and the sole thrust, which is presumed to follow the sub-Waipawan unconformity in this area. Northwest of the section line, the sole thrust 
underlies the Whaingaroan. It thus cuts down-section toward the southeast. In the Whaingaroan, the facies change from the siltstone or sandstone of sheets I-III to a unit of siltstone overlain by a unit of limestone is assumed to take place near the back of sheet III. Sheet III carries a slightly thicker Waitakian section than is present in sheets I and IV.

At the surface, thrust sheet IV carries a slightly thinner section of Whaingaroan than sheet III. This is entirely limestone, but the cutoff geometry shows that the underlying siltstone is present in the section plane at depth. The sub-IV fault is shown following the gently curved trajectory suggested by the bedding attitudes above it down to a point beneath the front of sheet $\mathrm{V}$, from which it cuts down through a thickening Whaingaroan section to the sole thrust. This segment of the fault follows an assumed Whaingaroan/Waipawan unconformity, leading to the presence of a thick Whaingaroan section immediately above the sole thrust at the back of sheet IV. A thick Whaingaroan section is exposed at the northwestern ends of sheet IV and the front of VI.

The sub-V fault meets the sub-VI fault at a leading branch point southeast of the section line, and a trailing branch point northwest of it. Sheet $\mathrm{V}$ is thus a small horse. The sub-VI fault (the Maungahaumia Slide) is shown following the projection of the folded beds northeastward along what is assumed to be the base of a thinning Whaingaroan section. This thinning appears profound on the map, but the map pattern is partly due to topography. The anticline in the beds and in the Maungahaumia Slide is presumed to be due to motion over a lower, later fault, which is shown as the lower boundary of a horse of lower Whaingaroan rocks intermediate in thickness between those at the front of sheet VI and those at the back of sheet IV. The faults and beds at the back of sheet VI are assumed to flatten above the sole thrust, as they appear to do around its exposure in the northwest (Fig. 6.2). The lowest possible position of the midWaitakian unconformity in sheet VI-determined from the highest elevation of nearby lower Waitakian rocks-is shown on both the deformed- and restored-state sections. The restored section shows that the facies change between the unconformable lower marl/ upper siltstone association and the 'undifferentiated', internally conformable Waitakian in the lower sheets has a distance of at least $5 \mathrm{~km}$ in which to occur.

Thrust sheet VII is a thin sliver in the vicinity of the section plane containing Waipawan and, above an unconformity, Whaingaroan rocks. The sub-VII thrust branches from the sub-VIIIA thrust in the northwest, and is therefore shown to do so at depth. The sub-VIIIA fault and the Mangaorapan-Porangan beds above it are drawn gently curving toward the sole thrust. The Mangaorapan-Porangan beds are shown truncated by the sole thrust as they are on the map (Fig. 6.2); this makes restoration of this part of the section impossible (see section 6.2.3.3). A thick $(\approx 750 \mathrm{~m}$ ) Bortonian section in this sheet is capped by Runangan beds in which there is an anticline that is probably due to 
blind thrusting beneath them. The Runangan/Bortonian boundary is shown on the map as cut out against the sole thrust. Such a geometry is not shown on the section because the rapid northeastward thinning of the Bortonian that would result seems unrealistic. Instead, the boundary is drawn parallel to the Bortonian/Porangan boundary until it meets the sub-IX thrust.

Sheet IX comprises almost entirely Bortonian rocks, a small sliver of Whaingaroan being present between an unconformity and the sub- $X$ thrust in the northeast. The increase in northeastward dip of the beds in sheet IX probably reflects a convex-upward fault geometry at depth. The sub-Whaingaroan unconformity is repeated in sheet $X$. The Bortonian beds in sheets X-XII are assumed to be the same thickness from sheet to sheet and to flatten into the sole thrust at depth, in accordance with the listric geometries deduced from the map pattern (section 6.2.2.1). The sub-XIV fault joins the fault beneath the Higher Thrust Masses (central zone) northwest of the section line and is likely to do so in the section plane at depth. The sole thrust continues beneath the "Teurian" (Whangai Formation) of the central zone of the allochthon to the northeast.

\subsubsection{Restoration: Amount and Rate of Deformation}

The cross-section (Fig. 6.6) was constructed to follow the thrust 'rules' (e.g., Dahlstrom, 1969; Boyer and Elliott, 1982; Woodward et al., 1989) where possible. This has resulted in sheets I-VI and sheets X-XII being restorable. Sheet VIII, however, is not restorable as the Mangaorapan-Porangan beds are shown as cut out against the sole thrust and have no equivalents beneath it to the northeast. Sheet IX has no suitable stratigraphic markers to locate its position in the undeformed state, and it too cannot be restored. The total shortening across the southern zone of the East Coast Allochthon thus cannot be determined; it can be estimated, however, from the percentage shortening of the restorable parts of the section.

The restored sections in Fig. 6.6 were constructed using the sinuous bed method (Dahlstrom, 1969; Woodward et al., 1989). For the first section, higher sheets were sequentially restored (in accordance with the dominantly foreland-directed thrust sequence determined in section 6.2.2.2) along the sole thrust to the horizontal Whaingaroan in the lower part of sheet I. The lower part of sheet I was not itself restored at this stage because the amount of transport on its underlying fault depends strongly on the poorly known geometry of the autochthon (see later). Because most hangingwall cutoffs are eroded, bed lengths were measured with reference to local pin lines (see Woodward et al., 1989) placed perpendicular to bedding near the fronts of sheets III, IV and VI. The similarity of the fault trajectories in the deformed and restored states shows that these pin lines are in positions of little interbed shear. The deformed- 
state dips of the sole thrust and the basement were maintained in the restoration. Restored stratigraphic horizons thus appear to dip because of variations in bed thicknesses (determined from the map and the deformed-state section).

Sheet V and the horse beneath sheet VI were located on the restored section according to their internal stratigraphy. The exposed part of sheet $\mathrm{V}$ is Whaingaroan limestone; the restored section requires a small part of it above the exposure level to be Waitakian. The sub-VI horse was assumed to consist of lower Whaingaroan (section 6.2.3.2) and is thus restored to a position overlying the sole thrust. The two horses were balanced by equating their deformed- and restored-state areas to within a few percent using a digitizer. Other thrust sheets and individual stratigraphic horizons were not area balanced because of uncertainties in the details of bed thickness variations. The section is thus line-length balanced only. All the sections were prepared at a scale of 1:31,680. Errors in line-length measurement are probably less than $3 \%$.

The amount of transport on the thrust in the upper part of sheet $\mathrm{I}$ is determined from the cutoffs of the top and bottom of the Whaingaroan as $600 \mathrm{~m}$. Transport on the sub-III fault relative to the lower part of sheet I is $900 \mathrm{~m}$ and relative to the upper part is only $200 \mathrm{~m}$, determined from the top of the Waipawan. The steep dip of the top of the sub-III fault in the restored section $\left(58^{\circ}\right)$ probably means that folding of sheet I took place before faulting. This is the same conclusion as was drawn from the widespread presence of footwall synclines on the map (section 6.2.2.2). The small amount of transport between sheet III and the upper part of sheet I means that the hangingwall cutoff of the top of the Whaingaroan would not have been very far above the present erosion surface. The amount of transport shown on the sub-IV thrust $(1700 \mathrm{~m})$ is a minimum determined by bringing the bottom of the Whaingaroan at the front of sheet IV into coincidence with the same horizon at the back of sheet III. It is probably close to the true value, however, as restoration beyond this point would further lower the horizons in sheet IV relative to their positions in sheet III.

The total transport of thrust sheet $\mathrm{V}$ is $2400 \mathrm{~m}$, and the amount of transport on the sub-VI horse is $1050 \mathrm{~m}$. Transport on the sub-VI thrust before movement of the two horses is $2400 \mathrm{~m}$, which is a minimum because the base of the Whaingaroan at the front of sheet VI restores to a position on the sole thrust. The sequence of deformation in these three sheets is assumed to be: movement of sheet VI (at least $2400 \mathrm{~m}$ ); incorporation of sheet $\mathrm{V}$ into its hangingwall; transport of sheets $\mathrm{V}$ and VI together (1350 $\mathrm{m})$; incorporation of the sub-VI horse; and transport of all three units together $(1050 \mathrm{~m})$. Steps 1 and possibly 2 and part of 3 took place prior to the deposition of the upper Waitakian, ramp-flat transport folding the lower Waitakian and older rocks; steps 4 and 5 took place after the early Otaian, folding the upper Waitakian to a lesser degree. The 
total (minimum) transport of sheet VI relative to sheet IV is $4800 \mathrm{~m}$. The total shortening between the lower part of sheet I and the back of sheet VI is $7.8 \mathrm{~km}, 49 \%$ of the distance between the top Whaingaroan cutoff at the back of sheet I and the base Whaingaroan cutoff at the back of sheet VI (Fig. 6.6).

The restoration of the lower part of sheet I depends strongly on the poorly known configuration of the autochthon (see section 6.2.3.1) so it is shown separately in Fig. 6.6. The configuration depicted is conservative and leads to a minimum slip (the hangingwall cutoff is eroded) on the Mangatawa Slide of $2700 \mathrm{~m}$. As stated earlier (section 6.2.3.2), the sub-I thrust is thought to have cut across a syncline which formed ahead of it. The restoration suggests a position for the footwall (autochthonous) part of this syncline. Because of the uncertainties in the restoration, however, the syncline is not shown. Slip of $2700 \mathrm{~m}$ on the sub-I thrust would increase the shortening beneath sheet VII to 10.5 $\mathrm{km}, 48 \%$ of the distance between the crest of the anticline in the autochthon and the base Whaingaroan cutoff at the back of sheet VI. The total fault slip across sheets I-VI is 10.1 $\mathrm{km}$. The other $400 \mathrm{~m}$ of shortening is expressed as folding.

The restored configuration of sheets $\mathrm{X}-\mathrm{XII}$ is also presented in Fig. 6.6. Because of the absence of hangingwall cutoffs, local pin lines through the central portions of each sheet were used. The restoration shows that these pin lines are in areas of significant interbed shear, as the restored-state trajectory of the sub-XIV fault is somewhat shallower than the deformed-state trajectory. Because no hangingwall cutoffs are preserved, the fault displacements depicted are all minima. The total shortening along the sole thrust beneath these three sheets is $2.4 \mathrm{~km}$, or $50 \%$ of the minimum restored distance across them. The dip of the sub-Whaingaroan angular unconformity in sheet $X$ is uncertain, but would appear from the map pattern to be moderately to steeply northeastward. Its southwest dip in the restored section suggests that some of the motion of sheet $X$ took place before its production. The unconformity may be Waitakian as suggested in section 6.2.2.2, of similar age to a sub-limestone angular unconformity in the allochthon further northeast (Mazengarb et al., 1991).

Because of the unrestorability of thrust sheets VIII and IX, the total shortening across the southern zone of the East Coast Allochthon can only be estimated. minimum shortening percentages across sheets I-VI and across sheets X-XII are $48 \%$ and $50 \%$ respectively. Transport on the sub-VIII and sub-IX thrusts is difficult to judge because it is difficult to relate the stratigraphy in those sheets to the sheets below. Transport of VIII must however be considerably more than the distance along its base from the sole thrust to the surface $(1500 \mathrm{~m})$ as restoration that far would put Mangaorapan-Heretaungan rocks adjacent to the Whaingaroan at the back of sheet VI and in sheet VII. This argument presumes that the map is correct in this area; there must be some doubt about 
this considering the cutoffs of some horizons against the sole thrust and the great thickness of Bortonian relative to that in sheets X-XII. Nonetheless, the geometry of sheets VIII and IX would appear to require a minimum shortening for those two sheets in excess of $50 \%$. Taking $50 \%$ as a conservative estimate of the minimum shortening across the entire section ( $\approx 18 \mathrm{~km}$ wide), the pre-thrusting width of the southern zone of the East Coast Allochthon would have been at least $36 \mathrm{~km}$. In a discussion of the stratigraphic trends, Stoneley (1968, p. 133) speculated that there had been $70 \%$ shortening when he said "it must be remembered that the succession has been telescoped considerably to the southwest and that facies changes over a present distance of 12 miles across the strike originally covered perhaps 40 miles". His estimate is probably too high.

The presence of angular unconformities which date thrust movement allows the approximate shortening rates throughout the thrusting history to be determined. The sheets below VII moved between the mid-Waitakian and and the late Otaian-early Altonian. Adopting ages of $23 \mathrm{Ma}$ for the former and $19 \mathrm{Ma}$ (Otaian/Altonian boundary) for the latter (see Appendix 1), the average rate of shortening across sheets I-VI was at least $10.5 \mathrm{~km}$ in $4 \mathrm{~m} . \mathrm{y}$. or $2.6 \mathrm{~mm} / \mathrm{yr}$. Movement of sheets I-IV and at least $1050 \mathrm{~m}$ of movement of sheet VI took place after the early Otaian and before the late Otaian-early Altonian. Adopting an upper limit of $21 \mathrm{Ma}$ for the former, the average rate of shortening across these sheets was a minimum of $6.45 \mathrm{~km}$ in $2 \mathrm{~m} . \mathrm{y}$., or $3.2 \mathrm{~mm} / \mathrm{yr}$. The regional geology (Moore et al., 1989; Mazengarb et al., 1991; see also previous chapters) shows that thrusting throughout Raukumara Peninsula started in the Waitakian. If the shortening of the entire $18 \mathrm{~km}$ length of section $\mathrm{N}-\mathrm{N}^{\prime}$ was greater than $50 \%$ and took place between 24 and $19 \mathrm{Ma}$, the average shortening rate across the southern zone of the East Coast Allochthon was at least $3.6 \mathrm{~mm} / \mathrm{yr}$.

The minimum shortening rates determined above have considerable uncertainties. Errors in shortening determinations are likely to be small $(<3 \%)$, but the configuration of the cross-section may be significantly in error because of the problems with the map and the lack of direct information on the deep structure immediately beneath the section line. Large uncertainties are inherent in the adoption of ages for the various stratigraphic datums. Because Stoneley (1968) inlcuded the Duntroonian with the lower Waitakian, his mid-Waitakian unconformity could in fact be base Waitakian (24 Ma). Edwards et al. (1988) put the Otaian/Waitakian boundary in their reliability category C3, meaning it is based on poorly defined bioevents which are widely spaced in time. If it can be recognized in a particular section, its error may be up to \pm 2 m.y.. There is also uncertainty in the assignation of a lower age limit to the postorogenic strata due to the difficulty of correlating Stoneley's "Awamoan"-early Altonian with an age on the current time scale. Taking these problems into account, the durations of periods of thrusting could be in error by as much as $\pm 1-2$ m.y.. Presuming the cross-section configuration 
and the shortening calculations to be correct, this would translate into errors of approximately $\pm 20 \%-100 \%$ in the minimum shortening rates.

The minimum shortening rates calculated above may be compared with shortening or transport rates determined in the frontal parts of other thrust belts in different tectonic settings. Continent-continent collision zones with known rates of deformation across their external portions include the Spanish Pyrenees, the Pakistan Himalaya, and the Swiss Alps. Burbank et al. (1992) showed that shortening of the frontal $35 \mathrm{~km}$ of the eastern South Central Unit of the Pyrenees took place at a roughly constant rate of $\approx 4.6 \mathrm{~mm} / \mathrm{yr}$ over 5 m.y. in the late Eocene and early Oligocene. In the eastern Salt Range and Potwar Plateau of Pakistan, the southern $100 \mathrm{~km}$ of the Himalayan collision zone has been shortening at an average rate of $7 \mathrm{~mm} / \mathrm{yr}$ since $2.5 \mathrm{Ma}$ (Pennock et al., 1989). Further west the Potwar Plateau has undergone only very slight shortening since ca. $2 \mathrm{Ma}$, but coeval slip on the frontal Salt Range Thrust has occurred at an average rate of 9-14 $\mathrm{mm} / \mathrm{yr}$ (Baker et al., 1988). In a section of the Molasse Basin adjacent to the Central Alps in Switzerland, Pfiffner (1986) estimated shortening rates during two orogenic pulses in the mid-Oligocene and early Miocene to have been $7-10 \mathrm{~mm} / \mathrm{yr}$.

Deformation rates have also been determined in the frontal parts of some landwardverging thrust belts above subduction zones ('retro-arc' systems). Wiltschko and Dorr (1983) calcuated average slip rates in the range $5 \pm 5 \mathrm{~mm} / \mathrm{yr}$ for thrusts in the Sevier belt of Idaho, Wyoming and Utah. In South America, Roeder (1988) suggested an average rate of transport on the sole thrust of the sub-Andean zone of northwest Bolivia of 27 $\mathrm{mm} / \mathrm{yr}$ since ca. $5 \mathrm{Ma}$. For the same structure in Argentina, a compilation of published work by Jordan et al. (1988) suggested an average shortening rate of $15-30 \mathrm{~mm} / \mathrm{yr}$ in the last 3-5 Ma. Across the $\approx 40 \mathrm{~km}$ wide Precordillera of northwest Argentina, Jordan et al. (1988) gave an average shortening rate of $6-7 \mathrm{~mm} / \mathrm{yr}$ since $8.5 \mathrm{Ma}$.

The most important factor which could influence the deformation rate at a thrust front is probably the plate convergence rate. However, many other factors are also likely to be important. The reasons for differences between particular examples must thus be evaluated carefully. It is sufficient to note here that the (poorly constrained) average minimum shortening rate across the frontal part of the East Coast Allochthon is at the lower end of the range of shortening/slip rates determined at the fronts of other fold and thrust belts.

\subsubsection{Conclusions}

Problems with biostratigraphic correlations and apparent geometric inconsistencies in some parts of Stoneley's (1968) map mean that before any study of the southern zone of 
the East Coast Allochthon can be considered authoritative, the area should be remapped. Nonetheless, the following conclusions were drawn from the present study:

1) The southern zone of the East Coast Allochthon is the $\approx 18 \mathrm{~km}$ wide region of imbricated Paleocene to Early Miocene rocks between the frontal thrust (Mangatawa Slide) and a thrust carrying the Whangai Formation ("Teurian") of the central zone. It comprises at least 15 northwest-striking, southwest-vergent thrust sheets above a sole thrust and a little-deformed autochthon which are exposed in the northwest due to the gentle southeasterly regional pitch. The thrust sheets are covered by late Early Miocene postorogenic sediments to the southeast.

2) The sole thrust is approximately planar in northeast-southwest sections along most of its length. It follows unconformities in the stratigraphic succession. The thrust system above it is an emergent imbricate fan, although at least two horses and one blind imbricate are also present. Footwall synclines are present beneath some thrusts. Parts of the autochthon are also folded.

3) Three groups of thrust sheets with slightly different transport directions can be distinguished: sheets I-IV moved toward $\approx 204^{\circ}$, sheets VI-IX moved toward $\approx 210^{\circ}$ $219^{\circ}$, and sheets $\mathrm{X}-\mathrm{XIV}$ (and probably XVI) moved toward $\approx 237^{\circ}$. Although sheet $\mathrm{V}$ has a similar strike to sheets I-IV, it moved as a horse attached to sheet VI.

4) Both stratigraphic and structural relations show that thrusting generally progressed from northeast to southwest, although some out-of-sequence thrusting did take place. Detachment folds formed ahead of some of the thrusts. The sequence of thrusting and the geometry of the system are compatible with thrusting in response to a push from the rear rather than by gravity sliding of individual sheets or groups of sheets.

5) Angular unconformities reveal the following kinematic history: sheet VII first moved in the mid-Waitakian (ca. $23 \mathrm{Ma}$ ), while higher sheets may have started to move slightly earlier; sheet VI moved in the mid-Waitakian, possibly during the late Waitakian, and after the early Otaian (ca. $21 \mathrm{Ma}$ ); sheets I-IV first moved after the early Otaian; and all thrusting ceased before the "Awamoan"-early Altonian (late Otaian-early Altonian; ca. $19 \mathrm{Ma}$ ). All thrusting therefore took place during $\approx 4-5$ m.y. in the Early Miocene. The dates on the unconformities have large uncertainties.

6) A partially restorable cross-section through the northwestern part of the structure suggests that shortening of sheets VI and lower was at least $10.5 \mathrm{~km}(48 \%)$ and that shortening of sheets X-XII was at least $2.4 \mathrm{~km}(50 \%)$. The entire section $(\approx 18 \mathrm{~km})$ is estimated to have shortened at least $50 \%$. 
7) Approximate minimum shortening rates were: $2.6 \mathrm{~mm} / \mathrm{yr}$ in sheets I-VI between ca. 23 and ca. $19 \mathrm{Ma}, 3.2 \mathrm{~mm} / \mathrm{yr}$ in sheets I-VI between ca. 21 and ca. $19 \mathrm{Ma}$, and an estimated $3.6 \mathrm{~mm} / \mathrm{yr}$ across the whole section between ca. 24 and ca. 19 Ma. Uncertainties in dating translate to errors of $\pm 20 \%-100 \%$ in the minimum shortening rates. Frrors in the cross section configuration sovoul aud to these. These minimum shortening rates are at the lower end of the range of shortening and slip rates determined in the frontal parts of both collisional and retro-arc thrust belts elsewhere.

\subsection{THE CENTRAL ZONE}

\subsubsection{Introduction}

The central zone of the East Coast Allochthon is the $\approx 45 \mathrm{~km}$ long, northeast- to east-trending strip of mid-Cretaceous to Early Miocene rocks between the sub-Whangai thrust which bounds the southern zone and the western Ihungia Fault (Figs. 6.1, 6.7). The southeasterly structural pitch of the southern zone continues into the central zone, swinging more southerly in the north, and results in exposure of its lower boundary (Te Rata Thrust and Waitahaia Fault) and the underlying Cretaceous to Paleocene autochthon in the northwest. To the southeast, the allochthon is tectonically overlain by Early Miocene rocks along a low-angle normal fault (the Whakoau Fault) which is itself cut by a number of high-angle faults including the Opossum Creek Fault (section 4.7).

Much of the central zone has recently been mapped at 1:50,000 by Mazengarb et al. (1991). The southwestern part was covered at 1:250,000 by Moore et al. (1989) and at $1: 63,360$ by Stoneley (1968), but Stoneley's mapping in that area was largely speculative. Large-scale maps of the northwestern part were given by Kenny (1980, 1984a, 1986) and in the present study (parts of Maps 1 and 2). Information from Moore et al. (1989), Mazengarb et al. (1991) and the present study was compiled at 1:100,000 to produce the map of the central zone shown as Fig. 6.7.

Neither Moore et al. (1989) nor Mazengarb et al. (1991) discussed the structure of the area in any detail. Mazengarb et al. (1991) presented two cross-sections through the area, but these were constructed in the southeasterly dip direction rather than in the thrust transport direction, which was southwestward (section 4.6.5). In the following, a new, 1:100,000 scale, northeast-southwest profile section is presented, and the structure and tectonic evolution of the area are discussed. 


\subsubsection{Tectonostratigraphy}

The stratigraphy in and adjacent to the central zone of the East Coast Allochthon is most conveniently described in terms of autochthonous, allochthonous, and postallochthon units. The autochthon southwest of the western Ihungia Fault is the Motu Block of Moore (1988a), the stratigraphy of which was described in sections 2.2.1.2 and 2.2.1.3. The stratigraphy of the area northeast of the western Ihungia Fault was described in sections 3.2 and 4.2. The Haumurian-Teurian rocks of the latter area are included on Fig. 6.7 with Whangai Formation.

Mazengarb et al. (1991) assigned the rocks in the allochthon to three groups: Ruatoria, Tinui and Mangatu. Their "undifferentiated Ruatoria Group" consists of Urutawan-Ngaterian rocks including those mapped in this study in the lower Mata River and Ihungia-Puketoro areas as Mokoiwi Formation (sections 3.2.1 and 4.2.1) and those mapped further south by Kenny (1986) as "allochthonous Waitahaia Formation". On Fig. 6.7, all these rocks are mapped as "lower Ruatoria Group". The Raukumara to Mata age Tikihore Formation (sections 2.2.2.1 and 3.2.3), in the upper Ruatoria Group, is shown separately. Tinui Group (Haumurian-Teurian) rocks in the allochthon are the Whangai and Waipawa Formations. The latter is present in the southeast as small outcrops which Mazengarb et al. (1991) did not separate from Whangai Formation, and as narrow slivers which are included on Fig. 6.7 with the lower Mangatu Group so as to differentiate them from the large mass of Whangai in that area.

The Mangatu Group was divided by Mazengarb et al. (1991) into two parts, lower and upper. Their lower part comprises marl, greensand and mudstone of PaleoceneEocene age. Their upper part comprises limestone, glauconitic sandstone and calcareous mudstone of Oligocene and possibly Waitakian age, and limestone, alternating sandstone and mudstone, mudstone, breccia and sandstone of Waitakian-Otaian age. The Oligocene rocks include the limestone/greensand lithotype of the Ihungia-Puketoro area (section 4.2.8) and the Waitakian-Otaian rocks include the Opossum Creek sandstone lithofacies and sandstone/breccia lithotype (sections 4.2.9 and 4.2.10). These Waitakian-Otaian rocks were deposited during allochthon emplacement; the limestone unconformably overlies allochthonous Tikihore Formation in the central part of the zone (Mazengarb et al., 1991, p. 21). Because of their tectonic significance, the Waitakian-Otaian rocks are mapped separately, where possible, on Fig. 6.7. "Mangatu Group" on the Figure thus refers to Oligocene and older rocks, in agreement with earlier usage (e.g., Moore et al., 1986, 1989; see also sections 2.1.2.2, 2.3.1, Table 2.1). Because the Oligocene and Waitakian-Otaian limestones are very similar in appearance, Mazengarb et al. (1991) were unable to differentiate every occurrence. Thus, Fig. 6.7 also shows areas of "undifferentiated Landon limestone". Most of these are close to limestone of known Oligocene age, and are 

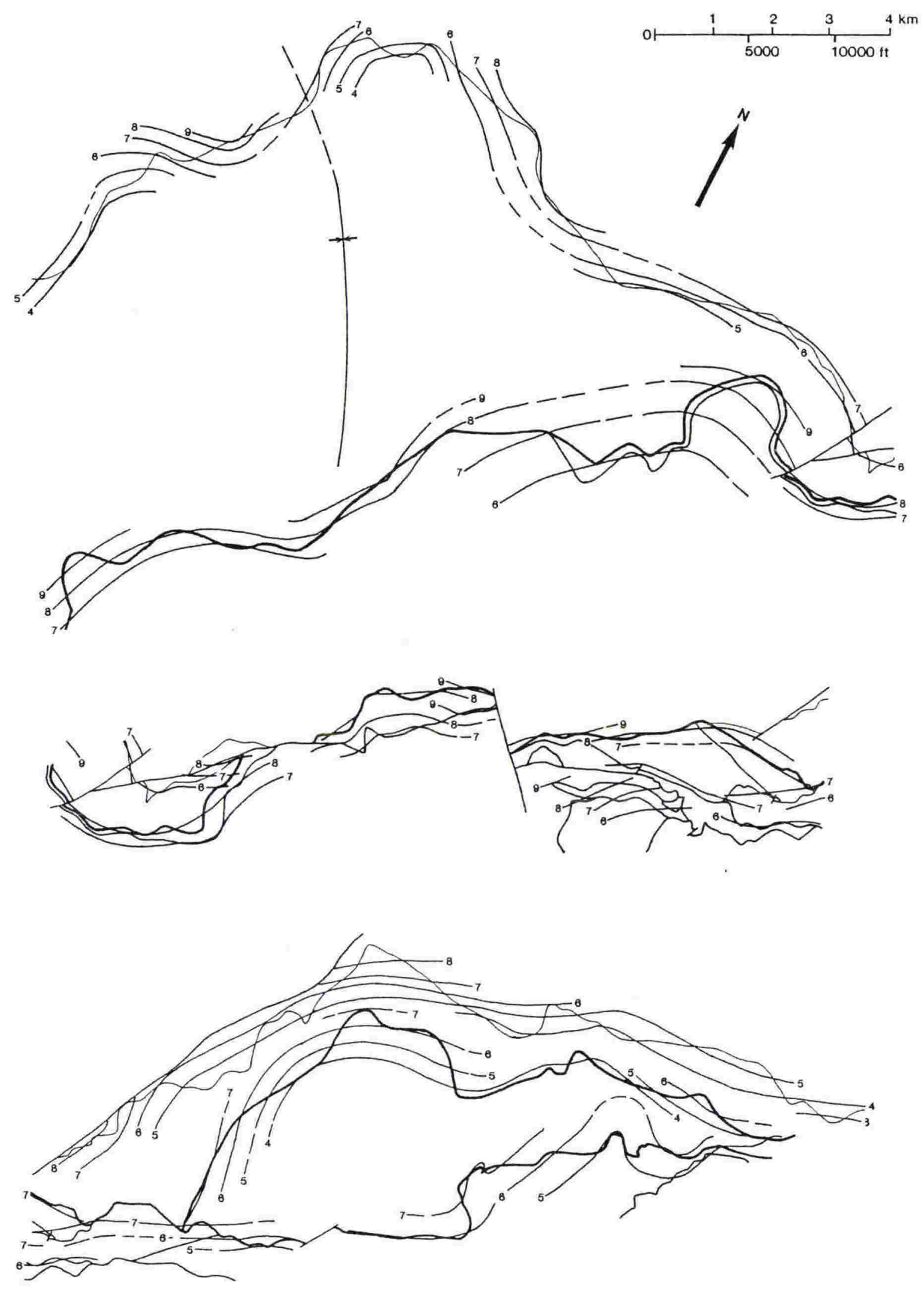

Figure 6.8: Structure contours on major structures in the central zone of the East Coast Allochthon. Contours were derived from NZMS 260 topographic maps X16, Y16 and Y15 $(1: 50,000)$. Values are in hundreds of metres above sea-level. 
therefore probably also Oligocene; limestones of proven Waitakian-Otaian age are present only in the central part of the zone.

The rocks tectonically overlying the East Coast Allochthon along the Whakoau, Opossum Creek and other faults are all assigned on Fig. 6.7 to the Tolaga Group, following Mazengarb et al. (1991). This includes rocks mapped as Thungia Formation in the Ihungia-Puketoro area (section 4.2.11; Map 2).

\subsubsection{Geometries of Major Structures}

Structure contours on the base of the Whangai Formation and on some of the thrusts in the central zone are shown in Fig. 6.8. The contours on the base of the Whangai show it to be gently folded. The non-parallelism of these contours with those on the Te Rata and Waitahaia thrusts - which lie at the top of the Whangai Formation-show that the folding is non-cylindrical. Also, its wavelength and amplitude change along the length of the zone. The contours on the thrusts in the central part of the zone and on the northeastern end of the Te Rata Thrust show that those structures also are not planar. However, the contours do show that all structures have a south-southeasterly component of dip, reflecting the regional structural pitch. In the southwest, this component is $\approx$ $5^{\circ}-28^{\circ}$ on the base of the Whangai and $\approx 10^{\circ}-27^{\circ}$ on the Te Rata Thrust; on the closely spaced thrusts of the central area, it is $\approx 12^{\circ}-27^{\circ}$; and in the northeast, it is $\approx 14^{\circ}-28^{\circ}$ on the base of the Whangai, $\approx 6^{\circ}-27^{\circ}$ on the Waitahaia Fault, and $\approx 10^{\circ}-24^{\circ}$ on the Te Rata Thrust.

\subsubsection{Profile Construction}

Two profiles across the central zone of the East Coast Allochthon are shown in Fig. 6.9. The northeastern profile, $G-G^{\prime}$, was presented in Chapter 4 and is based on data from the author's mapping in the Ihungia-Puketoro area. The southwestern profile, O-O', is derived from the maps of Mazengarb et al. (1991) and Moore et al. (1989). Its line was chosen to pass through or close to the major structures, to lie at a high angle to the southeast to south-southeasterly regional pitch, to lie close to the southwestward thrust transport direction, and so that its ends lie close to the ends of sections $\mathrm{N}-\mathrm{N}^{\prime}$ (southern zone) and $\mathrm{G}-\mathrm{G}^{\prime}$.

Like section $\mathrm{G}^{\prime} \mathrm{G}^{\prime}$, section $\mathrm{O}-\mathrm{O}^{\prime}$ was constructed as a profile to take advantage of the regional structural pitch. Because of the long (up to $12 \mathrm{~km}$ ) distances involved, however, projection of the markedly non-cylindrical map structure along a single straight axis onto a perpendicular profile plane gives innaccurate results. To circumvent this problem, the structures on the map were first projected, then adjusted to obey the conditions and 

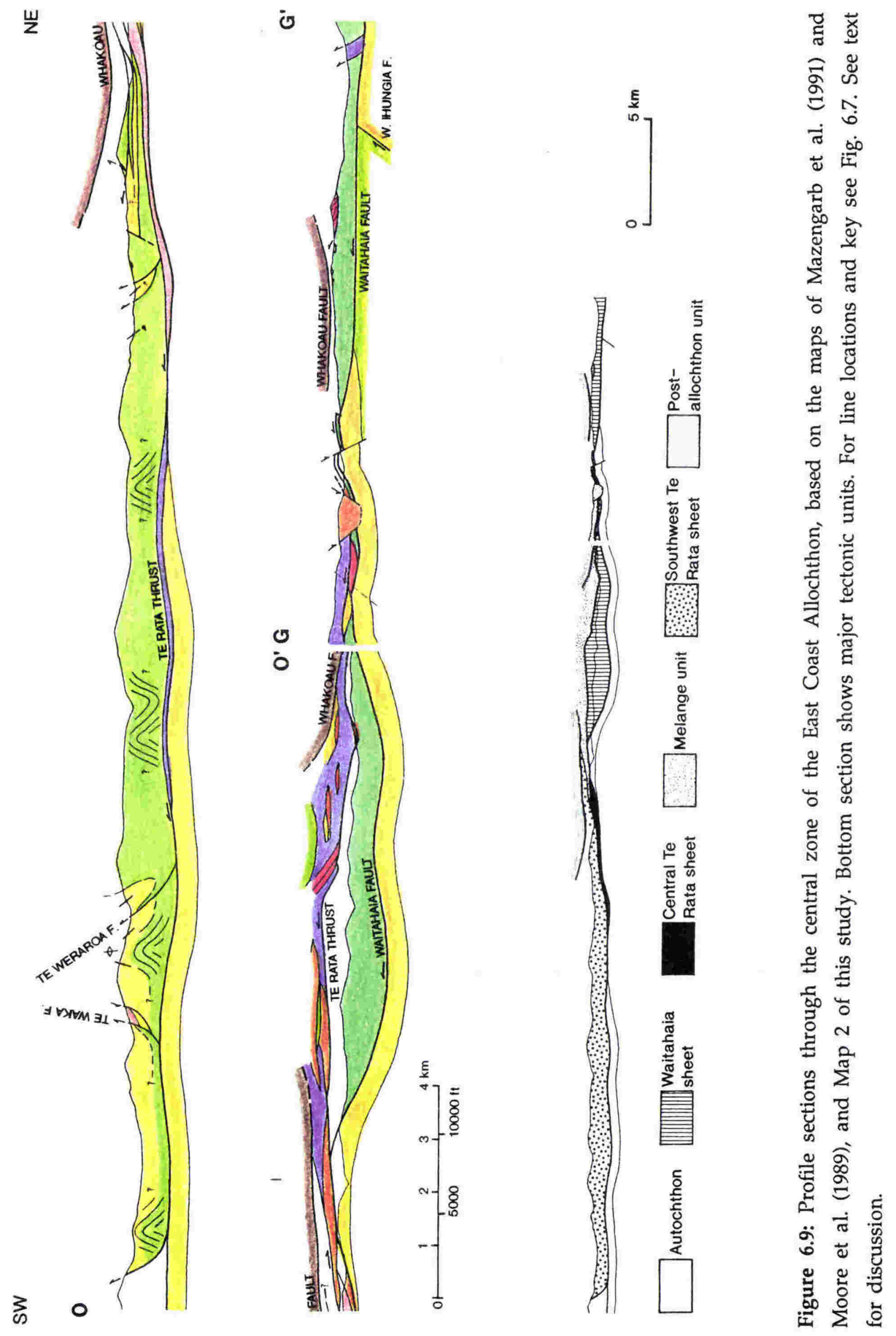
assumptions outlined in the following paragraphs. Section $\mathrm{O}-\mathrm{O}^{\prime}$ is thus "downplunge constrained" rather than being a rigorous downplunge profile. Two axes, one perpendicular to each segment of the bent profile line, were used for the projection. The plunges of both were $20^{\circ}$, this being the approximate average of the south-southeasterly dip components of the major structures (section 6.3.3, Fig. 6.8). The two segments of the profile plane dip northwestward at $70^{\circ}$; line $\mathrm{O}-\mathrm{O}^{\prime}$ on Fig. 6.9 is their $500 \mathrm{~m}$ elevation. The topographic profile along line $\mathrm{O}-\mathrm{O}^{\prime}$ is shown for reference.

Projection of the Waitahaia Fault and the base of the northeastern outcrop of Whangai Formation onto profile $\mathrm{O}-\mathrm{O}^{\prime}$ suggested some discordance between those two structures. It is known, however, that the Waitahaia Fault lies at or near the top of the Whangai for its entire length (Kenny, 1986; C. Mazengarb, pers. comm., 1991). The Waitahaia Fault is the closer structure to the profile line; its geometry on Fig. 6.9 follows that suggested by the projection fairly closely, but has been smoothed somewhat. The base of the Whangai is depicted a constant 350-400 m below the thrust, in accordance with measured thicknesses (Moore, 1988b; see also sections 2.2.1, 4.2.6). The geometry of the northeastern part of the Te Rata Thrust has not been modified from its projected configuration. Only the larger of the numerous thrust sheets above it are shown on Fig. 6.9, and their configurations are partly derived from projection, partly schematic. The segment of the Whakoau Fault adjacent to the northeastern part of the line is shown with its projected geometry. Note that the truncation of the Tolaga Group at the end of line $\mathrm{O}-\mathrm{O}^{\prime}$ is due to the effect of the Opossum Creek Fault having been removed from the adjacent section $\mathrm{G}-\mathrm{G}^{\prime}$.

The position of the Whakoau Fault in the central part of profile $\mathrm{O}-\mathrm{O}^{\prime}$ was raised somewhat from its projected position because its dip is greater than $20^{\circ}$. The closely spaced thrusts in the central area are shown in essentially their projected configurations. The high-angle fault which offsets the Te Rata thrust results in the structures to its southwest projecting approximately $200 \mathrm{~m}$ deeper than the structures to its northeast. Mazengarb et al. (1991) do not show this fault persisting into the area of line $\mathrm{O}-\mathrm{O}^{\prime}$, so its effect was removed on Fig. 6.9 by raising the southwestern side. The structures between the high-angle fault and the southward embayment in the Te Rata Thrust are also smoothed somewhat. Between the embayment and the southwest end of the profile, the northwestward shift of the Te Rata Thrust results in its projected position being approximately $800 \mathrm{~m}$ below the correlative structure at the end of the overlapping section $\mathrm{N}-\mathrm{N}^{\prime}$ (Fig. 6.6). Its depth on $\mathrm{N}-\mathrm{N}^{\prime}$ is considered the better constrained (section 6.2.3.1), so it was raised by $800 \mathrm{~m}$ on $\mathrm{O}-\mathrm{O}^{\prime}$. The gently folded geometry suggested by the projection is shown on the Figure slightly smoothed. The northwestward shift in the base of the Whangai between the embayment and the southwest end of the profile results in a greatly exaggerated projected thickness for the formation. As in the northeast, its 
thickness was taken as $350-400 \mathrm{~m}$; its base is shown at that depth below the Te Rata Thrust except where it is cut out on the east side of the embayment.

The Te Weraroa and Te Waka Faults and the faults surrounding the sliver of Whangai in the central area appear to dip moderately to steeply based on their relations with topography. They are depicted on Fig. 6.9 with the presumption that they shallow into the underlying thrusts. The folds depicted in the Tikihore and Whangai Formations are schematic, except in one case where opposing dips are shown. All these structures are discussed in more detail in the succeeding section.

\subsubsection{Structure and Kinematics}

\subsubsection{Tectonic Units}

The central zone of the East Coast Allochthon and its immediate surroundings can be subdivided into a number of tectonic units (Fig. 6.9). These are, from bottom to top: the autochthon; the Waitahaia sheet; the central Te Rata sheet; the mélange unit, which includes the rocks above the northern Te Rata Thrust and the slivers of CretaceousMiocene rocks beneath it in the northeast; the southwest Te Rata sheet; and the postallochthon unit, above the Whakoau Fault. The structure of and relationships between these units are described below.

\section{Autochthon:}

The autochthonous rocks beneath the sub-Whangai unconformity were folded and faulted during middle and Late Cretaceous tectonic events. The Whangai Formation itself is gently folded. The Waitahaia Fault cuts up-section through the Whangai across a monocline west of the western Thungia Fault, and the Te Rata Thrust cuts through the Whangai across an antiform east of the Arowhana Fault (Figs. 6.7, 6.9). The high adjacent to the western Ihungia Fault has been shown to be the result of uplift on that fault in post-Whangai (probably immediately pre-allochthon) times (sections 3.6.3, 3.6.4, 4.4.4). The high adjacent to the Arowhana Fault suggests that fault, a major Late Cretaceous structure like the Ihungia (Mazengarb, 1989), may also have been reactivated during the early stages of allochthon emplacement. Southwest of the Arowhana Fault, the structure of the Whangai is a broad, gentle synclinorium containing gentle second-order warps with wavelengths of 5-6 km (Figs. 6.8, 6.9).

\section{Waitahaia Sheet:}

The Waitahaia sheet is preserved only northeast of the structural high adjacent to the Arowhana Fault (Figs. 6.7, 6.9). Over most of its length, the Waitahaia Fault at its base lies at or near the top of the Whangai Formation. A few thin slivers of Waipawa 
Formation are present beneath it at places (Kenny, 1986). To the northeast, it cuts downsection through the Whangai and Waitahaia Formations, across the western Ihungia Fault, and onto Haumurian-Teurian rocks. The Waitahaia sheet consists entirely of complexly deformed lower Ruatoria Group except in the extreme northeast, where there is an infaulted sliver of mélange dominated by Haumurian-Teurian rocks (section 4.6.1). The sheet is overlain by the mélange unit along the Te Rata Thrust, and, in the northeast, by the post-allochthon unit (Tolaga Group) along the Whakoau Fault.

\section{Central Te Rata Sheet:}

The central Te Rata sheet overlies autochthonous Whangai and Waitahaia Formations along the Te Rata Thrust in the central part of the area (Figs. 6.7, 6.9). It is internally faulted, consisting of lenses of lower Mangatu Group (alternating glauconitic sandstone and mudstone; Mazengarb et al., 1991) and Waitakian-Otaian synorogenic sediments. Its eastern extremity is overlain by the mélange unit and the rest of its length is overlain by the southwest Te Rata sheet. The similarity of lithologies suggests that the central Te Rata sheet is closely related to the mélange unit.

\section{Mélange Unit:}

The mélange unit includes the complex mass of Cretaceous-Miocene rocks above the Te Rata Thrust in the northeastern part of the zone, and the allochthonous Late Cretaceous-Miocene rocks in the Ihungia-Puketoro area (Figs. 6.7, 6.9). At the map scale, this unit comprises slices of competent lithologies surrounded by a mélange-which contains smaller blocks of the same lithologies-with a matrix dominated by smectite mudstone (e.g., section 4.2.7). In general, the larger sheets in the mélange unit are stacked so that older rocks overlie younger: Whangai and Tikihore Formations occur toward the top (southeast) of the unit, and Oligocene limestone occurs nearer the base. This shows that piggy-back (forward and downward) thrust propagation operated during assembly of the mélange unit. Reversals in this general stacking order and the occurrence of the mobile mélange surrounding all of the sheets, however, show that out-of-sequence thrusting has also taken place (see also section 4.8.2). The presence of Waitakian-Otaian marine synorogenic sediments at all levels in the thrust pile including along its base shows that they were incorporated after deposition both in front of and on top of the moving sheet, and that the mélange unit was emplaced along the seafloor.

The southwest end of the mélange unit cuts across both the Waitahaia and central Te Rata sheets (Figs. 6.7, 6.9). That the mélange unit truncates the Waitahaia Fault rather than is folded by it is clearly shown by the structure contour pattern (Fig. 6.8). The southwestern extremity of the mélange unit is overlain by the southwest Te Rata sheet (Figs. 6.7, 6.9). 


\section{Southwest Te Rata Sheet:}

The southwest Te Rata sheet is the large mass of mostly Tikihore and Whangai Formations which occupies the southwestern half of the central zone (Figs. 6.7, 6.9). Its front is the sub-Whangai thrust which separates the central and southern zones. At its northeastern end, its base overlies the mélange unit and the central Te Rata sheet. In the autochthon southwest of the Arowhana high it cuts up-section to the top of the Whangai Formation, at which horizon it lies for the remainder of its length. A thin sliver of smectitic mélange is present along the central portion of the Te Rata Thrust. Along the Te Rata Thrust the gross structure of the sheet appears to be a hangingwall ramp, Tikihore Formation in the northeast giving way across a stratigraphic contact to Whangai Formation in the southwest. However, inliers south of the Te Rata Thrust show that Tikihore Formation is present at the base of the sheet there; the apparent hangingwall ramp also has a lateral component, the sole thrust cutting up-section to the northwest.

The internal structure of the sheet is complex. In the northeast, Tikihore and Whangai Formations are interleaved along a series of closely spaced thrusts (Fig. 6.9). A sliver of rocks mapped by Mazengarb et al. (1991) as questionably lower Ruatoria Group is present near the bottom of the pile. Toward the top of the pile, slivers of upper Mangatu limestone are present, as are small unconformable outliers of Waitakian-Otaian limestone which show that this part of the structure was emergent for a time during deformation. In the northern extremity of the sheet, structures within it are truncated by the fault at its base, showing its out-of-sequence character. Further southwest, bedding attitudes (Black, 1980; Mazengarb et al., 1991) show the Tikihore and Whangai Formations to be folded on a variety of scales about a northwest-trending axis. The data are not sufficient to allow reconstruction of the folds and estimation of the amount of shortening; the folds shown on Fig. 6.9 are schematic. The Te Weraroa and Te Waka Faults and less persistent faults further south juxtapose Tikihore Formation, Waipawa Formation, and lower Mangatu Group with Whangai Formation. The throws of the Te Weraroa and Te Waka Faults are on the order of a few hundred metres (Fig. 6.9). The Te Waka Fault is a late backthrust; it cuts the Te Weraroa Fault. Other thrusts similar to the Te Weraroa and Te Waka Faults are probably present within the poorly exposed, lithologically uniform masses of Tikihore and Whangai Formations comprising the bulk of the sheet.

\section{Post-Allochthon Unit:}

The Tolaga Group rocks which overlie the East Coast Allochthon along the low-angle Whakoau and associated high-angle faults constitute the post-allochthon unit. The structure of the rocks within this unit is far simpler than that of those within the allochthon. In general, the Tolaga Group rocks dip and young southeastwards into the northeast-trending Tutamoe Syncline (Mazengarb et al., 1991); only the older (Waitakian 
to Altonian) rocks close to the lower (northwest) boundary of the unit show gentle to open folding on the northwest structural trend which dominates the allochthon. The change in structural style across the Whakoau and associated faults shows that they are major tectonic boundaries (see also section 4.7).

\subsubsection{Thrust Sequence and Timing}

The earliest southwest-directed thrusting in the central zone took place along the Waitahaia Fault. The Waitahaia sheet was emplaced across the western Ihungia Fault, which was active immediately prior to arrival of the sheet, and onto the Whangai Formation to the southwest. During its emplacement the Waitahaia sheet was internally shortened, as shown by the complex folding of the Mokoiwi Formation and the infaulting and deformation of a strip of rocks from its undermass (section 4.6.1). It was subsequently folded, eroded down to the level of the Mokoiwi Formation, and cut across by the mélange unit, which incorporated some of the products of that erosion along its base.

The Tikihore and Whangai Formations of the southwest Te Rata sheet may originally have been part of the Waitahaia sheet, or they may have been thrust over it together with the mélange unit. If they were part of it, there are two possibilities: they may have lain ahead of the Mokoiwi Formation, in their present postion; or they may have been on top of it, moving in front along an out-of-sequence thrust during the subsequent emplacement of the mélange unit. The first possibility is appealing as it leads to interpretation of the Mokoiwi-Tikihore-Whangai cutoff sequence along the sole thrust as a large-scale hangingwall ramp, which was modified slightly around the Arowhana high by faulting associated with the emplacement of the mélange unit. It is flawed, however, in that it does not adequately explain what happened to the Mangatu Group which originally overlay the Whangai Formation northeast of the Arowhana inlier, as discussed below.

Assuming 50\% shortening (section 6.2.3.3), the Mangatu rocks at the back of the southern zone restore approximately $18 \mathrm{~km}$ to around the southwest side of the Arowhana high. If it lay at the front of the Waitahaia sheet, the southwest Te Rata sheet would have moved along the Whangai/Mangatu interface from just southwest of the Ihungia Fault, 20-25 km northeast of the restored limit of the southern zone. While some of the Mangatu rocks could have been overridden to form the central Te Rata sheet and the mélange sliver southwest of it, most would have been bulldozed ahead of the advancing allochthon. Assuming 50\% shortening, there should therefore be at least another $10 \mathrm{~km}$ of imbricated Mangatu rocks between the present limit of the southern zone and the Whangai Formation at the front of the southwest Te Rata sheet. The 
removal of these rocks is difficult to explain; their imbrication followed by their erosion and then imbrication of the southern zone seems very unlikely.

The second possibility is not feasible. The southwest Te Rata rocks cannot have moved off originally subjacent Mokoiwi Formation during emplacement of the mélange unit because synorogenic breccias at its base show that the latter was emplaced along the surface; it must have had a 'toe' which overrode the eroding material, and therefore there must have been free space in front of it.

If the Whangai and Tikihore Formations of the southwest $\mathrm{Te}$ Rata sheet did not originally lie in front or on top of the Waitahaia sheet, they must have been emplaced over it in association with the central Te Rata/mélange unit. The present position of the southwest Te Rata sheet on top of the mélange unit (Fig. 6.9) suggests that it was emplaced piggy-back onto the mélange from behind and subsequently cut down across it, possibly by out-of-sequence thrusting in response to the growth of the Arowhana high (see later) which would have acted as a buttress to movement of the lower sheets. However, the mélange unit continues across the northern zone (section 6.4.3.1). From the front of the southwest Te Rata sheet to the back of the mélange unit is approximately 80 $\mathrm{km}$. As the mélange must have been transported from behind the Waitahaia sheet to its present position, its minimum displacement is $40 \mathrm{~km}$ (see Figs. 6.7, 6.10). Also, the complex structure of the Te Rata/mélange unit shows shows that it has undergone considerable internal shortening; $50 \%$ is a conservative estimate (see also section 6.4.3.3). Therefore, if the southwest $\mathrm{Te}$ Rata sheet originally lay behind the mélange unit, its displacement would be around $200 \mathrm{~km}$. For a sheet so close to the front of a thrust belt, this figure is unreasonably large.

Rather than originating behind the mélange unit, the southwest Te Rata sheet is likely to have been derived from in front of it. Northeast of the Mokoiwi inlier, a large sheet of Tikihore Formation is underlain by a northeast-directed, probably reactivated Cretaceous thrust with Tapuwaeroa and Whangai Formations in its footwall (see Figs $6.10,6.11)$. It is thought that the central Te Rata/mélange unit was initially assembled northeast of this fault, and that during southwestward propagation of the sub-mélange thrust this fault was breached, leading to the accretion of a large mass of Whangai and Tikihore rocks - the present southwest Te Rata sheet-to the front of the mélange unit (see also section 6.4.3.2). The fault beneath this composite unit is thought to then have cut through the Mokoiwi inlier (see Fig. 6.13) and then southwestward across the Waitahaia sheet, emplacing the Te Rata/mélange unit in its present position. The fault beneath the northeast end of the southwest Te Rata sheet is in this scenario a backthrust (note the arrow on Fig. 6.9); motion on it may have continued during transport, accomodating shortening within the moving allochthon. The minimum displacement of 
the southwest Te Rata sheet in this scenario is just the distance from its present southwestern limit to the northern edge of the Mokoiwi inlier.

Figures 6.7 and 6.9 show that the Te Rata Thrust cuts across the Whangai Formation on either side of the Arowhana high, down-section in the transport direction on the northeast side and up-section on the southwest side. The figures also show that the Waitahaia Fault is folded with the Whangai Formation northeast of the high. These two observations show that growth of the high and folding of the Waitahaia sheet took place prior to the emplacement of the Te Rata/mélange unit. Lower Ruatoria rocks of the Waitahaia sheet, the Mangatu rocks which had been bulldozed in front of it, and the Whangai Formation of the autochthon would all have been eroded during this folding. When the Te Rata/mélange unit was emplaced across the high, its sole thrust propagated along the top of the uneroded Whangai to the southwest, and the southern zone was imbricated ahead of the advancing allochthon. Waitakian-Otaian lithotypes and the oldest Tolaga Group beds accumulated on top of this unit during its motion. Continued compression resulted in gentle folding of the southwest Te Rata sheet after its emplacement.

The sequence of deformation in the central zone, then, was as follows: emplacement, with internal deformation, of the Waitahaia sheet along the top of the Whangai Formation; folding and erosion of the Waitahaia sheet down to the level of the Mokoiwi Formation, associated with (probably fault-controlled) uplift and erosion of the Arowhana high; probably concurrent with this folding but further northeast, breaching of the Waitahaia sheet by a previously-assembled stack of Late Cretaceous-Early Tertiary rocks which include Whangai and Tikihore Formations formerly in the hangingwall of a northeast-directed thrust; and emplacement of this stack-with continued internal deformation-along the seafloor across exposed Mokoiwi Formation, across the Arowhana high onto the Whangai Formation to the southwest, piling up the Mangatu rocks of the southern zone ahead of it as it continued to move.

Constraints from stratigraphic relations, while not as well defined as those in the southern zone, show clearly that central zone thrusting began in the Waitakian and was active until some time in the Altonian (see also section 4.8.1). Carbonate/clastic transitions are present within the Waitakian both regionally (section 2.3) and within the central zone itself (e.g., sections 4.2.8, 4.2.9). late Waitakian-Otaian breccias and conglomerates containing clasts of Mokoiwi Formation and mélange unit lithologies show that those units were actively eroding during that period. The small outliers of late Waitakian-Otaian limestone which overlie Tikihore Formation in the central part of the zone show that the southwest Te Rata sheet was at the surface for at least part of that time, and the deformation of those outliers shows that the sheet continued to deform 
after their deposition. Close above the lower boundary of the post-allochthon unit, Waitakian-Altonian beds show northwest-trending, gentle folds which may have been produced by blind thrusting at depth. Younger Tolaga Group rocks dip consistently southeastward into the axis of the Tutamoe syncline. Generation of the northeast structural trend of the Tolaga Group and the faulting of its margin against the East Coast Allochthon occurred after the Middle Miocene (Kenny, 1984a, 1986; see also section 4.8.1).

\subsubsection{Amount of Thrust Transport}

The transport directions on the thrusts in the northeastern part of the central zone (section 4.6.5) and in the southern zone (section 6.2.2.1) have been established as southwestward. Transport on the thrusts linking these two areas must therefore be southwestward also. This southwestward transport direction and the fact that the sole thrust can be traced from beneath the southern zone to northeast of the western Ihungia Fault puts constraints on the minimum transport distances of the thrusts of the central zone.

The southwestern limit of the Waitahaia sheet is approximately $20 \mathrm{~km}$ southwest of the western Ihungia Fault. Northeast of that fault, the Mokoiwi inlier is itself allochthonous and the Aorangiwai Fault is probably a continuation of the Waitahaia Fault (section 4.8.3). Motuan rocks similar to the Mokoiwi Formation are present in the Mangaoporo area (section 2.2.2.1), $20 \mathrm{~km}$ northeast of the western Ihungia Fault. These underlie younger Tikihore Formation, however, and they have been exposed by PlioceneRecent uplift (see also section 6.4.3.2, Fig. 6.13); they would not have been present in the immediate footwall of the Waitahaia sheet. Younger rocks are present further northeast, so the Waitahaia sheet must have been derived from northeast of the present position of the Matakaoa Volcanics (see sections 6.4.3.2, 6.4.3.3). Its minimum displacement depends on its relationship with the overlying sheet prior to thrusting (discussed in section 7.3) but must be at least the distance between its present southwestern limit and the Matakaoa Volcanics, approximately $50 \mathrm{~km}$. Its present limit must be close to its original limit because the back of the southern zone-displaced after Waitahaia emplacement and erosion-restores to within about $10 \mathrm{~km}$ of it (section 6.3.5.2).

The amount of uplift on the Waitahaia Fault is uncertain. The Mangaoporo column (column 11, Fig. 2.3) and the typical thickness of the Whangai Formation (section 2.2) suggest that the fault has climbed over $6 \mathrm{~km}$ of section. However, the thickness of the Cretaceous succession is likely to have thinned northeastward (offshore) toward the original position of the Waitahaia sheet. 
The central Te Rata sheet, the mélange unit, and the southwest Te Rata sheet have all been thrust over the Waitahaia sheet, and thus must also have come from northeast of the Mokoiwi inlier. The truncation of Whangai Formation beneath the sole thrust around the Arowhana high suggests that some of the Whangai at the front of the southwest Te Rata sheet could have come from that area. However, the character of the allochthonous Whangai is different from that of the autochthon (Eastern Facies vs. Western Facies, respectively; Moore, 1988b), showing that all the Whangai now exposed in the southwest Te Rata sheet came from across the Ihungia Fault. The nearest possible footwall cutoffs of the Whangai and Tikihore Formations would have been along strike from the large area of present Tikihore exposure north of the Mokoiwi inlier (see also section 6.4.3.3); the minimum transport of the southwest Te Rata sheet is thus around 60 $\mathrm{km}$. In the most likely sequence of thrusting, the central Te Rata sheet and mélange unit originated behind the southwest Te Rata sheet (section 6.3.5.2). Minimum transport of the fronts of those sheets is therefore $60 \mathrm{~km}$, plus any shortening that occurred between them and the southwest Te Rata sheet, and within the southwest Te Rata sheet itself. If shortening was around $50 \%$ across the presently $25 \mathrm{~km}$ wide southwest Te Rata sheet, the fronts of the central Te Rata sheet and mélange unit would have been displaced at least about $85 \mathrm{~km}$.

The Whakoau Fault is a low angle normal fault which omits the original unconformable contact between the Tolaga Group and the East Coast Allochthon. It is at the northwestern limit of a regional structural association of northeast-striking, southeastside-down normal faults (Mazengarb, 1984; Mazengarb et al., 1991). The transport direction on the northeastern end of the Whakoau Fault, determined from the analysis of minor structures, is between east-southeast and south-southeast (section 4.7). The transport direction at other places along the fault is likely to be similar. The amount of section omitted by the Whakoau and associated high-angle faults is not known with any great precision. It was argued in sections 4.6 .4 and 4.7 that because the Tolaga Group is similar in age and lithology to the Opossum Creek sandstone and the basal Opossum Creek sandstone is similar in age and lithology to some pre-thrusting rocks of the allochthon, the total throw on the faults between the Tolaga Group and the allochthon in that area is in the order of hundreds of metres rather than of kilometers. Elsewhere, the predominance of upper Otaian to lower Altonian rocks along the hangingwall of the fault and the minimum thickness of $\approx 1000 \mathrm{~m}$ of the Otaian in the Tolaga Group type section (Mazengarb et al., 1991) suggests removal of around $1 \mathrm{~km}$ of strata from the hangingwall side. In the footwall, the thickness omitted is difficult to estimate but is probably not great, as slivers of synorogenic material probably deposited in basins on top of the allochthon are present close to the fault (Fig. 6.7). 
Examination of the central zone of the East Coast Allochthon during the present study has led to the following conclusions:

1) The central zone of the East Coast Allochthon is the $\approx 45 \mathrm{~km}$ long, northeast- to east-trending strip of complexly deformed mid-Cretaceous to Early Miocene rocks between the sub-Whangai thrust which bounds the southern zone and the western Ihungia Fault. Its lower boundary (Te Rata Thrust and Waitahaia Fault) and the underlying Cretaceous-Paleocene autochthon are exposed in the north due to the southeast to south-southeasterly regional pitch. The top of the zone is defined by the low-angle normal Whakoau Fault and associated high-angle faults.

2) The central zone and its immediate surroundings can be subdivided into five major tectonic units. These are, from bottom to top: the autochthon, comprising Whangai Formation unconformably overlying deformed mid- and Late Cretaceous rocks; the Waitahaia sheet, consisting mostly of complexly deformed Mokoiwi Formation; the central Te Rata sheet, comprising Early Tertiary and Early Miocene lithologies; the mélange unit, a complex stack of sheets of Late Cretaceous to Early Miocene rocks; the southwest Te Rata sheet, comprising deformed Tikihore, Whangai, and Waipawa Formations, Mangatu Group, and Waitakian-Otaian lithotypes; and the postallochthon unit, comprising structurally simple Tolaga Group rocks.

3) The autochthon is gently folded on a northwest trend. The faults at the base of the central zone generally follow the folds and lie at or near the top of the autochthonous Whangai Formation. Exceptions are west of the western Ihungia Fault, where the Waitahaia Fault cuts up-section southwestward from within Waitahaia Formation to the top of the Whangai; and around the Arowhana inlier, where the Te Rata Thrust cuts down-section through the Whangai, across mid-Cretaceous rocks, and then up-section through the Whangai from northeast to southwest.

4) Cross-cutting relations between the major sheets show that thrusting progressed in two stages. The first stage involved the emplacement of the Waitahaia sheet across the western Ihungia Fault-which was active immediately prior to that sheet's arrival-and southwestward to not far past its present limit. Emplacement was accompanied or closely followed by folding of the autochthon, uplift of the Arowhana inlier-probably in conjunction with movement on the Arowhana Faulterosion of the Waitahaia sheet down to the level of the Mokoiwi Formation, and erosion of the Whangai Formation from the Arowhana high. 
5) Probably concurrently with folding and erosion of the Waitahaia sheet and uplift of the Arowhana high, a stack of Late Cretaceous to Oligocene sheets and mélange was assembled by piggy-back thrusting northeast of the Mokoiwi inlier. The sole fault of this stack cut through a northeast-directed thrust with Tikihore Formation in its hangingwall, and the Tikihore and Whangai Formations of the present southwest Te Rata sheet were accreted to the front of the stack.

6) Subsequently, the sole fault of this stack breached the Mokoiwi inlier and the composite Te Rata/mélange unit was emplaced across the Waitahaia sheet. Thrusting during this stage was emergent, with terrigenous material eroding from the moving sheets and the underlying parautochthon and accreting beneath the thrust mass, or accumulating on top of it and being incorporated into it by continued deformation. Eventually this unit was emplaced across the Arowhana high and onto the Whangai Formation to the southwest, where it imbricated the Mangatu rocks of the southern zone ahead of it as it continued to move. Continued compression after emplacement led to gentle folding.

7) The onset of thrusting was marked by the appearance of terrigenous sediments in the Waitakian. Thrusting and concomitant sedimentation took place through the Waitakian and Otaian. The cessation of thrusting is probably marked by the dying out within the Altonian in the post-allochthon unit of gentle northwest-trending folds which probably formed due to blind thrusting beneath them.

8) Southwestward transport of the Waitahaia sheet was at least $50 \mathrm{~km}$, as no possible footwall equivalent is present southwest of the Matakaoa Volcanics. The minimum southwestward transport of the southwest Te Rata sheet is around $60 \mathrm{~km}$. If the southwest Te Rata sheet was shortened 50\%, the minimum transport of the central Te Rata sheet and mélange unit is around $85 \mathrm{~km}$. Transport on the Whakoau Fault, the low-angle normal fault marking the top of the East Coast Allochthon, was southeastward. The amount of section omitted in the hangingwall of this fault ranges up to at least $1 \mathrm{~km}$. The amount of section omitted in its footwall is uncertain, but is probably not great.

\subsection{THE NORTHERN ZONE}

\subsubsection{Introduction}

Northern zone of the East Coast Allochthon is the term used herein for the preMiocene rocks which underlie the northeastern end of Raukumara Peninsula (Figs. 6.1, 
6.10). Its boundaries are the coastline and the northeastern limits of the Urewera Group, Waitahaia Formation, and the Neogene rocks in the southeast. It is also taken to include the massifs of Mts. Hikurangi and Whanokao, which may be klippen of Taitai Sandstone (Gibson, 1987a). Important faults forming parts of the boundary are the Raukokore Fault, in the northwest; the Hukanui/Aorangiwai and western Ihungia Faults, in the central area; and the Whakoau Fault, the faults marking the southwestern boundary of the Te Puia inlier, and the Waikawa Fault, in the southeast (Fig. 6.10). The Mokoiwi Formation of the Waitahaia thrust sheet is continuous between the central and northern zones (compare Figs. 6.7 and 6.10); the zone boundary across that sheet is arbitrarily taken as the southeastward extension of the western Ihungia Fault. Note that the fault-bounded triangular area at the northwest end of the Mokoiwi inlier shown as Tikihore Formation on Fig. 6.10 was assigned to the Motu Block by Moore (1985, 1988a; see Fig. 1.3). The rocks in that area may be equivalent to the 'autochthonous' Waitahaia Formation to the south.

The southeast to south-southeasterly tilt seen in the southern and central zones is due to post-Early Pliocene uplift along the axis of the Raukumara Range. This uplift continues into the northern zone and has resulted in a core of structurally lower rocks in the centre of the peninsula being flanked by structurally higher rocks to the northwest and southeast. Unlike in the central and southern zones, however, this uplift has not led to the exposure of a sole thrust and underlying autochthon; the prevalence of northwesttrending folds and northwest-striking thrusts in the Late Cretaceous and Paleogene rocks of the northern zone shows that they all were affected by Early Miocene deformation (see also sections 3.8.2, 4.8.3).

Geological knowledge of most of the northern zone is poor compared to knowledge of the southern and central zones. The only detailed maps covering the pre-Miocene sedimentary rocks of the area are those of Moore (1957), who mapped the Cretaceous in the extreme northwest, and those of Laing (1971, 1972b, c, d) of parts of the southeast. Laing's maps, however, are suspect as they are based on patchy biostratigraphy, show few or no faults, and are known to be incorrect where there have been more recent investigations (e.g., Speden, 1976; Map 1). The only recent map, that of Moore et al. (1989), is at a scale of 1:250,000. The map of the northern zone shown as Fig. 6.10 was compiled from Moore et al. (1989) and Maps 1, 2 and 3 of this study. Because of the lack of detailed information and the complexity of the geology, any discussion of the structure of the northern zone can only be in broad terms and will be subject to many uncertainties. The following discussion, based on Fig. 6.10, on information presented in Chapters 2-5, and on information presented by Moore (1957), Gibson (1987a), and Mazengarb (1990), should be considered as preliminary. 


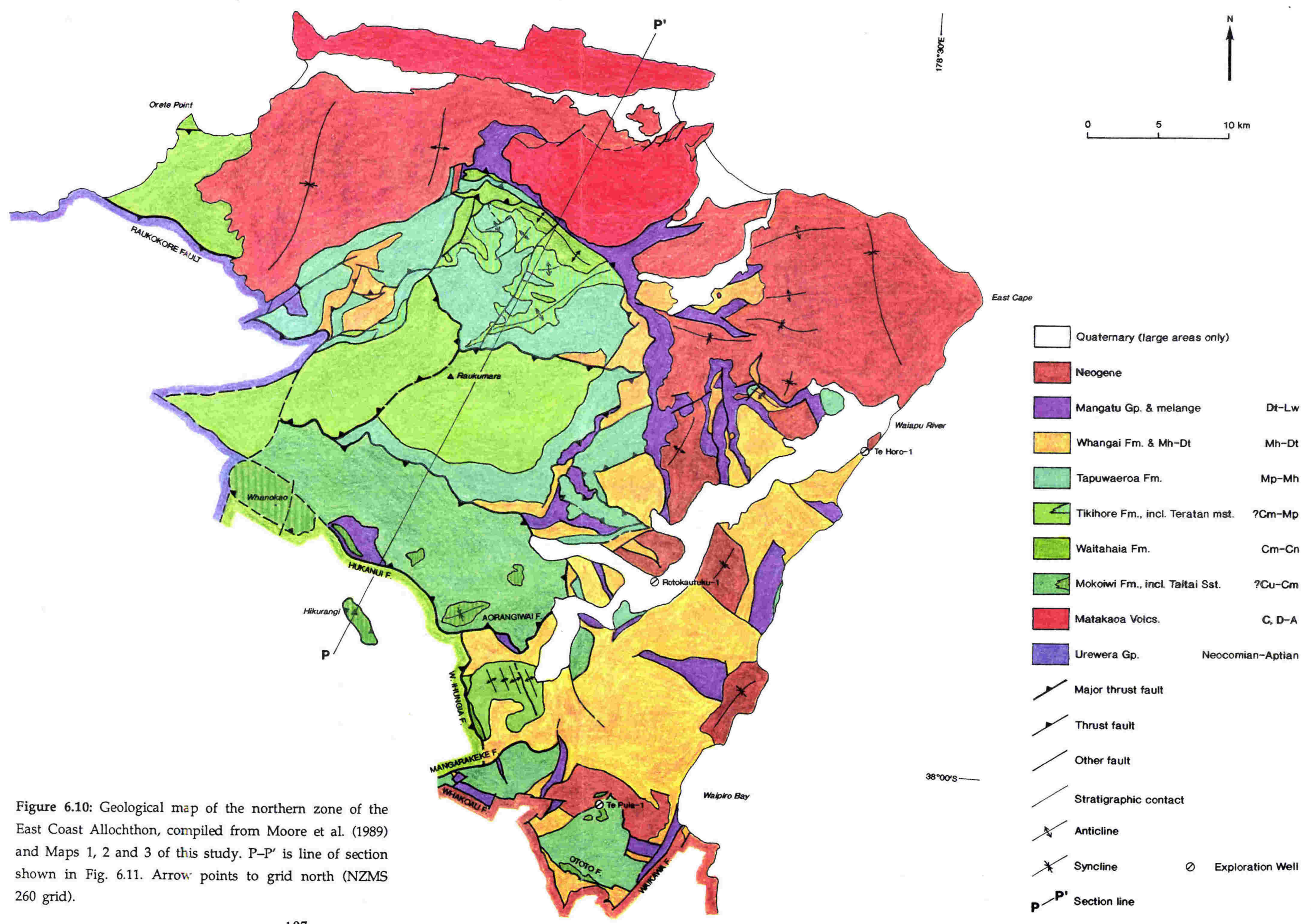


The stratigraphy of northeastern Raukumara Peninsula is described in general terms in section 2.2.2.1. The stratigraphies of the lower Mata River, Ihungia, and south Te Puia areas are described in sections 3.2, 4.2 and 5.2, respectively. On Fig. 6.10, the occurrences of ?Urutawan-Motuan siltstone, flysch and minor sandstone southeast of the Mokoiwi inlier are included in the Mokoiwi Formation, following the practice adopted in sections 4.2.1 and 5.2.1. The sandstone massifs of Hikurangi and Whanokao are also included in the Mokoiwi Formation, as they are similar to Taitai Sandstone (Gibson, 1987a). Late Cretaceous flysch is mapped as Tikihore Formation, following Mazengarb (1990) and section 3.2.3. In the area north of Raukumara (Fig. 6.10), a well developed, mainly Teratan mudstone unit (Mangaotane mudstone of Ongley and Macpherson, 1928, and others) was mapped separately by Moore et al. (1989). This is included as a member of the Tikihore Formation on Fig. 6.10. Piripauan-Haumurian Tapuwaeroa Formation was also distinguished by Moore et al. (1989) in some areas. Where Tapuwaeroa Formation overlies Tikihore Formation, the latter is of ?Motuan-Teratan age. Where Tapuwaeroa Formation is not distinguished-in the Orete Point and lower Mata River areas-the Tikihore Formation ranges up to the Piripauan. In the lower Mata River, Ihungia, and south Te Puia areas, rocks mapped by Moore et al. (1989) as Tapuwaeroa Formation were found to be of Haumurian-Teurian age (sections 3.2.4, 4.2.5, 5.2.2). On Fig. 6.10, these Haumurian-Teurian rocks are mapped together with Whangai Formation. Mangatu Group rocks-including mélange-and Miocene-Pliocene rocks are mapped as two composite units. Quaternary deposits are shown where they significantly obscure the underlying geological relations.

\subsubsection{Structure and Kinematics}

Unlike the southern and central zones, the northern zone has been affected by pervasive post-Early Miocene gentle folding and high-angle faulting, and the ages of some of the structures there are not known with certainty. However, the major structures-northwest-striking thrusts and associated folds-do not affect the Neogene rocks and so are almost certainly earliest Miocene or older. In the following, these major structures are described and discussed. To assist this discussion, a structure section (P- $\mathrm{P}^{\prime}$, Fig. 6.11) perpendicular to the predominant northwest strike (i.e., sub-parallel to the likely thrust transport direction) has been prepared.

\subsubsection{Major Structures}

The structure of the pre-Miocene rocks of northeastern Raukumara Peninsula is dominated by a number of major thrusts and thrust sheets. The multi-phase faulting in 


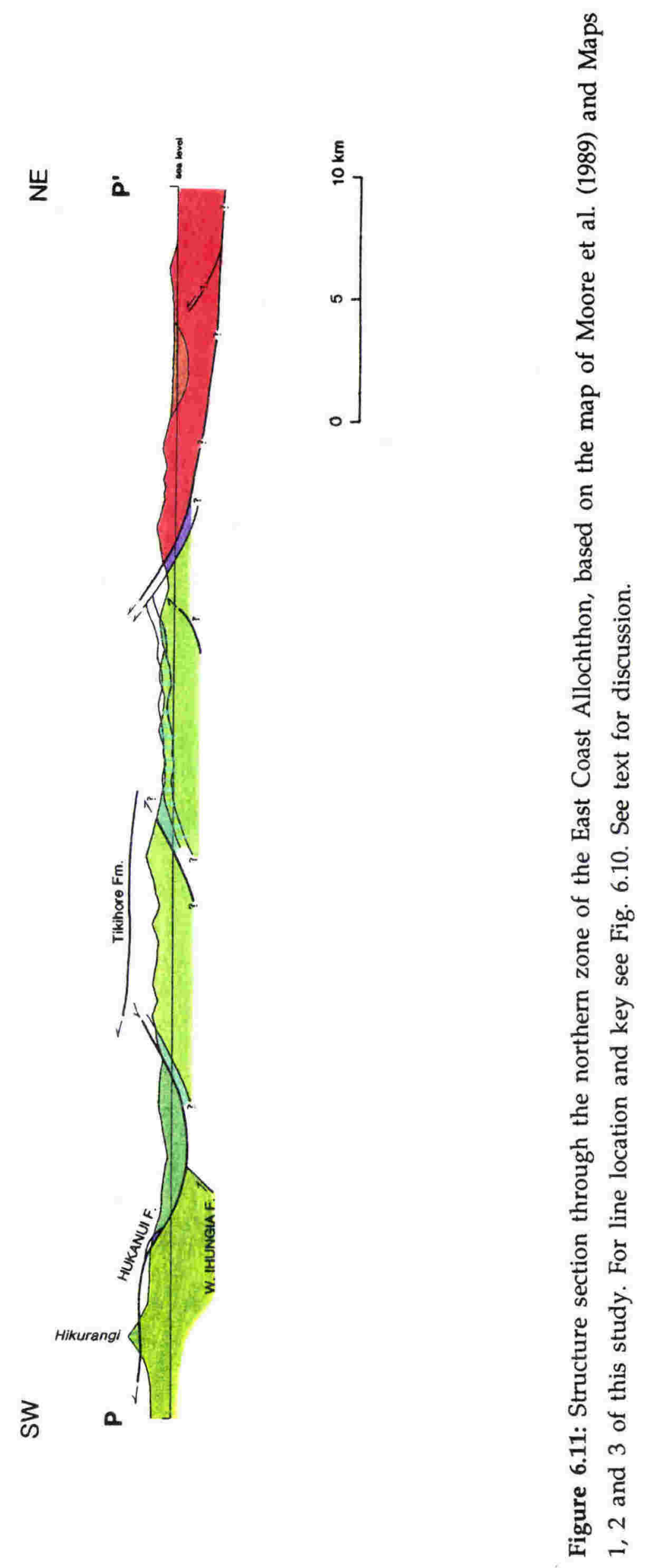


the region means that the boundaries of the major sheets cannot in all cases be precisely defined, and this and gaps in exposure mean that it is not in all cases clear to which sheet some of the rocks belong. Notwithstanding these difficulties, the following major tectonic elements have been distinguished:

1) The Ihungia and Raukokore Faults.

2) The area of upper Tikihore and Tapuwaeroa Formations between the thrust northeast of Raukumara (Fig. 6.11) and the Matakaoa Volcanics; this area is hereafter referred to as the Tikihore/Tapuwaeroa unit.

3) The sheet of predominantly Tikihore Formation bounded by the thrusts west and northeast of Raukumara, the Mokoiwi inlier, and the complex of Tapuwaeroa, Whangai, and Mangatu rocks to the southeast (hereafter referred to as the lower Tikihore sheet); this may also include the Tikihore Formation in the extreme northwest.

4) The occurrences of Mokoiwi Formation in and southeast of the Mokoiwi inlier, in the Waitahaia sheet, in the Te Puia inlier, and around Mts. Hikurangi and Whanokao (the Mokoiwi sheet).

5) The complex of sheets of Tapuwaeroa, Whangai, and Mangatu rocks east of the lower Tikihore sheet (the Cretaceous-Tertiary unit); this may also include much of the large tract of Whangai Formation in the southeast, although some of this allochthonous Whangai may underlie the Mokoiwi sheet (section 5.9.2).

6) The sheet of Tikihore Formation west of Raukumara (the upper Tikihore sheet).

7) The Matakaoa Volcanics and their underlying mélange (the Matakaoa sheet).

The Ihungia and Raukokore Faults:

The western Ihungia and Raukokore Faults form parts of the boundary of the northern zone (Fig. 6.10). The western Ihungia Fault was discussed in sections 3.6 .3 and 3.6.4. To recapitulate, it is a moderately southwest-dipping reverse fault which was active in the Late Cretaceous (post-early Piripauan) and again in the post-Teurian, probably in the earliest Miocene. Its post-Teurian throw in the Ihungia area is around 1.5-2 km (section 4.4.4). It juxtaposes Waitahaia Formation, on the southwest, against Tikihore Formation and Haumurian-Teurian rocks on the northeast. The Raukokore Fault is an analogous structure; its trace on the map suggests it is west-dipping, and as it has Urewera Group on the southwest and Tikihore Formation on the northeast, it also is a 
reverse fault. Its throw, however, is probably greater than that of the Ihungia Fault. Its movement is constrained to be pre-Late Miocene as it is overlain by lower Mangaheia Group (Moore et al., 1989).

Although the Ihungia Fault forms part of the boundary between the East Coast Allochthon and the Motu Block, the Tikihore Formation northeast of it was transported only a short distance relative to the Motu Block in the Early Miocene; it is not "allochthonous" to the same degree as the rocks above the Aorangiwai Fault, which cuts the Ihungia, and whose continuation-the Waitahaia Fault-forms the base of the allochthon to the southwest (sections 3.8.2, 4.8.3). The Tikihore Formation northeast of the Raukokore Fault also may have been transported only a short distance southwest relative to the Motu Block; this is discussed in a later paragraph.

The southeastward continuation of the Raukokore Fault is truncated by a northeaststriking, presumably strike-slip fault which also forms the northwestern end of the Mokoiwi inlier. The Thungia Fault is presumed to continue at depth beneath the Mokoiwi inlier until it meets this strike-slip fault. These three faults are presumed to have moved together in the Early Miocene, placing the Motu Block over the structurally lower parts of the East Coast Allochthon.

\section{The Tikihore/Tapuwaeroa Unit:}

The Tikihore/Tapuwaeroa unit comprises folded Tikihore alternating beds, Teratan mudstone and Tapuwaeroa Formation, and is overlain in the north by the Matakaoa sheet and in the south by the lower Tikihore sheet (Figs. 6.10, 6.11). The structures affecting this unit are predominantly folds. Northeast-dipping thrusts affecting Tikihore and Tapuwaeroa rocks in the extreme northwest branch from the base of the Matakaoa sheet. For the Tertiary rocks at the base of the Matakaoa sheet to overlie the the Cretaceous Tikihore/Tapuwaeroa sheet, the latter must have been structurally elevated prior to arrival of the former, unless the thrust beneath the Matakaoa sheet cut substantially downward in the transport direction. Because of its overall southwestward dip, uplift of the Tikihore/Tapuwaeroa unit most likely took place on one or more southwest-dipping, northeast-directed thrusts (Fig. 6.11), probably reactivated Cretaceous structures like the Ihungia Fault (section 3.6; see also section 4.4.1).

The area of Tikihore Formation to the west, between Orete Point and the Raukokore Fault (Fig. 6.10), may be part of the Tikihore/Tapuwaeroa unit or of the overlying lower Tikihore sheet. 

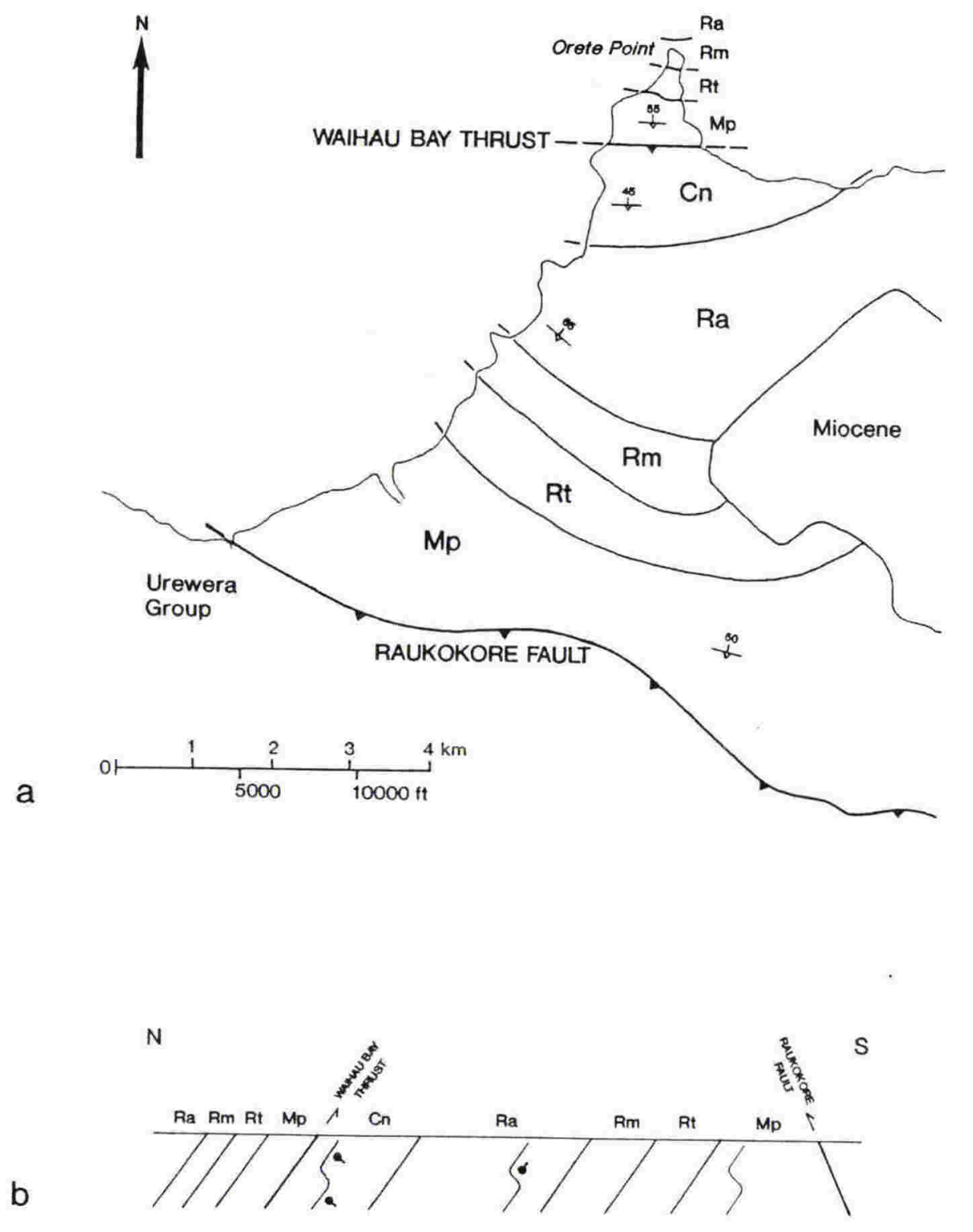

Figure 6.12: Tikihore Formation, Orete-Raukokore area. a: Simplified geological map, after Moore (1957) and Mazengarb (1990); b: Sketch cross-section showing overturned folds (scale exaggerated). 


\section{The Lower Tikihore Sheet:}

The lower Tikihore sheet overlies the Tikihore/Tapuwaeroa unit and dips southward and eastward beneath the Mokoiwi sheet and the Cretaceous-Tertiary unit (Figs. 6.10, 6.11). The throw on its northern bounding thrust is probably in excess of $2 \mathrm{~km}$ as it puts lower to middle Tikihore Formation against upper Tapuwaeroa and Whangai Formations. The pattern of its trace suggests its dip is shallow, so its slip is likely to be substantially greater than $2 \mathrm{~km}$. The lower Tikihore sheet lies immediately beneath the Mokoiwi sheet, at a similar structural level to the Tikihore Formation in the lower Mata River area. It is thus likely that the lower Tikihore sheet and the Mata River beds are contiguous, and that the lower Tikihore sheet is bounded to the southwest by the continuation of the Ihungia Fault. The Mata River beds were affected by northeast-directed thrusting and associated folding in the Late Cretaceous; they show no evidence of ever having moved southwest relative to their substrate (sections 3.4.2, 3.8.1). This makes it likely that the fault at the northern limit of the lower Tikihore sheet is a northeast-directed, reactivated Cretaceous structure rather than a wholly Miocene, southwest-directed thrust which has been tilted to a southwest dip (Fig. 6.11).

The area of Tikihore Formation in the Orete-Raukokore area is in a similar structural position to the lower Mata River Tikihore, and may thus be part of the lower Tikihore sheet. Maps of the Orete-Raukokore area by Moore (1957) and Mazengarb (1990) show two south-younging Late Cretaceous sections separated by a fault, the Waihau Bay Thrust, which juxtaposes Ngaterian rocks on the south against Piripauan rocks on the north (Fig. 6.12a; see also section 2.2.2.1). The northern section is $1200 \mathrm{~m}$ thick, the southern section is $4000 \mathrm{~m}$ thick, and corresponding stages are of different thicknesses in each section. These observations show that the slip on the fault is considerable. Most of the section is overturned, the predominant dip on both sides of the fault being moderately northward. Despite the overturning, the south-side-up apparent displacement on the thrust is confirmed by observations of asymmetric folds in the section in which "... the overturned limbs dominate and the normal limbs are minor features" (Moore, 1957 , p. 100), and by the asymmetry which can be inferred from the observation that $15 \%$ of the beds are upright and $85 \%$ are overturned (Moore, 1957; see Fig. 6.12b). The present disposition of these rocks is most likely the result of two deformations: northdirected thrusting on the Waihau Bay Thrust together with asymmetric folding and southward tilting in the Late Cretaceous, followed by continued steepening and finally overturning of the beds and the fault due to simple shear resulting from southwestward emplacement of higher thrust sheets in the Early Miocene. The Tikihore rocks themselves underthrust the Raukokore Fault, which was probably active during both the Late Cretaceous and the Early Miocene. Most of the stratigraphic separation on that fault could have taken place in the Late Cretaceous, so the Tikihore rocks probably did not move far southwestward relative to the Motu Block in the Early Miocene. 
The Mokoiwi Sheet:

Mokoiwi Formation rocks are now restricted to the Mokoiwi inlier and adjacent klippen, the Waitahaia sheet, and the Te Puia inlier (Fig. 6.10), but the similarity in structural position of the faults beneath each occurrence (sections 3.7, 4.5.1, 5.5.1) suggests that they all once formed a single large sheet. This is referred to here as the Mokoiwi sheet; it is equivalent to and continuous with the Waitahaia sheet of the central zone (section 6.3.5.1). In the northern zone it contains almost entirely Mokoiwi Formation, whereas further south it may also contain slightly younger lower Ruatoria Group rocks (Kenny, 1986; Mazengarb et al., 1991). In the northern zone it overlies Waitahaia, Tapuwaeroa, Whangai and Haumurian-Teurian rocks. Its southern extension lies at the top of the Whangai Formation. Horses of smectitic mélange along the base of the sheet (section 3.7) show that it passed over lower Tertiary rocks during transport. Its direction of transport was southwestward (Gibson, 1987a; section 3.7).

The structure of the Mokoiwi Formation within the sheet is complex (sections 3.7, 4.6.1, 5.4). Gibson (1987a) documented two phases of folding in the Mokoiwi inlier and found that two-thirds of the beds within it were overturned. This widespread overturning probably resulted from a similar sequence of events to that proposed for the Orete-Raukokore Tikihore: northeast-directed thrusting on a trench slope in the mid- to Late Cretaceous probably produced faulted asymmetric folds with long limbs dipping southwest, similar to the structures in the autochthonous Waitahaia Formation in the Mata River (Kenny, 1986; section 4.4.1); subsequently, shear associated with southwestward thrusting of the Mokoiwi sheet would have resulted in the long limbs being overturned, and the second phase of folding would have distributed their dips both northeast and southwest.

In the south Te Puia area, the complex structure and increased thickness of the Whangai Formation beneath the Mokoiwi sheet suggests that it too has been thrust southwestward (sections 5.5.1, 5.6, 5.9.2), in contrast to the 'autochthonous' Whangai in the central zone, and to the Haumurian-Teurian rocks in the lower Mata River area (sections 3.8.2, 4.8.3) which are probably part of the lower Tikihore sheet (see above). Deformed Whangai Formation occupies much of the southeast of the northern zone; some of this may belong to a thrust sheet or sheets beneath the Mokoiwi sheet, and some to the Cretaceous-Tertiary unit which probably overlies the Mokoiwi sheet (see below).

\section{The Cretaceous-Tertiary Unit:}

Immediately southeast of and overlying the lower Tikihore sheet is a complex of thrust slices of Tapuwaeroa, Whangai, and Mangatu rocks and mélange (Fig. 6.10). To the northeast, east and southeast, correlative rocks are shortened and structurally 
thickened by folds and thrusts visible in outcrops (author's observations) or inferable from overthickened and/or age-discordant sections encountered in petroleum exploration wells (Laing, 1972c, d; see Fig. 6.10 for locations). The complex adjacent to the lower Tikihore sheet and an uncertain proportion of the similar-aged rocks to the east are loosely assigned to the Cretaceous-Tertiary unit. Within this unit just east of the lower Tikihore sheet, slices of Tapuwaeroa Formation overlie Whangai Formation and mélange. Further east the rocks have been affected by post-Early Miocene faulting and the original stacking order is not clear.

Although the Cretaceous-Tertiary unit clearly overlies the lower Tikihore sheet, its relationship with the Mokoiwi sheet is uncertain. Some of the Cretaceous-Tertiary rocks in the southeast probably underlie the Mokoiwi sheet (see above), and would have been stripped from the top of the lower Tikihore sheet during Mokoiwi emplacement. However, the mélange unit of the central zone, which overlies the Waitahaia sheet, must have a northern zone equivalent. It is likely, then, that much of the material in the southeast of the northern zone tectonically overlies the Mokoiwi sheet. Use of the term 'Cretaceous-Tertiary unit' is reserved for the latest Cretaceous and Tertiary rocks which overlie the Mokoiwi sheet; those which underlie the Mokoiwi, like the Whangai Formation in the south Te Puia area, are not included.

\section{The Upper Tikihore Sheet:}

The upper Tikihore sheet is the unit consisting of Tikihore Formation flysch above the thrust west of Raukumara (Figs. 6.10, 6.11). It tectonically overlies the Tikihore/ Tapuwaeroa unit, the lower Tikihore sheet, and the Mokoiwi sheet. The fact that it overlies the Mokoiwi sheet shows that it has moved southwestward relative to the Motu Block. North of the upper Tikihore sheet and separated from it by a northeast-striking fault is a complex of slices of Tapuwaeroa, Whangai, and minor Tikihore Formations (Fig. 6.10). Their position adjacent to the upper Tikihore sheet suggests they may be part of it. However, the Tapuwaeroa/Whangai complex is cut by the continuation of the Raukokore Fault, and the main body of the upper Tikihore sheet overlies Mokoiwi Formation which overlies the Ihungia Fault. If, as is thought, the Raukokore and Ihungia Faults were kinematically linked and last moved at the same time, the Tapuwaeroa/ Whangai complex would be part of an older, lower unit than the upper Tikihore sheet. Favouring this interpretation is the apparent northwest-side-up component on the northeast-striking fault which truncates the Raukokore Fault and the upper Tikihore and Mokoiwi sheets (Fig. 6.10). This suggests that the Tapuwaeroa/Whangai complex was elevated to lie adjacent to the upper Tikihore sheet after that sheet's emplacement. The Tapuwaeroa/Whangai complex is thus likely to be part of the upper level of the upper Tikihore sheet and/or the Tikihore/Tapuwaeroa unit. Its structure is probably due to 
footwall collapse and imbrication during the overthrusting of the Mokoiwi sheet (see section 6.4.3.2).

\section{The Matakaoa Sheet:}

The Matakaoa sheet underlies the northern tip of the peninsula and comprises the two massifs of Matakaoa Volcanics, an underlying sliver of Mangatu Group rocks and mélange, and an overlying succession of Waitakian-Altonian mudstone and sandstone (Whakai Formation; Chapman-Smith and Grant-Mackie, 1971), some or all of which probably accumulated between the two massifs during transport. A small volcanic body a few kilometres southeast of the southern massif (Fig. 6.10) tectonically overlies Whangai Formation (Moore and Challis, 1985; section 2.2.2.1). The Mangatu/mélange sliver overlies the older rocks of the Tikihore/Tapuwaeroa unit (see above), and it was presumably thrust onto these rocks from the (original) offshore area to the northeast. At the western end of the southern massif, northeast-dipping thrusts which branch from the base of the mélange into the Tikihore/Tapuwaeroa unit show that material was accreted to the base of the Matakaoa sheet during its transport. At the southeastern end, the Mangatu/ mélange sliver appears to be continuous with Whangai and Mangatu rocks of the Cretaceous-Tertiary unit. The boundary between the two in this area is arbitrary.

\subsubsection{Thrust Sequence and Timing}

Thrusting in the northern zone of the East Coast Allochthon was two-directional, involving northeast-directed, probably reactivated Cretaceous imbricate thrusts interacting with southwest-directed thrusts which emplaced large allochthonous sheets of continental margin and oceanic material onto the region. The sequence of southwestward thrusting led to a stacking order in which slices of younger rocks overlie a sheet of older rocks (sections 6.3.5.1, 6.4.3.1), and must therefore have been more complicated than the simple forward-propagating sequence found in many thrust belts (e.g., Boyer and Elliott, 1982; Butler, 1987). Although the sequence of emplacement of the thrust sheets is reasonably clear, there is more than one solution for the sequence and geometry of thrusting involved in the detachment of the sheets from their origin. The different solutions require different amounts of thrust transport; these are determined from structural relations throughout the entire East Coast Allochthon, not just the northern zone. In the part of the following discussion that deals with the southwestward thrusting, only the emplacement history of the thrust sheets is considered; their detachment history is considered in a discussion of the sequence and amount of thrust displacement over the entire thrust belt in section 7.3.

The initial (pre-Miocene) configuration of the northern zone is depicted in diagram 1 of Fig. 6.13. Late Cretaceous activity on the Ihungia Fault juxtaposed Ngaterian Waitahaia 
1. PRE-MIOCENE CONFIGURATION
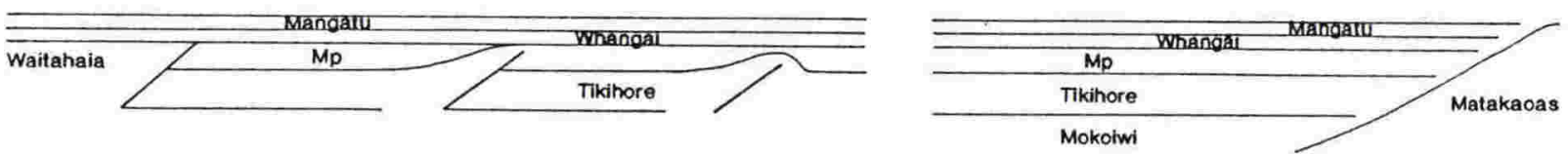

2. REACTIVATION OF K THRUSTS: EMPLACEMENT OF MOKOIWI SHEET

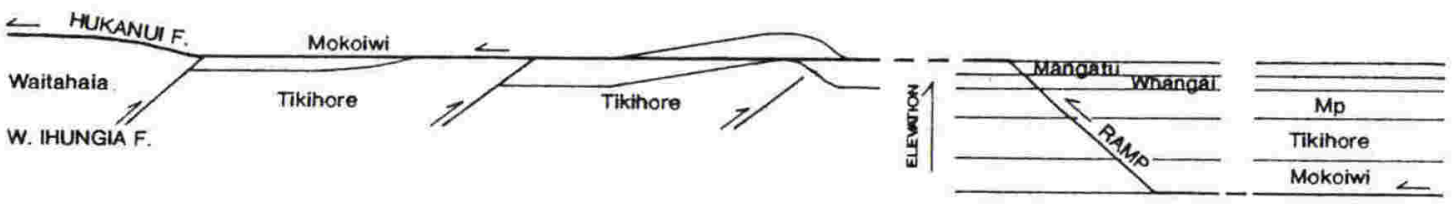

3. FOLDING OF MOKOIWI SHEET: EMPLACEMENT OF K-T, U. TIKIHORE SHEETS

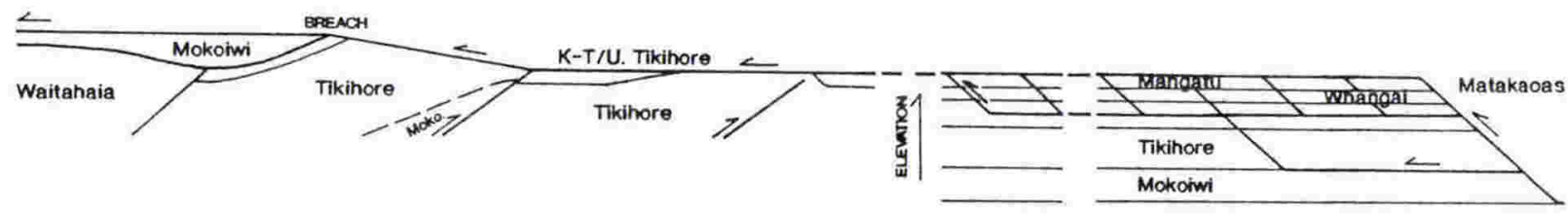

4. FINAL EMPLACEMENT OF MATAKAOA SHEET

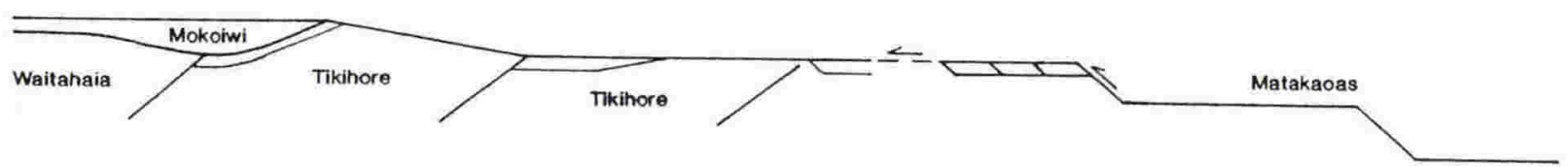

Figure 6.13: Schematic sections (not to scale) showing the sequence of deformation in the northern zone of the East Coast Allochthon. See text for discussion. 
Formation, on the southwest, against rocks as young as Piripauan on the northeast. In the lower Mata River area, at least, the northeastern rocks were folded. The faulted rocks were covered by Whangai Formation and Haumurian-Teurian strata after faulting had ceased (sections 3.6.4, 4.4.4). The fault northeast of Raukumara and the fault(s) beneath the Tikihore/Tapuwaeroa unit are probably also Late Cretaceous structures (section 6.4.3.1) with similar hangingwall/footwall relations to those across the Ihungia Fault. Other faults of this nature probably existed further northeast. Northeast of the present coastline, a succession of Mokoiwi, Tikihore-Tapuwaeroa, Whangai and Mangatu rocks a few kilometres thick (section 2.2.2.1) had accumulated by the end of the Oligocene. The pre-Haumurian parts of this succession, like their equivalents to the southwest, were probably cut by northeast-directed thrusts. Such faults are not shown on the diagram, however, for the sake of simplicity. Further northeast still-in a bathyal, open-ocean environment judging from the nature of interbedded sediments (Strong, 1980; section 2.2.2.1) - the Matakaoa Volcanics accumulated during two stages, mid-Cretaceous and Paleocene-Eocene.

The earliest stages of Miocene thrusting in the northern zone (diagram 2 in Fig. 6.13) involved reactivations of the northeast-verging Cretaceous thrusts and southwestward motions on new thrusts which originated some distance northeast of the region. The Ihungia Fault displaced the Whangai/Haumurian-Teurian rocks which overlay it around 1.5-2 km (section 4.4.4). The fault beneath the lower Tikihore sheet may have moved at this stage, placing Tikihore Formation over Tapuwaeroa and Whangai Formations, and the fault(s) beneath the Tikihore/Tapuwaeroa unit moved at this stage or subsequently, folding the rocks above. Other, similar faults which probably existed further northeast also moved at this stage, and the combined effect of all the northeast-directed thrusts was to elevate the rocks of the northern zone relative to correlative strata further northeast.

The southwestward thrusting of the northeastern rocks that took place during this interval is depicted on the right-hand sides of the diagrams in Fig. 6.13. A thrust which propagated beneath the Mokoiwi Formation cut up-section to Mangatu Group level and southwestward across the northeast-directed faults, and the Mokoiwi sheet was emplaced along it (diagram 2, Fig. 6.13). On the left side of Fig. 6.13 this thrust is shown at Tikihore-Tapuwaeroa level as that is its position in the vicinity of the section line (Fig. 6.11). It cuts up-section to Mangatu level to the southeast, however (Fig. 6.10). Allochthonous slices of Mangatu Group, Whangai Formation, and probably also Tapuwaeroa Formation (in the complex north of the upper Tikihore sheet) presently beneath the Mokoiwi sheet may have been accreted to it anywhere between the top of the ramp and its final position. After its emplacement, the Mokoiwi sheet was folded. The folding was probably partly due to tilting of the underlying lower Tikihore sheet 
associated with movement on its bounding thrust (diagram 3, Fig. 6.13), which brought Motuan rocks similar to Mokoiwi Formation close enough to the surface to be exposed by later uplift and erosion (section 2.2.2.1). The thrusts to the northeast probably also moved, further elevating northeastern Raukumara Peninsula relative to the offshore area.

In the offshore area, a thrust propagated at approximately Piripauan (upper Tikihore-Tapuwaeroa) level and cut southwestward into the northern zone. Above this thrust, the Cretaceous-Tertiary unit was assembled probably by progressive footwall collapse on closely spaced ramps, which would have led to small slices of Tapuwaeroa Formation overlying slices of Whangai and Mangatu rocks. Reversals of this stacking order in the central zone, however (sections 4.8.2, 6.3.5.1), show that subsequent out-ofsequence thrusting also took place. The sub-Piripauan thrust initially cut beneath the Mokoiwi sheet but subsequently breached it, leading to the Cretaceous-Tertiary rocks of the central zone being emplaced above the Waitahaia sheet (section 6.3.5.2). The breach may have been far enough southwest for the new fault to have cut beneath the uplifted Whangai and Tikihore Formations of the lower Tikihore sheet; if so, it would be these rocks which now form the southwest Te Rata sheet (see also section 6.3.5.3). Northeast of the central part of the peninsula, a thrust propagated beneath Tikihore Formation and cut up-section and southwestward across the lower Tikihore and Mokoiwi sheets. The upper Tikihore sheet was emplaced on this thrust.

After emplacement of the upper Tikihore sheet and the Cretaceous-Tertiary unit onto the Mokoiwi sheet, the Matakaoa Volcanics were emplaced. (diagram 4, Fig. 6.13). Some distance northeast of their present position the volcanics had reached Mangatu level, and a series of slices of Mangatu Group rocks accreted beneath and in front of them during their motion. The whole mass was subsequently thrust across the northeast-directed fault(s) and onto the Tikihore/Tapuwaeroa unit, and thrusts propagated from the base of the mass to incorporate slices of Tikihore and Tapuwaeroa Formation rocks. Thrusting culminated with the arrival of the Matakaoa sheet in its present position. The Matakaoa sheet probably pushed the upper Tikihore sheet and Cretaceous-Tertiary unit ahead of it (right side of diagram 3, Fig. 6.13), as the mélange at the base of the Matakaoa sheet appears to be continuous with the mélange assigned to the Cretaceous-Tertiary unit in the northeast (section 6.4.3.1, Fig. 6.10).

There are few constraints on the timing of the various thrust events in the northern zone. The general timing of the deformation is given by the regional stratigraphy: between the Haumurian and the top of the Oligocene, the sediments fine and increase in carbonate content up-section, showing that there was no major syn-depositional tectonic activity (see Chapter 2). The Matakaoa Volcanics are overlain by late Waitakian to Altonian mudstone and sandstone with a coarse basal breccia of volcanic clasts (Whakai 
Formation; Chapman-Smith and Grant-Mackie, 1971; Moore et al., 1989) which probably accumulated in a piggy-back basin during emplacement of the sheet. Thrusting is thus likely to have started in the Waitakian. The similarity of the post-Early Miocene sediments and structures of northeastern Raukumara Peninsula to those elsewhere in the region confirms that northern zone thrusting, like thrusting in the central and southern zones, was restricted to the Early Miocene.

\subsubsection{Amount of Thrust Transport}

Although minimum displacements of some of the units in the northern zone are immediately apparent from the structural geometry, the displacements of others depend on their interrelationships prior to detachment from their origins (see also section 6.4.3.2). These are considered in section 7.3. However, a preliminary discussion is given below.

The displacement of the Cretaceous-Tertiary unit in the northern zone is hard to determine because its distribution is imperfectly known (section 6.4.3.1) and because of its complex internal structure. An idea of its displacement can be gained if it is assumed that it is a continuation of the mélange/Te Rata unit of the central zone. The minimum transport of the southwest $\mathrm{Te}$ Rata sheet is approximately $60 \mathrm{~km}$ (section 6.3.5.3). However, the mélange/Te Rata unit has undergone considerable internal shortening. Given the approximately $50 \%$ shortening estimated for the southern zone (section 6.2.3.3) and the more complex structure of the central and northern zone rocks, shortening of $50 \%$ in the Te Rata/mélange/Cretaceous-Tertiary unit is considered a conservative estimate. Estimates of shortening within the allochthonous sedimentary sheets in front of the Semail Ophiolite in Oman, which show complex out-of-sequence relationships and were deformed in a similar tectonic environment to the Cretaceous-Tertiary sheets, mostly lie between $50 \%$ and $70 \%$ (see Table 1 of Cooper, 1988). Assuming 50\% shortening, the displacements of Cretaceous-Tertiary sheets in the northern zone may be on the order of $100-150 \mathrm{~km}$.

The upper Tikihore sheet must have been derived from north of the present southern limit of the Matakaoa sheet, as only small outcrops of the Tikhore flysch facies exist in the intervening Tikihore/Tapuwaeroa unit (Fig. 6.10). The minimum transport distance of the sheet is thus approximately $25 \mathrm{~km}$. If the upper Tikihore sheet was originally behind the Cretaceous-Tertiary unit and was emplaced over it into its present position by out-ofsequence thrusting, its minimum displacment would be the $60 \mathrm{~km}$ of Te Rata/mélange/ Cretaceous-Tertiary displacement plus the $20 \mathrm{~km}$ minimum overlap between the two sheets (Fig. 6.10). If shortening of the presently $80 \mathrm{~km}$ wide Te Rata/mélange/ Cretaceous-Tertiary unit was $50 \%$, minimum upper Tikihore displacement would come to approximately $180 \mathrm{~km}$. This figure seems too high. 
Minimum displacements of the Mokoiwi and Matakaoa sheets depend on the original relationship of the Mokoiwi sheet to the Cretaceous-Tertiary/mélange/Te Rata unit, which is discussed in section 7.3. It is immediately apparent, however, that the Mokoiwi sheet must have come from northeast of the present soutwestern limit of the Matakaoa sheet: only a small area of Mokoiwi Formation equivalent is exposed in the underlying lower Tikihore sheet and none is exposed in the Tikihore/Tapuwaeroa unit. The Matakaoa sheet must originally have come from behind the Mokoiwi sheet as it is partly equivalent in age to the Mokoiwi Formation and accumulated in a more distal environment (section 2.2.2.1). The Mokoiwi sheet has undoubtedly shortened internally, which would add to the minimum displacement of the Matakaoa sheet.

\subsubsection{Conclusions}

Because there are no recent detailed maps available, any discussion of the structure of the northern zone of the East Coast Allochthon must be considered as preliminary. Nonetheless, the following conclusions were drawn from the present study:

1) The northern zone of the East Coast Allochthon is the $\approx 20-50 \mathrm{~km}$ wide region of complexly deformed mid-Cretaceous to Oligocene rocks which underlie the part of Raukumara Peninsula northeast of the limits of exposed Urewera Group, Waitahaia Formation, and the Neogene rocks in the southeast. It is also taken to include Mts. Hikurangi and Whanokao, which may be klippen of Taitai Sandstone. Important faults forming parts of its boundary are the Raukokore Fault, the Hukanui/ Aorangiwai Fault, the western Ihungia Fault, the faults forming the southwestern limit of the Te Puia inlier, and the Waikawa Fault. It is unconformably overlain by Neogene rocks.

2) The rocks of the northern zone can be assigned with varying degrees of certainty to six major tectonic units. These are, from bottom to top: the Tikihore/Tapuwaeroa unit, comprising flysch and Teratan mudstone of the Tikihore Formation and Tapuwaeroa Formation; the lower Tikihore sheet, consisting of Tikihore, Tapuwaeroa and Whangai Formations; the Mokoiwi sheet, comprising Mokoiwi Formation, and its subjacent slices of Late Cretaceous-Early Tertiary rocks; the Cretaceous-Tertiary unit, a stack of slices of Tapuwaeroa and Whangai Formations and Mangatu Group; the upper Tikihore sheet, consisting of Tikihore Formation; and the Matakaoa sheet, comprising the Matakaoa Volcanics and their underlying sliver of Mangatu rocks and mélange. The relationship between the Cretaceous-Tertiary unit and the upper Tikihore sheet is uncertain; the two may be lateral equivalents. That the CretaceousTertiary unit overlies the Mokoiwi sheet cannot be demonstrated, but follows from the presumption that the Cretaceous-Tertiary unit is equivalent to the mélange unit 
of the central zone. The Mokoiwi sheet is a continuation of the Waitahaia sheet of the central zone.

3) The western Ihungia and Raukokore Faults and the faults beneath the lower Tikihore sheet and Tikihore/Tapuwaeroa unit are northeast-directed, Late Cretaceous thrusts which were reactivated in the Early Miocene. The Waihau Bay thrust is a Late Cretaceous fault which may or may not have been reactivated. The sub-Mokoiwi thrust and the thrusts bounding its underlying slices, the thrusts of the CretaceousTertiary unit, and the thrust beneath the Matakaoa sheet are southwest-directed, Early Miocene structures. Early Miocene thrusting in the northern zone was thus two-directional. The large proportion of overturned beds in the Tikihore Formation in the northwest and in the Mokoiwi Formation is probably explained by their involvement in two deformations of opposite vergence: northeast-directed Late Cretaceous thrusting which led to northeast-verging asymmetric folds with steep limb dips, and simple shear associated with southwest-directed Early Miocene thrusting which led to overturning of the backlimbs of these folds.

4) Early Miocene thrusting in the northern zone began with reactivations of the northeast-directed Cretaceous thrusts, which cut through Mangatu Group rocks and elevated the strata on northeastern Raukumara Peninsula relative to those offshore. Subsequently, the Mokoiwi/Waitahaia sheet was emplaced southwestward over these faults. Its base reached Mangatu level in the southeast, and slices of TapuwaeroaMangatu rocks were accreted beneath it by footwall collapse over much of its area. After its emplacement the Mokoiwi sheet was folded, partly by southwestward tilting of the underlying lower Tikihore sheet in association with motion on its underlying thrust. Northeast-directed thrusts further northeast may also have moved at this stage.

5) The Cretaceous-Tertiary/mélange unit was assembled by southwest-directed piggyback stacking above a floor thrust which was at Piripauan level in the east but lower in the Tikihore Formation adjacent to the central part of the peninsula. The propagating floor thrust cut through the sub-lower Tikihore thrust and eventually breached the Mokoiwi sheet, emplacing the mélange/Te Rata unit over the Waitahaia sheet in the central zone, and the upper Tikihore sheet over the lower Tikihore and Mokoiwi sheets in the northern zone. Thrusting culminated when the Matakaoa Volcanics, which had reached Mangatu level and accreted slices of Mangatu Group rocks beneath and ahead of them, were thrust over structurally elevated Cretaceous rocks to their present position overlying the Tikihore/Tapuwaeroa unit. 
6) Thrusting began in the Waitakian and was marked by the appearance of voluminous terrigenous sediment, including a Waitakian-Altonian succession with a coarse basal breccia deposited in a probable piggy-back basin on the Matakaoa sheet. As in the central and southern zones, thrusting probably stopped in the Altonian-the postEarly Miocene sediments and structures of northeastern Raukumara Peninsula are similar to those elsewhere in the region.

7) Southwestward transport of the Mokoiwi/Waitahaia sheet was at least $50 \mathrm{~km}$, as no possible footwall equivalent is present southwest of the Matakaoa Volcanics. The minimum transport of the southwest Te Rata sheet (central zone), which lies at the front of the Te Rata/mélange/Cretaceous-Tertiary unit, is $60 \mathrm{~km}$; assuming $50 \%$ internal shortening, southwestward displacements of the Cretaceous-Tertiary sheets in the northern zone may be around $100-150 \mathrm{~km}$. If the upper Tikihore sheet is a lateral equivalent of the Cretaceous-Tertiary unit, its displacement could be as little as 25 $\mathrm{km}$. If it was originally behind the Cretaceous-Tertiary unit, its minimum displacement-assuming 50\% Cretaceous-Tertiary shortening-is approximately 180 $\mathrm{km}$. The Matakaoa sheet must have come from behind the Mokoiwi sheet. The Mokoiwi sheet has shortened internally, so the minimum southwestward displacement of the Matakaoa sheet is somewhat greater than $50 \mathrm{~km}$. 


\section{Chapter 7}

\section{Evolution and Origin of the East Coast Allochthon}

\subsection{INTRODUCTION}

In this chapter, information on the structure and kinematics of the individual zones of the East Coast Allochthon is summarised and its implications regarding the kinematic evolution of the thrust belt and the tectonic regime which drove the deformation are discussed. Section 7.2 is a summary description of the major allochthonous units. In section 7.3, alternative kinematic histories for the allochthonous units which take into account the structural geometry, the sequence of thrust sheet emplacement and amounts of thrust transport are presented and discussed. Finally, section 7.4 is a discussion of the processes likely to have driven the Early Miocene deformation.

\subsection{ALLOCHTHONOUS UNITS}

The major tectonic elements of the East Coast Allochthon, described in Chapter 6, are shown on Fig. 7.1. To recapitulate, the East Coast Allochthon can be divided into three structural zones: southern, central and northern. Early Miocene deformation in the southern and central zones was 'thin-skinned', involving southwestward emplacement of thrust sheets above the Mangatawa and Maungahaumia Slides and the Te Rata and Waitahaia Thrusts. In contrast, deformation in the northern zone involved northeastdirected thrusting on faults which had probably been active in the Cretaceous as well as southwestward emplacement of allochthonous sheets. The southern zone is essentially an emergent imbricate fan composed of Mangatu Group rocks which were detached from the underlying Whangai Formation in a piggy-back sequence; shortening within it was about $50 \%$, and its northeastern limit has been moved only about $18 \mathrm{~km}$ from its original position. The central zone and the structurally higher parts of the northern zone, however, consist of a number of allochthonous sheets and complexes which were assembled and emplaced in a complicated sequence and have been transported some tens of kilometres from sources in the northern zone and beyond. In the following, the characteristics of these allochthonous units are summarised so they can be used to determine possible kinematic histories in section 7.3. 
Besides the northeast-directed sheets of the northern zone which underlie the Mokoiwi inlier and which have not been transported southwestward relative to their substrate, Five major thrust sheets or groups of sheets have been distinguished in the central and northern zones (Fig. 7.1): the Mokoiwi/Waitahaia sheet and the TapuwaeroaMangatu slices accreted to it during its motion; the southwest Te Rata sheet; the Cretaceous-Tertiary/mélange/central Te Rata unit; the upper Tikihore sheet; and the Matakaoa sheet. Note that because it is not possible to distinguish the sub-Mokoiwi slices from the sheets of the Cretaceous-Tertiary unit over most of the northern zone, they are shown together on Fig. 7.1.

The lowest unit above the northeast-directed sheets is the Mokoiwi/Waitahaia sheet and the slices in its footwall. The latter are confined to the northern zone. This sheet, along with part of the Matakaoa sheet, contains the oldest allochthonous rocks in the orogen (?Urutawan-Motuan). It is presently $\approx 35 \mathrm{~km}$ wide, but it is likely to have been shortened considerably during its motion. Its original southwestern limit cannot have been more than about $10 \mathrm{~km}$ southwest of its present one, as it did not displace the rocks of the southern zone from their original position just southwest of the Arowhana high (section 6.3.5.2). The Mokoiwi/Waitahaia sheet was transported from northeast of the present site of the Matakaoa sheet (section 6.3.5.2).

The southwest Te Rata sheet is the $\approx 25 \mathrm{~km}$ wide mass of Whangai and Tikihore Formations above the Te Rata Thrust at the front of the central zone. Its complex internal structure suggests it has been shortened at least 50\%. It was thrust over the Mokoiwi/ Waitahaia sheet after that sheet's emplacement (section 6.3.5.2) so its original position must have been behind the Mokoiwi inlier. The southwest Te Rata sheet overlies the central Te Rata sheet along a northeast-directed backthrust, and is overlain by the mélange unit along a southwest-directed thrust.

The central Te Rata/mélange/Cretaceous-Tertiary unit extends from the middle of the central zone northeastward as far as the Matakaoa sheet, a distance of $60 \mathrm{~km}$. It comprises a stack of Late Cretaceous-Early Miocene rocks in a predominantly older-onyounger order but with common reversals. Shortening within this stack is likely to exceed $50 \%$. In the central zone, it overlies the Waitahaia sheet along the Te Rata Thrust. It is presumed to overlie the Mokoiwi sheet in the northern zone. Because it lies behind the southwest Te Rata sheet, its original position must have been northeast of that sheet. The upper Tikihore sheet, consisting of Tikihore Formation flysch, overlies the Mokoiwi sheet and may be a lateral equivalent of or may have originated behind the CretaceousTertiary unit. 


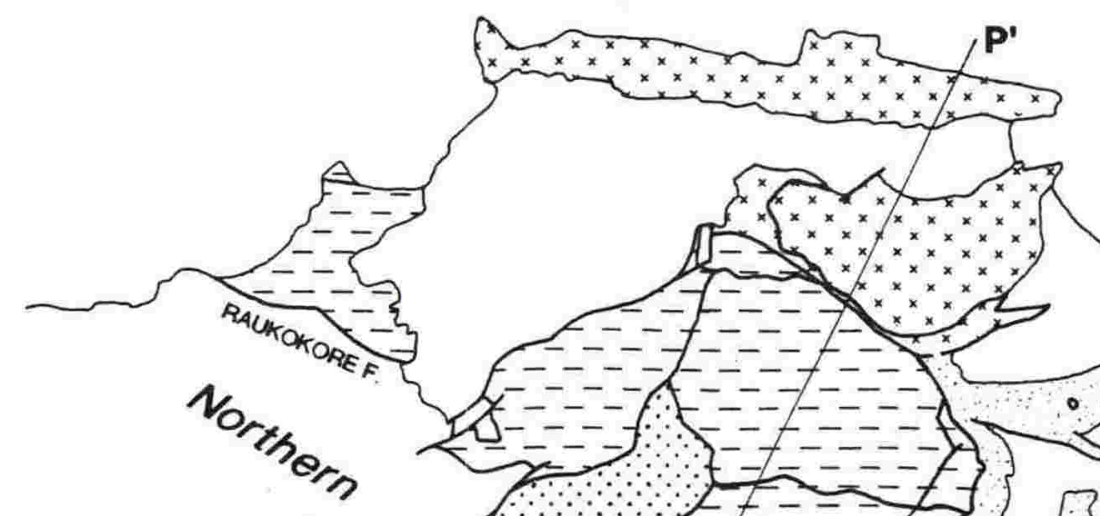

$\mathbf{P}$

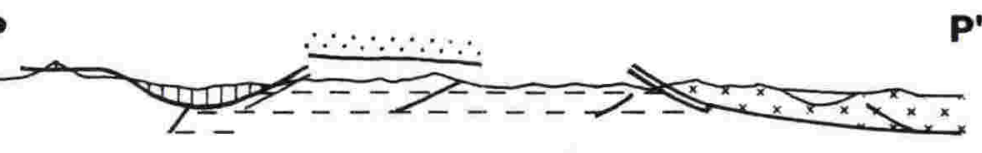

$N=G_{\text {WIHUNGIA. }}$

?
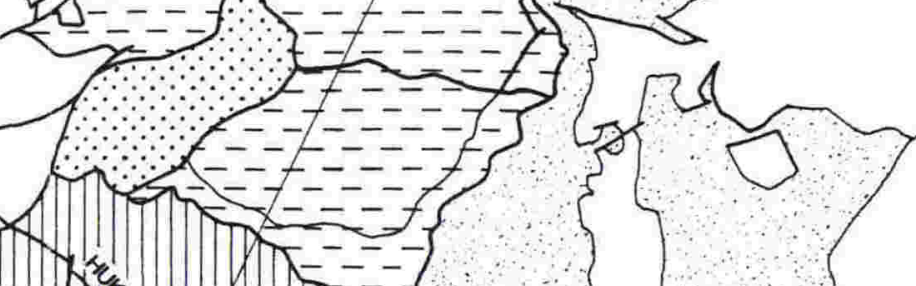

NE-directed

sheets

Mokoiwi/Waitahaia

sheet

Southern zone

$\because 0 \%$ SW Te Rata sheet

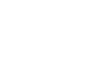

K-T/melange/
c. Te Rata unit \& $\quad \begin{aligned} & \text { Upper Tikihore } \\ & \text { sheet }\end{aligned}\left[\begin{array}{l}x^{x} x^{x} x^{x} \\ x^{x} x^{x} x^{x}\end{array}\right]$ Matakaoa sheet

sub-Mokoiwi slices

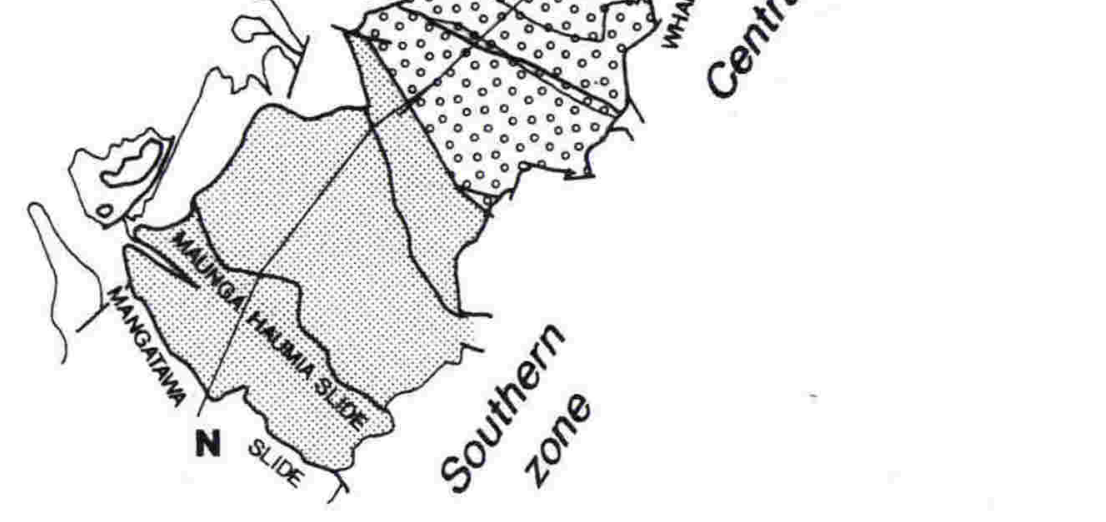

Figure 7.1: Map and structure sections showing major tectonic elements of the East Coast Allochthon. Map compiled from Figs. 6.2, 6.7 and 6.10; sections compiled from Figs. 6.6, 6.9 and 6.11. See text for discussion. 
The Matakaoa sheet is the most distal unit in the East Coast Allochthon and contains, in part, the oldest rocks. It is therefore presumed to be the highest and farthesttravelled unit in the thrust pile. Consistent with these presumptions, the sliver of Mangatu rocks and mélange along its base is continuous with the Cretaceous-Tertiary unit to the south. The Matakaoa Volcanics were probably formed as oceanic crust and/or seamounts (Pirajno, 1980; section 2.2.2.1). Basement rocks in the Raukumara Basin to the northeast are likely to be oceanic also (Gillies and Davey, 1986).

\subsection{KINEMATIC EVOLUTION}

Knowing the dimensions of the allochthonous sheets, the geometric relations between them, and the sequence of their emplacement, it is possible to propose alternative kinematic histories detailing the sequence and geometry of thrusting involved in the detachment of the sheets from their origins and the amounts of their transport. From a consideration of section 7.2 it is evident that there are three major allochthons whose interrelationships must be explained by any such history: the Mokoiwi/Waitahaia sheet, at the bottom of the thrust pile above the Waitahaia Fault and equivalent structures; the Te Rata/mélange/Cretaceous-Tertiary/upper Tikihore unit, assembled above a floor thrust (Te Rata Thrust in the central zone) which initially lay beneath but later breached the Mokoiwi sheet (sections 6.3.5.2, 6.4.3.2); and the Matakaoa sheet, which lies at the top and back of the thrust belt. These three units are referred to in the following as the Waitahaia allochthon, the Te Rata allochthon, and the Matakaoa sheet, respectively.

There are two possible thrust propagation histories, shown schematically in Fig. 7.2, for the major southwest-vergent allochthons of Raukumara Peninsula: Forward propagation (Fig. 7.2a), in which the floor thrust of the Te Rata allochthon propagates in front of the original position of the Waitahaia allochthon; and out-of-sequence propagation (Fig. 7.2b), in which the Te Rata allochthon was originally the upper part of the Waitahaia allochthon. In both cases, the Matakaoa sheet-the most northeasterly and originally the lowest unit in the thrust pile-is assumed to have been the first to move. Note that in Fig. 7.2, the northeast-directed thrusts of the northern zone are not shown for the sake of clarity. Their presence would not require modification of the proposed kinematic histories.

In the first of the two possible cases, propagation of the sub-Waitahaia fault from beneath the Matakaoa sheet and emplacement of the Waitahaia allochthon is followed by propagation of the sub-Te Rata thrust from the ramp at the front of the Waitahaia allochthon, breaching of the Waitahaia allochthon by this thrust, and emplacement of the Te Rata allochthon along it. In the second case, both the sub-Waitahaia and sub-Te Rata 


\section{a FORWARD PROPAGATION: TE RATA IN FRONT OF WAITAHAIA}

1. Initial configuration; propagation of sub-Waitahaia thrust

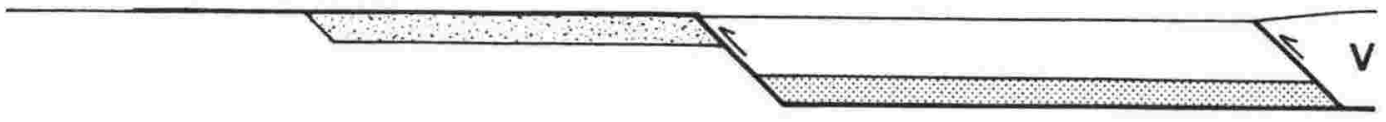

2. Emplacement of Waitahaia allochthon; propagation of sub-Te Rata thrust

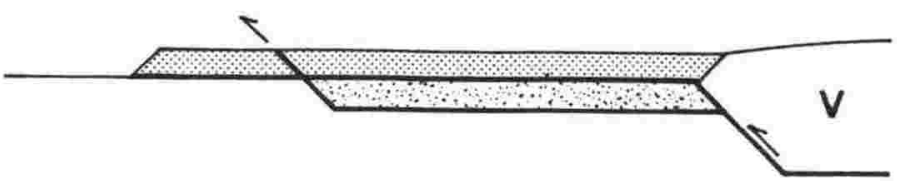

3. Emplacement of Te Rata allochthon

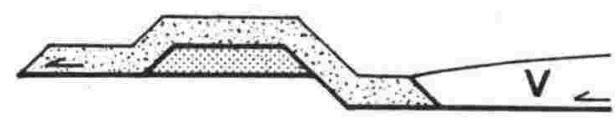

\section{b OUT-OF-SEQUENCE PROPAGATION: TE RATA ABOVE WAITAHAIA}

1. Initial configuration; propagation of sub-Waitahaia thrust

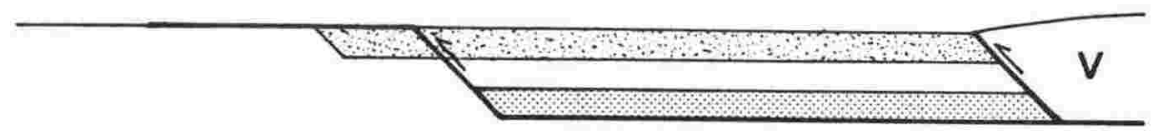

2. Emplacement of Waitahaia allochthon; propagation of sub-Te Rata thrust

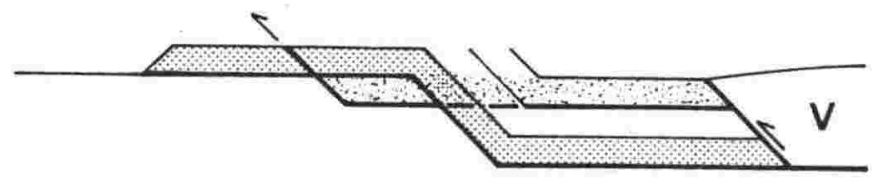

3. Emplacement of Te Rata allochthon
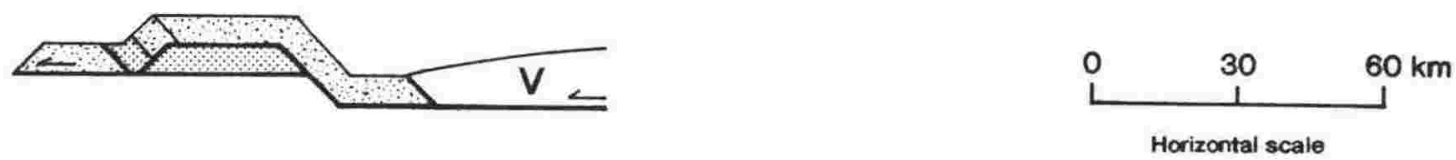

Figure 7.2: Alternative thrusting histories to explain the relations between major allochthonous units in the central and northern zones of the East Coast Allochthon. a: Forward propagation, b: Out-of-sequence propagation. Dots = Waitahaia allochthon, shingle pattern $=\mathrm{Te}$ Rata allochthon, $\mathrm{V}=$ Matakaoa sheet. See text for discussion. 
thrusts propagate from the beneath the Matakaoa sheet, the sub-Waitahaia first and the sub-Te Rata after emplacement of the Waitahaia allochthon. In this case the sub-Te Rata thrust cuts through the ramp in the sub-Waitahaia thrust rather than propagating entirely in front of it. This requires the Te Rata allochthon to contain a slice composed of Mokoiwi and Tikihore Formations originally in the hangingwall of the sub-Waitahaia thrust (diagrams 2 and 3, Fig. 7.2b). Mokoiwi rocks do not appear to be present in the Te Rata allochthon. However, the minimum transport distances used in the construction of Fig. 7.2 (see later) predict that the slice of Mokoiwi should lie just in front of the Waitahaia allochthon. The exposure of the thrust belt is at its narrowest in this area and a major backthrust, which could have excised the Mokoiwi rocks, is present.

The two possible thrust propagation histories predict different amounts of thrust transport. Figure 7.2 is constructed to show the minimum widths of the allochthonous units to scale, so minimum transport distances for the two cases can be measured from it. Note that these transport distances do not include the lengths of the ramps between the different allochthons, as these are unknown; the sections are thus not balanced, as the deformed-state lengths of the allochthons are longer than their restored-state lengths. Actual minimum thrust displacements, then, will be somewhat greater than those determined from the Figure. For both thrust propagation histories, the minimum width of the Waitahaia allochthon is determined by: the fact that the Te Rata allochthon was emplaced through it; the $60 \mathrm{~km}$ minimum distance from the present front of the Te Rata allochthon to its original position, behind the (presently) $35 \mathrm{~km}$ wide Waitahaia allochthon; and the present $80 \mathrm{~km}$ width of the Te Rata allochthon.

In the case of forward propagation, the Waitahaia allochthon restores behind the restored Te Rata allochthon (diagram 1, Fig. 7.2a). Emplacement of the Waitahaia allochthon to its present position, $35 \mathrm{~km}$ ahead of the southwesternmost possible position of the restored Te Rata allochthon (diagram 2), requires the Waitahaia allochthon to be at least $80+35=115 \mathrm{~km}$ wide and to have been transported at least that distance. Subsequently, the Te Rata allochthon was transported at least $60 \mathrm{~km}$ over the Waitahaia allochthon, carrying the Matakaoa sheet with it. Minimum transport of the Matakaoa sheet in this case is thus $115+60=175 \mathrm{~km}$.

In the case of out-of-sequence propagation, the restored Waitahaia allochthon lies beneath the restored Te Rata allochthon (diagram 1, Fig. 7.2b). The minimum length of the Waitahaia allochthon in this case must again be the $80 \mathrm{~km}$ length of the Te Rata allochthon plus the at least $35 \mathrm{~km}$ distance that the front of the Waitahaia allochthon lies ahead of the restored front of the Te Rata allochthon (diagram 2); however, the minimum transport of the Waitahaia allochthon need only be $35 \mathrm{~km}$ plus the $20 \mathrm{~km}$ minimum width of the Te Rata allochthon in front of the sub-Waitahaia ramp. The minimum 
Table 7.1: Estimated minimum transport distances for major allochthons, using different assumptions for internal shortening during the two stages of the alternative thrust propagation histories shown in Fig. 7.2. See text for details.

Forward prop. Out-of-sequence prop.

STAGE 1

Waitahaia/Matakaoa

$115 \mathrm{~km}$

$55 \mathrm{~km}$

transport, no shortening

STAGE 1

Waitahaia/Matakaoa transport,

$50 \%$ Te Rata shortening

$195 \mathrm{~km}$

$75 \mathrm{~km}$

STAGE 1

Matakaoa transport, $50 \% \mathrm{Te}$

$390 \mathrm{~km}$

$185 \mathrm{~km}$

Rata/Waitahaia shortening

STAGE 2

Te Rata transport

$60 \mathrm{~km}$

$60 \mathrm{~km}$

Total Matakaoa transport,

no shortening

$175 \mathrm{~km}$

$115 \mathrm{~km}$

Total Matakaoa transport, $50 \%$ Te Rata shortening

$335 \mathrm{~km}$

$215 \mathrm{~km}$

Total Matakaoa transport, $50 \%$ Te Rata/Waitahaia shortening

$530 \mathrm{~km}$

$325 \mathrm{~km}$ 
transport of the Te Rata allochthon is again $60 \mathrm{~km}$, so the minimum transport of the Matakaoa sheet in this case is $55+60=115 \mathrm{~km}$.

Figure 7.2 is drawn, and the above transport distances are calculated, assuming no internal shortening of the allochthonous units. However, the internal structure of the Te Rata allochthon suggests it has been shortened at least $50 \%$ (sections 6.3.5.2, 6.4.3.3). The Waiatahaia allochthon is likely to have been shortened considerably also. Such internal shortening increases the thrust transport distances predicted at each stage of each of the two possible thrust propagation sequences. The transport distances predicted assuming no shortening, $50 \%$ shortening of only the Te Rata allochthon, and $50 \%$ shortening of both the Te Rata and Waitahaia allochthons are summarised in Table 7.1. How the distances which take shortening into account were obtained is explained in the following paragraphs.

If in the case of forward propagation the Te Rata allochthon was originally twice its present width, another $80 \mathrm{~km}$ would have to be added to the width and transport of the Waitahaia allochthon. Total transport of the Waitahaia allochthon and transport of the Matakaoa sheet during the first stage of thrusting (diagram 1, Fig. 7.2a) would thus have been $195 \mathrm{~km}$. If in addition the Waitahaia allochthon was shortened 50\%, transport of the Matakaoa sheet would have been $390 \mathrm{~km}$. At the second stage of thrusting, 50\% Te Rata shortening would require the Matakaoa sheet to travel $80 \mathrm{~km}$ in addition to the $60 \mathrm{~km}$ minimum transport of the front of the Te Rata allochthon, leading to total Matakaoa transport of at least $195+80+60=335 \mathrm{~km}$. If in addition the Waitahaia allochthon had shortened $50 \%$, this figure would be $390+80+60=530 \mathrm{~km}$.

If in the case of out-of-sequence propagation the Te Rata allochthon was originally twice its present width, a minimum of only $20 \mathrm{~km}$ would have to be added to the width and transport of the Waitahaia allochthon, as only the part of the Te Rata allochthon in front of the sub-Waitahaia ramp determines the Waitahaia allochthon's transport (see diagram 2, Fig. 7.2b). Transport of the Waitahaia allochthon and the Matakaoa sheet during the first stage of thrusting would thus be $35+20+20=75 \mathrm{~km}$. If in addition the Waitahaia allochthon was shortened $50 \%$, transport of the Matakaoa sheet would have been 115 (the minimum width of the Waitahaia allochthon; see earlier) + $75=185$ $\mathrm{km}$. At the second stage of thrusting, 50\% Te Rata shortening would require the Matakaoa sheet to travel $80 \mathrm{~km}$ in addition to the $60 \mathrm{~km}$ minimum transport of the Te Rata allochthon (as in the case of forward propagation) leading to total Matakaoa transport of at least $75+80+60=215 \mathrm{~km}$. If in addition the Waitahaia allochthon had shortened $50 \%$, this figure would be $185+80+60=325 \mathrm{~km}$. 
The acceptability of the predicted total minimum transport distances can be evaluated by considering the time over which thrusting took place and calculating the rates of thrust motion for each case. It has been established (e.g., sections 6.3.5.2, 6.4.3.2) that central and northern zone deformation took place in Waitakian-early Altonian time (24 to ca. $18 \mathrm{Ma}$; Edwards et al., 1988, see Appendix 1). Displacement of the major allochthons was therefore completed in a period of $\approx 6 \mathrm{~m} . \mathrm{y}$. at the beginning of the Miocene. Assuming a uniform displacement rate for the Matakaoa sheet over that period, the forward propagation history predicts motion of $29 \mathrm{~mm} / \mathrm{yr}$ with no shortening of either the Te Rata or Waitahaia allochthons, $56 \mathrm{~mm} / \mathrm{yr}$ with $50 \%$ shortening of the Te Rata allochthon only, and $88 \mathrm{~mm} / \mathrm{yr}$ with $50 \%$ shortening of both allochthons. Under the same conditions the out-of-sequence history predicts $19 \mathrm{~mm} / \mathrm{yr}, 36 \mathrm{~mm} / \mathrm{yr}$ and $54 \mathrm{~mm} / \mathrm{yr}$, respectively.

Because obduction of the Matakaoa Volcanics was driven by convergence between the Pacific and Australian Plates (see section 7.4), motion of the Matakaoa sheet should be no faster than the Early Miocene plate convergence rate calculated from seafloorspreading studies. According to Walcott (1987) the average plate convergence rate between 36 and $20 \mathrm{Ma}$ (chrons 13 and 6) at Wellington, on the southern tip of the North Island (Fig. 1.1a), was $23 \mathrm{~mm} / \mathrm{yr}$, the Pacific Plate moving southwestward relative to the Australian. The Early Miocene position of East Cape was further from the rotation pole than that of Wellington and the average rate there would have been about $25-30 \mathrm{~mm} / \mathrm{yr}$. If relative plate motion during the $6 \mathrm{~m}$.y. period of thrusting was similar to the average rate between 36 and $20 \mathrm{Ma}$, only the thrust displacements calculated assuming no shortening would be reasonable.

While there can be little doubt that parts of the Te Rata and Waitahaia allochthons have been shortened considerably, their entire widths may not have contracted by as much as the estimated $50 \%$. Also, because subduction beneath Northland and the East Coast Deformed Belt started at approximately 25 Ma (section 1.2; Rait et al., 1991, see Chapter 8) it is possible that the plate convergence rate was faster during thrusting than the 36-20 Ma average. Considering all previously presented information, the most likely scenario is out-of-sequence thrust propagation with less than $50 \%$ shortening of the $\mathrm{Te}$ Rata and Waitahaia allochthons, and around 200-250 km southwestward displacement of the Matakaoa sheet at a rate of $30-40 \mathrm{~mm} / \mathrm{yr}$.

\subsection{ORIGIN}

Having described the structure of the East Coast Allochthon and having discussed the history and amount of thrusting within it, the tectonics which drove the deformation 
can now be considered. Stoneley (1968) postulated that thrust sheets slid under gravity both southwestward and northeastward from a 'high' in the Hikurangi-Te Puia area. Subsequently, most authors (e.g., Laing, 1972a; Speden, 1976; Kenny, 1980, 1984a, 1986) have invoked gravity sliding as the mode of emplacement of thrust sheets throughout the region. It has been shown (section 6.2.2.2) that the geometry and sequence of faulting in the southern zone is more compatible with thrusting in response to a push from the rear than with gravity sliding of individual sheets or groups of sheets. Furthermore, sliding down an incline could not have generated the synchronous, interlocking, northeast-directed and southwest-directed thrusts of the northern zone (sections 6.4.3.1, 6.4.3.2). Those structures could only have been produced by regional northeast-southwest compression. Such compression would have resulted from southwestward subduction of the Pacific Plate beneath the North Island, which began at about the start of the Miocene (e.g., Walcott, 1984, 1987; Rait et al., 1991). Gravity sliding may, however, have had a minor influence on the structure.

Plate reconstructions (Walcott, 1987; Rait et al., 1991) and considerations based on sedimentary facies trends (section 2.4.1) show that the southwestward transport undergone by the major allochthons was toward the continental interior, at a high angle to the developing subduction zone. The northeasternmost (and probably highest) exposed allochthon-the Matakaoa sheet-consists of basaltic volcanics and minor sediments proabably formed as oceanic crust and/or seamounts (Pirajno, 1980; section 2.2.2.1). It is therefore an ophiolite, the southwestward emplacement of which during the initiation of Pacific Plate subduction drove the thrusting in the East Coast Allochthon. The mode of emplacement of this ophiolite is not obvious. However, it is likely to be the same as that of the probably correlative ophiolite in Northland.

In Northland (Fig. 1.1a), a stack at least $3 \mathrm{~km}$ thick of allochthonous sheets of Early Cretaceous-earliest Miocene rocks was thrust westward over pre-Cretaceous greywacke and undeformed Eocene-Oligocene inner shelf strata in the earliest Miocene (e.g., Brothers, 1974; Ballance and Spörli, 1979; Hayward et al., 1989). The uppermost sheet (Tangihua Complex of Hayward et al., 1989) consists of basaltic volcanic rocks with interbedded pelagic sediments and associated subvolcanic to plutonic intrusions of Early Cretaceous to probably Paleogene age (Hayward, 1983; Hayward et al., 1989). It was probably formed in an ocean basin northeast of the present continental margin. The present southwestern limit of Tangihua rocks, off Northland's west coast, indicates southwestward transport of at least $150 \mathrm{~km}$. Similarities in rock type and age, structural style, thrust transport directions, and timing of deformation have led to Northland's allochthonous rocks (Northland Allochthon of Ballance and Spörli, 1979) being correlated with the allochthonous rocks of Raukumara Peninsula (Brothers, 1974; Ballance and Spörli, 1979; Brothers and Delaloye, 1982). 
Obduction mechanisms proposed for the Northland ophiolite include: attempted eastward subduction of Northland beneath oceanic crust (Brothers, 1974; Spörli, 1989; Malpas et al., 1992); gravity sliding, with associated diverticulation, off an oceanic high uplifted by the onset of westward subduction beneath the North Island (Ballance and Spörli, 1979); the onset of compression (southwestward subduction) across a northweststriking Cretaceous-Oligocene transform along which seamounts were extruded, and obduction of these seamounts during convergence (Brothers and Delaloye, 1982); and the peeling-off and obduction of the uppermost levels of oceanic crust during the early stages of southwestward subduction (Spörli, 1989; Rait et al., 1991; Malpas et al., 1992). Diverticulation accompanying gravity sliding off a rising oceanic high is unlikely because the presence of the ophiolites at the top of a $>3 \mathrm{~km}$ allochthonous pile requires oceanic crust to have been uplifted at least $6 \mathrm{~km}$ to an elevation $>3 \mathrm{~km}$ above continental Northland. Generation of the ophiolites in a transform zone is also unlikely because the ophiolites are mostly Cretaceous, but transform movement would have been associated with opening of the southern South Fiji Basin northeast of Northland in the Oligocene (Davey, 1982; Malahoff et al., 1982). In evaluating the remaining mechanisms, two sets of data are of primary importance: the composition and thickness of the obducted ophiolites, and the distribution and age of Northland's Late Tertiary andesitic volcanism.

The Tangihua Complex is composed predominantly of volcanic, subvolcanic and sedimentary lithofacies (Hayward et al., 1989). Serpentinised peridotite and cumulate gabbro occur only at North Cape (Brook, 1989). Gravity data over two of the larger ophiolite massifs indicate structural thicknesses generally not exceeding $1 \mathrm{~km}$, but up to $1.7 \mathrm{~km}$ at places (Sharp et al., 1989). Together, these observations suggest that only the uppermost levels of oceanic lithosphere were emplaced onto Northland. This suggestion is not refuted by the presence of the North Cape peridotite/gabbro association, as similar rocks-exhumed by extensional tectonism-occur on the seafloor adjacent to the MidAtlantic Ridge today (Cannat et al., 1992). Ophiolites emplaced by attempted continental subduction, such as the Semail of Oman (Coleman, 1981; Boudier et al., 1985) and the New Caledonia example (Collot et al., 1987) are generally several kilometres thick, include high proportions of mantle peridotite, and have a high-temperature metamorphic sole representing the base of the overriding oceanic lithosphere (e.g., Moores, 1982). The thinness of the Northland ophiolite, its upper-crustal character, and the lack of a metamorphic sole indicate that it is unlikely to have been emplaced by attempted continental subduction.

Ophiolite emplacement onto Northland was associated with andesitic volcanism along a northwest-trending arc (e.g., Ballance, 1976, 1988; Smith et al., 1989). The onset of volcanogenic sedimentation shows that the earliest volcanism was around North Cape at ca. $22 \mathrm{Ma}$, and by ca. $21 \mathrm{Ma}$, the arc was established along the entire length of the 
a

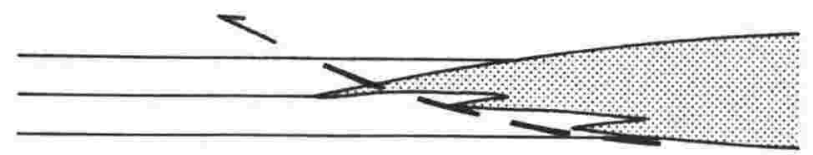

b

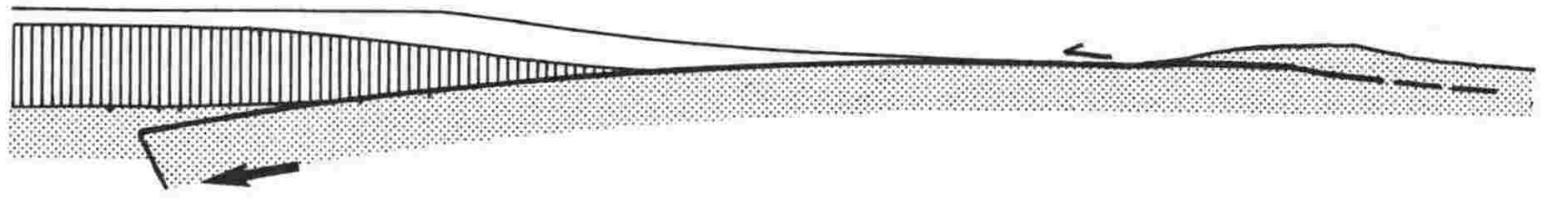

C

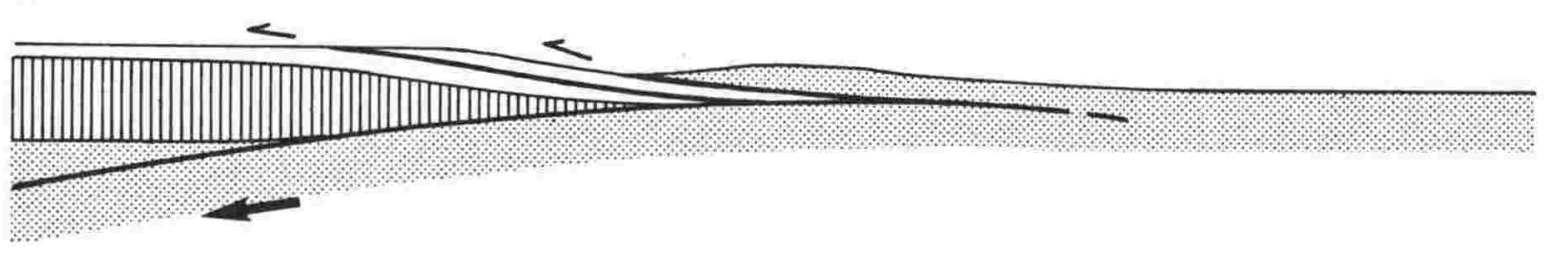

d

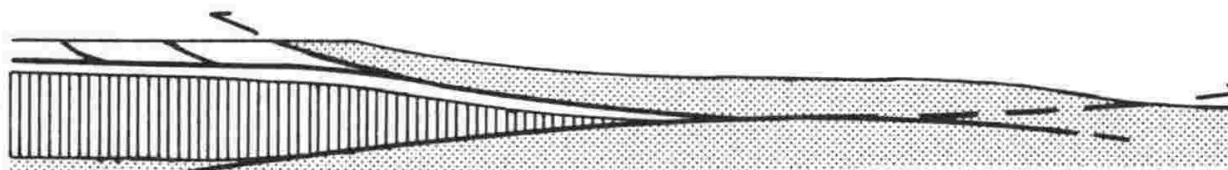

Figure 7.3: Schematic sections showing obduction mechanism of Matakaoa/Tangihua ophiolites. a: Probable original stratigraphic relationship of volcanics with continental margin sediments and likely initial thrust trajectory; b: Onset of Pacific Plate subduction and propagation of initial thrust beneath proto-ophiolite as a result of impingement of volcanics on margin sediments; c: Continued convergence, propagation of sub-ophiolite thrust back into Pacific Plate and landward thrusting in margin sediments; d: Final emplacement of ophiolite and allochthonous sedimentary sheets, and detachment of ophiolite from Pacific Plate. Vertical stripes = oceanic crust, dots = Early Cretaceous and older sedimentary 'basement', white areas = mid-Cretaceous-Paleogene 'cover'. Northeast-directed thrusts (Raukumara Peninsula) not shown for clarity. 
Northland peninsula (Ballance, 1988). The earliest sediments derived from the erosion of rocks of the Northland Allochthon occur at North Cape, and have an age of ca. $24 \mathrm{Ma}$ (Brook, 1989). Widespread synorogenic rocks elsewhere in Northland are WaitakianOtaian (e.g., Hayward et al., 1989). Therefore, volcanism related to southwestward subduction began shortly after the initiation of thrusting related to ophiolite obduction.

In almost all subduction zones, the volcanic front is around $110 \mathrm{~km}$ above the Benioff zone regardless of slab age, convergence rate or dip angle (e.g., Gill, 1981; Tatsumi, 1986). This constancy is a consequence of the likely melt generation process, the pressure-dependent breakdown of amphibole to release water into the mantle wedge (Plank and Langmuir, 1988). Andesitic volcanism in Northland at 22-21 Ma thus shows that the subducting Pacific Plate had reached at least $110 \mathrm{~km}$ depth by that time. Assuming a slab dip of $45^{\circ}$, a slab length of at least $\approx 150 \mathrm{~km}$ must have been subducted. At reasonable rates of $30-50 \mathrm{~mm} / \mathrm{yr}$ (section 7.3 ), this amount of subduction would have taken place in $\approx 3-5$ m.y. Subduction must thus have started at 24-27 Ma. As initial obduction-related thrusting took place in deep water where sediment supply would have been low, it could be expected to have started perhaps 1-2 m.y. before the appearance of the first synorogenic clastics at $24 \mathrm{Ma}$. However, it is very unlikely that it started any earlier-before the start of subduction-and was not recorded. Models for Tangihua obduction by attempted northeastward subduction of Northland require a subsequent flip in the polarity of the subduction zone to explain Northland's andesitic volcanism (see Brothers, 1974). However, the foregoing considerations demonstrate that obduction did not begin before southwestward subduction.

Accepting that the Northland ophiolite is thin and represents the uppermost levels of oceanic crust and its that obduction did not begin before southwestward subduction, it must be concluded that it was emplaced by the peeling-off of the upper part of the Pacific Plate during the early stages of subduction (Fig. 7.3), the second alternative of Spörli (1989) and Malpas et al. (1992) and the favoured process of Rait et al. (1991). This process is analogous to the 'flake tectonics' of Oxburgh (1972). Presuming the East Coast Allochthon to be the southeastward continuation of the Northland Allochthon, it would also apply to the Matakaoa sheet. The reason the upper oceanic crust was detached and obducted rather than subducted is probably because the topmost (latest Cretaceous and Paleogene) levels of it interfingered with and prograded southwestward over the most distal continental margin sediments. A sedimentary contact between Tangihua Volcanics and Late Cretaceous continental margin sediments has been observed in northernmost Northland (Brook, 1989). If the volcanics prograded southwestward over the sediments, the onset of convergence between the volcanics and the continent would have resulted in the nucleation of a thrust which dipped northeastward, beneath the volcanics (Fig. 7.3a, b). This thrust would have continued to propagate back into the Pacific Plate as 
convergence continued, allowing the ophiolites to climb up the continental slope while pushing the allochthonous sedimentary sheets ahead of them (Fig. 7.3c). Thrusting may have stopped-after $\approx 6$ m.y. and $150-250 \mathrm{~km}$ of movement-as a result of the ophiolite sheets becoming completely detached from the downgoing slab (Fig. 7.3d).

\subsection{CONCLUSIONS}

Synthesis of the information presented in preceding chapters has led to the following conclusions regarding the structure, evolution and origin of the East Coast Allochthon as a whole:

1) Early Miocene deformation in the southern and central zones of the East Coast Allochthon was thin-skinned, involving southwestward transport of sheets along thrusts which lay at or above the top of the Whangai Formation. In contrast, deformation in the northern zone was thick-skinned, involving reactivations of northeast-directed Cretaceous thrusts-which extend to unknown depths-as well as southwestward emplacement of allochthonous sheets.

2) The southern zone is an imbricate fan composed of Mangatu Group rocks detached from the underlying Whangai Formation and transported up to about $18 \mathrm{~km}$ southwestward. In the more complex central and northern zones, five major, southwest-directed sheets or sheet groups have been distinguished. These are, from lowest to highest and south to north: the Mokoiwi/Waitahaia sheet, consisting of Mokoiwi Formation, and the slices of Tapuwaeroa-Mangatu rocks accreted beneath it during its motion; the southwest Te Rata sheet, consisting of Whangai and Tikihore Formations; the central Te Rata/mélange/Cretaceous-Tertiary unit; the upper Tikihore sheet; and the Matakaoa sheet.

3) These five sheets or sheet groups make up three major allochthonous units: the Waitahaia/Mokoiwi sheet (referred to as the Waitahaia allochthon) above the Waitahaia Fault; the Te Rata/mélange/Cretaceous-Tertiary/upper Tikihore unit (the Te Rata allochthon), above the Te Rata thrust; and the Matakaoa sheet. The Waitahaia allochthon is the lowest unit in the thrust pile, the Te Rata allochthon is in the middle, and the Matakaoa sheet is at the top and back.

4) There are two thrust propagation histories which can explain the relationships between these three units: forward propagation and out-of-sequence propagation. In both, the Waitahaia allochthon was emplaced first. In forward propagation the Te Rata allochthon originally lay in front of the Waitahaia allochthon, and the sub-Te 



\section{Chapter 8}

\section{Regional Tectonics and the Onset of Subduction}

\subsection{INTRODUCTION}

The East Coast Allochthon and its correlative in Northland formed along part of a continental margin where Pacific Plate subduction was initiated in the Early Miocene (see section 1.2). Recent work on Early Miocene structures in Wairarapa by F. Chanier (Chanier and Ferrière, 1989, 1991) and in Marlborough by D.W. Waters (Waters, 1988) has shown that like the East Coast Allochthon, those structures were active for a short time ( $\approx 5$ m.y.) during the inception of the subduction zone and are unlike structures which form adjacent to long-lived subduction zones. These findings, along with those of other recent workers and the preliminary findings of this study, were summarised with reference to the Early Miocene plate configuration by this author in a paper entitled "Landward- and seaward-directed thrusting accompanying the onset of subduction beneath New Zealand" (Geology, v. 19 p. 230-231). So that the East Coast Allochthon can be appreciated in its context as one segment of this early-subduction related orogenic belt, that paper is included (overleaf) as the final chapter of this thesis. 


\title{
Landward- and seaward-directed thrusting accompanying the onset of subduction beneath New Zealand
}

\author{
Geoff Rait \\ Research School of Earth Sciences, Victoria University, P.O. Box 600, Wellington, New Zealand \\ Frank Chanier \\ Géologie Dynamique S.N. 5, Université des Sciences et Techniques de Lille, 59655 Villeneuve d'Ascq Cedex, France \\ David W. Waters* \\ Research School of Earth Sciences, Victoria University, P.O. Box 600. Wellington, New Zealand
}

\begin{abstract}
A short ( $\sim 5$ m.y.) episode of deformation accompanied the onset of the present phase of subduction beneath northern and eastern New Zealand in the earliest Miocene. At many places along the continental margin, the structures produced were dominated by subhorizontal thrust sheets with tens of kilometres of displacement. Thrusting was directed both landward (with or without involvement of the upper part of the downgoing plate) and seaward. The structures are different in style from those typical of active trench slopes, which are predominantly seaward-directed imbricate thrusts and associated folds. The structures show that delamination of the downgoing plate occurred at some places and suggest that a high degree of coupling between upper and lower plates occurred at others.
\end{abstract}

\section{INTRODUCTION}

Subduction complexes form on the edges of the upper plates of subduction zones and are places where considerable deformation occurs. Many examples, both active and ancient, have been intensively studied, and much is now known about the processes that operate and the structures that form in subduction complexes during subduction. Little is directly known, however, about what takes place on continental margins at the initiation of subduction.

The onset of deformation on the northern and eastern margin of New Zealand at the beginning of the Miocene has been correlated with the onset of subduction there. Herein, we show that the early Miocene deformation was a short episode ( $\sim 5 \mathrm{~m} . \mathrm{y}$.), that it produced structures varying in style along the margin, and that those structures are in general different from structures typical of active trench slopes. Throughout, we use the correlations by Edwards et al. (1988) of the New Zealand geologic time scale with the international time scale.

\section{TIMING OF ONSET OF SUBDUCTION BENEATH NEW ZEALAND}

Subduction of the westward-traveling Pacific plate beneath the eastern margin of the Australian plate is now occurring east of the North Island and Marlborough in the Hikurangi Trough (Fig. 1). Subduction beneath those areas

*Present address: Department of Earth Sciences, Cambridge University, Downing Street, Cambridge CB2 3EQ, England. and beneath Northland (Fig. 1) is widely considered to have started during the New Zealand Waitakian Stage (Aquitanian) (e.g., Ballance, 1976; van der Lingen, 1982; Spörli, 1987; Lamb and Bibby, 1989). Three main lines of evidence for the timing of the onset of subduction are usually cited: the beginning of andesitic volcanism, an abrupt change in sedimentation rate and

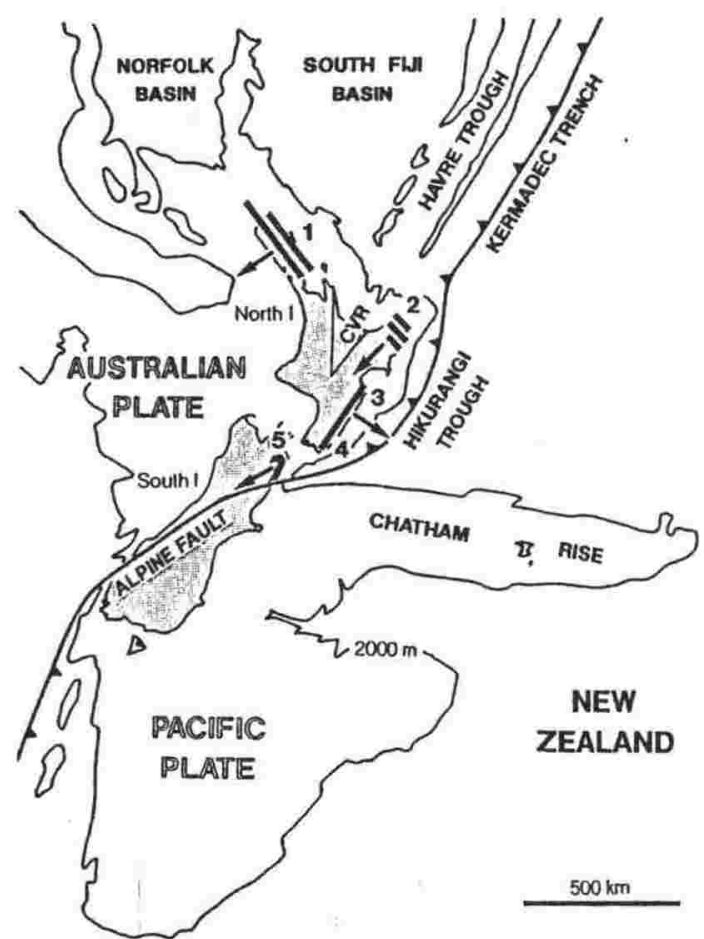

character, and the start of a period of intense deformation.

The earliest andesitic volcanism was at the northern tip of the Northland peninsula at ca. 22 $\mathrm{Ma}$, and by ca. $21 \mathrm{Ma}$, an arc was established along the length of the peninsula almost as far south as the Central Volcanic region (Ballance, 1988). There was no early Miocene arc in or 
adjacent to eastern North Island or Marlborough, but this does not necessarily contradict interpretations of early Miocene subduction there; subduction is occurring at present beneath those areas, but there is no arc volcanism south of the Central Volcanic region.

Mesozoic subduction beneath Northland, eastern North Island, Marlborough, and Chatham Rise stopped near the end of the Early Cretaceous (Spörli, 1987). The Mesozoic subduction complex is unconformably overlain by a relatively thin (1-2 km) Upper Cretaceous-Oligocene succession that fines and increases in carbonate content upward (Suggate et al., 1978; Moore, 1988; Hayward et al., 1989). In Northland, eastern North Island, and Marlborough, the sedimentation rate increased dramatically in the Aquitanian, and terrigenous sediments including olistostromes and flysch were deposited (Prebble, 1980; van der Lingen, 1982; Hayward et al., 1989). In Marlborough, $1500 \mathrm{~m}$ of sediment were deposited during the first $10 \mathrm{~m} . \mathrm{y}$. of the Miocene, about the same thickness as had been deposited during the preceding 60 m.y. (Prebble, 1980).

An episode of deformation involving foldand-thrust structures also began in the early Miocene. The locations of early Miocene thrust belts are shown in Figure 1. Aquitanian olistostromes and flysch in basins adjacent to structural highs in all the belts have been interpreted as marking the start of this deformation (Stoneley, 1968; van der Lingen, 1982; Hayward et al., 1989; Lamb and Bibby, 1989).

\section{EARLY MIOCENE PLATE- BOUNDARY GEOMETRY}

Since the early Miocene, relative plate motion and widespread intracontinental deformation have deformed the continental margin. To examine the initial geometry of the continental margin, the thrust belts, and the early Miocene plate boundary, it is necessary to remove that subsequent deformation.

Figure 2 is a reconstruction of the New Zealand region at $25 \mathrm{Ma}$. The zone of significant post-early Miocene deformation has been lef unshaded. Outside this zone, the relative positions of the continental fragments are from Walcott (1987, Fig. 4). Within the zone, Raukumara Peninsula has been restored to a position adjacent to Northland by closing the Central Volcanic region and Havre Trough, both of which are younger than $4 \mathrm{Ma}$ (Malahoff et al., 1982; Stern, 1985); the Marlborough thrust belt has been reconstructed by removing large late $\mathrm{Ce}$ nozoic rotations (Walcott, 1989); and the Hawkes Bay-Wairarapa sector has been reconstructed so as to be contiguous with Raukumara Peninsula and Marlborough. Its orientation is consistent with rotations observed in paleomagnetic studies (reviewed by Walcott, 1989).

The South Fiji Basin, currently northeast of
Northland (Fig. I), is Oligocene sea floor (Malahoff et al., 1982). Because Cretaceous oceanic volcanic rocks were emplaced onto Northland from the northeast in the earliest Miocene (see below), the South Fiji Basin must have reached its present position after that time. The Norfolk basin (Fig. 1) is underlain by sea floor of unknown age (Malahoff et al., 1982). In Figure 2 , we have closed the Norfolk basin, thus moving the South Fiji Basin northwestward along the Vening Meinesz fracture zone (Malahoff et al., 1982) and leaving old sea floor adjacent to Northland.

Although subduction beneath northeastern New Zealand began in the earliest Miocene, seafloor-spreading studies show that motion between the Pacific and Australian plates started in about the late Eocene (Stock and Molnar, 1982). Late Eocene-Oligocene deformation has been documented west of the North Island and in western South Island (Kamp, 1986). We infer that pre-Miocene relative plate motion took place in an intracontinental zone west of New Zealand, along the Vening Meinesz fracture zone, and in a west-dipping subduction zone east of the actively spreading South Fiji Basin (Fig. 2). The youngest magnetic anomaly in the South Fiji Basin is anomaly 7 (25.7 Ma) (Malahoff et al., 1982). If the Norfolk basin is a postOligocene feature, then the subduction zone east of the South Fiji Basin had rolled back to the position shown in Figure 2 just prior to the onset of subduction beneath New Zealand. From the earliest Miocene onward, relative plate motion was accommodated by subduction beneath northeastern New Zealand and by dextral motion on the Alpine fault, which started mov-

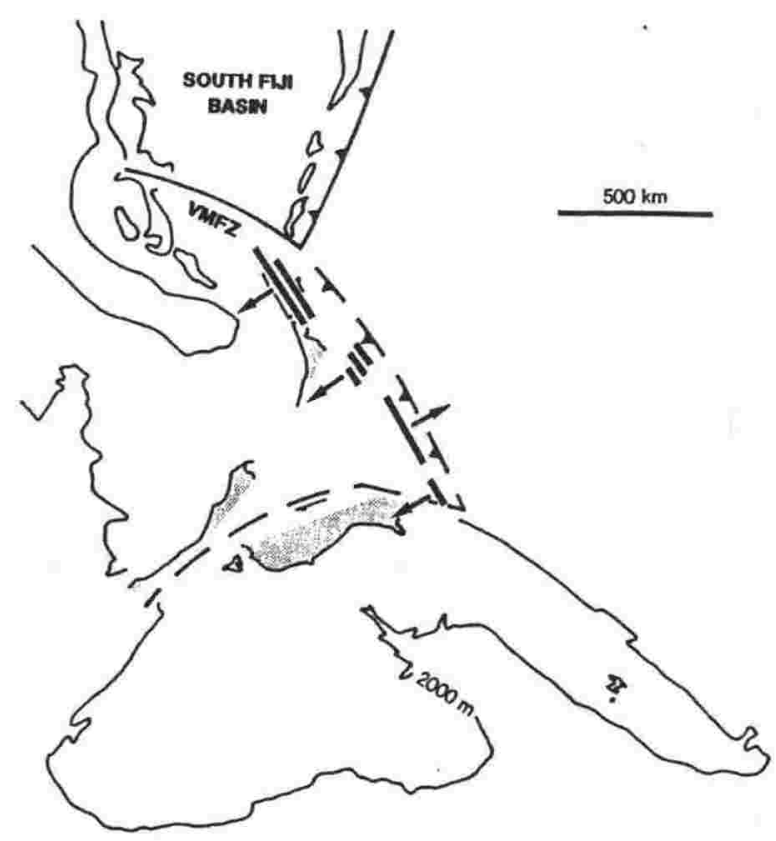
et al., 1987). ing at about that time (Kamp, 1986; Cooper

\section{EARLY MIOCENE DEFORMATION}

\section{IN NORTHERN AND EASTERN NEW}

\section{ZEALAND: A SHORT EPISODE}

The Northland and Raukumara Peninsula thrust belts are unconformably overlain by strata of late Burdigalian age (Stoneley, 1968; Hayward et al., 1989), suggesting that deformation in those belts was over by that time. Northland has undergone little post-early Miocene deformation (Spörli, 1987), a consequence of the subduction zone having migrated away from there (Ballance, 1976). Raukumara Peninsula has undergone post-middle Miocene open folding and normal faulting on a northeast trend, at a high angle to the earlier thrusting (Mazengarb, 1984).

Southern Hawkes Bay and Wairarapa have undergone post-early Miocene folding and thrusting. In coastal Wairarapa, deformation was discontinuous: early Miocene thrusts are unconformably overlain by an upper Burdigalian-middle Miocene succession that has been folded and faulted by late Miocene-Quaternary deformation (Chanier and Ferrière, 1989). Pettinga (1982) considered that thrusting in southern Hawkes Bay was essentially continuous from early Miocene to Quaternary time. However, the geologic relations there can be interpreted as indicating discontinuous deformation: strata of late early to early middle Miocene age are absent, and early Miocene structures are overlain by strata of late middle to late Miocene age (van der Lingen and Pettinga, 1980; Pettinga, 1982).
Figure 2. Reconstruction of plate configuration and positions of early Miocene thrust belts at $25 \mathrm{Ma}$, modified after Waicolt (1987). Dashed lines indicate positions of developing trench and Alpine fault. VMFZ = Vening Meinesz fracture zone. See lext for further discussion. 
In Marlborough, the cessation of thrusting can only be constrained with certainty to before the late middle Miocene, as an unconformity of that age overlies the thrust system there (Waters, 1988). Given that the youngest rocks in the system are Burdigalian, however, we infer that thrusting was entirely an early Miocene event.

The discontinuous deformation history we infer for eastern North Island and Marlborough may be a reflection of variations in the rate of plate convergence. Stock and Molnar (1982) showed that there was considerable PacificAustralia motion between the times of formation of magnetic anomalies 13 and 6 (35.6-19.9 Ma; Berggren et al., 1985) and between anomaly $5(9.7 \mathrm{Ma})$ and the present, but little between anomalies 6 and 5 (i.e., during the middle Miocene).

\section{STYLE OF EARLY MIOCENE CONTINENTAL-MARGIN \\ DEFORMATION}

The style of the early Miocene deformation varies along the continental margin. In Northland, a >3-km-thick stack of allochthonous sheets of Early Cretaceous-earliest Miocene age deep-water rocks has been thrust southwestward over pre-Cretaceous graywacke and undeformed Eocene and Oligocene inner-shelf strata (Hayward et al., 1989). The oceanic volcanic rocks of the uppermost sheet have often been referred to as ophiolites (e.g., Spörli, 1987; Hayward et al., 1989). However, these "ophiolites" are only 0.5-1 km thick (Cassidy and Locke, 1987) and are composed almost exclusively of intercalated basaltic lava flows and mudstone or limestone, with minor mafic sills and dikes (Hayward et al., 1989), suggesting that only the uppermost levels of oceanic lithosphere are present. Ultramafic rocks are present at only one place, North Cape (Brook, 1989), and no high-temperature metamorphic sole is present anywhere. Hayward et al. (1989) suggested that these volcanic rocks were derived from a thick oceanic plateau that formed adjacent to Northland in the Late Cretaceous and early Paleogene.

The oldest synorogenic deposits in Northland have an estimated age of $24 \mathrm{Ma}$ (Brook, 1989). Because the earliest andesitic volcanism was at ca. $22 \mathrm{Ma}$, oceanic lithosphere must have been descending during obduction of the "ophiolites" to have reached a depth at which magma could have been generated at that time. This observation and the inference that the "ophiolites" represent only the upper levels of oceanic lithosphere suggest that they were peeled off the subducting plate and driven up the continental slope onto the shelf. The most southwesterly "ophiolites" are now $\sim 150 \mathrm{~km}$ from the northeastern edge of the continent.

The Raukumara Peninsula thrust system (Fig. $3 \mathrm{~A})$ has an exposed cross-strike width of 110 $\mathrm{km}$. The thrust front is exposed in the southwest of the peninsula (Stoneley, 1968), and there are allochthonous oceanic volcanic rocks of midCretaceous and Paleocene-Eocene age in the extreme northeast (Strong, 1980). In the northeastern one-third of the system, all the exposed pre-Miocene rocks are complexly deformed. In the southwestern part, however, the sole thrust lies at or near the top of a Maastrichtian-Danian mudstone and ramps up through Oligocene shelf strata and lower Miocene flysch over a short distance close to the thrust front (Stoneley, 1968)

The structural style in the internal parts of the Raukumara system is complex. Figure $3 \mathrm{~B}$ shows that the northeast-directed thrust F1 and the folds in its footwall have been cut by the southwest-directed F2. F2 is the sole thrust southwest of F1. Late Cretaceous rocks above F2 $45 \mathrm{~km}$ southwest of F1 are equivalent to those beneath F2 immediately northeast of F1, showing that $\mathrm{F} 2$ has a minimum southwestward displacement of $45 \mathrm{~km}$ (Rait, unpub. data). By analogy with Northland, we consider the Raukumara Peninsula thrust system to have been driven by detachment and obduction of the upper levels of oceanic crust during the initiation of subduction.

In coastal southern Hawkes Bay, Pettinga (1982) documented complexly deformed rocks of Cretaceous-earliest Miocene age that formed northeast-striking structural highs in a basin of mid-slope to outer-slope olistostromes and flysch. He inferred that the main phase of deformation started in the early Miocene and involved southeast-directed thrusting that propagated northwestward with time. He also inferred a mid-late Oligocene episode involving north- to northwest-directed gravity-glide fold nappes. Evidence for this earlier phase, however, was based on microstructural analysis in the overturned limb of a fold.

In coastal Wairarapa (Fig. 3C), the early Miocene structure consisted of subhorizontal sheets, up to $1 \mathrm{~km}$ thick, of Cretaceous-Paleocene shelf and upper-slope rocks thrust southeastward over imbricated Upper Cretaceous-Eocene pelagic rocks (Chanier and Ferrière, 1989) (Fig. 3D). In the west, the structurally highest sheets are Lower Cretaceous flysch of the previous subduction episode. A window into pelagic rocks through the shelf and upper-slope rocks above the dominant thrust (F3, Fig. 3D) occurs $10 \mathrm{~km}$ northwest of the front of that thrust, showing that its horizontal displacement is at least $10 \mathrm{~km}$. Because the thrust juxtaposes Lower Cretaceous and Eocene rocks at both localities, however, its true displacement is likely to be much greater.

In Marlborough (Fig. 3E), the early Miocene
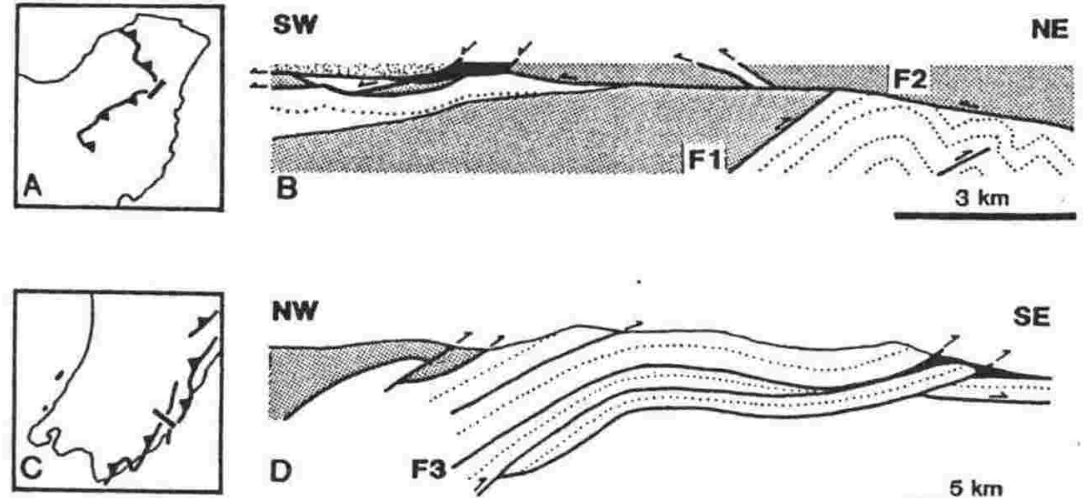

NW
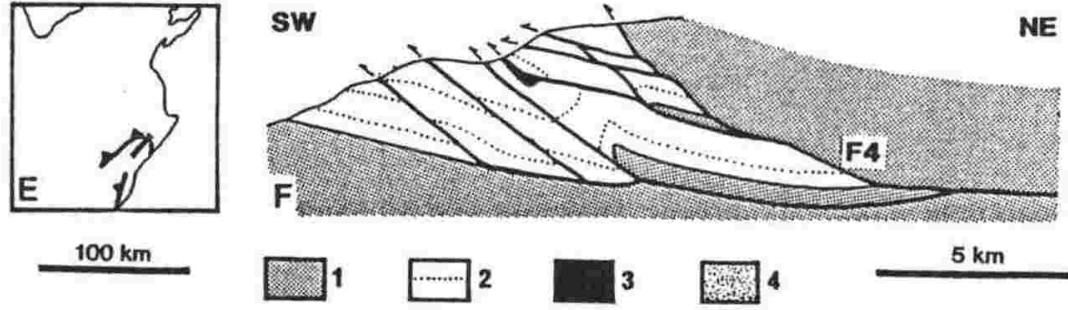

$100 \mathrm{~km}$

mart

mara P. A, C, E: Maps showing early Miocene structures and locations of profiles in Rauku(Rait) Peninsula, Wairarapa, and Marlborough, respectively. B: Raukumara Peninsula profile st-thrust normal faulting removed. F1 and F2 are thrusts referred to in text. D: Coastal thrust. thrust. F: Marlborough profile (Waters); $18^{\circ}$ post-thrust tilting removed. $F 4=$ dominant thrust. 1 = Lower Cretaceous graywacke basement, 2 = Late Cretaceous-Paleogene passive margin sequence, 3 = lower Miocene synorogenic sedimentary rocks, 4 = tectonic melange. 
thrust system has been deformed and dismembered by subsequent thrust and strike-slip faulting. The least-disturbed remnant of it is a northwest-striking segment (Fig. 3F) where the structure consists of moderately to steeply northeast dipping, southwest-directed thrusts that cut moderately northeast dipping Cretaceous-lower Miocene strata. The amount of displacement on the dominant thrust (F4, Fig. $3 \mathrm{~F})$ is poorly constrained. Restoring the stratigraphy in its hanging wall to that in its footwall, the minimum displacements consistent with initial dips of $\mathrm{F} 4$ of $5^{\circ}$ and $25^{\circ}$ (typical initial dips of the other faults) are $23 \mathrm{~km}$ and $10 \mathrm{~km}$, respectively. If the fault flattened at depth, these figures would be increased. Total shortening across the system is $50 \%$ and $70 \%$ for the two cases. The amount of vertical stacking is $-5 \mathrm{~km}$. The nature of the synorogenic deposits suggests that the deformation took place in slope to inner-shelf environments (Waters, 1988)

\section{DISCUSSION}

In the foregoing, we showed that there was a short ( $\sim 5$ m.y.) episode of deformation on the northeastern margin of New Zealand in the early Miocene. This deformation began at the same time as the onset of subduction there. The individual early Miocene thrust belts varied in style. Some were landward directed, with or without involvement of the upper part of the downgoing plate, and some were seaward directed. All, with the possible exception of southern Hawkes Bay, were dominated by subhorizontal thrust sheets with tens of kilometres of displacement. Such structures are not typical of active trench slopes and accretionary prisms, which are dominated by seaward-directed thrusts and associated folds (e.g., Moore et al., 1985; Davey et al., 1986).

The structures we have described provide an insight into the processes that operated on the New Zealand margin during the onset of subduction. Delamination of the downgoing plate occurred adjacent to Northland and Raukumara Peninsula, and "ophiolites" and continentalmargin sedimentary rocks were pushed up the slope onto the shelf. Beneath the obducted material in Raukumara Peninsula, the upper plate of the developing subduction zone deformed by folding and seaward-directed thrusting in its more trenchward part, but the shelf to the southwest did not deform. The inner shelf beneath the obducted material in Northland remained undeformed. Delamination of the downgoing plate did not take place adjacent to southern Hawkes Bay and Wairarapa, where thrusting was sympathetic to the subduction thrust, or adjacent to Marlborough, where thrusting was landward directed. In southern Hawkes Bay, deformation in the upper plate started on the mid-slope to outer slope and propagated landward. In Wairarapa and Marlborough, the large fault displacements and the amount of shortening across the shelf and slope suggest a high degree of coupling between the upper and lower plates. This is perhaps surprising, as subduction had been taking place there up to the Late Cretaceous, and reactivation of the old subduction thrust would presumably be mechanically favored.

\section{REFERENCES CITED}

Ballance, P.F., 1976, Evolution of the upper Cenozoic magmatic arc and plate boundary in norther New Zealand: Earth and Planetary Science Letters, v. 28, p. $356-370$

- 1988, Late Cenozoic time-lines and calc-alkaline volcanic ares in northern New Zeaiand-Furthe discussion: Royal Society of New Zealand Journal, v. 18 , p. $347-358$

Berggren, W.A., Kent, D.V., Flynn, J.J., and Van Couvering, J.A., 1985, Cenozoic geochronology: Geological Society of America Bulletin, v. 96, p. 1407-1418.

Brook, F.J., 1989, Sheets N1 and N2-North Cape and Three Kings, geological map of New Zealand: Wellington, Department of Scientific and Industrial Research, scale 1:63360.

Cassidy, J., and Locke, C.A., 1987, Thin ophiolites of North Island, New Zealand: Tectonophysics, v. 139, p. 315-319.

Chanier, F, and Ferrière, J., 1989, On the existence of major tangential movements in the East Coast Range of New Zealand: Their significance within the framework of Pacific Plate subduction: Paris, Académie des Sciences Comptes Rendus, v. 308 sér. II, p. 1645-1650.

Cooper, A.F., Barriero, B.A., Kimbrough, D.L., and Mattinson, J.M., 1987, Lamprophyre dike intrusion and the age of the Alpine fault, New Zealand: Geology, v. 15, p. 941-944.

Davey, F.J., Hampton, M., Childs, J., Fisher, M.A. Lewis, K.B., and Pettinga, J.R., 1986, Structure of a growing accretionary prism, Hikurangi margin, New Zealand: Geology, v. 14, p. 663-666.

Edwards, A.R., Hornibrook, N., Raine, J.I., Scoth, G.H., Stevens, G.R., Strong, C.P., and Wilson, G.J., 1988, A New Zealand Cretaceous-Cenozoic geological time scale: New Zealand Geological Survey Record 35, p. 135-149.

Hayward, B.W., Brook, F.J., and Isaac, M.J., 1989 Cretaceous to middle Tertiary stratigraphy, paleogeography, and tectonic bistory of Northland New Zealand: Royal Society of New Zealand Bulletin 26, p. 47-64.

Kamp, P.J.J., 1986, The mid-Cenozoic Challenger rif system of western New Zealand and its implications for the age of Alpine fault inception: Geological Society of America Bulletin, v. 97, p. 255-281.

Lamb, S.H., and Bibby, H.M., 1989, The last 25 Ma of rotational deformation in part of the New Zealand plate-boundary zone: Journal of Structural Geology, v. II, p. 473-492.

Malahoff, A., Feden, R.H., and Fleming, H.S., 1982 Magnetic anomalies and tectonic fabric of marginal basins north of New Zealand: Journal of Geophysical Research, v. 87, p. $4109-4125$.

Mazengarb, C., 1984, The Fernside fault: An active normal fault, Raukumara Peninsula, New Zealand: New Zealand Geological Survey Record 3, p. 98-103.

Moore, J.C., Cowan, D.S., and Karig, D.E., 1985 Penrose Conference report: Structural styles and deformation fabrics of accretionary complexes: Geology, v. 13, p. 77-79.

Moore, P.R., 1988, Structural divisions of eastern North Island: New Zealand Geological Survey Record 30, $24 \mathrm{p}$.
Pettinga, J.R., 1982, Upper Cenozoic structural history, coastal southern Hawkes Bay, New Zealand: New Zealand Journal of Geology and Geophysics, v. 25, p. 149-191.

Prebble, W.M., 1980, Late Cainozoic sedimentation and tectonics of the East Coast Deformed Belt, in Marlborough, New Zealand, in Ballance, P.F., and Reading, H.G., eds., Sedimentation in oblique-slip mobile zones: International Association of Sedimentologists Special Publication 4, p. 217-228.

Spörli, K.B., 1987, Development of the New Zealand microcontinent, in Monger, JW. $\mathrm{H}_{\text {, and Fran- }}$ chetau, J., eds., Circum-Pacific orogenic belts and evolution of the Pacific Ocean basin: Washington, D.C., American Geophysical Union, p. $115-132$

Stern, T.A., 1985, A back-arc basin formed within continental lithosphere: The Central Volcanic region of New Zealand: Tectonophysics, v. 112, p. 385-409.

Stock, J.M., and Molnar, P., 1982, Uncertainties in the relative motions of the Australia, Antarctica, and Pacific plates since the Late Cretaceous: Journal of Geophysical Research, v. 87, p. 4697-4714.

Stoneley, R., 1968, A lower Tertiary decollement on the East Coast, North Island, New Zealand: New Zealand Journal of Geology and Geophysics, v. 11, p. 128-156.

Strong C.P. 1980, Early Paleogene foraminifera from the Matakaoa Volcanic Group: New Zealand Journal of Geology and Geophysics, v. 23, p. $267-272$

Suggate, R.P. Stevens, G.R and Te Punga, M.T. eds., 1978, The geology of New Zealand: Wellington, Government Printer, p. 482-487.

van der Lingen, G.J., 1982, Development of the North Island subduction system, New Zealand, in Leggett, J.K., ed., Trench-forearc geology: Geological Society of London Special Publication 10, p. 259-272.

van der Lingen, G.J., and Pettinga, J.R., 1980, The Makara basin: A Miocene slope-basin along the New Zealand sector of the Australian-Pacific obliquely convergent plate boundary, in Ballance, P.F., and Reading, H.G., eds., Sedimentation in oblique-slip mobile zones: International Association of Sedimentologists Special Publication 4, p. 191-215

Waicott, R.I., 1987, Geodetic strain and the deformational history of the North Island of New Zealand during the late Cainozoic: Royal Society of London Philosophical Transactions, v. A 321, p. 163-181.

- 1989, Paleomagnetically observed rotations along the Hikurangi margin of New Zealand, in Kissel, C., and Laj, C., eds., Paleomagnetic rotations and continental deformation: Dordrecht, Kluwer, p. 459-471.

Waters, D.W., 1988, The Flags Creek thrust [B.Sc. (honors) thesis]: Wellington, Victoria University, $150 \mathrm{p}$.

\section{ACKNOWLEDGMENTS}

Chanier received funding from the Institut National des Sciences de l'Univers and Centre National de Recherche Scientifique (France). Much of the impetus for this paper came from D. J. May. We thank J. Ferrière, D. J. May, and R. I. Walcot for discussions and assistance; A. S. Jayko and A. P. Roberts for helpful comments; and J. C. Moore and J. R. Pettinga for useful reviews.

Manuscript received June 15, 1990

Revised manuscript received September 24, 1990 Manuscript accepted October 15, 1990 


\section{References}

Adams, J.H., 1910, The geology of Whatatutu Subdivision: N.Z. Geological Survey Bulletin 9.

Allmendinger, R.W., 1981, Structural geometry of Meade thrust plate in northern Blackfoot Mountains, southeastern Idaho: American Association of Petroleum Geologists Bulletin 65, 509-525.

Baker, D.M., Lillie, R.J., Yeats, R.S., Johnson, G.D., Yousuf, M., and Zamin, A.S.H., 1988, Development of the Himalayan thrust zone: Salt Range, Pakistan: Geology 16, 3-7.

Ballance, P.F., 1976, Evolution of the upper Cenozoic magmatic arc and plate boundary in northern New Zealand: Earth and Planetary Science Letters 28, 356-370.

Ballance, P.F., 1988, Late Cenozoic time-lines and calc-alkaline volcanic arcs in northern New Zealand-further discussion: Journal of the Royal Society of N.Z. 18, 347358.

Ballance, P.F., and Spörli, K.B., 1979, Northland Allochthon: Journal of the Royal Society of N.Z. 9, 259-275.

Bally, A.W., Gordy, P.L., and Stewart, G.A., 1966, Structure, seismic data and orogenic evolution of southern Canadian Rocky Mountains: Bulletin of Canadian Petroleum Geology 14, 337-381.

Black, R.A., 1980, Upper Cretaceous and Tertiary geology of Mangatu State Forest, Raukumara Peninsula: N.Z. Journal of Geology and Geophysics 23, 293-312.

Black, R.A., 1981, Upper Cretaceous and Tertiary geology of Mangatu State Forest, Raukumara Peninsula: Reply: N.Z. Journal of Geology and Geophysics 24, 302-303.

Boudier, F., Bouchez, J.L., Nicolas, A., Cannat, M., Ceuleneer, G., Misseri, M., and Montigny, A., 1985, Kinematics of oceanic thrusting in the Oman ophiolite: Model of plate convergence: Earth and Planetary Science Letters 75, 215-222. 
Boyer, S.E., 1986, Styles of folding within thrust sheets: Examples from the Appalachian and Rocky Mountains of the U.S.A. and Canada: Journal of Structural Geology 8, 325-339.

Boyer, S.E., and Elliott, D., 1982, Thrust systems: American Association of Petroleum Geologists Bulletin 66, 1196-1230.

Brook, F.J., 1989, Sheets N1 \& N2, North Cape-Three Kings: Geological Map of New Zealand 1:63,360: DSIR, Wellington, N.Z.

Brothers, R.N., 1974, Kaikoura Orogeny in Northland, New Zealand: N.Z. Journal of Geology and Geophysics 17, 1-18.

Brothers, R.N., and Delaloye, M., 1982, Obducted ophiolites of North Island, New Zealand: origin, age, and implications for Tertiary and Quaternary volcanicity: N.Z. Journal of Geology and Geophysics 25, 257-274.

Burbank, D.W., Vergés, J., Muñoz, J.A., and Bentham, P., 1992, Coeval hindward- and foward-imbricating thrusting in the south-central Pyrenees, Spain: Timing and rates of shortening and deposition: Geological Society of America Bulletin 104, 3-17.

Butler, R.W.H., 1982, The terminology of structures in thrust belts: Journal of Structural Geology 4, 239-245.

Butler, R.W.H., 1983, Balanced cross-sections and their implications for the deep structure of the NW Alps: Journal of Structural Geology 5, 125-138.

Butler, R.W.H., 1987, Thrust sequences: Journal of the Geological Society of London 144, 619-634.

Butler, R.W.H., and Coward, M.P., 1984, Geological constraints, structural evolution and deep geology of the Northwest Scottish Caledonides: Tectonics 3, 347-365.

Cannat, M., Bideau, D., and Bougault, H., 1992, Serpentinised peridotites and gabbros in the Mid-Atlantic Ridge axial valley at $15^{\circ} 37^{\prime} \mathrm{N}$ and $16^{\circ} 52^{\prime} \mathrm{N}$ : Earth and Planetary Science Letters 109, 87-106.

Casas, J.M., and Sàbat, F., 1987, An example of three-dimensional analysis of thrustrelated tectonites: Journal of Structural Geology 8, 341-360. 
Cawood, P.A., Green, F.K., and Calon, T.J., 1990, Origin of culminations within the southeast Oman Mountains at Jebel Ma-jhool and Ibra dome, in: Robertson, A.H.F., Searle, M.P., and Ries, A.C., eds., The Geology and Tectonics of the Oman Region: Geological Society of London Special Publication 49, 429-445.

Chapman-Smith, M., and Grant-Mackie, J.A., 1971, Geology of the Whangaparaoa area, eastern Bay of Plenty: N.Z. Journal of Geology and Geophysics 14, 3-38.

Chanier, F., and Ferrière, J., 1989, On the existence of major tangential movements in the East Coast Range of New Zealand: their significance within the framework of Pacific Plate subduction: Compte Rendus de 1' Academie des Sciences, Paris 308 Série II, 1645-1650.

Chanier, F., and Ferrière, J., 1991, From a passive to an active margin: Tectonic and sedimentary processes linked to the birth of an accretionary prism (Hikurangi margin, New Zealand): Bulletin de la Société Géologique de France 162, 649660.

Chester, J.S., and Chester, F.M., 1990, Fault-propagation folds above faults with constant dip: Journal of Structural Geology 12, 903-910.

Coleman, R.G., 1981, Tectonic setting for ophiolite emplacement in Oman: Journal of Geophysical Research 86, 2497-2508.

Collot, J.Y., Malahoff, A., Recy, J., Latham, G., and Missegue, F., 1987, Overthrust emplacement of the New Caledonia ophiolite: Geophysical evidence: Tectonics $6,215-232$.

Cooper, D.J.W., 1988, Structure and sequence of thrusting in deep-water sediments during ophiolite emplacement in the south-central Oman Mountains: Journal of Structural Geology 10, 473-485.

Cooper, M.A., 1981, The internal geometry of nappes: criteria for models of emplacement, in: McClay, K.R., and Price, N.J., eds., Thrust and Nappe Tectonics: Geological Society of London Special Publication 9, 225-234.

Cooper, M.A., 1983, The calculation of bulk strain in oblique and inclined balanced sections: Journal of Structural Geology 5, 161-165. 
Coward, M.P., 1980, The Caledonian thrust and shear zones of N.W. Scotland: Journal of Structural Geology 2, 11-17.

Coward, M.P., 1982, Surge zones in the Moine thrust zone of N.W. Scotland: Journal of Structural Geology 4, 247-256.

Davey, F.J., 1982, The structure of the South Fiji Basin: Tectonophysics 87, 185-241.

Davey, F.J., Hampton, M., Childs, J., Fisher, M.A., Lewis, K.B., and Pettinga, J.R., 1986, Structure of a growing accretionary prism, Hikurangi margin, New Zealand: Geology 14, 663-666.

Dahlstrom, C.D.A., 1969, Balanced cross sections: Canadian Journal of Earth Sciences 6, 743-757.

Delphia, J.G., and Bombolakis, E.G., 1988, Sequential development of a frontal ramp, imbricates, and a major fold in the Kemmerer region of the Wyoming thrust belt, in: Mitra, G., and Wojtal, S., eds., Geometries and Mechanisms of Thrusting: Geological Society of America Special Publication 222, 207-222.

De Mets, C., Gordon, R.G., Argus, D.F., and Stein, S., 1990, Current plate motions: Geophysical Journal International 101, 425-478.

Diegel, F.A., 1986, Topological constraints on imbricate thrust networks, examples from the Mountain City window, Tennessee, U.S.A.: Journal of Structural Geology 8, 269-279.

Edwards, A.R., Hornibrook, N.de B., Raine, J.I., Scott, G.H., Stevens, G.R., Strong, C.P., and Wilson, G.J., 1988, A New Zealand Cretaceous-Cenozoic time scale: N.Z. Geological Survey Record 35, 135-149.

Elliott, D., and Johnson, M.R.W., 1980, Structural evolution in the northern part of the Moine thrust belt, NW Scotland: Transactions of the Royal Society of Edinburgh 71, 69-96.

Faill, R.T., 1969, Kink band structures in the Valley and Ridge Province, central Pennsylvania: Geological Society of America Bulletin 80, 2539-2550.

Faill, R.T., 1973, Kink-band folding, Valley and Ridge Province, Pennsylvania: Geological Society of America Bulletin 84, 1289-1314. 
Fergusson, L., 1985, The Mineralogy, Geochemistry, and Origin of Lower Tertiary Smectite-Mudstones, East Coast Deformed Belt, New Zealand: Unpublished M.Sc. thesis, University of Canterbury.

Forsyth, P.J., Hoolihan, K., and Lock, R.G., 1979, A geological bibliography, Raukumara Peninsula, northern and central Hawkes Bay: N.Z. Geological Survey Report 88.

Francis, D.A., 1983, The Marau Beach Fault - a late Quaternary active fault in the East Cape region (abstract): Geological Society of N.Z. Miscellaneous Publication 30A.

Francis, D.A., and Mazengarb, C., 1983, Outline of post-Eocene stratigraphy from Gisborne to Tokomaru Bay, East Coast Deformed Belt (abstract): Geological Society of N.Z. Miscellaneous Publication 30A.

Gibson, J.D., 1987a, Tectonic History of the Cretaceous Mokoiwi Formation and Adjacent Units, Northeastern North Island, New Zealand: Unpublished Ph.D. thesis, University of Auckland.

Gibson, J.D., 1987b, provisional subdivision of northeastern North Island, New Zealand, into tectonostratigraphic terranes, in: Leitch, E.C., and Scheibner, E., eds., Terrane Accretion and Orogenic Belts: American Geophysical Union, Washington, 161-168.

Gill, J., 1981, Orogenic Andesites and Plate Tectonics: Springer-Verlag, Berlin.

Gillies, P.N., and Davey, F.J., 1986, Seismic reflection and refraction studies of the Raukumara forearc basin, New Zealand: N.Z. Journal of Geology and Geophysics 29, 391-403.

Hancock, P.L., 1985, Brittle microtectonics: Principles and practice: Journal of Structural Geology 7, 437-457.

Hanna, S.S., 1990, The Alpine deformation of the central Oman Mountains, in: Robertson, A.H.F., Searle, M.P., and Ries, A.C., eds., The Geology and Tectonics of the Oman Region: Geological Society of London Special Publication 49, 341359.

Haq, B.U., Hardenbol, J., and Vail, P.R., 1987, Chronology of fluctuating sea levels since the Triassic: Science 235, 1156-1166. 
Hayward, B.W., 1983, Microfaunal age of the Tangihua Volcanics, Northland: Geological Society of N.Z. Newsletter 62, 37-38.

Hayward, B.W., Brook, F.J., and Isaac, M.J., 1989, Cretaceous to middle Tertiary stratigraphy, paleogeography, and tectonic history of Northland, New Zealand, in: Spörli, K.B., and Kear, D., eds., Geology of Northland: Royal Society of N.Z. Bulletin 26, 47-64.

Heron, D.W., Hoolihan, K., and Lock, R.G., 1986, Register of geological maps in open-file petroleum reports and university theses, Raukumara Peninsula and northern and central Hawkes Bay: N.Z. Geological Survey Report G103.

Hill, P.J., 1974, Taitai Series Rocks at Te Kaha: Unpublished M.Sc. thesis, University of Auckland.

Hobbs, B.E., Means, W.D., and Williams, P.F., 1976, An Outline of Structural Geology: John Wiley and Sons, New York.

Hossack, J.R., 1979, The use of balanced cross-sections in the calculation of orogenic contraction: A review: Journal of the Geological Society of London 136, 705-711.

Isaac, M.J., 1977, Mesozoic Geology of the Matawai District, Raukumara Peninsula: Unpublished Ph.D. thesis, University of Auckland.

Jamison, W.R., 1987, Geometric analysis of fold development in overthrust terranes: Journal of Structural Geology 9, 207-219.

Joass, Y.J., 1987, The Geology of the Tahora District, Southern Raukumara Peninsula: Unpublished M.Sc. thesis, Victoria University of Wellington.

Jones, P.B., 1971, Folded faults and sequences of thrusting in Alberta foothills: American Association of Petroleum Geologists Bulletin 55, 292-306.

Jordan, T.E., Flemings, P.B., and Beer, J.A., 1988, Dating thrust-fault activity by use of foreland-basin strata, in: Kleinspehn, K.L., and Paola, C., eds., New Perspectives in Basin Analysis: Springer-Verlag, New York, 307-330.

Kamb, W.B., 1959, Petrofabric observations from Blue Glacier, Washington, in relation to theory and experiment: Journal of Geophysical Research 64, 1908-1909. 
Kenny, J.A., 1980, Geology of the Ihungia Catchment, Raukumara Peninsula: Unpublished M.Sc. thesis, University of Auckland.

Kenny, J.A., 1984a, Stratigraphy, sedimentology and structure of the Ihungia décollement, Raukumara Peninsula, New Zealand: N.Z. Journal of Geology and Geophysics 27, 1-19.

Kenny, J.A., 1984b, Petrography of Cretaceous and Tertiary sedimentary rocks from the Ihungia catchment, Raukumara Peninsula, North Island, New Zealand: N.Z. Journal of Geology and Geophysics 27, 291-298.

Kenny, J.A., 1986, Alternating Convergent and Non-Convergent Tectonics, 100 Million Years to Present, Puketoro Area, Northeastern New Zealand: Unpublished Ph.D. thesis, University of Auckland.

Katz, H.R., 1976, Cretaceous foraminifera from the Matakaoa Volcanic Group: Comment: N.Z. Journal of Geology and Geophysics 19, 945-946.

Kingma, J.T., 1965, Geological map of New Zealand 1:250,000: Sheet 6, East Cape: Department of Scientific and Industrial Research, Wellington.

Laing, A.C.M., 1971, Geological maps, Ruatoria area: Open-file petroleum report PR 254, held at Institute of Geological and Nuclear Sciences, Lower Hutt.

Laing, A.C.M., 1972a, Geology and petroleum prospects, Ruatoria area, East Coast, North Island, New Zealand: The APEA Journal 12, 45-52.

Laing, A.C.M., 1972b, Te Puia-1 well completion report: Open-file petroleum report PR 257, held at Institute of Geological and Nuclear Sciences, Lower Hutt.

Laing, A.C.M., 1972c, Te Horo-1 well completion report: Open-file petroleum report PR 256, held at Institute of Geological and Nuclear Sciences, Lower Hutt.

Laing, A.C.M., 1972d, Rotokautuku-1 well completion report: Open-file petroleum report PR 255, held at Institute of Geological and Nuclear Sciences, Lower Hutt.

Lamb., S.H., 1988, Tectonic rotations about vertical axes during the last $4 \mathrm{Ma}$ in part of the New Zealand plate boundary zone: Journal of Structural Geology 10, 875-893. 
Lamb, S.H., and Bibby, H.M., 1989, The last $25 \mathrm{Ma}$ of rotational deformation on part of the New Zealand plate-boundary zone: Journal of Structural Geology 11, 473492.

Laubscher, H.P., 1977, Fold development in the Jura: Tectonophysics 37, 337-362.

Lillie, A.R., 1953, The geology of Dannevirke Subdivision: N.Z. Geological Survey Bulletin 46.

Lugeon, M., 1943, Une nouvelle hypothèse tectonique: La diverticulation: Bulletin Societé Vaudoise des Sciences Naturelles 62, 260-261.

Malahoff, A., Feden, R.H., and Fleming, H.S., 1982, Magnetic anomalies and tectonic fabric of marginal basins north of New Zealand: Journal of Geophysical Research 87, 4109-4125.

Malpas, J., Spörli, K.B., Black, P.M., and Smith, I.E.M., 1992, Northland ophiolite, New Zealand, and implications for plate-tectonic evolution of the southwest Pacific: Geology 20, 149-152.

Mazengarb, C., 1982, Structure and Stratigraphy at the Front of the Maungahaumi Nappes, Mangatawa, Raukumara Peninsula: Unpublished M.Sc. thesis, University of Auckland.

Mazengarb, C., 1983, Structure of the Ihungia area, East Coast Deformed Belt (abstract): Geological Society of N.Z. Miscellaneous Publication 30A.

Mazengarb, C., 1984, The Fernside Fault: an active normal fault, Raukumara Peninsula, New Zealand: N.Z. Geological Survey Record 3, 98-103.

Mazengarb, C., 1989, Autochthonous Cretaceous stratigraphy in central Raukumara Peninsula (abstract): Geological Society of N.Z. Miscellaneous Publication 43, 63.

Mazengarb, C., 1990, Raukumara Peninsula (field trip guide): Geological Society of N.Z. Miscellaneous Publication 50B, 1-12.

Mazengarb, C., and Beggs, J.M., 1990, An interpretation of Raukumara Peninsula mid to Late Cretaceous facies distribution (abstract): Geological Society of N.Z. Miscellaneous Publication 50A, 92. 
Mazengarb, C., Beggs, J.M., Crampton, J.S., and Wilson, G.J., 1990, Late Cretaceous geology of Waihau Bay, eastern Bay of Plenty (abstract): Geological Society of N.Z. Miscellaneous Publication 50A, 93.

Mazengarb, C., Francis, D.A., and Moore, P.R., 1991, Sheet Y16, Tauwhareparae: Geological Map of New Zealand 1:50,000: DSIR, Wellington, N.Z.

Milici, R.C., 1975, Structural patterns in the southern Appalachians: Evidence for a gravity slide mechanism for Alleghanian deformation: Geological Society of America Bulletin 86, 1316-1320.

Mitra, S., 1988, Three-dimensional geometry of the Pine Mountain thrust sheet, southern Appalachians: Geological Society of America Bulletin 100, 72-95.

Mitra, S., 1990, Fault-propagation folds: Geometry, kinematic evolution, and hydrocarbon traps: American Association of Petroleum Geologists Bulletin 74, 921-945.

Moore, P.R., 1978, Geology of western Koranga Valley, Raukumara Peninsula: N.Z. Journal of Geology and Geophysics 21, 1-20.

Moore, P.R., 1981, Upper Cretaceous and Tertiary geology of Mangatu State Forest, Raukumara Peninsula: Comment: N.Z. Journal of Geology and Geophysics 24, 301-302.

Moore, P.R., 1985, Distribution, age, and relationships of volcanic rocks ("East Coast Volcanics") in the Gisborne-East Cape region: N.Z. Geological Survey Record 8, 16-23.

Moore, P.R., 1988a, Structural divisions of eastern North Island: N.Z. Geological Survey Record 30.

Moore, P.R., 1989, Kirks Breccia: a Late Cretaceous submarine channelised debris flow deposit, Raukumara Peninsula, New Zealand: Journal of the Royal Society of N.Z. 19, 195-203.

Moore, P.R., Adams, A.G., Isaac, M.J., Mazengarb, C., Morgans, H.E.G., and Phillips, C.J., 1986, A revised Cretaceous-Early Tertiary stratigraphic nomenclature for eastern North Island, New Zealand: N.Z. Geological Survey Report G104. 
Moore, P.R., and Challis, G.A., 1985, Origin of the volcanic outlier at Te Kiwikiwi, East Cape District: N.Z. Geological Survey Record 8, 52-58.

Moore, P.R., Francis, D.A., and Mazengarb, C., 1989, DSIR sheet QM303, Raukumara: Geological map of New Zealand 1:250,000: N.Z. Geological Survey Report G138.

Moore, P.R., and Morgans, H.E.G., 1989, The Late Cretaceous-Paleogene sequence of eastern North Island: stratigraphy, facies, maturity, and petroleum potential (abstract), in: Recent Advances in East Coast Geology and Geophysics: A One-Day Review of Current Ideas and Recent Progress: N.Z. Geological Survey, Lower Hutt, 31.

Moore, P.R., and Speden, I.G., 1980, Geology of the East Cape region (abstract): Geological Society of N.Z. Annual Conference programme and abstracts, 1980, 70.

Moore, W.R., 1957, Geology of the Raukokore Area, Raukumara Peninsula, North Island: Unpublished M.Sc. thesis, Victoria University of Wellington.

Moore, W.R., 1959, Notes on H.W. Wellman's paper "Divisions of the New Zealand Cretaceous": Open-file petroleum report PR 365, held at Institute of Geological and Nuclear Sciences, Lower Hutt.

Moores, E.M., 1982, Origin and emplacement of ophiolites: Reviews of Geophysics and Space Physics 20, 735-760.

Morley, C.K., 1986, A classification of thrust fronts: American Association of Petroleum Geologists Bulletin 70, 12-25.

Morley, C.K., 1988, Out-of-sequence thrusts: Tectonics 7, 539-561.

Mumme, T.C., Lamb, S.H., and Walcott, R.I., 1989, The Raukumara paleomagnetic domain: constraints on the tectonic rotation of the East Coast, North Island, New Zealand, from paleomagnetic data: N.Z. Journal of Geology and Geophysics 32, 317-326.

Ongley, M., and Macpherson, E.O., 1928, The geology of the Waiapu Subdivision: N.Z. Geological Survey Bulletin 30.

Oxburgh, E.R., 1972, Flake tectonics and continental collision: Nature 239, 202-204. 
Pennock, E.S., Lillie, R.J., Zaman, A.S.H., and Yousaf, M., 1989, Structural interpretation of seismic reflection data from eastern Salt Range and Potwar Plateau, Pakistan: American Association of Petroleum Geologists Bulletin 73, 841-857.

Pettinga, J.R., 1982, Upper Cenozoic structural history, coastal southern Hawkes Bay, New Zealand: N.Z. Journal of Geology and Geophysics 25, 149-191.

Pfiffner, O.A., 1986, Evolution of the north Alpine foreland basin in the Central Alps, in: Allen, P.A., and Homewood, P., eds., Foreland Basins: International Association of Sedimentologists Special Publication 8, 219-228.

Phillips, C.J., 1985, Upper Cretaceous and Tertiary geology of the upper Waitahaia River, Raukumara Peninsula, New Zealand: N.Z. Journal of Geology and Geophysics 28, 595-607.

Pick, M.C., 1962, The Stratigraphy, Structure, and Economic Geology of the Cretaceo-Tertiary Rocks of the Waiapu District, New Zealand: Unpublished Ph.D. thesis, University of Bristol.

Pirajno, F., 1979, Geology, geochemistry, and mineralisation of a spilite-keratophyre association in Cretaceous flysch, East Cape area, New Zealand: N.Z. Journal of Geology and Geophysics 22, 307-328.

Pirajno, F., 1980, Subseafloor mineralisation in rocks of the Matakaoa Volcanics around Lottin Point, East Cape, New Zealand: N.Z. Journal of Geology and Geophysics 23, 313-334.

Plank, T., and Langmuir, C.H., 1988, An evaluation of the global variations in the major element chemistry of arc basalts: Earth and Planetary Science Letters 90, 349370 .

Platt, J.P., and Leggett, J.K., 1986, Stratal extension in thrust footwalls, Makran accretionary prism: Implications for thrust tectonics: American Association of Petroleum Geologists Bulletin 70, 191-203.

Price, R.A., 1981, The Cordilleran foreland fold and thrust belt in the southern Canadian Rocky Mountains, in: McClay, K.R., and Price, N.J., eds., Thrust and Nappe Tectonics: Geological Society of London Special Publication 9, 427-448. 
Ramsay, J.G., and Huber, M.I., 1987, The Techniques of Modern Structural Geology, Volume 2: Folds and Fractures: Academic Press, London.

Rait, G., Chanier, F., and Waters, D.W., 1991, Landward- and seaward-directed thrusting accompanying the onset of subduction beneath New Zealand: Geology 19, 230233.

Rich, J.L., 1934, Mechanics of low-angle overthrust faulting as illustrated by Cumberland thrust block, Virginia, Kentucky, and Tennessee: American Association of Petroleum Geologists Bulletin 18, 1584-1596.

Roeder, D., 1988, Andean-age structure of Eastern Cordillera (province of La Paz, Bolivia): Tectonics 7, 23-39.

Royse, F. Jr., Warner, M.A., and Reese, D.L., 1975, Thrust belt structural geometry and related problems, Wyoming-Idaho-northern Utah, in: Rocky Mountain Association of Geologists Symposium on Deep Drilling Frontiers in the Central Rocky Mountains, 41-54.

Searle, M.P., 1985, Sequence of thrusting and origin of culminations in the northern and central Oman mountains: Journal of Structural Geology 7, 129-143.

Sharp, B.M., Locke, C.A., and Cassidy, J., 1989, Gravity investigations of the Maungataniwha and Ahipara ophiolite massifs, Northland, New Zealand, in: Spörli, K.B, and Kear, D., eds., Geology of Northland: Royal Society of N.Z. Bulletin 26, 175-181.

Smith, I.E.M., Ruddock, R.S., and Day, R.A., 1989, Miocene arc-type volcanic/plutonic complexes of the Northland Peninsula, New Zealand, in: Spörli, K.B., and Kear, D., eds., Geology of Northland: Royal Society of N.Z. Bulletin 26, 205-213.

Speden, I.G., 1975, Cretaceous Stratigraphy of Raukumara Peninsula: N.Z. Geological Survey Bulletin 91.

Speden, I.G., 1976, Geology of Mt. Taitai, Tapuaeroa Valley, Raukumara Peninsula: N.Z. Journal of Geology and Geophysics 19, 71-119.

Speden, I.G., 1978, New Zealand: Cretaceous, in: Moullade, M., and Nairn, A.E.M., eds., The Phanerozoic Geology of the World II: The Mesozoic, A: Elsevier, Amsterdam, 281-309. 
Spörli, K.B., 1980, New Zealand and oblique-slip margins: tectonic development up to and during the Cenozoic, in: Ballance, P.F., and Reading, H.G., eds., Sedimentation in Oblique-Slip Mobile Zones: International Association of Sedimentologists Special Publication 4, 147-170.

Spörli, K.B., 1987, Development of the New Zealand microcontinent, in: Monger, J.W.H., and Franchetau, J., eds., Circum-Pacific Orogenic Belts and Evolution of the Pacific Ocean Basin: American Geophysical Union, Washington, 115-132.

Spörli, K.B., 1989, Tectonic framework of Northland, New Zealand, in: Spörli, K.B., and Kear, D., eds., Geology of Northland: Royal Society of N.Z. Bulletin 26, 3-14.

Stoneley, R., 1968, A lower Tertiary décollement on the East Coast, North Island, New Zealand: N.Z. Journal of Geology and Geophysics 11, 128-156.

Strong, C.P., 1976a, Cretaceous foraminifera from the Matakaoa Volcanic Group: N.Z. Journal of Geology and Geophysics 19, 140-143.

Strong, C.P., 1976b, Cretaceous foraminifera from the Matakaoa Volcanic Group: Reply: N.Z. Journal of Geology and Geophysics 19, 943-945.

Strong, C.P., 1980, Early Paleogene foraminifera from the Matakaoa Volcanic Group: N.Z. Journal of Geology and Geophysics 23, 267-272.

Suppe, J., 1983, Geometry and kinematics of fault-bend folding: American Journal of Science $283,684-721$.

Suppe, J., 1985, Principles of Structural Geology: Prentice Hall, Englewood Cliffs, New Jersey.

Suppe, J., and Medwedeff, D.A., 1984, Fault-propagation folding: Geological Society of America Abstracts with Programs 16, 670.

Tatsumi, Y., 1986, Formation of the volcanic front in subduction zones: Geophysical Research Letters 13, 717-720.

van der Lingen, G.J., 1982, Development of the North Island subduction system, New Zealand, in: Leggett, J.K., ed., Trench-Forearc Geology: Geological Society of London Special Publication 10, 259-272. 
Walcott, R.I., 1978, Present tectonics and Late Cenozoic evolution of New Zealand: Geophysical Journal of the Royal Astronomical Society 52, 137-164.

Walcott, R.I., 1984, Reconstructions of the New Zealand region for the Neogene: Palaeogeography, Palaeoclimatology, Palaeoecology 46, 217-231.

Walcott, R.I., 1987, Geodetic strain and the deformational history of the North Island of New Zealand during the Late Cainozoic: Philosophical Transactions of the Royal Society, London A321, 163-181.

Walcott, R.I., 1989, Paleomagnetically observed rotations along the Hikurangi margin of New Zealand, in: Kissel, C., and Laj, C., eds., Paleomagnetic Rotations and Continental Deformation: Kluwer Academic, Dordrecht, 459-472.

Waters, D.W., 1988, The Flags Creek Thrust: Unpublished B.Sc.(Hons.) thesis, Victoria University of Wellington.

Wellman, H.W., 1959, Divisions of the New Zealand Cretaceous: Transactions of the Royal Society of N.Z. 87, 99-163.

Wilson, G.J., Moore, P.R., and Isaac, M.J., 1988, Age of greywacke basement in the Urewera Ranges, eastern North Island: N.Z. Geological Survey Record 25, 29-33.

Wiltschko, D.V., and Dorr, J.A., 1983, Timing of deformation in the Overthrust Belt and foreland of Idaho, Wyoming and Utah: American Association of Petroleum Geologists Bulletin 67, 1304-1322.

Wojtal, S., 1986, Deformation within foreland thrust sheets by populations of minor faults: Journal of Structural Geology 8, 341-360.

Wojtal, S., 1988, Chapter 13: Objective methods for constructing profiles and block diagrams of folds, in: Marshak, S., and Mitra, G., eds., Basic Methods of Structural Geology: Prentice Hall, Englewood Cliffs, New Jersey.

Woodward, N.B., Boyer, S.E., and Suppe, J., 1989, Balanced Geological Cross-Sections: An Essential Technique in Geological Research and Exploration: American Geophysical Union, Washington D.C. 
Woodward, N.B., Wojtal, S., Paul, J.B., and Zadins, Z.Z., 1988, Partitioning of deformation within several external thrust zones of the Appalachian orogen: Journal of Geology 96, 351-361.

Yin, A., and Kelty, T.K., 1991, Development of normal faults during emplacement of a thrust sheet: An example from the Lewis allochthon, Glacier National Park, Montana (U.S.A.): Journal of Structural Geology 13, 37-47. 


\section{Appendix 1}

\section{Geological Time Scale}

Table A1.1 (overleaf): Chart from Edwards et al. (1988) showing correlation of New Zealand Cretaceous-Cenozoic Series and stages with the international divisions, with the paleomagnetic reversal time scale, and with time in millions of years before present (Ma). 

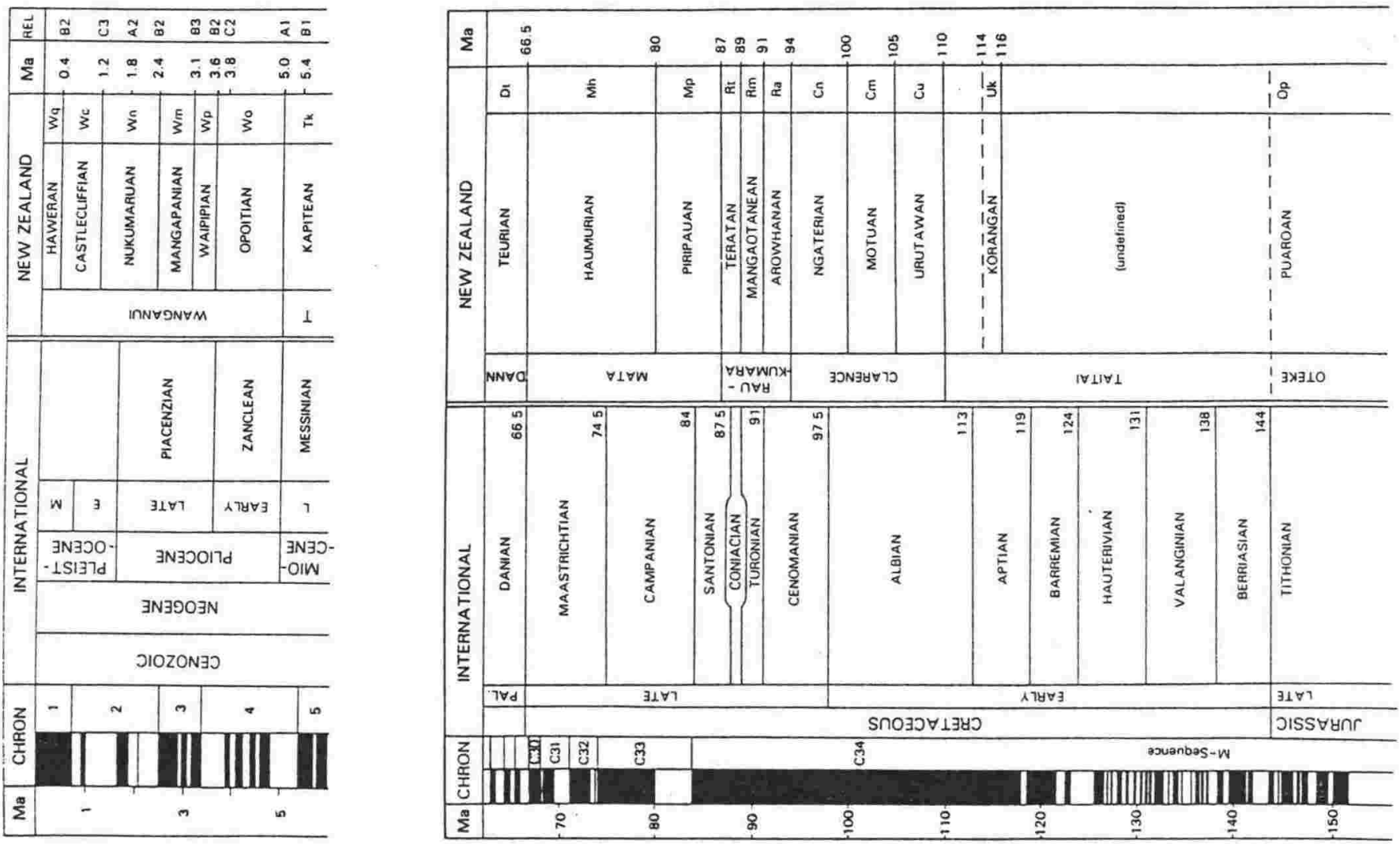

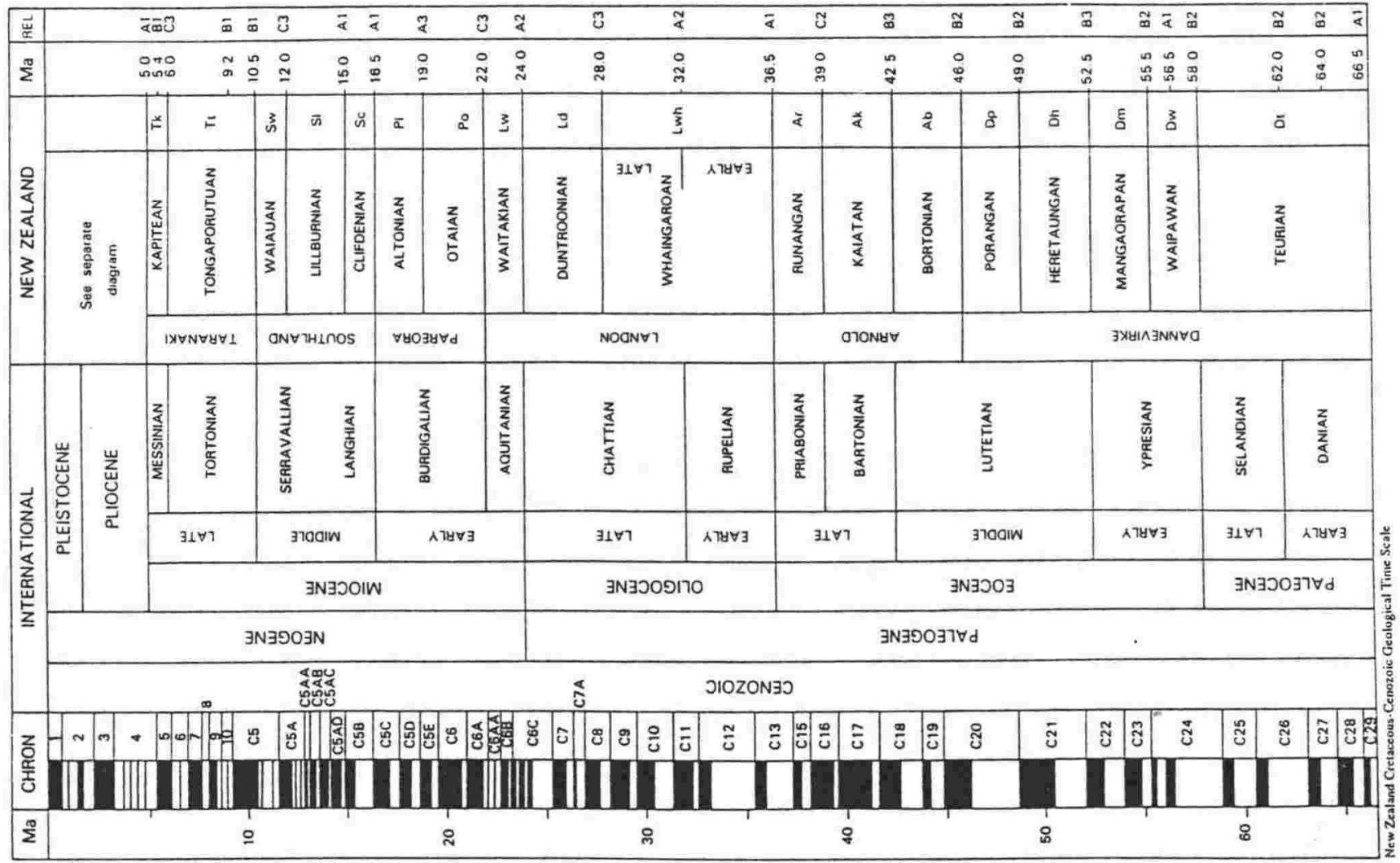




\section{Appendix 2}

\section{Paleontology}

\section{A2.1 INTRODUCTION}

This Appendix contains details of the locations of micro- and macrofossil collections made during this study, their corresponding New Zealand Fossil Record File numbers, faunal lists, and inferred ages. Collections are listed in order by Fossil Record number under the appropriate New Zealand Map Series 260 (1:50,000) map sheet number. The NZMS 260 grid reference and the name of the unit from which the collection was made (following the stratigraphic nomenclature adopted herein) are given for each. The name of the paleontologist who identified the fossils in each collection is also given.

For further details on collection localities and lithologies, consult the New Zealand Fossil Record File, presently curated at the Institute of Geological and Nuclear Sciences, Lower Hutt. The fossil collections themselves are held by the Geology Department, Victoria University of Wellington.

\section{A2.2 EXTRACTION OF FORAMINIFERA}

Fist-sized samples were first broken into small lumps with a mortar and pestle and dried overnight in an oven at $50-60^{\circ} \mathrm{C}$. They were then left to soak for 24 hours, after which time they were washed through a $75 \mu \mathrm{m}$ seive. The more resistant samples (generally pre-Miocene) were in addition heated for 1-2 minutes on a hot plate with water and a few drops of hydrogen peroxide, vibrated for 30-60 seconds in an ultrasonic tank, and then seived again. Some samples required more than one cycle of breaking down, soaking, heating and vibrating.

After final seiving, the coarse fractions were dried at $50-60^{\circ} \mathrm{C}$ in an oven. The foraminifera were then picked under a binocular microscope and mounted on display slides using PVA glue. 
NZMS 260 sheet Y15 (Hikurangi):

Y15/f 110 (Y15 66624998; Eocene smectite mudstone)

Foraminiferida (H.E.G. Morgans):

Abyssamina poagi Schinitker \& Tjalsma

Acarinina cf. aquiensis (Loeblich \& Tappan)

Arenobulimina sp.

Bathysiphon sp.

Buliminella cf. browni Finlay

Cibicides sp.

Conotrochammina whangaia Finlay

Haplophragmoides sp.

Hyperamina sp.

Karrerulina bortonica Finlay

Lituotuba sp.

Nuttallides carinotruempyi Finlay

Parafissurina sp.

Subbotina triloculinoides Plummer

Tappanina glaessneri (Finlay)

Trochammina sp.

Turborotalia reissi Loeblich \& Tappan

Age: early Waipawan

Y15/f 111 (Y15 67415069; Haumurian-Teurian formation)

Foraminiferida (H.E.G. Morgans):

Alabamina creta (Finlay)

Bolivinopsis spectabilis (Grzybowski)

Bulimina subbortonica Finlay

Gaudryina whangaia Finlay

Gavelinella infrafossa (Finlay)

Lenticulina sp.

Nodosaria sp.

Rzehakina epigona (Rzehak)

Trochammina sp.

Age: Teurian

Y15/f 114 (Y15 66614603; Haumurian-Teurian formation)

Foraminiferida (H.E.G. Morgans):

Bolivinopsis spectabilis (Grzybowski)

Age: $\underline{\text { Haumurian-Teurian }}$

Y15/f 115 (Y15 63494923; Haumurian-Teurian formation)

Foraminiferida (H.E.G. Morgans):

Bolivinopsis cf. spectabilis (Grzybowski)

Nuttallides cf. carinotruempyi Finlay

Tappanina cf. glaessneri (Finlay)

Age: Teurian-Waipawan 


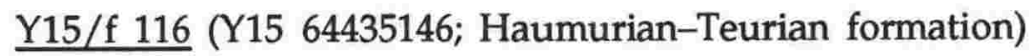

Foraminiferida (H.E.G. Morgans):

Bathysiphon sp.

Bolivinopsis cf. spectabilis (Grzybowski)

Rhezkina epigona (Rzehak)

Age: $\underline{\text { Haumurian-Teurian }}$

Y15/f 117 (Y15 63534938; Haumurian-Teurian formation)

Foraminiferida (H.E.G. Morgans):

Bathysiphon sp.

Bolivinopsis spectabilis (Grzybowski)

Haplophragmoides sp.

Kalamopsis sp.

Pelosina sp.

Thalmannammina cf. subturbinata (Grzybowski)

Age: Haumurian-Teurian

$\underline{\mathrm{Y} 15 / \mathrm{f} 118}$ (Y15 663555; Haumurian-Teurian formation)

Foraminiferida (H.E.G. Morgans):

Bathysiphon sp.

Bolivinopsis spectabilis (Grzybowski)

Eggerella sp.

Kalamopsis sp.

Age: Haumurian-Teurian

$\underline{\text { Y15/f } 119}$ (Y15 63714986; Haumurian-Teurian formation)

Foraminiferida (H.E.G. Morgans):

Alabamina creta (Finlay)

Ammodiscus cretaceus (Reuss)

Bolivinopsis spectabilis (Grzybowski)

Glomospira charoides (Jones \& Parker)

Lituotuba sp.

Nuttallides florialis (White)

Pullenia bulloides (d'Orbigny)

Quadrimorphina sp.

Rzehakina epigona (Rzehak)

Age: Haumurian-Teurian

$\underline{\text { Y15/f } 120}$ (Y15 63314848; Haumurian-Teurian formation)

Foraminiferida (H.E.G. Morgans):

Ammodiscus cretaceus (Reuss)

Bolivinopsis spectabilis (Grzybowski)

Gaudryina whangaia Finlay

Kalamopsis sp.

Rzehakina epigona (Rzehak)

Age: Teurian 
$\underline{\text { Y15/f } 121}$ (Y15 65134524; Haumurian-Teurian formation)

Foraminiferida (H.E.G. Morgans):

Bolivinopsis spectabilis (Grzybowski)

Age: Haumurian-Teurian

$\underline{\text { Y15/f } 122}$ (Y15 64854205; Haumurian-Teurian formation)

Foraminiferida (H.E.G. Morgans):

Rzehakina cf. epigona (Rzehak)

Age: Haumurian-Bortonian

$\underline{\text { Y15/f } 123}$ (Y15 64764900; Tikihore Formation)

Foraminiferida (H.E.G. Morgans):

Kalamopsis sp.

Age: $\underline{\text { ND }}$

Y15/f 124 (Y15 65514623; Haumurian-Teurian formation)

Foraminiferida (H.E.G. Morgans):

Ammodiscus cretaceus (Reuss)

Bathysiphon sp.

Bolivinopsis cf. compta (Finlay)

Bolivinopsis spectabilis (Grzybowski)

Dorothia elongata Finlay

Gaudryina sp. cf. whangaia Finlay

Karrerulina cf. aegra Finlay

Rzehakina epigona (Rzehak)

Age: Haumurian

Y15/f 125 (Y15 63194782; Tikihore Formation)

Bivalvia (P.P. Vella):

Inoceramus bicorrugatis Marwick

Age: Mangaotanean

$\underline{\text { Y15/f } 126}$ (Y15 62824770; Tikihore Formation)

Bivalvia (P.P. Vella):

Inoceramus ?pacificus Woods

Age: Piripauan

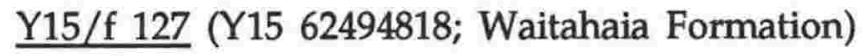

Bivalvia (P.P. Vella):

Inoceramus sp. cf. fyfei Wellman cf. warakius Wellman

Age: ?Ngaterian 


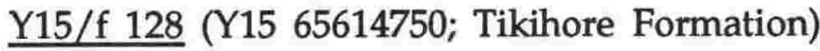

Bivalvia (J.C. Crampton):

Inoceramus bicorrugatis Marwick

Age: Mangaotanean

Y15/f 129 (Y15 65784748; Tikihore Formation)

Bivalvia (P.P. Vella):

Inoceramus ?opetius Wellman

Age: Teratan

Y15/f 130 (Y15 65934745; Tikihore Formation)

Bivalvia (P.P. Vella):

Inoceramus opetius Wellman

Age: Teratan

Y15/f 131 (Y15 63314779; ?Waitahaia Formation-boulder in stream)

Bivalvia (P.P. Vella):

Inoceramus ?fyfei Wellman

Age: ?Ngaterian

NZMS 260 sheet Y16 (Tauwhareparae):

$\underline{\text { Y16/f } 793}$ (Y16 57353970; sandstone/breccia lithotype)

Foraminiferida (H.E.G. Morgans):

Alabamina tenuimarginata (Chapman, Parr \& Collins)

Bathysiphon sp.

Bolivina sp.

Bulimina sp.

Cassidulina laevigata d'Orbigny

Cassidulina subglobosa Brady

Catapsydrax dissimilis (Cushman \& Bermudez)

Chilostomella ovoidea (Reuss)

Cibicides perforatus (Karrer)

Globigerina connecta Jenkins

Globigerina woodi Jenkins

Parafissurina sp.

Paragloborotalia sp.

Pullenia bulloides (d'Orbigny)

Age: late Waitakian-Otaian 
$\underline{\text { Z16/f } 65}$ (Z16 71803330; Tongaporutuan mudstone)

Foraminiferida (P.P. Vella):

Amphicoryna scalaris (Batsch)

Bolivina lapsus Finlay

Bulimina marginata d'Orbigny

Bulimina senta Finlay

Cibicides ihungia Finlay

Cyclammina incisa (Stache)

Dentalina sp.

Fissurina marginata Walker \& Boys

Globorotalia ?periferoronda Blow \& Banner

Globorotalia continuosa Blow

Globorotalia mayeri Cushman \& Ellisor

Globorotalia miozea conoidea Walters

Gyroidinoides neosoldanii (Brotzen)

Haplophragmoides sp.

Hopkinsina mioindex Finlay

Lagena striata (d'Orbigny)

Lenticulina dicampyla (Franzenau)

Lenticulina loculosa (Stache)

Nodosaria longiscata d'Orbigny

Pullenia bulloides (d'Orbigny)

Sigmoilopsis schlumbergeri (Costa)

Sphaeroidinellopsis seminulina (Schwager)

Uvigerina notohispida (Finlay)

Age: Tongaporutuan

Z16/f 66 (Z16 72503243; Tongaporutuan mudstone)

Foraminiferida (P.P. Vella):

Biloculina sp.

Bolivina albatrossi Finlay

Bolivinita affiliata Finlay

Bolivinita aff. pliozea Finlay

Bolivinita pohana Finlay

Bulimina senta Finlay

Globigerina bulloides d'Orbigny

Globigerina eamesi Blow

Globigerina falconensis Blow

Globoquadrina dehiscens (Chapman, Parr \& Collins)

Globorotalia miozea conoidea Walters

Karreriella cylindrica Finlay

Notorotalia cf. Taranakia Vella

Orbulina universa d'Orbigny

Pleurostomella alternans Schwager

Quinqueloculina lamarckiana d'Orbigny

Sigmoilopsis schlumbergeri (Costa)

Sphaeroidinellopsis seminulina (Schwager)

Stilostomella antipoda (Stache)

Uvigerina mioschwageri Finlay

Age: Tongaporutuan 
Z16/f 67 (Z16 72433295; Tongaporutuan mudstone)

Foraminiferida (P.P. Vella):

Ammodiscus sp.

Bolivina sp.

Bulimina senta Finlay

Fissurina marginata (Walker \& Boys)

Globigerina bulloides d'Orbigny

Globigerina woodi Jenkins

Globigerinoides conglobata (Brady)

Globoquadrina dehiscens (Chapman, Parr \& Collins)

Globorotalia mayeri Cushman \& Ellisor

Globorotalia miozea Finlay

Globorotalia miozea conoidea Walters

Gyroidinoides zelandicus Finlay

Haplophragmoides sp.

Hopkinsina mioindex Finlay

Lenticulina loculosa (Stache)

Marginulina sp.

Marginulinopsis sp.

Nodosaria hochstetteri Schwager

Nodosaria sp.

Orbulina universa d'Orbigny

Planulina wuellerstorfi (Schwager)

Sigmoilopsis schlumbergeri (Costa)

Siphonina australis Cushman

Sphaeroidina bulloides d'Orbigny

Stilostomella antipoda (Stache)

Uvigerina ?miozea Finlay

Uvigerina paeniteres Finlay

Age: Tongaporutuan

Z16/f 68 (Z16 74903387; Ihungia Formation-boulder in stream)

Foraminiferida (P.P. Vella):

Bolivina punctatostriata Kreuzberg

Bulimina senta Finlay

Cassidulina carinata Vella

Cibicides amoenus Finlay

Cibicides molestus Hornibrook

Fissurina marginata (Walker \& Boys)

Globigerina bulloides d'Orbigny

Globigerina woodi Jenkins

Globigerinita incrusta Akers

Globigerinoides aff. bisphericus Todd aff. trilobus (Reuss)

Globocassidulina subglobosa (Brady)

Globoquadrina dehiscens (Chapman, Parr \& Collins)

Globorotalia miozea Finlay

Gyroidinoides neosoldanii (Brotzen)

Haeuslerella pukeuriensis Parr

Lagena striata (d'Orbigny)

Lenticulina calcar (Defrance)

Neouvigerina sp.

Nodosaria hochstetteri Schwager

Plectofrondicularia parri Finlay 